\title{
Procesy konwergencji na europejskich rynkach mieszkaniowych \\ Ujęcie międzynarodowe i regionalne
}


送 
Ewa Kucharska-Stasiak, Ewa Kusidet Magdalena Załęczna, Konrad Żelazowski

\section{Procesy konwergencji na europejskich rynkach mieszkaniowych}

Ujęcie międzynarodowe i regionalne 
Ewa Kucharska-Stasiak, Magdalena Załęczna, Konrad Żelazowski - Uniwersytet Łódzki

Wydział Ekonomiczno-Socjologiczny, Katedra Inwestycji i Nieruchomości Instytut Gospodarki Przestrzennej, 90-214 Łódź, ul. POW 3/5

Ewa Kusideł - Uniwersytet Łódzki, Wydział Ekonomiczno-Socjologiczny

Katedra Ekonometrii Przestrzennej, Instytut Gospodarki Przestrzennej, 90-214 Łódź, ul. POW 3/5

\author{
RECENZENT \\ Stanisław Belniak \\ REDAKTOR INICJUJĄCY \\ Beata Koźniewska \\ OPRACOWANIE REDAKCYJNE \\ Bogusława Kwiatkowska \\ SKŁAD I ŁAMANIE \\ AGENT PR \\ KOREKTA TECHNICZNA \\ Leonora Gralka \\ PROJEKT OKŁADKI \\ Agencja Reklamowa efektoro.pl
}

Zdjęcie wykorzystane na okładce: @ Depositphotos.com/BrianAJackson

(c) Copyright by Authors, Łódź 2020

(c) Copyright for this edition by Uniwersytet Łódzki, Łódź 2020

Publikacja powstała w wyniku realizacji projektu badawczego nr UMO-2016/21/B/HS4/00750

finansowanego ze środków Narodowego Centrum Nauki

Wydane przez Wydawnictwo Uniwersytetu Łódzkiego

Wydanie I. W.09569.19.0.K

Ark. wyd. 12,5; ark. druk. 15,875

e-ISBN 978-83-8142-936-8

http://dx.doi.org/10.18778/8142-936-8

Wydawnictwo Uniwersytetu Łódzkiego

90-131 Łódź, ul. Lindleya 8

www.wydawnictwo.uni.lodz.pl

e-mail: ksiegarnia@uni.lodz.pl

tel. (42) 6655863 


\section{Spis treści}

Wstęp

Część 1

Procesy rozwojowe rynków nieruchomości mieszkaniowych

Rozdział 1

\section{Rynek nieruchomości mieszkaniowych jako część systemu}

mieszkaniowego - podstawy teoretyczne

1.1. Mieszkalnictwo w ujęciu systemowym 17

1.2. Rynek mieszkaniowy i determinanty jego rozwoju $\quad 19$

1.3. Społeczny i ekonomiczny wymiar rynku mieszkaniowego 25

Rozdział 2

\section{Ewolucja europejskich systemów mieszkaniowych w okresie} powojennym

2.1. Modele polityki mieszkaniowej $\quad 43$

2.2. Instrumenty polityki mieszkaniowej 51

2.3. Społeczno-gospodarcze uwarunkowania rozwoju rynków mieszkaniowych

od lat 50. do 80.

2.3.1. Powojenne uwarunkowania demograficzne $\quad 57$

2.3.2. Wielkość i struktura własnościowa zasobu mieszkaniowego 59

2.4. Społeczno-gospodarcze uwarunkowania rozwoju rynków mieszkaniowych od lat 80. do roku 2017

2.4.1. Uwarunkowania demograficzne 63

2.4.2. Wielkość i struktura własnościowa zasobu mieszkaniowego 65

Rozdział 3

\section{Ewolucja rynków nieruchomości mieszkaniowych w wybranych} państwach UE

3.1. Ewolucja rynków nieruchomości mieszkaniowych w wybranych państwach UE od lat 50. do 80.

3.2. Ewolucja rynków nieruchomości mieszkaniowych w wybranych państwach UE od lat 80 . do roku 2017

3.2.1. Odrębności uwarunkowań rozwoju i ewolucji rynków nieruchomości mieszkaniowych państw postsocjalistycznych

3.2.2. Ewolucja rynków nieruchomości mieszkaniowych w pozostałych państwach 
Część 2

Konwergencja rynków nieruchomości mieszkaniowych w państwach Unii Europejskiej

Rozdział 4

Istota konwergencji gospodarczej i metody jej weryfikacji $\quad 111$

4.1. Pojęcie i rodzaje konwergencji 111

$\begin{array}{ll}\text { 4.1.1. Definicje i istota konwergencji } & 111\end{array}$

4.1.2. Realna konwergencja w teoriach ekonomii 113

4.1.3. Rodzaje konwergencji $\quad 115$

4.2. Metody weryfikacji hipotezy o konwergencji $\quad 117$

$\begin{array}{ll}\text { 4.2.1. Beta konwergencja } & 117\end{array}$

4.2.2. Sigma konwergencja $\quad 123$

4.2.3. Relatywna konwergencja $\quad 126$

4.2.4. Gamma konwergencja $\quad 128$

Rozdział 5

Weryfikacja konwergencji na rynkach nieruchomości

mieszkaniowych $\quad 131$

5.1. Procesy konwergencji na rynkach nieruchomości mieszkaniowych w świetle literatury przedmiotu

5.2. Procesy konwergencji na rynkach nieruchomości mieszkaniowych w świetle badań własnych

5.2.1. Cel i zakres badań 135

$\begin{array}{ll}\text { 5.2.2. Metodologia badawcza } & 137\end{array}$

5.2.3. Cenowa konwergencja rynków mieszkaniowych 139

$\begin{array}{ll}\text { 5.2.3.1. Ujęcie międzynarodowe } & 139\end{array}$

$\begin{array}{ll}\text { 5.2.3.2. Ujęcie regionalne } & 141\end{array}$

5.2.4. Pozacenowa konwergencja rynków mieszkaniowych 143

$\begin{array}{ll}\text { 5.2.4.1. Ujęcie międzynarodowe } & 143\end{array}$

$\begin{array}{ll}\text { 5.2.4.2. Ujęcie regionalne } & 151\end{array}$

$\begin{array}{ll}\text { 5.2.5. Wnioski } & 167\end{array}$

Część 3

Ocena przebiegu konwergencji mieszkaniowej i jej efektów $\quad 169$

Rozdział 6

Konwergencja europejskich rynków mieszkaniowych

na tle konwergencji gospodarczej krajów członkowskich UE $\quad 171$

6.1. Proces integracji gospodarek europejskich 171

6.2. Konwergencja gospodarcza krajów członkowskich UE 173

6.2.1. Polityka spójności jako odpowiedź na rosnące nierówności gospodarcze w UE $\quad 173$

6.2.2. Beta konwergencja gospodarcza wśród krajów UE 176

$\begin{array}{ll}\text { 6.2.3. Relatywna konwergencja } & 178\end{array}$

$\begin{array}{lr}\text { 6.2.4. Sigma konwergencja } & 180\end{array}$

6.2.5. Wnioski 181

6.3. Konwergencja rynków mieszkaniowych na tle konwergencji gospodarczej 182 
Rozdział 7

\section{Próba oceny konwergencji mieszkaniowej wraz z jej efektami}

7.1. Kierunki zmian na rynkach nieruchomości mieszkaniowych w kontekście procesów konwergencji

7.1.1. Zmiany polityki mieszkaniowej i obecna sytuacja mieszkaniowa w państwach UE

$\begin{array}{ll}\text { 7.1.2. Procesy konwergencji w odniesieniu do państw postsocjalistycznych } & 199 \\ \text { 7.1.3. Kierunki zmian na poziomie regionów } & 202\end{array}$

7.2. Konwergencja mieszkaniowa a problem nierówności społecznych 202

7.2.1. Kierunki zmian sytuacji mieszkaniowej gospodarstw domowych w różnych grupach dochodowych w latach 2007 i 2017

7.2.2. Trendy w zakresie kosztów mieszkaniowych w różnych grupach dochodowych $\quad 207$

7.2.3. Trendy w zakresie przeludnienia mieszkań w różnych grupach dochodowych $\quad 214$

7.3. Wnioski

Zakończenie

Bibliografia

Załącznik. Źródła danych wykorzystanych w analizie konwergencji rynków mieszkaniowych UE

Spis tabel

Spis rysunków

Spis schematów 



\section{Wstęp}

Badania poświęcone sytuacji gospodarstw domowych ujawniają w ujęciu historycznym narastające nierówności. Świadczyć to może o niesprawiedliwym podziale światowego bogactwa, co prowadzi do wyodrębnienia dwóch światów: świata głodnych i świata sytych [Sachs 1964]. Prowadzi to do powstania, jak to nazwał I. Sachs, „kielicha wstydu”: 80-90\% światowego bogactwa, zobrazowanego przez czaszę kielicha skoncentrowana jest w rękach 10-20\% ludności świata. Na pozostałą część ludności (80-90\%) przypada zaledwie 10-20\% tego bogactwa. Powyższe oznacza, że gospodarka rynkowa posiada potężne siły destabilizujące, co zagraża rozwojowi i poczuciu sprawiedliwości społecznej [Acemoglu, Robinson 2014].

Świadomość narastających nierówności dała impuls do rozwoju koncepcji tzw. kapitalizmu inkluzywnego, bardziej sprawiedliwego od obecnego [Mączyńska 2019]. Pogłębia się przekonanie, że forma kapitalizmu, jaka istnieje obecnie, nastawiona na zysk i pomijająca kwestie społeczne, musi się zmienić.

Narastające nierówności widoczne są na obszarze:

- pogłębiających się rozbieżności dochodowych. Badania przeprowadzone na danych pochodzących z ponad dwudziestu krajów na przestrzeni trzech wieków ujawniają, że bogaci stają się coraz bardziej bogaci, biedni coraz bardziej relatywnie biednieją. Niesie to konsekwencje nie tylko społeczne, ale także ekonomiczne. Z punktu widzenia rozwoju gospodarczego największym problemem staje się bariera popytu. Biedni nie mają za co kupić dóbr, bogatych cechuje malejąca krańcowa użyteczność dochodów. Swoje nadmierne dochody, nie mogąc znaleźć ich zastosowania w sferze wytwórczości materialnej, przeznaczają oni na inwestycje spekulacyjne [Piketty 2015];

- akumulacji i koncentracji majątków. Ten proces został uznany za bardziej destabilizujący niż dywergencja dochodów, stanowiąc główne zagrożenie dla dynamiki podziału bogactwa w długiej perspektywie czasowej [tamże].

W warunkach rosnących nierówności popularnym problemem badawczym stały się badania nad konwergencją, która stanowi element ekonomii rozwoju ${ }^{1}$. Konwergencja rozumiana jest jako proces wyrównywania zmiennych ekonomicznych

1 Ekonomia rozwoju urosła do oddzielnej dyscypliny w latach 50. XX w., zyskując na znaczeniu w latach 90. ubiegłego stulecia. 
pomiędzy poszczególnymi krajami lub regionami, spowodowany szybszym rozwojem obszarów biedniejszych. Niestety, procesy wyrównywania są zaburzane przeciwnymi siłami, działającymi w kierunku dywergencji, czyli nasilania się różnic i dysproporcji pomiędzy krajami (regionami).

W literaturze przedmiotu wyróżnia się szereg typów konwergencji. Uwzględniając kryterium przedmiotowe wyodrębnia się konwergencję realną oraz nominalną. Konwergencja realna odnosi się do poziomu podobieństwa struktur badanych gospodarek (w tym struktury sektorowej, struktury własnościowej, struktury konsumpcji) oraz podobieństwa w zakresie wahań cykli koniunkturalnych. Konwergencja nominalna dotyczy zbieżności makroekonomicznych wskaźników nominalnych (poziomu cen, kursów walutowych, inflacji czy deficytu budżetowego). Uwzględniając kwestie metodologiczne, wyodrębnia się konwergencję typu beta (absolutną i warunkową), konwergencję typu sigma oraz typu gamma. Konwergencja beta dotyczy procesu, w którym jednostki przestrzenne dążą do osiągnięcia określonego stanu równowagi. Wówczas gdy poziom ten jest identyczny dla wszystkich jednostek niezależnie od ich warunków początkowych, konwergencja ma charakter absolutny. Jeżeli badane jednostki dążą do różnych stanów równowagi zależnych od ich wewnętrznych charakterystyk, wyodrębnia się konwergencję warunkową [m.in. Mankiw, Romer i Weil 1992; Barro, Sala-i-Martin 1990]. Sigma konwergencja dotyczy zjawiska zmniejszającego się zróżnicowania badanych jednostek przestrzennych w odniesieniu do określonej zmiennej ekonomicznej. W ramach gamma konwergencji następuje zmiana pozycji badanych jednostek w rankingu uwzględniającym określoną zmienną.

W literaturze przedmiotu wyodrębniona została również koncepcja konwergencji klubowej, zgodnie z którą zmienne ekonomiczne w gospodarkach (regionach) o podobnych charakterystykach zbliżają się do siebie w długim okresie przy założeniu, że ich warunki początkowe są podobne.

Badania poświęcone konwergencji i dywergencji obejmują różne obszary. Jednym $\mathrm{z}$ nich jest sfera mieszkaniowa. $\mathrm{Z}$ pewnością należy ona do jednego $\mathrm{z}$ najważniejszych obszarów, na których rozbieżności społeczne i ekonomiczne nie są aprobowane. Na rynku tym występują dobra podstawowe dla człowieka, pożądane przez wszystkich uczestników rynku. Sfera mieszkaniowa odgrywa ogromną rolę nie tylko $\mathrm{w}$ wymiarze indywidualnym, zaspokajając podstawowe potrzeby człowieka, ale również $\mathrm{w}$ wymiarze wspólnotowym, dając podstawę dla powstania więzi społecznych w wymiarze materialnym, gdyż aktywa mieszkaniowe stanowią jeden z podstawowych składników majątku rodzinnego, wspólnotowego i państwowego, oraz w wymiarze gospodarczym - sektor mieszkaniowy jest jedną z najważniejszych składowych systemu gospodarczego, kreuje miejsca pracy, tworzy infrastrukturę techniczną i podstawę dla infrastruktury społecznej. Rynek nieruchomości generuje nie tylko popyt na mieszkania, ale wywołuje efekt popytowy także na innych rynkach, gdyż jest silnie powiązany z rynkami komplementarnymi, takimi jak rynek materiałów budowlanych i terenów budowlanych, 
powiązany z rynkami kredytowymi, w tym kredytów budowlanych i mieszkaniowych, i wreszcie z rynkami artykułów wyposażenia wnętrz [Nykiel 2009, s. 8-10]. Ze względu na istotny udział nieruchomości mieszkaniowych w majątku gospodarstw domowych (ok. 40-80\%) rynek ten, poprzez efekt majątkowy, wpływa na decyzje gospodarstw domowych dotyczące poziomu konsumpcji [Żelazowski 2009]. Ponadto nieruchomości pełnią istotne funkcje fiskalne, stanowiąc źródło dochodów dla budżetów lokalnych.

Przestrzenne zróżnicowanie rynków mieszkaniowych było przedmiotem badań od wielu dziesięcioleci. Proces integracji gospodarek europejskich wzmocnił zainteresowanie zróżnicowaniem rynków mieszkaniowych i dążeniem do ich ujednolicenia. Wpłynęło to na zmianę podejścia do badania krajowych i regionalnych rynków nieruchomości: odejście od prostych analiz porównawczych, od konfrontacji instytucji i zjawisk występujących w różnych państwach bez rozwiniętych podstaw teoretycznych, co było typowe dla tzw. nurtu historycznego, poprzez badanie podobieństw (element konwergencji) między poszczególnymi systemami zaspokajania potrzeb mieszkaniowych ze względu na tożsamość sił oddziałujących w kierunku ujednolicania rynków krajowych (nurt podejścia uniwersalistycznego), do stworzenia typologii rynków mieszkaniowych [Kemeny, Lowe 1998]. Ta ostatnia koncepcja poszukuje wspólnych wzorców rozwoju i typów rynków mieszkaniowych, wskazuje czynniki kształtujące oraz podtrzymujące istnienie danego wzorca.

Z punktu widzenia tematyki niniejszej pracy interesującym jest, że podejście uniwersalistyczne typologii rynków nieruchomości zastosowane zostało do badań rynków mieszkaniowych w państwach postsocjalistycznych, w szczególności w aspekcie stosunku do prawa własności [Mandric, Clapham 1996]. Transformacja ustrojowa spowodowała, iż pojawiła się niezwykła możliwość przetestowania teorii w praktyce. Oczekiwano, iż zgodnie z podejściem uniwersalistycznym wspólna przeszłość krajów post-socjalistycznych zaowocuje wspólnymi instytucjami, mechanizmami i procesami w przyszłości w ramach upodabniania się do rynków państw zachodnich [Clapham 1995]. Proces masowej prywatyzacji był wskazywany jako podstawowy etap przejścia $z$ gospodarki planowej do gospodarki wolnorynkowej. Z perspektywy 25 lat można jednak stwierdzić, że w państwach postsocjalistycznych drogi rozwojowe rynków mieszkaniowych oraz ich stan obecny różnią się. Bardzo cenne $z$ badawczego punktu widzenia jest więc włączenie ich do istniejącej typologii zachodnich rynków mieszkaniowych.

Dotychczasowe badania konwergencji na obszarze rynków mieszkaniowych dotyczyły przede wszystkim konwergencji cenowej. Były próbą odpowiedzi na pytanie, czy ceny mieszkań na szczeblu regionalnym lub w ujęciu międzynarodowym wykazują tendencję do osiągania stabilnych stanów równowagi. Obok konwergencji cenowej w literaturze poświęconej problematyce funkcjonowania rynków mieszkaniowych zainicjonowane zostały badania dotyczące realnej konwergencji systemów mieszkaniowych. W kontekście integrujących się gospodarek 
europejskich istotne stało się pytanie dotyczące kierunku zmian strukturalnych w obszarze mieszkalnictwa. Prowadzone badania dotyczyły m.in. oceny zakresu i dynamiki procesów konwergencji w obszarze struktury własnościowej rynków mieszkaniowych, systemów ich finansowania, ze szczególnym uwzględnieniem kredytowania hipotecznego, a także instytucjonalnego otoczenia rynków mieszkaniowych [Żelazowski 2018]. Badania miały jednak charakter wycinkowy i często niepozwalający na wysunięcie konstruktywnych wniosków.

Bazując na trzecim podejściu badawczym (typologii rynków mieszkaniowych), Autorzy postawili sobie za cel główny ocenę przebiegu procesów konwergencji na europejskich rynkach mieszkaniowych i identyfikację skutków tejże konwergencji. Badania wykroczyły poza tradycyjnie analizowaną konwergencję nominalną, stanowiąc również próbę oceny przebiegu realnej konwergencji systemów mieszkaniowych.

Do celów pośrednich umożliwiających realizację celu głównego należą:

1. Ocena zakresu konwergencji rynków mieszkaniowych;

2. Ocena dynamiki procesów konwergencji rynków mieszkaniowych;

3. Identyfikacja przyczyn procesów konwergencji rynków mieszkaniowych;

4. Ocena zgodności procesów konwergencji rynków nieruchomości mieszkaniowych z procesami konwergencji gospodarek europejskich.

Poszukiwanie odpowiedzi na pytanie o kierunek i źródła zmian zachodzących na europejskich rynkach mieszkaniowych zostało poparte analizą:

1. Czynników wewnętrznych o charakterze regionalnym i krajowym, związanych przede wszystkim $\mathrm{z}$ historycznymi uwarunkowaniami funkcjonowania rynków mieszkaniowych, priorytetami polityki mieszkaniowej, potencjałem gospodarczym i atrakcyjnością inwestycyjną regionu oraz kraju;

2. Czynników zewnętrznych, obejmujących procesy społeczno-gospodarcze w skali międzynarodowej. Ich źródłem jest postępująca integracja gospodarek europejskich i towarzysząca jej swoboda przepływu kapitału, migracja zasobów ludzkich, ujednolicanie wzorców kulturowych i stylu życia (proces kalifornizacji potrzeb).

Dotychczasowy dorobek naukowy dotyczący uwarunkowań rozwoju rynków nieruchomości mieszkaniowych, czynników determinujących ich ewolucję, a także dorobek z zakresu konwergencji stanowiły podstawę postawienia czterech hipotez badawczych: (H1) rynki mieszkaniowe w krajach europejskich podlegają procesom konwergencji, (H2) procesy konwergencji na rynkach mieszkaniowych determinowane są uwarunkowaniami zewnętrznymi i wewnętrznymi, (H3) konwergencja mieszkaniowa jest przestrzennie niejednolita i przyjmuje charakter konwergencji klubowej, (H4) długoterminowym następstwem konwergencji nie jest ujednolicenie systemów mieszkaniowych, lecz zmniejszenie różnic w poziomie ich rozwoju (ich harmonizacja).

Realizacja celu głównego i celów pośrednich przedstawiona została sekwencyjnie w siedmiu rozdziałach, które tworzą wyraźnie wyróżniające się trzy części pracy: 
- Część I pracy, zatytułowana Procesy rozwojowe rynków nieruchomości mieszkaniowych podejmuje rozważania teoretyczne dotyczące rynku nieruchomości mieszkaniowych jako części systemu mieszkaniowego (rozdział I), ewolucji europejskich systemów mieszkaniowych w okresie powojennym (rozdział II), co zostało uszczegółowione w rozdziale III poświęconym ewolucji rynków nieruchomości mieszkaniowych w wybranych krajach UE. Pierwsza część pracy stanowi istotne wprowadzenie do dalszych rozważań: przedstawia mieszkalnictwo w ujęciu systemowym, specyfikę rynków nieruchomości mieszkaniowych, społeczne i ekonomiczne znaczenie rynku mieszkaniowego, kształtowanie się różnych modeli polityki mieszkaniowej ze wskazaniem politycznych, społecznych i gospodarczych ich uwarunkowań.

- Część II Konwergencja rynków nieruchomości mieszkaniowych w państwach Unii Europejskiej ma dominujące znaczenie z punktu widzenia celu pracy i stawianych hipotez badawczych: wyjaśnia zjawisko konwergencji gospodarczej, przedstawiając metody jej pomiaru (rozdział IV), prezentuje przegląd literatury poświęconej dotychczas podejmowanym badaniom nad przebiegiem konwergencji na rynkach nieruchomości mieszkaniowych, podejmuje autorską próbę weryfikacji konwergencji cenowej i pozacenowej rynków mieszkaniowych w dwóch ujęciach: ujęciu międzynarodowym i regionalnym (rozdział V).

- Część III, poświęcona Ocenie przebiegu konwergencji mieszkaniowej i jej efektów, pozwoliła, na tle przytoczonych badań literaturowych, a także badań własnych, dokonać oceny konwergencji europejskich rynków mieszkaniowych w odniesieniu do konwergencji gospodarczej. W szóstym rozdziale podjęta została dyskusja nad wzajemnymi relacjami konwergencji gospodarczej krajów członkowskich UE oraz konwergencji ich rynków mieszkaniowych. Zaprezentowane zostały wyniki badań dotyczące zasięgu i tempa konwergencji gospodarczej krajów UE, a w ich świetle zweryfikowano, czy i w jakim stopniu konwergencja rynków mieszkaniowych stanowi konsekwencję postępującej integracji członków wspólnoty europejskiej. Rozdział siódmy, istotny z punktu widzenia realizacji celu pracy i weryfikacji postawionych hipotez, przedstawia kierunki zmian na rynkach nieruchomości mieszkaniowych, podlegających zjawisku konwergencji: zmian w obszarze polityki mieszkaniowej, kształtowania się cen, a także sytuacji mieszkaniowej. Analiza prowadzona jest w dwóch wymiarach: w wymiarze międzynarodowym i regionalnym. Elementem tego rozdziału jest podjęcie próby oceny kształtowania się procesów konwergencji w przyszłości.

W zakończeniu zawarto podstawowe wnioski wynikające z rozważań teoretycznych, a także przeprowadzonych badań.

Na potrzeby przygotowania niniejszego opracowania zastosowano różnorodne metody badawcze, służące zarówno gromadzeniu, jak i analizie danych: (1) metodę analizy literatury przedmiotu, (2) metodę analizy porównawczej, (3) metodę analizy aktów prawnych, (4) metody statystyczne i (5) metody ekonometryczne. 
14 Wstęp

Książka, koncentrująca się na procesach konwergencji rynków mieszkaniowych, stanowi efekt realizacji grantu finansowanego przez Narodowe Centrum Nauki (Nr UMO-2016/21/B/HS4/00750). Zaadresowana jest do szerokiego odbiorcy: do osób zajmujących się teorią wzrostu gospodarczego, osób zajmujących się zawodowo problematyką funkcjonowania rynków nieruchomości, a zwłaszcza do studentów kierunków, które włączyły problematykę nieruchomościową do programów nauczania. 


\section{Część 1 \\ Procesy rozwojowe rynków nieruchomości mieszkaniowych}





\section{Rozdział 1}

\section{Rynek nieruchomości mieszkaniowych jako część systemu mieszkaniowego - podstawy teoretyczne}

\subsection{Mieszkalnictwo $w$ ujęciu systemowym}

System mieszkaniowy to złożony organizm, który przekształca się w odpowiedzi na zmiany polityczne, instytucjonalne i kulturowe. Sam także wpływa na społeczeństwo i gospodarkę. Wyjaśnienia pojęcia systemu mieszkaniowego, które można prześledzić od lat 80., są pośrednim wskaźnikiem zachodzących zmian społeczno-gospodarczych. W 1981 r. wskazywano, że system mieszkaniowy to wzajemne relacje pomiędzy głównymi uczestnikami, rynkiem mieszkaniowym i kontekstem polityczno-instytucjonalnym [Bourne 1981]. Za podstawowych aktorów systemu uważano właścicieli nieruchomości, kredytodawców, spekulantów, firmy budowlane, pośredników, planistów, polityków i konsumentów. Wskazywano, że współdziałają oni przy transakcjach prawami do nieruchomości w określonych uwarunkowaniach, do których zaliczano system prawny, rozwarstwienie społeczne, prawa do nieruchomości, system finansowy, regulacje prawne odnoszące się do gruntu, budynków i infrastruktury oraz politykę rządu. Wskazywano, że w efekcie zachodzących oddziaływań następuje określone rozmieszczenie w przestrzeni zasobów mieszkaniowych, identyfikowane poprzez m.in. obowiązujące wzorce zaspokajania potrzeb mieszkaniowych, zmiany sposobu użytkowania gruntu, ceny mieszkań i zmiany wymagań jakościowych [Bourne 1981].

Kolejni autorzy modyfikowali ten schemat, m.in. podkreślając wagę kontekstu politycznego i instytucjonalnego wpływającego na relacje i oddziaływania pomiędzy uczestnikami systemu. Ten kontekst analizowano dokładniej, badając uwarunkowania gospodarcze, demograficzne, polityczne i przestrzenne określające procesy produkcji, konsumpcji mieszkaniowej i regulacje dotyczące mieszkalnictwa [Priemus 1983]. Kolejna modyfikacja definicji systemu mieszkaniowego 
została dokonana poprzez wyodrębnienie wzajemnych relacji i oddziaływań struktury rynku mieszkaniowego (jako struktury instytucjonalnej), uczestników systemu i polityki mieszkaniowej, będących pod wpływem czynników zewnętrznych [Boelhouwer, Van der Heijden 1992]. Te relacje i oddziaływania kształtują rynek mieszkaniowy, wpływając na jego wielkość, aktywność budowlaną, dystrybucję zasobu pomiędzy gospodarstwa domowe i relację wydatków mieszkaniowych do dochodów.

Kolejni badacze widzieli system mieszkaniowy jako zestaw zorganizowanych części, które oddziałują na siebie w czasie i przestrzeni [Bekebrede, Mayer 2006]. Szczegółowo wyodrębniano popyt (reprezentowany przez gospodarstwa domowe i ich preferencje), podaż (reprezentowaną przez firmy budowlane, deweloperów, właścicieli nieruchomości z pomocniczą rolą pośredników) i instytucje (normy formalne i nieformalne) decydujące o tym, jak system funkcjonuje [Van der Heijden $i$ in. 2011].

Zakorzenienie systemu mieszkaniowego $\mathrm{w}$ unikalnym systemie społeczno-gospodarczym konkretnego państwa oznacza obustronne oddziaływania pomiędzy nimi i powstanie unikalnych uwarunkowań i rozwiązań. Należy w tym miejscu podkreślić wagę historycznej ścieżki rozwoju (path dependence), z której bardzo trudno jest zejść [David 1985; Arthur 1989, 1990]. Centralną kwestią jest proces zamknięcia na nowe rozwiązania - „zakleszczenie się”, które wyklucza lub bardzo utrudnia stosowanie nowych rozwiązań, wprowadzanie nowych produktów, tworzenie zupełnie nowych instytucji. Wśród wielu nurtów badania wpływu path dependence na szczególne wyróżnienie zasługuje stanowisko Northa. Stwierdził on mianowicie, iż to nie zdarzenie historyczne z przeszłości ma charakter sprawczy, a proces instytucjonalizacji [North 1990, 1994]. Ograniczona racjonalność, wysokie koszty transakcyjne tworzą bariery dla zmiany instytucjonalnej. Zmiana ta może mieć miejsce dopiero wtedy, gdy zostaną poniesione wysokie koszty transakcyjne. North dostrzegł ruch instytucji, ciągłość procesu zmian i wskazał podmioty sprawcze - podmioty walczące o własny interes oraz organizacje, które konkurują między sobą. Według niego zakres zachodzących zmian jest ograniczany doświadczeniami podmiotów, a przeszłość kształtuje aktualne „modele mentalne”. Takie podejście zakładało historyczną kontynuację instytucji.

$\mathrm{W}$ odniesieniu do systemu mieszkaniowego szczególnego znaczenia nabiera w tym kontekście polityka mieszkaniowa [Kleinman 1996]. Uważa się, że jest ona bardziej podatna na oddziaływanie path dependence niż inne sfery życia społeczno-politycznego [Bengtsson, Ruonavaara 2010]. Wynika to z pewnych specyficznych cech, utrudniających szybkie zmiany. Należą do nich: związanie z jednym miejscem zasobu mieszkaniowego (zakotwiczenie w przestrzeni), trwałość jego struktury jakościowej i ilościowej, emocjonalny stosunek użytkowników, ich przywiązanie do konkretnych lokalizacji, interwencja publiczna jako czynnik korygujący nieprawidłowości rynku w obliczu konieczności akceptacji nowych reguł gry przez konsumentów i producentów przestrzeni mieszkaniowej. Śledzenie zmian 
polityki mieszkaniowej na poziomie konkretnych państw umożliwia odpowiedź na pytanie o istnienie i oddziaływanie path dependence. Rolę path dependence potwierdzają studia, które były przeprowadzone m.in. w odniesieniu do państw skandynawskich [Bengtsson i in. 2006] czy Wielkiej Brytanii [Malpass 2011].

\subsection{Rynek mieszkaniowy i determinanty jego rozwoju}

Zasadniczym elementem każdego systemu mieszkaniowego w gospodarce rynkowej jest rynek mieszkaniowy. Powstaje pytanie, czym on jest i jakie czynniki warunkują jego funkcjonowanie i rozwój. W literaturze występuje szereg koncepcji i definicji podkreślających wagę różnych aspektów rynku mieszkaniowego, wiele jest badań i analiz konkretnych procesów i mechanizmów, ale trudność sprawia sformułowanie spójnej i kompleksowej definicji podstawowego elementu, czyli właśnie rynku mieszkaniowego. W ujęciu neoklasycznym w definicji rynku podkreśla się wagę równowagi rynkowej, szczególne cechy rynku mieszkaniowego nie są brane pod uwagę, dopasowuje się ten rynek do sztywnych założeń teoretycznych, co uniemożliwia pogłębione analizy, a wyciągane wnioski niekoniecznie mają realne podstawy. Może to prowadzić do podejmowania nieodpowiednich decyzji politycznych, nieodpowiednich, ponieważ wywołujących skutki rozbieżne z założonymi i oczekiwanymi [Maclennon 2012]. Wydaje się, że połączenie elementów psychologii ekonomicznej, ekonomii politycznej pozwoliłoby na wzięcie pod uwagę aspektów pomijanych w ujęciu makro i analizowanie wielowymiarowości rynku mieszkaniowego.

Aby zrozumieć odrębność rynku mieszkaniowego, trzeba przyjrzeć się samym nieruchomościom. Mają one wiele charakterystycznych atrybutów. Ich wartość jest odbiciem nie tylko lokalizacji czy sąsiedztwa, ale także uwarunkowań ekonomiczno-finansowych, demograficznych, a nawet politycznych. Niejednorodność nieruchomości spotyka się ze zróżnicowaniem samych konsumentów, oni także są odmienni pod względem preferencji, zamożności, wieku, różne grupy dokonują własnych, odrębnych wyborów. Związanie z jednym miejscem nieruchomości, jej trwałość, a jednocześnie wysoka kapitałochłonność oznaczają, że wybór obarczony jest wieloma źródłami ryzyka. Gospodarstwa domowe są ze sobą sąsiedzko i społecznie powiązane, mają określone oczekiwania i preferencje, mogą generować silne trendy na rynku lokalnym ${ }^{1}$. Rzadkość transakcji na rynku

1 Te trendy mogą być zarówno pozytywne, jak i negatywne, np. po kryzysie finansowym silnie wystąpił problem tzw. zombie buildings. 
nieruchomości oznacza konieczność zmniejszenia ryzyka poprzez skorzystanie z profesjonalnych usług pośrednictwa.

Rynek jest pewnym aparatem instytucjonalnym, który służy wymianie. Jest złożony z mechanizmów, układów i relacji, które umożliwiają i ułatwiają przepływ informacji między potencjalnymi stronami transakcji. W zasadzie obecne negocjacje między stronami nie wymagają ich osobistego kontaktu, podobnie przepływ praw i pieniędzy. Jednakże nieruchomość jest dobrem szczególnym - przedmiotem transakcji są prawa, może ich być wiele w stosunku do tej samej nieruchomości, niezbędne jest zrozumienie istoty nabywanych praw (nie ma tu pełnej standaryzacji, w poszczególnych państwach występują unikalne prawa oraz rozmaite ograniczenia). Ponadto nieruchomość jest związana z konkretnym miejscem w przestrzeni i przez to niepowtarzalna. Potencjalny uczestnik transakcji musi więc zaangażować znacznie więcej swojego czasu i środków w porównaniu z transakcją standardowym dobrem, aby nie popełnić błędu w wyborze dobra i negocjacji ceny. Na każdym rynku podstawą jego prawidłowego funkcjonowania jest przepływ informacji, im jest ona pełniejsza i powszechnie dostępna, tym rynek jest bardziej transparenty i ma większe możliwości rozwoju dzięki niższym kosztom transakcyjnym. Na rynku nieruchomości nie ma przejrzystości i równości w dostępie do informacji, korzystanie $\mathrm{z}$ informacji może być ograniczone poprzez odpłatność za ich uzyskanie ${ }^{2}$ - ponoszenie kosztów transakcyjnych związanych z uzyskaniem informacji może ograniczać liczbę potencjalnych uczestników rynku.

Na rynku nieruchomości działają podmioty, które ułatwiają przepływ informacji oraz mogą służyć jako ich weryfikatorzy - typowo należą do nich pośrednicy w obrocie, a w digitalizującym się świecie ich usługi są uzupełniane cyfrowymi zbiorami danych przestrzennych, podatkowych i technicznych. Prawidłowe i pełne odczytanie informacji wymaga jednak często specjalistycznej wiedzy, więc pojawienie się nowych źródeł informacji nie oznacza automatycznego wypierania usług świadczonych przez pośredników, ekspertów, doradców. Ponadto, transakcje na rynku realizowane są przez poszczególnych uczestników stosunkowo rzadko, oznacza to, że brak im możliwości odwołania się do przeszłych doświadczeń, zapoznania się z mechanizmami specyficznymi dla danego rynku, a nawet mogą odczuwać oni trudność w określeniu tego, co preferują, a co można nabyć na konkretnym rynku lub za jaką cenę można sprzedać. Podtrzymuje to rolę instytucji świadczących usługi pośrednictwa i doradztwa.

Poza instytucjami, które warunkują bezpieczeństwo i dostęp do informacji o mechanizmach rynku, na kształt i rozmiar rynku wpływają zachowania jego uczestników będące wynikiem oddziaływania norm formalnych i nieformalnych - zwyczajów. Mogą się one znacząco różnić na poziomie lokalnym czy krajowym, a brak wiedzy o nich i świadomości ich oddziaływania może znacząco podwyższać

2 Dlatego tak istotne jest zapewnienie przez podmioty publiczne powszechnego dostępu do podstawowych danych o stanie prawnym nieruchomości. 
koszty transakcyjne i utrudniać wymianę na rynku³. Odmienności w zakresie istnienia i działania instytucji, norm formalnych i nieformalnych multiplikują rynek i wpływają na cenę równowagi.

Definiując rynek mieszkaniowy, należy odnieść się bezpośrednio do jego przedmiotu wyrażonego wprost jako mieszkanie rozumiane szeroko. Jest to pewien skrót myślowy, ponieważ jak już wcześniej wspomniano, przedmiotem obrotu i zawieranych umów są prawa do mieszkania. Podstawowe i najpełniejsze, aczkolwiek nie absolutne prawo to prawo własności, poza nim, w zależności od rozwiązań przyjętych w danym porządku prawnym, możliwe są prawa zbliżone do własności (w Polsce np. własnościowe spółdzielcze prawo do lokalu). Uprawnienie do korzystania z mieszkania może też wynikać z prawa najmu, w odniesieniu do usługi mieszkaniowej prawo takie często zapewnia szczególną ochronę najemcy w jego relacji prawnej z właścicielem. Jednostka mieszkalna jako centralny element rynku mieszkaniowego może być różnie rozumiana ${ }^{4}$.

Zaspokajanie potrzeb mieszkaniowych ma znaczenie nie tylko społeczne, gospodarcze, polityczne, ale także kulturowe. Jest ono niezbędne dla dobrostanu człowieka, a jednocześnie ukorzenione w kulturze, relacjach społecznych [Mallett 2004]. Pozostając przy uwarunkowaniach ekonomicznych, można powiedzieć, że jednostka mieszkalna to pewna konstrukcja techniczna, która powstaje na gruncie przy wykorzystaniu kapitału i pracy. Obiekt ten ma charakter trwały, jest związany z konkretnym miejscem i jego otoczeniem, co powoduje jego unikalny charakter. Struktura i procesy rynkowe są kształtowane wieloma czynnikami, należą do nich m.in. rozwiązania architektoniczno-urbanistyczne i technologiczne zastosowane przy konkretnej nieruchomości, lokalizacja ekonomiczna (czyli dostępność usług, dróg, środków komunikacji publicznej), co oddziałuje na możliwość podjęcia

3 Można tu wspomnieć o takich kwestiach jak podpisywanie lub nie umów przedwstępnych, korzystanie lub nie z usług rzeczoznawców budowlanych do oceny stanu technicznego, ponoszenie opłaty za usługi pośrednictwa czy wysokość różnicy między ceną ofertową a transakcyjną.

4 W Polsce definicja prawna mieszkania zawarta jest m.in. w Rozporządzeniu Ministra Infrastruktury z 12.04.2002 r. w sprawie warunków technicznych, jakim powinny odpowiadać budynki i ich usytuowanie, Dz.U. z 2019 r., poz. 1065. Mieszkanie wg definicji to zespół pomieszczeń mieszkalnych i pomocniczych, mający odrębne wejście, wydzielony stałymi przegrodami budowlanymi, umożliwiający stały pobyt ludzi i prowadzenie samodzielnego gospodarstwa domowego; budynek mieszkalny to a) budynek mieszkalny wielorodzinny, b) budynek mieszkalny jednorodzinny. Definicja przyjęta przez GUS oparta jest na ustawie z dnia 2 grudnia 1999 r. o narodowym spisie powszechnym ludności i mieszkań w 2002 r., Dz.U z 2000 r., nr 1, poz.1 z późn. zm. oraz ustawie 24 czerwca 1994 r. o własności lokali, Dz.U. z 2019 r., poz. 737. Ta definicja stanowi, że mieszkanie to lokal składający się z jednej lub kilku izb i pomieszczeń pomocniczych, przeznaczony na stały pobyt osób - wybudowany lub przebudowany do celów mieszkalnych; konstrukcyjnie wydzielony trwałymi ścianami w obrębie budynku, do którego to lokalu prowadzi niezależne wejście z klatki schodowej, ogólnego korytarza, wspólnej sieni bądź z ulicy, podwórza lub ogrodu. 
pracy, założenia rodziny i codzienne funkcjonowanie. Koszt usługi mieszkaniowej wpływa na dobrostan gospodarstwa domowego, ponieważ jest znaczącym składnikiem kosztów w jego budżecie 5 . Wybór zarówno sposobu zaspokojenia potrzeby mieszkaniowej (zakup własności czy korzystanie z najmu), jak i konkretnego obiektu wymaga dużego wysiłku, a popełnione błędy są trudne do usunięcia i bardzo kosztowne. Gospodarstwo domowe jest narażone na ryzyko negatywnej selekcji (adverse selection) i pokusy nadużycia (moral hazard), co wynika z m.in. z braku doświadczenia $\mathrm{w}$ dokonywaniu takich wyborów, asymetrii informacji między zbywcą i nabywcą. W tych warunkach uzyskanie pogłębionej informacji o cenach wymaga skorzystania z usług eksperta [Quigley 1999]. Poziom rozwoju instytucjonalnego w kontekście rozbudowanych usług ekspercko-doradczych, także niezbędna konkurencja między podmiotami świadczącymi takie usługi wpływają na sposób podejmowania decyzji oraz ich adekwatność w stosunku do potrzeb. Należy tu także zauważyć, że można wyraźnie wskazać dwie grupy nabywców o odmiennych celach - właścicieli użytkowników i właścicieli czerpiących zyski z najmu. Dla tej pierwszej grupy osobisty kontakt z nieruchomością jest w zasadzie niezbędny, ponieważ mają oni swoje preferencje i pragnienia, które będą chcieli zrealizować. Natomiast dla inwestorów w mieszkania na wynajem nie mają znaczenia osobiste preferencje, mogą oni dokonać wyboru na podstawie wirtualnej wizyty i opisu dokonanego przez eksperta, jeżeli obiekt spełnia ich założenia inwestycyjne.

Wybierając konkretne mieszkanie lub dom, wybiera się określoną przestrzeń, liczba ofert jest ograniczona, nie ma jednego rynku, na którym uwidocznione są wszystkie istniejące w danej chwili propozycje, istnieje wiele subrynków z własnymi cenami. Ważnym czynnikiem dla zrozumienia źródeł ryzyka związanych z wyborem nieruchomości jest to, że o ile sama nieruchomość jest związana z jednym miejscem, to jej otoczenie może się zmieniać niezależnie, a czasem wbrew woli jej właściciela. Wobec tego wzrost lub spadek wartości nieruchomości może pozostawać poza sferą kontroli właściciela. Nabywca musi wobec tego ustalić wszystkie potencjalne źródła ryzyka, może tego dokonać samodzielnie lub z pomocą profesjonalisty ${ }^{6}$.

5 Koszt usługi mieszkaniowej jest tu rozumiany szeroko, to nie tylko czynsz najmu, to także koszt kredytu mieszkaniowego, koszty utrzymywania odpowiedniego stanu technicznego lokalu.

6 Można tu wskazać, że zgodnie ze wzorcem prospektu deweloperskiego deweloper ma obowiązek wskazać informacje zawarte w publicznie dostępnych dokumentach dotyczących przewidzianych inwestycji w promieniu $1 \mathrm{~km}$ od przedmiotowej nieruchomości, w szczególności o budowie lub rozbudowie dróg, budowie linii szynowych oraz przewidzianych korytarzach powietrznych, a także znanych innych inwestycjach komunalnych, w szczególności oczyszczalniach ścieków, spalarniach śmieci, wysypiskach, cmentarzach - ustawa z dnia 16 września 2011 r. o ochronie praw nabywcy lokalu mieszkalnego lub domu jednorodzinnego, Dz.U. z 2017 r., poz. 1468 z późn. zm. 
Oczekiwania co do cen i ich zmian oraz lokalizacji wpływają silnie na funkcjonowanie rynku, ponadto istotne są czynniki kulturowe, ponieważ wybór miejsca zamieszkania to niejednokrotnie manifest przyjętego stylu życia, statusu społecznego, próba budowy prestiżu. Zgodnie z badaniami [Owczarek 2011; Mantey 2017] gospodarstwa domowe wybierają miejsca zamieszkania wśród podobnych do siebie, stosujących te same zasady i uznających podobne wartości. Zmiana - postępujące osiedlanie nowych „innych” może skutkować odwrotem grupy „starych” mieszkańców. Popyt może się więc nagle zmienić pod wpływem czynników kulturowych.

Strona podażowa rynku mieszkaniowego charakteryzuje się powolną odpowiedzią na zgłaszany popyt, jak wskazuje się w literaturze, wynika to z długotrwałości procesu budowy, a w szczególności wstępnej fazy, związanej z dostosowaniem się do obowiązującego systemu planistycznego [Glaeser i in. 2008; Grimes, Aitken 2010]. Niektórzy uważają, że dokonuje się zbyt dużych uproszczeń w ramach analiz ekonomiki budownictwa [Ball, Wood 1996; Ball 2003]. Sektor budowlany jest bardzo zróżnicowany, rozdrobniony, zyski są nierównomiernie rozłożone w czasie, często wynikają nie z samej budowy, a ze wzrostu wartości gruntów utrzymywanych w bankach ziemi. Koszty prac budowlanych i popyt mogą się dynamicznie zmieniać i trudno przewidzieć natężenie tych zmian. Ponadto, przedsiębiorstwa konkurują ze sobą.

Aby rynek sprawnie działał, potrzebne są aktualne i wiarygodne informacje. To jeden z podstawowych problemów rynku mieszkaniowego, jeśli bowiem informacje są dostępne, to najczęściej są opóźnione. Poza tym pewne subrynki są bardziej widoczne - informacje, które ich dotyczą, są rozpowszechniane, wywołują więc wrażenie, że wskazywane zjawiska, fluktuacje cen, dynamika zmian są powszechne, co nie jest prawdą. Dostosowywanie się subrynków do zmian wymaga czasu, zmierzają one do równowagi, ale to proces rozciągnięty w czasie.

W warunkach gospodarki rynkowej funkcjonowanie rynku mieszkaniowego, jego skuteczność w alokacji istniejących zasobów mieszkaniowych, możliwości kreowania nowej podaży adekwatnej w ujęciu ilościowym i jakościowym do zgłaszanego zapotrzebowania stanowią wypadkową oddziaływania czynników ekonomicznych i pozaekonomicznych, które najprościej można podzielić na czynniki o znaczeniu ogólnokrajowym oraz determinanty o znaczeniu/zasięgu lokalnym. Wśród czynników o charakterze ogólnokrajowym należy wymienić:

- wzrost gospodarczy, jego dynamikę oraz perspektywy jego zmian,

- realizowaną przez bank centralny politykę monetarną i związany z nią poziom stóp procentowych,

- stopień rozwoju krajowego rynku kapitałowego,

- programy mieszkaniowe realizowane przez centralne organy państwowe,

- inwestycje finansowane z budżetu państwa.

Ich cechą wspólną jest kształtowanie ram funkcjonowania i potencjału rozwojowego rynku mieszkaniowego w ujęciu makroekonomicznym [Andrew 2003; 
Leung 2004]. Analiza lokalnych rynków wymaga jednak poszerzenia tego zbioru o dodatkowe informacje, takie jak:

- istniejące lokalne zasoby mieszkaniowe;

- czynniki demograficzne, np.: liczba ludności, struktura wiekowa i płciowa lokalnych społeczności;

- zamożność gospodarstw domowych, w tym dochody płacowe i pozapłacowe;

- poziom bezrobocia, aktywność ekonomiczna ludności w wieku produkcyjnym;

- ceny oraz dostępność gruntów przeznaczonych pod inwestycje mieszkaniowe;

- rozwój lokalnych rynków budowlanych.

Są to fundamentalne czynniki, warunkujące przestrzenne zróżnicowanie rozwoju lokalnych rynków nieruchomości i poziomu zaspokojenia potrzeb mieszkaniowych. Rynek mieszkaniowy charakteryzuje się nie tylko silnym uzależnieniem od polityki państwa sterowanej wzajemnymi relacjami między państwem a jego obywatelami tworzącymi gospodarstwa domowe, ale jego stan i poziom rozwoju zależy również od rozwoju instytucji finansowych, stanu sektora budowlanego i struktury własnościowej. Model dostarczania zasobu mieszkaniowego zakłada ważną rolę komercyjnych deweloperów, których działania są uzależnione od cyrkulacji kapitału (dostępnych źródeł kapitału), dostępności gruntów i przewidywanych kosztów w sektorze budowlanym.

Popyt jest wynikiem oddziaływania czynników zarówno ekonomicznych, jak i demograficzno-społecznych. Wzrost dochodów oraz obniżenie kosztów finansowania są najważniejszymi warunkami gospodarczymi, wpływającymi na podwyższenie popytu. W długim czasie obniżenie kosztów finansowania zachęca do inwestycji na rynku mieszkaniowym. Należy zauważyć, że rynek wpływa na alokację mieszkań według istniejącego rozkładu dochodów. Dla mniej zasobnych gospodarstw domowych dostępne są mieszkania o niższym standardzie. W długim okresie wzrost dochodu i powiększenie zasobu mieszkaniowego powinny umożliwić nabywanie mieszkań o wyższym standardzie, ponieważ ich właściciele także starają się poprawić swoje warunki mieszkaniowe.

Jakkolwiek nowa podaż nie ma bezpośredniego wpływu na poziom cen, to w dłuższej perspektywie wpływa na rynek, równoważąc (lub doprowadzając do poziomu bliskiego równowagi) stronę popytową. Wpływ na stan rynku ma nie tylko wzajemna relacja popytu i podaży, ale również oczekiwania właścicieli lub potencjalnych inwestorów co do dalszego ruchu cen. Te oczekiwania są również pochodną braku odpowiedzi strony podażowej.

Niedostateczna podaż przyczynia się do wzrostu cen, co z jednej strony oznacza poczucie wzrostu zamożności gospodarstw domowych posiadających mieszkania i wzrost ich wydatków konsumpcyjnych (efekt majątkowy) [Case, Quigley, Shiller 2005; Shiller 2006], z drugiej strony jednak wpływa na zwiększenie kosztów życia tych, którzy nie są właścicielami mieszkań oraz na ograniczenie mobilności poszukujących pracy. Struktura własnościowa zasobu mieszkaniowego ma tu niewątpliwie istotne znaczenie. 


\subsection{Społeczny i ekonomiczny wymiar rynku mieszkaniowego}

Nieruchomości pełnią szczególną funkcję w gospodarce, stanowiąc podstawę zaspokojenia zróżnicowanych potrzeb. Wytwarzanie produkcji i usług wymaga bowiem zasobu nieruchomościowego. Dlatego też problematyka rynku nieruchomości stanowi zarówno ważny element rozważań teoretycznych, jak i badań empirycznych.

Rynek nieruchomości jest niejednolity, można wyróżnić szereg jego segmentów. Jednym z segmentów rynku nieruchomości jest rynek nieruchomości mieszkaniowych. Na rynku tym ujawniają się dwa rodzaje popytu: popyt konsumpcyjny, związany z zaspokajaniem potrzeb mieszkaniowych zaliczanych do podstawowych potrzeb człowieka, i popyt inwestycyjny, kiedy mieszkanie traktowane jest jako dobro kapitałowe. W obu sytuacjach rolą mieszkania jest generowanie strumienia usług mieszkaniowych celem zaspokajania potrzeb mieszkaniowych. Potrzeby mieszkaniowe mogą bowiem być zaspokojone poprzez:

- nabycie na własność mieszkania, co wymaga przeznaczenia na ten cel wieloletnich dochodów rodziny;

- wynajmowanie mieszkania - zaspokajający potrzeby mieszkaniowe występuje w roli najemcy, który za możliwość użytkowania mieszkania płaci czynsz. W warunkach rynkowych jego wysokość powinna uwzględniać: koszt utrzymania mieszkania, zwrot wyłożonego przez właściciela kapitału, dochód na wyłożonym przez właściciela kapitale.

Zaspokajając potrzeby mieszkaniowe, mieszkanie pełni funkcję społeczną [Kucharska-Stasiak 2016a]. W podejściu społecznym uwaga koncentruje się na mieszkaniu rozumianym głównie w sensie techniczno-budowlanym oraz architektoniczno-urbanistycznym [Cesarski 2013a, s. 9]. Wyznacza ono przestrzeń zamieszkaną sensu stricto, stwarza możliwość zaspokajania różnorodnych funkcji, związanych $z$ egzystencją człowieka, takich jak: zaspokajanie podstawowych potrzeb, związanych z ochroną przed wpływem zmiennych warunków otoczenia, zapewnienie możliwości odpoczynku i snu, gotowania, wychowywania potomstwa, umożliwia poprawę jakości życia, zwiększa motywację do działania, umożliwia rozwój intelektualny, zmniejsza frustrację i zwiększa poczucie bezpieczeństwa, staje się wyrazem ambicji i dążeń każdego człowieka, dając mu „możliwość uzewnętrzniania własnego, osobistego stylu życia” [Krakowińska 2007, s. 78].

Oprócz aspektu indywidualnego mieszkania ujawnia się jego aspekt wspólnotowy: jest materialną bazą zaspokajania podstawowych potrzeb społeczno-gospodarczych, związanych z osiadłym charakterem cywilizacji ludzkiej [Cesarski 2017, s. 17], stanowi jedną z niewielu form aktywności społeczno-gospodarczej człowieka zostawiającej trwały ślad kultury materialnej, aktywności stojącej zarazem u jej podłoża [tamże, s. 19]. Mieszkanie jest fundamentem kształtowania życia 
społecznego, tworząc więzi społeczne osób zamieszkałych w sąsiedztwie. Poprzez kształtowanie podstawowych więzi społecznych mieszkanie decyduje o trwałości rodziny, modelu życia, kulturze zamieszkiwania, a także o rozwoju demograficznym. Statystycznie udowodniono, że liczba oddawanych do użytku mieszkań bardzo silnie wpływa na liczbę zawieranych małżeństw i liczbę dzieci przychodzących na świat. Analiza statystyczna, obejmująca lata 1965-2005, potwierdziła, że po uwzględnieniu przesunięcia w czasie współczynnik korelacji (Pearsona) pomiędzy liczbą budowanych mieszkań a liczbą urodzeń wyniósł dla rynku krajowego 0,941 [Raport Polski rynek mieszkaniowy 2006, s. 82].

Mieszkanie zaspokaja coraz bardziej rozbudowane i skomplikowane potrzeby indywidualne, uznane za potrzeby wyższego rzędu przez stworzenie warunków do społecznego i kulturalnego rozwoju jednostki i grup (kultura, oświata, rozrywka), pobudza aktywność zawodową i twórczy stosunek do wykonywanej pracy, wyzwala chęć do podnoszenia kwalifikacji zawodowych, wyzwala zdolność do innowacyjności [Krakowińska 2007, s. 79]. Społeczne funkcje pełnione przez mieszkanie ulegają zmianom, co stanowi efekt zachodzących zmian w modelu życia małżeńsko-rodzinnego i zmian struktury gospodarstw domowych. Upowszechniający się nowoczesny styl życia rodzinnego prowadzi do powstania dwóch sposobów traktowania mieszkania. Jeden, tradycyjny, odwzorowuje mieszkaniowy model życia, mieszkanie stanowi wartość naczelną, w nim koncentruje się życie rodzinne, stanowi przedmiot dumy. Drugi, reprezentujący niemieszkaniowy model życia, traktuje mieszkanie jako środek, narzędzie do zaspokajania podstawowych potrzeb gospodarstwa domowego, jest „[...] swoistym punktem serwisowym, odwiedzanym w razie potrzeby, pozwalającym na realizację wartości wobec niego zewnętrznych, takich jak praca zawodowa, aktywność w życiu publicznym, podróże, spotkania towarzyskie poza nim. Tym razem mieszkanie jest jedynie wartością instrumentalną" [Lipski 2009, s. 25]. Pomimo ewolucji modelu życia siła funkcji społecznej mieszkania nie tylko nie maleje, ale rośnie. Decyduje o tym m.in. powszechność zaspokojenia potrzeb mieszkaniowych.

Szerokie rozumienie mieszkania, wykraczające poza mikroprzestrzeń zamieszkałą sensu stricto, obejmuje również elementy środowiska naturalnego, przetwarzanego przez człowieka [Andrzejewski 1987, s. 16-19], co pozwala dostrzec potencjalność mieszkania wykraczającą poza jego funkcje społeczne [Cesarski 2013b, s. 10].

Mieszkanie zaliczane jest do dóbr wiodących, czyli dóbr o przeznaczeniu konsumpcyjnym, które dynamizują gospodarkę, pobudzając zachowania ludności zarówno na etapie wytwarzania, dystrybucji, jak i konsumpcji, wpływając jednocześnie w największym stopniu na strukturę spożycia przez swoją atrakcyjność dla konsumentów i pobudzanie popytu na inne dobra [Krakowińska 2008, s. 75-82]. Mieszkanie pełni zatem nie tylko funkcje społeczne, ale także ekonomiczne, stanowiąc warunek trwałego rozwoju [Cesarski 2017, s. 11-30]. Mieszkanie jako dobro wiodące wywołuje efekt komplementarny i substytucyjny. Na obszarze efektów 
komplementarnych rodzi ono nowe potrzeby i wydatki związane z jego wykończeniem (pokrycia podłóg, tapety, oświetlenie) i wyposażeniem (meble, sprzęt RTV oraz AGD itp.). W trakcie użytkowania wymaga ponoszenia wydatków na energię elektryczną, cieplną, koszty zarządzania. Ponieważ mieszkanie pochłania znaczną część dochodów, wywiera wpływ na zmiany w strukturze konsumpcji gospodarstw domowych, wywołując efekt substytucyjny. Może przyczynić się do zmniejszenia wydatków na odzież czy spędzanie czasu wolnego. Rozważania nad ekonomiczną funkcją mieszkania, a zatem i rynku nieruchomości mieszkaniowych kierują uwage na materialny i gospodarczy wymiar mieszkania. Bogactwo mieszkaniowe mierzone wartością rynkową zasobu mieszkaniowego stanowi istotny element bogactwa narodowego. Według badań Savills w 2015 r. wartość nieruchomości mieszkaniowych szacowana była na świecie na 162 biliony dolarów, ich wartość przekraczała ponad 5,5-krotnie wartość nieruchomości komercyjnych. Nieruchomości mieszkaniowe stanowiły blisko 75\% wartości światowych nieruchomości i 43,5\% wartości głównych aktywów światowych [Savills 2016]. Szacowana wartość majątku nieruchomości mieszkaniowych w Polsce na koniec 2017 r. wynosiła 3,25 bln zł wobec 3,15 bln w 2016 r., podczas gdy wartość nieruchomości komercyjnych to około 0,25 bln zł, czyli ponad 13-krotnie mniej [Raport o sytuacji na rynku..., 2018; Rola mieszkalnictwa... 2015].

Nieruchomości mieszkaniowe stanowią nie tylko dominującą część bogactwa narodowego, ale stanowią również dominującą część bogactwa gospodarstw domowych, pozostając jednym z podstawowych składników ich majątku. Przykładowo, we Francji mniej niż jedna czwarta gospodarstw domowych posiada akcje, ale prawie $60 \%$ nieruchomości [Min 2014]. W większości krajów rozwiniętych wartość zasobu mieszkaniowego stanowi około 50\% bogactwa gospodarstw domowych [Ma, Li i Qu 2017]. Gospodarczy wymiar mieszkania ujawnia powiązanie rynku nieruchomości mieszkaniowych i pracującego na jego potrzeby rynku budowlanego (łącznie zwanego sektorem nieruchomości) z innymi działami gospodarki, wpływając na rynek pracy, na konsumpcję, kondycję sektora bankowego, na przebieg cykli koniunkturalnych, w efekcie na poziom i kierunki zmian PKB.

\section{Wpływ sektora nieruchomości na rynek pracy}

Wpływ na rynek pracy ujawnia się poprzez proces budowy mieszkań, ich wyposażenie, utrzymanie, remontowanie, modernizację, konieczność budowy infrastruktury, a także obrót nieruchomościami. W 2016 r. w budownictwie oraz obsłudze rynku nieruchomości pracowało w Polsce ponad 7\% pracujących ogółem [Rocznik Statystyczny GUS 2017], utrzymując się również na tym poziomie w 2017 r. [Rocznik Statystyczny Rzeczypospolitej Polskiej 2018]. Prace budowlane są pracochłonne, wymagają zatrudnienia osób o zróżnicowanych kwalifikacjach. Umożliwia to szybkie wchłanianie wolnej siły roboczej. W okresie dekoniunktury, 
z uwagi na podatność budownictwa i rynku nieruchomości na rozwój szarej strefy [Kucharska-Stasiak 2016b], łagodzone są skutki bezrobocia. Szara strefa „oliwi gospodarkę”, umożliwia bowiem prowadzenie działalności zarobkowej w pewnych obszarach i sytuacjach, gdzie ta działalność nie mogłaby być prowadzona w ramach oficjalnej gospodarki [Fundowicz i in. 2018; Schneider 2009]. Dotyczy to szczególnie zatrudniania osób bez kwalifikacji czy z niskimi kwalifikacjami. Zatrudnieni w szarej strefie nie obciążają funduszy pomocy społecznej, a zarobione pieniądze wydają w przeważającej części już w ramach legalnej gospodarki. Rozwojowi szarej strefy w sektorze nieruchomości sprzyja silnie rozwinięta funkcja fiskalna nieruchomości, nieprzejrzystość rynku nieruchomości i dominacja małych podmiotów zarówno w budownictwie, jak i w obsłudze rynku nieruchomości. Powszechnie uznaje się, że w małych przedsiębiorstwach łatwiej jest ukryć dochody, widoczna tu jest również słabsza postawa etyczna. M. Bednarski zauważa, że „małemu przedsiębiorcy łatwo jest utracić firmę i potem trudno ją odbudować. Jedynym ratunkiem może być przejście do szarej strefy, gdzie nie ma szeregu obciążeń, co może umożliwić egzystencję firmy" [Bednarski 2013, s. 48]. Wejście do szarej strefy staje się jednak pułapką, bowiem firma z szarej strefy ma

... trudny dostęp do: kapitału, sieci korporacyjnych (produkty tu powstające są poza ewidencją, „wybielanie” ich wymaga działań nielegalnych), do dobrych pracowników, wymiany międzynarodowej czy programów wsparcia MŚP. W konsekwencji trudno jest wrócić na legalny rynek [...]. Stąd w tej sytuacji działanie w szarej strefie staje się przymusem [tamże].

Działalność w szarej strefie pozwala jednak przetrwać okres dekoniunktury. Powyższe oznacza, że w sektorze nieruchomości pracuje znacznie większa liczba osób niż wykazuje to oficjalna statystyka, wskazująca na 7\% ogółu pracujących.

Sektor nieruchomości nie tylko tworzy miejsca pracy w gospodarce legalnej i w szarej strefie, ale także poprzez powiązanie procesu budowy i utrzymania mieszkań z innymi działami generuje tzw. efekt mnożnikowy ujawniający się we wzroście zatrudnienia w działach współpracujących z budownictwem, w takich jak: przemysły wytwarzające materiały i wyroby dla budownictwa, przemysły produkujące maszyny i urządzenia budowlane, przewody, kable, przemysły dostarczające wyroby wyposażenia wnętrz, usługi transportowe, usługi geodetów, architektów, obsługa nieruchomości i wielu innych. Szacunkowe dane ujawniają, że w 2005 r. w Polsce na 100 zatrudnionych bezpośrednio w budownictwie przypadało od 180 do 200 zatrudnionych w sektorach zależnych od budownictwa. Dominująca liczba (140) zatrudnionych przypada na produkcję sprzętu budowlanego, materiałów budowlanych i wyposażenie mieszkań [Raport 2006 zał. 1, s. 77]. Inne badania, przeprowadzone w 2013 r. przez Bolkowską, wskazują na wyższy efekt mnożnikowy: szacunkowo około 100 osób zatrudnionych w budownictwie tworzy 200-300 miejsc pracy w dziedzinach współpracujących z budownictwem [Rola mieszkalnictwa... 2015]. Polski Związek Firm Deweloperskich szacuje, że udział zatrudnionych w sektorze mieszkaniowym, łącznie z efektami mnożnikowymi (bez szarej strefy), sięga 15,4\% ogółu zatrudnionych [Rola mieszkalnictwa... 2015, s. 2]. 


\section{Wpływ rynku nieruchomości mieszkaniowych na konsumpcję}

Problematyka konsumpcji zajęła centralne miejsce w rozważaniach ekonomistów zarówno w skali makro jak i mikro [Hall, Taylor 2007, s. 251]. W skali makro konsumpcja rozważana jest jako główny składnik tworzący PKB, a jej przebieg, relatywnie wygładzony w porównaniu do zmian PKB, stanowi ważną cechę cyklu koniunkturalnego [tamże, s. 252-253]. W skali mikro ekonomiści starają się zidentyfikować czynniki, które decydują o sposobie podziału osobistych dochodów rozporządzalnych na konsumpcję obecną i przyszłą. Odłożona konsumpcja stanowi oszczędności. Zachowania konsumpcyjne gospodarstw domowych mają istotne znaczenie dla prognozowania i polityki gospodarczej. Keynes dowodził, że konsumpcja całego społeczeństwa zależy przede wszystkim od bieżącego docho$\mathrm{du}$ rozporządzalnego ${ }^{7}$. Ustalenia te zostały nazwane hipotezą dochodu absolutnego. Wzrost dochodów prowadzi do wzrostu oszczędności. Okazało się, że model keynesowski jest zbyt daleko idącym uproszczeniem. Sprawdza się w krótkich okresach, zawodzi w długich. Na decyzje konsumenta wpływają nie tylko dochody bieżące, ale również oczekiwania co do przyszłego dochodu. Gdy dochód rozporządzalny spadnie, chcąc utrzymać konsumpcję, gospodarstwo domowe może zaciągnąć kredyt lub korzystać ze zgromadzonych aktywów. W większości rozważanych modeli decyzje o konsumpcji są oparte na dożywotnim majątku gospodarstwa domowego, obejmującym bieżące i przyszłe dochody oraz aktualne aktywa finansowe i rzeczowe [Claessens, Kose 2017, s. 8]. Obawy przed utratą zdolności kredytowej czy wyczerpaniem aktywów są dowodem występowania tzw. międzyokresowego ograniczenia budżetowego. Gdy dochód rozporządzalny jest wyższy od konsumpcji, powstaną oszczędności, które mogą być dodane do aktywów, by wykorzystać je na konsumpcję w późniejszych latach. W latach poprzedzających okres emerytalny konsumpcja jest relatywnie niska, bowiem gospodarstwo domowe oszczędza więcej z myślą o przyszłości [Hall, Taylor 2007, s. 262]. Dlatego też w długim okresie konsumpcja waha się mniej niż rozporządzalny dochód. Ludzie dążą do utrzymania poziomu konsumpcji na względnie stałym poziomie podczas trwania całego życia. Konsument podejmuje decyzje, ile przeznaczy na konsumpcję bieżącą, a ile zaoszczędzi na przyszłość w ramach międzyokresowego ograniczenia budżetowego. W okresie aktywności zawodowej oszczędza, by móc sfinansować konsumpcję w okresie emerytalnym. Oznacza to, że bieżący i przyszły poziom konsumpcji zależą nie tylko od bieżącego dochodu, ale także od przyszłego dochodu i realnej stopy procentowej.

Na tych obserwacjach oparte zostały dwie kolejne teorie: teoria trwałego dochodu, sformułowana przez Miltona Friedmana, i teoria cyklu życia, zaproponowana

7 Dochód rozporządzalny jest sumą dochodu z aktywów i z pracy, pomniejszoną o podatek [Hall, Taylor 2007, s. 262]. 
przez F. Modiglianiego. Obie teorie dostrzegają, że w decyzjach o wysokości konsumpcji gospodarstwa domowe kierują się przyszłością.

Teoria trwałego, czyli przeciętnego dochodu z ostatnich kilku lat osadzona jest na stwierdzeniu, że konsumpcja zależy zarówno od dochodu bieżącego, jak i z lat poprzednich. Oznacza to, że o konsumpcji gospodarstw domowych nie decydują tylko ich bieżące dochody, ale też „[...] dochody uzyskane w okresach wcześniejszych, których część została zamieniona w majątek trwały, a część odłożona w postaci papierów wartościowych czy innych produktów oszczędnościowych, a ponadto efekty dochodowe uzyskane ze spodziewanych zmian kapitału ludzkiego" [Bywalec 2017, s. 99-100]. O decyzjach konsumpcyjnych, według Friedmana, decydują nie tylko zakumulowane aktywa majątkowe w danym okresie, nie tylko aktualnie osiągane dochody rozporządzalne, ale także długoterminowe, spodziewane dochody permanentne, utożsamiane z dochodami stałymi. Dawny dochód pozwala ludziom przewidywać dochody osiągane w przyszłości [Hall, Taylor 2007, s. 262]. Dochody przejściowe, takie jak premie, spadki, darowizny tylko w nieznacznym stopniu wpłyną na modyfikację bieżących rozmiarów konsumpcji, będą raczej zaoszczędzone lub przeznaczone na powiększenie składników majątku trwałego. Badania prowadzone w ostatnich dekadach podważają jednak zasadność wniosków Friedmana. Okazuje się, że coraz silniejsza jest reakcja gospodarstw na dochody przejściowe, w coraz większym stopniu na decyzje konsumentów wpływają czynniki psychologiczne, a także ideologia konsumpcjonizmu [Bywalec 2017, s. 101-102].

Druga teoria, teoria cyklu życia zakłada, że ludzie dążą do wygładzenia poziomu konsumpcji w ciągu całego życia. Przyjmuje ona upraszczające założenie, że zachowania konsumentów są racjonalne, planują oni konsumpcję na cały okres swojego życia, jaki są w stanie w przybliżeniu określić. W trakcie życia zawodowego oszczędzają po to, by zabezpieczyć swoją konsumpcję na starość, w okresie pobierania emerytury. Wtedy utrzymanie dotychczasowego standardu życia jest możliwe tylko w sytuacji posiadania odpowiednich oszczędności w postaci majątku rzeczowego czy aktywów finansowych. W swoich decyzjach konsumpcyjnych podlegają ograniczeniom budżetowym. Funkcja konsumpcji zostaje wyrażona w postaci:

$$
C=b_{1} \cdot Y_{d}+b_{2} \cdot A \text {, }
$$

gdzie:

C - wydatki konsumpcyjne gospodarstw domowych,

$Y_{d}$ - dochód rozporządzalny,

$A$ - wartość aktywów, bogactwo gospodarstw domowych,

$b_{1}, b_{2}$ - parametry modelu.

W krótkim okresie, kiedy zgromadzony majątek pozostaje stały, konsumpcja zależy wyłącznie od dochodu, co potwierdza koncepcję Keynesa. W długim 
okresie, kiedy majątek rośnie, skłonność do konsumpcji pozostaje stała dzięki nagromadzonym aktywom ${ }^{8}$.

Wśród rozważań teoretycznych wyeksponowana została rola nagromadzonego majątku. Sugeruje to, że wzrost zgromadzonego majątku, rozpatrywanego jako suma płynnych dóbr finansowych i wartości nieruchomości mieszkaniowych pozwala podtrzymać konsumpcję dzięki korzystaniu z już posiadanych zasobów. Zmiany w cenach aktywów mogą wpływać na bieżącą konsumpcję, gdyż zmieniają finansowe i rzeczywiste bogactwo jednostek [Claessens, Kose 2017, s. 8]. Ponieważ nieruchomości mieszkaniowe stanowią podstawowy składnik majątku gospodarstw ${ }^{9}$, w literaturze przedmiotu postawiona została hipoteza badawcza o pozytywnym wpływie rynku nieruchomości mieszkaniowych na konsumpcję. Przejawia się on poprzez tzw. efekt majątkowy i efekt zabezpieczenia. Efekt majątkowy powinien być widoczny w rosnącej skłonności do konsumpcji w relacji do wzrostu wartości majątku. Efekt majątkowy rozważany jest w dwóch płaszczyznach: na przykładzie modeli opartych na ograniczeniu budżetowym oraz na modelach opartych na funkcji konsumpcji [Lis 2012, s. 130-134]. Modele oparte na ograniczeniach budżetowych odpowiadają na pytanie, w jakim stopniu zmieni się konsumpcja, jeśli majątek ogółem zmieni się o 1 procent. W modelach opartych na funkcji konsumpcji zakłada się, że konsument unika gwałtownych wahań konsumpcji. Gdy konsument oczekuje, że w ciągu swojego życia jego dochód będzie się powiększał, wygładzając konsumpcję, będzie zaciągał zobowiązania w młodości i spłacał je, gdy będzie starszy. Jeżeli konsument oczekuje przejściowego spadku dochodów, wydaje swoje oszczędności, może również zaciągać zobowiązania. W sytuacji przejściowego, oczekiwanego wzrostu dochodów oszczędza lub spłaca zaciągnięte wcześniej zobowiązania. W tym modelu konsumpcja zależy od majątku fizycznego, który odwzorowuje skutki zmian dochodów w każdym okresie, oraz od dochodu bieżącego. Odzwierciedla wzrost marginalnej skłonności do konsumpcji w wyniku wzrostu marginalnego majątku

8 Okazuje się, że również ta teoria ulega przewartościowaniu. „Normatywne podejście prezentowane w modelu cyklu życia zakłada pełną racjonalność podmiotów, dalekowzroczność oraz optymalizacyjny charakter ich działań" [Bańbuła 2006, s. 49]. Okazuje się, że tak nie jest. W coraz większym stopniu wydatki konsumpcyjne zależą od oddziaływania czynników kulturowych i socjopsychologicznych, trudno poddających się analizom naukowym. Prowadzito to do powstania nowych hipotez: hipotezy dochodu relatywnego (względnego) [Bywalec 2017, s. 101-106] czy Behawioralnej Hipotezy Cyklu Życia [Bańbuła 2006]. Uwzględnienie zachowań behawioralnych konsumentów potwierdza, że krańcowa skłonność do konsumpcji w największym stopniu zależy od dochodów trwałych, zwanych permanentnymi, rozumianych jako długookresowa średnia z dochodów, w mniejszym stopniu od bieżącego dochodu czy bieżącego majątku, w najmniejszym stopniu od dochodów przyszłych [Bańbuła 2006].

9 Majątek gospodarstwa domowego utożsamiany jest z zasobem „...dóbr materialnych, niematerialnych oraz finansowych, stanowiący wspólną własność gospodarstwa domowego lub jego poszczególnych członków i służący do działalności wytwórczej lub konsumpcyjnej całego gospodarstwa albo tylko jego niektórych członków [...] W skład majątku gospodarstwa domowego wchodzi majątek trwały oraz majątek nietrwały (obrotowy)" [Bywalec 2017, s. 179]. 
ogółem [Lis 2012, s. 131-144]. Skoro majątek mieszkaniowy zajmuje dominującą pozycję $\mathrm{w}$ strukturze majątku gospodarstw domowych, poszukiwanie związku pomiędzy zgromadzonym majątkiem mieszkaniowym a konsumpcją wydaje się w pełni zasadne.

Badania o wpływie zmian wartości nieruchomości mieszkaniowych na konsumpcję są trudne. Trudność wynika z pewnością z niskiej dostępności odpowiednich danych. Ponadto nieruchomość mieszkaniowa jest dobrem konsumpcyjnym, co oznacza, że dla jej właściciela, który nie zamierza jej sprzedać, poczucie realnej wartości bogactwa może nie ulec zmianie i nie wpłynąć na konsumpcję.

Pomimo niewątpliwych trudności w pomiarze efektu majątkowego, badania na ogół potwierdzają teoretycznie słuszne zależności, że krańcowa skłonność do konsumpcji ma związek z wartością posiadanego majątku [przegląd badań podaje Trojanek 2018]. Szacunki empiryczne różnią się między krajami, są znacznie wyższe w Stanach Zjednoczonych niż w innych krajach. Badania przeprowadzone w Stanach Zjednoczonych ukazały, że krańcowa skłonność do konsumpcji wynosi od 4 do 7\% ogólnego majątku, czyli aktywów finansowych i aktywów niepłynnych, w tym aktywów mieszkaniowych [Claessens, Kose 2017, s. 10], podczas gdy marginalna skłonność do konsumpcji w wyniku wzrostu majątku mieszkaniowego w Wielkiej Brytanii o 1\% wyniosła nieco powyżej 3\% [Muelbauer 2008 za: Lis 2012, s. 133]. Efekt majątkowy, mierzony skłonnością do konsumpcji w relacji do wzrostu wartości majątku, wykazuje nie tylko zróżnicowanie przestrzenne, ale także zróżnicowanie w czasie: po pierwszym roku jest on niższy, jego siła rośnie w dłuższym okresie [Żelazowski 2009].

Teoretycznie majątek mieszkaniowy powinien mieć mniejszy wpływ na konsumpcję niż majątek zgromadzony na rynku akcji, gdyż jest wyraźnie mniej związany z przyszłymi wzrostami potencjału produkcyjnego [Mishkin 2007 za: Claessens, Kose 2017, s. 10]. Badania nie potwierdzają jednak tego kierunku związku. Krańcowa skłonność do konsumpcji silniej reaguje na wartość majątku mieszkaniowego niż finansowego. $Z$ jednej strony zmiany cen nieruchomości mieszkaniowych są postrzegane jako mniej zmienne niż ceny akcji, z drugiej strony majątek mieszkaniowy stanowi zazwyczaj większą część majątku całkowitego, co powoduje, że mają one większy wpływ na decyzje konsumpcyjne gospodarstw domowych. Dla samych zasobów finansowych jedne szacunki sugerują zmiany w konsumpcji rzędu od 0,03 do 0,07\% [Claessens, Kose 2017, s. 10], inne od 0,041 do 0,10\% [Żelazowski 2009], podczas gdy jednoprocentowy wzrost wartości zasobu nieruchomości mieszkaniowych niósł ze sobą średnio 0,09-0,23\% wzrost konsumpcji [tamże]. Zmiany cen domów postrzegane są jako bardziej trwałe niż zmiany cen akcji i mają bardziej wyraźny wpływ na konsumpcję niż zmiany w majątku kapitałowym, co potwierdziły wyniki badań w USA, Korei czy w Hong Kongu [Claessens, Kose 2017, s. 10-11].

Siła oddziaływania mieszkaniowego efektu majątkowego zależy od szeregu czynników [Trojanek 2018], takich jak: 
- Struktura własnościowa nieruchomości mieszkaniowych. Efekt majątkowy może mieć wpływ na konsumpcję właścicieli nieruchomości, nie wywiera wpływu na konsumpcję najemców. Z jednej strony wzrost wartości posiadanego już majątku mieszkaniowego pozytywnie wpływa na poziom konsumpcji, z drugiej strony dążenie do własności może spowodować spadek konsumpcji. Gospodarstwa domowe muszą bowiem długo oszczędzać na wkład własny warunkujący udzielenie kredytu, a w trakcie jego spłacania na koszty obsługi długu.

- Struktura wiekowa gospodarstw. Badania wskazują, że wpływ wartości majątku mieszkaniowego na konsumpcję raczej słabiej ujawnia się w wypadku osób starszych. Może to wynikać z faktu, że skłonność do konsumpcji może być silnie osadzona w kulturze danego społeczeństwa. W jednych kulturach osoby starsze mogą wykazywać większą skłonność do powiększania konsumpcji wraz ze wzrostem wartości majątku mieszkaniowego. W innych chęć pozostawienia majątku następnym pokoleniom nie przełoży się na wzrost konsumpcji, stanowiąc efekt międzypokoleniowych transferów majątkowych. Zwiększona skłonność do oszczędzania kosztem bieżącej konsumpcji może stanowić u nich również efekt zachowań ostrożnościowych.

- Status ekonomiczny gospodarstw domowych. Niższemu poziomowi zamożności towarzyszy niższy mieszkaniowy efekt majątkowy niż gospodarstwom o wyższym poziomie zamożności. Grupa gospodarstw zamożniejszych odpowiada w największym stopniu za wpływ krańcowej skłonności do konsumpcji w relacji na wzrost bogactwa mieszkaniowego.

- Uwarunkowania instytucjonalne, w tym dostępność zewnętrznych źródeł finansowania czy możliwości odmrażania kapitału zakumulowanego w nieruchomościach. Przyjmowane rozwiązania na rynku kredytowym czy regulacje podatkowe wpływają na popyt na kredyt, co warunkuje popyt na nieruchomości mieszkaniowe, wpływa na ich wartość i poziom konsumpcji. $\mathrm{Na}$ bardziej zliberalizowanych rynkach finansowych, takich jak rynek w Stanach Zjednoczonych czy w Kanadzie, jest większy wpływ zmian w wartości mieszkaniowego bogactwa na poziom konsumpcji niż w krajach o mniej zliberalizowanych rynkach, jak rynek w Niemczech czy w Japonii [Trojanek 2018].

Wzrost wartości majątku mieszkaniowego może prowadzić do wzrostu konsumpcji nie tylko poprzez efekt majątkowy, ale także efekt zabezpieczenia. W sektorze finansowym hipoteka uznawana jest za dobrą prawną formę zabezpieczenia wierzytelności. Wzrost cen nieruchomości mieszkaniowych zwiększa zdolność kredytową gospodarstw domowych, umożliwiając wzrost konsumpcji. Efekt zabezpieczenia jest świadectwem traktowania nieruchomości jako kapitału. Oznacza to, że nieruchomość mieszkaniowa stanowi nie tylko element fizyczny w postaci gruntów i budynków, ale kryje w sobie potencjał pod względem wytwarzania wartości dodatkowej, stanowiąc źródło bogactwa. Kapitał jest uśpiony w nieruchomości, on jest martwy, dopóki nie jest ożywiony, funkcjonuje jedynie w sferze fizycznej, nie 
uwalniając energii, która w nim tkwi. „Ożywianie go wymaga od nas, byśmy przestali jedynie widzieć nasze zasoby takie, jakimi one są, a zaczęli aktywnie myśleć o tym, czym mogłyby one być. Potrzebujemy mechanizmu, który nada ekonomicznemu potencjałowi zasobów poręczną formę, umożliwiającą wykorzystanie ich do zapoczątkowania nowej produkcji” [De Soto, 2002, s. 64]. Jedną z form ożywienia kapitału jest „odmrażanie” wydatkowanych środków na zakup nieruchomości poprzez zaciągnięcie kredytu, dla którego formą zabezpieczenia jest hipoteka. Wzrost cen mieszkań umożliwia zwiększenie zdolności kredytowych gospodarstw domowych. Pozyskany kredyt może być przeznaczony na konsumpcję i odwrotnie: pogorszenie koniunktury na rynku nieruchomości przełoży się na spadek cen nieruchomości, spadek wartości zabezpieczenia i spadek konsumpcji. Poprzez zjawisko akceleracji finansowej negatywne zjawiska potęgują się, niekorzystnie wpływając na wielkości realne w gospodarce.

Efekt majątkowy i zabezpieczeniowy pozwala wnioskować, że istnieje związek nie tylko pomiędzy kondycją rynku nieruchomości mieszkaniowych a popytem konsumpcyjnym, ale również pomiędzy kondycją rynku nieruchomości mieszkaniowych a kondycją całej gospodarki.

\section{Wpływ rynku nieruchomości mieszkaniowych na sektor bankowy}

Wysoka kapitałochłonność mieszkania powoduje, że zaspokojenie potrzeb mieszkaniowych finansowane jest często ze źródeł obcych, w tym z kredytu hipotecznego. W 2010 r. 48\% ankietowanych w Polsce deklarowało sfinansowanie zakupu mieszkania z kredytu hipotecznego, o 9\% więcej (57\%) deklarowało zakup za gotówkę pochodzącą z własnych oszczędności, 9\% ze sprzedaży innej nieruchomości, 8\% $\mathrm{z}$ funduszy przekazanych przez rodzinę, $3 \% \mathrm{z}$ pracy za granicą [Raport... 2010].

O dużej skali zaciąganych kredytów dla zaspokojenia potrzeb mieszkaniowych świadczy relacja kredytów hipotecznych do PKB: w krajach Unii Europejskiej relacja ta w 2017 r. wynosiła od 7,6\% w Rumunii, w Polsce 20\%, do 86,1\% w Danii i $91,2 \%$ w Holandii [Hypostat 2018]. Dowodzi to, że w wielu krajach kredyt pozostaje jednym z głównych sposobów sfinansowania inwestycji mieszkaniowych, kształtując popyt na nieruchomości i wpływając na poziom ich cen.

Zaangażowanie sektora bankowego w finansowanie rynku nieruchomości ma wpływ na bezpieczeństwo kredytodawcy, a także całego systemu bankowego. Za miarę bezpieczeństwa przyjmuje się poziom wypłacalności sektora bankowego. W procesie kredytowania banki ponoszą szereg ryzyk. Decydujące znaczenie dla bezpieczeństwa kredytodawcy ma ryzyko kredytowe związane z powodzeniem danego przedsięwzięcia i zdolnością kredytobiorcy do spłaty zadłużenia łącznie z odsetkami. Poziom tego ryzyka zależy zatem od zdolności kredytobiorcy do obsługi długu, jego wiarygodności (w tym chęci spłaty długu), a także od jakości zabezpieczeń (jakości nieruchomości i sposobu jej wyceny). Istotne dla kredytodawcy jest 
ryzyko rynkowe, które wynika ze zmienności cen nieruchomości, a także możliwości sprzedaży nieruchomości przy akceptowanej przez wierzyciela cenie zbliżonej do wartości rynkowej, jaka stanowiła zabezpieczenie wierzytelności kredytodawcy. Kolejny rodzaj ryzyka to ryzyko płynności, które oznacza łatwość wyjścia z rynku za cenę zbliżoną do wartości rynkowej. Niestety, nieruchomości należą do aktywów mało płynnych. Oznacza to, że w razie niewypłacalności kredytobiorcy bank długo może czekać na odzyskanie kapitału poprzez sprzedaż nieruchomości.

Kredyt hipoteczny wpływa na stronę popytową i podażową nieruchomości, oddziałując na poziom ich cen. Siła wpływu akcji kredytowej na wzrost cen zależy nie tylko od wolumenu kredytu, ale także od jego struktury: proporcji kredytu skierowanego na finansowanie strony popytowej (nabywców mieszkań) i strony podażowej (deweloperów). Preferowanie strony popytowej kosztem strony podażowej wobec małej elastyczności cenowej podaży przyspiesza wzrost cen, wywołując korzystne warunki do kształtowania się bańki cenowej.

W literaturze przedmiotu przytacza się zachowania kredytodawców prowadzące do zjawisk kryzysowych w sektorze bankowym ${ }^{10}$. Książkowym wręcz obrazem były zachowania kredytodawców w Stanach Zjednoczonych poprzedzające kryzys 2007-2008. Należały do nich [Łaszek 2006, s. 19-21]:

- niedostrzeganie katastrofy, co ma swoje źródło w rzadko występujących kryzysach (raz na pokolenie). W konsekwencji banki nie dostrzegają zbliżającego się zagrożenia;

- wyolbrzymianie katastrofy. W sytuacji kryzysowej banki, a także instytucje nadzorujące reagują nadmiernie nerwowo, ograniczając dopływ środków finansowych, co skutkuje dalszym ograniczeniem popytu, pogłębiając kryzys;

- instynkt stadny, który ujawnia się, kiedy ekspansywna polityka kredytowa jednych banków zostaje zaakceptowana przez kolejne banki bez należytej dbałości o jakość zabezpieczeń, wiarygodność i zdolność kredytową kredytobiorców. W warunkach niskich stóp procentowych prowadzi to do spekulacji, która stanowi efekt zachowań stadnych;

- pokusa nadużycia przejawiająca się w chęci przerzucenia skutków wysokiego ryzyka na inne podmioty [Iwanicz-Drozdowska 2009, s. 33]. Pokusie nadużycia podlegali zarówno kredytodawcy, agencje ratingowe, jak i kredytobiorcy nieposiadający odpowiedniej zdolności kredytowej. Uleganie pokusie nadużycia ze strony kredytodawców było możliwe dzięki rozwojowi nowych instrumentów finansowych. Ich wartość była powiązana z portfelem kredytów hipotecznych. Wśród tych instrumentów pochodnych szczególne znaczenie miały obligacje hipoteczne będące zobowiązaniem zabezpieczonym długiem, powstałe przez sekurytyzację wierzytelności. Innym instrumentem pochodnym były tzw. kontrakty wymiany ryzyka kredytowego. Dzięki

10 Przegląd dysfunkcji na rynku nieruchomości w okresie kryzysu prezentuje E. Kucharska-Stasiak [2018]. 
możliwości sprzedaży tych instrumentów procent kredytów w posiadaniu banków i kas uległ zmniejszeniu: z około 55\% w 1985 r. do 25\% w 2009 r. [Bair 2010, s. 4], tworząc złudne poczucie bezpieczeństwa;

- złe praktyki bankowe. W obliczu rosnącego popytu na rynku nieruchomości i wzrostu ich cen banki lekceważyły zagrożenie wynikające z możliwości załamania się rynku nieruchomości mieszkaniowych. Zabezpieczeniem dla banków był oczekiwany wzrost wartości domów, na kupno których zaciągnięte zostały kredyty. Możliwość łatwego pozyskania w drodze sekurytyzacji środków na kontynuację akcji kredytowej, a także możliwość przerzucenia ryzyka kredytowego na inny podmiot powodowało akceptację klientów o coraz niższej zdolności i wiarygodności kredytowej [m.in. Szyszka 2009, s. 13]. Emitowane w drodze sekurytyzacji instrumenty miały bardzo skomplikowaną konstrukcję, były niezrozumiałe, nie stanowiły przedmiotu obrotu rynkowego, nie były zatem wyceniane przez rynek. Wyceniane były na podstawie modeli matematycznych. Bogle nazwał to współczesną odmianą alchemii [Bogle 2009, s. 79]. Odmowa zawyżania przez rzeczoznawców wycen wywołała dążenia do zakładania przez banki własnych firm, zajmujących się wyceną, co podważa niezależność wyceny [Stiglitz 2010, s. 103]. Kredytobiorców „[...] zachęcano do traktowania ich nieruchomości jak bankomatów, umożliwiając im wielokrotne zadłużanie się pod zastaw ich wartości” [tamże, s. 322]. Zyski brokerów były najwyższe wówczas, gdy „wpuszczali” kredytobiorców w najbardziej ryzykowne kredyty hipoteczne o zmiennym oprocentowaniu z karami za wcześniejszą spłatę zadłużenia” [tamże, s. 104]. Udzielane kredyty były często świadectwem oszustw, wykorzystywano niewiedzę klientów i zachęcano do podpisywania umów kredytowych z niekorzystnymi warunkami spłaty. Kredytobiorcy podpisywali je, często nie rozumiejąc ich treści [Bair 2010, s. 43]. Czynnikiem pobudzającym aktywność kredytową banków był system wynagrodzeń na podstawie zysków krótkoterminowych bez uwzględnienia ryzyka długoterminowego, a także oczekiwanie akcjonariuszy wzrostu wartości akcji. Bankom towarzyszyło przekonanie, że w razie kłopotów Rezerwa Federalna i Departament Skarbu udzielą im finansowej pomocy [Stiglitz 2010, s. 8-9]. Prezesi banków żyli w przekonaniu, że ich przedsiębiorstwa są zbyt duże, aby rząd pozwolił na ich upadek (too big to fail). Boom na rynku nieruchomości mieszkaniowych prowadził do zmiany polityki kredytowej w sektorze bankowym: banki zmniejszały pulę kredytów komercyjnych na rzecz powiększenia kredytów mieszkaniowych, zwiększając popyt i potęgując wzrost cen. Silne zaangażowanie sektora bankowego w finansowanie rynku nieruchomości stwarza zagrożenie dla jego płynności w sytuacji spadku cen nieruchomości mieszkaniowych [Cunăt i in. 2018].

Maleje wartość zabezpieczeń kredytów, rosną koszty obsługi kredytów trudnych. W obliczu spadku zdolności kredytobiorców do obsługi długu, zaostrzane są standardy przyznawania nowych kredytów, co ogranicza ich podaż. Spadek cen nie tylko negatywnie oddziałuje na sek- 
tor bankowy poprzez kanał rynku nieruchomości mieszkaniowych, ale także przez rynek deweloperski. Spadek cen to zmniejszenie rentowności rozpoczętych i finansowanych kredytem projektów deweloperskich, które powiększają pulę kredytów trudnych, co w efekcie ogranicza działalność budowlaną i prowadzi do zmniejszenia podaży kredytów dla rynku deweloperskiego i rynku budowlanego. Wpływa to na pogorszenie sytuacji finansowej sektora bankowego. Na politykę kredytową banków wpływają nie tylko wzrosty, ale także spadki cen nieruchomości mieszkaniowych. Spadki cen nieruchomości mieszkaniowych wyhamowują zaangażowanie się tego sektora w finansowanie rynku mieszkaniowego, co przyczynia się do ograniczenia popytu i dalszego spadku cen [tamże]. Badania MFW pokazują, że na 50 kryzysów bankowych w ostatnich dziesięcioleciach ponad dwie trzecie było poprzedzonych załamaniami cen na rynku nieruchomości mieszkaniowych [Min 2014].

Siła zagrożeń płynących ze strony rynku nieruchomości mieszkaniowych dla sektora bankowego zależy od modelu finansowania rynku mieszkaniowego. W modelu banku uniwersalnego, w którym kredyty hipoteczne emitowane są na bazie krótkoterminowych depozytów, występuje szczególnie silne zagrożenie dla płynności sektora bankowego, jest ono mniejsze w modelu banku hipotecznego, gdzie podstawą udzielanych kredytów są listy zastawne. Niebezpieczeństwo eskalacji ryzyka dla sektora bankowego i całej gospodarki niesie ze sobą model sekurytyzacji. Dzieje się tak wtedy, gdy banki - zamiast zarządzać ryzykiem - stają się pośrednikami transferującymi ryzyko na zewnątrz sektora. Mechanizm ten umożliwia zwiększanie akcji kredytowej, która prowadzi do pobudzenia aktywności na rynku nieruchomości, wywołując wzrost cen często bez należytej dbałości o ryzyko związane ze spłatą zobowiązań.

\section{Wpływ rynku nieruchomości mieszkaniowych na przebieg cykli koniunkturalnych}

Cykl koniunkturalny jest wypadkową cykli specyficznych, występujących w poszczególnych sferach gospodarki. Przykładem cyklu specyficznego jest cykl rynku nieruchomości. Cykl rynku nieruchomości tworzą dwa cykle: cykl popytowy, kierowany cyklem koniunkturalnym i cykl podażowy, związany z działalnością deweloperską. Rynki nieruchomości podlegają silnym ruchom falowym z nieregularną prawidłowością.

Wpływając na zmienne makroekonomiczne, takie jak inwestycje czy konsumpcja, rynek nieruchomości może pobudzać gospodarkę, może również spowolnić wejście gospodarki w fazę recesji [The Houses... 2002], a poprzez silne powiązanie $\mathrm{z}$ sektorem bankowym może zdestabilizować ten sektor i strefę realną w gospodarce.

Związki między cenami aktywów, w tym aktywów nieruchomościowych, a wynikami makroekonomicznymi są w centrum powiązań makrofinansowych, ujawniając dwukierunkowe interakcje między realną gospodarką i sektorem finansowym. Wstrząsy, powstające $\mathrm{w}$ realnej gospodarce mogą być rozprzestrzeniane za pośrednictwem cen aktywów poprzez operacje w sektorze finansowym, wzmacniając tym samym cykle koniunkturalne [Claessens, Kose 2017]. 
Silne związki rynku nieruchomości z sektorem bankowym spowodowały, że mechanizm powstawania cykli koniunkturalnych i cykli rynku nieruchomości analizowany jest przez pryzmat powiązań dwóch rynków [Muller 1995]:

- rynku nieruchomości w ujęciu rzeczowym (physical property market), determinowanym przez relację popytu i podaży na nieruchomości;

- rynku kapitału (financial property market), który reprezentowany jest przez środki finansowe (własne i kredyty) przeznaczone na realizację nowych projektów lub zakup już istniejących.

Poszczególne fazy cyklu w ujęciu rzeczowym i cyklu kapitału nie muszą przebiegać równolegle. Decyduje o tym trudność w przewidywaniu popytu, długi cykl realizacji inwestycji, mała przejrzystość rynku nieruchomości, a także konkurencyjność innych segmentów rynku kapitałowego, głównie rynku papierów wartościowych.

W fazie dna cyklu koniunkturalnego na rynku nieruchomości w ujęciu rzeczowym rynek pogrążony jest w nadpodaży. Spada bowiem popyt na powierzchnie i jednocześnie pojawia się strumień nowej podaży. Stanowi on efekt wcześniej rozpoczętych działań deweloperskich. Rynek przyciąga niewielki kapitał inwestowany w istniejące nieruchomości.

Faza ożywienia w gospodarce spowoduje wzrost popytu na nowe powierzchnie, co przełoży się na spadek pustostanów i wzrost stawek czynszów, wzrośnie wartość nieruchomości. Gdy ceny istniejących nieruchomości wzrosną ponad koszt odtworzenia, rynek przyciągnie nowy kapitał, deweloperzy rozpoczną nowe budowy. Istotny wpływ na postawy inwestorów i deweloperów wywiera atmosfera optymizmu. Następuje wzrost zapotrzebowania na kapitał przeznaczony na nabycie już istniejących powierzchni, a także na realizację nowych.

Wzrost cen nieruchomości prowadzi do podwyższenia rynkowej wartości zabezpieczenia wierzytelności, obniża ryzyko kredytodawców i prowadzi do zwiększenia ich skłonności do angażowania się $\mathrm{w}$ finansowanie rynku nieruchomości. Sprzyja temu, pomimo rosnących cen, malejąca relacja kredytów i pożyczek do wartości nieruchomości dla pozostających do spłacenia kredytów. Wzrost wartości nieruchomości może zachęcić sektor bankowy do finansowania kolejnych przedsięwzięć, dla których nieruchomość stanowi formę zabezpieczenia. Zachęca to deweloperów do inicjowania bardziej ryzykownych przedsięwzięć. Wysoki udział środków obcych powoduje, że przerzucają oni większość ryzyka rynku na kredytodawców.

Nawet jeżeli aktywność rynku nieruchomości w ujęciu rzeczowym wygasa - stawki czynszu i pustostany stabilizują się, a zainteresowanie inwestorów nabyciem nieruchomości słabnie - na rynek nieruchomości napływa jeszcze ciągle kapitał potrzebny do realizacji rozpoczętych wcześniej projektów deweloperskich. Długi cykl realizacji inwestycji deweloperskich, niedoskonałe przewidywanie przyszłego popytu sprzyjają niedoszacowaniu ryzyka finansowania rynku nieruchomości przez sektor bankowy, co powoduje, że pomimo wzrostu pustostanów podaż może nadal przez kilka lat się zwiększać. Cykl podażowy może objąć dwa 
cykle popytowe. Potwierdzenia tej tezy dostarczają badania, które pozwoliły rozpoznać 10-letnie cykle na rynku deweloperskim, prowadzące do silnej nadpodaży, które omijają co drugi cykl popytowy [Coleman, Gentle 2001].

Dopływ kapitału z sektora bankowego zostaje silnie zahamowany dopiero wtedy, gdy rynek nieruchomości wchodzi w pogłębioną fazę recesji. Stanowi to następstwo spadku wartości zabezpieczeń i wzrostu ryzyka banków. Spadek dopływu kapitału przełoży się na spadek popytu i cen. W rezultacie wartość zabezpieczeń może szybko spaść poniżej kwoty niespłaconych wierzytelności, prowadząc do ograniczenia wypłacalności kredytodawcy.

W literaturze przedmiotu postawione zostały dwie tezy badawcze dotyczące wpływu rynku nieruchomości mieszkaniowych na przebieg cyklu koniunkturalnego:

- ceny nieruchomości mieszkaniowych mają wpływ na przebieg cykli koniunkturalnych. Wzrost cen to wzrost bogactwa mieszkaniowego. Bogactwo mieszkaniowe i wydatki konsumpcyjne są procykliczne [Ma, Li i Qu 2017].

- na przebieg cykli koniunkturalnych wpływa nie tylko cykl popytowy poprzez zmiany cen, lecz głównie cykl podażowy mierzony wielkością inwestycji mieszkaniowych (ilością wybudowanych mieszkań).

Dowody empiryczne nie dostarczyły jednoznacznych odpowiedzi dla poparcia którejś z postawionych tez. Przegląd badań zawiera praca Trojanka [2018]. Potwierdzeniem pierwszej tezy były m.in. badania przeprowadzone w Stanach Zjednoczonych w latach 1975-2010. Wykazały one korelację pomiędzy wahaniami cen nieruchomości mieszkaniowych i cyklem koniunkturalnym: współczynnik korelacji wyniósł 0,52 [Ma, Li i Qu 2017]. Wskazuje się na większe znaczenie spadków niż wzrostów cen dla przebiegu cyklu koniunkturalnego, co oznacza, że poprzez silne związki rynku nieruchomości z sektorem bankowym spadki cen nieruchomości mogą pobudzić tendencje spadkowe w gospodarce. Wynikać to może z relatywnie mniejszej, niż przy popycie, elastyczności cenowej podaży. Ceny spadają, a rynek zasilany jest jeszcze nową podażą z projektów wcześniej rozpoczętych. Liczne badania wskazują na słuszność drugiej tezy, że na przebieg cyklu koniunkturalnego silniejszy wpływ ma strona podażowa [Lis 2012, s. 48-88]. Istotnym głosem w tej dyskusji są rozważania E. Leamera [2007]. Leamer dostrzegł, że recesja w gospodarce poprzedzana była często załamaniem w cyklach podażowych [tamże, s. 164]. Osią rozważań jest stwierdzenie, że spadek popytu na rynku mieszkaniowym nie skutkuje dostosowaniem się cen do nowej sytuacji rynkowej. Ceny mieszkań pozostają sztywne. Właściciele mieszkań nie chcą ich sprzedać po niższej cenie, pamiętając ceny historyczne. Oznacza to, że w przypadku spadku popytu mieszkaniowego dostosowanie wystąpi po stronie ilości dostarczanych mieszkań, a nie spadku ich cen. Zmiany liczby mieszkań są gwałtowne, amplituda liczby sprzedanych domów jest znacznie większa niż amplituda wahań cen domów. W konsekwencji spadek liczby mieszkań wpłynie na spadek liczby zatrudnionych w budownictwie, a poprzez efekt mnożnikowy przełoży się na spadek zatrudnienia w branżach współpracujących z budownictwem. 
Kanał powiązań rynku nieruchomości mieszkaniowych przez rynek hipoteczny ujawnia możliwość wystąpienia negatywnych następstw w sytuacjach przeinwestowania rynku nieruchomości przez sektor bankowy, przekładając się na gospodarkę w skali makro. Skłoniło to analityków do wysunięcia tezy, że zmiany cen nieruchomości mieszkaniowych $\mathrm{w}$ połączeniu $\mathrm{z}$ akcją kredytową pozwalają przewidywać kryzysy finansowe [Borio, Drehmann 2009, s. 29-46]. Jednocześnie badania wykazują, że siła predykcyjna zmian cen tych nieruchomości jest nieco słabsza niż cen akcji, które okazują się lepszymi wiodącymi wskaźnikami inwestycji niż PKB czy konsumpcja [Claessens, Kose 2017, s. 11].

Analiza licznych kryzysów, jakie wystąpiły na rynkach nieruchomości, ujawniła, że przełożyły się one na gospodarkę w tych krajach, w których system bankowy w sposób niekontrolowany zaangażował się w finansowanie rynku nieruchomości. Cykle rynku nieruchomości nie przełożyły się na załamanie sektora bankowego w krajach, w których systemy bankowe były zdrowe. Potwierdzają to badania prowadzone przez Międzynarodowy Fundusz Walutowy [Hilbers i in. 2001]. Jako przykłady podaje się cykl rynku nieruchomości w Singapurze i Hongkongu [tamże]. We wszystkich analizowanych przypadkach kryzysów bankowych ceny nieruchomości mieszkaniowych silnie rosły, realnie przeciętnie więcej niż $20 \%$, a następnie zaczynały spadać (o ponad 15\% w ciągu 2 lat), poprzedzając kryzys sektora bankowego. Ceny nieruchomości osiągnęły szczytowy poziom na 2-3 lata przed rozpoczęciem kryzysu w sektorze bankowym. Przeciętnie ceny nieruchomości mieszkaniowych spadły o $35 \%$, ale ich spadek był procesem stopniowym - trwał od 3 (Kanada) do 8 lat (Japonia). Badania te doprowadziły do ciekawych wniosków: to nie rynek nieruchomości stanowi źródło kryzysu sektora bankowego i w rezultacie gospodarki. Inwestycje mieszkaniowe mają zbyt mały udział w PKB. Ponieważ są one bardzo wrażliwe na wahania stóp procentowych, przedstawiciel Europejskiego Banku Centralnego źródeł kryzysu szuka właśnie w zmianach poziomu tych stóp [Smets 2007]. Rynek nieruchomości ma zatem pośredni udział w powstaniu fazy kryzysu. Źródłem powstania jest deregulacja sektora bankowego i jego nadmierne zaangażowanie się przy niskich stopach procentowych w finansowanie działań deweloperskich i inwestycji kapitałowych na tym rynku, w oderwaniu od rynku najmu.

Historia cykli rynków nieruchomości potwierdza, że im silniejsze jest powiązanie banków z rynkiem nieruchomości, tym bardziej wzmocnione stają się cykle na tym rynku. Wzrost znaczenia sektora finansowego oraz globalizacja zwiększyły skalę i częstotliwość występowania kryzysów rynku nieruchomości [Łaszek 2006]. Istnieje bowiem silna korelacja pomiędzy dynamiką cen nieruchomości i przyrostem kredytu. Wzrosty cen nieruchomości są poprzedzone wzrostem kredytu bankowego, a spadek cen silnym ograniczeniem przyrostu kredytu. Potwierdza to badanie dla 11 tys. nieruchomości [Hillbers i in. 2001, s. 8-27]. Ujawniło ono również możliwość wystąpienia silnego związku pomiędzy załamaniem się cen na rynku nieruchomości a powstaniem problemów sektora 
bankowego. Kryzys sektora bankowego powoduje z kolei dalszy spadek cen nieruchomości, co oznacza, że sektor bankowy może zaostrzyć zjawiska kryzysowe na rynku nieruchomości.

\section{Wpływ na poziom PKB}

Związki między cenami aktywów, w tym aktywów nieruchomościowych, a wynikami makroekonomicznymi są w centrum powiązań makrofinansowych, ujawniając dwukierunkowe interakcje między realną gospodarką i sektorem finansowym [Claessens, Kose 2017, s. 1]. Pomiędzy rynkiem nieruchomości a całą gospodarką istnieją obopólne związki: ożywienie w gospodarce pobudza rynek nieruchomości, z drugiej strony wzrost gospodarczy powinien być napędzany wzrostem cen nieruchomości mieszkaniowych. Wskazuje się na wpływ całego sektora nieruchomości mieszkaniowych (rynku nieruchomości mieszkaniowych i rynku budowlanego) na PKB poprzez podejmowaną działalność inwestycyjną, polegającą na budowie, przebudowie, remontach zasobu mieszkaniowego (efekt inwestycyjny), a także poprzez wydatki związane z usługami mieszkaniowymi. Wpływ jest większy im większa jest integracja finansowa gospodarek [Loutskina, Strahan 2015]. Wzrost cen nieruchomości mieszkaniowych jako efekt wzrostu popytu zwiększa zainteresowanie deweloperów podejmowaniem nowych projektów deweloperskich, pobudzając rynek budowlany.

Według danych z Eurostatu łączny udział budownictwa mieszkaniowego i wydatków konsumpcyjnych na usługi mieszkaniowe w tworzeniu PKB w 2014 r. sięgał 13,8\% w Polsce, w strefie Euro 18,3 i 18,1\% średnio w krajach UE. W 2017 r. nieruchomości mieszkaniowe stanowiły 17,0\%, a komercyjne ok. 12\% PKB. Doceniając wpływ budownictwa na PKB, należy zauważyć, że za udział w PKB odpowiadają głównie wydatki konsumpcyjne: odpowiednio 11,4\% w Polsce, 13,3\% w strefie euro i 13,5\% średnio w UE [Trojanek 2018, s. 18].

O randze rynku nieruchomości mieszkaniowych świadczy również wartość strumienia usług mieszkaniowych szacowana na podstawie wysokości rynkowych stawek transakcyjnych czynszów najmu (tzw. czynszów imputowanych) oraz szacowany udział podatków od nieruchomości mieszkaniowych w relacji do PKB. W 2017 r. wartość strumienia usług mieszkaniowych ${ }^{11}$ stanowiła ok. $12 \% \mathrm{PKB}$, pozostając na stałym poziomie przez cztery lata [Raport o sytuacji... 2018, s. 16], podczas gdy wartość usług generowanych przez nieruchomości komercyjne tylko 0,7\% PKB [tamże, s. 16]. Szacowany udział podatków od nieruchomości mieszkaniowych i komercyjnych wyniósł ok. 1,2\% PKB [tamże, s. 17].

11 Wartość oszacowana jako iloczyn powierzchni mieszkaniowych i średniej stawki najmu na koniec roku według bazy NBP dla poszczególnych 16 badanych miast. Dla pozostałej powierzchni Polski stawkę najmu oszacowano jako 50\% średniej stawki najmu wyznaczonej dla 10 miast [Raport o sytuacji... 2018, s. 16]. 
Pomimo powiązań sektora nieruchomości mieszkaniowych, rozumianego jako rynek budowlany i rynek nieruchomości mieszkaniowych, sektor ten nie był odpowiednio doceniony przez makroekonomistów [Min 2014]. Dopiero wielki kryzys 2007-2008 ujawnił znaczenie ożywienia i załamania cen mieszkań dla stabilności finansowej sektora bankowego i stanu gospodarki realnej. Doświadczenia kryzysu spowodowały, że mimo relatywnie niewielkiego udziału sektora nieruchomości w tworzeniu PKB, włączono go do modeli równowagi ogólnej [m.in. Kaplan, Mitman i Violante 2017]. 


\section{Rozdział 2}

\section{Ewolucja europejskich systemów mieszkaniowych w okresie powojennym}

\subsection{Modele polityki mieszkaniowej}

W dyskusjach nad polityką mieszkaniową, jako dyscypliną badawczą, kwestią sporną pozostaje stopień ingerencji państwa $\mathrm{w}$ mechanizm funkcjonowania rynków nieruchomości mieszkaniowych. Badania nad systemami mieszkaniowymi pozwoliły wyróżnić różne wzorce rozwiązań tej ingerencji i typy (modele) systemów mieszkaniowych, często nazywane modelami polityki mieszkaniowej [Hoekstra 2003].

Zainteresowanie modelami polityki mieszkaniowej datuje się od lat 60. XX w. Dla państw Europy Zachodniej D. Donnison sformułował trzy modele: embrionalny, socjalny i kompleksowy [Cesarski 2010, s. 23-33]. W modelu embrionalnym, w którym mieszkanie traktowane jest jako przedmiot konsumpcji, inwestycje mieszkaniowe ograniczają nakłady na podstawowe dziedziny gospodarki. Państwo przyjmuje rolę pasywną w zaspokajaniu potrzeb mieszkaniowych. Model ten został zidentyfikowany w Grecji, Portugalii i Hiszpanii. W modelu socjalnym o zaspokajaniu potrzeb decydują warunki rynkowe, pomoc publiczna skierowana jest do ludności niemogącej zaspokoić potrzeb mieszkaniowych na wolnym rynku. Model ten wystąpił w Wielkiej Brytanii, Irlandii i Szwajcarii. W modelu kompleksowym inwestycje mieszkaniowe stanowią istotny czynnik wzrostotwórczy, państwo przejmuje odpowiedzialność za zaspokajanie potrzeb mieszkaniowych wszystkich obywateli. Model ten zidentyfikowany został w Niemczech, Holandii, Danii, Norwegii, Szwecji, Islandii i Finlandii.

Dla gospodarek centralnie planowanych Andrzejewski, współpracujący z Donnisonem, zaproponował inny podział modeli polityki mieszkaniowej [Cesarski 2013a, s. 113]. Wyróżnił model administracyjno-dotacyjny oraz akumulacyjno-interwencyjny. Oba modele oparte były na koncepcji nieprodukcyjnej funkcji nakładów inwestycyjnych ponoszonych na mieszkalnictwo, co oznaczało 
nieuwzględnianie tych nakładów $\mathrm{w}$ modelach wzrostu gospodarczego. Model administracyjno-dotacyjny o charakterze nakazowym, oparty na własności publicznej zasobów, scentralizowanym systemie akumulacji i alokacji środków przeznaczonych na gospodarkę mieszkaniową, stosowany był powszechnie w środkowoeuropejskich państwach socjalistycznych do lat 70. XX w. Zarówno faza jego tworzenia, faza podziału, jak też faza użytkowania dofinansowywane były ze środków $\mathrm{z}$ budżetu państwa. W modelu tym cena mieszkania i wysokość czynszu były niskie ${ }^{1}$, w skrajnym przypadku całość środków mogła być finansowana $\mathrm{z}$ funduszu spożycia zbiorowego [Andrzejewski 1987, s. 486]. W 1958 r. czynsze i pobierane przez administracje domów dodatkowe opłaty w tzw. mieszkaniach kwaterunkowych stanowiły w Polsce 1\% dochodów gospodarstw pracowniczych [Litterer-Marwege 1961]. Niski udział wydatków na mieszkanie umożliwiał utrzymywanie niskich płac. Model ten nie uwzględniał indywidualnych preferencji mieszkaniowych. Bezpłatne lub zbliżone do bezpłatnego otrzymanie mieszkania wyzwalało niedający się zaspokoić popyt na mieszkania.

Model akumulacyjno-interwencyjny dopuszczał inne formy własności mieszkań. Pozwalał na uwzględnienie preferencji indywidualnych [Andrzejewski 1969, s. 316-322]. Zaczął być wdrażany w Polsce, Czechosłowacji i na Węgrzech na przełomie lat 60.-70. XX w. Istotnym jego założeniem było oparcie rozwoju budownictwa mieszkaniowego na rosnącym udziale środków ludności w finansowaniu mieszkalnictwa. Związany był z rozwojem lokatorskiej spółdzielczości mieszkaniowej. Spółdzielnie mieszkaniowe rozwinęły się w Czechach, Słowacji, na Węgrzech i w Polsce. Przykładowo, w byłej Czechosłowacji gospodarstwa domowe finansowały ok. 18\% kosztów budowy, w Polsce 50\% kosztów finansowane było z budżetu państwa, członek spółdzielni zobowiązany był do wniesienia wkładu mieszkaniowego w wysokości 10-15\% kosztów budowy, a opłata za mieszkanie obejmowała oprócz kosztów eksploatacji i remontów ratę spłaty kredytu budowlanego. Opłaty za mieszkania spółdzielcze były pięciokrotnie wyższe od czynszów za tzw. mieszkania kwaterunkowe [Kaczorowski 1963]. Model akumulacyjno-interwencyjny nie przyczynił się do istotnego przyspieszenia budownictwa mieszkaniowego. Niskie stawki czynszów rodziły negatywne skutki ekonomiczne i społeczne: odbijały się negatywnie na możliwości utrzymania zasobu we właściwym stanie [Kucharska-Stasiak 1990], stwarzały nierównomierne obciążenie ludności wydatkami na mieszkanie, model doprowadził do rozwarstwienia społecznego, do korzystania z tzw. renty czynszowej przez osoby, która zamieszkiwały zasoby komunalne w relacji do osób zamieszkujących zasób spółdzielczy.

W latach 90. zarówno w krajach zachodnich, jak i w państwach postkomunistycznych polityka mieszkaniowa uległa dynamicznej zmianie. Na Zachodzie

1 W Polsce Dekretem Komitetu Wyzwolenia Narodowego z 7.09.1944 r. o komisjach mieszkaniowych (Dz.U., nr 4, poz. 18) zamrożono czynsze za mieszkania na poziomie z 1939 r. 
stanowiło to efekt przekonania o zawodności państwa², co spowodowało reformy na obszarze polityki społecznej, w krajach Europy Środkowej i Wschodniej również efekt transformacji. Hasło „mniej państwa, więcej rynku” utorowało drogę do ożywienia dyskusji nad modelami polityki mieszkaniowej, przyczyniając się do rozszerzenia ich klasyfikacji.

Klasyfikacja ta nie jest jednolita. Uzależniona jest ona od stosowanych metod analizy systemów mieszkaniowych ${ }^{3}$. Dwie z tych analiz: analiza dywergencji, zwana metodą pośrednią i analiza konwergencji, zwana metodą uniwersalną otworzyły drogę bogatej klasyfikacji modeli polityki mieszkaniowej [Kemeny, Lowe 1998].

$\mathrm{W}$ metodzie pośredniej stworzone zostały wyidealizowane wzorce, $\mathrm{z}$ którymi porównuje się poszczególne systemy mieszkaniowe. W literaturze wyróżniono trzy zasadnicze typologie tych modeli [za: Lis 2005]:

a) typologia J. Barlowa i S. Duncana,

b) typologia J. Kemeny,

c) typologia J. Dolinga bazująca na typologii G. Ambrose.

W 1994 r. Barlow i Duncan, rozwijając klasyfikację D. Donnisona [Cesarski 2010, s. 26], wyróżnili cztery modele: rudymentarny, liberalny, korporacyjny i socjaldemokratyczny. Podstawą klasyfikacji były takie kryteria, jak: stopień subsydiowania mieszkań, kontrola i regulacje cen i czynszów mieszkań, alokacja mieszkań i organizacja nowego budownictwa mieszkaniowego. Model rudymentarny to odpowiednik modelu embrionalnego w klasyfikacji D. Donnisona. Występuje on w państwach południowej Europy, takich jak: Grecja, Hiszpania, Portugalia,

2 Teoria zawodności państwa rozwijana była w ramach ekonomii wyboru publicznego (public choice theory), zaliczanej do ekonomii instytucjonalnej. Zajmuje się ona badaniem popytu i podaży dóbr publicznych. Teoria ta, rozwijana m.in. przez J. Buchanana koncentruje się nie na wadach rynku, ale na wadach rozwiązań rządowych, dotyczących spraw ekonomicznych. Twórcy tej koncepcji (Buchanan i Tullock) wady rozwiązań upatrują w tym, że jednostki podejmujące wyborów publicznych dokonują ich przede wszystkim w oparciu o własny interes [Legiędź 2005, s. 277-283].

3 Lis podaje trzy metody badania systemów mieszkaniowych [Lis 2005]:

1) metodę szczegółową, która ma charakter empiryczny, traktuje każde państwo jako system jedyny w swym rodzaju, co uniemożliwia zastosowanie wyników badań w ramach innych systemów mieszkaniowych;

2) metodę pośrednią, która posługuje się analizą dywergencji, umożliwia typologię poszczególnych systemów mieszkalnictwa, wynikających z kulturowych, ideologicznych, politycznych uwarunkowań gospodarki lub które są rezultatem wykorzystania istniejących teorii ekonomii i/lub socjologii. Metoda ta umożliwia przełożenie wyników badań na podobne (według stosowanych kryteriów) systemy mieszkaniowe;

3) metodę uniwersalną, posługującą się analizą konwergencji. Zakłada ona, że wszystkie państwa są postrzegane jako podmioty podlegające temu samemu nadrzędnemu imperatywowi przemian. Oznacza to, że po spełnieniu określonych założeń uzasadnione jest przenoszenie rozwiązań pomiędzy systemami mieszkaniowymi. Oparcie analizy systemów mieszkaniowych na metodzie pośredniej i uniwersalnej pozwala wyróżnić modele polityki mieszkaniowej. 
Włochy, szczególnie ich południowa część. Cechuje go duży udział mieszkań właścicieli-użytkowników, niewielki udział mieszkań społecznych. W modelu liberalnym występuje prorynkowe nastawienie, państwo ingeruje i pomaga w nieznaczny sposób. Państwo wspomaga tylko niewielką część społeczeństwa o bardzo niskich dochodach. Taki model jest widoczny w Stanach Zjednoczonych, Australii, w mniejszym stopniu w Wielkiej Brytanii i Irlandii. W modelu korporacyjnym państwo odgrywa aktywną rolę na etapie dostarczania zasobu mieszkaniowego. Model ten funkcjonuje w Austrii, Niemczech, we Włoszech i Belgii. W modelu socjaldemokratycznym silnie realizowane są cele społeczne. Celem alokacji zasobów jest zaspokojenie potrzeb mieszkaniowych. Państwo ingeruje w ustalanie cen i czynszów mieszkań. Modele korporacyjny i socjaldemokratyczny odpowiadają modelowi kompleksowemu u D. Dennisona.

W dyskusjach nad socjaldemokratycznym modelem polityki mieszkaniowej podkreśla się konieczność oparcia go na:

1) dążeniu do zarządzania ryzykiem na szczeblu rynku nieruchomości (tłumienie wahań cen domów poprzez stymulację rozwoju rynku mieszkaniowego za pomocą różnych instrumentów polityki mieszkaniowej, uzależnionych od fazy cyklu rynku mieszkaniowego) oraz na dążeniu do zmniejszania ryzyka na szczeblu indywidualnych gospodarstw domowych nie tyle przez przyznawanie zasiłków mających charakter jałmużny, ale przez podanie przez państwo ręki w procesie inwestowania we własną przyszłość przede wszystkim przez oświatę i naukę;

2) rozwijaniu mechanizmów solidarności społecznej widocznej np. w dbałości o jakość sąsiedztwa;

3) dążeniu do kontroli dostępu do publicznych mieszkań czynszowych i umacnianiu poczucia własnej wartości poprzez udzielanie „regenerującej pomocy społecznej", która umożliwia im wybory mieszkaniowe zgodne z własnym stylem życia [Clapham 2006, s. 55-76].

Metodę pośrednią, czyli analizę dywergencji, stosował Kemeny. Podstawą wyróżnienia modeli jest rola publicznego mieszkalnictwa czynszowego w zasobie mieszkaniowym. Pozwoliło mu to wyróżnić dwa modele: model dualny i unitarny. W modelu dualnym, który występuje głównie w krajach anglosaskich, zasób państwowy i prywatny uczestniczy w zaspokajaniu potrzeb, nie konkurując ze sobą, ma bowiem różnych adresatów. Sektor publiczny zaopatruje w mieszkania tylko najbiedniejszą część społeczeństwa. W modelu unitarnym, który występuje m.in. w Szwecji, Holandii, Niemczech i Szwajcarii, znaczącą rolę odgrywa sektor publiczny, który konkuruje z sektorem prywatnym.

Szersze ujęcie modelowe prezentuje typologia zaprezentowana przez J. Dolinga, który wyróżnił model liberalny, socjalistyczny, korporacyjny oraz azjatycki. Oznacza to, że typologia ta może być zastosowana do klasyfikacji także państw azjatyckich byłego bloku wschodniego. W modelu liberalnym mieszkanie postrzegane jest jako dobro prywatne, rola państwa jest nieznaczna. Dominuje zasób mieszkań 
własnościowych lub prywatnych czynszowych. W modelu socjalistycznym, który identyfikowany jest w krajach Europy Środkowo-Wschodniej, Europy Południowo-Wschodniej i w krajach nadbałtyckich, inicjatorem rozwoju, przebiegu procesu budowy i podziału zasobu jest państwo ustalające czynsze na minimalnym poziomie. W wyróżnionym przez J. Dolinga modelu korporacyjnym, który funkcjonuje w Szwecji, Danii i Holandii, państwo odgrywa znaczącą rolę w produkcji budowlanej, ilości i rodzaju oddawanych mieszkań, ich lokalizacji. W modelu azjatyckim, który występuje w Hongkongu i Singapurze, Tajwanie, w Izraelu i Korei Południowej za etap rozwoju mieszkalnictwa odpowiada państwo: organizuje środki finansowe, udostępnia grunty, ustala plany zagospodarowania przestrzennego. Zasadom rynkowym podlega etap budowy i konsumpcji.

Stosowanie metody uniwersalnej, opartej na analizie konwergencji, zmierza do poszukiwania praw uniwersalnych, które determinują rozwój systemów mieszkaniowych niezależnie od różnic kulturowych, politycznych i społecznych. Stosowanie metody uniwersalnej stało się podstawą wyróżnienia przez ekspertów Banku Światowego - S. Angel i S. Mayo modelu rynkowego polityki mieszkaniowej [Lis 2008, s. 30]. Model promuje własność prywatną. Główną tezą modelu jest oparcie rozwoju sektora mieszkaniowego na ograniczaniu wpływu państwa opiekuńczego i promowaniu prywatyzacji zasobu mieszkaniowego. W modelu tym państwo przyjmuje rolę koordynatora sektora mieszkaniowego, który nie tylko koordynuje, ale także usprawnia jego funkcjonowanie. Model ten przewiduje tylko nieznaczną pomoc socjalną w postaci dodatków mieszkaniowych i publicznego budownictwa, zaadresowanego jedynie do najbiedniejszych uczestników rynku. Model promuje trzy instrumenty po stronie popytowej (ochrona praw własności do nieruchomości, rozwój i regulacje instytucji finansujących mieszkalnictwo i racjonalizację subsydiów mieszkaniowych) oraz trzy instrumenty strony podażowej (regulacje dotyczące zagospodarowania przestrzennego, budowa i konserwacja urządzeń infrastruktury technicznej oraz organizacja sektora budownictwa mieszkaniowego), a także jeden instrument administracyjny w postaci rozwoju instytucji umożliwiających i wspierających zarządzanie sektorem budownictwa mieszkaniowego [Lis 2008, s. 27]. Zastosowanie poszczególnych instrumentów uwarunkowane jest poziomem rozwoju gospodarczego i instytucjonalnego. Efektem tych założeń było wyróżnienie czterech grup państw: (1) państw o niskim dochodzie narodowym (Tanzania, Bangladesz); (2) wysoko zadłużonych państw o średnim dochodzie narodowym (Argentyna, Brazylia); (3) byłych państw o gospodarce centralnie planowanej (kraje Europy Środowo-Wschodniej, Południowo-Wschodniej i kraje nadbałtyckie; (4) pozostałych państw o średnim dochodzie narodowym (Korea Południowa, Malezja).

Zastosowanie metody konwergencji posłużyło do skonstruowania na początku lat 90. XX w. modelu systemu mieszkaniowego dla byłych państw gospodarki centralnie planowanej. Autorzy tego modelu J. Hegedus i I. Tosics wykazywali, że w państwach Europy Wschodniej przyjmowane były podobne założenia, dotyczące 
polityki mieszkaniowej: decyzje dotyczące ilości oddawanych mieszkań, ich rodzaju i lokalizacji podejmowane były centralnie, zasób tworzony był przez przedsiębiorstwa państwowe, kryterium alokacji były potrzeby mieszkaniowe, a nie możliwości finansowe gospodarstw domowych, brak barier finansowych na etapie przydziału mieszkań, a także użytkowania z uwagi na niskie czynsze, wyłączenie mechanizmu rynkowego i własności prywatnej [Lis 2008, s. 30]. Założenia tego modelu nigdy nie zostały w pełni wdrożone. Zadecydowała o tym mała aktywność państw na obszarze gospodarki mieszkaniowej, priorytetem był rozwój przemysłu. Mieszkalnictwo w tych państwach traktowane było jako część sektora opieki społecznej, a nie część gospodarki poddawanej ocenie efektywności ekonomicznej. Deficyt środków finansowych przeznaczanych na gospodarkę mieszkaniową potęgował deficyt mieszkań. Środkiem zaradczym była własność prywatna i dopuszczenie mechanizmu rynkowego do gospodarki mieszkaniowej. Widoczne to było w postaci rozwoju spółdzielczości mieszkaniowej i budownictwa indywidualnego.

Przechodzeniu do gospodarki rynkowej towarzyszyły w tych państwach wspólne problemy $\mathrm{w}$ gospodarce mieszkaniowej. Wspólnym elementem poszukiwań było sięgnięcie po wzorce zaoferowane przez instytucje międzynarodowe, takie jak: Bank Światowy i USAID. Zaowocowało to podobnymi scenariuszami przemian w polityce mieszkaniowej, takimi jak: zmiany własnościowe zasobów mieszkaniowych, a także wzrost roli lokalnych władz w polityce mieszkaniowej. Obok wspólnych kierunków przemian, stanowiących dowody konwergencji systemów mieszkaniowych, w tej części Europy wykazywały one różnice. Dotyczyły one zmian w publicznym zasobie mieszkań na wynajem. Nie doszło do wykształcenia się jednego modelu, wytworzyły się dwa modele reform publicznego zasobu na wynajem [Lis 2008, s. 34]. W takich państwach, jak: Bułgaria, Litwa, Rumunia, Słowenia i Węgry wytworzył się model rezydualny publicznego zasobu mieszkaniowego. Cechował go niewielki udział publicznych mieszkań na wynajem i niewielki wzrost czynszów. Drugi model, nazwany modelem całościowym, odznaczał się dużym udziałem tego sektora w zasobie i wysokimi wzrostami czynszów.

Jednym $\mathrm{z}$ istotnych podejść stosowanych w ostatnich latach do klasyfikacji modeli mieszkaniowych jest oparcie się na sposobie akumulacji majątku. Wydaje się, że powiązanie mieszkalnictwa i majątku należy do bardzo interesujących i aktualnych zagadnień, należących do podstawowych problemów współczesnego kapitalizmu [Harvey 2005; Ronald, Dewilde 2017]. Polityka mieszkaniowa była przez dziesięciolecia częścią nowoczesnych systemów politycznych, aczkolwiek jej stosowanie w praktyce generowało liczne problemy o charakterze zarówno gospodarczym, jak i społecznym, dowodem tego było chociażby powszechnie powtarzane zdanie o mieszkalnictwie jako niestabilnym filarze gospodarki państwa dobrobytu [Torgersen 1987]. Przekształcenia w podejściu do dobra, jakim są prawa do mieszkania, doprowadziły do nowego spojrzenia na rolę i znaczenie rynku mieszkaniowego.

Podejście oparte na sposobie akumulacji majątku mieszkaniowego ewoluuje pod wpływem nowych zjawisk gospodarczo-społecznych i politycznych. Główne 
kryteria, na których jest oparte, to poziom własności oraz sposób finansowania, co jest powiązane ze znaczeniem inwestycyjnym jednostek mieszkalnych. W wersji wcześniejszej wyróżniono 5 odrębnych sposobów akumulacji majątku mieszkaniowego: rozwijający się śródziemnomorski (developing Mediterranean), rozwijający się dzięki prywatyzacji (developing privatisation), ograniczony czynszowy (restricted rental), regulowanego wzrostu (regulated expansion) i liberalnego wzrostu (liberal expansion) [Dewilde, De Decker 2016]. Natomiast w wersji późniejszej autorzy wskazali już siedem grup państw o odrębnych modelach mieszkaniowych (por. tabela 2.1) [Wind, Lersch, Dewilde 2017]. Mamy tu wyróżniony model regulowany czynszowy (regulated rental), sprywatyzowany czynszowy (privatised rental), regulowanego wzrostu (regulated expansion), liberalnego wzrostu (liberal expansion), własności rodzinnej (family ownership), sprywatyzowany własnościowy (privatised ownership) i liberalny własnościowy (liberal ownership). Ten podział wskazuje, które podmioty mają dostęp do własności (w jakim wieku i za jaką cenę), w jakim stopniu mogą czerpać korzyści ze wzrostu rynku mieszkaniowego i są narażone na straty związane $z$ jego stanem.

Tabela 2.1. Systemy akumulacji majątku mieszkaniowego a dominujący sposób władania nieruchomościami mieszkaniowymi

\begin{tabular}{|l|c|c|c|c|c|}
\hline \multirow{2}{*}{$\begin{array}{c}\text { Systemy } \\
\text { akumulacji majątku } \\
\text { mieszkaniowego }\end{array}$} & \multirow{2}{*}{ Państwo } & \multicolumn{4}{|c|}{ Poziom własności (\%) } \\
\cline { 3 - 6 } & & $\mathbf{1 9 6 0}$ & $\mathbf{1 9 8 0}$ & $\mathbf{2 0 1 0}$ & $\mathbf{2 0 1 7}$ \\
\hline \multirow{2}{*}{ Regulowany czynszowy } & Niemcy & 29 & 30 & 53 & 51 \\
& Austria & 38 & 52 & 57 & 55 \\
\hline \multirow{2}{*}{ Sprywatyzowany } & Estonia & b.d. & 26 & 86 & 82 \\
czynszowy & Polska & b.d. & 36 & 81 & 84 \\
& Czechy & b.d. & 53 & 79 & 79 \\
\hline \multirow{2}{*}{ Regulowanego wzrostu } & Belgia & 50 & 59 & 72 & 73 \\
& Francja & 42 & 47 & 62 & 64 \\
\hline \multirow{3}{*}{ Liberalnego wzrostu } & Dania & 40 & 56 & 67 & 62 \\
& Szwecja & 47 & 58 & 56 & 65 \\
\hline \multirow{2}{*}{ Własności rodzinnej } & Holandia & 30 & 42 & 67 & 69 \\
\hline Sprywatyzowany & Włochy & 46 & 59 & 72 & 72 \\
własnościowy & Portugalia & 45 & 52 & 75 & 75 \\
\hline Liberalny własnościowy & Słowenia & b.d. & 69 & 78 & 76 \\
\hline
\end{tabular}

Źródło: opracowanie własne na podstawie [Wind, Lersch, Dewilde 2017, s. 628].

Modele o charakterze czynszowym w przeszłości, różnią się obecnie znacząco. Można tu wskazać niektóre państwa Europy Zachodniej i postsocjalistyczne. 
Wcześniej ograniczony dostęp do kredytów hipotecznych oraz szeroka oferta najmu, który nie był negatywnie postrzegany społecznie, powodowały popularność segmentu czynszowego. Niemcy i Austria stosowały instrumenty polityki mieszkaniowej, których celem było wspieranie dostosowanej do potrzeb struktury ilościowej i jakościowej segmentu najmu, system finansowania nabycia własności był raczej konserwatywny w porównaniu $\mathrm{z}$ innymi państwami [Wind, Lersch, Dewilde 2017]. Obecnie popularność własności jest większa niż w latach 80., ale znacznie mniejsza $\mathrm{w}$ porównaniu $\mathrm{z}$ innymi państwami, $\mathrm{w}$ szczególności postsocjalistycznymi, których polityka mieszkaniowa także była wcześniej nastawiona na wspieranie sektora najmu. W państwach postsocjalistycznych występuje najwyższy udział właścicieli, ale wynika to ze sposobu przeprowadzenia prywatyzacji. Można wskazać, że problemy mogą istnieć w grupach pokoleniowych - ci, którzy wzięli udział w prywatyzacji są na znacznie lepszej pozycji niż młode pokolenia, które muszą polegać na systemie rynkowym. Nie można tu oczywiście zapominać o transferach międzypokoleniowych, ale problemem może być stałość lokalizacji zasobu mieszkaniowego i niedostosowanie rozkładu przestrzennego zasobu mieszkaniowego do obecnych potrzeb mieszkaniowych, wynikających z uwarunkowań społeczno-gospodarczych.

Dwa modele wzrostu własności - regulowanego i liberalnego obejmują określone państwa Europy Północnej i Zachodniej. Jako część polityki powojennej odbudowy stymulowano $\mathrm{w}$ tych państwach nabywanie mieszkań na własność, ale także rozwijano segment czynszowy. W krajach skandynawskich stosowano rozwiązania, które miały umożliwić nabycie także osobom mniej zamożnym, natomiast w Danii, Holandii i Francji deregulacja systemu finansowego przejawiająca się w zwiększeniu dostępności kredytów hipotecznych (dzięki rozwojowi papierów wartościowych opartych na kredytach hipotecznych, wydłużeniu okresu spłaty, zwiększeniu kwoty kredytu w stosunku do wartości nieruchomości) sprzyjała nabywaniu mieszkań na własność przez osoby co najmniej średniozamożne.

Modele tradycyjnie popierające własność to model wsparcia rodzinnego, który dotyczy wybranych państw Europy Południowej, ale także potransformacyjnych Węgier i Słowenii. W tych krajach rola państwa w zaspokajaniu potrzeb mieszkaniowych obywateli była ograniczona, sektor czynszowy, społeczny był niewielki, prywatyzacja zasobu została przeprowadzona po II wojnie światowej. Ze względu na brak rozwiniętego systemu finansowania i tolerowanie samowoli budowlanych podstawowe znaczenie miało wsparcie rodzinne [Allen 2006]. $Z$ biegiem czasu system finansowy rozwinął się, a tolerancja dla samowoli zmniejszyła, jednak brak rozwiniętego sektora czynszowego społecznego w dalszym ciągu skazywał część potencjalnych nabywców, w szczególności młodych, na korzystanie ze wsparcia rodziny.

Węgry i Słowenia klasyfikowane są jako model sprywatyzowany własnościowy ze względu na wysoki poziom własności w przeszłości. Konieczność korzystania ze wsparcia rodzinnego po wycofaniu się państwa z pomocy mieszkaniowej i szeroka prywatyzacja, skutkująca wysokim poziomem własności charakteryzują te państwa. 
Hiszpania jest jedynym krajem reprezentującym model własnościowy liberalny, została tak sklasyfikowana ze względu na odrębność przemian, których doświadczyła. W latach 90. wprowadzono tam bowiem liberalne zasady finansowania rynku mieszkaniowego, co przyczyniło się do wzrostu popytu na mieszkania i boomu budowlanego [Cano Fuentes i in. 2013]. Dotychczasowy model wsparcia rodzinnego przekształcił się w model oparty na systemie finansowym.

Dyskusje nad klasyfikacjami modeli, szczególnie w zakresie terminologii, nie ustają [Cesarski 2010a, s. 23-33]. Uznaje się, że typologie systemów mieszkaniowych znajdują się w fazie rozwoju zarówno na etapie teoretycznych ich założeń, jak i aplikacji [Lis 2008, s. 23]. Z pewnością jednym z czynników warunkujących kierunek dyskusji i wprowadzanie dalszych zmian w modelach polityki mieszkaniowej są doświadczenia globalnego kryzysu finansowego z 2008 r. W okresie poprzedzającym kryzys w warunkach niskich stóp procentowych euforia na rynkach mieszkaniowych zarówno po stronie kredytobiorców, jak i kredytodawców wywołała zjawisko bańki cenowej, wzrosły wartości udzielanych kredytów. Nadużywanie kredytów kierowanych na upowszechnianie indywidualnej własności mieszkaniowej stało się przyczyną wybuchu kryzysu. Załamanie rynków nieruchomości mieszkaniowych, zakończone kryzysem w sferze finansowej i realnej, spowodowało wzrost zadłużenia gospodarstw domowych, spadek dostępności kredytów hipotecznych, co postawiło pod znakiem zapytania koncepcje zaspokajania potrzeb tylko poprzez nabywanie własności, szczególnie przez gospodarstwa o średnich dochodach. Może to oznaczać zwrot modeli polityki mieszkaniowej w kierunku rozwoju budownictwa publicznego bądź społecznego [Polakowski i in. 2017]. Zmiany w modelach polityki mieszkaniowej świadczą o istotnym wpływie zmian zachodzących w politycznych koncepcjach ekonomicznych. Przyjmowanie błędnych kierunków polityki mieszkaniowej stanowi element błędnego paradygmatu wzrostu ekonomicznego [Cesarski 2013b].

\subsection{Instrumenty polityki mieszkaniowej}

Realizacja założeń przyjętej polityki mieszkaniowej opiera się na zastosowaniu konkretnych instrumentów, ze względu na ich bardzo duże zróżnicowanie trudno jest dokonać klasyfikacji, która w sposób kompleksowy i jednoznaczny ujęłaby je wszystkie. Jednymi z najczęściej stosowanych kryteriów, pomagających odróżnić poszczególne narzędzia polityki mieszkaniowej jest to, czy działają po stronie popytowej, czy podażowej [Clapham i in. 2012]. Nie jest ono jednak bez wad, ponieważ niektóre instrumenty należą do obydwu klas, w zależności od stosującego je podmiotu. Inne kryteria klasyfikacji to np. wsparcie określonych typów władania czy bezpośredniość, jawność wsparcia [Salvi del Pero i in. 2016]. 
Zestawienie najważniejszych instrumentów polityki mieszkaniowej zawiera tabela 2.2. Największy wybór rozwiązań widoczny jest w kategorii dotyczącej wsparcia własności, wymieniono tu 8 różnych instrumentów. Według badań OECD wsparcie własności jest najbardziej powszechnym instrumentem polityki mieszkaniowej, nawet jeśli państwo deklaruje wsparcie mieszkalnictwa czynszowego, to stosuje też narzędzia ułatwiające dostęp do własności [OECD QuASH 2014]. Do poparcia ideologicznego takiego działania stosuje się argumenty przemawiające za dobrostanem gospodarstw domowych - właścicieli i otoczenia nieruchomości [Glaser 2011; McCabe 2016], natomiast nie można nie zauważyć, że dla niezamożnych gospodarstw domowych własność może być obciążeniem ponad uzyskiwane korzyści [Norris, Winston 2011; Norris, Coates 2014; Köppe 2017]. Innym argumentem o charakterze polityczno-gospodarczo-społecznym popierającym własność jest to, że akumulacja majątku mieszkaniowego przez osoby starsze, które mają problemy finansowe w wieku emerytalnym i niechętnie zmieniają miejsce zamieszkania, pozwala im wzmocnić się finansowo dzięki wykorzystaniu hipoteki odwróconej [European Commission 2015; Müller 2019]. Jednakże istnieją także negatywne strony takiego rozwiązania [Fornero, Rossi, Brancati 2016].

Należy również zauważyć, że wsparcie nabywania własności przy ograniczonej podaży generuje wzrost cen, co ogranicza dostępność mieszkań dla mniej zamożnych. Ze względu na niską płynność nieruchomości i wysokie koszty transakcyjne własność ogranicza także mobilność w związku z poszukiwaniem pracy.

Tabela 2.2. Zestawienie instrumentów polityki mieszkaniowej

\begin{tabular}{|l|l|}
\hline \multicolumn{1}{|c|}{ Kategoria } & \multicolumn{1}{c|}{ Narzędzia polityki mieszkaniowej } \\
\hline \multicolumn{1}{|c|}{1} & \multicolumn{1}{c|}{2} \\
\hline \multirow{5}{*}{ Wsparcie własności } & Granty na zakup na własność \\
\cline { 2 - 3 } & Pomoc finansowa w dostępie do własności \\
\cline { 2 - 3 } & Ulgi podatkowe w dostępie do własności \\
\cline { 2 - 3 } & Dopłaty do nowego budownictwa na własność \\
\cline { 2 - 3 } & Wykup częściowy (rent-to-buy) \\
\cline { 2 - 3 } & Ulgi w wypadku problemów ze spłatą kredytu hipotecznego \\
\cline { 2 - 3 } & Dopłaty w wypadku modernizacji energetycznej i regeneracji \\
\cline { 2 - 3 } & Opodatkowanie nieruchomości mieszkaniowych \\
\hline Dodatki mieszkaniowe & W gotówce lub w formie voucherów \\
\hline Mieszkalnictwo społeczne & Zasób społeczny \\
\cline { 2 - 3 } & Opodatkowanie zasobu społecznego \\
\cline { 2 - 3 } & Dopłaty do nowego budownictwa mieszkań społecznych \\
\hline
\end{tabular}




\begin{tabular}{|l|l|}
\hline \multicolumn{1}{|c|}{1} & \multicolumn{1}{c|}{2} \\
\hline \multicolumn{1}{|c|}{ Kategoria } & \multicolumn{1}{c|}{ Narzędzia polityki mieszkaniowej } \\
\hline $\begin{array}{l}\text { Regulacja czynszów } \\
\text { i wsparcie w zakresie } \\
\text { opłacania czynszu }\end{array}$ & Dopłaty do nowego budownictwa czynszowego \\
\cline { 2 - 2 } & Opodatkowanie mieszkań czynszowych prywatnych \\
\cline { 2 - 2 } & Ulgi podatkowe dla najemców z tytułu opłaconego czynszu \\
\cline { 2 - 2 } & Kontrola czynszu w segmencie mieszkań czynszowych \\
\cline { 2 - 2 } & Gwarancje wysokości czynszu \\
\cline { 2 - 2 } & Regulacja prawna sytuacji najemców \\
\hline
\end{tabular}

Źródto: opracowanie na podstawie [Salvi del Pero i in. 2016, s. 29].

Bliższe zapoznanie się z dostępnymi instrumentami polityki mieszkaniowej wymaga ich krótkiego scharakteryzowania. Jak wskazano już wcześniej, w zasadzie każde państwo spośród badanych wykorzystywało narzędzia promujące własność. W tej grupie wymieniono 8 możliwych rozwiązań: granty na zakup własności mieszkania, pomoc finansowa w dostępie do własności, ulgi podatkowe w dostępie do własności, dopłaty do nowego budownictwa na własność, wykup częściowy (rent-to-buy), ulgi w wypadku problemów ze spłatą kredytu hipotecznego, dopłaty w wypadku modernizacji energetycznej i regeneracji, sposób opodatkowania nieruchomości mieszkaniowych.

Granty na nabycie własności mają postać jednorazowej pomocy finansowej w związku z uzyskaniem prawa własności do mieszkania. Pomoc finansowa natomiast jest związana $\mathrm{z}$ korzystaniem $\mathrm{z}$ kredytu hipotecznego przez beneficjenta i może polegać na niższym niż rynkowe oprocentowaniu kredytu mieszkaniowego, gwarancji dla kredytodawcy udzielonej przez podmiot publiczny, pomocy w zgromadzeniu wkładu własnego przez kredytobiorcę. Inny obszar, w którym występuje publiczne wsparcie własności, to polityka podatkowa. Może ona mieć postać ulg podatkowych w podatkach i opłatach płaconych z tytułu przeniesienia własności (np. podatek od czynności cywilnoprawnych, opłaty sądowe) oraz możliwości dokonania odliczeń od dochodu przed opodatkowaniem lub odliczeń od podatku płatności związanych z obsługą kredytu mieszkaniowego. Niskie stawki podatkowe oraz ulgi mogą także być stosowane w odniesieniu do opodatkowania nieruchomości mieszkalnych w porównaniu z innymi rodzajami nieruchomości.

Pomoc dla strony podażowej to dofinasowanie budownictwa mieszkaniowego na własność, obwarowana jest ona wieloma zastrzeżeniami o charakterze prawnym, ponieważ nie może prowadzić do zaburzenia konkurencyjności i wystąpienia pomocy publicznej.

Inny sposób wsparcia - nabywanie udziałów we własności użytkowanego mieszkania pozwala na stopniowe dojście do własności bez konieczności jednorazowego i znacznego wydatku lub zaciągnięcia zobowiązania finansowego. Ma to szczególne 
znaczenie dla tych gospodarstw domowych, które nie mają zdolności kredytowej, a aspirują do bycia właścicielami.

Światowy kryzys gospodarczy zwrócił uwagę na problem niemożności wywiązania się z zaciągniętych długów, także hipotecznych w wypadku dekoniunktury gospodarczej. W odpowiedzi na ten problem można zastosować instrumenty pozwalające na "przeczekanie" złej sytuacji przez gospodarstwa domowe obciążone kredytami mieszkaniowymi. Konkretne regulacje prawne mogą zamrozić sprzedaż licytacyjną za długi lub w inny sposób wspomóc właścicieli w trudnym położeniu.

Dofinansowanie poprawy efektywności energetycznej i rewitalizacji (regeneracji) to następny instrument wśród wspierających własność. Ma to znaczenie dla zapobiegania katastrofie klimatycznej i szczególnie dotyczy mniej zamożnych gospodarstw domowych, które nie byłyby w stanie finansowo sprostać wymianie lub modernizacji urządzeń grzewczych.

Druga grupa instrumentów pomocy to dodatki mieszkaniowe w postaci gotówkowej albo specjalnych vaucherów. Stosuje się je, aby wspomóc gospodarstwa domowe w pokrywaniu kosztów użytkowania mieszkania. Wysokość dodatków uzależniona jest od ponoszonych kosztów mieszkaniowych i składu gospodarstwa domowego. Uprawnione są do niej podmioty spełniające określone kryteria, najczęściej ich dochód nie może przekraczać określonego limitu, często także wielkość mieszkania nie może przekraczać określonego metrażu. W niektórych państwach pomoc $\mathrm{w}$ postaci dodatków mieszkaniowych jest przyznawana niezależnie od formy władania mieszkaniem przez beneficjenta, czyli może ją otrzymać również właściciel. Różnice pomiędzy poszczególnymi regulacjami dotyczą także sposobu wypłaty, często dodatki są przekazywane z pominięciem beneficjenta, bezpośrednio właścicielowi mieszkania lub zarządcy. Ten instrument polityki mieszkaniowej ma wiele odmian, skutki, jakie wywołuje, także różnią się między sobą [McCrone, Stephens 2017; Howenstine 2017]. Można wskazać, że jego stosowanie nie oznacza stygmatyzacji, jaka często jest związana z zamieszkiwaniem w zasobie społecznym. W przypadku dodatków mieszkaniowych beneficjent dokonuje swobodnego wyboru miejsca zamieszkania. W literaturze wskazuje się na pewne negatywne aspekty, przede wszystkim związane z niebezpieczeństwem wzrostu stawek czynszu pod wpływem świadomości właścicieli zasobu mieszkaniowego, że koszty te poniesie podmiot publiczny [Laferrère, Le Blanc 2004].

Trzecia grupa instrumentów polityki mieszkaniowej dotyczy zasobu mieszkań społecznych. Wyróżniono tutaj narzędzia dotyczące udostępniania, opodatkowania i wspierania aktywności budowlanej mieszkań społecznych. Jak wskazano w punkcie $2.1, \mathrm{w}$ ramach różnych modeli mieszkaniowych wyodrębniono dwa główne systemy dotyczące miejsca zasobu społecznego w zasobie całkowitym - powszechny i rezydualny, jednak w praktyce obserwuje się przemieszanie właściwych dla nich elementów. Pierwszy charakteryzowała powszechna dostępność mieszkań społecznych, co miało swój wyraz w wielkości zasobu mieszkań społecznych oraz cenie ich udostępniania, a także konkurencji z prywatnym segmentem 
mieszkań na wynajem [szerzej: Kemeny 1995]. Najpełniej model ten był realizowany w Szwecji, jego elementy widoczne były także w Holandii i Danii. Zaletą tego modelu był zmniejszony rozmiar stygmatyzacji wynikającej z mieszkania w zasobie społecznym (przemieszanie najemców $\mathrm{z}$ różnych grup społecznych, o zróżnicowanych dochodach). Natomiast system rezydualny polegał na przydziale mieszkań społecznych tylko ograniczonej grupie osób [Szelągowska 2011].

Istotnym czynnikiem, który pojawił się w ostatnich latach i znacząco wpływa na podejście podmiotów publicznych do realizacji zadań w postaci pomocy mieszkaniowej, było sformułowanie przez Komisję Europejską definicji mieszkań społecznych [Communication from the Commission 2012]. Definicja ta zawęziła je do mieszkań dla najbardziej potrzebujących, takie ujęcie pozwala na sklasyfikowanie mieszkalnictwa społecznego jako usługi w ogólnym interesie gospodarczym, a pomoc publiczna, rekompensując straty wywołane przede wszystkim zredukowanymi stawkami czynszu, może przyjmować postać obniżonej ceny za grunt pod budownictwo społeczne, przywilejów podatkowych czy specjalnych gwarancji kredytowych. Definicja przyjęta przez KE była wynikiem problemów, jakie pojawiały się na styku konieczności zachowania konkurencji i pomocy publicznej [Priemus, Gruis 2011]. Oznaczało to jednak konieczność wprowadzenia zmian $\mathrm{w}$ istniejących systemach.

Różnice pomiędzy poszczególnymi rozwiązaniami wykorzystania zasobu społecznego dotyczą, poza samą jego wielkością i dystrybucją, także tego, kto ma go dostarczać oraz w jakiej jakości i za jaką cenę. W wielu państwach obecnie prowadzi się działania zmierzające do ograniczenia znaczenia podmiotów publicznych jako właścicieli zasobu i zachęcania prywatnych inwestorów do udziału w dostarczaniu mieszkań społecznych. Od lat budują i zarządzają takimi mieszkaniami podmioty non-profit [Fields, Uffer 2016; Poggio, Whitehead 2017].

$\mathrm{W}$ wielu państwach podmiotami odpowiedzialnymi za pomoc w zaspokajaniu potrzeb mieszkaniowych są samorządy lokalne, mogą się starać o dofinansowanie tworzenia nowego zasobu i modernizacji istniejącego. Dofinansowanie może być także przyznawane bezpośrednio podmiotom prywatnym, które dostarczają zasobu społecznego (może mieć również formę obniżenia ceny gruntu, przyznania niekomercyjnych kredytów, ulg podatkowych).

Samo wytworzenie zasobu społecznego nie kończy problemów z nim związanych, pojawia się bowiem pytanie o cenę udostępniania - związane jest to także z systemem dodatków mieszkaniowych. Użytkownicy to obecnie z założenia gospodarstwa domowe o ograniczonych możliwościach finansowych, z drugiej strony niezbędne są środki na zarządzanie i podtrzymanie standardu technicznego budynków [Scanlon, Fernández, Arrigoitia, Whitehead 2014].

Ostatnią wyróżnioną grupą instrumentów polityki mieszkaniowej jest regulacja czynszów i wsparcie w zakresie opłacania czynszu, wymieniono tu dopłaty do nowego budownictwa czynszowego, opodatkowanie mieszkań czynszowych prywatnych, ulgi podatkowe z tytułu opłaconego czynszu dla najemców, kontrolę czynszu 
w segmencie mieszkań czynszowych, gwarancje wysokości czynszu i regulację prawną sytuacji najemców. Ogólnie można podsumować wymienione środki jako istniejące w zróżnicowanym wymiarze od dziesięcioleci, uzależnione od przyjętych założeń politycznych i modeli mieszkaniowych. Kwestie związane z limitowaniem wysokości czynszu, jego kontrolą podlegały zmianom wynikającym ze zmian ideowo-politycznych oraz gospodarczych. Podobnie różne rozwiązania polityki podatkowej mogą stymulować lub destymulować powstawanie i funkcjonowanie zasobu prywatnych mieszkań czynszowych [Arnott 1995; Balchin 2013; O’Sullivan, De Decker 2007].

Realizacja założeń polityki mieszkaniowej wymaga wykorzystania jednocześnie co najmniej kilku instrumentów, według badań OECD przeprowadzonych w 29 państwach najmniejsza liczba stosowanych w jednym kraju rozwiązań to 6 instrumentów, wskazuje to wyraźnie na kompleksowość problematyki [OECD QuASH 2014].

Najczęściej używanymi instrumentami były dodatki mieszkaniowe, dofinansowanie poprawy efektywności energetycznej i rewitalizacji oraz pomoc finansowa w nabyciu mieszkań na własność. Najrzadziej korzystano z przywilejów podatkowych dla najemców, stopniowego dochodzenia do własności, dofinansowania budownictwa społecznego i gwarancji wysokości czynszu [OECD QuASH 2014].

\subsection{Społeczno-gospodarcze uwarunkowania rozwoju rynków mieszkaniowych od lat 50. do 80.}

Patrząc z perspektywy nie indywidualnego państwa, a grupy, która obecnie tworzy UE, można dostrzec pewne podobieństwa i różnice uwarunkowań społeczno-gospodarczo-politycznych, które wywołały określone zmiany struktury ilościowej i jakościowej zasobów mieszkaniowych. W Europie Zachodniej mieszkalnictwo stało się sprawą państwową wobec powszechnego powojennego dążenia społeczeństw do poprawy warunków życia i uznania, że każdy człowiek ma prawo do godnych warunków mieszkaniowych, co przy błędach rynku nie było możliwe bez ingerencji publicznej. Nie bez znaczenia było oddziaływanie - poprzez zagrożenie dla państw zachodnich - wdrażanych w życie teorii komunistycznych i socjalistycznych. W rezultacie nastąpiła dekomodyfikacja usługi mieszkaniowej, która przejawiała się w postaci regulowania rynku np. poprzez wprowadzenie kontroli czynszów w prywatnych zasobach mieszkaniowych czy przejęcie na siebie przez państwa obowiązku dostarczania mieszkań (mieszkania społeczne). Inna była ścieżka państw Europy Południowej i Centralnej. Podstawowa kwestia - zakres 
pomocy i jej rozmiar - była problemem o charakterze ideologiczno-politycznym. Można więc mówić o swoistych grupach - klubach państw o podobnych założeniach polityki mieszkaniowej i obserwować kierunki ewolucji tej polityki do czasów współczesnych.

Analiza kierunków zmian, podobieństw i różnic wykorzystywanych rozwiązań i ich rezultatów wymaga pewnego uproszczenia, schematu myślowego, który jest wyborem badającego. W niniejszej pracy oparto się na transformacji struktury własnościowej zasobu mieszkaniowego jako podstawowym elemencie otoczenia instytucjonalnego.

\subsubsection{Powojenne uwarunkowania demograficzne}

Skutki II wojny światowej nie były jednakowe dla państw europejskich, w niektórych zasób mieszkaniowy uległ poważnym zniszczeniom, w wielu silnie odczuwalne były migracje ze wsi do miast ze względu na rozwój przemysłu, ponadto widoczny był boom urodzeń. Zmiany granic i wywołane tym wielkie migracje także miały wpływ na sytuację i politykę mieszkaniową. Presja na zaspokojenie podstawowej potrzeby posiadania schronienia w niektórych państwach była bardzo silna, różnie ją realizowano, w zależności od hierarchii spraw przyjętej w ogólnokrajowej polityce.

Analiza historycznych danych demograficznych wskazuje, że w latach 1947-1954 we Francji, Niemczech Zachodnich, Włoszech, Polsce przybyło po kilka milionów mieszkańców, w Holandii, Hiszpanii i Wielkiej Brytanii także znacząco zwiększyła się populacja - por. tabela 2.3. W następnych latach ten trend się utrzymywał, co oznaczało konieczność podjęcia działań ułatwiających dostęp do mieszkań.

Tabela 2.3. Zmiany populacyjne w państwach europejskich od lat 30. do 70.

\begin{tabular}{|c|c|c|c|c|c|c|}
\hline \multirow{2}{*}{ Państwo } & \multicolumn{6}{|c|}{ Liczba ludności w mln } \\
\hline & 1937 & 1947 & 1954 & 1963 & 1971 & 1979 \\
\hline 1 & 2 & 3 & 4 & 5 & 6 & 7 \\
\hline Austria & 6,7 & 6,9 & 6,9 & 7,2 & 7,4 & 7,5 \\
\hline Belgia & 8,3 & 8,4 & 8,8 & 9,3 & 9,7 & 9,8 \\
\hline Bułgaria & 6,2 & 7,0 & 7,5 & 8,0 & 8,5 & 9,0 \\
\hline Czechosłowacja & 14,4 & 12,1 & 12,9 & 13,9 & 14,5 & 15,2 \\
\hline Dania & 3,7 & 4,1 & 4,4 & 4,6 & 5,0 & 5,1 \\
\hline Finlandia & 3,6 & 3,9 & 4,2 & 4,5 & 4,7 & 4,7 \\
\hline Francja & 41,9 & 41,0 & 43,0 & 47,8 & 51,2 & 53,5 \\
\hline Niemcy Zachodnie* & $(67,8)$ & $(67,3) 45,3$ & 49,5 & 55,4 & 59,1 & 61,3 \\
\hline
\end{tabular}


Tabela 2.3 (cd.)

\begin{tabular}{|l|r|r|r|r|r|r|}
\hline \multicolumn{1}{|c|}{1} & \multicolumn{1}{c|}{2} & \multicolumn{1}{c|}{3} & \multicolumn{1}{c|}{4} & \multicolumn{1}{c|}{5} & \multicolumn{1}{c|}{6} & 7 \\
\hline Niemcy Wschodnie & & 22,0 & 20,5 & 17,0 & 17,0 & 16,7 \\
\hline Grecja & 6,9 & 7,5 & 7,9 & 8,5 & 9,0 & 9,4 \\
\hline Węgry & 9,1 & 9,1 & 9,7 & 10,0 & 10,4 & 10,7 \\
\hline Irlandia & 2,9 & 3,0 & 3,0 & 2,8 & 2,9 & 3,3 \\
\hline Włochy & 42,6 & 45,3 & 47,6 & 50,6 & 54,0 & 56,9 \\
\hline Holandia & 8,6 & 9,6 & 10,6 & 11,9 & 13,2 & 14,0 \\
\hline Polska & 34,4 & 23,8 & 26,5 & 30,6 & 32,7 & 35,2 \\
\hline Portugalia & 7,4 & 8,3 & 8,7 & 9,0 & 9,0 & 9,9 \\
\hline Rumunia & 15,5 & 15,8 & 17,1 & 18,8 & 20,5 & 22,0 \\
\hline Hiszpania & 25 & 27,5 & 28,7 & 31,4 & 34,1 & 37,2 \\
\hline Szwecja & 6,2 & 6,8 & 7,2 & 7,6 & 8,1 & 8,3 \\
\hline Wielka Brytania & 47,2 & 49,5 & 51,0 & 53,6 & 55,5 & 55,8 \\
\hline
\end{tabular}

Objaśnienia:

* W nawiasach całkowita populacja Niemiec.

Źródto: opracowanie własne na podstawie UN Demographic Yearbooks 1948, 1955, 1962, 1971, 1979.

Można także stwierdzić, że wzrost potrzeb mieszkaniowych był nie tylko efektem powojennego wzrostu populacji jako takiej, ale także nowego rozłożenia przestrzennego ludności. Migracje związane z poszukiwaniem pracy i miejsca do mieszkania przyczyniały się do zwiększenia znaczenia dużych miast.

Tabela 2.4. Populacja w miastach od 100 tys. mieszkańców (w mln) od lat 40. do 80.

\begin{tabular}{|l|c|c|c|c|c|c|c|c|}
\hline \multicolumn{1}{|c|}{ Państwo } & Rok & $\begin{array}{c}\text { Populacja } \\
(\mathbf{m} \mathbf{l n})\end{array}$ & Rok & $\begin{array}{c}\text { Populacja } \\
(\mathbf{m} \mathbf{l n})\end{array}$ & Rok & $\begin{array}{c}\text { Populacja } \\
(\mathbf{m} \mathbf{l n})\end{array}$ & Rok & $\begin{array}{c}\text { Populacja } \\
\text { (mln) }\end{array}$ \\
\hline 1 & 2 & 3 & 4 & 5 & 6 & 7 & 8 & 9 \\
\hline Austria & 1951 & 2,3 & 1961 & 2,3 & 1971 & 2,3 & 1981 & 2,2 \\
\hline Belgia & 1947 & 0,9 & b.d. & b.d. & 1970 & 1,3 & 1980 & 1,3 \\
\hline Butgaria & 1946 & 1,7 & 1956 & 0,9 & 1965 & 1,4 & b.d. & b.d. \\
\hline Czechosłowacja & 1947 & 1,6 & 1961 & 2,0 & 1970 & 2,3 & b.d. & b.d. \\
\hline Dania & 1950 & 1,4 & 1960 & 1,5 & 1965 & 1,7 & 1970 & 1,8 \\
\hline Finlandia & 1950 & 0,5 & 1960 & 0,7 & b.d. & b.d. & b.d. & b.d. \\
\hline Francja & 1946 & 6,6 & 1954 & 7,2 & 1968 & 20,4 & b.d. & b.d. \\
\hline
\end{tabular}




\begin{tabular}{|l|c|c|c|c|c|c|c|c|}
\hline \multicolumn{1}{|c|}{1} & 2 & 3 & 4 & 5 & 6 & 7 & 8 & 9 \\
\hline $\begin{array}{l}\text { Niemcy } \\
\text { Zachodnie }\end{array}$ & 1946 & 10,2 & 1950 & 12,9 & 1961 & 16,5 & 1970 & 24,0 \\
\hline $\begin{array}{l}\text { Niemcy } \\
\text { Wschodnie }\end{array}$ & 1946 & 2,3 & 1964 & 3,7 & 1971 & 3,7 & 1981 & 4,3 \\
\hline Grecja & 1951 & 0,9 & 1961 & 2,5 & b.d. & b.d. & b.d. & b.d. \\
\hline Węgry & b.d. & b.d. & 1960 & 2,2 & 1970 & 2,7 & 1980 & 3,1 \\
\hline Irlandia & 1951 & 0,5 & 1960 & 0,6 & 1966 & 0,8 & 1981 & 1,0 \\
\hline Włochy & 1951 & 9,7 & b.d. & b.d. & 1971 & 15,8 & 1981 & 15,9 \\
\hline Holandia & 1947 & 0,6 & b.d. & b.d. & b.d. & b.d. & b.d. & b.d. \\
\hline Polska & 1946 & 2,4 & 1960 & 6,1 & b.d. & b.d. & 1978 & 9,7 \\
\hline Portugalia & 1950 & 1,0 & b.d. & b.d. & b.d. & b.d. & 1981 & 1,1 \\
\hline Rumunia & 1948 & 1,3 & 1956 & 2,1 & 1966 & 3,1 & 1977 & 5,0 \\
\hline Hiszpania & 1950 & 6,7 & b.d. & b.d. & 1970 & 12,4 & 1981 & 15,8 \\
\hline Szwecja & 1950 & 1,3 & 1960 & 1,7 & 1970 & 1,7 & 1980 & 1,8 \\
\hline Wielka Brytania & 1951 & 22,7 & 1961 & 16,6 & b.d. & b.d. & b.d. & b.d. \\
\hline
\end{tabular}

Źródło: opracowanie własne na podstawie UN Demographic Yearbooks 1948, 1955, 1962, 1971, Compendium of Human Settlements Statistics 1983.

Niestety, także w tym przypadku dane statystyczne są fragmentaryczne - por. tabela 2.4. Ich analiza pozwala jednak zauważyć znaczące różnice w tempie przyrostu ludności w miastach mających co najmniej 100 tys. mieszkańców, w takich państwach, jak przede wszystkim: Francja, Niemcy Zachodnie, Włochy, Polska i Hiszpania.

\subsubsection{Wielkość i struktura własnościowa zasobu mieszkaniowego}

Dane statystyczne opisujące zasoby mieszkaniowe z wczesnego okresu powojennego nie są kompletne, podstawowe źródło - czyli spisy powszechne przeprowadzane były w różnym czasie i przy użyciu różnej metodologii. Można jednak zauważyć pewne cechy charakterystyczne ówczesnej sytuacji mieszkaniowej, przede wszystkim zróżnicowana była dynamika przyrostu zasobu mieszkaniowego w poszczególnych latach - por. tabela 2.5. W państwach, dla których są dostępne dane z lat 50., można zauważyć, że w tych latach wzrost liczby mieszkań był umiarkowany, zapewne wynikało to z trudności gospodarczych, a w szczególności materiałowych (deficyt oraz wysokie koszty materiałów budowlanych). Dopiero w okresie lat 60. można zaobserwować zwiększenie dynamiki przyrostu zasobu mieszkaniowego. 
Tabela 2.5. Liczba mieszkań w państwach europejskich od lat 50. do 80.

\begin{tabular}{|l|c|c|c|c|c|c|c|c|}
\hline \multicolumn{1}{|c|}{ Państwo } & Rok & $\begin{array}{c}\text { Liczba } \\
\text { mieszkań } \\
\text { (mln) }\end{array}$ & Rok & $\begin{array}{c}\text { Liczba } \\
\text { mieszkań } \\
\text { Amln) }\end{array}$ & Rok & $\begin{array}{c}\text { Liczba } \\
\text { mieszkań } \\
\text { (mln) }\end{array}$ & Rok & $\begin{array}{c}\text { Liczba } \\
\text { mieszkań } \\
\text { (mln) }\end{array}$ \\
\hline Belgia & 1951 & 2,14 & 1961 & 2,25 & 1972 & 2,65 & 1981 & 2,69 \\
\hline Butgaria & 1947 & 2,81 & 1961 & 3,01 & 1970 & 3,22 & b.d. & b.d. \\
\hline Czechosłowacja & 1956 & 1,73 & 1965 & 2,01 & 1975 & 2,33 & 1985 & 2,70 \\
\hline Dania & 1950 & 3,61 & 1961 & 3,82 & 1970 & 4,40 & 1980 & 4,90 \\
\hline Finlandia & 1960 & 1,48 & 1965 & 1,57 & 1970 & 1,80 & 1981 & 2,03 \\
\hline Francja & 1950 & 0,99 & 1960 & 1,21 & 1970 & 1,46 & 1980 & 1,72 \\
\hline Niemcy Zachodnie & 1956 & 12,66 & 1968 & 19,64 & 1972 & 20,12 & 1978 & 23,06 \\
\hline Niemcy Wschodnie & b.d. & b.d. & 1967 & 5,95 & 1971 & 6,05 & b.d. & b.d. \\
\hline Grecja & 1951 & 1,7 & 1961 & 2,07 & 1971 & 3,08 & b.d. & b.d. \\
\hline Węgry & 1960 & 2,72 & 1970 & 3,03 & 1973 & 3,34 & 1980 & 3,41 \\
\hline Irlandia & 1961 & 0,67 & 1966 & 0,68 & 1970 & 0,70 & 1986 & 0,96 \\
\hline Włochy & 1951 & 10,75 & 1961 & 13,03 & 1971 & 17,43 & b.d. & b.d. \\
\hline Holandia & 1956 & 2,51 & 1960 & 2,82 & 1971 & 3,72 & 1977 & 4,50 \\
\hline Polska & b.d. & b.d. & 1960 & 7,02 & 1970 & 8,29 & 1977 & 10,71 \\
\hline Portugalia & 1950 & 2,03 & 1960 & 2,2 & 1970 & 2,70 & bd & bd \\
\hline Rumunia & b.d. & b.d. & 1966 & 5,24 & b.d. & b.d. & 1992 & 7,18 \\
\hline Hiszpania & 1950 & 6,29 & 1960 & 7,72 & 1970 & 10,65 & 1991 & 11,82 \\
\hline Szwecja & 1960 & 2,58 & 1965 & 2,77 & 1975 & 3,53 & 1980 & 3,49 \\
\hline Wielka Brytania & 1961 & 14,64 & 1966 & 15,69 & 1971 & 16,45 & 1981 & 17,85 \\
\hline Obiasnienia: & & & & 1973 & 18,12 & 1978 & 18,64 \\
\hline
\end{tabular}

Objaśnienia:

W przypadku krajów, w których nie ma danych o latach 70 . i wczesnych 80 . wykorzystano dane późniejsze.

Źródło: opracowanie własne na podstawie UN Compendium of Housing Statistics 1971, 1975-1977, Compendium of Human Settlements Statistics 1983, 1995, TenLaw.

Ważną kwestią był udział gospodarstw domowych, które były właścicielami wykorzystywanych mieszkań i domów, fragmentaryczne dane wskazują na ogromne zróżnicowanie w poszczególnych państwach, przy czym, co ciekawe, nadzwyczaj wysoki poziom własności cechuje niektóre państwa socjalistyczne - por. tabela 2.6. 
Tabela 2.6. Udział procentowy gospodarstw domowych zamieszkujących własne mieszkania od lat 60. do 80.

\begin{tabular}{|c|c|c|c|c|}
\hline Państwo & Rok & $\begin{array}{c}\text { Udział gospodarstw } \\
\text { domowych } \\
\text { zamieszkujących } \\
\text { własne mieszkania (\%) }\end{array}$ & Rok & $\begin{array}{c}\text { Udziat gospodarstw } \\
\text { domowych } \\
\text { zamieszkujących } \\
\text { własne mieszkania (\%) }\end{array}$ \\
\hline Austria & 1970 & 47,7 & 1981 & 48,1 \\
\hline Belgia & 1961 & 49,7 & b.d. & b.d. \\
\hline Bułgaria & 1965 & 71,0 & 1985 & 72,5 \\
\hline Czechosłowacja & 1961 & 50,4 & b.d. & b.d. \\
\hline Dania & 1965 & 44,4 & b.d. & b.d. \\
\hline Finlandia & 1960 & 60,8 & 1989 & 71,2 \\
\hline Francja & 1968 & 60,8 & 1968 & 54,4 \\
\hline Niemcy Zachodnie & 1961 & 29,4 & 1987 & 37,6 \\
\hline Niemcy Wschodnie & b.d. & b.d. & b.d. & b.d. \\
\hline Grecja & b.d. & b.d. & b.d. & b.d. \\
\hline Węgry & 1970 & 62,9 & 1990 & 74,0 \\
\hline Irlandia & 1961 & 59,8 & 1981 & 74,4 \\
\hline Włochy & 1961 & 45,8 & b.d. & b.d. \\
\hline Holandia & 1956 & 25,7 & 1989 & 44,0 \\
\hline Polska & b.d. & b.d. & 1988 & 35,3 \\
\hline Portugalia & 1960 & 44,5 & b.d. & b.d. \\
\hline Rumunia & b.d. & b.d. & 1992 & 75,4 \\
\hline Hiszpania & b.d. & b.d. & 1991 & 77,6 \\
\hline Szwecja & 1970 & 35,5 & 1990 & 40,4 \\
\hline Wielka Brytania & 1961 & 43,0 & b.d. & b.d. \\
\hline
\end{tabular}

Źródło: opracowanie własne na podstawie UN Compendium of Housing Statistics 1971, Compendium of Human Settlements Statistics 1995.

Popularnym, aczkolwiek niedoskonałym, wskaźnikiem pozwalającym na porównanie sytuacji mieszkaniowej w poszczególnych państwach jest liczba mieszkań na 1000 mieszkańców. Na podstawie wcześniej wskazywanych fragmentarycznych danych dokonano przeliczenia, które pozwoliło na wyłonienie wskaźników w pewnym odstępie czasu. Daje to pole do analizy rozmiaru i szybkości zmian w sytuacji mieszkaniowej poszczególnych państw - por. tabela 2.7 . 
Tabela 2.7. Wskaźnik liczby mieszkań na 1000 mieszkańców od lat 50. do 70 .

\begin{tabular}{|c|c|c|c|c|}
\hline Państwo & Rok & $\begin{array}{c}\text { Wskaźnik liczby mieszkań } \\
\text { na } 1000 \text { mieszkańców }\end{array}$ & Rok & $\begin{array}{c}\text { Wskaźnik liczby mieszkań } \\
\text { na } 1000 \text { mieszkańców }\end{array}$ \\
\hline Austria & 1951 & 310 & 1972 & 353 \\
\hline Belgia & 1947 & 330 & 1970 & 335 \\
\hline Butgaria & 1956 & 227 & 1975 & 268 \\
\hline Czechosłowacja & 1950 & 293 & 1970 & 308 \\
\hline Dania & 1960 & 329 & 1970 & 367 \\
\hline Finlandia & 1950 & 247 & 1970 & 317 \\
\hline Francja & 1962 & 304 & 1973 & 344 \\
\hline Niemcy Zachodnie & 1956 & 249 & 1972 & 327 \\
\hline Niemcy Wschodnie & 1967 & 372 & 1971 & 356 \\
\hline Grecja & 1951 & 223 & 1971 & 354 \\
\hline Węgry & 1960 & 273 & 1973 & 321 \\
\hline Irlandia & 1961 & 239 & 1970 & 235 \\
\hline Włochy & 1951 & 229 & 1971 & 325 \\
\hline Holandia & 1956 & 235 & 1971 & 286 \\
\hline Polska & 1960 & 236 & 1970 & 254 \\
\hline Portugalia & 1950 & 241 & 1970 & 318 \\
\hline Rumunia & 1966 & 274 & b.d. & b.d. \\
\hline Hiszpania & 1950 & 225 & 1970 & 313 \\
\hline Szwecja & 1960 & 344 & 1975 & 430 \\
\hline Wielka Brytania & 1951 & 274 & 1971 & 338 \\
\hline
\end{tabular}

Źródto: opracowanie własne na podstawie UN Demographic Yearbooks 1948, 1955, 1962, 1971, Compendium of Human Settlements Statistics 1983.

Najtrudniejszą sytuację mieszkaniową na podstawie badanego wskaźnika w latach 50. miały Grecja, Hiszpania, Włochy i Bułgaria. Polska, Holandia i Irlandia prezentowały się niewiele lepiej. Jednakże badając wskaźnik w latach 70., widać ogromną różnicę w tempie przyrostu zasobu mieszkań - niekwestionowanym liderem jest Grecja, która w ciągu 20 lat poprawiła wynik z 223 do 354 mieszkań na 1000 mieszkańców, znacznie lepszą sytuację można było odnotować we Włoszech i Hiszpanii. Natomiast w dalszym ciągu najniższe wartości wskaźnika wykazywały Irlandia, Polska i Bułgaria. 


\subsection{Społeczno-gospodarcze uwarunkowania rozwoju rynków mieszkaniowych od lat 80. do roku 2017}

Problemy gospodarcze lat 70. wywołały odwrotny trend niż w latach wcześniejszych - mówi się bowiem o rekomodyfikacji zasobu mieszkaniowego [Forrest, Williams 1984]. Państwa zaczęły się wycofywać z bezpośredniego udziału w dostarczaniu usług mieszkaniowych (co oznaczało też zmniejszenie wydatków publicznych przeznaczonych na cele mieszkaniowe), cedując część swoich uprawnień na podmioty prywatne, często non-profit, prywatyzując zasoby społeczne, wspierając stronę popytową, a nie jak wcześniej podażową [Dewilde, De Decker 2016]. Promowano prawo własności także poprzez bonusową prywatyzację na rzecz najemców, a likwidując ograniczenia czynszowe wspierano prywatne inwestycje na rynku najmu.

W latach 80. pojawiły się nowe czynniki, które w dłuższej perspektywie wywołały obecny proces finansjalizacji. Liberalizacja zasad obowiązujących na rynkach finansowych, rozwój globalnych relacji, także w odniesieniu do kredytodawców hipotecznych, sekurytyzacja, przyczyniły się do wzrostu popytu na kredyty hipoteczne, wzrostu liczby właścicieli, rosnących cen na rynkach mieszkaniowych, a w konsekwencji baniek cenowych na rynkach mieszkaniowych wielu państw. Nie bez znaczenia były także czynniki zewnętrze o charakterze demograficznym i kulturowym, w tym zmiany na rynku pracy. Rezultatem tych oddziaływań i zmian jest rosnący poziom nierówności w dostępie do usługi mieszkaniowej o odpowiednim standardzie. Świadczą o tym badania wpływu komodyfikacji i finansjalizacji na dostępność mieszkań wśród gospodarstw domowych o niskich dochodach. Zarówno w odniesieniu do grupy średniozamożnej, jak i w przypadku gospodarstw niezamożnych w państwach, które mają wyższy poziom komodyfikacji i finansjalizacji, pomiędzy latami 1995 a 2012 nastąpiło pogorszenie dostępności mieszkań [Dewilde, De Decker 2016].

\subsubsection{Uwarunkowania demograficzne}

W większości państw UE widoczny jest wzrost liczby ludności w analizowanym okresie lat 1980-2017, jakkolwiek jego tempo jest zróżnicowane - por. tabela 2.8. Kraje tracące mieszkańców to byłe państwa socjalistyczne, takie jak: Bułgaria, Chorwacja, Estonia, Węgry, Łotwa, Litwa i Rumunia. 
Tabela 2.8. Zmiany populacyjne od lat 80 . do roku 2017

\begin{tabular}{|c|c|c|c|c|c|}
\hline \multirow{2}{*}{ Państwo } & \multicolumn{5}{|c|}{ Liczba ludności w mln } \\
\hline & 1980 & 1990 & 2000 & 2010 & 2017 \\
\hline Austria & 7,5 & 7,7 & 8,1 & 8,4 & 8,7 \\
\hline Belgia & 9,8 & 10,0 & 10,5 & 10,9 & 11,4 \\
\hline Butgaria & 8,8 & 8,9 & 8,0 & 7,5 & 7,0 \\
\hline Chorwacja & b.d. & 4,8 & 4,4 & 4,4 & 4,1 \\
\hline $\begin{array}{l}\text { Czechosłowacja } \\
\text { (od } 1990 \text { r. Czechy) }\end{array}$ & 15,3 & 10,3 & 10,3 & 10,5 & 10,6 \\
\hline Dania & 5,1 & 5,1 & 5,3 & 5,5 & 5,7 \\
\hline Estonia & b.d. & 1,6 & 1,4 & 1,3 & 1,3 \\
\hline Finlandia & 4,8 & 5,0 & 5,2 & 5,5 & 5,5 \\
\hline Francja & 53,7 & 56,7 & 59,0 & 61,2 & 64,9 \\
\hline $\begin{array}{l}\text { Niemcy Zachodnie } \\
\text { (od } 1990 \text { r. jako jeden kraj) }\end{array}$ & 61,5 & \multirow[t]{2}{*}{79,4} & \multirow[t]{2}{*}{82,0} & \multirow[t]{2}{*}{82,4} & \multirow[t]{2}{*}{82,5} \\
\hline Niemcy Wschodnie & 16,7 & & & & \\
\hline Grecja & 9,6 & 10,0 & 10,0 & 11,1 & 10,8 \\
\hline Węgry & 10,7 & 10,3 & 10,0 & 10,0 & 9,8 \\
\hline Irlandia & 3,4 & 3,5 & 3,8 & 4,5 & 4,8 \\
\hline Włochy & 57,0 & 57,6 & 57,7 & 60,5 & 60,5 \\
\hline Łotwa & b.d. & 2,6 & 2,4 & 2,2 & 2,1 \\
\hline Litwa & b.d. & 3,7 & 3,7 & 3,3 & 3,1 \\
\hline Holandia & 14,1 & 14,9 & 15,8 & 16,6 & 17,1 \\
\hline Polska & 35,6 & 38,1 & 38,6 & 38,2 & 38,0 \\
\hline Portugalia & 9,9 & 9,9 & 10,0 & 10,6 & 10,3 \\
\hline Rumunia & 22,2 & 23,2 & 22,4 & 21,4 & 19,6 \\
\hline Stowacja & b.d. & 5,3 & 5,4 & 5,4 & 5,4 \\
\hline Stowenia & b.d. & 2,0 & 2,0 & 2,0 & 2,0 \\
\hline Hiszpania & 37,4 & 38,9 & 39,5 & 46,0 & 46,5 \\
\hline Szwecja & 8,3 & 8,6 & 8,9 & 9,4 & 10,0 \\
\hline Wielka Brytania & 55,9 & 57,5 & 59,5 & 62,2 & 65,8 \\
\hline
\end{tabular}

Źródło: opracowanie własne na podstawie UN Demographic Yearbooks 1983, 1994, 2000, 2010, 2017.

Biorąc pod uwagę samą liczbę obywateli jako swoisty wyznacznik potrzeb mieszkaniowych, można wskazać, że konieczność dostarczenia znacznej liczby jednostek mieszkalnych dotyczyła w badanym okresie Francji, Wielkiej Brytanii i Hiszpanii. Warto zauważyć, że inne państwa o dużej populacji - Niemcy i Włochy nie doświadczyły takiego wzrostu liczby ludności. 


\subsubsection{Wielkość i struktura własnościowa zasobu mieszkaniowego}

Zmiany populacyjne można zestawić $\mathrm{z}$ wynikami spisów powszechnych $\mathrm{w}$ odniesieniu do liczby zamieszkanych jednostek mieszkalnych. W zasadzie występuje wzrost liczby wykorzystywanych mieszkań i domów, natomiast zróżnicowane jest jego tempo - por. tabela 2.9. Niestety, nie ma możliwości odwołania się do liczby mieszkań zamieszkałych w 2017 r. w stosunku do wszystkich państw, wynika to $\mathrm{z}$ braku danych spisowych ${ }^{4}$, przedstawiono wobec tego całkowitą liczbę mieszkań.

Tabela 2.9. Zmiany liczby mieszkań w poszczególnych państwach UE od lat 80. do roku 2017

\begin{tabular}{|c|c|c|c|c|c|c|c|}
\hline Państwo & Rok & $\begin{array}{l}\text { Liczba } \\
\text { mieszkań } \\
(m \ln )\end{array}$ & Rok & $\begin{array}{c}\text { Liczba } \\
\text { mieszkań } \\
(\text { mln) }\end{array}$ & $\begin{array}{l}\text { Liczba } \\
\text { mieszkań } \\
\text { w } 2001 \text { r. } \\
(m \ln )\end{array}$ & $\begin{array}{c}\text { Liczba } \\
\text { mieszkań } \\
\text { w } 2011 \text { r. } \\
\text { (mln) }\end{array}$ & $\begin{array}{c}\text { Liczba } \\
\text { mieszkań } \\
\text { w } 2017 \text { r.* }^{*} \\
\text { (mln) }\end{array}$ \\
\hline 1 & 2 & 3 & 4 & 5 & 6 & 7 & 8 \\
\hline Austria & 1981 & 2,7 & 1997 & 3,2 & 3,3 & 3,6 & $3,9(4,6)$ \\
\hline Belgia & b.d. & b.d. & 1991 & 3,7 & 4,0 & 4,6 & $(5,4)$ \\
\hline Bułgaria & 1985 & 2,7 & 1992 & 2,7 & 2,8 & 2,6 & $(3,9)$ \\
\hline Chorwacja & b.d. & b.d. & 1991 & 1,5 & 1,7 & 1,9 & $(2,2)$ \\
\hline $\begin{array}{l}\text { Czechosłowacja } \\
\text { (od } 1990 \text { r. Czechy) }\end{array}$ & b.d. & b.d. & 1991 & 3,7 & 3,8 & 4,1 & $(4,7)$ \\
\hline Dania & b.d. & b.d. & 1991 & 2,1 & 2,4 & 2,5 & $2,6(2,8)$ \\
\hline Estonia & b.d. & b.d. & b.d. & b.d. & 0,5 & 0,5 & $0,6(0,7)$ \\
\hline Finlandia & 1989 & 2,0 & 1998 & 2,2 & 2,3 & 2,5 & $2,7(3,0)$ \\
\hline Francja & b.d. & b.d. & 1990 & 21,5 & 23,8 & 27,9 & $28,7(35,0)$ \\
\hline $\begin{array}{l}\text { Niemcy Zachodnie } \\
\text { (od } 1990 \text { r. jako } \\
\text { jeden kraj) }\end{array}$ & 1987 & 25,9 & \multirow[t]{2}{*}{1998} & \multirow[t]{2}{*}{34,5} & \multirow[t]{2}{*}{ b.d. } & \multirow[t]{2}{*}{36,9} & \multirow[t]{2}{*}{$(40,5)$} \\
\hline $\begin{array}{l}\text { Niemcy } \\
\text { Wschodnie }\end{array}$ & b.d. & b.d. & & & & & \\
\hline Grecja & b.d. & b.d. & b.d. & b.d. & 3,5 & 4,1 & $(6,5)$ \\
\hline Węgry & b.d. & b.d. & 1990 & 3,7 & 3,7 & 3,9 & $(4,4)$ \\
\hline Irlandia & 1986 & 0,9 & b.d. & b.d. & 1,3 & 1,6 & $1,7(2,0)$ \\
\hline Włochy & b.d. & b.d. & 1991 & 19,7 & 21,6 & 24,1 & $25,7(35,8)$ \\
\hline
\end{tabular}

4 Autorzy kontaktowali się z krajowymi urzędami statystycznymi w celu uzyskania danych, ale uzyskali odpowiedzi w większości przypadków, że takich danych nie ma. 
Tabela 2.9 (cd.)

\begin{tabular}{|l|c|c|c|c|c|c|c|}
\hline \multicolumn{1}{|c|}{1} & 2 & 3 & 4 & 5 & 6 & 7 & 8 \\
\hline Łotwa & b.d. & b.d. & 1991 & 0,9 & 0,8 & 0,8 & $(1,0)$ \\
\hline Litwa & b.d. & b.d. & 1998 & 1,3 & 1,2 & 1,2 & $(1,4)$ \\
\hline Holandia & 1989 & 5,8 & 1998 & 6,7 & 6,5 & 6,9 & $(7,7)$ \\
\hline Polska & 1988 & 10,7 & 1995 & 11,0 & 11,6 & 12,6 & $(14,4)$ \\
\hline Portugalia & b.d. & b.d. & 1991 & 3,0 & 3,5 & 3,9 & $(5,9)$ \\
\hline Rumunia & b.d. & b.d. & 1992 & 7,2 & 7,2 & 7,3 & $(8,8)$ \\
\hline Stowacja & b.d. & b.d. & 1991 & 1,6 & 1,6 & 1,7 & $(1,9)$ \\
\hline Stowenia & b.d. & b.d. & b.d. & b.d. & 0,6 & 0,7 & $0,7(0,9)$ \\
\hline Hiszpania & b.d. & b.d. & 1991 & 11,8 & 14,2 & 18,0 & $(25,2)$ \\
\hline Szwecja & b.d. & b.d. & 1990 & 3,8 & 4,0 & 4,0 & $(4,8)$ \\
\hline Wielka Brytania & b.d. & b.d. & 1996 & 20,4 & 24,4 & 26,3 & $(28,0)$ \\
\hline
\end{tabular}

Objaśnienia:

* Dane z roku 2017 dotyczą mieszkań zamieszkałych i ogółu mieszkań, te ostatnie wyrażone są w nawiasach.

Źródło: opracowanie własne na podstawie UN Compendium of Human Settlements Statistics 1995, 2001, 2011, Eurostat Census time series, Croatian Bureau of Statistics; dane za 2017 r. pochodzą z publikacji Pittini i in. 2017, ECB Structural Housing Indicators Statistics, weryfikacja za pomocą danych krajowych urzędów statystycznych.

Liderzy tworzenia nowego zasobu mieszkaniowego w badanym okresie to Irlandia, Portugalia, Hiszpania, Chorwacja oraz Wielka Brytania. Wyraźnie widoczna jest znacząca różnica między wielkością zasobu w większości państw Europy Zachodniej i niektórymi państwami postsocjalistycznymi.

Wskaźnik, który pozwala na ocenę zmian i ich dynamiki w odniesieniu do zaspokajania potrzeb mieszkaniowych, czyli liczba mieszkań na 1000 mieszkańców, obrazuje różnice między blokiem państw kapitalistycznych i postsocjalistycznych - por. tabela 2.10 .

Tabela 2.10. Wskaźnik liczby mieszkań na 1000 mieszkańców w wybranych państwach UE od lat 90. do roku 2017

\begin{tabular}{|l|c|c|c|c|c|}
\hline \multicolumn{1}{|c|}{ Państwo } & Rok & Wskaźnik & $\begin{array}{c}\text { Wskaźnik } \\
\text { w 2001 r. }\end{array}$ & $\begin{array}{c}\text { Wskaźnik } \\
\text { w 2011 r. }\end{array}$ & $\begin{array}{c}\text { Wskaźnik } \\
\text { w 2017 r. }\end{array}$ \\
\hline \multicolumn{1}{|c|}{1} & 2 & 3 & 4 & 5 & 6 \\
\hline Austria & 1997 & 400 & 407 & 429 & 547 \\
\hline Belgia & 1991 & 377 & 388 & 422 & 474 \\
\hline Butgaria & 1992 & 303 & 354 & 356 & 551 \\
\hline
\end{tabular}




\begin{tabular}{|c|c|c|c|c|c|}
\hline 1 & 2 & 3 & 4 & 5 & 6 \\
\hline Chorwacja & 1991 & 312 & 386 & 432 & 524 \\
\hline $\begin{array}{l}\text { Czechosłowacja (od } 1990 \mathrm{r} \text {. } \\
\text { Czechy) }\end{array}$ & 1991 & 359 & 369 & 390 & 454 \\
\hline Dania & 1991 & 411 & 444 & 446 & 490 \\
\hline Estonia & & & 384 & 384 & 385 \\
\hline Finlandia & 1989 & 400 & 442 & 463 & 545 \\
\hline Francja & 1990 & 379 & 402 & 441 & 539 \\
\hline $\begin{array}{l}\text { Niemcy Zachodnie } \\
\text { (od } 1990 \text { jako jeden kraj) }\end{array}$ & 1987 & \multirow[t]{2}{*}{421} & \multirow[t]{2}{*}{ b.d. } & \multirow[t]{2}{*}{451} & \multirow[t]{2}{*}{490} \\
\hline Niemcy Wschodnie & b.d. & & & & \\
\hline Grecja & b.d. & b.d. & 350 & 362 & 601 \\
\hline Węgry & 1990 & 359 & 363 & 391 & 449 \\
\hline Irlandia & 1986 & 257 & 342 & 355 & 416 \\
\hline Włochy & 1991 & 342 & 372 & 397 & 551 \\
\hline Łotwa & 1991 & 360 & 348 & 400 & 476 \\
\hline Litwa & 1998 & 351 & 343 & 375 & 551 \\
\hline Holandia & 1989 & 386 & 406 & 413 & 476 \\
\hline Polska & 1988 & 282 & 300 & 330 & 379 \\
\hline Portugalia & 1991 & 303 & 340 & 371 & 573 \\
\hline Rumunia & 1992 & 313 & 321 & 341 & 449 \\
\hline Słowacja & 1991 & 302 & 296 & 315 & 352 \\
\hline Słowenia & b.d. & b.d. & 300 & 350 & 450 \\
\hline Hiszpania & 1991 & 303 & 352 & 390 & 542 \\
\hline Szwecja & 1990 & 442 & b.d. & 423 & 480 \\
\hline Wielka Brytania & 1996 & 349 & 408 & 421 & 425 \\
\hline
\end{tabular}

Objaśnienia:

*Wskaźnik za 2017 r. dotyczy całkowitej liczby mieszkań. Źródto: opracowanie własne na podstawie UN Compendium of Human Settlements Statistics 1995, 2001, 2011, Eurostat Census time series, Croatian Bureau of Statistics; dane za 2017 r. pochodzą z publikacji Pittini i in. 2017, ECB Structural Housing Indicators Statistics, weryfikacja za pomocą danych krajowych urzędów statystycznych.

Wzrost liczby mieszkań na 1000 mieszkańców najsilniej wystąpił w Grecji i Portugalii, ale bez wątpienia duże znaczenie mają mieszkania wakacyjne. Zwracają 
uwagę różnice pomiędzy państwami postsocjalistycznymi, niedobór ilościowy nie powinien silnie wystąpić w Czechach, na Łotwie, Litwie, Słowenii, Bułgarii i Chorwacji. Istnieją tu jednak specyficzne uwarunkowania, które zaburzają wyciągnięcie takiego wniosku, przede wszystkim dotyczą one jakości zasobu oraz jego przeznaczenia na mieszkania wakacyjne. Nie bez znaczenia są także ubytki populacji, które skutkują podwyższeniem ogólnej liczby mieszkań na 1000 mieszkańców. 


\section{Rozdział 3}

\section{Ewolucja rynków nieruchomości mieszkaniowych w wybranych państwach UE ${ }^{1}$}

\subsection{Ewolucja rynków nieruchomości mieszkaniowych w wybranych państwach UE od lat 50. do 80.}

Dane statystyczne są odzwierciedleniem efektywności prowadzonej przez poszczególne państwa polityki mieszkaniowej. Państwa są głównym konstruktorem ładu instytucjonalnego i podmiotem odpowiedzialnym za tworzenie filtrów instytucjonalnych, które łagodzą skutki tzw. szoków globalnych i innych zagrożeń wynikających z otoczenia międzynarodowego [Wilkin 2017]. Decydujące znaczenie przy realizacji tych zadań ma przyjęty przez polityków system wartości priorytetowych, wartościom tym podporządkowane są cele polityki. Matryca instytucjonalna społeczeństwa jest wynikiem przyjętych przez dane społeczeństwo norm formalnych (prawnych), jak i nieformalnych.

1 Rozdział ten został oparty na publikacjach będących wynikiem projektu TenLaw, TENLAW: Tenancy Law and Housing Policy in Multi-level Europe: Austria R. Hofmann, Belgium M. Haffner, H. Bounjouh; Bulgaria B. Zahariev, D. Giteva, I. Yordanov; Cratia A. Jakopič, M. Žnidarec; Czech Republic P. Podrazil, R. Jadamus, P. Petr; Denmark J. Juul-Sandberg; P. Orji, P. Sparkes; Estonia A. Hussar; Finland T. Ralli; France J. Hoekstra, F. Cornette; Germany J. Cornelius, J. Rzeznik; Greece T. Konistis; Hungary J. Hegedüs, V. Horváth, N. Teller, N. Tosics; Ireland M. Jordan; Italy R. Bianchi; Latvia J. Kolomijceva; Lithuania A. Mikelènaitė; the Netherlands M. Haffner, M. van der Veen, H. Bounjouh; Poland G. Panek; Portugal D. Correia, N. Santos, M. Olinda Garcia; Romania I. Bejan, F. Botonogu, I. Armasu, Scotland M. Jordan; Slovakia J. Štefanko, M. Filo, Z. Jurcova; Slovenia T. Pertovic; Spain E. Molina Roig; Sweden O. Bååth, https://cordis.europa.eu/project/rcn/102183/results/en. 
Austria $^{2}$ w ramach prowadzonej polityki mieszkaniowej skoncentrowała się na odtworzeniu zasobów zniszczonych w trakcie działań wojennych, starano się wspierać przede wszystkim gospodarstwa domowe o niskich dochodach. Ze względu na problemy gospodarcze w latach 50 . budowano niezbyt wiele - w latach 1951-1961 ok. 112 tys. jednostek mieszkalnych, prawdziwy boom budowlany miał miejsce w latach 60., przybyło wtedy ok. 416 tys. mieszkań. Państwo wspierało producentów mieszkań poprzez system subsydiów, a docelowymi beneficjentami były osoby nisko uposażone, które uzyskiwały prawa do mieszkań społecznych po cenach niższych niż rynkowe.

W Belgii ${ }^{3}$ uznano własność mieszkania za przyjęty model kulturowy. Już przed II wojną światową wprowadzono rozwiązania, które miały umożliwiać nabywanie mieszkań na własność także osobom mniej zamożnym. Po wojnie, pomimo odczuwania znacznych niedoborów mieszkań, budowano niezbyt wiele. Wpływał na to z jednej strony wzrost kosztów budowy nieadekwatny do rozmiaru pomocy państwa, a z drugiej zamrożenie stawek czynszów mieszkań do najmu. Najem był tani, w efekcie budownictwo czynszowe nie było konkurencyjną inwestycją, dodatkowe trudności wynikały z niemożności wypracowania przez kilka lat kompleksowych rozwiązań legislacyjnych (spór polityczny).

Dania $^{4}$ przed drugą wojną światową nie odczuwała głodu mieszkaniowego, jednak wybuch wojny i zatrzymanie aktywności budowlanej wywołały niedobór mieszkań, a w efekcie wprowadzono regulacje prawe chroniące najemców. Dania nie odniosła większych szkód wojennych w zasobach mieszkaniowych, jednak w latach 40. odczuwany był duży niedobór mieszkań ze względu na brak nowych inwestycji, niski standard istniejących obiektów, wzrost liczby ludności i falę migracji do miast. Dotyczyło to przede wszystkim określonych lokalizacji. Inwestorzy nie byli zainteresowani inwestycjami w mieszkania na wynajem, ponieważ obowiązywało zamrożenie czynszów. W tej sytuacji politycy zgodzili się, że konieczna jest poważna interwencja na rynku mieszkaniowym, polegająca na wsparciu budowy mieszkań o niskich kosztach. Wprowadzono ułatwienia w finansowaniu za pomocą kredytów dla właścicieli nieruchomości. Wraz z poprawą sytuacji gospodarczej wzrastała aktywność budowlana, przede wszystkim w segmencie domów jednorodzinnych. Nowe zasoby prywatnego rynku najmu zostały zwolnione z restrykcji czynszowych, przez co stawki wzrastały szybko. W latach 60. wprowadzono kondominia - odpowiednik wspólnot mieszkaniowych i możliwość bycia właścicielem mieszkania w budynku wielomieszkaniowym, była to

2 Liczba ludności w 1947 r. 6,9 mln, w 1979 r. 7,5 mln; liczba mieszkań w 1951 r. 2,14 mln, w 1981 r. 2,69 mln.

3 Liczba ludności w 1947 r. 8,4 mln, w 1979 r. 9,8 mln; liczba mieszkań w 1947 r. 2,81 mln, w 1970 r. $3,22 \mathrm{mln}$.

4 Liczba ludności w 1947 r. 4,1 mln, w 1979 r. 5,1 mln; liczba mieszkań w 1960 r. 1,48 mln, w 1981 r. 2,03 mln. 
część liberalizacji rynku mieszkaniowego. Ponadto, spółdzielnie mieszkaniowe zwiększyły rozmiar działalności. W efekcie tych wszystkich działań wzrosła liczba mieszkań oddawanych do użytku. W latach 70. wprowadzono prawo pierwokupu dla najemców.

W opisywanych państwach socjalistycznych - Bułgarii, Czechosłowacji, Niemczech Wschodnich, Polsce, Rumunii ${ }^{5}$ polityka mieszkaniowa była traktowana w podobny sposób - jako dodatek do najważniejszych polityk dotyczących obronności i gospodarki. Z przyczyn ideologicznych promowano określone typy działalności przemysłowej (kopalnie, huty, elektrownie, wielkie zakłady przemysłowe), wymagało to ogromnych nakładów kapitałowych. Na budowę mieszkań brakowało sił i środków, jakkolwiek aspekt propagandowy budownictwa mieszkaniowego jako realizacji potrzeb socjalistycznego społeczeństwa był chętnie wykorzystywany. Potrzeby mieszkaniowe w poszczególnych państwach były zróżnicowane, ponieważ zniszczenia wojenne dotknęły najbardziej Polskę i Niemcy Wschodnie, pozostałe państwa socjalistyczne nie ucierpiały tak mocno. Gospodarka centralnie planowana zdominowała sektor mieszkaniowy, budowa, dystrybucja i zasady utrzymania zasobu były uzależnione od decyzji centralnych, wieloletnich planów gospodarczych, wolny rynek funkcjonował w niektórych państwach w bardzo ograniczonym zakresie. Jeśli nawet pozostawiano prawo własności do mieszkań prywatnym osobom, to nie miały one możliwości decydowania o sposobie wykorzystania ich dóbr. Po pierwszym okresie silnych restrykcji i nacisku na nacjonalizację, nastąpiło zmniejszenie ingerencji państwa, często mające wymiar sankcjonowania prywatnego obrotu, który odbywał się nieformalnie. Aktywność budowlana w sferze mieszkaniowej w latach 50 . i 60 . była zdecydowanie za mała w stosunku do potrzeb demograficznych i społecznych - por. tabele 2.3 i 2.5.

Finlandia $^{6} \mathrm{w}$ okresie powojennym cierpiała na poważny niedobór mieszkań, w odpowiedzi ustanowiono system subsydiów dla strony podażowej (też właścicieli nieruchomości). Uruchomiono ponadto system specjalnych pożyczek mieszkaniowych. W latach 60. miała miejsce wielka migracja do miast, w których wobec ogromnego wzrostu potrzeb zaczęto budować mieszkania dla robotników i wprowadzono restrykcje dla prywatnych właścicieli zasobu czynszowego. Od 1968 r. stosowano kryterium dochodowe przy przyznawaniu prawa do mieszkania społecznego i wspieraniu nabycia prawa własności mieszkania, obowiązywała też kontrola wysokości czynszów. W latach 70. bardzo dużo budowano, w szczególności na przedmieściach, środki finansowe pochodziły z pożyczek wspomaganych przez państwo, brak było komercyjnego kredytowania hipotecznego, rynek finansowy był ściśle regulowany. Zmiana uwarunkowań została wywołana deregulacją rynku finansowego oraz wycofaniem się państwa $\mathrm{z}$ dotychczasowych form wsparcia.

5 W tym czasie Litwa, Łotwa i Estonia były częściami ZSRR, Chorwacja była częścią Jugosławii.

6 Liczba ludności w 1947 r. 3,9 mln, w 1979 r. 4,7 mln; liczba mieszkań w 1950 r. 0,99 mln, w 1980 r. $1,72 \mathrm{mln}$. 
Podobnie jak wiele innych państw Francja ${ }^{7}$ cierpiała po wojnie na znaczny deficyt mieszkań. W odpowiedzi na potrzeby społeczne wprowadzono subsydia i nisko oprocentowane pożyczki na budowę, co zaowocowało boomem budowlanym w latach 60. i 70. Stymulowano także rozwój sektora mieszkań społecznych, ale charakteryzowały się one niską jakością. Starano się także wspierać własność, umożliwiając tanie finansowanie deweloperom budującym na sprzedaż, co w efekcie miało sprzyjać niższym cenom. Popyt stymulowały nisko oprocentowane kredyty hipoteczne i system premii w spłatach. Od połowy lat 60. zmniejszono rozmiar pomocy państwa dla sektora mieszkaniowego, jednakże pozostawiono główne instrumenty wsparcia.

Niemcy ${ }^{8}$ są wyjątkowym przykładem rozwoju sektora mieszkaniowego. Podział państwa w 1949 r. powołał do życia dwa odrębne kraje, które starały się ze sobą konkurować na wszystkich możliwych polach. Obszar był ogromnie zniszczony, ponadto głód mieszkaniowy był wzmacniany napływem ludności z terenów, które po nowym ustaleniu granic przestały należeć do Niemiec. W Niemczech Zachodnich stworzono system pomocy opierający się na mieszkaniach społecznych. Jednakże w odróżnieniu od innych państw, w ramach przyjętych rozwiązań wykorzystano aktywność podmiotów prywatnych. Stały się one dostarczycielami zasobu społecznego, który charakteryzował się wysoką jakością, a jego użytkownikami miało być całe społeczeństwo, a nie jedynie najbiedniejsi. Rynek był ograniczony w ten sposób, że to państwo przyznawało prawa do zasobu społecznego, decydowało o wysokości czynszu czy jego czasowym zamrożeniu (z czego po pewnym czasie zrezygnowano). O skali budownictwa może świadczyć to, że w 1949 r. oddano do użytku 220 tys. nowych mieszkań, w 1952 r. 460 tys., a w 1964 r. 620 tys. Ogółem w latach 1949-1965 wybudowano ok. 9 mln mieszkań, z czego ok. 51\% to były mieszkania społeczne. System podatkowy i uwolnienie czynszów wsparły sektor prywatny inwestujący w mieszkania do najmu i nabywanie na własność.

Grecję ${ }^{9}$ charakteryzował brak oficjalnej polityki mieszkaniowej państwa, uznawano, że zaspokojenie potrzeb mieszkaniowych to sprawa prywatna, rodzinna. Jednocześnie w konstytucji była wzmianka o konieczności pomocy państwa dla potrzebujących wsparcia. Problem mieszkaniowy był poważny ze względu na fale migracji do miast, czego skutkiem były koczowiska bezdomnych. Państwo nie było w stanie kontrolować aktywności budowlanej, powszechne były samowole budowlane i brak planowania przestrzennego. Państwo za pośrednictwem organizacji, m.in. związków zawodowych, starało się oferować pomoc dla robotników,

7 Liczba ludności w 1947 r. 41,0 mln, w 1979 r. 53,5 mln; liczba mieszkań w 1962 r. 14,14 mln, w 1978 r. 18,64 mln.

8 Liczba ludności w 1947 r. w Niemczech Zachodnich 45,3 mln, w 1979 r. 61,3 mln; liczba mieszkań w 1956 r. 12,66 mln, w 1978 r. 23,06 mln.

9 Liczba ludności w 1947 r. 7,5 mln, w 1979 r. 9,4 mln; liczba mieszkań w 1951 r. 1,7 mln, w 1970 r. 3,01 mln. 
a także wdów bez środków do życia. Udzielano pożyczek i pomagano w opłacaniu czynszów. Znaczący wzrost liczby mieszkań w latach 1951-1971 wskazuje, że aktywność budowlana, pomimo braku oficjalnej polityki mieszkaniowej, ale przy jednoczesnym wsparciu instytucjonalnym (system tanich pożyczek), rozwijała się bardzo dobrze.

Irlandia $^{10}$ uzyskała byt państwowy w 1948 r., był to kraj na niskim poziomie rozwoju gospodarczego, bardzo silnie uzależniony gospodarczo od Wielkiej Brytanii. Polityka mieszkaniowa stała się szczególnie istotna dla samorządu $\mathrm{z}$ racji nałożenia na niego odpowiedzialności w sferze mieszkaniowej i rozmiaru koniecznych działań. Poza wsparciem aktywności budowlanej (subsydia były także dla budownictwa samorządowego) starano się promować nabywanie mieszkań na własność. Poza tym wyburzano slumsy i starano się rewitalizować obszary problemowe. Prywatny sektor czynszowy nie był wspierany.

Włochy $^{11}$ były jednym z państw, które odczuły bezpośrednie działania wojenne, w związku z czym niezbędna była odbudowa zasobu mieszkaniowego. Ponadto, migracje do miast przyczyniły się do tego, że problem niezaspokojonych potrzeb mieszkaniowych stał się bardzo poważny. Kwestiom mieszkaniowym nadano bardzo duże znaczenie polityczne, a w efekcie postawiono na budowanie mieszkań społecznych, które były wynajmowane lub sprzedawane potrzebującym. Ułatwienia dla budownictwa społecznego były już na etapie planowania przestrzennego.

W Holandii ${ }^{12}$ uznawano już w okresie przedwojennym, że mieszkanie na wynajem jest dobrym zabezpieczeniem na starość. Wprowadzenie systemu emerytalnego zmieniło to podejście, a dodatkowy czynnik zniechęcający do budowy mieszkań na wynajem wynikał z regulowania czynszów przez państwo. W 1947 r. zasób mieszkaniowy był wykorzystywany do prywatnego najmu w 60\%, 12\% stanowiły mieszkania społeczne, a 28\% domów i mieszkań było zamieszkałe przez właścicieli. Część rentierów sprzedawała mieszkania czynszowe podmiotom publicznym w ramach procesów rewitalizacji. Inwestorami w segmencie czynszowym były nie tylko osoby fizyczne, ale także inwestorzy instytucjonalni, np. towarzystwa ubezpieczeniowe. Zachęty wynikały z możliwości uzyskania wsparcia w procesie budowy. Udział gospodarstw domowych zamieszkujących własne zasoby stopniowo wzrastał wraz z poprawą sytuacji materialnej obywateli.

Portugalia $^{13}$ jest przykładem państwa, które doświadczało podobnych procesów społeczno-gospodarczych do państw zachodnioeuropejskich, ale ze znacznym

10 Liczba ludności w 1947 r. 3,0 mln, w 1979 r. 3,3 mln; liczba mieszkań w 1961 r. 0,67 mln, w 1970 r. 0,7 mln.

11 Liczba ludności w 1947 r. 45,3 mln, w 1979 r. 56,9 mln; liczba mieszkań w 1951 r. 10,75 mln, w 1971 r. $17,43 \mathrm{mln}$.

12 Liczba ludności w 1947 r. 9,6 mln, w 1979 r. 14,0 mln; liczba mieszkań w 1956 r. 2,51 mln, w 1977 r. 4,5 mln.

13 Liczba ludności w 1947 r. 8,3 mln, w 1979 r. 9,9 mln; liczba mieszkań w 1950 r. 2,03 mln, w 1970 r. 2,7 mln. 
przesunięciem w czasie. Okres migracji do miast miał miejsce dopiero w latach 60. i pierwszej połowie lat 70. Charakterystyczne były problemy z przestrzeganiem prawa budowlanego, powszechne były samowole budowlane w odniesieniu do domów. Próbowano rozwiązać problem niedoboru mieszkań poprzez dostarczanie mieszkań społecznych, ale brak było powszechnej akceptacji dla tego rozwiązania. Zły stan zasobu wynikał z wieloletniej blokady podwyżek czynszów, co przy trudności z usunięciem lokatora powodowało nieopłacalność inwestowania w prywatny zasób do najmu. Efektem tego była konieczność działań rewitalizacyjnych na wielką skalę, w szczególności w Lizbonie i Porto, gdzie obowiązywało wiele starych umów najmu, które nie podlegały nowelizacjom przepisów (od $1966 \mathrm{r}$. wprowadzono możliwość podwyżek stawek czynszu co 5 lat).

W Hiszpanii ${ }^{14}$ niedobór mieszkań wystąpił silnie po wojnie domowej, w latach 50. najem był bardziej powszechny niż własność (51,4 do 46,9\%), jednakże ta sytuacja zmieniła się $\mathrm{w}$ następnym okresie, ponieważ celem polityki państwa było poszerzenie grona właścicieli. Oferta prywatnych mieszkań do najmu zmniejszała się ze względu na silną ochronę najemców i wysokie ryzyko, że użytkownik będzie zalegał z opłatami, zniechęcało to do tego rodzaju inwestycji. Od 1959 r. nastąpiło otwarcie polityczne, które zaowocowało wzrostem gospodarczym, mieszkania stały się istotnym elementem polityki, zapewniono przywileje podatkowe w postaci odliczeń podatkowych dla nabywców. Funkcjonowały też instrumenty wsparcia dla mieszkań społecznych. Z drugiej strony kurczył się rynek czynszowy prywatny, ponieważ właściciele nie uzyskiwali konkurencyjnych do innych inwestycji zwrotów, więc często odsprzedawali mieszkania ich najemcom. Sytuację komplikowało to, że obowiązywało stare i nowe prawo, odnoszące się do zasad najmu lokali mieszkalnych. Z upływem czasu głównym segmentem strony podażowej stało się budowanie w celu sprzedaży mieszkań własnościowych.

Szwecja ${ }^{15}$ ma podobną historię do wielu innych państw w odniesieniu do mieszkalnictwa. Rewolucja przemysłowa i migracje z nią związane wywołały zapotrzebowanie na mieszkania $\mathrm{w}$ miastach, najem był powszechny i nie przewidywano szczególnej ochrony najemców. Została ona wprowadzona w 1939 r., od 1942 r. obowiązywała kontrola wysokości stawek czynszu. Od 1956 r. obowiązywały limity czynszowe, w 1969 r. wprowadzono nowe reguły, które wiązały wysokość stawek czynszu w zasobie prywatnym z czynszami w zasobie społecznym. To właśnie budownictwo społeczne rozwijało się intensywnie po drugiej wojnie światowej. Duże znaczenie miały spółdzielnie mieszkaniowe, które dostarczały zasób dla mniej zamożnych obywateli. Państwo wspierało nabywanie mieszkań na własność przez gospodarstwa domowe o mniejszych zasobach, funkcjonował system tanich kre-

14 Liczba ludności w 1947 r. 27,5 mln, w 1979 r. 37,2 mln; liczba mieszkań w 1950 r. 6,29 mln, w 1970 r. 10,64 mln.

15 Liczba ludności w 1947 r. 6,8 mln, w 1979 r. 8,3 mln; liczba mieszkań w 1960 r. 2,58 mln, w 1980 r. 3,49 mln. 
dytów dla strony podażowej, gminy wspierały jednostki non-profit dostarczające mieszkań. Spowodowało to bardzo duży przyrost zasobu mieszkaniowego, w tym społecznego, od późnych lat 60. można było wręcz mówić o nadwyżce mieszkań. Dostępne dane statystyczne wskazują, że między rokiem 1960 a 1975 nastąpił znaczący wzrost liczby mieszkań na 1000 mieszkańców: od 344 do 430.

Wielka Brytania ${ }^{16}$ po drugiej wojnie światowej była w bardzo trudnym położeniu gospodarczym ze względu na utratę statusu mocarstwa kolonialnego i kryzys gospodarczy oraz konieczność odbudowy po zniszczeniach wojennych. W ramach polityki mieszkaniowej uznano, że pomoc dla osób, które ze względów finansowych nie miały zaspokojonych potrzeb mieszkaniowych, jest niezbędna. Wśród podejmowanych działań znalazło się m.in. zablokowanie możliwości podwyższania stawek czynszu w mieszkaniowym zasobie prywatnym do najmu oraz nałożenie na samorząd terytorialny obowiązku dostarczania mieszkań społecznych. W 1951 r. szacowano całkowitą liczbę mieszkań i domów na 13,7 mln, z czego przeważająca część miała charakter zasobu czynszowego prywatnego - 7,1 mln, a lokale komunalne miały najmniejszy udział, ponieważ było ich $2,5 \mathrm{mln}$. Konsekwentne zniechęcanie do inwestycji w mieszkania prywatne do najmu doprowadziło do zmiany tej struktury - w 1971 r. na 18,8 mln mieszkań i domów jedynie 3,6 mln miało charakter czynszowy prywatny, najwięcej było lokali zamieszkałych przez właścicieli - 9,4 mln, a w zasobie komunalnym znajdowało się 5,7 mln jednostek mieszkalnych.

\subsection{Ewolucja rynków nieruchomości mieszkaniowych w wybranych państwach UE od lat 80. do roku 2017}

\subsubsection{Odrębności uwarunkowań rozwoju i ewolucji rynków nieruchomości mieszkaniowych państw postsocjalistycznych}

Systemy mieszkaniowe państw socjalistycznych były opisywane jako „nieruchomości bez rynków nieruchomości” [Zavisca 2012]. Konsekwencją odrębności, które wynikały z powojennych uwarunkowań polityczno-gospodarczych, było stworzenie osobnych ścieżek rozwoju (path dependence), które odbiegały od wzorców istniejących w państwach Europy Zachodniej, ale także różniły się między sobą. Podstawowy podział socjalistycznych systemów mieszkaniowych nawiązuje

16 Liczba ludności w 1947 r. 49,5 mln, w 1979 r. 55,8 mln; liczba mieszkań w 1961 r. 14,64 mln, w 1981 r. 17,85 mln. 
do przyjętych zasad ustrojowych i pozwala wyróżnić dwie grupy i w ich ramach trzy modele, są to: model radziecki (ZSRR i w jego ramach Litwa, Łotwa i Estonia oraz NRD), model klasyczny (Albania, Bułgaria, Rumunia) jako grupa państw o klasycznym ustroju socjalistycznym oraz model reformistyczny (Jugosławia, Węgry, Polska, Czechosłowacja) jako grupa państw o ustroju zreformowanego socjalizmu [Soaita, Dewilde 2017, s. 8].

Transformacja systemów mieszkaniowych w tych państwach odzwierciedla sytuację wyjściową, zasadnicze reformy lat 90 . oraz rozwój gospodarczy i zmiany demograficzne. Przekształcenia własnościowe w postaci prywatyzacji i reprywatyzacji stanowiły kamień węgielny dalszego rozwoju. Reprywatyzacja, poza Polską, miała charakter ustawowy - nowe akty prawne stanowiły o możliwości oraz zakresie odzyskania mienia lub rekompensaty na rzecz byłych właścicieli i ich spadkobierców. Pojawiały się tu różne rozwiązania - od zwrotów w naturze poprzednim właścicielom, przez wypłatę odszkodowań w pieniądzu, do wypłat w postaci bonów reprywatyzacyjnych, za które można było nabyć majątek państwowy. Niejako równolegle toczył się proces prywatyzacji publicznego zasobu mieszkaniowego, w tym procesie także wykorzystywano różne rozwiązania, przede wszystkim odmienności wynikały z poziomu podejmowania decyzji - czy podejmowały je organy na poziomie krajowym i te same zasady obowiązywały powszechnie, czy decydowały indywidualnie gminy, które zostały wyposażone w majątek mieszkaniowy. Przekształcenia własnościowe spowodowały rekordowe w skali Europy poziomy własności mieszkań i domów uzyskane dzięki powszechnej chęci bycia właścicielem i bonifikatom w koszcie wykupu mieszkań. Uzyskanie własności w drodze prywatyzacji nie wiązało się z koniecznością zaciągnięcia kredytu hipotecznego lub był on zaciągany w wysokości nieproporcjonalnie niskiej w stosunku do wartości rynkowej uzyskanej nieruchomości. W efekcie struktura własności nie odpowiada poziomowi zamożności gospodarstw domowych, co w powiązaniu ze znacznym stopniem zużycia technicznego zasobu mieszkaniowego, który występuje w niektórych państwach, utrudnia utrzymywanie i gospodarowanie nim.

W większości państw postsocjalistycznych zasób mieszkań społecznych ma marginalne znaczenie ze względu na swój bardzo niewielki rozmiar. Nie odpowiada to potrzebom mieszkaniowym zgłaszanym przez gospodarstwa domowe [np. Raport Habitat for Humanity 2018]. Istnieje świadomość, że zasób czynszowy prywatny jest niedoszacowany, ponieważ z przyczyn podatkowych ukrywa się często fakt, że mieszkanie jest wynajęte. Pogłębione analizy wskazują, że pomimo wielu podobnych problemów dotykających mieszkalnictwo w tych państwach wybrały one osobne ścieżki rozwoju, mówi się o „równoległych szlakach” [Soaita, Dewilde 2017].

Polityka mieszkaniowa państw postsocjalistycznych jest ściśle związana z przemianami ustrojowymi, które w nich zachodziły. 
Bułgaria $^{17}$ jest jednym $\mathrm{z}$ najbiedniejszych państw UE, w ostatnich latach traciła obywateli, którzy migrują w poszukiwaniu lepszych warunków życia, niska też jest liczba urodzeń, co w efekcie spowodowało spadek populacji o prawie $2 \mathrm{mln}$, porównując lata 1990 i 2017. Charakterystyczna dla struktury własności zasobu mieszkaniowego była zmiana w postaci szybkiego wzrostu prywatnej własności kosztem zasobu publicznego. Wynikało to z prowadzonych procesów prywatyzacji oraz reprywatyzacji. Obecnie ok. $87 \%$ zasobu jest zamieszkiwanych przez prywatnych właścicieli, a jedynie 2,5\% przez najemców komunalnych. Niski poziom dochodów, szybki wzrost kosztów życia w połączeniu z niską jakością starego i zużytego zasobu mieszkaniowego (nieefektywnego energetycznie) spowodowały, że własność stała się dla wielu podmiotów obciążeniem, a nie uprawnieniem. Wiele osób często nie jest w stanie pokrywać kosztów niezbędnych prac remontowych wynikających z bardzo dużego zużycia technicznego budynków. Bułgaria jest na czele państw, w których zasób mieszkaniowy charakteryzuje się wysokim poziomem deprywacji mieszkaniowej oraz przeludnienia.

Do 2008 r. obserwowano szybki wzrost cen nieruchomości mieszkaniowych, jednak swoista bańka pękła w końcu 2008 r. Kryzys dotknął także sektor budowlany i finansowy, banki stały się znacznie ostrożniejsze w udzielaniu kredytów hipotecznych. Brak stabilności gospodarczej i politycznej odbija się m.in. w realizowanej polityce mieszkaniowej, problem braku dostępnych mieszkań o charakterze społecznym jest poważny, biorąc pod uwagę wzrost liczby niezamożnych gospodarstw domowych. Osobną kwestią są nielegalne budowy, w szczególności realizowane przez Romów. W 2017 r. w Bułgarii wprowadzono nową strategię mieszkaniową, której celem jest zrównoważona polityka mieszkaniowa, wyrażana przez pomoc dla najbiedniejszych, w tym w zakresie pokrywania kosztów ogrzewania oraz kosztów niezbędnych remontów.

Chorwacja ${ }^{18}$, poza problemami wynikającymi z transformacji ustrojowej, odczuła także konsekwencje wojny, czyli konieczna była odbudowa zniszczonego zasobu. Podobnie jak w przypadku Bułgarii, zmniejszyła się populacja państwa. Analizując sytuację mieszkaniową, należy wspomnieć o dwóch podstawowych procesach, które ją kształtowały, czyli o prywatyzacji i reprywatyzacji. Spowodowały one zmianę struktury własnościowej - w $1991 \mathrm{r}$. zasoby społeczne stanowiły ok. 25\% zasobu ogółem, obecnie ponad 90\% zasobu jest zamieszkiwane przez prywatnych właścicieli. Pozostałości socjalistycznego prawa mieszkaniowego były widoczne przez wiele lat pomimo wprowadzenia zasad gospodarki rynkowej. W 1996 r. wprowadzono nowe zasady, ale niemożliwe było całkowite odcięcie się od przeszłości. Konstytucja wskazuje, że obowiązki w zakresie zaspokajania

17 Liczba ludności w 1947 r. 7 mln, w 1979 r. 9 mln, w 2010 r. 7,5 mln; liczba mieszkań w 1956 r. $1,73 \mathrm{mln}, \mathrm{w} 1975$ r. 2,33 mln, w 2011 r. 2,6 mln.

18 Liczba ludności w 1990 r. 4,8 mln, w 2010 r. 4,4 mln; liczba mieszkań w 1991 r. 1,5 mln, w 2011 r. 1,9 mln. 
potrzeb mieszkaniowych obywateli spoczywają na samorządzie terytorialnym, państwo zostało niejako od nich uwolnione. Gminy nie posiadały jednak ani niezbędnej wiedzy ani zasobów do gospodarowania zasobem mieszkaniowym, starały się więc ich pozbyć, wykorzystując rozdawniczą prywatyzację (na ogół płacono 10-15\% wartości wykupowanego mieszkania). Co do zasady pieniądze uzyskane z prywatyzacji powinny służyć pokryciu kosztów budowy i remontów zasobów społecznych, tak się jednak na ogół nie działo. Zakłady pracy także pozbywały się zasobów mieszkaniowych. Obecnie poważnym problemem jest zły stan techniczny budynków i brak środków na remonty, które powinny być przeprowadzone na koszt właścicieli, czyli wspólnot mieszkaniowych. Rynek najmu prywatnego jest częściowo ukryty, rynek najmu społecznego jest bardzo niewielki. Nie istnieje ogólnokrajowa strategia mieszkaniowa, przejawem polityki mieszkaniowej jest wprowadzenie programów wspomagających finansowanie budowy lub zakupu mieszkań na własność, wspiera się także budownictwo społeczne dla najbiedniejszych. Specyficzna dla Chorwacji jest różnica w cenach nieruchomości położonych w atrakcyjnych miejscach na wybrzeżu i w głębi kraju.

Czechy $^{19}$, jeszcze jako część Czechosłowacji, przeprowadziły reprywatyzację na początku okresu transformacji, do 1993 r. większość postępowań była już zakończona. W 1994 r. wprowadzono nowe zasady odnoszące się do nieruchomości mieszkaniowych i wspólnot, toczyły się procesy prywatyzacyjne i przekształcenia prawno-organizacyjne. Sytuacja mieszkaniowa Czech jest znacznie lepsza niż większości państw postsocjalistycznych zarówno pod względem ilości, jak i jakości zasobu mieszkaniowego. Liczba właścicieli - użytkowników jest wysoka, ale nie przekracza $80 \%$, ocenia się, że w zasobie publicznym pozostało 6-7\% mieszkań [Lux 2017]. Kryzys 2008 r. spowodował znaczne zmniejszenie aktywności budowlanej, jednak wzrost popytu w następnych latach i wzrost cen $w$ dużych miastach spowodowały wzrost podaży. Widoczny jest brak dostępnych mieszkań dla gospodarstw domowych w trudnej sytuacji finansowej. Podstawowe cele polityki mieszkaniowej są określane na poziomie krajowym, ministerialnym, wskazuje się potrzebę zwiększenia dostępności mieszkań dla gospodarstw domowych, obowiązek wspierania obywateli z niezaspokojonymi potrzebami mieszkaniowymi, co oznacza potrzebę zwiększenia zasobu mieszkań społecznych. Podstawą prowadzonych działań jest strategia mieszkaniowa do 2020 r., brak jest jednak konsensusu w zakresie szczegółowych regulacji i trwają spory polityczne w odniesieniu do mieszkań społecznych. Stworzono specjalny państwowy fundusz mieszkaniowy, który zajmuje się finansowaniem budownictwa na wynajem, remontów w szczególności bloków z wielkiej płyty i infrastruktury technicznej. Młodzi ludzie mogą korzystać ze wsparcia w nabyciu pierwszych mieszkań.

Estonia $^{20}$ nie istniała po drugiej wojnie światowej do 1991 r. jako odrębne państwo. Wyzwania, które przed nią stanęły dotyczyły odbudowy podstaw państwowości.

19 Liczba ludności w 1990 r. 10,3 mln, w 2010 r. 10,5 mln; liczba mieszkań w 1991 r. 3,7 mln, w 2011 r. 4,1 mln.

20 Liczba ludności w 1990 r. 1,6 mln, w 2010 r. 1,3 mln; liczba mieszkań w 1991 r. 0,5 mln, w 2011 r. 0,5 mln. 
Koncentrując się na rynku nieruchomości, należy podkreślić, że przeprowadzono prywatyzację, reprywatyzację i liberalizację obrotu prawami do nieruchomości. W okresie socjalistycznym istniała własność prywatna, ale dominowały mieszkania państwowe. Cieszyły się popularnością, ponieważ były tanie (płacono ok. 20\% rzeczywistych kosztów utrzymania), najemcy mieli silną pozycję, de facto istniała możliwość dziedziczenia, zamiany mieszkania. W 1989 r. ok. 21\% populacji mieszkało w prywatnych domach i mieszkaniach, ok. 61\% w zasobie państwowym. Transformacja ustrojowa bardzo szybko zmieniła te wielkości - w 2000 r. w zasobie społecznym mieszkało już tylko $4 \%$ populacji, obecnie ok. 1,7\%. Było to wynikiem prowadzonej reprywatyzacji i prywatyzacji. Zakładano pierwszeństwo reprywatyzacji, wobec czego możliwy był zakup mieszkań najmowanych z zasobu publicznego, tylko jeśli nie było podmiotu uprawnionego do zwrotu lub nie chciał on nieruchomości. Generalnie reprywatyzacja zakładała zwrot w naturze. Aby poprawić sytuację najemców w reprywatyzowanych domach wielolokalowych zastrzeżono kontynuację umów najmu, początkowo na 3 lata, potem ten okres przedłużono o 5 i kolejne 5 lat. Prywatyzacja polegała na gratyfikacji w postaci bonów, za które można było nabyć prawo własności najmowanego lokalu, ta zasada obowiązywała do 1 grudnia 1994 r., od początku 1995 r. gminy mogły już swobodnie sprzedawać swój zasób mieszkaniowy na zasadach rynkowych. Po 2000 r. zaczął się budować prywatny rynek czynszowy, ale ze względów podatkowych funkcjonował on poza oficjalnym obiegiem.

W Estonii statystycznie nie występuje problem braku mieszkań, jednak w rzeczywistym rozkładzie popytu i podaży obserwuje się pustostany na terenach wiejskich i niedobór w dwóch największych miastach. Ponadto, należy pamiętać o silnej emigracji i spadku liczby ludności. Nowe budownictwo mieszkaniowe ma niewielki rozmiar, natomiast budynki powstałe w okresie socjalistycznym nie były często remontowane przez dziesięciolecia i obecnie są bardzo zdegradowane. Sama wysoka liczba mieszkań w stosunku do liczby mieszkańców nie oznacza więc, że problem mieszkaniowy nie istnieje.

Państwo wspiera własność poprzez instrumenty podatkowe, od 2015 r. wprowadzono wsparcie publiczne na działania remontowe. Problemem jest niedostosowanie wielkości mieszkań do wielkości gospodarstw domowych, te ostatnie są coraz mniejsze. Problemy mieszkaniowe silnie dotykają młodych ludzi, w szczególności w dwóch największych miastach.

Lotwa ${ }^{21}$, podobnie jak Estonia i Litwa, nie była niezależnym państwem od zajęcia terytorium przez ZSRR do przełomu ustrojowego. Niezbędne były procesy denacjonalizacji, reprywatyzacji i prywatyzacji, aby wprowadzić w życie nowe zasady społeczno-gospodarcze. W okresie socjalistycznym istniała własność prywatna, ale z licznymi ograniczeniami, najem zasobu publicznego był podstawową formą zaspokajania potrzeb mieszkaniowych. Koszty użytkowania były niskie, ponieważ

21 Liczba ludności w 1990 r. 2,6 mln, w 2010 r. 2,2 mln; liczba mieszkań w 1991 r. 0,9 mln, w 2011 r. 0,8 mln. 
państwo przejęło na siebie znaczącą część utrzymania zasobu. W okresie socjalistycznym zbudowano zasadniczą część zasobu mieszkaniowego. Nowe reguły ustrojowe i regulacje prawne wprowadzane od 1990 r. dotyczyły m.in.: ochrony prawa własności, zasad zwrotu nieprawnie przejętych nieruchomości, zasad najmu. Sąd Konstytucyjny stanął na stanowisku, że Łotwa jako państwo nie jest odpowiedzialna za działania podejmowane na jej terenie przez ZSRR, chodziło przede wszystkim o nacjonalizację i wywłaszczenia.

Jako zasadniczy element reformy przeprowadzono reprywatyzację, która miała osobną regulację w stosunku do terenów wiejskich i miejskich. Oddawano nieruchomości, które zostały wcześniej przejęte na podstawie określonych przepisów, jeśli podmioty uprawnione składały wnioski o zwrot. Zmiany wywołane reprywatyzacją dotknęly najbardziej najemców w zwracanych domach wielomieszkalnych. Aby zapobiec drastycznym zmianom warunków najmu, ustalono na poziomie rządowym maksymalną wysokość czynszu, wymówienie umowy było możliwe, przede wszystkim jeśli właściciel chciał zamieszkać w danym lokalu. W 2007 r. Sąd Konstytucyjny uznał, że limity czynszowe łamią podstawowe prawa konstytucyjne.

Specyficzną cechą regulacji prawnej obowiązującej na Łotwie jest możliwość oddzielenia prawa własności gruntu i budynku, przy czym oba prawa mogą należeć do osób prywatnych, które nie są współwłaścicielami nieruchomości. Wywołało to wiele problemów, m.in. spory o wysokość czynszu za korzystanie z gruntu, trudności w zakończeniu procesów reprywatyzacji i prywatyzacji. Prywatyzacja miała charakter kuponowy, obywatele otrzymywali bony, za które mogli nabyć własność nieruchomości, w tym zajmowanych na zasadach najmu mieszkań. W wyniku tych działań na Łotwie jest bardzo wysoki poziom własności, oficjalnie rynek czynszowy prywatny jest bardzo niewielki, nieoficjalnie działa w szarej strefie z powodów podatkowych (unikanie podatków przez właścicieli udostępniających mieszkania). Zasób czynszowy społeczny jest dostarczany przez gminy, mają one obowiązek wspierać obywateli, którzy nie są w stanie samodzielnie zaspokoić swoich potrzeb mieszkaniowych. Pomimo wysokich oficjalnych wskaźników liczby mieszkań na 1000 mieszkańców obserwuje się problem braku mieszkań dostępnych cenowo. Grupą, której to dotyczy, są przede wszystkim młodzi ludzie w miastach. Zasób mieszkań społecznych liczy mniej niż 1\% zasobu ogółem. Pomoc państwa skierowana jest do właścicieli i potencjalnych właścicieli, ma postać przywilejów podatkowych dla kredytobiorców hipotecznych, remontujących własne mieszkania. Gminy mogą starać się o dofinansowanie w wypadku budowy mieszkań społecznych. Problemy dotyczą także jakości zasobu, który nieremontowany charakteryzuje się dużym zużyciem technicznym i niedostosowaniem do obecnych standardów życia.

Podobnie jak wcześniej opisane państwa, również Litwa ${ }^{22}$ musiała zmierzyć się ze stworzeniem instytucji niezależnego państwa na początku lat 90. Podstawową kwestią były stosunki własnościowe, w okresie socjalistycznym możliwa była wła-

22 Liczba ludności w 1990 r. 3,7 mln, w 2010 r. 3,3 mln; liczba mieszkań w 1991 r. 1,3 mln, w 2011 r. 1,2 mln. 
sność prywatna, ale z licznymi ograniczeniami (np. przedmiotem własności prywatnej mógł być dom do 130 m kw.). W 1991 r. wydano akty prawne określające zasady przeprowadzenia prywatyzacji i reprywatyzacji, starano się przeprowadzić te procesy szybko, ponieważ były niezbędne do stworzenia systemu gospodarki wolnorynkowej. Prywatyzację zakończono w zasadniczej części do 1993 r., narzędziem były otrzymane przez obywateli vouchery, którymi płacili m.in. za nabywane mieszkania i inne typy nieruchomości.

Reprywatyzacja okazała się być procesem bardziej skomplikowanym, niezbędne stało się wydanie uzupełniającej regulacji prawnej w 1997 r. Część nieruchomości oddawano w naturze, a jeśli nie było to możliwe, wypłacano odszkodowanie lub proponowano nieruchomości zamienne. Lokatorzy odzyskanych kamienic mogli liczyć na przyznanie im mieszkań w zasobach komunalnych lub mogli uzyskać działki budowlane.

Mieszkania społeczne przeznaczane są dla najbardziej potrzebujących, jest ich ok. 3\% w zasobie całkowitym, czynsze są odgórnie regulowane. W oficjalnych statystykach rozmiar rynku czynszowego prywatnego jest niewielki, wynika to z szarej strefy, która powstała, aby unikać płacenia podatków.

Występuje duże zróżnicowanie przestrzenne, zarówno jeśli chodzi o popyt, podaż, jak i ceny. Miasta uniwersyteckie, miejscowości uzdrowiskowe cieszą się wzmożonym popytem. Do 2007 r. notowano boom inwestycyjny i cenowy, następnie z powodu kryzysu ceny gwałtownie spadły i kilka lat trwała stagnacja, która w ostatnich latach przekształciła się w ożywienie.

W założeniach polityki mieszkaniowej i w dokumentach rządowych obecnie nie faworyzuje się własności, wskazuje się na znaczenie sektora czynszowego, w szczególności w odniesieniu do zaspokajania potrzeb mieszkaniowych młodych ludzi i konieczność aktywizacji sektora budownictwa. Działania państwa były i są skierowane na wspomaganie określonych grup obywateli w nabywaniu własności, jest to realizowane m.in. poprzez pomoc w spłacie kredytu mieszkaniowego oferowaną rodzinom osiągającym dochody do określonego limitu, możliwość odliczeń podatkowych z tytułu spłaty odsetek kredytu mieszkaniowego, przy spełnieniu określonych warunków. Problemem jest brak mieszkań dostępnych, w szczególności dla rodzin mniej zamożnych.

Rumunia $^{23}$ jest państwem o najwyższym poziomie prawa własności mieszkań w UE, jest także jednym z najbiedniejszych krajów we wspólnocie. Wskazuje to na poważne nieprawidłowości w systemie zaspokajania potrzeb mieszkaniowych. W okresie socjalistycznym istniała własność prywatna mieszkań, dotyczyło to przede wszystkim obszarów wiejskich. W miastach budowano przede wszystkim bloki z wielkiej płyty, najwięcej nowych jednostek mieszkaniowych oddano do użytku w latach 70. i 80. na zasadach najmu.

23 Liczba ludności w 1990 r. 23,2 mln, w 2010 r. 21,4 mln; liczba mieszkań w 1992 r. 7,2 mln, w 2011 r. 7,3 mln. 
Prywatyzacja i reprywatyzacja były niezbędne do stworzenia fundamentów nowego ustroju społeczno-gospodarczego. Prywatyzacja umożliwiła podmiotom publicznym pozbycie się uciążliwych kosztów i problemów, początkowo inicjowana była na szczeblu państwa (płacono 10-30\% ceny ustalonej administracyjnie), w latach późniejszych to gminy decydowały o zasadach prywatyzacji nieruchomości komunalnych. $\mathrm{W}$ ramach reprywatyzacji dokonywano zwrotów w naturze, także kamienic z lokatorami, lub wypłacano odszkodowanie. Jeśli oddawano zamieszkany dom, nowy właściciel miał obowiązek utrzymać warunki najmu przez następnych 5 lat. Reprywatyzacja wywołała wiele problemów, w 2012 r. konieczne stało się wydanie nowej regulacji prawnej, mówiącej o odszkodowaniach.

Sytuacja mieszkaniowa obywateli jest bardzo trudna. Oficjalnie prawie nie istnieje sektor czynszowy prywatny - z powodów podatkowych właściciele nie przyznają się do wynajmowania mieszkań. Sektor mieszkań społecznych jest bardzo niewielki, odpowiedzialne są za niego gminy, które z powodu braku środków nie są w stanie zaspokoić zgłaszanych potrzeb mieszkaniowych. Wpływa to negatywnie na mobilność ludzi, czynsze w zasobie do najmu są na tak wysokim poziomie, że nabycie własności jest ekonomicznie jedynym wyjściem. Szczególnie trudna jest sytuacja mieszkaniowa młodych rodzin, osób migrujących do miast i niezamożnych. Pośrednim tego dowodem jest widoczny w statystykach trend przenoszenia się z miast na obszary wiejskie, gdzie łatwiej jest znaleźć tańsze zakwaterowanie, ponadto wiele osób emigruje za granicę. Stan techniczny istniejącego zasobu jest zły, występuje największe w UE przeludnienie mieszkań. Istniejące wspólnoty borykają się z koniecznością znalezienia znacznych środków na niezbędne remonty.

Polityka mieszkaniowa prowadzona jest w sposób doraźny, na szczeblu kraju podzielona jest między kilka organów, lokalnie zajmują się nią gminy. Wprowadzane są instrumenty, które bez odpowiedniego wsparcia finansowego nie wywołują oczekiwanych efektów. Od 1999 r. funkcjonuje specjalna agencja wspierająca budowę mieszkań czynszowych, program pomocy dla młodych ludzi został okrojony $\mathrm{z}$ powodów budżetowych. $\mathrm{W}$ sferze finansowania wprowadzono podmioty podobne do niemieckich kas oszczędnościowo-budowlanych. Państwo daje gwarancje bankom udzielającym kredytów hipotecznych na określonych warunkach.

Od 2007 r. wprowadzono możliwość wykupu własności w nowo wybudowanym zasobie czynszowym, co świadczy o braku strategii działania w sektorze mieszkań społecznych. Pozytywne jest wprowadzenie kompleksowych programów walki $\mathrm{z}$ biedą, dotyczą one także sfery mieszkaniowej, prowadzone są działania rewitalizacyjne.

Budownictwo mieszkaniowe rozwija się w określonych lokalizacjach, przede wszystkim wokół stolicy, tam też silnie wzrastają ceny. Silne są nierówności dochodowe na linii miasto - wieś, szczególnie trudna jest sytuacja rodzin romskich. 
Słowacja ${ }^{24}$ stała się niezależnym państwem 1 stycznia 1993 r. poprzez wyodrębnienie się z Czechosłowacji. Oznacza to, że pewna część nowych regulacji prawnych ustanawianych na początku lat 90. była wspólna dla Czech i Słowacji, m.in. wprowadzono równą dla wszystkich podmiotów ochronę prawa własności, uregulowano formy władania, określono zasady dokonywania reprywatyzacji. Z biegiem czasu dokonywano zmian w istniejących przepisach, aby je dostosować do potrzeb i sytuacji.

W okresie socjalistycznym Słowacja posiadała pewną autonomię, w szczególności po „praskiej wiośnie” w 1968 r. Prywatna własność mieszkań w dużych miastach była w zasadzie niedozwolona, użytkowano mieszkania na zasadach szczególnych praw, mających charakter zbliżony do najmu z bardzo dużą ochroną lokatora, czynsze odgórnie regulowane były niskie, nie pokrywały kosztów utrzymania zasobu mieszkaniowego. Właścicielem zasobu były przede wszystkim szeroko rozumiane państwo, przedsiębiorstwa państwowe, spółdzielnie mieszkaniowe. Możliwe było dziedziczenie prawa użytkowania lokalu, bardzo duża była ochrona przed eksmisją. Ponadto, nie działała zasada superficies solo cedit, czyli występowała rozłączność własności gruntu i naniesień. Istniał niedobór mieszkań, w szczególności w stolicy i miastach przemysłowych, starano się temu zaradzić poprzez masowe budownictwo z wielkiej płyty. Brak rynku mieszkaniowego, w szczególności segmentu prywatnego najmu, powodował małą mobilność ludzi.

Transformacja ustrojowa oznaczała zmianę stosunków własnościowych, konieczne były procesy prywatyzacji i reprywatyzacji. Problem zwrotu nieruchomości byłym właścicielom rozpoczęto rozwiązywać już na początku lat 90. Pierwszą grupę uprawnioną do żądań stanowili byli właściciele, którzy zostali pozbawieni swoich nieruchomości za długi, mieli oni bowiem obowiązek przeprowadzania remontów, ale brak możliwości czerpania dochodów z nieruchomości powodował, że nie byli w stanie zapłacić za niezbędne prace techniczne. Za remonty płaciło państwo i przejmowało nieruchomości. Zbyt krótki czas przedstawiania i dokumentowania roszczeń spowodował, że zwroty nie były realizowane, wydawano kolejne akty prawne dotyczące reprywatyzacji. Sytuacja konfliktowa wytworzyła się na linii: odzyskujący nieruchomości właściciele, a ich użytkownicy, czyli na linii korzystających z uprawnień reprywatyzacyjnych i prywatyzacyjnych. Mieszkaniowe zasoby komunalne były sprzedawane użytkownikom na korzystnych warunkach, ceny były negocjowalne, ale limity ustalone odgórnie. Z tych zasad nie mogli skorzystać użytkownicy zwracanych poprzednim właścicielom budynków. W 2011 r. wydano kolejne przepisy, aby uregulować kwestie sporne - przyznano najemcom w zreprywatyzowanych budynkach prawo żądania lokali zamiennych i zwrotu kosztów przeprowadzki, pokrywał je podmiot publiczny. Uprawnieni byli ci najemcy, którzy nie mieli możliwości samodzielnego zaspokojenia potrzeb

24 Liczba ludności w 1990 r. 5,3 mln, w 2010 r. 5,4 mln; liczba mieszkań w 1991 r. 1,6 mln, w 2011 r. 1,7 mln. 
mieszkaniowych. Gminy starały się pozbyć obowiązków poprzez przeniesienie ich na inne podmioty - nabywców budynków czynszowych z przeznaczeniem na lokale zamienne, przyznawały takim podmiotom specjalne granty.

Wykorzystywano środki wsparcia sektora własnościowego - nagradzano oszczędzanie z przeznaczeniem na cel mieszkaniowy, pomagano kredytobiorcom hipotecznym. Wskutek zmian własnościowych bardzo silnie wzrósł udział właścicieli prywatnych, mieszkań komunalnych zostało bardzo niewiele, natomiast zgłaszane są duże potrzeby na mieszkania społeczne, w szczególności w Bratysławie i innych dużych miastach. Osobnym problemem jest zły stan techniczny zasobu mieszkaniowego, powstałe nowe formy organizacyjno-prawne - kondominia (podobne do polskich wspólnot mieszkaniowych) muszą znaleźć środki na remonty, co nie zawsze jest możliwe. Spółdzielnie mieszkaniowe wskutek procesu prywatyzacji stały się podmiotami, które nie są już właścicielami, a jedynie zarządzają zasobem mieszkaniowym. Segment najmu prywatnego dopiero zaczął się rozwijać, ze względów podatkowych częściowo pozostaje w szarej strefie.

Polityka mieszkaniowa po przełomie ustrojowym nie odgrywała istotnej roli, dopiero z biegiem lat zauważono wpływ warunków mieszkaniowych i rynku mieszkaniowego na rozwój społeczno-gospodarczy. Należy przy tym zauważyć, że słowacki rynek mieszkaniowy charakteryzuje się niską liczbą mieszkań na 1000 mieszkańców. Przedstawiona koncepcja Krajowej Polityki Mieszkaniowej 2015 wskazywała na konieczność zwiększenia liczby mieszkań dostępnych oraz wprowadzenia nowych aktorów do systemu mieszkaniowego - podmiotów o charakterze non-profit, które działałyby po stronie podażowej. Na poziomie kraju wskazano zadania o charakterze koncepcyjno-legislacyjnym, a realizację zadań przekazano gminom. Wskazano konieczność posiadania przez nie programów rozwoju rynku mieszkaniowego, które określają m.in.: stan zaspokojenia lokalnych potrzeb mieszkaniowych, słabe i mocne strony rynku mieszkaniowego, rozwiązania, które należy przyjąć w krótkim i średnim okresie. Gminy, które posiadają takie dokumenty, mogą się starać o dofinansowanie budownictwa społecznego i infrastruktury. Podstawowe zadania związane są z dostarczaniem mieszkań społecznych, rewitalizacją, podwyższeniem standardów jakościowych istniejącego zasobu (w tym efektywności energetycznej), współpracą z trzecim sektorem w zakresie mieszkalnictwa, szczególne środki kierowane są do pomocy Romom. Obecnie państwo wspiera szczególnie budujący się sektor najmu.

Słowenia ${ }^{25}$ jest jednym z państw, które wyodrębniło się w 1991 r. z Jugosławii, jej sytuacja gospodarcza była najlepsza spośród wszystkich państw postsocjalistycznych przystępujących do Unii Europejskiej. W okresie socjalistycznym mieszkanie traktowane było jako dobro społeczne, a nie ekonomiczne, możliwa była własność prywatna i najem, ale podstawowa była własność społeczna. Jako część Jugosławii Słowenia miała autonomię w decydowaniu o określonych sprawach,

25 Liczba ludności w 1990 r. 2,0 mln, w 2010 r. 2,0 mln; liczba mieszkań w 2001 r. 0,6 mln, w 2011 r. 0,7 mln. 
w tym o zasadach udostępniania mieszkań obywatelom. W połowie lat 60 . przeprowadzono reformę systemową, która spowodowała obciążenie obowiązkami w sferze mieszkaniowej przedsiębiorstwa oraz przyznawała szczególną rolę bankom kredytującym. W 1980 r. wprowadzono nowe prawo o własności, swoiste połączenie kodeksu cywilnego i prawa socjalistycznego, przewidywano szczególne zasady korzystania z mieszkań - przyznawały one użytkownikom mniej uprawnień niż własność, ale więcej niż najem. Istniały też mieszkania przeznaczone dla osób z problemami materialnymi lub osobistymi, ich budowę finansowały przedsiębiorstwa, czynsze mogły być niższe. Struktura własnościowa była specyficzna, mieszkania o charakterze publicznym w ok. $68 \%$ należały do przedsiębiorstw, w $30 \%$ do gmin, a w $2 \%$ miały charakter rządowy. Sektor prywatny czynszowy prawie nie istniał.

W końcu lat 80. problemy gospodarczo-społeczne znalazły odzwierciedlenie w zmniejszonej aktywności budowlanej, przedsiębiorstwa i spółdzielnie ograniczały nowe inwestycje mieszkaniowe. Przełom ustrojowy spowodował konieczność stworzenia nowych ram prawnych. W konstytucji Słowenii zapisano obowiązek wykreowania przez państwo takich warunków, aby obywatele mogli zaspokoić swoje potrzeby mieszkaniowe. Państwo działa wobec tego na rzecz wszystkich obywateli w sposób kompleksowy i powinno współdziałać z innymi aktorami polityki mieszkaniowej. Jego zadaniem jest tworzenie zasad, norm decydujących o kształcie rynku mieszkaniowego. Zaprzestano bezpośredniego finansowania budownictwa mieszkaniowego, dostarczania nowego zasobu. Obowiązki państwa w zakresie bezpośredniej pomocy w zaspokajaniu potrzeb mieszkaniowych zostały ograniczone do grupy obywateli w złej sytuacji materialnej i życiowej. Zniesiono własność społeczną mieszkań, która w okresie socjalistycznym stanowiła ok. 33\% zasobu.

Dotychczasowi użytkownicy mieszkań mieli prawo je wykupić na własność, chyba że budynki były przedmiotem reprywatyzacji. Warunki sprzedaży były bardzo korzystne - płacono 10-20\% wartości rynkowej mieszkań. Pod koniec 1994 r. w zasadzie zakończono proces prywatyzacji, zbyto ok. 60,7\% mieszkań z zasobu publicznego, ok. 5,7\% zostało zreprywatyzowane. Pieniądze uzyskane dzięki prywatyzacji miały być wykorzystane do stymulacji podaży mieszkań, w rzeczywistości jednak ich przeznaczenie było odmienne.

Użytkownicy mieszkań i budynków, które podlegały zwrotowi byłym właścicielom, mieli prawo do nierynkowego czynszu i specjalną ochronę przed wypowiedzeniem umowy najmu, ale ich sytuacja prawna była znacznie gorsza niż najemców korzystających z prywatyzacji. Uznano, że doszło do kolizji interesów najemców i byłych właścicieli, starano się dostosować regulację prawną, ale w praktyce zdarzało się wiele sytuacji nieprawidłowych (nowi właściciele starali się za wszelką cenę pozbyć najemców). Ostatecznie uregulowano tę kwestię poprzez przyznanie najemcom prawa do wykupu mieszkania w ciągu 5 lat (pod warunkiem, że nowy właściciel się zgadzał) lub zakupu innego mieszkania, lub budowy domu, a część środków była zwracana przez państwo (36\% wartości w gotówce i 25\% w bonach). 
Ustanowiono Fundusz Mieszkaniowy Republiki Słowenii, swoje fundusze miały też gminy, w działania włączyły się NGO. Fundusz Mieszkaniowy udzielał długoterminowych pożyczek zarówno obywatelom, jak i podmiotom instytucjonalnym. Ponadto w celu wsparcia finansowania wprowadzono w 1999 r. system długoterminowego oszczędzania na mieszkanie. Wsparcie w zakresie finansowania straciło na atrakcyjności ze względu na zmianę uwarunkowań gospodarczych, w 2006 r. zmieniono zasady na bardziej elastyczne, wprowadzono specjalne granty dla młodych osób kupujących mieszkanie po raz pierwszy. Wycofano się z tych form pomocy w 2012 r. ze względu na niewielkie zainteresowanie nimi.

W 2003 r. wprowadzono nowe regulacje prawne w celu stymulowania rozwoju segmentu czynszowego, starano się tak uregulować relacje między właścicielami i najemcami, aby obie strony czuły się bezpiecznie, dostosowano również politykę podatkową. Starano się także rozwiązać problem istniejących pustostanów oraz stymulować działalność remontową. Problemem ogólnopaństwowym była mała aktywność budownictwa mieszkaniowego, natomiast wzrost liczby oddawanych do użytku jednostek mieszkalnych w następnych latach związany był ze wzrostem cen i spadkiem dostępności mieszkań. Zużycie techniczne zasobu mieszkaniowego także wymieniano jako jeden z głównych problemów. Polityka mieszkaniowa była zarysowana wyraźnie dzięki odpowiednim dokumentom, jednak nie była w pełni realizowana, przede wszystkim zakładano dużą aktywność w zakresie budowy mieszkań społecznych, jednak nie zapewniono odpowiednich środków finansowych na ten cel. Nowa Polityka Mieszkaniowa na lata 2015-2025 także wskazuje, że niezbędne jest zwiększenie dostępności mieszkań, w szczególności dla osób, które nie są w stanie same zaspokoić swoich potrzeb mieszkaniowych, jednak gminy, które mają ten obowiązek realizować w praktyce, nie mają środków. Wprowadzono rozwiązania promujące wynajem na zasadach non-profit.

Polska ${ }^{26}$ jest państwem, w którym deficyt mieszkaniowy na wysokim poziomie istnieje od dziesięcioleci. Składają się na niego zarówno uwarunkowania gospodarcze, jak i historyczno-społeczne. Państwo odzyskało niepodległość w 1918 r., nie udało się zunifikować systemów prawnych ani znacząco poprawić sytuacji gospodarczej w ciągu następnych 21 lat. Istniały bardzo duże dysproporcje przestrzenne także w zakresie zaspokajania potrzeb mieszkaniowych, nie można również zapominać o zniszczeniach, które powstały w wyniku obu wojen światowych. Już w 1919 r. zamrożono czynsze za lokale mieszkalne, zasada ta obowiązywała również po zakończeniu II wojny światowej. Niedobór mieszkań pogłębiała masowa migracja do miast. Państwo socjalistyczne wykorzystywało pretekst zaniedbania budynków przez prywatnych właścicieli (ze względu na ogromne potrzeby techniczne i brak środków nie byli oni w stanie płacić za remonty) i odbierało własność budynków mieszkalnych.

26 Liczba ludności w 1990 r. 38,1 mln, w 2010 r. 38,2 mln; liczba mieszkań w 1988 r. 10,7 mln, w 2011 r. 12,6 mln. 
Od 1957 r. nastąpiło uelastycznienie w podejściu do prywatnej własności, była ona dozwolona w ograniczonym zakresie, jednak najem miał charakter administracyjny i właściciel lokalu czy budynku nie mógł zdecydować ani kto będzie mieszkał w jego mieszkaniu, ani jaka będzie wysokość czynszu.

Aktywność budowlana była uzależniona od decyzji politycznych, państwo przejęło na siebie rolę dostarczyciela mieszkań, jednak rola ta nie miała znaczenia priorytetowego z punktu widzenia rozwoju społeczno-gospodarczego. Spółdzielnie mieszkaniowe zostały uznane za podmioty, które mają dostarczać nowego zasobu, rozwinęło się budownictwo wielkopłytowe, a użytkownicy uzyskiwali prawa do lokali będące połączeniem najmu i własności. Pomimo dużej aktywności budowlanej w przededniu transformacji, w 1988 r. deficyt mieszkaniowy był oceniany na ok. 1,3 mln jednostek mieszkalnych. Pogłębił się on w następnych latach, ponieważ wraz z transformacją przyszedł kryzys budownictwa mieszkaniowego ze względu na brak finansowania (kończono jeszcze wcześniej zaczęte inwestycje, ale nie rozpoczynano nowych). Problem utraty możliwości finansowych dotyczył także obywateli, ze względu na wysoką inflację i brak systemowego wsparcia finansowania mieszkalnictwa osoby fizyczne były zdane na pożyczki o charakterze przede wszystkim rodzinnym.

Ramy legislacyjne związane z nowym kształtem rynku mieszkaniowego pojawiły się dopiero w 1994 r., wskazuje to zarówno na niską wagę problemu w ocenie ówczesnych elit politycznych, jak i ogrom i skalę trudności nowej regulacji. Ustawa o najmie lokali mieszkalnych i dodatkach mieszkaniowych z 1994 r. miała wprowadzić nowe zasady na linii właściciel - najemca, zasady nie były w pełni rynkowe - przesunięto czas zmniejszenia skali ochrony najemców na 2004 r. Ustawa ta mówiła także o obowiązkach gmin w zakresie zaspokajania potrzeb mieszkaniowych obywateli, gminy jako zadanie własne miały tworzyć warunki do zaspokajania potrzeb mieszkaniowych przez samych obywateli, a bezpośrednio pomagać osobom, które nie były w stanie zrobić tego samodzielnie.

Druga ustawa - o własności lokali także z 1994 wprowadzała nowe podmioty - wspólnoty mieszkaniowe (kondominia) składające się z właścicieli lokali będących jednocześnie współwłaścicielami części wspólnych. W 1997 r. wydano ustawę o gospodarce nieruchomościami, która kompleksowo obejmowała wiele aspektów rynku nieruchomości, w tym także prywatyzację zasobu mieszkaniowego. Gminy miały całkowitą swobodę w ustalaniu bonifikat przyznawanych najemcom wykupującym swoje lokale. Ze względu na bardzo silne zużycie techniczne gminy starały się pozbyć jak największej części zasobu komunalnego i bonifikaty dochodziły do ponad $90 \%$ wartości lokalu.

Reprywatyzacja nie doczekała się rozwiązań kompleksowych, spory w parlamencie nad kształtem ustawy trwały do 2001 r., wtedy to udało się przegłosować ustawę reprywatyzacyjną. Jednak została ona zawetowana przez prezydenta i nigdy nie weszła w życie. Zniecierpliwieni byli właściciele starali się odzyskać swoje dobra na drodze indywidualnych postępowań przed sądami powszechnymi. Należy 
tu wspomnieć, że szczególne zasady dotyczyły nieruchomości przejętych w Warszawie tzw. dekretem Bieruta, tu także nie zastosowano rozwiązań ustawowych, ale byłym właścicielom łatwiej było odzyskiwać nieruchomości na drodze sądowo-administracyjnej ze względów proceduralnych. Podobnie jak w pozostałych państwach postsocjalistycznych pojawił się konflikt pomiędzy właścicielami odzyskującymi swoje nieruchomości a ich dotychczasowymi użytkownikami. Przyznano pierwszeństwo roszczeniom reprywatyzacyjnym, ale nowy właściciel wchodził w sytuację prawną poprzedniego wraz z zawartymi umowami. Wypowiedzenie umowy najmu było możliwe tylko $\mathrm{w}$ określonych okolicznościach, podwyższenie czynszu także było obwarowane określonymi warunkami. W tej sytuacji właściciele starali się pozbywać najemców nie zawsze legalnymi sposobami.

Spółdzielnie mieszkaniowe przez wiele lat miały szczególne regulacje prawne, które umacniały ich pozycję, jednak ostatecznie zostały zmuszone do masowej prywatyzacji własnego zasobu. Obecnie pełnią rolę współwłaściciela i zarządcy, wygasiły prawie całkowicie działalność budowlaną, ich rolę dostarczyciela nowego zasobu przejęły firmy deweloperskie.

W ramach wspierania rynku mieszkaniowego w 1995 r. powołano Krajowy Fundusz Mieszkaniowy, określono podstawy prawne funkcjonowania podmiotów non-profit statutowo koncentrujących się na budowie i wynajmowaniu zasobu mieszkaniowego, ustalono reguły oszczędzania długoterminowego w celu zaspokajania potrzeb mieszkaniowych. KFM został zlikwidowany w 2009 r., jego rolę z ograniczeniami przejął Bank Gospodarstwa Krajowego. Towarzystwa Budownictwa Społecznego, które początkowo rozwijały swoją działalność dzięki uprzywilejowanemu finansowaniu, musiały się bardzo ograniczyć, ponieważ nie było dostępnych środków budżetowych, system oszczędzania w postaci kas mieszkaniowych nie był dostosowany do ówczesnych warunków gospodarczych i nie był wykorzystywany. W latach 90. wprowadzono także ulgi mieszkaniowe z tytułu budowy, zakupu lub remontu nieruchomości mieszkaniowych, zniesiono je w zasadzie w 2001 r. W 2006 r. zaczęto działania wspierające młodych nabywców (Rodzina na Swoim, potem Mieszkanie dla Młodych). Wsparcie kierowano do średniozamożnych, którzy byli w stanie zaciągnąć kredyt hipoteczny i nabyć własność, w efekcie stosowanych rozwiązań ceny wzrastały.

Gminy mogą starać się o dofinansowanie stworzenia nowych mieszkań społecznych. Obecnie największy problem to brak mieszkań dostępnych cenowo, część rynku prywatnego czynszowego jest w szarej strefie ze względów podatkowych. Mieszkania komunalne w większości zostały sprywatyzowane, te które zostały, są zablokowane przez dotychczasowych najemców, których sytuacja ekonomiczna i osobista nigdy nie została zweryfikowana. Listy oczekujących na mieszkania społeczne są bardzo długie. Stan techniczny zasobu zarówno wykupionego przez najemców, jak i pozostającego własnością gmin jest często bardzo zły, brak środków na remonty i modernizacje, w niektórych miastach prowadzi się rewitalizacje. Nowe inicjatywy rządowe zmierzają w kierunku 
rozwoju rynku najmu, także o charakterze non-profit, ale pomimo istniejących regulacji prawnych nie są faktycznie realizowane.

Węgry $^{27}$ już w czasie I wojny światowej posiadały regulację prawną ograniczającą swobodę działania na rynku czynszowym, zmieniała się ona w następnych latach, ale restrykcje w zakresie wysokości czynszu dla lokali mieszkalnych i możliwości zakończenia umowy obowiązywały. Po zakończeniu II wojny światowej nastąpiła zmiana ustrojowa, która przyniosła nacjonalizację lub ścisłą kontrolę państwa w stosunku do prywatnych zasobów mieszkaniowych, spełniających określone warunki. Jeszcze w czasach socjalistycznych starano się zmniejszyć ówczesny deficyt mieszkaniowy, wywołany procesem migracji do miast za pomoca wieloletnich planów inwestycyjnych, dotyczących budowy nowych mieszkań. Od lat 70. poza znacznym przyrostem ilościowym nowych mieszkań, poprawiał się także ich standard i wielkość. Od początku lat 80. złagodzono reglamentacyjną politykę mieszkaniową z powodu niewydolności państwa (problemy finansowe), umożliwiono większą samodzielność w realizacji potrzeb mieszkaniowych obywateli. Jeszcze przed zmianą ustrojową rozpoczęto prywatyzację publicznego zasobu mieszkaniowego, bardzo wzrosło jej tempo od lat 90. Regulacja prawna w 1993 r. określiła szczegółowe zasady wykupu mieszkań komunalnych przez ich najemców, gminy w zasadzie nie mogły odmówić, ale nakreślono granice czasowe dla żądań najemców - był to 1995 r., co zostało następnie przedłużone do 2000 r. Obecnie w dalszym ciągu te gminy, które chcą się pozbyć zasobu mieszkaniowego, mogą starać się go sprzedać.

Reprywatyzacja w postaci zwrotu w naturze nie została przeprowadzona, nie powstał więc problem konfliktu między najemcami a prywatnymi właścicielami, odzyskującymi własność. Właściciele pozbawieni bezprawnie własności w okresie socjalistycznym oraz ich spadkobiercy mieli prawo do odszkodowania w formie bonów reprywatyzacyjnych. Mogli je wykorzystać do zapłaty za np. własność mieszkań, których byli najemcami, własność innych nabywanych nieruchomości czy przedsiębiorstw zbywanych przez państwo. Przed zmianą ustrojową ok. 50\% zasobów mieszkaniowych w miastach należała do zasobu publicznego i płacono za nie czynsz regulowany. Powszechna prywatyzacja spowodowała, że obecnie szacuje się udział mieszkań publicznych na jedynie ok. 3\%. Ponadto należy wspomnieć, że wykupowi na własność podlegały przede wszystkim zasoby w lepszym stanie technicznym, co zostało w gestii gmin często nie nadaje się do zamieszkiwania. Skutkiem tego powstaje dziwny obraz zasobu komunalnego, ponieważ pomimo bardzo wielu aplikacji, długich kolejek oczekujących część mieszkań to pustostany. Ta sytuacja jest charakterystyczna dla dużych miast. Gminy zostały obciążone obowiązkiem pomocy najbardziej potrzebującym, ale nie mają na to środków. Wysokość czynszów w zasobie publicznym jest znacznie niższa niż w zasobie rynkowym do

27 Liczba ludności w 1990 r. 10,3 mln, w 2010 r. 10,0 mln; liczba mieszkań w 1990 r. 3,7 mln, w 2011 r. 3,9 mln. 
najmu. Część zasobu czynszowego rynkowego pozostaje w szarej strefie ze względów podatkowych.

Polityka mieszkaniowa Węgier zmieniała się - początkowo, podobnie jak w większości państw postsocjalistycznych, rząd starał się doprowadzić do zakończenia bezpośredniego oddziaływania państwa na rynku mieszkaniowym. Sfera mieszkaniowa została przekazana gminom, natomiast brak było konkretnych ram prawnych. Pojawiły się one dopiero ok. połowy lat 90., powstały nowe instytucje m.in. kasy oszczędnościowo-pożyczkowe i banki hipoteczne. Pozwoliło to na rozwój kredytowania hipotecznego i samego rynku mieszkaniowego. Ze względu na urbanizację i szybki rozwój niektórych miast obserwowano silne zapotrzebowanie na mieszkania $\mathrm{w}$ tych ośrodkach, $\mathrm{z}$ jednoczesnym brakiem zainteresowania istniejącym zasobem w mniej popularnych rejonach. Do wybuchu kryzysu finansowego można zaobserwować wiele pozytywnych zmian, które związane były ze wsparciem nabywców korzystających z kredytów hipotecznych (mogli skorzystać z różnego typu przywilejów podatkowych, dopłat). Polityka mieszkaniowa silnie nastawiona na wspieranie własności spowodowała dynamiczny przyrost kredytów hipotecznych, wzrost cen nieruchomości, ale także obciążenie budżetu państwa w skali, której nikt wcześniej nie przewidywał. Tymi, którzy korzystali na wprowadzonych zasadach, byli najzamożniejsi, natomiast ze względu na brak mieszkań społecznych dla osób o niskich dochodach ta grupa znalazła się w gorszym położeniu. Ograniczenie szczodrości państwa ze względów politycznych nie było łatwe, zostało zapoczątkowane w 2004 r. poprzez ograniczenie dopłat dla kredytobiorców, w 2007 r. zniesiono odliczenia od podatków dochodowych. Nie zahamowało to jednak dynamicznego rozwoju kredytowania hipotecznego, ponieważ korzystano powszechnie $\mathrm{z}$ tańszych kredytów denominowanych w walutach obcych. Sektor bankowy był zainteresowany podtrzymywaniem tego zaangażowania m.in. z powodu dodatkowych zarobków na spreadzie walutowym.

Dramatyczna zmiana nastąpiła w wyniku wybuchu kryzysu finansowego. Spadek wartości waluty węgierskiej uderzył w kredytobiorców i banki, które zbyt mocno zaangażowały się w kredyty walutowe. Ponadto banki zmieniały oprocentowanie kredytów, które w sumie stały się poważnym obciążeniem dla kredytobiorców. Udzielanie nowych kredytów stało się rzadkie, deweloperzy ograniczali aktywność budowlaną, spadały ceny nieruchomości i liczba transakcji. Wprowadzono różne rozwiązania, mające pomóc kredytobiorcom, którzy nie byli w stanie wywiązać się z obowiązku spłaty kredytu, m.in. państwo kupowało mieszkania dłużników i następnie zawierało z nimi długoterminowe umowy najmu z opcją zakupu.

W celu zwiększenia aktywności budowlanej w 2016 r. obniżono stawkę podatku VAT w budownictwie mieszkaniowym, przyniosło to oczekiwany rezultat. Ponadto zwiększono wsparcie finansowe dla rodzin, w szczególności posiadających trójkę i więcej dzieci, jeśli nabywa się nową jednostkę mieszkalną. Efektem różnych narzędzi stymulacji rynku mieszkaniowego nastąpił wzrost cen, wzrosła także liczba transakcji. 
W odniesieniu do mniej zamożnej grupy istotne było zniesienie dodatków mieszkaniowych wypłacanych przez państwo, przeniesiono to zadanie na szczebel gmin. Zgłaszane jest duże zapotrzebowanie na mieszkania społeczne, jednak gminy nie są w stanie dostarczyć podaży, współpracują z NGO w ramach dostarczania pomocy mieszkaniowej.

\subsubsection{Ewolucja rynków nieruchomości mieszkaniowych w pozostałych państwach}

Austria była jednym z państw, które nie poddało się trendom liberalizacji rynku mieszkaniowego i ograniczania zakresu pomocy mieszkaniowej państwa, w dalszym ciągu bowiem utrzymano wsparcie dla mniej zamożnych gospodarstw domowych i nie prywatyzowano masowo zasobu publicznego. Należy także zauważyć, że kryzys nie dotknął bezpośrednio austriackiego mieszkalnictwa. Najem utrzymał wysoki udział, a część o charakterze socjalnym jest większa niż o charakterze rynkowym (57 do 43\%), mieszkania charakteryzuje wysoka jakość. Dla większości gospodarstw domowych mieszkania są dostępne. Ze względu na wzrost kosztów pogłębiła się jednak różnica udziału przeciążenia kosztami mieszkaniowymi wśród gospodarstw domowych ogółem i zagrożonych ubóstwem. W miastach wyraźny jest niedobór mieszkań społecznych dla gospodarstw domowych w trudnej sytuacji finansowej. Polityka mieszkaniowa ma nadal charakter podażowy, skoncentrowana jest na udostępnianiu mieszkań do najmu. Wobec dużego popytu na mieszkania społeczne wprowadzono nowe reguły, które mają spowodować wzrost podaży. Przede wszystkim proponuje się obniżenie kosztów budowy poprzez obniżenie standardu mieszkań społecznych, ułatwienia na etapie planowania przestrzennego. $W$ dalszym ciągu problemem jest reforma czynszów. Zmiany udziału właścicieli były niższe niż w wielu innych państwach europejskich.

W Belgii przekazano politykę mieszkaniową ze szczebla centralnego na regionalny w latach 80., ale promowanie własności pozostało podstawowym celem polityki mieszkaniowej wszystkich decydentów. Do tego celu wykorzystywano przywileje podatkowe, wynikiem był wzrost udziału właścicieli i spadek najemców. Właściciele stanowią bardzo dużą część użytkowników zasobu, mieszkania społeczne dostępne są nielicznej grupie, a popyt na nie jest znacznie większy niż podaż. Kryzys nie wpłynął bezpośrednio na rynek mieszkaniowy, pojawiły się nowe inicjatywy regionalne, np. w Walonii uznano, że należy dążyć do zmniejszenia stygmatyzacji najemców lokali społecznych i wprowadzono do zasobu społecznego osoby o wyższych dochodach, aby promować odpowiednią strukturę najemców (tenant mix), zmieniono także nazwę mieszkań społecznych na housing of public interest.

W Danii w sektorze mieszkań społecznych od lat 70. znacząco wzrosły stawki czynszu, co spowodowało, że stały się one niedostępne dla części gospodarstw 
domowych, próbowano temu przeciwdziałać specjalnymi kredytami dla zasobu społecznego na wydatki związane z utrzymaniem. W drugiej połowie lat 80 . zmniejszył się udział własności ze względu na zniesienie przywilejów podatkowych. W latach 90. wielu właścicieli, którzy wykupili swoje nieruchomości, zakładało spółdzielnie mieszkaniowe. Struktura praw do nieruchomości zmieniła się, ponieważ znacząco zmniejszył się udział mieszkań czynszowych prywatnych, ich właściciele sprzedawali je ze względu na restrykcje czynszowe, zwiększył się natomiast udział mieszkań społecznych. Zwolniono nowsze budownictwo na wynajem z ograniczeń czynszowych (te zasoby, które zostały zbudowane po 31.12.1991 r.), jednak nie były one konkurencyjne w stosunku do mieszkań społecznych. Ta ostatnia grupa jest wspierana wieloma instrumentami, środki przeznacza się na budownictwo, remonty i modernizacje. Odnowione zasoby mają wysoką jakość, stawki czynszu porównywalne z tymi, które obowiązują na rynku, występują problemy definicyjne i klasyfikacyjne dotyczące zasobu mieszkań społecznych. Kryzys 2008 r. spowodował problemy finansowe, co było szczególnie dotkliwe ze względu na wcześniejszy wzrost koniunktury i aktywności budowlanej. Należy także zauważyć, że Dania i Holandia to państwa z najwyższym poziomem długu hipotecznego. Wiele spółdzielni mieszkaniowych zostało rozwiązanych, a mieszkania z braku nabywców przeznaczano do najmu. Obecnie prowadzi się wiele działań o charakterze rewitalizacyjnym, mają one charakter inicjatyw lokalnych, a ponadto wprowadza się udogodnienia dla poprawy efektywności energetycznej.

W Finlandii w latach 80. przeprowadzono deregulację rynku finansowego, co umożliwiło m.in. rozwój komercyjnego rynku kredytów zabezpieczonych hipotecznie. Państwo wycofało się z udzielania pożyczek, ale w zamian wprowadzono pomoc w spłacie kredytów, a od lat 80 . stało się gwarantem pożyczek i kredytów udzielanych na cele mieszkaniowe w określonych warunkach. Budowano wiele mieszkań czynszowych, ale wprowadzono restrykcje dla podmiotów korzystających ze wsparcia publicznego - ograniczanie wysokości czynszów, selekcja najemców, generalnie wzmożenie budownictwa czynszowego miało pomóc $\mathrm{w}$ aktywizacji budownictwa. $\mathrm{Z}$ czasem restrykcje były łagodzone, ale nie zniesiono ich całkowicie. Od 2000 r. deweloperzy, którzy chcieli korzystać z pomocy państwa musieli rejestrować się jako podmioty działające w interesie publicznym (nie oznaczało to, że musieli działać non-profit). W końcu lat 80. zaczęła się tworzyć bańka na rynku mieszkaniowym, wzrost udziału własności został zahamowany kryzysem na początku lat 90. Państwo zadziałało antycyklicznie w latach 1992-1993, wspierając rynek mieszkaniowy, co przyniosło efekty. Zmniejszenie przywilejów najemców, zmiana przepisów podatkowych w przypadku korzystania z kredytów hipotecznych, niskie stopy procentowe przyczyniły się do ponownego wzrostu zainteresowania własnością. W latach 90. wprowadzono też specyficzne prawo przejściowe pomiędzy najmem a własnością, które obowiązuje w zasobie społecznym. Restrykcje planistyczne ograniczające podaż gruntów pod budowę, w szczególności w okolicy Helsinek, wzrost cen od lat 90., spowodowały spadek 
dostępności mieszkań w określonych lokalizacjach przy jednoczesnym, stosunkowo wysokim poziomie pustostanów na północy kraju. Problem z zaspokojeniem potrzeb mieszkaniowych mają młodzi ludzie, ponadto trudności wynikają z niedostosowania zasobu mieszkaniowego do potrzeb starzejącego się społeczeństwa i zmniejszającej się wielkości gospodarstw domowych.

Czynsze zostały w zasadzie uwolnione, w wypadku mieszkań społecznych obowiązują kryteria dochodowe. Funkcjonuje wiele programów pomocowych, m.in. działających przeciw długotrwałej bezdomności.

We Francji po złotej erze budownictwa społecznego w latach 60. i 70. zaczęto wspierać własność, m.in. poprzez zachęty finansowe do oszczędzania na cele mieszkaniowe, wspomagano też prywatnych właścicieli zasobu czynszowego poprzez pomoc w finansowaniu działań remontowych. Od 1977 r. nastąpiła zmiana z systemu wspierania strony podażowej na wsparcie o charakterze podmiotowym. Wprowadzono limity dochodowe dla najemców zasobu społecznego i wymagania jakościowe co do zasobu mieszkaniowego. W 1981 r. zaostrzono kontrolę wysokości czynszów, ponadto wysokie stopy procentowe i kryzys gospodarczy spowodowały zmniejszenie aktywności budowlanej. Aby przeciwdziałać spowolnieniu, rząd przyznał przywileje podatkowe właścicielom mieszkań czynszowych, co wywołało oczekiwane skutki w postaci wzrostu aktywności w zakresie budownictwa mieszkaniowego. W latach 90. skoncentrowano się na działaniach regeneracyjnych, nisko oprocentowane pożyczki przyznawano podmiotom dostarczającym zasób społeczny, a w ostatnich latach też prywatnym właścicielom. Po 2000 r. stworzono programy służące integracji wokół idei regeneracji społeczności lokalnych i lokalnych instytucji, celem było zidentyfikowanie i przywrócenie do użytkowania pustostanów, budowa większej liczby mieszkań dostępnych. Stworzono możliwość korzystania z uprawnień pomiędzy najmem a własnością (ze względu na koszty dla budżetu zrezygnowano $\mathrm{z}$ tego rozwiązania po kilku latach). Przeprowadzono decentralizację polityki mieszkaniowej, jej prowadzeniem zajmują się obecnie departamenty i związki gminne. Wprowadzono ułatwienia dla przekazywania gruntów pod budownictwo społeczne. Od 2015 r. obserwuje się poprawę sytuacji na rynku mieszkaniowym, sprzyja temu niski poziom stóp procentowych, wzrost liczby transakcji i zwiększony rozmiar budownictwa mieszkaniowego. Problemy dotyczą dostępności mieszkań w dużych miastach, 25\% nowego zasobu społecznego ma być przeznaczane dla najuboższych. Postuluje się mieszanie najemców społecznych i rynkowych, aby nie doprowadzić do powstawania swoistych gett dla najbiedniejszych, emigrantów tworzonych w wielopiętrowych budynkach, zlokalizowanych na przedmieściach. W 2017 r. ogłoszono rządowy projekt ogólnonarodowej strategii mieszkaniowej, której celem ma być doprowadzenie do zwiększenia liczby mieszkań dostępnych.

Niemcy, rozdzielone na dwa państwa o różnych ustrojach polityczno-gospodarczych, miały oddzielne ścieżki rozwoju, które połączyły się dopiero w latach 90. Niemcy Zachodnie dzięki bardzo intensywnemu rozwojowi budownictwa 
mieszkaniowego w okresie powojennym znacząco poprawiły warunki mieszkaniowe obywateli. Charakterystyczna była silna ochrona najemców oraz regulacja czynszów. Uwolniono od niej mieszkania nowe, budowane na wynajem. Nawet jeśli mieszkania były budowane $\mathrm{z}$ udziałem środków publicznych, po pewnym czasie przechodziły do sektora czynszowego prywatnego. W założeniu duża liczba mieszkań czynszowych - społecznych i prywatnych miała sprzyjać konkurencji i utrzymywaniu niskiego poziomu czynszów. W Niemczech Wschodnich nie było tak silnego popytu mieszkaniowego, polityka mieszkaniowa nie znajdowała się wśród priorytetów państwa socjalistycznego, populacja nie zwiększała się, budowano wokół miast przemysłowych osiedla dla pracowników. Po upadku muru berlińskiego nastąpiło wiele zjawisk, które odbiły się na sytuacji mieszkaniowej Niemiec Wschodnich i Zachodnich. Przede wszystkim wielu obywateli z części wschodniej postanowiło przenieść się na zachód, zostawiali wolne mieszkania, bardzo szybko wzrastał poziom pustostanów, w szczególności w lokalizacjach, które utraciły atrakcyjność (np. nieczynne zakłady przemysłowe powodowały, że $\mathrm{z}$ osiedli położonych wokół nich emigrowało bardzo wiele osób). Wprowadzono akty prawne regulujące zasady zwrotu i odszkodowań za nieruchomości przejęte w okresie socjalistycznym. Ocenia się, że roszczenia spowodowały powrót do poprzednich właścicieli ok. 600 tys. mieszkań. Ponadto wprowadzono zasady prywatyzacji mieszkań będących własnością państwa i przedsiębiorstw państwowych. Wskutek tych procesów zmieniła się struktura władania, w 1993 r. wskaźnik własności mieszkań był na poziomie 26,1\% w Niemczech Wschodnich i 41,7\% w Niemczech Zachodnich, natomiast w 2014 r. odpowiednio na poziomie 34,4 i 48,4\% (Destatis). W dalszym ciągu więc wśród państw UE Niemcy są krajem o najniższym udziale mieszkań zamieszkałych przez właścicieli. Od 2006 r. zdecentralizowano politykę mieszkaniową, kraje związkowe prowadzą ją samodzielnie z wyjątkiem wspólnych zasad dotyczących dodatków mieszkaniowych i premii budowlanej. Mogą one występować $\mathrm{z}$ żądaniami przekazania środków z budżetu centralnego na realizację polityki mieszkaniowej na określonych warunkach.

W Niemczech występuje silnie tendencja do koncentracji ludności w największych miastach, tam też najsilniej występuje deficyt mieszkań dostępnych. Według klasyfikacji Espin-Andersen Niemcy to konserwatywne państwo dobrobytu, podobnie jak Austria, czego wyrazem jest m.in. polityka mieszkaniowa. Co do zasady państwo powinno zaopiekować się obywatelami w potrzebie. Społeczna gospodarka rynkowa $\mathrm{w}$ aspekcie polityki mieszkaniowej powinna wyważyć wpływ rynku i polityki społecznej. Szczególna rola przypada krajom związkowym i wielkim miastom, które, jak wskazano wcześniej, decydują o wykorzystywanych narzędziach i celach lokalnej polityki mieszkaniowej. Swoistym dopełnieniem polityki mieszkaniowej jest polityka energetyczna i odnosząca się do zmian klimatu. Bezpośrednim realizatorem polityki mieszkaniowej są gminy, są obowiązane udzielać pomocy podmiotom, które nie są w stanie samodzielnie zaspokoić swoich potrzeb mieszkaniowych. Służą temu m.in. regulacje skłaniające deweloperów 
do przekazywania części wybudowanych mieszkań do najmu o ograniczonych czynszach osobom o niskich dochodach lub sprzedawania lokali z upustami. Deweloperzy mogą także przekazać część wybudowanych mieszkań gminom do rozporządzania. Tradycyjnie, silnie chronieni są najemcy oraz grupy znajdujące się w trudnym położeniu życiowym np. osoby starsze, niepełnosprawne.

W ostatnich latach poważnym wyzwaniem dla zaspokajania potrzeb mieszkaniowych stała się wielka fala migracji, w wielkich miastach aktywność budowlana jest zbyt niska w stosunku do zgłaszanych potrzeb, czynsze rosną szybciej niż dochody ludności. Z tego powodu wprowadza się lokalnie ograniczenia podwyżek czynszu za lokale mieszkalne. Trzeba także dodać, że koszty budowy między latami 2000 i 2016 wzrosły o prawie $50 \%$ z powodu wymogów stosowania nowoczesnych technologii i rozwiązań energooszczędnych. Ocenia się także, że zasób mieszkaniowy nie jest przygotowany na potrzeby ludzi starszych, a Niemcy są najstarszym społeczeństwem w UE i problem braku mieszkań dla osób starszych będzie narastał.

Grecja kontynuowała swoje wyjątkowe w wśród państw UE podejście do problemu mieszkaniowego, czyli brak oficjalnej polityki mieszkaniowej. W dalszym ciągu jednym z naważniejszych elementów systemu zaspokajania potrzeb mieszkaniowych była pomoc rodzinna. W ramach działalności deweloperskiej bazowano na kontraktach zawieranych pomiędzy właścicielami gruntu a przedsiębiorstwami budowlanymi. Ustanowiona współwłasność pozwalała na rozliczenie się w postaci przekazania dotychczasowemu właścicielowi gruntu umówionej wcześniej części mieszkań. Takie kontrakty odpowiadały stronom, ponieważ własność była bardzo rozdrobniona i trudno było prowadzić duże projekty ze względu na niewielki rozmiar działek w miastach. Deweloperzy często zapewniali sobie nabywców już na wczesnym etapie budowy i mogli korzystać z ich środków. Zaciągali także kredyty hipoteczne. Po wybudowaniu budynku funkcjonowało w nim kondominium, podobne do polskiej wspólnoty.

W latach 1987 i 1994 rynek najmu lokali mieszkalnych został całkowicie zliberalizowany, najem mieszkań społecznych nie występuje, wycofano się także z dodatków czynszowych. Charakterystyczna dla Grecji jest duża liczba pustostanów, część z nich funkcjonuje jako mieszkania wakacyjne. Problemem jest szara strefa mieszkań czynszowych, które z przyczyn podatkowych pozostają poza oficjalnym rynkiem. W 2014 r. przeprowadzono reformę podatku od nieruchomości, w jej wyniku wysokość podatku znacząco wzrosła.

Kryzys finansowy jest w dalszym ciągu odczuwalny w Grecji, koszty związane z zaspokajaniem potrzeb mieszkaniowych są znaczącą częścią wydatków gospodarstw domowych, spada poziom własności. Obniżyła się także aktywność budowlana i spadły ceny mieszkań i domów. Część właścicieli nie jest w stanie spłacić zaciągniętych wcześniej kredytów hipotecznych. Ze względu na ograniczenia budżetowe i złą sytuację gospodarczą pomoc mieszkaniowa jest skierowana obecnie do osób 
bezdomnych i znajdujących się w skrajnie złej sytuacji materialnej. Podmioty publiczne udostępniają pomieszczenia do mieszkania i pomagają w opłacie czynszu.

Irlandia wraz z Wielką Brytanią przystąpiła do UE w 1973 r., jednak jej sytuacja gospodarcza nie zmieniła się zasadniczo w związku z tym faktem. Urbanizacja i industrializacja postępowały, ale nie były bardzo dynamiczne. Od lat 70 . większość populacji mieszkała w miastach, co spowodowało wzrost popytu na lokale mieszkalne i wzrost cen w określonych lokalizacjach, ale do połowy lat 90. zmiany były powolne. Od lat 60 . trwały procesy regeneracyjne polegające na wyburzaniu slamsów i tworzeniu nowej tkanki miejskiej, państwo wspierało nabywanie domów i mieszkań na własność. Już w latach 70. poziom własności mieszkań był wysoki - ok. 70\% zasobu. Było to efektem prywatyzacji zasobów samorządu terytorialnego. Na terenach niezurbanizowanych ceny były niskie, pracujący uzyskiwali też niższe dochody $\mathrm{w}$ porównaniu $\mathrm{z}$ pracownikami zatrudnionymi $\mathrm{w}$ miastach. Wraz z rozwojem gospodarczym wzrosła także aktywność budowlana, w drugiej połowie lat 90. rozpoczął się boom mieszkaniowy, który zakończył się wraz z wybuchem kryzysu finansowego. Bardzo szybki wzrost gospodarczy spowodował dodatnie saldo migracji (także wracali Irlandczycy, którzy wcześniej opuścili kraj) i dynamiczny wzrost popytu na mieszkania. Dostępność kredytów hipotecznych spowodowała bardzo szybki wzrost cen mieszkań, co z kolei dalej stymulowało aktywność budowlaną. Ponadto polityka mieszkaniowa wspierała w dalszym ciągu nabywanie mieszkań na własność poprzez ulgi podatkowe (z tytułu zaciągania kredytów hipotecznych, a także w podatku od czynności cywilnoprawnych (stamp duty) i w podatku od zysków kapitałowych), państwo stymulowało także działalność remontową poprzez jej dofinansowanie. Kryzys finansowy spowodował krach na rynku mieszkaniowym, załamało się budownictwo, pojawiły się problemy ze spłatą kredytów mieszkaniowych ze względu na wzrost bezrobocia i złą sytuację finansową gospodarstw, wywołaną spadkiem cen mieszkań i domów, wzrosła liczba pustostanów. Wzrosła liczba wniosków o mieszkania społeczne i pomoc społeczną. Mieszkaniami takimi dysponowały przede wszystkim samorządy lokalne, niewiele było zarówno spółdzielni mieszkaniowych, jak i podmiotów non-profit dostarczających mieszkań społecznych. W tej sytuacji zdecydowano o zmianie polityki mieszkaniowej, w 2011 r. wprowadzono zasadę neutralności władania, czyli uznano, że celem państwa przestaje być stymulowanie nabywania na własność. Obecnie samorząd może zawrzeć umowę z prywatnym właścicielem zasobu czynszowego i w tym zasobie lokować najemców, którzy zostali zakwalifikowani do pomocy mieszkaniowej. Wprowadzono także system dodatków mieszkaniowych.

Do 1981 r. segment prywatnych mieszkań na wynajem nie rozwijał się ze względu na odgórne restrykcje czynszowe i wywołaną tym nieopłacalność ekonomiczną. Zmiany prawne spowodowały większe zainteresowanie inwestycjami w mieszkania do najmu, schemat buy-to-let w ostatnich latach przed kryzysem finansowym stał się bardzo popularny. Ze względu na kryzys wielu z inwestorów, którzy byli kredytobiorcami, miało poważne problemy ze spłatą zadłużenia, część 
sprzedawała mieszkania najemcom. Relacje między najemcą i wynajmującym są dokładnie uregulowane prawnie, od 2008 r. funkcjonują standardy mieszkaniowe wskazujące minimalne warunki mieszkania do najmu. Najemca, który ma zastrzeżenia, może zgłosić je do gminy, a ta przeprowadza kontrolę. Jeśli wykaże ona nieprawidłowości, podmiot publiczny może zakazać wynajmu lokalu do czasu usunięcia problemów. Od 2004 r. działa prywatny podmiot (Private Rented Tenancy Board), który zajmuje się mediacją między najemcami i wynajmującymi w wypadku sporu między nimi.

Silne ograniczenie aktywności budowlanej, które nastąpiło po kryzysie finansowym, przyczyniło się do niskiej podaży mieszkań, obserwuje się wzrost cen i stawek czynszu. Występuje także niedobór mieszkań społecznych. W 2016 r. rozpoczęto nowy program polityki mieszkaniowej, którego celami są: zwiększenie aktywności budowlanej sektora prywatnego, zwiększenie dostępności mieszkań społecznych, poprawa funkcjonowania prywatnego rynku czynszowego, zagospodarowanie pustostanów i walka z bezdomnością.

Włochy to jedno z tych państw, w których silne jest znaczenie więzi rodzinnych w zaspokajaniu potrzeb mieszkaniowych. Duże znaczenie ma także zróżnicowanie przestrzenne na rozwiniętą gospodarczo północ i zapóźnione południe, ponieważ powoduje to wewnętrzne migracje do rozwiniętych miast północnych Włoch, gdzie występuje niedobór mieszkań, w szczególności publicznych i społecznych ${ }^{28}$. Ponadto, należy pamiętać, że Włochy były przez lata kierunkiem migracyjnym i część problemów mieszkaniowych była i jest wynikiem przyrostu populacji o niskich dochodach i ograniczonych możliwościach podjęcia pracy. W latach przedkryzysowych kredyty hipoteczne zyskiwały na popularności jako źródło finansowania inwestycji mieszkaniowych, jednakże w dalszym ciągu poziom obciążenia kredytami mieszkaniowymi jest niższy niż przeciętna UE, wynika to m.in. z wieloletniej tradycji korzystania z pożyczek wewnątrzrodzinnych. Już w okresie powojennym rozwijano mieszkalnictwo społeczne, przyznawano m.in. przywileje dla spółdzielni mieszkaniowych, wzmacniano pozycję najemcy. Ze względu na trudności budżetowe najemcom mieszkań publicznych umożliwiono ich wykup z wysokimi bonifikatami, proces ten trwa do dziś, co powoduje, że zasób takich mieszkań jest niewielki. W założeniu uzyskiwane środki miały być przeznaczane na potrzeby mieszkaniowe, ale nie było to realizowane. Wykorzystuje się także schemat rent-to buy, natomiast w segmencie prywatnym powszechne są kondominia.

Specyficzne dla rynku włoskiego jest prawo do bezpłatnego korzystania z mieszkania, dotyczy to przede wszystkim członków rodziny, ale faktycznie jest często wykorzystywane jako obchodzenie przepisów podatkowych. Część mieszkań

28 Specyficzny dla Włoch jest podział mieszkań na publiczne i społeczne, te pierwsze pochodzą z wcześniejszego okresu, ich właścicielami są przede wszystkim gminy, te drugie powstają dzięki zaangażowaniu sektora prywatnego, charakteryzują się wyższym poziomem czynszów. 
wynajmowanych prywatnie pozostaje poza oficjalnym rynkiem ze względów podatkowych. Zarówno w sektorze publicznym, jak i prywatnym występują pustostany, ich przyczyną jest niski standard i zużycie techniczne zasobu. Część mieszkań publicznych jest nielegalnie zamieszkiwana, oficjalnie oczekuje na pomoc mieszkaniową ok. 650 tys. rodzin.

Kryzys finansowy odbił się na możliwościach zaspokajania potrzeb mieszkaniowych przede wszystkim uboższych gospodarstw domowych. W efekcie usamodzielnianie się młodych ludzi, w szczególności mężczyzn, jest odsunięte w czasie (57,9\% mężczyzn w wieku 25-34 ciągle mieszka $\mathrm{z}$ rodzicami, dotyczy to także $40,6 \%$ kobiet w tym wieku). Ze względów gospodarczych nasiliła się migracja do miast $\mathrm{w}$ północnych Włoszech, gdzie spowodowało to spiętrzenie problemów mieszkaniowych.

W 2001 r. zdecydowano o zakończeniu tworzenia polityki mieszkaniowej na szczeblu kraju i przekazano kompetencje w tym zakresie regionom, jednakże w 2005 r. powrócono do polityki krajowej, ponieważ istniały zbyt duże różnice regionalne zarówno w celach polityki mieszkaniowej, jak i wykorzystywanych instrumentach. W 2008 r. wprowadzono definicję mieszkań społecznych jako lokali wykorzystywanych na zasadach ciągłości, pozyskanych przez budowę i regenerację ze środków publicznych i prywatnych. Użytkownicy mają zawarte umowy najmu na co najmniej 8 lat lub nabywają mieszkania po cenie dostępnej. Ta ostatnia opcja służy zróżnicowaniu społecznemu w budynkach o charakterze społecznym. W 2009 r. przyjęto narodowy plan mieszkaniowy, jego głównymi celami są zwiększenie podaży mieszkań społecznych do wynajęcia oraz pomoc w nabyciu domu. Zrezygnowano ze wspierania nabywania mieszkań na własność jako głównego celu, uznając, że największy popyt dotyczy najmu mieszkań społecznych.

W celu zwiększenia podaży mieszkań wprowadzono konstrukcję funduszy inwestycyjnych finansujących budowę mieszkań na wynajem, podobną do amerykańskich REIT-ów. Zakłada się także wykorzystywanie partnerstwa między samorządami terytorialnymi a przedsiębiorstwami budowlanymi, ulgi podatkowe dla prywatnych właścicieli, wynajmujących swój zasób za stawki czynszu niższe niż rynkowe. Funkcjonuje system dodatków mieszkaniowych, ale pomoc udzielana w ten sposób jest ograniczona do niewielkiej liczby gospodarstw domowych.

W Holandii wsparcie państwa dotyczyło właścicieli zamieszkujących własne lokale oraz podmiotów będących właścicielami zasobu społecznego, nie stymulowano sektora prywatnego czynszowego, co w połączeniu z restrykcjami czynszowymi zniechęcało do inwestowania w mieszkania na wynajem. Od lat 80., podobnie jak $\mathrm{w}$ wielu innych państwach, zasady rynkowe, które stymulowały m.in. prywatyzację zasobu mieszkań społecznych, miały dominujący wpływ na politykę mieszkaniową. Państwo wycofywało się z bezpośredniego ingerowania i minimalizowało własną odpowiedzialność w zakresie zaspokajania potrzeb mieszkaniowych obywateli, co miało swój wyraz w redukcji wsparcia finansowego działalności budowlanej (w końcu wieku wycofano się z niego całkowicie). Mimo tych działań, duże zyski 
kapitałowe (dzięki dynamicznemu wzrostowi cen), które uzyskiwali właściciele, często inwestorzy instytucjonalni, podtrzymywały ich zainteresowanie rynkiem mieszkaniowym. Zmiana zasad finansowania spowodowała, że od lat 90. towarzystwa mieszkaniowe (housing associations), które dostarczały i zarządzały zasobem społecznym, musiały przeorganizować swoje źródła finansowania. Przekształcenia dotyczyły także zasobu komunalnego, uznano, że lepiej niż gminy będą zarządzać mieszkaniami towarzystwa mieszkaniowe, a samorząd powinien sprawować funkcje kontrolne i nadzorcze.

Segment właścicieli zamieszkujących własne zasoby rozwijał się w latach 90 . dzięki wzrostowi gospodarczemu i wzrostowi zamożności w połączeniu z popularnością kredytów hipotecznych (niskie stopy procentowe). Kryzys z początku lat 2000 zmniejszył zainteresowanie drogimi mieszkaniami, co spowodowało zmniejszenie produkcji budowlanej. W następnych latach sytuacja ustabilizowała się, ale od 2008 r. na skutek kryzysu finansowego nastąpiło ograniczenie inwestycji mieszkaniowych, co przyczyniło się do zwiększenia niedoboru mieszkań, w szczególności w dużych miastach.

Dynamiczny wzrost liczby i wartości kredytów hipotecznych w okresie przedkryzysowym wynikał z warunków finansowania - LtV mogło być wyższe niż $100 \%$, a przez maksymalnie 30 lat można było odliczać odsetki od kredytu w ramach płaconych podatków dochodowych. Od 1995 r. towarzystwa mieszkaniowe musiały szukać źródeł finansowania poza budżetem, więc pożyczały od banków komercyjnych, natomiast państwo mogło gwarantować takie pożyczki i kredyty. Dodatkowo, aby zgromadzić środki, towarzystwa mieszkaniowe sprzedawały najemcom mieszkania na uprzywilejowanych zasadach. W sektorze czynszowym prywatnym w Holandii podmioty gospodarcze, takie jak: towarzystwa emerytalne czy ubezpieczeniowe mogły być właścicielami mieszkań do najmu, obok podmiotów indywidualnych.

Polityka mieszkaniowa w Holandii przez wiele lat stymulowała wzrost własności, w szczególności pomoc była skierowana do osób wchodzących na rynek mieszkaniowy o określonym poziomie zamożności. Ponadto, dofinansowywano właścicieli zasobu czynszowego zarówno społecznego, jak i prywatnego. Polityka planistyczna pozwalała na znaczący wpływ organów publicznych na lokalizację, ilość i jakość nowych budów. Polityka czynszowa nie różnicowała zasadniczo zasobu społecznego i prywatnego, najemcy mogli się starać o dodatki mieszkaniowe. Generalnie polityka mieszkaniowa nie była nastawiona tylko na pomoc najbiedniejszym. Zmiana, która nastąpiła w latach 90. i wynikała z bardziej liberalnego podejścia, nie spowodowała eliminacji wszystkich wcześniej wykorzystywanych instrumentów. Zrezygnowano jednak z subsydiowania budownictwa mieszkaniowego na rzecz pośredniego wpływania na aktywność budowlaną poprzez stworzenie odpowiednich ram instytucjonalnych dla współdziałania samorządu terytorialnego, właścicieli zasobu społecznego i podmiotów prywatnych. Uznano, że cele polityki mieszkaniowej będą realizowane za pomocą regulacji czynszów, wypłaty 
dodatków mieszkaniowych, ulg podatkowych dla zaciągających kredyty hipoteczne, instrumentów polityki planistycznej oraz ustalenia zasad wykorzystywania zasobu społecznego. Polityka mieszkaniowa powinna być prowadzona kompatybilnie z polityką społeczną, podatkową i regeneracyjną. Samorząd terytorialny miał możliwość przekazywania własnych gruntów pod społeczne budownictwo mieszkaniowe po niższych cenach niż rynkowe. Jego współdziałanie z lokalnymi stowarzyszeniami mieszkaniowymi dotyczyło w szczególności planów inwestycyjnych rozwoju zasobu społecznego, ponadto samorząd współpracował ze stowarzyszeniami i organizacjami non-profit w sektorze mieszkaniowym.

Obecnie obowiązujące regulacje między wynajmującym i najemcą zostały ustanowione w 1998 r., wskazano obowiązki i uprawnienia obu stron, celem polityki mieszkaniowej jest wsparcie pozycji najemcy w stosunku do właściciela. Ponadto na podstawie innych przepisów wyposażono samorząd w silne prawo ingerencji, np. prawo do zagospodarowania pustostanów w sytuacjach trudnych (np. brak innych możliwości ulokowania uchodźców). W sektorze społecznym pierwszeństwo uzyskały gospodarstwa domowe o niskich dochodach, trudnej sytuacji życiowej, o określonych cechach. Ustawowo uregulowano początkową wysokość czynszu i zasady jego zmian, opracowano system trybunałów czynszowych (rent tribunals). Wyjątkowe w systemie holenderskim jest to, że regulacja odnosi się do obu zasobów - i społecznego, i prywatnego. Zliberalizowano te czynsze, które od początku przekraczały pewne graniczne wielkości. Pomoc państwa jest skierowana do użytkowników zasobu czynszowego, w którym obowiązują czynsze regulowane, wysokość czynszu jest uzależniona od jakości mieszkania i jego lokalizacji (system punktowy). Maksymalny wzrost roczny czynszu regulowanego jest określany na szczeblu parlamentu. Czynsz, który jest płacony w wyższej wysokości może być dowolnie zmieniany przez właściciela w porozumieniu z najemcą (zgodnie $\mathrm{z}$ obowiązującymi przepisami).

Niska dostępność mieszkań jest szczególnie widoczna w największych miastach, gdzie ceny szybko rosną. Aktywność budowlana stowarzyszeń mieszkaniowych jest znacznie mniejsza niż w latach przedkryzysowych. Ponadto problemem zasobu społecznego jest stygmatyzacja jego mieszkańców, podejmowane są działania, aby różnicować gospodarstwa domowe pod kątem zamożności, w szczególności na obszarach poddanych rewitalizacji. W ostatnich latach rozpoczęto też program wsparcia osób starszych w niezależnym zamieszkiwaniu.

Portugalia była opóźniona w przekształceniach społeczno-gospodarczych, wielki niedobór mieszkań został opanowany dzięki przede wszystkim inwestycjom państwa dopiero w latach 80. W 1986 r. Portugalia weszła do UE i była jej najbiedniejszym członkiem. Od 1981 r. ograniczono aktywność państwa w sferze mieszkaniowej i przekazano obowiązek pomocy w zaspokajaniu potrzeb mieszkaniowych niezamożnych gospodarstw domowych gminom. Generalnie były dwa kierunki działań - wsparcie poprzez udostępnienie mieszkań z zasobu społecznego, a dla zamożniejszych subwencje w przypadku nabywania 
własności (zrezygnowano z nich w 2002 r.). Problemy mieszkaniowe związane były ze strukturą władania - ze względu na bardzo silną ochronę najemców, zarówno przed zakończeniem umowy, jak i podniesieniem czynszu, sektor czynszowy prywatny był bardzo niewielki. Ponadto szybki wzrost gospodarczy, niskie stopy procentowe, przywileje podatkowe, wysoka aktywność budowlana, która powodowała dużą podaż mieszkań, powodowały, że najkorzystniej było nabywać mieszkania na własność. W następnych latach zmiana sytuacji gospodarczej spowodowała cięcia instrumentów polityki mieszkaniowej, co skutkowało zatrzymaniem przyrostu udziału właścicieli w strukturze władania. Wzrosło zapotrzebowanie na mieszkania czynszowe, ale ich w zasadzie nie było na rynku. Zaczęto podejmować próby reaktywacji zainteresowania rynkiem czynszowym prywatnym, ale regulacja prawna dawała tak silną pozycję najemcom, że powierzchowne zmiany nie przyniosły efektów. W latach 90. starano się całkowicie zmienić zasady najmu lokali mieszkalnych, wyróżniono najmy miejskie, mogły być one bezterminowe lub z terminem 5-letnim, strony mogły uzgadniać wysokość czynszu. Jednak ze względu na to, że nowe przepisy dotyczyły tylko nowych umów, na rynku niewiele się zmieniło. W 2006 r. ponownie podjęto próbę zmiany ram instytucjonalnych, zniesiono automatyczne przedłużanie umów najmu, zmodyfikowano przepisy o eksmisji, wprowadzono możliwość wypowiadania umów zawartych na czas bezterminowy (ale z 5-letnim okresem wypowiedzenia). Pomimo tych zmian w dalszym ciągu bardzo trudno jest podnieść czynsz czy wypowiedzieć umowę najmu zawartą na starych zasadach. Na rynku obok siebie funkcjonują dwa różne systemy. W 2012 r. kolejna reforma miała spowodować wzrost liczby mieszkań czynszowych prywatnych dzięki zrównoważeniu pozycji najemcy i wynajmującego oraz wprowadzeniu uproszczeń w procedurach administracyjnych dotyczących rewitalizacji. Po raz kolejny ułatwiono wypowiadanie umów najmu na czas nieokreślony, wprowadzono możliwość nadzwyczajnego podniesienia czynszu i zmieniono procedury eksmisyjne. Zmiany te były wyrazem nowego kierunku polityki mieszkaniowej - zaprzestano silnego wsparcia własności na rzecz pomocy w rozwoju segmentu czynszowego.

Prawo do mieszkania jest wskazane w portugalskiej konstytucji jako jedno z praw społecznych, mówi się ogólnie o obowiązkach państwa w kontekście polityki mieszkaniowej, współpracy z samorządem terytorialnym w takich dziedzinach, jak m.in.: planowanie przestrzenne, urbanizacja, polityka transportowa, promocja niskokosztowego budownictwa mieszkaniowego, stymulowanie aktywności budowlanej. Państwo ma także obowiązek prowadzenia adekwatnej do potrzeb obywateli polityki mieszkaniowej. W praktyce organy państwa na szczeblu kraju są odpowiedzialne za działania ustawodawcze, inicjowanie konkretnych programów mieszkaniowych, natomiast ich realizacją zajmują się gminy. Mieszkania społeczne są przeznaczane tylko dla gospodarstw domowych w najtrudniejszej sytuacji finansowej i życiowej. Programy rządowe mogą wspierać gminy w tworzeniu zasobu społecznego (np. konkretne lokalizacje - Lizbona, Porto), wspomagać 
gospodarstwa domowe w opłacaniu czynszu (np. wsparcie młodych ludzi wynajmujących mieszkania w zasobie prywatnym).

Specyficzna dla rynku portugalskiego jest duża liczba pustostanów, jednocześnie brak mieszkań dostępnych i współzamieszkiwanie wielu młodych ludzi z rodzicami ze względu na za wysokie ceny mieszkań w stosunku do dochodów i ograniczenia w udzielaniu kredytów mieszkaniowych. W ostatnich latach dostrzeżono lukę w grupie adresatów pomocy - są to gospodarstwa domowe niekwalifikujące się do zamieszkiwania w zasobie społecznym, ale za biedne na nabycie własności. Program Społeczny Rynek Najmu (Social Market for Tenancy) stworzył nowy segment - pomiędzy sektorem czynszowym prywatnym a dotychczasowym zasobem społecznym. Mieszkania w wyniku partnerstwa między rządem, gminą i bankiem są wynajmowane za cenę niższą o $30 \%$ od ceny rynkowej (chodzi o mieszkania zajęte przez bank za długi).

Problemy mieszkaniowe nie są postrzegane jako powszechne, uznaje się, że dotyczą pewnej niewielkiej grupy. Po zmianach ram instytucjonalnych określono rolę państwa jako regulatora, a nie dostawcy zasobu. Zgodnie z nimi państwo działa poprzez politykę podatkową, partnerstwo publiczno-prywatne i wsparcie finansowe określonych podmiotów. Najważniejsze cele to zmiana sytuacji na rynku czynszowym, co umożliwi większą mobilność obywateli i poprawę warunków mieszkaniowych, odnowę istniejącej tkanki miejskiej.

Rynek mieszkaniowy w Portugalii jest na niższym poziomie rozwoju instytucjonalnego ze względu na problemy z przejrzystością, brak danych historycznych o obrocie, ograniczenia w finansowaniu inwestycji mieszkaniowych.

Hiszpania w 1978 r. przyjęła konstytucję, która określała demokratyczne zasady ustrojowe i dopiero po zmianach politycznych mogła efektywnie starać się o członkostwo w UE, weszła do UE razem z Portugalią w 1986 r. W założeniu Hiszpania to państwo dobrobytu (welfare state) z ważnym komponentem społecznym. Prawo do mieszkania było wyraźnie wymienione w konstytucji jako prawo społeczne. Obowiązkiem państwa było tworzenie warunków i ustalanie standardów, które umożliwią zaspokajanie potrzeb mieszkaniowych obywateli. Pomimo tak sformułowanych zasad, przez wiele lat wspierano czynnie własność i wzmacniano wartość mieszkania jako dobra ekonomicznego, sektor społeczny był niewielki i był przeznaczony tylko dla gospodarstw domowych w najtrudniejszych sytuacjach życiowych. Na obszarach autonomicznych możliwe było tworzenie własnych zasad polityki mieszkaniowej, niesprzecznych z zasadami na szczeblu państwa. To rady miast i prowincji decydują o konkretnych instrumentach polityki mieszkaniowej. Na szczeblu państwa tworzy się kilkuletni plan mieszkaniowy, podobne są kreowane w obszarach autonomicznych, zawierają one informacje o kierunkach polityki mieszkaniowej, w tym: zobowiązaniach podmiotów publicznych w zakresie wspieranego budownictwa mieszkaniowego i zarządzania zasobem mieszkaniowym.

W pierwszej połowie lat 80 . dekoniunktura gospodarcza wpływała także na rynek mieszkaniowy. $Z$ końcem lat 80 . poprawiła się sytuacja finansowa gospodarstw 
domowych, ponieważ faza ożywienia spowodowała wzrost zatrudnienia. Od połowy lat 90. budownictwo mieszkaniowe stało się kołem zamachowym całej gospodarki Hiszpanii, budowano nie tylko obiekty całoroczne, ale także o przeznaczeniu wakacyjnym w atrakcyjnych turystycznie lokalizacjach (w 2006 r. wydano ponad 700 tys. pozwoleń na budowę). Powszechnie dostępne były kredyty hipoteczne, pożyczano nawet na $100 \%$ LtV. Ze względu na dynamiczny wzrost cen i duży popyt deweloperzy nie korzystali ze wsparcia państwa i sprzedawali budowane obiekty na wolnym rynku ${ }^{29}$. Boom trwał do września 2007 r., kiedy to kryzys finansowy położył kres koniunkturze. Budownictwo mieszkaniowe wytraciło cały impet, pojawiła się ogromna liczba osób bez zatrudnienia, stan ten trwał przez następnych kilka lat (w 2011 r. wydano jedynie 77 tys. pozwoleń na budowę jednostek mieszkalnych). Banki zaostrzyły politykę kredytową, wysokość kredytu została obniżona do $80 \%$ LtV (chyba, że bank sprzedawał zajęte przez siebie za długi mieszkania, wtedy mógł kredytować do 100\% LtV). Wiele gospodarstw domowych zaprzestało spłacania kredytów ze względu na brak dostatecznych środków, ceny spadały, banki przejmowały nieruchomości za długi. W tej sytuacji coraz większego znaczenia nabierał rynek najmu.

Podobnie jak w Portugalii, w Hiszpanii istniało stare i nowe prawo najmu. Zmiany w regulacji prawnej, które miały doprowadzić do zwiększenia podaży mieszkań czynszowych i w konsekwencji do obniżenia stawek czynszu rynkowego, przyniosły odwrotny efekt - czynsze wzrosły, a sytuacja prawna nowych najemców była znacznie gorsza niż tych, których obowiązywały stare reguły. Segment czynszowy społeczny był niewielki, prywatny także nie był duży, dominowała własność, co wynikało ze wsparcia państwa w postaci przywilejów podatkowych, wzrostu zamożności gospodarstw domowych i dostępności kredytów hipotecznych. W 1994 r. po raz kolejny uregulowano obowiązki i uprawnienia najemców i wynajmujących, zmiany dotyczyły m.in. czasu trwania umowy i możliwości zmiany wysokości czynszu. Nowe zasady nie aktywizowały jednak segmentu czynszowego, sytuacja stała się jeszcze bardziej skomplikowana, ponieważ równolegle funkcjonowały 3 systemy najmu (w zależności od momentu zawarcia umowy), czynsze nie spadały, a najemcy czuli się mniej bezpiecznie. W sferze finansowania inwestycji w najem starano się stymulować działania funduszy inwestycyjnych nieruchomości, ponieważ uważano, że będą one ważnym kanałem finansowania takich działań. W latach 2002-2005 próbowano wpłynąć na budowę większej liczby mieszkań społecznych, ale nie powiodło się to. Ceny mieszkań bardzo szybko rosły, inwestowano powszechnie na rynku mieszkaniowym. Kolejna próba oddziaływania na zwiększenie aktywności podaży mieszkań czynszowych prywatnych polegała

29 W Hiszpanii instrumentem pozwalającym na utrzymywanie dostępnych cen mieszkań było wsparcie deweloperów przez państwo, w zamian za które nie mogli oni sprzedawać mieszkań drożej niż limity określone przez podmiot publiczny. Pomimo podwyższenia limitów deweloperzy nie byli zainteresowani tym mechanizmem. 
na stworzeniu ram instytucjonalnych - specjalnych jednostek doradczych, spółek udzielających porad i gwarancji. Zrezygnowano z tego instrumentu w $2012 \mathrm{r}$. ze względu na brak efektów. W 2007 r. koniunktura na rynku mieszkaniowym zmieniła się diametralnie - popyt się załamał, bardzo szybko wzrastało bezrobocie, bardzo utrudnione było uzyskanie kredytu hipotecznego. Gospodarstwa domowe wchodzące na rynek mieszkaniowy poszukiwały obiektów do najmu, ale był wysoki niedobór takich lokali. Stawki czynszu były wysokie, więc starano się poprawić sytuację młodych gospodarstw poprzez specjalne dodatki ułatwiające zapłatę czynszu. Różnego typu wsparcie najemców wprowadzono też na poziomie regionu i lokalnie. W 2009 r. wprowadzono nowy podmiot - specjalne spółki inwestycyjne na rynku nieruchomości, w założeniu miało to uelastycznić rynek, ale tak się nie stało. Ze względu na kryzys i zahamowanie popytu wzrósł poziom pustostanów, także na rynku pierwotnym. Wydawałoby się, że w obliczu dużego popytu na najem wykorzystanie pustostanów byłoby najlepszym rozwiązaniem. Jednak obawa właścicieli przed niepłacącymi najemcami w związku z trudnościa$\mathrm{mi} z$ ich usunięciem $\mathrm{z}$ mieszkania oraz niedopasowanie przestrzenne powodowały, że na rynku było wiele gospodarstw domowych z niezaspokojonymi potrzebami mieszkaniowymi i puste mieszkania. Można także zauważyć, że potrzeby najemców i jakość mieszkań nie były dopasowane, ze względu na wysoki standard nowych mieszkań i niewielkie środki gospodarstw domowych. Ponadto, na rynku najmu obserwowano szarą strefę w celu unikania podatków i łatwości pozbycia się niepłacących najemców. Najem mieszkań społecznych był tylko dla najbardziej potrzebujących, umowy zawierano na 10 lub 25 lat, istniało kilka typów takich mieszkań (np. rotacyjne, chronione). W związku z brakiem środków niektóre samorządy prywatyzowały zasób mieszkaniowy.

Nowy kierunek polityki mieszkaniowej to promocja najmu i stymulowanie działań rewitalizacyjnych, a także budownictwa energooszczędnego. Specjalne działania mają chronić osoby starsze, młode oraz niepełnosprawne.

Polityka mieszkaniowa Szwecji była ważnym elementem systemu państwa dobrobytu. Zasada dobrych warunków mieszkaniowych została wyrażona w konstytucji jako podstawowe prawo społeczne i odnosiła się do wszystkich obywateli. Po okresie wzmożonego powojennego budownictwa mieszkaniowego nastąpiło nasycenie mieszkaniowe poza obszarami o największym poziomie urbanizacji. Jednakże brakowało mieszkań o określonych cechach, przede wszystkim małych. Od końca lat 80. obserwowano, że wybudowano za dużo mieszkań w nieodpowiednich lokalizacjach, przede wszystkim na obszarach poza metropoliami i miastami studenckimi. Natomiast w największych miastach był niedobór mieszkań, tam bowiem kierowali się poszukujący pracy i migranci zagraniczni. Aby zmniejszyć koncentrację tych ostatnich, w 1985 r. wprowadzono przepisy nakazujące odgórnie miejsce osiedlenia imigranta (miały to być obszary pozametropolitalne), jednak po uzyskaniu prawa pobytu i tak imigranci przenosili się do największych miast. Zniesiono te przepisy w $1994 \mathrm{r}$. 
Propagowano prawo własności poprzez wiele przywilejów, z których mogli korzystać nabywcy, jeszcze w latach 70. kombinacja regulacji prawnej (przywileje podatkowe, dopłaty do kredytów mieszkaniowych) i warunków gospodarczych (niskie stopy procentowe) powodowały, że wręcz zarabiano przy zakupie mieszkania z pomocą kredytu. Ograniczono te przywileje w związku z kryzysem gospodarczym początku lat 90., ponieważ wzrost stóp procentowych wywołał ogromny wzrost kwoty pomocy państwa. W kolejnych latach starano się promować energooszczędność, ochronę środowiska. Nabywca mieszkania na własność może odliczać część odsetek (do 30\%) w ramach płaconych podatków, natomiast działalność remontowa i modernizacyjna jest wspierana ulgami podatkowymi. Kredyty hipoteczne są powszechnie wykorzystywane, ze względu na kryzys finansowy zaostrzono regulację w 2010 r. w ten sposób, że nie można uzyskać wyższego kredytu niż 85\% LtV.

Niedopasowanie przestrzenne zasobu mieszkaniowego widoczne już w latach 80. niosło ze sobą problemy finansowe dla mieszkaniowych przedsiębiorstw komunalnych, które utrzymywały się z wpływów za mieszkania. Przedsiębiorstwa te dostarczały mieszkań do najmu, a jednocześnie stawki czynszu, które obowiązywały w zasobie komunalnym, były swoistym wyznacznikiem wysokości czynszu obowiązującego w zasobie prywatnym, obowiązywała bowiem wartość użytkowa (utylity value), która wynikała z lokalizacji i standardu mieszkania. Nie było zasadniczych różnic pomiędzy zasadami dotyczącymi zasobu publicznego i prywatnego do najmu, m.in. obowiązują wspólne minimalne standardy mieszkaniowe, odnoszące się do jakości. Każdy miał prawo starać się o mieszkanie w zasobie komunalnym, brak było limitów dochodowych. Gospodarstwa domowe o niskich dochodach, a także emeryci mogli wnioskować o dodatki mieszkaniowe.

W 1975 r. wprowadzono przepisy, które nakładały na prywatnego właściciela mieszkań czynszowych obowiązek poinformowania gminy o pustostanach, gmina mogła podjąć decyzję o ich zasiedleniu (co do zasady chodziło o wymieszanie najemców należących do różnych klas społecznych). W 1987 r. przekazano to uprawnienie tzw. trybunałom czynszowym. Były to podmioty, przed którymi właściciel i unia najemców uzgadniały wysokość czynszu i które rozpatrywały sprawy sporne. Zniesiono to prawo decydowania za właściciela w 1993 r. Zmiany w definiowaniu zasobu publicznego przyniosło wskazanie przez Komisję Europejską znaczenia mieszkalnictwa społecznego (social housing), zostało ono bowiem ograniczone do mieszkań dla gospodarstw domowych o niskich dochodach, trudnej sytuacji życiowej. Należy tu zauważyć, że skarżono m.in. obowiązujące w Szwecji zasady wsparcia mieszkaniowych przedsiębiorstw komunalnych jako niezgodnych z zasadami pomocy publicznej. Parlament szwedzki podjął decyzję w 2010 r., że w tym państwie nie będzie zasobu mieszkań społecznych, pozbawił mieszkaniowe przedsiębiorstwa komunalne przywilejów podatkowych i szczególnych zasad finansowania. Miały one działać jak podmioty gospodarcze.

Zadania mieszkaniowe są dzielone między państwo i samorząd, każda gmina musi planować podaż mieszkań na swoim terenie. Problemem jest niska 
aktywność budowlana i niedobór mieszkań w największych miastach. Aby zaradzić problemom, w szczególności w odniesieniu do ludzi starszych i migrujących młodych, stworzono wsparcie dla budownictwa czynszowego przeznaczonego dla takich gospodarstw domowych.

W Wielkiej Brytanii nie ma jednego aktu prawnego pełniącego rolę ustawy zasadniczej, zasady konstytucyjne wywodzone są z szeregu aktów prawnych uchwalanych na przestrzeni wielu wieków. W sferze mieszkaniowej istotne znaczenie ma Europejska Konwencja Praw Człowieka przyjęta przez Wielką Brytanię w 1998 r.

Masowa produkcja domów i mieszkań społecznych w okresie powojennym spowodowała, że w 1980 r. sektor publiczny był właścicielem ok. 1/3 zasobu mieszkaniowego. W tym okresie obowiązywały restrykcje czynszowe dotyczące zasobu prywatnego na wynajem, szeroko pojmowano obowiązki państwa w zakresie pomocy obywatelom w zaspokajaniu potrzeb mieszkaniowych, sprzyjało to zwiększaniu zasobu publicznego i zmniejszaniu udziału mieszkań czynszowych prywatnych. W następnych latach udział ten zaczął się zmniejszać, było to wyrazem zmian polityki mieszkaniowej ery premier Thatcher. Zmiana, która nastąpiła w latach 80., spowodowała ograniczenie roli państwa, zmniejszenie zasobu społecznego i wyraźny prymat własności prywatnej. Umożliwiono znacznej części najemców w zasobie społecznym wykup użytkowanych mieszkań z wysoką bonifikatą (right to buy), umożliwiono wykup udziałów w mieszkaniu rozłożony na wiele lat (shared ownership). Struktura użytkowników zasobu społecznego zmieniła się, ponieważ najzamożniejsi stali się właścicielami. Ci, którzy nie mieli środków, m.in. ludzie młodzi, emeryci pozostali najemcami. Zmiany dotyczyły dostarczycieli zasobu społecznego - po latach aktywności samorząd terytorialny usunął się w cień, a jego miejsce zajęły podmioty nazywane Registered Social Landlords, a w późniejszym okresie housing associations. Należy też zauważyć, że w sferze politycznej, gospodarczej i społecznej widoczne są duże różnice pomiędzy poszczególnymi częściami państwa - zostało to jeszcze wzmocnione w 1997 r. poprzez rozdział na osobne systemy z własnymi reprezentantami (Anglia, Walia, Szkocja i Irlandia Północna), a dalsze wyodrębnienie na cztery osobne organizmy nastąpiło w 2006 r. Szkocja pozostała przy socjalnym nastawieniu do mieszkalnictwa, Anglia zmieniła podejście na bardziej liberalne, rozwiązania pośrednie wybrała Walia.

Nowoczesne prawo najmu lokali mieszkalnych zostało wprowadzone w 1989 r., właściciele prywatni mogli sami decydować o wysokości czynszu. W drugiej połowie lat 90. wprowadzono wsparcie zakupów mieszkań w celu wynajmu (Buy-to-let), miało to zachęcić prywatnych inwestorów do zwiększenia podaży lokali na rynku najmu. Zmiana przepisów dotyczyła też eksmisji lokatorów, łatwiej można było ich usunąć. Dodatkowo wprowadzono nowe podmioty na wzór amerykańskich REIT-ów, które w założeniu także miały stymulować rozwój sektora czynszowego. Osiągnięto wzrost udziału prywatnych mieszkań na wynajem, ale kryzys finansowy spowodował zatrzymanie inwestycji. Aby temu zaradzić, wprowadzono następne instrumenty wsparcia w $2009 \mathrm{r}$. W sektorze prywatnym umowy 
najmu są często zawierane na czas określony i bardzo krótki, co nie sprzyja bezpieczeństwu i stabilizacji sytuacji najemców. Obowiązują określone minimalne standardy jakości mieszkań.

W segmencie czynszowym społecznym prywatyzacja i wyburzenia starego zasobu oraz zaprzestanie budowania nowych mieszkań przez samorząd spowodowały, że udział mieszkań komunalnych w zasobie ogółem znacznie się obniżył. Swoje działania aktywizowały podmioty prywatne RSL i housing associations, które często przejmowały od samorządu mieszkania (zostały one uznane za podmioty prywatne ze względu na zasady obliczania długu publicznego, w ten sposób ich zobowiązania nie są zaliczane do zobowiązań publicznych). Ponadto wprowadzono możliwość korzystania z partnerstwa-publiczno-prywatnego w sferze mieszkaniowej. W dalszym ciągu w zasobie publicznym czynsze są niższe od rynkowych (w Anglii do 80\% czynszu rynkowego), a umowy dają wysoką ochronę najemców, w ostatnim czasie wprowadzono terminowość nowych umów najmu. Ze względu na silny napływ imigrantów niezbędna stała się pomoc mieszkaniowa skierowana do tej grupy, zamieszkują oni często zasoby społeczne. Dofinansowanie do budowy mieszkań społecznych trafia teraz do housing associations, które są głównym kreatorem takich mieszkań.

W okresie przedkryzysowym wprowadzono wiele produktów hipotecznych, ale oferta spłaty kredytu przez 25 lat z limitem 2,5-letnich zarobków, potem 90\% LtV jako maksimum kwoty udzielonego kredytu nie wystarczały na zakup mieszkania w dużym mieście przy szybkim wzroście cen. Kryzys finansowy spowodował spadki cen w niektórych lokalizacjach i obostrzenia kredytowe, m.in. obowiązek wkładu własnego. Ze względu na trudności z jego zgromadzeniem w 2013 r. wprowadzono nowy instrument wspierający - gwarancje państwa dla kredytodawców udzielających kredytów hipotecznych, jeśli nabywca miał co najmniej 5\% wkładu własnego, inna możliwość to pożyczka rządowa do $20 \%$ kosztów budowy przy spełnieniu określonych warunków.

Wzrost cen spowodował, że wiele gospodarstw domowych, w szczególności złożonych z młodych ludzi, nie mogło zaspokoić samodzielnie potrzeb mieszkaniowych. Wzrosła liczba osób bezdomnych. Niedobór mieszkań, w szczególności w dużych miastach, i wysokie stawki czynszu powodują wysokie przeciążenie kosztami mieszkaniowymi najemców. Aktywność budowlana jest za niska w stosunku do potrzeb.

Samorząd terytorialny jest odpowiedzialny za monitorowanie potrzeb i popytu mieszkaniowego na swoim terenie, korzysta $z$ różnych instrumentów, których celem jest aktywizacja strony podażowej i pomoc stronie popytowej. Polityka mieszkaniowa koncentruje się obecnie na stymulowaniu budownictwa mieszkaniowego, wspieraniu poprzez zachęty finansowe segmentu czynszowego prywatnego i zwiększeniu dostarczania mieszkań społecznych. 

Część 2

Konwergencja rynków nieruchomości mieszkaniowych w państwach Unii Europejskiej 



\section{Rozdział 4}

\section{Istota konwergencji gospodarczej i metody jej weryfikacji}

\subsection{Pojęcie i rodzaje konwergencji}

\subsubsection{Definicje i istota konwergencji}

Pojęcie konwergencji ewoluowało na przestrzeni lat. Encyklopedia PWN z 1999 r. definiuje pojęcie konwergencji rozwoju jako zbieżności rozwoju ewolucyjnego, upodabniania się narządów lub kształtów osobników różnych grup systemowych, żyjących w podobnych warunkach środowiska oraz konwergencję teorii jako politologiczną koncepcję popularną w latach 60. i 70. na Zachodzie, głoszącą tezę o stopniowym upodabnianiu się do siebie społeczeństw socjalistycznych i kapitalistycznych pod wpływem czynników organizacyjnych i technicznych [Encyklopedia 1999, s. 392]. Pojęcie konwergencji w sensie używanym współcześnie w badaniach ekonomicznych narodziło się z neoklasycznej koncepcji teorii wzrostu (lata 50. i 60. XX w.), lecz znaczące badania empiryczne w tym zakresie dotyczą lat 80 . XX w. W badaniach tych zdefiniowano typ konwergencji absolutnej i warunkowej, konwergencję typu beta, sigma, gamma i inne. Najważniejsze różnice widoczne są w konwergencji typu beta i sigma - pierwszy typ dotyczy hipotezy doganiania (catching up) bogatszych krajów przez biedniejsze, drugi zakłada redukcję nierówności w czasie (formalnie rzecz biorąc, konwergencja typu beta jest warunkiem koniecznym, lecz niewystarczającym do wystąpienia konwergencji typu sigma). W literaturze można spotkać pogląd, że proces doganiania bogatszych krajów przez biedniejsze między państwami zachodnioeuropejskimi trwa już od końca XIX w., choć tempo konwergencji w ciągu ostatnich 20 lat utrzymywało się na stosunkowo niskim poziomie poniżej $2 \%$ rocznie; według M. Ferry proces ten zatrzymał się podczas drugiej wojny światowej, w latach 70., oraz w latach 1982-1986 [por. Yuill, Ferry 2008]. W Polsce wiele badań wskazuje, że zjawisko konwergencji gospodarczej (odnoszącej się do dochodów aproksymowanych wielkością PKB 
per capita) na poziomie regionów czy też subregionów nie występuje (por. Gorzelak [2009], Wójcik [2008], Kusideł [2013], Wójcik [2018])². W wielu przypadkach mamy wręcz do czynienia ze zjawiskiem dywergencji, a więc zwiększania się różnic w poziomie rozwoju gospodarczego. $Z$ drugiej strony inne badania [Kusideł 2011, 2013ab, 2014] pokazują, że hipotezę o konwergencji można pozytywnie zweryfikować w odniesieniu do regionalnych rynków pracy, pewnych obszarów ładu społecznego i instytucjonalnego, lecz już nie $\mathrm{HDI}^{2}$. Często można zauważyć, że silnemu procesowi konwergencji zewnętrznej krajów, oznaczającej szybkie doganianie średnich UE, towarzyszy jednocześnie dywergencja wewnętrzna.

Badania nad konwergencją są ważne co najmniej z trzech powodów. Pierwszy powód jest natury społecznej i wynika z faktu, że różnice w poziomie życia zwiększają się, co powoduje niepokoje społeczne. Drugi powód wynika ze sporu naukowego co do czynników wzrostu gospodarczego. Według szkoły neoklasycznej konwergencja jest zjawiskiem, które jest konsekwencją wzrostu gospodarczego. Inaczej twierdzą zwolennicy teorii wzrostu endogenicznego, którego konsekwencją jest przeciwne konwergencji zjawisko - dywergencja. Trzeci powód wynika z realizacji jednej z największych polityk europejskich - polityki spójności. Z tego tytułu do krajów członkowskich, szczególnie o niskim poziomie rozwoju (niskim PKB) trafiają znaczne kwoty, których głównym zadaniem jest zniwelowanie różnic rozwojowych. Powstaje pytanie, czy środki przeznaczane na wyrównywanie poziomów rozwoju regionów - czyli konwergencję - są skuteczne. Inaczej mówiąc, czy efekty realizacji polityki spójności są zgodne z jej celami³ ${ }^{3}$.

1 Wg hipotezy Williamsona ze zjawiskiem konwergencji spotkać się można dopiero na wyższych etapach rozwoju poszczególnych państw. Dla krajów opóźnionych wzrost dochodów powoduje początkowo wzrost nierówności pomiędzy poszczególnymi regionami. W miarę wzrostu dochodów wzrost nierówności ma tendencje malejącą aż do momentu, gdy w miarę wzrostu dochodów, nierówności gospodarcze pomiędzy regionami ulegają zmniejszeniu. Wynika to z tego, iż w początkowych stadiach rozwoju powiązania międzyregionalne, przepływ czynników oraz centralna polityka władz działają selektywnie na korzyść ośrodków i centrów dobrze rozwiniętych. Natomiast stały wzrost dochodów per capita, przyczynia się do odwrócenia trendu w kolejnych stadiach [Gawlikowska-Hueckel, Zielińska-Głębocka 2004, s. 223].

2 W pracy Kusidet [2011] pokazano, że w podziale na dwa podokresy: po akcesji do Unii i analogiczny okres poprzedzający zbieżność wskaźników dot. rynków pracy widoczna jest w pierwszym z wymienionych okresów. W artykule wyciągnięto z tego ostrożny wniosek, że realizacja polityki spójności może wpływać na osiąganie konwergencji na regionalnych rynkach pracy.

3 Pomimo, że środki z EFRR są lokowane w regionach najbiedniejszych, rosną nierówności regionalne w państwach członkowskich. Zgodnie z pierwszymi tego rodzaju obserwacjami z okresu 1988-1999 Komisja Europejska przyjęła do wiadomości fakt pewnej wymiany pomiędzy procesem konwergencji na narodowym i regionalnym szczeblu (por. J. Perez, M. Dones, C. Liano 2009, s. 512). Pod tym względem KE twierdzi, że wewnątrzkrajowe nierówności dotyczące zróżnicowania dochodu pomiędzy regionami są przejściowe, tylko w początkowym etapie ekonomiczne doganianie ma postać specjalizacji, polaryzacji i regionalnego zróżnicowania (jest to generalnie zgodne z hipotezą Williamsona, o której wspomniano we wcześniejszym przypisie). 


\subsubsection{Realna konwergencja w teoriach ekonomii}

Hipoteza o występowaniu konwergencji jest wnioskiem płynącym z neoklasycznych modeli wzrostu, zapoczątkowanych przez Solowa [1956] (czasami łączony jest również z nazwiskiem Swana [1956]). Zgodnie z neoklasyczną teorią wzrostu warunkiem koniecznym do zaistnienia konwergencji między badanymi obszarami (krajami, regionami) są malejące produktywności krańcowe kapitału. Oznacza to, że różnice pomiędzy obszarami zmniejszają się, bowiem te biedniejsze, konkurując niższymi cenami i kosztami, przyciągają inwestycje. Inaczej mówiąc, spadająca produktywność w regionach bogatszych skłania przedsiębiorców do realokacji kapitału do regionów o mniejszych jego zasobach - w celu podniesienia wydajności produkcji. Prowadzi to do wyrównywania się kapitału (i kapitału na zatrudnionego) pomiędzy krajami (regionami), co przy założeniu podobnego zaawansowania technologicznego ${ }^{4}$ powoduje wyrównywanie produkcji (produkcji na zatrudnionego) - a więc konwergencję.

Opisany powyżej mechanizm dotyczy tzw. efektu doganiania, oznaczającego osiąganie przez obszary biedniejsze wyższych stóp wzrostu gospodarczego niż kraje bogatsze i sugeruje silne powiązanie tego procesu ze wzrostem gospodarczym. Konwergencja wynikająca z neoklasycznego modelu Solowa-Swana jest zjawiskiem będącym naturalną konsekwencją wzrostu gospodarczego, bowiem w warunkach malejącej krańcowej produktywności kapitału (która jest jednym z założeń modelu Solowa) w miarę dochodzenia gospodarki do długookresowej równowagi - długookresowa stopa wzrostu produkcji będzie asymptotycznie malała. W związku z malejącą krańcową produktywnością kapitału, przepływa on do krajów (regionów), w których jego zasób (w przeliczeniu na mieszkańca lub pracownika) jest mniejszy, czyli do obszarów uboższych. Stąd wyrównywanie poziomów kapitału, co implikuje konwergencję dochodów (produktów) i wydajności pracy.

Mimo że hipoteza o występowaniu konwergencji była znana od połowy lat 50 . XX w., intensywny rozwój badań jej poświęconych nastąpił dopiero na przełomie lat 80. i 90. XX w. Prawdziwy wysyp badań empirycznych i teoretycznych w tym temacie

Z bardziej pesymistycznego punktu widzenia, niektórzy autorzy twierdzą [Boldrin, Canova 2001], że alokacja inwestycji w najgorzej rozwiniętych regionach jest nieefektywnym i utrudniającym doganianie procesem. Argument ten może być wzmocniony, jeśli weźmiemy pod uwagę zasadę dodatkowości, która warunkuje regionalną alokację oraz krajowe publiczne i prywatne inwestycje na bazie raczej redystrybucji niż efektywności.

Co więcej Puga [2002] dostarczył dalszych argumentów nieefektywności polityki regionalnej UE. Pokazuje on, że tradycyjnie zróżnicowanie dochodów pomiędzy regionami było tłumaczone czynnikami endowments. W tym kontekście usunięcie przeszkód w ruchu towarów i/lub czynników produkcji przyczynia się do konwergencji tych czynników.

4 O roli zaawansowania technologicznego w teoriach ekonomicznych pisze Kusidet [2013], podrozdział 1.3.2. 
wywołała praca Barro i Sala-i-Martina [1992] $]^{5}$. Prace empiryczne pokazały, że konwergencja nie zawsze zachodzi ${ }^{6}$ i do głosu zaczęły dochodzić konkurencyjne do neoklasycznych teorie ekonomiczne - wzrostu endogenicznego [Romer 1994; Temole 1999; Lucas Jr. 1988; Krugman, De la Fuente 1995; 2002, Aghion-Howitt 1988].

Najważniejszą cechą nowych teorii w stosunku do teorii neoklasycznej było osłabienie założenia malejących przychodów. W szczególności w układach regionalnych możliwa jest zarówno konwergencja, jak i dywergencja. Na przykład różnice w płacach mogą sprzyjać konwergencji poprzez lokalizację produkcji w regionach o niższych kosztach pracy - to tradycyjne podejście do teorii lokalizacji przedsiębiorstw. $\mathrm{Z}$ drugiej strony wzajemne powiązania przedsiębiorców stymulują innowacje, a powstające w ten sposób technologie są zasadniczym źródłem rosnącej krańcowej produktywności kapitału (czemu dodatkowo sprzyjają lepiej rozwinięta infrastruktura oraz bliskość odbiorców, kooperantów, lepiej wykwalifikowana siła robocza). Ostatecznie, w niektórych sytuacjach można mieć do czynienia nie z malejącymi (jak to postuluje teoria neoklasyczna), lecz rosnącymi przychodami skali. Dopuszczenie ich istnienia stwarza teoretyczne podstawy samonapędzającego się procesu rozwoju gospodarczego, który skupia aktywność ekonomiczną wokół dużych ośrodków miejskich - metropolii ${ }^{7}$ Czy możliwa jest w takich warunkach konwergencja? Tak, ale nie (tylko) jako konsekwencja akumulacji kapitału, lecz (również) jako konsekwencja dyfuzji innowacji i technologii [Kusideł 2013, s. 17 i dalsze]. Teoretycznie tempo dyfuzji zależy od wielkości luki technologicznej - w miarę zmniejszania się luki technologicznej jej dalsze ograniczanie staje się coraz trudniejsze. Oprócz uchylenia założenia o malejących przychodach z zastosowanego kapitału, teorie endogenicznego wzrostu były rozbudowywane o wiele dodatkowych czynników wzrostu niż to miało miejsce w modelu neoklasycznym ( $w$ którym czynnikami tymi był kapitał fizyczny, praca i technologia, która traktowana była egzogenicznie). Modele wzrostu endogenicznego w zależności od przyjętych założeń mogą przewidywać zarówno konwergencję, jak i dywergencję badanych gospodarek.

Ostatecznie zatem nie można powiedzieć, że zjawisko konwergencji zostało jednoznacznie wyjaśnione w teorii ekonomii. Modele wzrostu gospodarczego dają zróżnicowane wyniki dotyczące występowania realnej konwergencji gospodarczej.Z pewnością

5 Należy tutaj zauważyć, że główne podwaliny pod te prace, jak i terminologię dała praca doktorska Sala-i-Martina z 1990 r.

6 Dotyczyło to również państw Unii Europejskiej, której gospodarki przez wiele dziesięcioleci po wojnie charakteryzowało zmniejszanie nierówności gospodarczych (konwergencja). Nierówności zaczęły narastać od lat 80 . XX w., co zapoczątkowało reformę funduszy strukturalnych polegających na przebudowie zasad ich przydzielania i znacznego zwiększania budżetu w celu wspieraniu regionów słabiej rozwijających się (por. [Kusideł 2013, s. 146-147]).

7 Koncepcja rosnących przychodów skali została sformułowana przez Myrdala [1944] już w pierwszej połowie XX w. Zakładała ona, że proces wzrostu gospodarczego ma charakter kumulatywny, tzn. po osiągnięciu pewnego krytycznego poziomu aktywności ekonomicznej ośrodek metropolitalny może rozwijać się coraz szybciej dzięki występowaniu sprzężeń zwrotnych (por. Spójność wewnętrzna a konkurencyjność..., [2009], s. 15). 
natomiast modele ekonomiczne opisują różnorodne mechanizmy, które mogą doprowadzić do konwergencji lub ją uniemożliwić [por. Wójcik 2018, s. 24]. Z teorii neoklasycznej wiadomo, że konwergencja gospodarcza może wystąpić w przypadku występowania malejących przychodów krańcowych z kapitału fizycznego oraz z możliwości wykorzystania egzogenicznego postępu technologicznego, czyli najczęściej technologii wytworzonych w krajach (regionach) lepiej rozwiniętych. Taki efekt nie będzie jednak trwał w nieskończoność - możliwości absorpcji (imitacji) zewnętrznych technologii i korzyści skali nie będą mogły trwać w długim okresie, jeśli dany kraj (region) nie będzie dysponował odpowiednim zapleczem naukowo-instytucjonalnym, pozwalającym na coraz lepsze wykorzystanie początkowych przewag.

\subsubsection{Rodzaje konwergencji}

Intensywne badania nad zjawiskiem konwergencji realnej w latach $80 . \mathrm{XX}$ w. oraz późniejszych doprowadziły do zdefiniowania wielu jego typów i odmiennych sposobów weryfikacji. W literaturze przedmiotu wymienia się konwergencje typu beta, sigma, gamma, a ostatnio stochastyczną, konwergencję społeczną, przestrzenną, dochodową, technologiczną, sektorową, klubową i inne. Różnorodność definicji i metod pomiaru zjawiska konwergencji skłania do refleksji nad samym pojęciem, jego źródłami, rodzajami i metodami badania. Klasyfikacje konwergencji według kryterium metodologicznego można znaleźć w pracy Islam [1995]. Klasyfikacje koncepcji i metod analizy konwergencji przeprowadził Nowak [2003, 2006], Gajewski [2006], Kusideł [2013], Bernardelli i in. [2017].

Mówiąc o konwergencji, mamy na myśli najczęściej konwergencję gospodarczą, której najpopularniejszym miernikiem jest PKB per capita. Tymczasem problem konwergencji można rozszerzyć na wiele innych płaszczyzn życia poza gospodarką. Na przykład realizowana w ramach polityki regionalnej UE polityka spójności obejmuje aspekty gospodarcze, społeczne i terytorialne (przestrzenne), analizowane dla regionów NUTS II i NUTS III [Kudełko, Prusek i Zieliński 2011, s. 23] $]^{8}$. W szczególności konwergencja na rynkach mieszkaniowych może być rozważana zarówno w obszarze gospodarczym, jak i społecznym. Klasyfikacja zjawiska konwergencji według różnych kryteriów jej podziału przedstawiona została na schemacie 4.1.

8 W celu weryfikacji hipotezy o konwergencji należy przyjąć syntetyczne mierniki realizacji badanego aspektu spójności. I tak w zakresie konwergencji gospodarczej przyjmuje się zazwyczaj PKB per capita (choć istnieje wiele prac, które używają innych mierników gospodarczych, jak wydajności pracy, konkurencyjność, TFP i inne). Spójność społeczna oznacza zmniejszanie różnic w wykorzystaniu kapitału ludzkiego oraz poziomie życia. Do ich pomiaru stosuje się wskaźnik stopy bezrobocia lub wskaźnik stopy partycypacji (wskaźnik zatrudnienia) czy wskaźniki obrazujące poziom życia. Zwiększanie spójności przestrzennej (regionalnej) odbywa się przez eliminowanie barier dostępności regionów zwłaszcza regionów peryferyjnych poprzez lepszą komunikację i powiązania z obszarami położonymi centralnie (mierzoną czasem dojazdu). 
116 Konwergencja rynków nieruchomości mieszkaniowych...

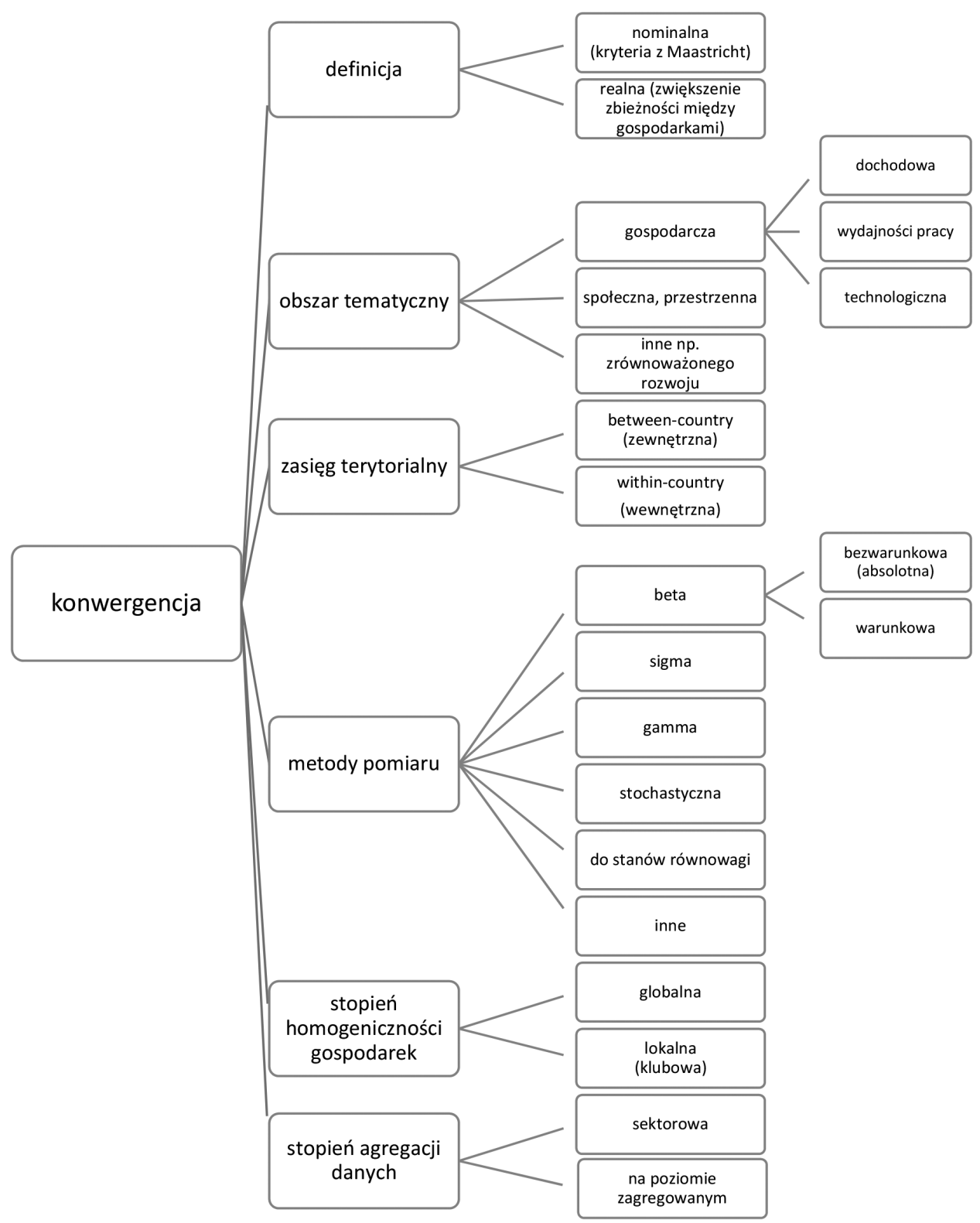

Schemat 4.1. Klasyfikacja zjawiska konwergencji wg różnych kryteriów Źródło: opracowanie własne 


\subsection{Metody weryfikacji hipotezy o konwergencji}

W punkcie 4.1 wspomniano o różnych rodzajach konwergencji, które można wyróżnić z punktu widzenia: obszaru tematycznego badań, zasięgu terytorialnego i rodzaju badanych jednostek, ich stopnia homogeniczności, podziału gospodarki na sektory gospodarcze czy w szczególności ze względu na metodę weryfikacji tego zjawiska. Jeśli chodzi o to ostatnie kryterium, to szczególną popularnością cieszą się dwie „najstarsze” koncepcje, które zaproponowane zostały w pracach Barro i Sala-i-Martina: beta i sigma konwergencja.

Pierwszy rodzaj konwergencji - beta - oznacza, najogólniej mówiąc, doganianie (catch-up effect) początkowo bogatszych obszarów (krajów, regionów) przez biedniejsze, drugi - sigma - zakłada redukcję nierówności w czasie ${ }^{9}$. Rozróżnienie pomiędzy beta i sigma konwergencją nabiera specjalnego znaczenia w sytuacjach, gdy wyniki badania tych dwóch rodzajów pozostają ze sobą w sprzeczności: można otrzymać dla tej samej cechy pozytywnie zweryfikowaną beta konwergencję i brak sigma konwergencji. Formalnie, beta konwergencja jest warunkiem koniecznym, lecz niewystarczającym do występowania konwergencji typu sigma ${ }^{10}$ (zob. Quach [1993], Sala-i-Martin [1996b], Phillips, Sul [2007]), co oznacza, że sytuacja, gdy biedne regiony/kraje rozwijają się szybciej niż bogate, nie musi oznaczać zmniejszania dystansu między nimi.

\subsubsection{Beta konwergencja}

Jak już wspominano, konwergencja typu beta zachodzi, jeśli obszary o początkowo mniejszej wartości badanej cechy (np. PKB per capita) wykazują szybsze tempo wzrostu niż obszary o początkowo jej wyższej wartości. Statystycznym narzędziem weryfikacji tego faktu są najczęściej modele ekonometryczne, w których zmienną objaśnianą jest tempo wzrostu badanej cechy, a zmienną objaśniającą jej początkowa wartość. Jeśli jest to jedyna zmienna objaśniająca, to testowana jest hipoteza o występowaniu konwergencji absolutnej lub bezwarunkowej. Jeśli w modelu występują dodatkowe czynniki warunkujace wzrost, to testowana jest hipoteza o konwergencji warunkowej. Weryfikacji obu typów konwergencji można dokonać w oparciu o dane przekrojowe (dotyczące grupy badanych krajów/regionów

9 Procesy odwrotne - gdy kraje (regiony) o początkowo niższych (wyższych) wartościach badanej zmiennej charakteryzują się jej niższą (wyższą) stopą zwrotu oraz gdy zwiększa się dyspersja badanej cechy w czasie - nazywane są odpowiednio beta dywergencją i sigma dywergencją.

10 Jednocześnie sigma konwergencja jest wystarczającym, lecz niekoniecznym warunkiem konwergencji typu beta (co oznacza, że brak sigma konwergencji nie pozwala jednocześnie stwierdzić, że biedniejsze początkowo kraje nie rozwijają się szybciej niż inne). 
i dwóch skrajnych lat analizy) lub dane panelowe (dotyczące grupy badanych krajów/regionów i wielu następujących po sobie lat analizy). W zależności od rodzaju danych należy użyć innych metod szacowania modelu oceniającego konwergencję.

\section{Beta konwergencja dla danych przekrojowych}

Do weryfikacji hipotezy beta konwergencji przy użyciu danych przekrojowych używa się modelu objaśniającego przyrost badanej cechy $(y) \mathrm{w}$ regionach/krajach $(i=1, \ldots, N)$, pomiędzy okresem $t_{0} \mathrm{i} t_{0}+T$ za pomocą początkowej wartości tej cechy w regionach (por. np. Sala-i-Martin [1996b, s. 1334]):

$$
\frac{1}{T} \ln \left(\frac{y_{i t_{0}+T}}{y_{i t_{0}}}\right)=a+b \ln \left(y_{i t_{0}}\right)+u_{i t_{0}, t_{0}+T}
$$

gdzie ujemna (dodatnia) i istotna statystycznie wartość estymatora $b$ :

$$
b=-\frac{\left(1-e^{-\beta T}\right)}{T}
$$

oznacza występowanie konwergencji (dywergencji) ${ }^{11}$. Brak istotności parametru $b$ oznacza, że nie występuje ani konwergencja, ani dywergencja badanego zjawiska ${ }^{12}$.

Estymator $b$ służy najczęściej do wyliczenia kluczowego, dla konwergencji, parametru $\beta$ zwanego współczynnikiem zbieżności, który wylicza się z przekształcenia równania (4.2), do postaci:

$$
\beta=-\frac{\ln (1+b T)}{T}
$$

11 Czasami regresję (4.1) zapisuje się z ujemnym znakiem przed parametrem $b$ i wówczas dodatnia (ujemna) wartość b oznacza konwergencję (dywergencję), zaś współczynnik zbieżności należy wyliczyć jako $\beta=-\ln (1-b)$.

12 Badanie istotności statystycznej $b$ jest, w literaturze przedmiotu, czasami pomijane. Usprawiedliwieniem takiego postępowania może być fakt, że parametr ten wykorzystywany jest głównie do oszacowania tempa konwergencji danego wzorem (4.3) - wówczas nieistotna statystycznie wartość $b$ przełoży się na niskie tempo konwergencji (dywergencji). Należy jednakże zauważyć, że postępowanie takie jest słuszne tylko do pewnego stopnia, bowiem dla dużych wartości odchylenia standardowego $S(b)$ ( w 4.1) jeden z krańców przedziału ufności dla $b$ może mieć inny znak niż parametr. W takim przypadku należy założyć, że istnieje prawdopodobieństwo, że prawdziwa wartość estymatora parametru $b$ ma nie tylko inną wartość (co wpływa na tempo zbieżności), ale również inny znak - co zmienia wniosek co do istnienia konwergencji. Istotność statystyczna $b$ daje gwarancję, że taka sytuacja nie wystąpi, lecz jednocześnie, przy standardowo przyjmowanych w badaniach ekonomicznych poziomach ufności nie niższych niż $90 \%$, powoduje, że w wielu analizach pomimo ujemnej wartości $b$ należałoby stwierdzić brak konwergencji. W szczególności w regresjach przekrojowych dla stosunkowo niewielkich prób, standardowe błędy estymatorów są zazwyczaj na tyle duże, że często nie można potwierdzić istotności statystycznej estymatorów parametrów. W takich sytuacjach wydaje się lepszym rozwiązaniem „złagodzenie" reżimu poziomu ufności niż nieprzeprowadzanie w ogóle testów istotności. 
Znak parametru $\beta$, podobnie do $b$, informuje o występowaniu konwergencji lub dywergencji, a mianowicie, jeżeli:

- $\beta<0$, zachodzi proces dywergencji (rozbieżności) pomiędzy regionami $i$,

- $\beta>0$, zachodzi proces konwergencji (zbieżności) pomiędzy regionami $i$.

W kategoriach konwergencji do stanów równowagi współczynnik zbieżności $\beta$ informuje o tym, jaki procent odległości od stanu równowagi zostaje pokonany w jednym okresie (najczęściej jednym roku) lub o ile zmniejsza się w danej jednostce czasu różnica między faktyczną wartością badanej zmiennej a wartością tej zmiennej w stacjonarnym stanie równowagi (por. Malaga, Kliber [2007, s. 85]). Im wyższa wartość (co do modułu) współczynnika $\beta$, tym szybsze tempo konwergencji (dywergencji). Na podstawie współczynnika zbieżności można obliczyć tzw. half-life informujący, jaki czas jest potrzebny, aby obecne różnice zostały zredukowane o połowę ${ }^{13}$ :

$$
h l=-\frac{\ln 2}{\beta}
$$

Regresja 4.1 jest prostym i intuicyjnym sposobem badania konwergencji, do których można sformułować jednak pewne zarzuty (por. np. [Quah 1993], [Friedman 1992], [Ciołek 2007]). Jednym $\mathrm{z}$ nich jest to, że pomija się w nich inne, niż początkowa wartość analizowanej zmiennej, cechy indywidualne każdej gospodarki. Ich pominięcie sprawia, że stanowią one czynnik zakłócający, w związku z czym warunek o nieskorelowaniu składnika losowego ze zmiennymi objaśniającymi często nie jest spełniony, co powoduje obciążoność estymatorów (powoduje również niskie wartości $R^{2} \mathrm{w}$ regresjach przekrojowych, bowiem nieuwzględnione explicite zmienne znajdują swoje odbicie w składniku losowym).

Uzupełnienie powyższych równań beta konwergencji absolutnej o dodatkowe czynniki wzrostu $y$ prowadzi do modelu konwergencji warunkowej postaci:

$$
\frac{1}{T} \ln \left(\frac{y_{i t_{0}+T}}{y_{i t_{0}}}\right)=a+b \ln \left(y_{i t_{0}}\right)+\Pi X_{i}+u_{i t_{0}, t_{0}+T}
$$

gdzie wektor $\boldsymbol{X}_{i}$ reprezentuje wszystkie indywidualne cechy rozpatrywanych gospodarek.

13 Lub, jak definiują to autorzy pracy [Malaga, Kliber 2007, s. 85], wartość ta określa liczbę lat niezbędną do zmniejszenia o połowę różnicy między wartością badanej zmiennej w regionie $i$ w momencie $t$, a jej wartością w stacjonarnym stanie równowagi. Autorzy nazywają ten współczynnik okresem połowicznej zbieżności. 


\section{Beta konwergencja dla danych panelowych}

Teoria ekonomiczna angażująca regresje panelowe rozwija się ostatnio bardzo szybko, czemu towarzyszy rosnąca liczba zastosowań ekonomicznych wykorzystujących dane w skali mikro- i makroekonomicznej, jak i międzynarodowej czy regionalnej [por. Phillips, Sul 2007, s. 1771]. Stosowanie modeli beta konwergencji opartych o analizę szeregów przekrojowych wiąże się z utratą informacji dotyczącej zmienności gospodarek poszczególnych obszarów w czasie (poza skrajnymi latami), a także z pominięciem cech indywidualnych dla każdej gospodarki. Pominięcie nieobserwowalnych cech poszczególnych gospodarek sprawia, że stanowią one czynnik zakłócający, w związku z czym warunek o nieskorelowaniu składnika losowego ze zmiennymi objaśniającymi może nie być spełniony, a estymatory wówczas nie są zgodne i nieobciążone. Jako kolejną wadę stosowania szeregów przekrojowych wymienia się małą liczbę obserwacji, która przekłada się na niewielką liczbę stopni swobody, co ogranicza liczbę zmiennych objaśniających w modelu. Islam [1995] oraz Canova i Mercet [1995] pokazują, że $\mathrm{w}$ tradycyjnej analizie konwergencji beta na danych przekrojowych parametr $\beta$ może być niedoszacowany. Połączenie danych czasowych i przekrojowych w jedną próbę - panelową - pozwala przezwyciężyć ten ostatni problem, jak również, poprzez zastosowanie odpowiednich metod estymacji (dla danych panelowych), pozwala na uwzględnienie efektów specyficznych dla obiektów (regionów) i/lub dla czasu. Równania dla danych panelowych, pozwalających zweryfikować hipotezę o beta konwergencji, mają postać (4.6) w przypadku testowania konwergencji absolutnej:

$$
\log \left(\frac{Y_{i t}}{Y_{i t-1}}\right)=a-\left(1-e^{-\beta}\right) \log \left(y_{i t-1}\right)+\eta_{i}+v_{t}+u_{i t}
$$

lub (4.7) w przypadku konwergencji warunkowej:

$$
\log \left(\frac{Y_{i t}}{Y_{i t-1}}\right)=a-\left(1-e^{-\beta}\right) \log \left(y_{i t-1}\right)+\delta X_{i t}+\eta_{i}+v_{t}+u_{i t}
$$

gdzie:

$\eta_{i}$ - efekty specyficzne dla poszczególnych obiektów (krajów/regionów) i. Efekty $\eta_{i}$ pokazują zróżnicowanie pomiędzy nimi wynikające z innych, niż uwzględnione po prawej stronie równania, czynników, które są zwykle niemierzalne i dlatego nie mogą explicite zostać uwzględnione w równaniu;

$v_{t}$ - efekty okresowe dla roku $t$ odzwierciedlają wspólne dla wszystkich obiektów (krajów, regionów) wydarzenia w latach objętych analizą (np. efekt wpływu kryzysu z lat 2008/2009);

$u_{i t}$ - składnik losowy równania. 
W celu oszacowania powyższych funkcji stosuje się zazwyczaj postać zlinearyzowaną względem parametrów, tzn.:

$$
\begin{gathered}
\log \left(\frac{Y_{i t}}{Y_{i t-1}}\right)=a+b \log \left(y_{i t-1}\right)+\eta_{i}+v_{t}+u_{i t} \\
\log \left(\frac{Y_{i t}}{Y_{i t-1}}\right)=a+b \log \left(y_{i t-1}\right)+\delta X_{i t}+\eta_{i}+v_{t}+u_{i t}
\end{gathered}
$$

gdzie: $b=-\left(1-e^{-\beta t}\right) \Rightarrow \beta=-\ln (1+b)$.

Modele panelowe mogą przybrać postać modelu tzw. pooled regression, dla którego próbę łączy się w panel, lecz poza zwiększeniem liczby stopni swobody nie dokonuje się wyróżnienia żadnych dodatkowych efektów. Najczęściej jednak szacuje się model z efektami nielosowymi (nazywanymi czasami ustalonymi), tzw. FEM - Fixed Effects Model oraz modele z efektami losowymi: REM - Random effects Model. Wyboru jednego z tych trzech typów modeli (pooled, FEM, REM) dokonuje się na podstawie testów statystycznych, najczęściej: Chowa, Breucha-Pagana oraz Hausmana.

Istnieje szereg metod służących analizie danych panelowych. Wśród najpopularniejszych estymatorów, służących do szacowania danych panelowych, poza Klasyczną Metodą Najmniejszych Kwadratów, wymienia się modele z efektami ustalonymi (Fixed Effects Model - FEM) oraz modele z efektami losowymi (Random effects Model - REM).

Modele panelowe szacowane KMNK nie uwzględniają ani efektów indywidualnych, ani efektów czasowych. W literaturze przedmiotu podaje się, że w przypadku zastosowania KMNK do danych panelowych w analizie konwergencji wyniki często są przeszacowane. Niemniej jednak metoda ta może być stosowana jako punkt wyjściowy w analizach danych panelowych (model szacowany KMNK może być zastosowany w przypadku, gdy wszystkie obiekty w panelu są jednorodne, a ewentualne odchylenia wartości empirycznych od teoretycznych wynikają z przyczyn losowych).

Modele z efektami nielosowymi (FEM) pozwalają na wychwycenie efektów indywidualnych dla każdego obiektu w przekroju. Wyróżniamy trzy typy modeli FE. Pierwszy z nich to model between. Szacowany jest za pomocą MNK. Jednak zamiast poszczególnych obserwacji w modelu wykorzystywane są średnie grupowe zmiennych. Modele te pozwalają na redukcję błędów pomiaru. Drugi model to LSDV. Istnieje kilka podejść do budowy takiego modelu. Pierwsze podejście to model jednokierunkowy uwzględniający jedynie różnice w grupach, budowany poprzez dołączenie do modelu KMNK zmiennych zero-jedynkowych dla $n$-1 obiektów. W przypadku braku istotnych różnic między grupami budowany jest 
model uwzględniający różnice w czasie. Wówczas do modelu KMNK dołącza się zmienne zero-jedynkowe dla każdego obiektu w czasie. Oba te modele mają charakter modeli jednokierunkowych. Istnieje także możliwość budowy modelu dwukierunkowego, w którym uwzględnione są zarówno efekty indywidualne, jak i efekty czasowe. Tak zbudowane modele estymowane są MNK. Ostatnim - trzecim typem modelu FE, często stosowanym w analizach konwergencji jest model within. W przeciwieństwie do modelu LSDV zamiast zmiennych zero-jedynkowych w modelu uwzględnia się odchylenia zmiennej od średniej grupowej. W modelu także nie uwzględnia się stałej. Parametry modelu szacowane są za pomocą MNK, a współczynnik kierunkowy jest taki sam jak w przypadku estymacji modelu LSDV.

Modele z efektami losowymi (REM) są takimi modelami panelowymi, według których efekty indywidualne wynikają z efektów losowych i nie ulegają zmianom w czasie. Różnice między poszczególnymi obiektami w takich modelach odwzorowane są $\mathrm{w}$ postaci wariancji międzygrupowej błędu. Aby oszacować efekty indywidualne w modelu, szacuje się parametry rozkładu. W celu oszacowania estymatora RE wykorzystuje się najczęściej Uogólnioną Metodę Najmniejszych Kwadratów. Niestety w przypadku małych prób estymatory RE często są obciążone i nieefektywne.

Aby spośród omówionych trzech rodzajów modeli panelowych wybrać model najlepszy, należy posłużyć się dwoma podstawowymi testami dla panelu: testem Breuscha-Pagana oraz testem Hausmana, które są opisane w wielu podręcznikach i pakietach komputerowych.

Generalnie wyniki analizy konwergencji z wykorzystaniem danych panelowych różnią się istotnie od wyników na danych przekrojowych, bowiem uzyskiwane $\mathrm{w}$ modelach panelowych oszacowania tempa konwergencji są znacznie wyższe. Na przykład tempo konwergencji krajów OECD wyniosło 9\% [Islam 1995], dla regionów UE - aż 23\% [Cannova, Marcet 1995], dla regionów Hiszpanii - 12,7\% [de la Fuente 2002]. Częściowym wyjaśnieniem tak wysokich temp konwergencji w modelach panelowych jest fakt, że są to prędkości zbiegania do indywidualnego dla każdej jednostki terytorialnej (a nie wspólnego) punktu równowagi okresowej [Wójcik 2018, s. 52].

Drugą przyczyną wysokich temp wzrostu w modelach konwergencji dla danych panelowych jest problem endogeniczności zmiennych objaśniających czy autokorelacji składnika losowego. Arellano i Bond [1991] oraz Blundell i Bond [1998] wykazują, że szacowanie omówionych powyżej równań regresji za pomocą UMNK prowadzi do uzyskania obciążonych estymatorów tempa konwergencji. Należy bowiem zauważyć, że modele wzrostu stosowane w analizie konwergencji są $\mathrm{w}$ istocie modelami autoregresyjnymi, bowiem można je zapisać w postaci:

$$
\ln \left(Y_{i t}\right)=a+(1+b) \ln \left(y_{i t-1}\right)+\delta X_{i t}+\eta_{i}+v_{t}+u_{i t}
$$


W przypadku dynamicznej postaci modelu panelowego (jakim jest powyższe równanie), literatura zaleca stosowanie specjalnych metod estymacji. Wśród tych metod (których przegląd można znaleźć w Baltagi [1995], Dańska-Borsiak [2011]) większość wykorzystuje Uogólnioną Metodę Momentów (GMM).

\subsubsection{Sigma konwergencja}

Od końca lat 80. ubiegłego wieku coraz więcej mówiło się o pewnej kontradykcji, pojawiającej się w wynikach testów na konwergencję, polegającej na tym, że fakt występowania beta konwergencji (ujemnej zależności pomiędzy stopą wzrostu i początkową wartością zmiennej, będącą odzwierciedleniem idei beta konwergencji) nie musi oznaczać zmniejszania dyspersji rozkładu badanej zmiennej ${ }^{14}$. W niektórych artykułach (w szczególności Friedmana [1992] i Quaha [1993], a także Lichtenberga [1994]) sprzeciwiano się badaniom konwergencji za pomocą testów, które jedynie pokazują, że biedne regiony rozwijają się szybciej niż bogate, skoro może okazać się, że nierówności pomiędzy nimi nie ulegają zmniejszeniu. Krytyka beta konwergencji sprzyjała zdefiniowaniu i ugruntowaniu się innej jej koncepcji: sigma konwergencji oznaczającej zmniejszanie się nierówności badanej cechy w czasie. Pierwszym krokiem w ocenie tego rodzaju konwergencji jest oszacowanie miary nierówności (zróżnicowania, zmienności, dyspersji, rozproszenia) badanego zjawiska wśród analizowanych obszarów w kolejnych okresach analizy. W kroku drugim należy ocenić, czy zastosowane miary nierówności badanego zjawiska istotnie zmniejszyły się w czasie. Jeśli tak, to występuje sigma konwergencja. W praktyce stosowane są różne podejścia do testowania, czy nierówności istotnie zmniejszyły się w czasie [Kusideł 2013].

Najprostszym testem stwierdzającym, czy dyspersja badanego zjawiska istotnie zmniejszyła się w czasie jest porównanie wariancji w dwóch okresach analizy. Test taki został zaproponowany w pracy Lichtenberga [1994], w którym dokonuje się porównania wariancji w skrajnych okresach (tzn. pierwszym i ostatnim) ${ }^{15}$. Jeśli można wykazać, że wariancja na końcu analizowanego okresu jest istotnie niższa niż na początku, możemy mówić o sigma konwergencji. W przeciwnym wypadku, tzn. gdy wariancja na końcu okresu jest istotnie wyższa, mówimy o sigma dywergencji. W celu formalnego zbadania występowania sigma konwergencji (sigma dywergencji) należy zweryfikować następujący zespół hipotez [Kusideł 2013, s. 61]: $H_{0}: \sigma_{1}^{2}=\sigma_{T}^{2}=\sigma^{2}$ (brak konwergencji i dywergencji), $H_{1}: \sigma_{1}^{2}>\sigma_{T}^{2}$ (występuje konwergencja) lub

14 Podobne zjawisko opisywane jest w paradoksie regresji w stronę średniej (paradoks Galtona), który polega na błędnej interpretacji przejściowej natury obserwacji skrajnych jako dowodu na zmniejszanie się dyspersji rozkładu.

$15 \mathrm{~W}$ praktyce porównuje się estymatory $-S^{2}$ - wariancji $-\sigma^{2}$. 
$H_{1 a}: \sigma_{1}^{2}<\sigma_{T}^{2}$ (występuje dywergencja),

gdzie: $\sigma_{1}^{2}, \sigma_{T}^{2}$ oznaczają odpowiednio wariancję badanej cechy wśród $N$ badanych obszarów w pierwszym i ostatnim okresie badania.

Do zweryfikowania powyższych hipotez służy statystyka ${ }^{16}$ :

$$
T_{1}=\frac{\hat{\sigma}_{1}^{2}}{\hat{\sigma}_{T}^{2}}
$$

która ma rozkład F-Snedecora z $(N-2, N-2)$ stopniami swobody. Wartości wyższe od wartości krytycznych pozwalają na odrzucenie hipotezy zerowej mówiącej o równości wariancji (a więc o braku konwergencji na korzyść hipotezy o konwergencji $-H_{1}$ lub dywergencji $-H_{1 \mathrm{a}}$ ).

Niektórzy autorzy twierdzą, że powyższy test nie bierze pod uwagę zależności pomiędzy badanymi wariancjami i, w związku z tym, jest obarczony popełnieniem błędu II rodzaju (niepoprawnego odrzucenia hipotezy o występowaniu konwergencji). Ma to znaczenie szczególnie dla niewielkich prób. Caree i Klomp [1997] do zweryfikowania hipotez o równości wariancji proponują statystyki $T_{2}$ i $T_{3}$, które, zdaniem autorów, są wolne od powyższego obciążenia (można je stosować nawet dla krótkich prób).

Statystyka $T_{2}$ ma postać:

$$
T_{2}=(N-2,5) \ln \left[1+\frac{1}{4} \frac{\left(\hat{\sigma}_{1}^{2}-\hat{\sigma}_{T}^{2}\right)^{2}}{\hat{\sigma}_{1}^{2} \hat{\sigma}_{T}^{2}-\hat{\sigma}_{1 T}^{2}}\right]
$$

gdzie: $\hat{\sigma}_{1 T}$ jest kowariancją obliczaną dla pierwszego i ostatniego roku badania: $\hat{\sigma}_{1 T}=\sum_{i}\left(y_{i 1}-\bar{y}_{1}\right)\left(y_{i T}-\bar{y}_{T}\right) / N$. Statystyka (4.12) ma rozkład $\chi^{2}(1)$.

Statystyka $T_{3}$ ma postać:

$$
T_{3}=\frac{\sqrt{N}\left(\hat{\sigma}_{1}^{2} / \hat{\sigma}_{T}^{2}-1\right)}{2 \sqrt{1-\hat{\pi}^{2}}}
$$

gdzie: $\hat{\pi}$ jest estymatorem z równania: $y_{i T}=\pi y_{i 1}+u_{i}{ }^{17}$.

16 Wzór 4.11 dotyczy sytuacji, gdy wariancja maleje w czasie: wtedy licznik jest większy od mianownika. Jeśli wariancja rośnie w czasie (wyższa jest wariancja dla końcowego okresu, a niższa dla początkowego), wówczas testowana jest hipoteza o dywergencji, a składniki ilorazu (4.11) należy odwrócić (tak, aby w liczniku pojawiła się wyższa wartość).

17 Równanie beta konwergencji można zapisać w postaci: $y_{i T}-y_{i 0}=b y_{i 1}+u_{i}$ gdzie $\pi=(1+b)$, w przypadku gdy pomiędzy stopą wzrostu a początkową wartością jest zależność ujemna, tzn. gdy $b<0$, wówczas $\pi \in(0 ; 1)$. Dla dodatniej korelacji pomiędzy stopą wzrostu 
Statystka (4.13) ma standaryzowany rozkład normalny. Powyższy test, zaproponowany przez Caree i Klomp [1997] do testowania konwergencji, można zmodyfikować do celów testowania również dywergencji. Otóż w przypadku, gdy wariancja rośnie w czasie, tzn. gdy $\hat{\sigma}_{1}^{2}<\hat{\sigma}_{T}^{2}$, wówczas statystyka $T_{3}$ jest ujemna, lecz wydaje się możliwe wówczas zastosowanie wartości bezwzględnej statystyki i następujący sposób wnioskowania: jeśli $\left|T_{3}\right|>1,64$ (ostatnia wartość jest wartością krytyczną rozkładu normalnego dla 5\% poziomu istotności), to występuje dywergencja dla $\hat{\sigma}_{1}^{2}<\hat{\sigma}_{T}^{2}$ oraz konwergencja dla $\hat{\sigma}_{1}^{2}>\hat{\sigma}_{T}^{2}$.

Carre i Klomp [1997] dokonali porównania wyników dotyczących konwergencji liczonej na podstawie wzorów (4.12) i (4.13) z wcześniej przytaczanymi przez Lichtenberga [1994] wykorzystującego wzór (4.10). Badanie dotyczyło konwergencji produktywności w 22 krajach OECD dla lat 1950-1994 i potwierdziło, że w okresie tym konwergencja występowała. Jednakże dla okresu 1960-1985 (który był przedmiotem badań Lichtenberga) statystyka $T_{1}$ sugeruje brak konwergencji PKB per capita, podczas gdy dwie pozostałe statystyki sugerują jej występowanie. Powodem tej rozbieżności jest stosowanie statystyki $T_{1}$ dla krótkich okresów i związane z tym prawdopodobieństwo popełnienia błędu II rodzaju.

\section{Staba sigma konwergencja}

Sposób testowania sigma konwergencji za pomocą statystyk (4.10)-(4.13) pomija zmiany w badanym zjawisku, które występują pomiędzy skrajnymi okresami analizy. Badanie konwergencji typu sigma można wspomóc wizualizacją miar zróżnicowania w poszczególnych okresach na wykresie, który pomaga ocenić, czy spadek zróżnicowania ma charakter ciągły, czy nie. Dla tak stworzonego szeregu danych (składającego się z miar zmienności badanego zjawiska - np. regionalnego PKB per capita dla poszczególnych lat) można zastosować liniowy model trendu postaci:

$$
S_{y t}=\alpha_{0}+\alpha_{1} t+\xi_{t}
$$

gdzie:

$S_{y t}$ - jest miarą rozproszenia lub koncentracji badanej zmiennej $y$ między poszczególnymi obszarami (krajami, regionami) w okresie $t(t=1, \ldots, T)$,

$\alpha_{0}, \alpha_{1}$ - parametry strukturalne,

$t$ - zmienna czasowa,

$\xi_{t}$ - składnik losowy równania.

i początkową wartością badanego zjawiska wzór (4.13) nie może być zastosowany, bowiem liczba podpierwiastkowa w mianowniku (4.13) byłaby ujemna. 
Na podstawie równania (4.14) wnioskujemy o konwergencji typu sigma, jeśli parametr $\alpha_{1}$ jest ujemny i istotny statystycznie ${ }^{18}$. Powyższe podejście do badania konwergencji (zaproponowane w pracy Kusideł [2013, s. 62] oraz Konga, Phillipsa i Sula [2017, s. 7 i dalsze]) może jednakże skutkować błędnymi wskazaniami, jeżeli $\mathrm{w}$ testowanych zjawiskach występują wspólne trendy stochastyczne i/lub deterministyczne, które mogą towarzyszyć panelowym próbom, na podstawie których testowana jest konwergencja. Jeśli takie trendy występują, to należy zastosować koncepcję relatywnej konwergencji opisaną w podrozdziale 4.2.3.

\subsubsection{Relatywna konwergencja}

Opisywany poniżej test zaproponowany został w pracy Phillipsa i Sula [2007]. Polega on na przeprowadzeniu tzw. testu regresji $\log (t)$ dla danych panelowych. Filozofia testu polega na obserwacji, że dane panelowe w pewnych przypadkach mogą być zdekomponowane na dwa czynniki:

gdzie:

$$
X_{i t}=g_{i t}+a_{i t}
$$

$g_{\text {it }}$ - element wspólny,

$a_{i t}$ - element przejściowy,

$i=1, \ldots, N-$ liczba obiektów,

$t=1, \ldots, T-$ liczba obserwacji.

W celu wyodrębnienia składnika wspólnego (common component) oraz specyficznego (idiosyncratic component) wzór (4.15) podlega przekształceniu do:

gdzie:

$$
X_{i t}=\left(\frac{g_{i t}+a_{i t}}{u_{t}}\right) u_{t}=\delta_{i t} u_{t}
$$

$\delta_{i t}$ - zmienny w czasie składnik specyficzny,

$u_{t}$ - zmienny w czasie składnik wspólny dla wszystkich obiektów w panelu.

Zgodnie z modelem Phillipsa i Sula pomiędzy badanymi obiektami opisanymi przez zmienną $X_{i t}$ zachodzi konwergencja wówczas, gdy:

$$
\lim _{t \rightarrow \infty} \frac{X_{i t}}{X_{j t}}=1 \text { dla wszystkich } i \text { oraz } j .
$$

18 Parametr $\alpha_{1}$ ma również sensowną interpretację ekonomiczną. Mówi o tym, o ile rośnie (dla estymatora $\alpha_{1}>0$ ) lub spada $\left(\alpha_{1}<0\right)$ rozproszenie (lub koncentracja, w zależności od użytego miernika $S$ ) pomiędzy obszarami średnio z okresu na okres (najczęściej z roku na rok). Badanie sigma konwergencji poprzez analizę trendu we współczynniku zmienności zostało zaproponowane przez Friedmana [1992]. 
Warunek ten określany jako konwergencja relatywna może zostać przedstawiony również jako:

$$
\lim _{t \rightarrow \infty} \delta_{i t}=\delta \text { dla wszystkich } i .
$$

Zmiany składnika specyficznego $\delta_{t} \mathrm{w}$ czasie ujęte zostały w formie semiparametrycznego modelu w postaci:

$$
\begin{gathered}
\delta_{i t}=\delta_{i}+\sigma_{i t} \xi_{i t}, \quad \xi_{i t} \sim \operatorname{iid}(0,1) ; \\
\sigma_{i t}=\sigma_{i} L(t)^{-1} t^{-\alpha}, t \geq 1, \quad \sigma_{i}>0 \text { dla wszystkich } i
\end{gathered}
$$

gdzie:

$L(t)$ - dowolna funkcja o niewielkiej zmienności, przykładem takiej funkcji jest funkcja $\log (t)$, $\alpha$ - tempo procesu konwergencji, $\delta_{1}, \sigma_{i}-$ specyficzne dla obiektów efekty stałe.

Phillips i Sul [2007, s. 1788] zaproponowali procedurę testową, zgodnie z którą hipoteza zerowa zakłada występowanie konwergencji między obiektami w przeciwieństwie do hipotezy alternatywnej zakładającej brak konwergencji:

$H_{0}: \delta_{\mathrm{i}}=\delta$ oraz $\alpha \geq 0^{19}$, $H_{1}: \delta_{\mathrm{i}} \neq \delta$ dla wszystkich $i$ oraz $\alpha<0$.

Weryfikacja hipotezy wymaga w pierwszym etapie kalkulacji serii współczynników wariancji $H_{i} / H_{t}$ wyznaczonych jako:

$$
H_{t}=\frac{1}{N} \sum_{i=1}^{N}\left(h_{i t}-1\right)^{2}
$$

gdzie:

$H_{t}$ - przekrojowa wariancja zmiennej w okresie $t$,

$N$ - liczba obiektów w panelu,

$h_{i t}$ - parametr charakteryzujący ścieżkę zmian obiektu $i$ na tle średniej arytmetycznej ustalonej dla wszystkich obiektów panelu:

$$
h_{i t}=\frac{X_{i t}}{N^{-1} \sum_{i=1}^{N} X_{i t}} .
$$

W długim okresie w warunkach zachodzenia procesu konwergencji $h_{i t} \rightarrow 1$, natomiast $H_{t} \rightarrow 0$ [Holmes, Otero, Panagiotidis 2019]. Drugi etap procedury testowej wymaga oszacowania regresji $\log (t)$ w postaci:

19 Współczynnik alpha jest wyliczany na podstawie modelu $\log (t)$ opisanego równaniem (4.23). 


$$
\begin{gathered}
\log \left(\frac{H_{1}}{H_{t}}\right)-2 \log L(t)=\hat{a}+\hat{b} \cdot \log (t)+\hat{\varepsilon}_{t} \\
\text { dla } t=[r T],[r T]+1, \ldots, T
\end{gathered}
$$

gdzie:

$L(t)=\log (t)$

$\breve{b}=2 \check{\alpha}-$ oszacowany parametr regresji, potrzebny do wyliczenia estymatora $\hat{\alpha}$ - uwzględnionego w testowanych hipotezach,

$[r, T]$ - pierwsza obserwacja okresu uwzględnionego w regresji, którą najczęściej ustala się na poziomie $1 / 3$ całej próby (wówczas $r=1 / 3$ ).

$\mathrm{W}$ ostatnim etapie, występowanie konwergencji weryfikowane jest $\mathrm{z}$ wykorzystaniem jednostronnego testu $t \mathrm{w}$ odniesieniu do nierówności $\alpha \geq 0 \mathrm{z}$ hipotezy zerowej na podstawie oszacowanego parametru $\hat{b}$ oraz jego błędu standardowego (HAC standard error). Przy poziomie istotności 5\% hipoteza zerowa zostaje odrzucona, gdy $t_{b}<-1,65$ [Philips, Sul 2007].

Odrzucenie hipotezy zerowej zakładającej konwergencję wszystkich badanych obiektów nie wyklucza jednak występowania konwergencji klubowej. Phillips i Sul [2007, s. 1798 i dalsze] definiują algorytm identyfikacji klubów według 4 etapów:

1. Wyodrębnienie z szeregów czasowych tendencji długookresowej (trendu) z wykorzystaniem stosownych narzędzi statystycznych (np. zastosowanie filtrów częstotliwościowych) oraz uporządkowanie szeregów na podstawie wartości ostatniej obserwacji. W przypadku szeregów o dużej zmienności uporządkowanie następuje na podstawie średnich wartości z ostatnich $50 \%$ obserwacji w szeregach;

2. Utworzenie pierwszej grupy $k$ obiektów $(2 \leq k<N)$, na podstawie rankingu $\mathrm{z}$ poprzedniego etapu, o najwyższej wartości statystyki $t_{k}$ dla oszacowanej regresji $\log (t)$ spełniającej warunek $t_{k}>-1,65$;

3. Sukcesywne zwiększanie liczby obiektów w grupie (wraz z ponownym oszacowaniem regresji $\log (t))$ do momentu, gdy $t_{k}>-1,65$;

4. Utworzenie z pozostałych obiektów kolejnych klubów konwergencji z wykorzystaniem regresji $\log (t)$. Algorytm przedstawiony w punktach $1-3$ jest powtarzany do momentu, gdy nie można zbudować grupy $k$ obiektów, dla których statystyka $t_{k}$ spełnia warunek $t_{k}>-1,65$ [Holmes, Otero, Panagiotidis 2019, s. 9].

\subsubsection{Gamma konwergencja}

Pod koniec lat 80 . XX w. pojawiły się głosy, że to nie doganianie (catch-up) będące podstawą beta konwergencji (opisanej w podrozdziale 4.2.1), lecz malejące zróżnicowanie w poszczególnych latach, czyli $\sigma$-konwergencja (opisana w podrozdziale 4.2.2) powinna być 
podstawą do wnioskowania o konwergencji. Odpierając te zarzuty, Sala-i-Martin [1994] argumentował, że konwergencja jest szeroką koncepcją, która dotyczy oceny mobilności poszczególnych obszarów w czasie w ramach rozkładu badanej cechy (np. dochodów per capita). Sala-i-Martin zrównuje jednocześnie ten intra-rozkład mobilności z koncepcją beta konwergencji. Jeśli taka interpretacja beta konwergencji jest właściwa, to równie właściwe wydaje się zbadanie zmian w rankingu badanych obiektów. Podejście to, zaprezentowane przez Boyle'a i McCarthy'ego [1997, s. 257-264], nazywane jest gamma konwergencją. Autorzy cytowanej pracy ponownie przeliczyli dane z artykułu Barro i Sala-i-Martina [1992] i pokazali, że w przeciwieństwie do wniosków Barro i Sala-i-Maritna nie można stwierdzić konwergencji pomiędzy krajami OECD w okresie po roku 1972. Sprzeczność tę Boyle, McCarthy [1997, s. 263] wyjaśniają obciążeniem estymatorów, które dla podejścia Barro i Sala-i-Martina jest 20 razy większe niż w przypadku podejścia konkordancji rang, będącego podstawą gamma konwergencji. Gamma konwergencja polega na obliczeniu następującego współczynnika konkordancji rang Kendalla [Kusideł 2013, s. 66]:

$$
\gamma_{t}=\frac{\operatorname{var}\left(R_{i t}+R_{i 0}\right)}{\operatorname{var}\left(2 \cdot R_{i 0}\right)}
$$

gdzie:

$\gamma_{t}$ - współczynnik konkordancji rang w okresie $t$, który mierzy zgodność rang w przedziale $(0,1)$,

$R_{i 0} ; R_{i t}$ - ranga $i$-tego obiektu w pierwszym i ostatnim okresie badania.

Im niższa wartość współczynnika $\gamma_{t}$, tym zmiany w rankingu jednostek pomiędzy badanymi okresami są większe - co wskazuje na gamma konwergencję. Do statystycznej oceny wielkości $\gamma_{t}$ służy statystyka chi-kwadrat postaci:

$$
\chi_{t}^{2}=2 \cdot(n-1) \cdot \gamma_{t}
$$

gdzie:

$\chi_{t}^{2}$ - empiryczna wartość statystyki w okresie $t$,

$n$ - liczba jednostek,

$\gamma_{t}-$ współczynnik konkordancji rang w okresie $t$.

Wartość empiryczna statystyki chi-kwadrat mniejsza od wartości teoretycznej (dla $n-1$ stopni swobody i poziomu istotności $\alpha$ ) pozwala potwierdzić występowanie gamma konwergencji [Dittmann 2014]. W przeciwnym przypadku hipoteza zerowa odrzucana jest na rzecz hipotezy alternatywnej przyjmującej brak gamma konwergencji (brak istotnych zmian w uporządkowaniu badanych jednostek). 



\section{Rozdział 5}

\section{Weryfikacja konwergencji na rynkach nieruchomości mieszkaniowych}

\subsection{Procesy konwergencji na rynkach nieruchomości mieszkaniowych w świetle literatury przedmiotu}

Rynki mieszkaniowe od wielu lat są popularnym obszarem identyfikacji procesów konwergencji. Wiąże się to z ich istotnym znaczeniem społeczno-ekonomicznym zarówno w wymiarze makro-, jak i mikroekonomicznym (por. rozdział 1). Szczególny charakter rynku mieszkaniowego jak i jego wieloaspektowy wpływ na funkcjonowanie jednostki oraz całej gospodarki stanowią ważną przesłankę do podjęcia badań nad kierunkiem i charakterem zmian zachodzących w sferze mieszkaniowej zarówno w ujęciu międzynarodowym, jak i regionalnym. Analiza konwergencji rynków mieszkaniowych stanowi naturalne dopełnienie dotychczasowych badań nad uwarunkowaniami i mechanizmami rozwoju rynków krajowych i regionalnych. Pozwala ona zweryfikować, czy przestrzenne zróżnicowanie rynków mieszkaniowych wykazuje tendencje do spadku, czy też ma trwały lub pogłębiający się charakter, a także jakie procesy za tym stoją oraz jakie są krótkoi długookresowe konsekwencje badanych tendencji.

Konwergencja mieszkaniowa może być jednak postrzegana wielorako. W pierwszej kolejności istotne jest zdefiniowanie obszarów identyfikacji konwergencji mieszkaniowej. W przeciwieństwie do klasycznego ujęcia makroekonomicznego w przypadku rynku mieszkaniowego trudno jednoznacznie zdefiniować uniwersalny wskaźnik jego rozwoju. Można w związku z tym odwoływać się do miar określających poziom i jakość zaspokojenia potrzeb mieszkaniowych, miar charakteryzujących siłę nabywczą gospodarstw na rynku mieszkaniowym, wskaźników rozwoju finansowania mieszkalnictwa jak również jakości otoczenia instytucjonalnego rynku. 
$\mathrm{W}$ praktyce najpopularniejszą zmienną referencyjną uwzględnianą w procedurze badawczej są jednak ceny nieruchomości mieszkaniowych.

Wybór odpowiedniego wskaźnika nie rozwiązuje problemów natury metodologicznej. Jak wskazuje literatura przedmiotu, na konwergencję rynków mieszkaniowych można patrzeć przez pryzmat klasycznych metod jej pomiaru, wyodrębniających konwergencję typu beta, sigma oraz gamma. Umożliwiają one identyfikację procesów zbieżności bądź malejącego zróżnicowania rynków mieszkaniowych w ujęciu przekrojowym. Mając na uwadze zasadniczy wpływ czynników lokalnych i regionalnych na funkcjonowanie rynków nieruchomości, a w konsekwencji ich przestrzenną segmentację, wielu badaczy odwołuje się do szerszej interpretacji zjawiska konwergencji. Charakteryzowana jest ona jako tendencja rynków mieszkaniowych do reagowania w podobnym zakresie na pojawiające się rynkowe szoki. Weryfikowane są w związku z tym zakres i siła współbieżności wybranych wskaźników mieszkaniowych w długim horyzoncie [Ghiraldo, Ciula, Festa 2013, s. 64]. Metodami identyfikacji tak rozumianej konwergencji są najczęściej testy stacjonarności (także dla danych panelowych) oraz analiza kointegracji.

Dotychczasowy dorobek badawczy w zdecydowanej większości związany jest z empiryczną weryfikacją konwergencji cenowej na regionalnych i lokalnych rynkach mieszkaniowych. Analizy o tym charakterze wielokrotnie realizowane były dla rynku amerykańskim oraz brytyjskim. Rozwijane w toku kolejnych badań metody detekcji konwergencji cenowej sukcesywnie implementowane były w ocenie zmian zachodzących na rynkach mieszkaniowych Europy, Azji, Afryki czy Australii. Wnioski z nich płynące nie są jednak jednoznaczne.

Weryfikacja konwergencji cenowej dla rynku amerykańskiego przeprowadzona m.in. przez Kima oraz Rousa czy też Nissana i Payne’a nie wykazała jednego uniwersalnego kierunku zmian cen mieszkań dla wszystkich rynków regionalnych. Zidentyfikowane zostało jednak zjawisko konwergencji klubowej [Kim, Rous 2012 oraz Nissan, Payne 2013]. Również badania Montanesa i Olmos podkreślają wyraźną segmentację regionalnych rynków mieszkaniowych w USA, wykazując występowanie konwergencji klubowej [Montanes, Olmos 2013].

Badania rynków brytyjskich zrealizowane przez MacDonalda oraz Taylora nie potwierdziły hipotezy zakładającej dążenie rynków regionalnych do osiągania długookresowej równowagi [MacDonald, Taylor 1993]. Natomiast wyniki uzyskane przez Holmesa i Grimesa wskazują na słabą, długoterminową konwergencję cen nieruchomości na rynkach regionalnych [Holmes, Grimes 2008]. Ponadto analiza przeprowadzona na poziomie rynków lokalnych sugeruje, iż ceny nieruchomości doświadczają konwergencji klubowej, która determinowana jest w znacznej mierze przez czynniki lokalizacyjne, dochody gospodarstw czy gęstość zaludnienia badanych jednostek terytorialnych [Holmes, Otero, Panagiotidis 2019]. 
Prace poświęcone rynkom mieszkaniowym Chin nie dostarczają dowodów potwierdzających konwergencję cenową regionów [Zhang, Morley 2014]. Zgodnie z uzyskanymi wynikami brak jest jednego wspólnego mechanizmu zmian cen na rynkach regionalnych. Nie wyklucza to jednak zachodzenia konwergencji o charakterze klubowym [Lin, Zhang, Li, Dong 2015].

Konwergencja cenowa była przedmiotem badań także na wielu innych rynkach, w tym na: rynku australijskim [Ma, Liu 2015], indyjskim [Aye, Goswami, Gupta 2013], hiszpańskim [Blanco, Martin, Vazquez 2015], francuskim [Holmes, Otero, Panagiotidis 2017], polskim [Gnat 2016; Dittmann 2014; Żelazowski 2019] czy południowoafrykańskim [Das, Gupta, Kaya 2010]. Szczegółowy przegląd literatury poświęconej problematyce konwergencji rynków mieszkaniowych prezentuje tabela 5.1.

Tabela 5.1. Przegląd literatury poświęconej problematyce konwergencji mieszkaniowej

\begin{tabular}{|l|l|l|l|l|}
\hline Opracowanie & \multicolumn{1}{|c|}{$\begin{array}{c}\text { Rodzaj } \\
\text { konwergencji }\end{array}$} & \multicolumn{1}{|c|}{$\begin{array}{c}\text { Przedmiot } \\
\text { badania }\end{array}$} & \multicolumn{1}{|c|}{$\begin{array}{c}\text { Metoda } \\
\text { badawcza }\end{array}$} & \multicolumn{1}{c|}{ Wyniki } \\
\hline 1 & \multicolumn{1}{|c|}{3} & \multicolumn{1}{c|}{4} & \multicolumn{1}{c|}{5} \\
\hline $\begin{array}{l}\text { Montanes, } \\
\text { Olmos [2013] }\end{array}$ & $\begin{array}{l}\text { Konwergencja } \\
\text { cen mieszkań } \\
\text { na rynkach regio- } \\
\text { nalnych }\end{array}$ & $\begin{array}{l}\text { 19 obszarów } \\
\text { metropolitalnych } \\
\text { USA }\end{array}$ & $\begin{array}{l}\text { Regresja log(t) } \\
\text { Phillipsa i Sula }\end{array}$ & $\begin{array}{l}\text { Potwierdzona kon- } \\
\text { wergencja klubowa }\end{array}$ \\
\hline $\begin{array}{l}\text { Nissan, } \\
\text { Payne [2013] }\end{array}$ & $\begin{array}{l}\text { Konwergencja } \\
\text { cen mieszkań } \\
\text { na rynkach regio- } \\
\text { nalnych }\end{array}$ & 50 stanów USA & $\begin{array}{l}\text { Test istotności } \\
\text { dla dwóch } \\
\text { wariancji, Anali- } \\
\text { za wariancji } \\
\text { (ANOVA) }\end{array}$ & $\begin{array}{l}\text { Potwierdzona kon- } \\
\text { wergencja wybranych } \\
\text { rynkogionalnych }\end{array}$ \\
\hline $\begin{array}{l}\text { Hiebert, } \\
\text { Roma [2010] }\end{array}$ & $\begin{array}{l}\text { Konwergencja } \\
\text { relatywnych cen } \\
\text { mieszkań }\end{array}$ & $\begin{array}{l}\text { Niemcy, } \\
\text { Włochy, Francja, } \\
\text { Hiszpania, USA }\end{array}$ & $\begin{array}{l}\text { Panelowe testy } \\
\text { pierwiastka } \\
\text { jednostko- } \\
\text { wego }\end{array}$ & $\begin{array}{l}\text { Brak wyrażniej ten- } \\
\text { dencji do długookre- } \\
\text { sowej konwergencji } \\
\text { cen mieszkań }\end{array}$ \\
\hline Ma, Liu [2015] & $\begin{array}{l}\text { Konwergencja } \\
\text { cen mieszkań } \\
\text { na rynkach regio- } \\
\text { nalnych }\end{array}$ & $\begin{array}{l}\text { Miasta } \\
\text { regionalne } \\
\text { Australii }\end{array}$ & $\begin{array}{l}\text { Model czaso- } \\
\text { wo-przestrzen- } \\
\text { ny }\end{array}$ & $\begin{array}{l}\text { Konwergencja } \\
\text { potwierdzona dla } \\
\text { wybranych miast } \\
\text { (Sydney, Brisbane, } \\
\text { Canberra, Melbourne, } \\
\text { Perth) }\end{array}$ \\
\hline $\begin{array}{l}\text { Lin, Zhang, Li, } \\
\text { Dong [2015] }\end{array}$ & $\begin{array}{l}\text { Konwergencja } \\
\text { non mieszkań }\end{array}$ & $\begin{array}{l}\text { Chińskie regiony } \\
\text { oraz wybrane } \\
\text { miasta }\end{array}$ & $\begin{array}{l}\text { Model } \\
\text { czynnikowy }\end{array}$ & $\begin{array}{l}\text { Potwierdzona słaba } \\
\text { konwergencja klubo- } \\
\text { wa, brak konwergen- } \\
\text { cji wszystkich rynków } \\
\text { regionalnych }\end{array}$ \\
\hline
\end{tabular}


Tabela 5.1 (cd.)

\begin{tabular}{|c|c|c|c|c|}
\hline 1 & 2 & 3 & 4 & 5 \\
\hline $\begin{array}{l}\text { Zhang, } \\
\text { Morley [2014] }\end{array}$ & $\begin{array}{l}\text { Konwergencja } \\
\text { cen mieszkań } \\
\text { na rynkach } \\
\text { regionalnych }\end{array}$ & $\begin{array}{l}35 \text { chińskich } \\
\text { miast oraz gmin }\end{array}$ & $\begin{array}{l}\text { Panelowe testy } \\
\text { pierwiastka } \\
\text { jednostko- } \\
\text { wego }\end{array}$ & $\begin{array}{l}\text { Brak silnych } \\
\text { dowodów } \\
\text { na konwergencję cen } \\
\text { mieszkań } \\
\text { na rynkach } \\
\text { regionalnych }\end{array}$ \\
\hline $\begin{array}{l}\text { Aye, Goswami, } \\
\text { Gupta [2013] }\end{array}$ & $\begin{array}{l}\text { Konwergencja } \\
\text { cen mieszkań } \\
\text { na rynkach me- } \\
\text { tropolitalnych }\end{array}$ & $\begin{array}{l}15 \text { miast } \\
\text { metropolitalnych } \\
\text { w Indiach }\end{array}$ & $\begin{array}{l}\text { Panelowe testy } \\
\text { pierwiastka } \\
\text { jednostko- } \\
\text { wego }\end{array}$ & $\begin{array}{l}\text { Niepotwierdzona kon- } \\
\text { wergencja cenowa }\end{array}$ \\
\hline $\begin{array}{l}\text { Das, Gupta, } \\
\text { Kaya [2010] }\end{array}$ & $\begin{array}{l}\text { Konwergencja } \\
\text { cen mieszkań na } \\
\text { rynkach metro- } \\
\text { politalnych }\end{array}$ & $\begin{array}{l}5 \text { głównych } \\
\text { obszarów } \\
\text { metropolitalnych } \\
\text { RPA }\end{array}$ & $\begin{array}{l}\text { Panelowe testy } \\
\text { pierwiastka } \\
\text { jednostko- } \\
\text { wego }\end{array}$ & $\begin{array}{l}\text { Potwierdzona } \\
\text { konwergencja rynków } \\
\text { metropolitalnych }\end{array}$ \\
\hline $\begin{array}{l}\text { Abbott, } \\
\text { De Vita [2013] }\end{array}$ & $\begin{array}{l}\text { Konwergencja } \\
\text { cen mieszkań } \\
\text { na rynkach } \\
\text { regionalnych }\end{array}$ & $\begin{array}{l}12 \text { rynków } \\
\text { regionalnych UK }\end{array}$ & $\begin{array}{l}\text { Panelowe testy } \\
\text { pierwiastka } \\
\text { jednostko- } \\
\text { wego }\end{array}$ & $\begin{array}{l}\text { Niepotwierdzona kon- } \\
\text { wergencja wszystkich } \\
\text { rynków regionalnych, } \\
\text { słaba konwergencja } \\
\text { klubowa }\end{array}$ \\
\hline $\begin{array}{l}\text { Montagnoli, } \\
\text { Nagayasu } \\
{[2015]}\end{array}$ & $\begin{array}{l}\text { Konwergencja } \\
\text { cen mieszkań } \\
\text { na rynkach } \\
\text { regionalnych }\end{array}$ & $\begin{array}{l}12 \text { rynków } \\
\text { regionalnych UK }\end{array}$ & $\begin{array}{l}\text { Regresja } \log (t) \\
\text { Phillipsa i Sula }\end{array}$ & $\begin{array}{l}\text { Potwierdzona kon- } \\
\text { wergencja klubowa }\end{array}$ \\
\hline Holmes [2007] & $\begin{array}{l}\text { Konwergencja } \\
\text { cen mieszkań } \\
\text { na rynkach } \\
\text { regionalnych }\end{array}$ & $\begin{array}{l}13 \text { rynków } \\
\text { regionalnych UK }\end{array}$ & $\begin{array}{l}\text { Panelowe testy } \\
\text { pierwiastka } \\
\text { jednostkowe- } \\
\text { go, z uwzględ- } \\
\text { nieniem testu } \\
\text { SURADF }\end{array}$ & $\begin{array}{l}\text { Potwierdzona } \\
\text { długookresowa } \\
\text { konwergencja } \\
\text { większości rynków } \\
\text { regionalnych }\end{array}$ \\
\hline $\begin{array}{l}\text { Holmes, Otero, } \\
\text { Panagiotidis } \\
{[2019]}\end{array}$ & $\begin{array}{l}\text { Konwergencja } \\
\text { cen mieszkań } \\
\text { na rynkach } \\
\text { lokalnych }\end{array}$ & $\begin{array}{l}348 \text { rynków } \\
\text { lokalnych Anglii } \\
\text { oraz Walii }\end{array}$ & $\begin{array}{l}\text { Regresja log(t) } \\
\text { Phillipsa i Sula }\end{array}$ & $\begin{array}{l}\text { Potwierdzona } \\
\text { konwergencja } \\
\text { klubowa, } \\
\text { zidentyfikowane } \\
\text { czynniki lokalizacyjne } \\
\text { oraz społeczno- } \\
\text {-ekonomiczne ją } \\
\text { determinujące }\end{array}$ \\
\hline $\begin{array}{l}\text { Holmes, Otero, } \\
\text { Panagiotidis } \\
{[2017]}\end{array}$ & $\begin{array}{l}\text { Konwergencja } \\
\text { cen mieszkań na } \\
\text { rynku lokalnym }\end{array}$ & $\begin{array}{l}20 \text { dzielnic } \\
\text { Paryża }\end{array}$ & $\begin{array}{l}\text { Testy pier- } \\
\text { wiastka jed- } \\
\text { nostkowego }\end{array}$ & $\begin{array}{l}\text { W większości przy- } \\
\text { padków cen relatyw- } \\
\text { nych konwergencja } \\
\text { potwierdzona }\end{array}$ \\
\hline
\end{tabular}




\begin{tabular}{|l|l|l|l|l|}
\hline \multicolumn{1}{|c|}{1} & \multicolumn{1}{|c|}{2} & \multicolumn{1}{|c|}{3} & \multicolumn{1}{c|}{4} & \multicolumn{1}{c|}{5} \\
\hline $\begin{array}{l}\text { Blanco, Martin, } \\
\text { Vazquez [2015] }\end{array}$ & $\begin{array}{l}\text { Konwergencja } \\
\text { cen mieszkań } \\
\text { na rynkach } \\
\text { regionalnych }\end{array}$ & $\begin{array}{l}\text { Rynki regionalne } \\
\text { Hiszpanii }\end{array}$ & $\begin{array}{l}\text { Regresja log(t) } \\
\text { Phillipsa i Sula }\end{array}$ & $\begin{array}{l}\text { Potwierdzona kon- } \\
\text { wergencja klubowa, } \\
\text { brak konwergencji } \\
\text { wszystkich rynków } \\
\text { regionalnych }\end{array}$ \\
\hline $\begin{array}{l}\text { Dittmann } \\
\text { [2014] }\end{array}$ & $\begin{array}{l}\text { Gamma } \\
\text { konwergencja } \\
\text { cen mieszkań } \\
\text { na rynkach } \\
\text { lokalnych }\end{array}$ & $\begin{array}{l}16 \text { miast } \\
\text { wojewódzkich } \\
\text { w Polsce }\end{array}$ & $\begin{array}{l}\text { Współczynnik } \\
\text { konkordancji } \\
\text { rang Kendalla }\end{array}$ & $\begin{array}{l}\text { Brak potwierdzenia } \\
\text { gamma konwergencji } \\
\text { cen mieszkań }\end{array}$ \\
\hline $\begin{array}{l}\text { Żelazowski } \\
\text { [2019] }\end{array}$ & $\begin{array}{l}\text { Konwergencja } \\
\text { cen mieszkań } \\
\text { na rynkach } \\
\text { regionalnych }\end{array}$ & $\begin{array}{l}16 \text { rynków } \\
\text { regionalnych } \\
\text { Polski }\end{array}$ & $\begin{array}{l}\text { Panelowe testy } \\
\text { pierwiastka } \\
\text { jednostkowego, } \\
\text { z uwzględnie- } \\
\text { niem testu } \\
\text { SURADF }\end{array}$ & $\begin{array}{l}\text { Potwierdzona kon- } \\
\text { wergencja } \\
\text { dla 7 rynków regional- } \\
\text { nych }\end{array}$ \\
\hline
\end{tabular}

Źródło: opracowanie własne.

Poza konwergencją cenową w literaturze przedmiotu zainicjowany został także nurt badań poświęconych konwergencji szeroko rozumianych systemów mieszkaniowych. Przedmiotem analizy w tym obszarze są m.in. zmiany w strukturze własnościowej rynków mieszkaniowych, ewolucja ich instytucjonalnego otoczenia, procesy upodabniania i różnicowania krajowych polityk mieszkaniowych czy systemów finansowania sektora mieszkaniowego [Governa, Saccomani 2010 oraz Chiu 2008]. Prowadzone badania nie dają jednak jednoznacznego obrazu zmian zachodzących na krajowych i regionalnych rynkach mieszkaniowych.

\subsection{Procesy konwergencji na rynkach nieruchomości mieszkaniowych w świetle badań własnych}

\subsubsection{Cel i zakres badań}

Rynki mieszkaniowe zazwyczaj charakteryzują się wyraźną segmentacją przestrzenną. W literaturze przedmiotu znaleźć możemy szeroki przegląd źródeł i mechanizmów zróżnicowania rynków mieszkaniowych. Problematyka ta poruszana 
była m.in. w pracach Van Nieuwerburgha i Weilla [2010], Galati i Teppa [2010] czy też Murphiego i Muelbauera [1994].

W procesie integracji gospodarek europejskich ujawniło się jednak dążenie do ujednolicania rynków mieszkaniowych. Dwie grupy czynników mają zasadniczy wpływ na analizowane procesy:

1. Czynniki wewnętrzne o charakterze regionalnym oraz krajowym, związane przede wszystkim $z$ historycznymi uwarunkowaniami funkcjonowania rynków mieszkaniowych, priorytetami polityki mieszkaniowej, potencjałem gospodarczym i atrakcyjnością inwestycyjną regionu oraz kraju;

2. Czynniki zewnętrzne obejmujące procesy społeczno-gospodarcze w skali międzynarodowej. Ich źródłem jest postępująca integracja gospodarek europejskich i towarzysząca jej swoboda przepływu kapitału, migracja zasobów ludzkich, ujednolicanie wzorców kulturowych i stylu życia (proces kalifornizacji potrzeb).

W kontekście integrujących się gospodarek europejskich istotne stało się pytanie dotyczące kierunku zmian strukturalnych w obszarze mieszkalnictwa. Dotychczas prowadzone badania koncentrowały się w głównej mierze na konwergencji cenowej rynków regionalnych, nie wyczerpując tym samym potencjału eksploracyjnego rynków mieszkaniowych. Ponadto miały one charakter selektywny, ograniczając się do wybranych gospodarek europejskich, a uzyskane wyniki były często niekonkluzywne.

Biorąc powyższe pod uwagę, zasadne jest przeprowadzenie pogłębionej analizy procesów konwergencji na europejskich rynkach mieszkaniowych, obejmującej ocenę zakresu i dynamiki konwergencji w wymiarze międzynarodowym i regionalnym. Na potrzeby badania zdefiniowane zostały dwa podstawowe obszary identyfikacji konwergencji mieszkaniowej:

1. Konwergencja cenowa, w ramach której analizie poddano ceny nieruchomości mieszkaniowych.

2. Konwergencja pozacenowa, w ramach której analizie poddano: poziom zaspokojenia potrzeb mieszkaniowych gospodarstw domowych ( $w$ wymiarze ilościowym i jakościowym), siłę nabywczą gospodarstw na rynku mieszkaniowym, otoczenie instytucjonalne rynku mieszkaniowego.

Badaniem objętym zostały kraje członkowskie Unii Europejskiej. Przyjęty horyzont analizy, obejmujący lata 2000-2017, pozwala uwzględnić zarówno okres formalnego członkostwa w UE krajów Europy Środkowo-Wschodniej, jak również lata przedakcesyjne obejmujące proces dostosowań społeczno-gospodarczych krajów kandydatów. 


\subsubsection{Metodologia badawcza}

W ramach identyfikacji procesów konwergencji mieszkaniowej zastosowano procedurę dwuetapową. W pierwszym etapie analizie poddano ceny nieruchomości mieszkaniowych, w drugim natomiast wskaźniki pozacenowe. Analizę przeprowadzono zarówno w wymiarze międzynarodowym, jak i regionalnym.

Weryfikacja konwergencji cenowej przeprowadzona została $\mathrm{z}$ wykorzystaniem testu regresji $\log (t)$ [Philips, Sul 2007], szczegółowo scharakteryzowanego w rozdziale czwartym. W badaniu uwzględniono średnie ceny nieruchomości mieszkaniowych $\mathrm{z}$ rynku wtórnego $\mathrm{w}$ formie zlogarytmowanej. Zgodnie z założeniami przedmiotowego testu z szeregów cen nieruchomości wyodrębniono tendencję długookresową (trend). W tym celu wykorzystano zaproponowany przez Hodricka i Prescotta filtr górnoprzepustowy [Hodrick, Prescott 1997]. Następnie weryfikacji poddano występowanie konwergencji cenowej dla wszystkich badanych rynków na podstawie oszacowanej regresji $\log (t)$ (wzór 4.23). W przypadku braku łącznej konwergencji cenowej wszystkich rynków testowana była konwergencja klubowa zgodnie z algorytmem opracowanym przez Phillipsa i Sula (por. podrozdział 4.2.3).

Konwergencja pozacenowa weryfikowana była w kilku kluczowych dla funkcjonowania rynków mieszkaniowych obszarach. Pierwszy z nich dotyczył zakresu zaspokojenia potrzeb mieszkaniowych gospodarstw domowych w ujęciu ilościowym i jakościowym. W ocenie sytuacji mieszkaniowej gospodarstw zastosowano wskaźnik liczby mieszkań na 1000 mieszkańców oraz wskaźnik deprywacji mieszkaniowej. Drugi obszar badawczy dotyczył siły nabywczej gospodarstw na rynku mieszkaniowym, mierzonej liczbą $\mathrm{m}^{2}$ powierzchni mieszkania możliwych do nabycia za średni miesięczny dochód rozporządzalny. Odwołano się również do instytucjonalnego wymiaru rynków mieszkaniowych poprzez uwzględnienie trzech wskaźników: wskaźnika własności mieszkań (odzwierciedlającego w uproszczonej formie strukturę własnościową zasobu mieszkaniowego), wskaźnika publicznych wydatków mieszkaniowych na 1000 mieszkańców (definiującego zakres interwencjonizmu publicznego w sektorze mieszkaniowym) oraz wskaźnika zadłużenia hipotecznego gospodarstw domowych $w$ relacji do PKB (jako miary poziomu rozwoju rynku kredytowania hipotecznego ${ }^{1}$. Zakres identyfikacji konwergencji pozacenowej przedstawia schemat 5.1.

Konwergencja pozacenowa weryfikowana była $\mathrm{z}$ uwzględnieniem trzech podstawowych miar: beta, sigma oraz gamma konwergencji². Ich istota oraz szczegółowa

1 Szczegółowe informacje dot. wskaźników mieszkaniowych uwzględnionych w badaniu, a także wykorzystanych źródeł informacji zawiera załącznik.

2 Zastosowanie aternatywnych metod identyfikacji konwergencji pozacenowej, w tym relatywnej konwergencji, wynikało z krótszych szeregów zmiennych diagnostycznych (18 obserwacji rocznych dla lat 2000-2017). 


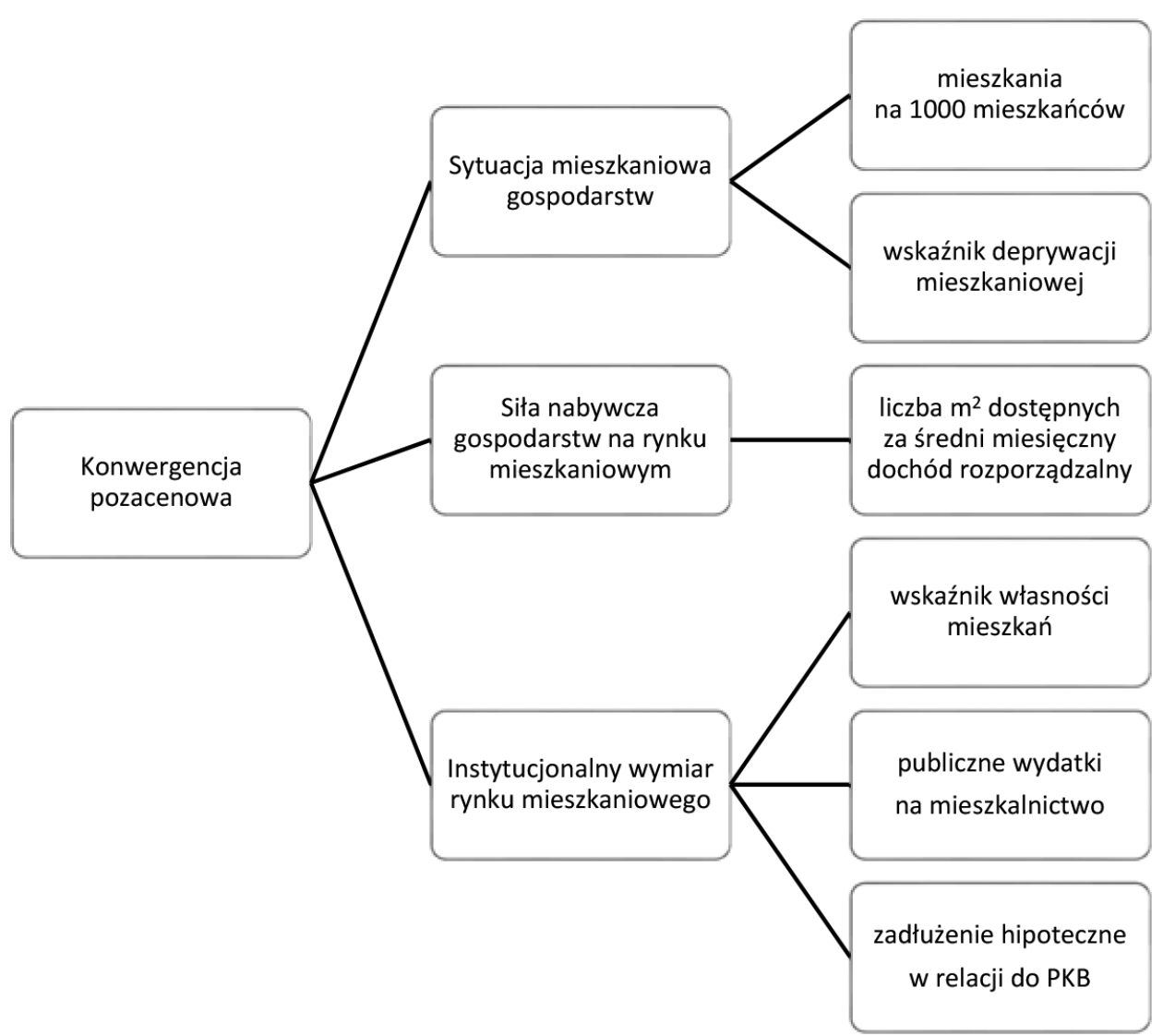

Schemat 5.1. Obszary identyfikacji konwergencji pozacenowej na rynkach mieszkaniowych Źródto: opracowanie własne

metodologia przedstawione zostały w rozdziale czwartym. W niniejszym rozdziale zachodzenie beta konwergencji weryfikowano na podstawie modelu (wzór 4.1). Dodatni oraz statystycznie istotny współczynnik zbieżności $(\beta)$ stanowi potwierdzenie występowania zjawiska konwergencji pomiędzy badanymi rynkami. Na podstawie oszacowanych współczynników beta wyznaczone zostały statystyki half-life określające horyzont czasowy, w ramach którego występujące pomiędzy rynkami różnice zostaną zredukowane o połowę (wzór 4.4).

Identyfikacja sigma konwergencji przeprowadzona została z wykorzystaniem współczynnika zmienności. Sukcesywny spadek zróżnicowania rynków względem przyjętych zmiennych diagnostycznych potwierdzał występowanie sigma konwergencji. Formalną podstawą wnioskowania o sigma konwergencji był test istotności trendu szacowanego dla przyjętej miary zróżnicowania (wzór 4.14). Statystycznie istotny oraz ujemny parametr $\propto_{1}$ stanowił wskazanie zachodzenia konwergencji typu sigma. 
W procesie wnioskowania o zachodzeniu gamma konwergencji posłużono się współczynnikiem konkordancji rang Kendalla (wzór 4.24). Weryfikacja hipotezy zakładającej występowanie gamma konwergencji nastąpiła na podstawie statystyki chi-kwadrat (wzór 4.25). Zgodnie z procedurą testową, gamma konwergencja występuje wówczas, gdy wartość empiryczna statystyki chi-kwadrat jest mniejsza od wartości teoretycznej (dla n-1 stopni swobody i poziomu istotności $\alpha$ ). W przeciwnym przypadku gamma konwergencji nie można potwierdzić.

\subsubsection{Cenowa konwergencja rynków mieszkaniowych}

\subsubsection{Ujęcie międzynarodowe}

Weryfikacja konwergencji cenowej w wymiarze międzynarodowym przeprowadzona została dla 14 gospodarek europejskich ${ }^{3} \mathrm{z}$ uwzględnieniem zlogarytmowanych średnich cen mieszkań wyrażonych w euro za $1 \mathrm{~m}^{2}$ powierzchni użytkowej. W analizie wykorzystano dane kwartalne za okres 2000-2017 (72 obserwacje).

W pierwszym etapie zweryfikowano zachodzenie konwergencji cenowej pomiędzy wszystkimi badanymi rynkami mieszkaniowymi. Regresja log $(t)$ oszacowana została z pominięciem 25\% pierwszych obserwacji w szeregach cen (18 obserwacji). Empiryczna wartość statystyki $t$ dla współczynnika kierunkowego regresji $\log (t)$ wynosząca $-4,09$ była niższa od wartości krytycznej $(-1,65)$, co pozwoliło odrzucić hipotezę o występowaniu łącznej konwergencji cenowej (por. tabela 5.2). Uzyskane wyniki wskazują, iż zróżnicowanie cen między badanymi rynkami nie wykazuje statystycznie istotnej tendencji do spadku z czasem.

Tabela 5.2. Wyniki estymacji regresji log $(t)$ dla 14 rynków mieszkaniowych

\begin{tabular}{|c|c|c|c|}
\hline Zmienna & Wspótczynnik & Błąd standardowy & t-studenta* $^{*}$ \\
\hline $\log (t)$ & $-0,1419$ & 0,0347 & $-4,0894$ \\
\hline
\end{tabular}

Objaśnienia:

* Wartość krytyczna $(-1,65)$.

Źródto: opracowanie własne.

W kolejnym etapie procedury badawczej zweryfikowano zachodzenie konwergencji klubowej poprzez zastosowanie algorytmu grupowania obiektów opisanego przez Phillipsa i Sula. Tabela 5.3 przedstawia wyniki analizy konwergencji klubowej.

3 Bułgarii, Belgii, Finlandii, Francji, Grecji, Hiszpanii, Holandii, Irlandii, Niemiec, Polski, Portugalii, Słowacji, Wielkiej Brytanii oraz Włoch. Ograniczenie analizy do wymienionych rynków wynikało z dostępności danych w zakresie średnich cen mieszkań za $1 \mathrm{~m}^{2}$ powierzchni użytkowej (z rynku wtórnego). 
Tabela 5.3. Wyniki estymacji regresji $\log (t)$ dla zidentyfikowanych klubów konwergencji cenowej

\begin{tabular}{|c|c|c|c|}
\hline Klub & Zmienna & Współczynnik & t-studenta $^{*}$ \\
\hline Klub 1 & $\log (t)$ & 0,320 & 11,729 \\
\hline Klub 2 & $\log (t)$ & 0,123 & 11,504 \\
\hline
\end{tabular}

Objaśnienia:

* Wartość krytyczna $(-1,65)$.

Źródto: opracowanie własne.

Zidentyfikowano dwa kluby, w ramach których średnie ceny nieruchomości wykazywały statystycznie istotny spadek zróżnicowania w uwzględnionym horyzoncie analizy. Do pierwszego klubu zaklasyfikowane zostały rynki mieszkaniowe: Belgii, Finlandii, Francji, Holandii, Irlandii, Niemiec, Polski, Słowacji, Wielkiej Brytanii oraz Włoch (10 obiektów). W drugim klubie znalazły się rynki Bułgarii, Grecji, Portugalii oraz Hiszpanii (4 obiekty). Długookresowe tendencje zmian cen nieruchomości w poszczególnych klubach przedstawia rysunek 5.1.
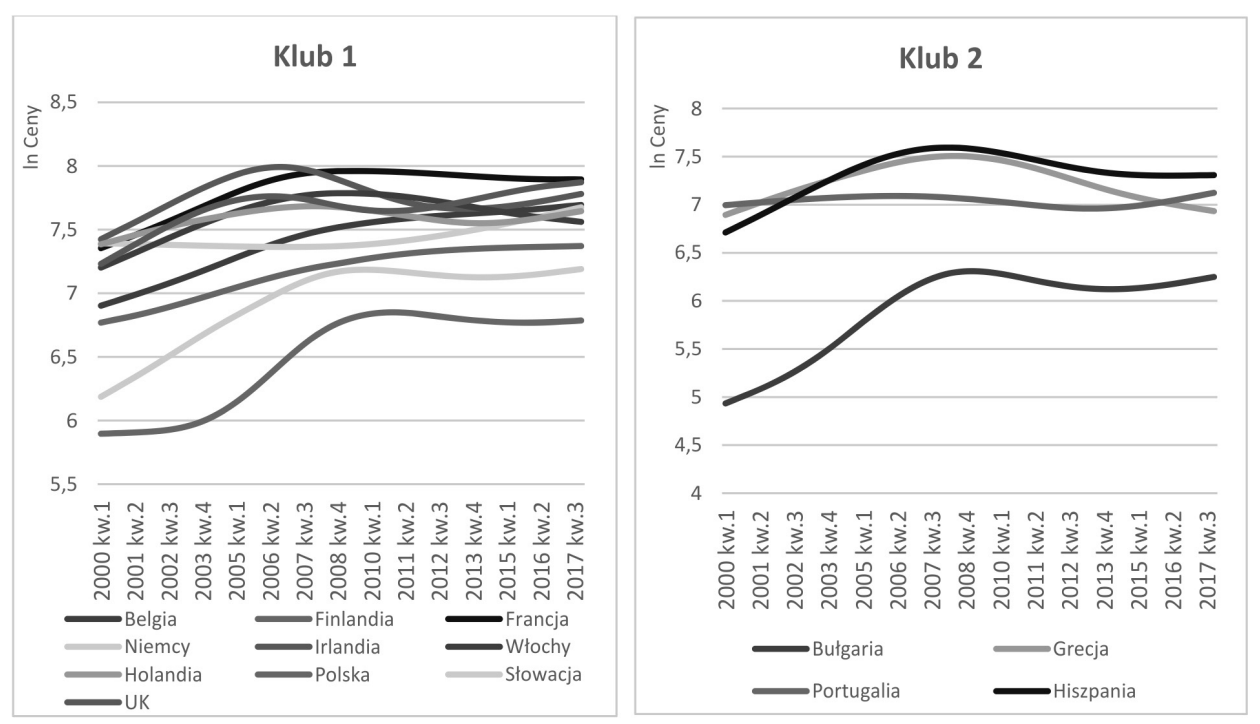

Rysunek 5.1. Długookresowe zmiany cen nieruchomości w zidentyfikowanych klubach konwergencji

Źródło: opracowanie własne

Zmiany zróżnicowania cen $\mathrm{w}$ ramach poszczególnych klubów nie miały jednostajnego charakteru. W przypadku klubu 1 spadek zróżnicowania cen wystąpił przede wszystkim w latach 2005-2010, natomiast w klubie 2 zróżnicowanie cen 
wykazywało tendencję spadkową w całym horyzoncie analizy. Ponadto w wyodrębnionych klubach zauważyć można pewne zależności przestrzenne. Klub 2 tworzą przede wszystkim kraje Europy Południowej, natomiast klub 1 obejmuje zasadniczo kraje Europy Zachodniej oraz Środkowej.

\subsubsection{Ujęcie regionalne}

Konwergencja cenowa w wymiarze regionalnym testowana była dla 6 gospodarek europejskich (Bułgarii, Holandii, Polski, Słowacji, Hiszpanii orazUK). Przedmiotem analizy były zlogarytmowane szeregi średnich cen nieruchomości mieszkaniowych z rynku wtórnego (dane kwartalne z lat 2000-2017). Podobnie jak w przypadku konwergencji międzynarodowej dla każdego z krajów weryfikowano w pierwszej kolejności występowanie konwergencji cenowej pomiędzy wszystkimi rynkami regionalnymi, a w przypadku jej braku wtórnie identyfikowano konwergencję klubową.

Przeprowadzone testy nie potwierdziły generalnej konwergencji cenowej wszystkich rynków regionalnych w poszczególnych gospodarkach (por. tabela 5.4). Wartości empiryczne statystyk $t$ uzyskane na podstawie oszacowanych regresji $\log (t)$ były wyraźnie niższe od wartości krytycznej $(-1,65)$. Świadczy to o zauważalnej segmentacji rynków, istotnej roli czynników regionalnych w kształtowaniu ich rozwoju oraz o słabej ich tendencji do osiągania wspólnego stanu równowagi długookresowej.

Tabela 5.4. Wyniki estymacji regresji $\log (t)$ dla regionalnych rynków mieszkaniowych

\begin{tabular}{|l|c|c|c|}
\hline \multicolumn{1}{|c|}{ Kraj } & $\begin{array}{c}\text { Współczynnik } \\
\text { Zmienna log(t) }\end{array}$ & Błąd standardowy & t-studenta* $^{*}$ \\
\hline Butgaria & $-0,2095$ & 0,0231 & $-9,0735$ \\
\hline Holandia & $-0,6502$ & 0,0302 & $-21,5190$ \\
\hline Polska & $-0,2228$ & 0,0226 & $-9,8503$ \\
\hline Stowacja & $-0,4319$ & 0,0083 & $-51,8349$ \\
\hline Hiszpania & $-0,7321$ & 0,0166 & $-44,2165$ \\
\hline UK & $-1,7095$ & 0,1735 & $-9,8557$ \\
\hline
\end{tabular}

Objaśnienia:

* Wartość krytyczna $(-1,65)$.

Źródto: opracowanie własne.

Pogłębiona analiza pozwoliła jednak wyodrębnić w poszczególnych krajach grupy rynków mieszkaniowych, w ramach których zróżnicowanie cen wykazywało tendencję spadkową. Liczba zidentyfikowanych klubów konwergencji cenowej wahała się od 1 do 4 klubów. W wybranych gospodarkach pojawiły się również 
142 Konwergencja rynków nieruchomości mieszkaniowych...

przypadki rynków regionalnych, które zgodnie z przyjętą metodologią nie zostały zaklasyfikowane do żadnej z grup doświadczających konwergencji cenowej. Były to rynki o wyraźnie odmiennej w stosunku do pozostałych regionów długookresowej ścieżce zmian cen. W ramach rynku brytyjskiego były to regiony: East Midlands, East of England, Greater London, South East, South West, West Midlands, na rynku hiszpańskim: Asturias, Castilla La Mancha oraz Murcja, na rynku słowackim: Bratysława, Koszyce, Nitra, Trenczyn, natomiast w przypadku Polski - mazowiecki rynek mieszkaniowy. Szczegółową klasyfikację rynków regionalnych z konwergencją klubową przedstawia tabela 5.5.

Tabela 5.5. Konwergencja klubowa regionalnych rynków mieszkaniowych

\begin{tabular}{|c|c|c|c|}
\hline Kraj & Kluby konwergencji & $\begin{array}{l}\text { Współczynnik } \\
\text { Zmienna } \log (t)\end{array}$ & t-studenta ${ }^{*}$ \\
\hline 1 & 2 & 3 & 4 \\
\hline \multirow{3}{*}{ Butgaria } & $\begin{array}{l}\text { Klub } 1 \text { (14): Burgas; Dobricz; Haskowo; } \\
\text { Łowecz; Pazardżik; Płowdiw; Razgrad; Ruse; } \\
\text { Szumen; Silistra; Sofia; Sofiastolitsa; Stara } \\
\text { Zagora; Warna }\end{array}$ & 0,1313 & 2,9024 \\
\hline & $\begin{array}{l}\text { Klub } 2 \text { (12): Błagojewgrad; Jamboł; Kardzhali; } \\
\text { Kiustendit; Montana; Pernik; Plewen; Sliwen; } \\
\text { Smolan; Tyrgowiszte; Weliko Tyrnowo; Widin; }\end{array}$ & 0,122 & 2,080 \\
\hline & Klub 3 (2): Gabrowo; Wraca & 2,477 & 1,444 \\
\hline \multirow{4}{*}{ Holandia } & Klub 1 (2): Noord Holland; Utrecht & 0,173 & 0,393 \\
\hline & $\begin{array}{l}\text { Klub } 2 \text { (5): Gelderland; Noord Brabant; } \\
\text { Overijssel; Zeeland; Zuid_Holland }\end{array}$ & 0,082 & 5,399 \\
\hline & Klub 3 (3): Drenthe; Flevoland; Limburg & 0,395 & 1,698 \\
\hline & Klub 4 (2): Friesland; Groningen & 0,676 & 18,566 \\
\hline \multirow{3}{*}{ Polska } & $\begin{array}{l}\text { Klub } 1 \text { (6): lubelskie; małopolskie; } \\
\text { podkarpackie; podlaskie; pomorskie; } \\
\text { wielkopolskie }\end{array}$ & 0,043 & 2,214 \\
\hline & $\begin{array}{l}\text { Klub } 2 \text { (9): dolnośląskie; kujawsko-pomorskie; } \\
\text { łódzkie; lubuskie; opolskie; śląskie; } \\
\text { świętokrzyskie; warmińsko-mazurskie; } \\
\text { zachodniopomorskie }\end{array}$ & 0,212 & 3,871 \\
\hline & $\begin{array}{l}\text { Rynki niepodlegające konwergencji (1): } \\
\text { mazowieckie }\end{array}$ & - & - \\
\hline \multirow{2}{*}{ Stowacja } & $\begin{array}{l}\text { Klub } 1 \text { (4): Banska Bystrzyca; Preszów; } \\
\text { Trnawa; Żilina }\end{array}$ & 0,631 & 4,264 \\
\hline & $\begin{array}{l}\text { Rynki niepodlegające konwergencji (4): } \\
\text { Bratysława; Koszyce; Nitra; Trenczyn }\end{array}$ & $-0,471$ & $-43,188$ \\
\hline
\end{tabular}




\begin{tabular}{|c|l|c|c|}
\hline 1 & \multicolumn{1}{|c|}{2} & \multicolumn{1}{|c|}{3} & 4 \\
\hline \multirow{4}{*}{ Hiszpania } & $\begin{array}{l}\text { Klub 1 (6): Balears; Cantabria; Cataluna; Ceuta } \\
\text { y Melilla; Madrid Comunidad; Paisvasco }\end{array}$ & 0,082 & 1,371 \\
\cline { 2 - 4 } & $\begin{array}{l}\text { Klub 2 (9): Andalucia; Aragon; Comunidad } \\
\text { Valenciana; Extremadura; Canarias; Galicia; } \\
\text { Navarra; Castilla y Leon; Rioja }\end{array}$ & 0,188 & 4,645 \\
\cline { 2 - 4 } & $\begin{array}{l}\text { Rynki niepodlegające konwergencji (3): } \\
\text { Asturias; Castilla La Mancha; Murcia }\end{array}$ & $-1,927$ & $-11,504$ \\
\hline \multirow{2}{*}{ UK } & $\begin{array}{l}\text { Klub 1 (4): North West; Scotland; Wales; } \\
\text { Yorkshire and the Humber }\end{array}$ & 1,500 & 6,378 \\
\cline { 2 - 4 } & Klub 2 (2): North East; Northern Ireland & 3,770 & 2,494 \\
\cline { 2 - 4 } & $\begin{array}{l}\text { Rynki niepodlegające konwergencji (6): East } \\
\text { Midlands; East of England; Greater London; } \\
\text { South East; South West; West Midlands }\end{array}$ & $-1,632$ & $-19,770$ \\
\hline
\end{tabular}

Objaśnienia:

* Wartość krytyczna $(-1,65)$.

Źródto: opracowanie własne.

\subsubsection{Pozacenowa konwergencja rynków mieszkaniowych}

\subsubsection{Ujęcie międzynarodowe}

W wymiarze międzynarodowym konwergencja pozacenowa testowana była dla wszystkich sześciu wskaźników scharakteryzowanych w punkcie 5.2.2. Zmienna liczba rynków krajowych poddanych analizie w poszczególnych obszarach badawczych wynikała z dostępności danych statystycznych. Horyzont badawczy objął lata 2000-2017. W celu dokładniejszej charakterystyki dynamiki zjawiska konwergencji mieszkaniowej podstawowy okres analizy podzielony został dodatkowo na 2 podokresy: okres przedkryzysowy (lata 2000-2007) oraz okres pokryzysowy (lata 2008-2017). Pozwoliło to zweryfikować w podstawowej formie, czy zmiana uwarunkowań makroekonomicznych miała wpływ na przebieg konwergencji mieszkaniowej.

Podstawą wnioskowania o zachodzeniu beta konwergencji były wyniki oszacowań modelu (4.1). W przypadku wszystkich wskaźników diagnostycznych współczynniki kierunkowe regresji były ujemne. Za wyjątkiem wydatków publicznych na mieszkalnictwo były one również statystycznie istotne (por. rysunek 5.2 oraz tabela 5.6). Silne procesy beta konwergencji zdiagnozowano w obszarze zadłużenia hipotecznego gospodarstw domowych (współczynnik zbieżności wynoszący 6,47\%) oraz wskaźnika własności mieszkań (współczynnik zbieżności na poziomie 4,09\%). Co istotne, potwierdzony efekt doganiania wykazywał 
144 Konwergencja rynków nieruchomości mieszkaniowych...

zmienność w czasie. W latach dobrej koniunktury gospodarczej (2000-2007) beta konwergencja cechowała się wyższą dynamiką. Zauważalne jest to przede wszystkim dla wskaźników siły nabywczej gospodarstw (współczynnik zbieżności wynoszący 10,5\%) oraz wskaźnika skali kredytowania hipotecznego (współczynnik zbieżności wynoszący 12,18\%). W latach 2008-2017 tempo beta konwergencji dla większości zmiennych diagnostycznych istotnie spadło.
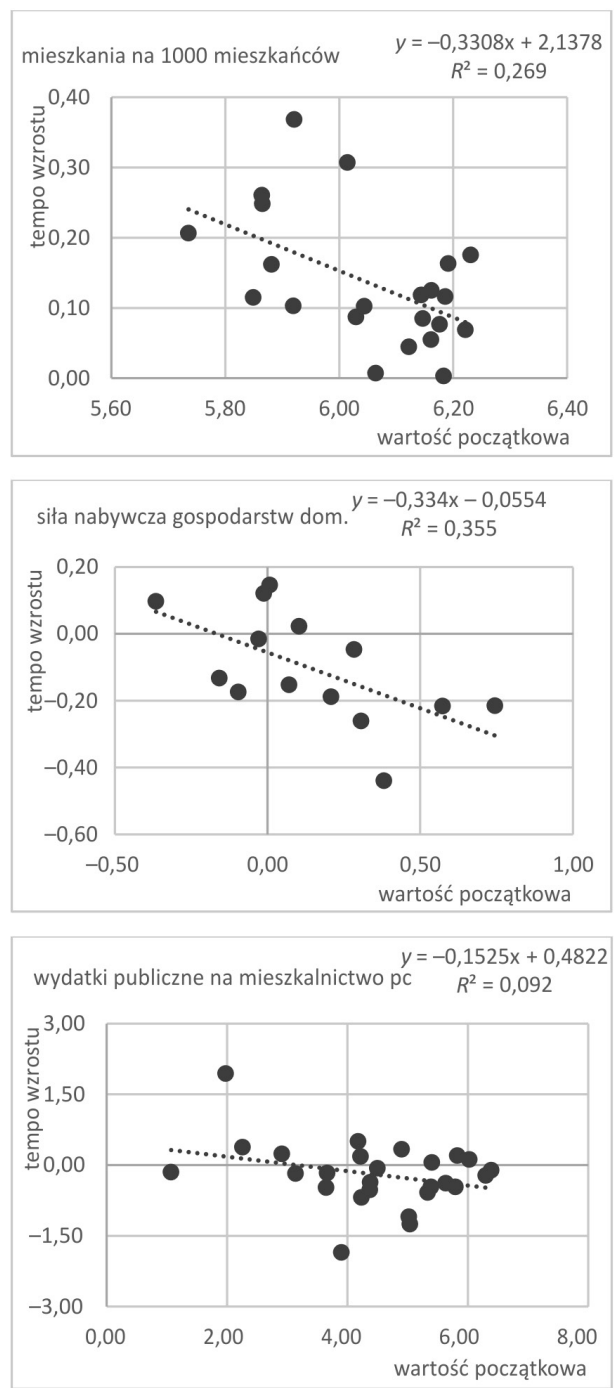
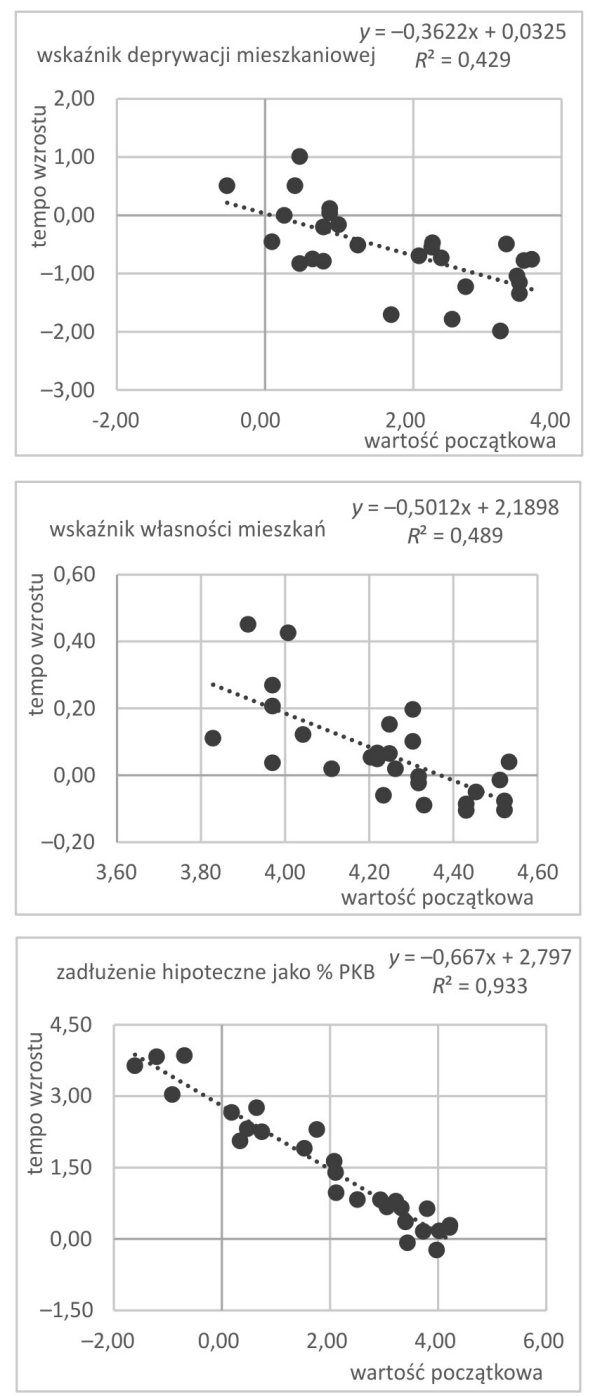

Rysunek 5.2. Identyfikacja beta konwergencji na europejskich rynkach mieszkaniowych (lata 2000-2017)

Źródło: opracowanie własne 
Tabela 5.6. Wyniki estymacji beta konwergencji

\begin{tabular}{|c|c|c|c|c|}
\hline \multirow{2}{*}{ Zmienna } & \multicolumn{4}{|c|}{ Wyniki estymacji KMNK } \\
\hline & & 2000-2017 & 2000-2007 & 2008-2017 \\
\hline 1 & 2 & 3 & 4 & 5 \\
\hline \multirow{5}{*}{ 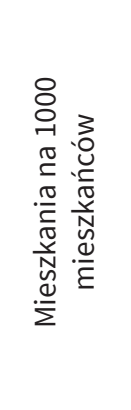 } & $\begin{array}{l}\text { Wyraz wolny } \\
\text { (p-value) } \\
\text { Parametr b } \\
\text { (p-value) }\end{array}$ & $\begin{array}{c}2,138 \\
(0,009) \\
\\
-0,331 \\
(0,013)\end{array}$ & $\begin{array}{c}1,124 \\
(0,015) \\
\\
-0,173 \\
(0,022)\end{array}$ & $\begin{array}{c}0,830 \\
(0,217) \\
-0,127 \\
(0,245)\end{array}$ \\
\hline & $R^{2}$ & 0,269 & 0,235 & 0,067 \\
\hline & SEE & 0,082 & 0,047 & 0,062 \\
\hline & Beta & $2,36 \%$ & $2,72 \%$ & $1,51 \%$ \\
\hline & Half-life & 20,34 & 25,53 & 45,97 \\
\hline \multirow{5}{*}{ 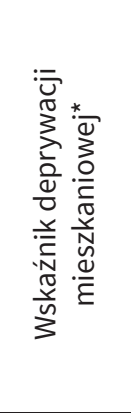 } & $\begin{array}{l}\text { Wyraz wolny } \\
\text { (p-value) } \\
\text { Parametr b } \\
\text { (p-value) }\end{array}$ & $\begin{array}{c}0,032 \\
(0,858) \\
\\
-0,362 \\
(0,000) \\
\end{array}$ & $\begin{array}{l}-0,140 \\
(0,239) \\
-0,077 \\
(0,165)\end{array}$ & $\begin{array}{c}0,129 \\
(0,330) \\
\\
-0,294 \\
(0,000)\end{array}$ \\
\hline & $R^{2}$ & 0,429 & 0,075 & 0,421 \\
\hline & SEE & 0,543 & 0,352 & 0,436 \\
\hline & Beta & $3,21 \%$ & $2,01 \%$ & $3,88 \%$ \\
\hline & Half-life & 21,58 & 34,42 & 17,89 \\
\hline \multirow{5}{*}{ 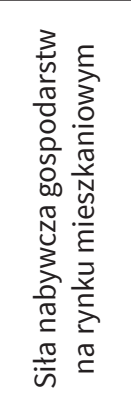 } & $\begin{array}{l}\text { Wyraz wolny } \\
\text { (p-value) } \\
\text { Parametr b } \\
\text { (p-value) }\end{array}$ & $\begin{array}{l}-0,055 \\
(0,207) \\
\\
-0,334 \\
(0,024)\end{array}$ & $\begin{array}{l}-0,213 \\
(0,009) \\
\\
-0,508 \\
(0,036)\end{array}$ & $\begin{array}{c}0,121 \\
(0,082) \\
\\
-0,440 \\
(0,084)\end{array}$ \\
\hline & $R^{2}$ & 0,355 & 0,317 & 0,229 \\
\hline & SEE & 0,138 & 0,230 & 0,204 \\
\hline & Beta & $2,39 \%$ & $10,14 \%$ & $6,45 \%$ \\
\hline & Half-life & 28,99 & 6,84 & 10,75 \\
\hline \multirow{5}{*}{ 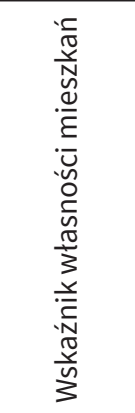 } & $\begin{array}{l}\text { Wyraz wolny } \\
\text { (p-value) } \\
\text { Parametr b } \\
\text { (p-value) }\end{array}$ & $\begin{array}{c}2,189 \\
(0,000) \\
\\
-0,501 \\
(0,000)\end{array}$ & $\begin{array}{l}1,755 \\
(0,000) \\
\\
-0,395 \\
(0,000)\end{array}$ & $\begin{array}{c}0,380 \\
(0,337) \\
\\
-0,092 \\
(0,316)\end{array}$ \\
\hline & $R^{2}$ & 0,489 & 0,575 & 0,040 \\
\hline & SEE & 0,106 & 0,070 & 0,066 \\
\hline & Beta & $4,09 \%$ & $7,18 \%$ & $1,07 \%$ \\
\hline & Half-life & 16,94 & 9,655 & 64,71 \\
\hline
\end{tabular}


146 Konwergencja rynków nieruchomości mieszkaniowych...

Tabela 5.6 (cd.)

\begin{tabular}{|c|c|c|c|c|}
\hline 1 & 2 & 3 & 4 & 5 \\
\hline \multirow{5}{*}{ 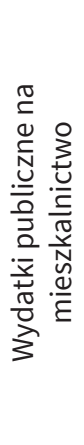 } & $\begin{array}{l}\text { Wyraz wolny } \\
\text { (p-value) } \\
\text { Parametr b } \\
\text { (p-value) }\end{array}$ & $\begin{array}{c}0,482 \\
(0,299) \\
\\
-0,153 \\
(0,133)\end{array}$ & $\begin{array}{c}0,584 \\
(0,059) \\
\\
-0,118 \\
(0,076)\end{array}$ & $\begin{array}{c}-0,388 \\
(0,386) \\
\\
0,015 \\
(0,873)\end{array}$ \\
\hline & $R^{2}$ & 0,091 & 0,125 & 0,001 \\
\hline & SEE & 0,668 & 0,434 & 0,556 \\
\hline & Beta & $0,97 \%$ & $1,80 \%$ & - \\
\hline & Half-life & 71,21 & 38,54 & - \\
\hline \multirow{5}{*}{ 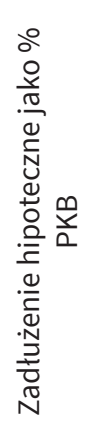 } & $\begin{array}{l}\text { Wyraz wolny } \\
\text { (p-value) } \\
\text { Parametr b } \\
\text { (p-value) }\end{array}$ & $\begin{array}{c}2,797 \\
(0,000) \\
\\
-0,667 \\
(0,000)\end{array}$ & $\begin{array}{c}2,466 \\
(0,000) \\
\\
-0,574 \\
(0,000)\end{array}$ & $\begin{array}{l}1,051 \\
(0,003) \\
-0,287 \\
(0,004)\end{array}$ \\
\hline & $R^{2}$ & 0,933 & 0,911 & 0,281 \\
\hline & SEE & 0,329 & 0,330 & 0,377 \\
\hline & Beta & $6,47 \%$ & $12,18 \%$ & $3,76 \%$ \\
\hline & Half-life & 10,71 & 5,69 & 18,43 \\
\hline
\end{tabular}

Objaśnienia:

* Dane za 2003-2017.

Źródto: opracowanie własne.

Występowanie beta konwergencji jest warunkiem koniecznym zachodzenia drugiego jej rodzaju - sigma konwergencji. Uzyskane wyniki potwierdzają zgodność obu procesów dla przyjętych zmiennych diagnostycznych. Statystycznie istotny trend spadkowy współczynników zmienności uzyskano dla wszystkich wskaźników poza publicznymi wydatkami na mieszkalnictwo. Wydatki te wykazywały ponadto w latach 2006-2008 wyższe od długookresowej średniej zróżnicowanie. Świadczy to prawdopodobnie o różnym podejściu podmiotów publicznych do interwencyjnych wydatków na sferę mieszkaniową we wskazanych latach kryzysu gospodarczego. Zróżnicowanie przekrojowe pozostałych wskaźników charakteryzowało się silniejszą dynamiką spadkową w latach 2000-2007 (por. rysunek 5.3 oraz tabela 5.7). 

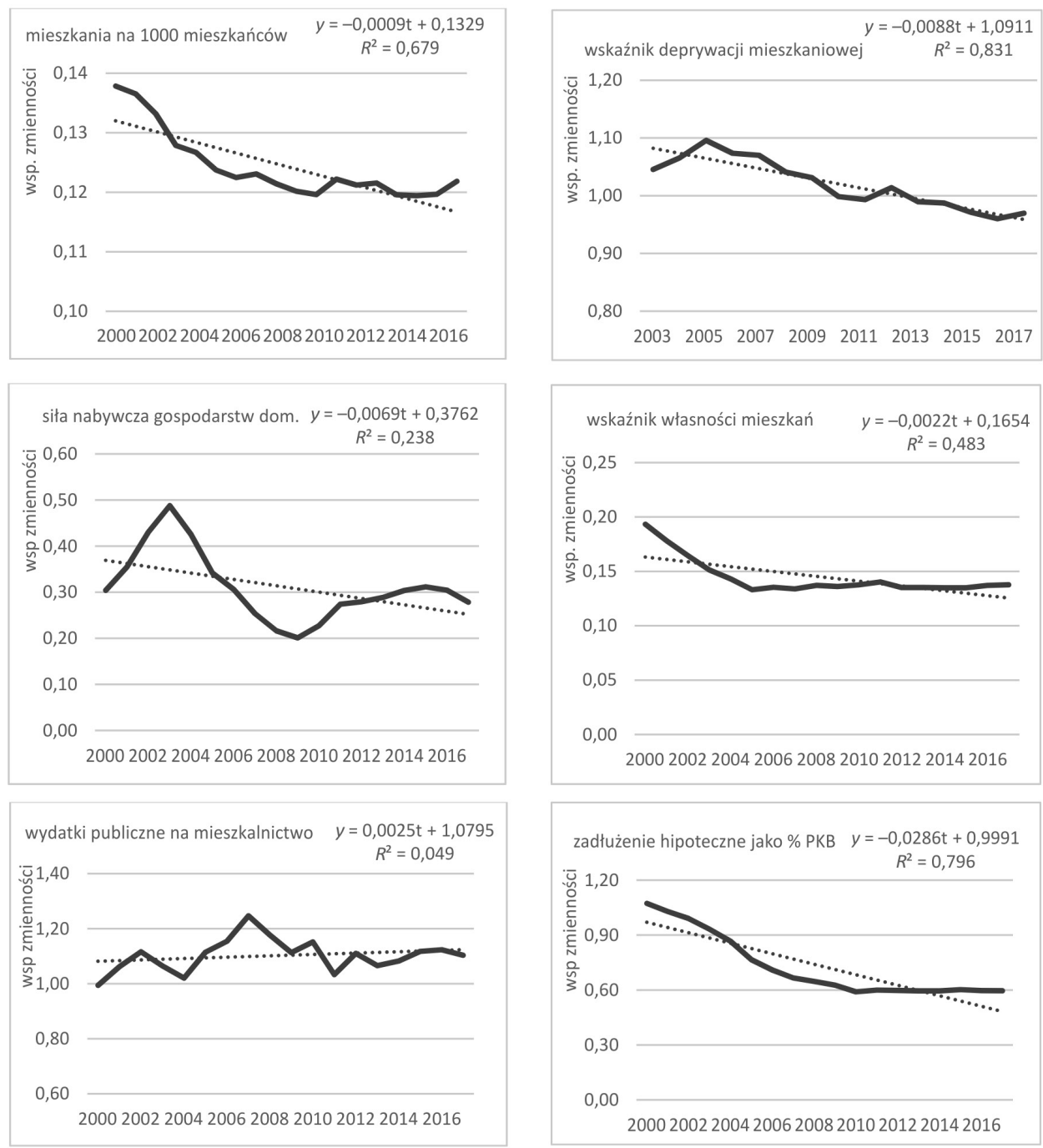

Rysunek 5.3. Identyfikacja sigma konwergencji na europejskich rynkach mieszkaniowych

(lata 2000-2017)

Źródto: opracowanie własne 
148 Konwergencja rynków nieruchomości mieszkaniowych...

Tabela 5.7. Wyniki estymacji sigma konwergencji

\begin{tabular}{|c|c|c|c|c|}
\hline \multirow{2}{*}{ Zmienna } & \multicolumn{4}{|c|}{ Wyniki estymacji KMNK } \\
\hline & & 2000-2017 & 2000-2007 & 2008-2017 \\
\hline \multirow{4}{*}{ 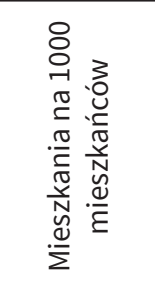 } & $\begin{array}{l}\text { Wyraz wolny } \\
\text { (p-value) }\end{array}$ & $\begin{array}{c}0,133 \\
(0,000)\end{array}$ & $\begin{array}{c}0,140 \\
(0,000)\end{array}$ & $\begin{array}{c}0,121 \\
(0,000)\end{array}$ \\
\hline & $\begin{array}{l}\text { Parametr } \alpha_{1} \\
\text { (p-value) }\end{array}$ & $\begin{array}{c}-0,0009 \\
(0,000)\end{array}$ & $\begin{array}{c}-0,0024 \\
(0,000)\end{array}$ & $\begin{array}{c}-0,0001 \\
(0,688)\end{array}$ \\
\hline & $R^{2}$ & 0,679 & 0,929 & 0,021 \\
\hline & SEE & 0,003 & 0,002 & 0,001 \\
\hline \multirow{4}{*}{ 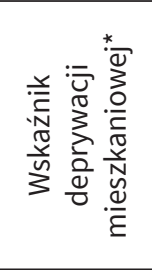 } & $\begin{array}{l}\text { Wyraz wolny } \\
\text { (p-value) }\end{array}$ & $\begin{array}{c}1,091 \\
(0,000)\end{array}$ & $\begin{array}{c}1,053 \\
(0,000)\end{array}$ & $\begin{array}{c}1,039 \\
(0,000)\end{array}$ \\
\hline & $\begin{array}{l}\text { Parametr } \alpha_{1} \\
\text { (p-value) }\end{array}$ & $\begin{array}{c}-0,0088 \\
(0,000) \\
\end{array}$ & $\begin{array}{l}0,0057 \\
(0,392) \\
\end{array}$ & $\begin{array}{c}-0,0079 \\
(0,000) \\
\end{array}$ \\
\hline & $R^{2}$ & 0,831 & 0,249 & 0,834 \\
\hline & SEE & 0,018 & 0,018 & 0,011 \\
\hline \multirow{4}{*}{ 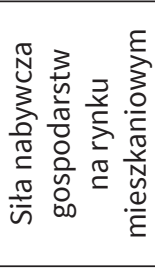 } & $\begin{array}{l}\text { Wyraz wolny } \\
\text { (p-value) }\end{array}$ & $\begin{array}{c}0,376 \\
(0,000)\end{array}$ & $\begin{array}{c}0,413 \\
(0,000)\end{array}$ & $\begin{array}{c}0,209 \\
(0,000)\end{array}$ \\
\hline & $\begin{array}{l}\text { Parametr } \alpha_{1} \\
\text { (p-value) }\end{array}$ & $\begin{array}{c}-0,0069 \\
(0,040)\end{array}$ & $\begin{array}{l}-0,011 \\
(0,405)\end{array}$ & $\begin{array}{l}0,0109 \\
(0,002)\end{array}$ \\
\hline & $R^{2}$ & 0,238 & 0,118 & 0,702 \\
\hline & SEE & 0,068 & 0,080 & 0,023 \\
\hline \multirow{4}{*}{ 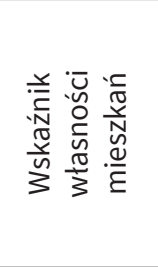 } & $\begin{array}{l}\text { Wyraz wolny } \\
\text { (p-value) }\end{array}$ & $\begin{array}{c}0,165 \\
(0,000)\end{array}$ & $\begin{array}{c}0,193 \\
(0,000)\end{array}$ & $\begin{array}{c}0,137 \\
(0,000)\end{array}$ \\
\hline & $\begin{array}{l}\text { Parametr } \alpha_{1} \\
\text { (p-value) }\end{array}$ & $\begin{array}{c}-0,0022 \\
(0,001) \\
\end{array}$ & $\begin{array}{r}-0,0087 \\
(0,000) \\
\end{array}$ & $\begin{array}{c}-0,0001 \\
(0,615) \\
\end{array}$ \\
\hline & $R^{2}$ & 0,483 & 0,898 & 0,033 \\
\hline & SEE & 0,013 & 0,008 & 0,002 \\
\hline \multirow{4}{*}{ 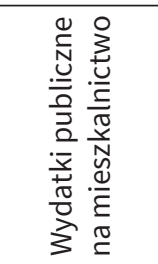 } & $\begin{array}{l}\text { Wyraz wolny } \\
\text { (p-value) }\end{array}$ & $\begin{array}{c}1,080 \\
(0,000)\end{array}$ & $\begin{array}{c}0,981 \\
(0,000)\end{array}$ & $\begin{array}{c}1,130 \\
(0,000)\end{array}$ \\
\hline & $\begin{array}{l}\text { Parametr } \alpha_{1} \\
\text { (p-value) }\end{array}$ & $\begin{array}{l}0,0045 \\
(0,377)\end{array}$ & $\begin{array}{l}0,0259 \\
(0,019)\end{array}$ & $\begin{array}{c}-0,0040 \\
(0,411)\end{array}$ \\
\hline & $R^{2}$ & 0,049 & 0,626 & 0,086 \\
\hline & SEE & 0,060 & 0,053 & 0,042 \\
\hline \multirow{4}{*}{ 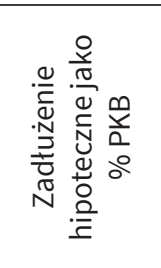 } & $\begin{array}{l}\text { Wyraz wolny } \\
\text { (p-value) }\end{array}$ & $\begin{array}{c}0,999 \\
(0,000)\end{array}$ & $\begin{array}{l}1,157 \\
(0,000)\end{array}$ & $\begin{array}{c}0,626 \\
(0,000)\end{array}$ \\
\hline & $\begin{array}{l}\text { Parametr } \alpha_{1} \\
\text { (p-value) }\end{array}$ & $\begin{array}{c}-0,0286 \\
(0,000)\end{array}$ & $\begin{array}{c}-0,0617 \\
(0,000)\end{array}$ & $\begin{array}{c}-0,0038 \\
(0,045)\end{array}$ \\
\hline & $R^{2}$ & 0,796 & 0,986 & 0,413 \\
\hline & SEE & 0,079 & 0,020 & 0,015 \\
\hline
\end{tabular}

Objaśnienia:

* Dane za 2003-2017.

Źródto: opracowanie własne. 
Przeprowadzone badanie nie potwierdziło generalnej tendencji do występowania gamma konwergencji między krajowymi rynkami mieszkaniowymi (rys. 5.4). Spadek wartości współczynnika konkordancji rang poniżej wartości krytycznej zaobserwowano jedynie w przypadku wskaźnika siły nabywczej gospodarstw domowych (tab. 5.8). Miał on jednak charakter okresowy (w latach 2006-2016) i wynikał w znacznej mierze z silnych fluktuacji cen nieruchomości
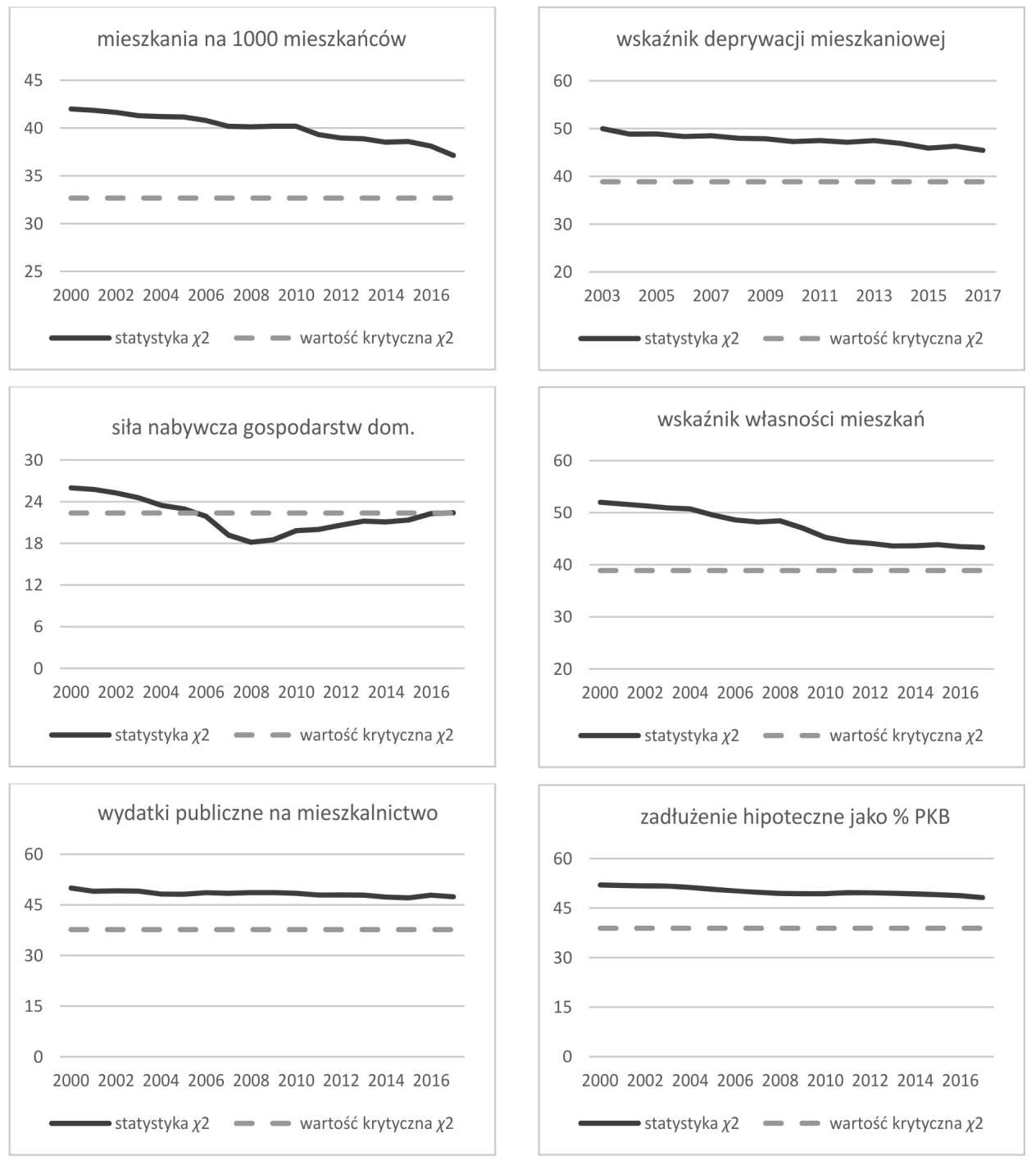

Rysunek 5.4. Identyfikacja gamma konwergencji na europejskich rynkach mieszkaniowych

(lata 2000-2017)

Źródło: opracowanie własne 


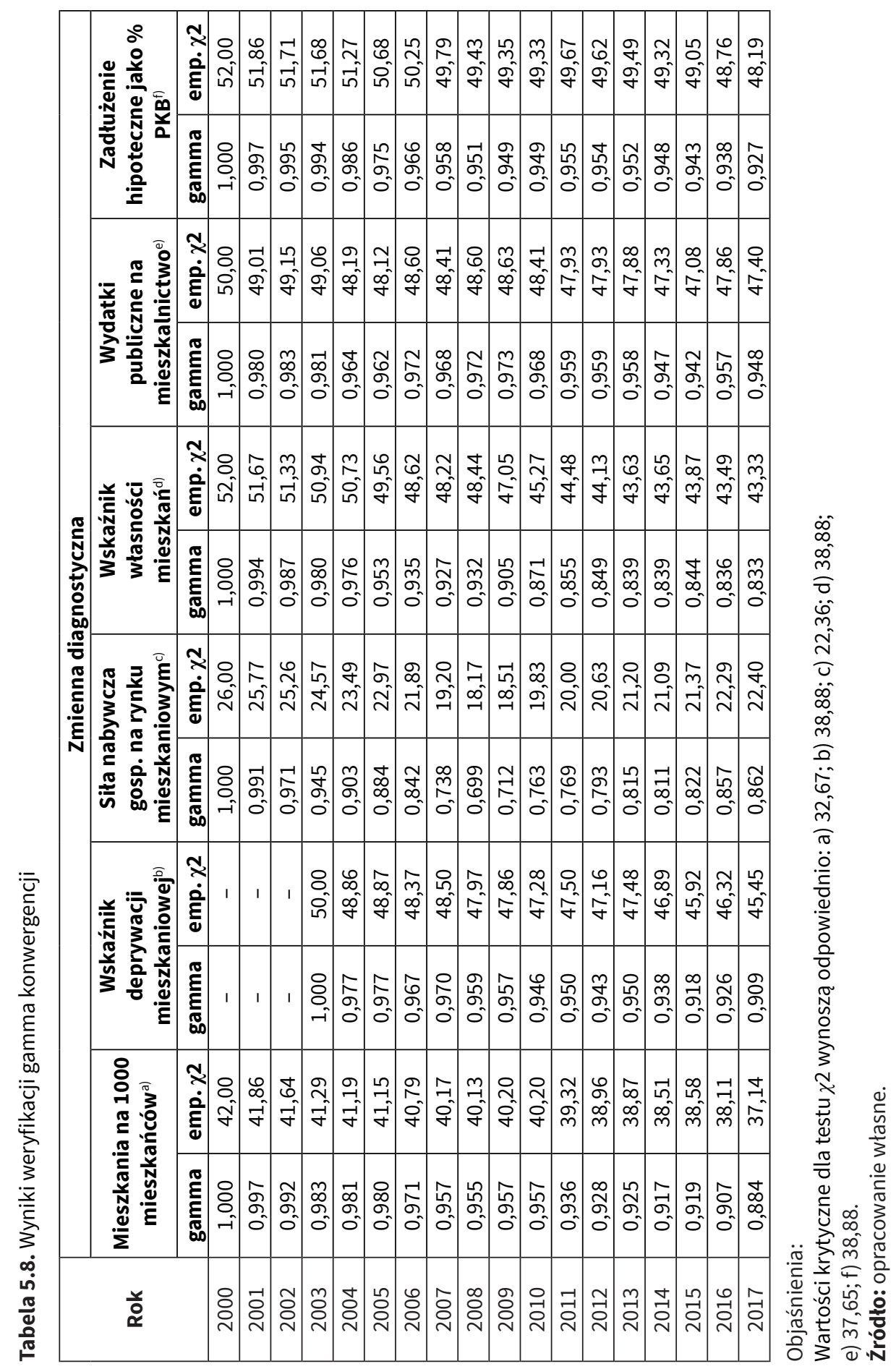


na poszczególnych rynkach. Nie potwierdzono statystycznie istotnego przepozycjonowania rynków krajowych w rankingach sporządzonych na podstawie pozostałych wskaźników mieszkaniowych. Brak konwergencji typu gamma potwierdza utrzymujące się w okresie 18 lat różnice w funkcjonowaniu krajowych rynków mieszkaniowych.

\subsubsection{Ujęcie regionalne}

W analizie porównawczej regionalnych rynków mieszkaniowych uwzględniono dwa wskaźniki pozacenowe: liczbę mieszkań na 1000 mieszkańców, a także siłę nabywczą gospodarstw domowych mierzoną liczbą $\mathrm{m}^{2}$ dostępnych za średni dochód rozporządzalny ${ }^{4}$. Weryfikacji poddano sześć gospodarek europejskich (Bułgaria, Holandia, Polska, Słowacja, Hiszpania oraz Wielka Brytania), ich wybór podyktowany był w głównej mierze dostępnością danych statystycznych $\mathrm{z}$ regionalnych rynków mieszkaniowych. Przyjęta w tej części badania metodologia była tożsama z rozwiązaniami zastosowanymi w ocenie konwergencji międzynarodowej.

$\mathrm{Na}$ każdym z uwzględnionych w analizie rynków regionalnych obserwowany był długookresowy trend przyrostu zasobu mieszkaniowego. Charakter tych zmian był jednak odmienny od procesów obserwowanych w ujęciu międzynarodowym. Uzyskane wyniki nie potwierdziły występowania efektu doganiania między rynkami regionalnymi w zakresie ich infrastruktury mieszkaniowej (brak beta konwergencji). Oszacowane współczynniki kierunkowe regresji (4.1) były dodatnie i w większości przypadków statystycznie nieistotne (rys. 5.5 oraz tab. 5.9).

Pośród rynków poddanych analizie, najsilniejsze zróżnicowanie regionalne w kontekście istniejących zasobów mieszkaniowych na 1000 mieszkańców wykazywały rynki Bułgarii, Słowacji oraz Hiszpanii (współczynniki zmienności powyżej 10\%), najniższym zaś rynki Holandii oraz Wielkiej Brytanii (współczynniki zmienności poniżej 5\%). Wspólną cechą badanych krajów było jednak zjawisko pogłębiających się różnic w zasobach mieszkaniowych regionów wraz z upływem lat (rys. 5.6 oraz tab. 5.10). Potwierdzone beta i sigma dywergencja, pozwalają wnioskować o koncentracji przestrzennej procesów inwestycyjnych w obszarze infrastruktury mieszkaniowej. Nowe inwestycje mieszkaniowe podejmowane są na rynkach oferujących inwestorom odpowiednio atrakcyjne stopy zwrotu. Silne ekonomicznie regiony pomimo relatywnie większych zasobów mieszkaniowych pozostają atrakcyjne inwestycyjnie. Tendencje te znajdują swoje odzwierciedlenie w skali budownictwa mieszkaniowego, a w konsekwencji także w rosnących różnicach w regionalnych zasobach mieszkaniowych.

4 Zastosowanie pozostałych wskaźników, uwzględnionych w analizie międzynarodowej, nie było możliwe ze względnu na brak dostępnych danych. 

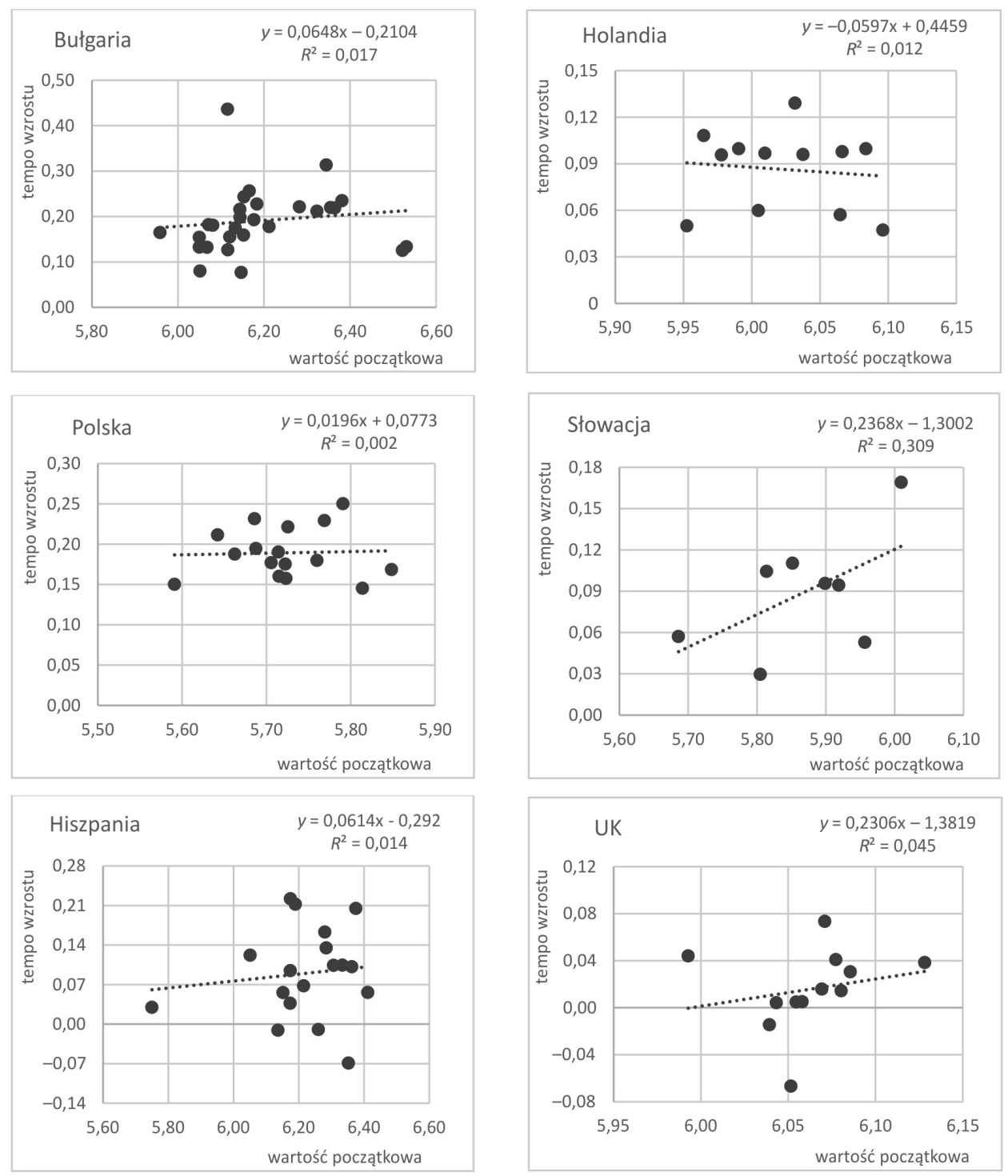

Rysunek 5.5. Identyfikacja beta konwergencji dla wskaźnika mieszkań na 1000 mieszkańców (lata 2000-2017)

Źródto: opracowanie własne 
Tabela 5.9. Wyniki estymacji beta konwergencji dla wskaźnika mieszkań na 1000 mieszkańców

\begin{tabular}{|c|c|c|c|c|}
\hline \multirow{2}{*}{ Gospodarka } & \multicolumn{4}{|c|}{ Wyniki estymacji KMNK } \\
\hline & & 2000-2017 & 2000-2007 & 2008-2017 \\
\hline 1 & 2 & 3 & 4 & 5 \\
\hline \multirow{6}{*}{ 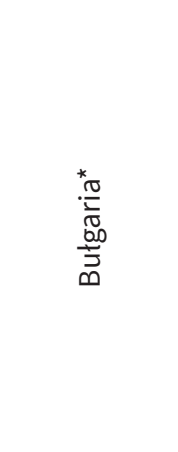 } & $\begin{array}{l}\text { Wyraz wolny } \\
\text { (p-value) }\end{array}$ & $\begin{array}{l}-0,210 \\
(0,729)\end{array}$ & $\begin{array}{l}-0,179 \\
(0,280)\end{array}$ & $\begin{array}{l}-0,205 \\
(0,626)\end{array}$ \\
\hline & $\begin{array}{l}\text { Parametr b } \\
\text { (p-value) }\end{array}$ & $\begin{array}{c}0,065 \\
(0,510)\end{array}$ & $\begin{array}{c}0,036 \\
(0,181)\end{array}$ & $\begin{array}{c}0,054 \\
(0,421)\end{array}$ \\
\hline & $R^{2}$ & 0,017 & 0,068 & 0,025 \\
\hline & SEE & 0,072 & 0,020 & 0,052 \\
\hline & Beta & - & - & - \\
\hline & Half-life & - & - & - \\
\hline \multirow{6}{*}{$\begin{array}{l}\frac{\pi}{7} \\
\frac{0}{0} \\
\text { 우 }\end{array}$} & $\begin{array}{l}\text { Wyraz wolny } \\
\text { (p-value) }\end{array}$ & $\begin{array}{c}0,446 \\
(0,676)\end{array}$ & $\begin{array}{l}-0,272 \\
(0,645)\end{array}$ & $\begin{array}{c}0,449 \\
(0,503)\end{array}$ \\
\hline & $\begin{array}{l}\text { Parametr b } \\
\text { (p-value) }\end{array}$ & $\begin{array}{l}-0,060 \\
(0,736)\end{array}$ & $\begin{array}{c}0,050 \\
(0,613)\end{array}$ & $\begin{array}{l}-0,065 \\
(0,553)\end{array}$ \\
\hline & $R^{2}$ & 0,012 & 0,027 & 0,036 \\
\hline & SEE & 0,027 & 0,015 & 0,018 \\
\hline & Beta & $0,36 \%$ & - & $0,75 \%$ \\
\hline & Half-life & 191,43 & - & 92,23 \\
\hline \multirow{5}{*}{$\frac{\frac{\pi}{\tilde{N}}}{\frac{\pi}{O}}$} & $\begin{array}{l}\text { Wyraz wolny } \\
\text { (p-value) } \\
\text { Parametr b } \\
\text { (p-value) }\end{array}$ & $\begin{array}{c}0,077 \\
(0,104) \\
\\
0,020 \\
(0,151)\end{array}$ & $\begin{array}{c}0,335 \\
(0,519) \\
\\
-0,042 \\
(0,641)\end{array}$ & $\begin{array}{c}-0,397 \\
(0,231) \\
\\
0,083 \\
(0,151)\end{array}$ \\
\hline & $R^{2}$ & 0,002 & 0,016 & 0,142 \\
\hline & SEE & 0,033 & 0,022 & 0,014 \\
\hline & Beta & - & $0,62 \%$ & - \\
\hline & Half-life & - & 112,53 & - \\
\hline
\end{tabular}


154 Konwergencja rynków nieruchomości mieszkaniowych...

Tabela 5.9 (cd.)

\begin{tabular}{|c|c|c|c|c|}
\hline 1 & 2 & 3 & 4 & 5 \\
\hline \multirow{6}{*}{ 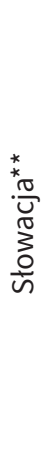 } & $\begin{array}{l}\text { Wyraz wolny } \\
\text { (p-value) }\end{array}$ & $\begin{array}{l}-1,300 \\
(0,176)\end{array}$ & $\begin{array}{c}0,434 \\
(0,320)\end{array}$ & $\begin{array}{l}-1,821 \\
(0,063)\end{array}$ \\
\hline & $\begin{array}{l}\text { Parametr b } \\
\text { (p-value) }\end{array}$ & $\begin{array}{c}0,237 \\
(0,152)\end{array}$ & $\begin{array}{l}-0,071 \\
(0,339)\end{array}$ & $\begin{array}{c}0,322 \\
(0,056)\end{array}$ \\
\hline & $R^{2}$ & 0,309 & 0,153 & 0,483 \\
\hline & SEE & 0,039 & 0,018 & 0,034 \\
\hline & Beta & - & $1,84 \%$ & - \\
\hline & Half-life & - & 37,65 & - \\
\hline \multirow{6}{*}{ 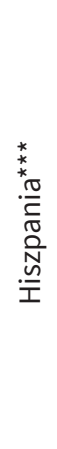 } & $\begin{array}{l}\text { Wyraz wolny } \\
\text { (p-value) }\end{array}$ & $\begin{array}{c}-0,2919 \\
(0,723)\end{array}$ & $\begin{array}{l}0,8056 \\
(0,095)\end{array}$ & $\begin{array}{c}-1,3662 \\
(0,000)\end{array}$ \\
\hline & $\begin{array}{l}\text { Parametr b } \\
\text { (p-value) }\end{array}$ & $\begin{array}{c}0,061 \\
(0,643)\end{array}$ & $\begin{array}{l}-0,122 \\
(0,114)\end{array}$ & $\begin{array}{c}0,224 \\
(0,000)\end{array}$ \\
\hline & $R^{2}$ & 0,013 & 0,148 & 0,678 \\
\hline & SEE & 0,082 & 0,046 & 0,023 \\
\hline & Beta & - & $2,16 \%$ & - \\
\hline & Half-life & - & 32,02 & - \\
\hline \multirow{5}{*}{$\stackrel{\searrow}{\supset}$} & $\begin{array}{l}\text { Wyraz wolny } \\
\text { (p-value) } \\
\text { Parametr b } \\
\text { (p-value) }\end{array}$ & $\begin{array}{c}-1,3819 \\
(0,512) \\
\\
0,231 \\
(0,507)\end{array}$ & $\begin{array}{c}-0,8685 \\
(0,165) \\
0,145 \\
(0,160)\end{array}$ & $\begin{array}{c}-1,330 \\
(0,277) \\
\\
0,219 \\
(0,277)\end{array}$ \\
\hline & $R^{2}$ & 0,045 & 0,187 & 0,117 \\
\hline & SEE & 0,036 & 0,010 & 0,024 \\
\hline & Beta & - & - & - \\
\hline & Half-life & - & - & - \\
\hline
\end{tabular}

Objaśnienia:

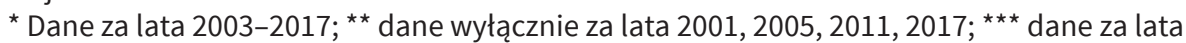
2001-2017.

Źródto: opracowanie własne. 

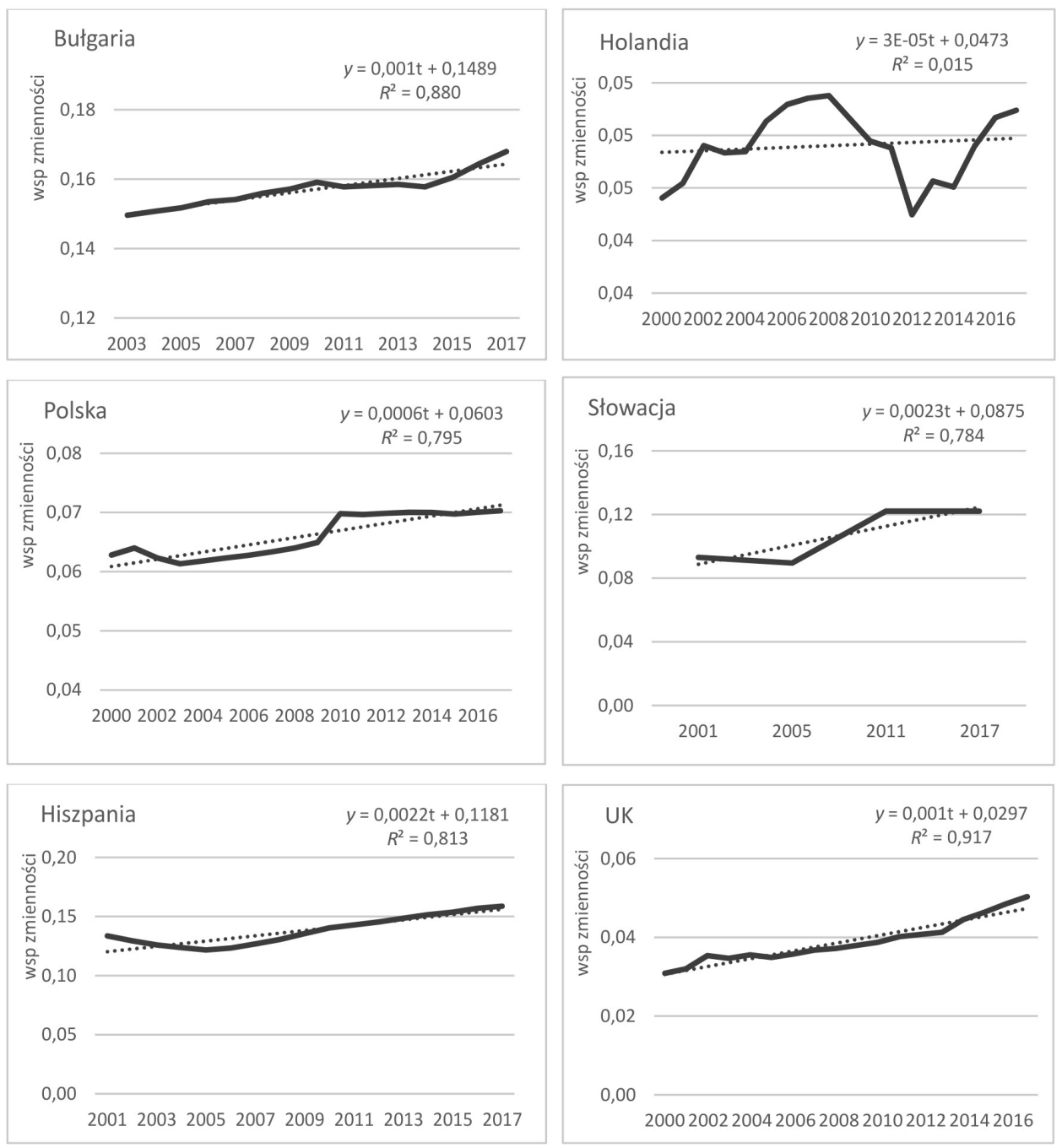

Rysunek 5.6. Identyfikacja sigma konwergencji dla wskaźnika mieszkań na 1000 mieszkańców Źródto: opracowanie własne 
156 Konwergencja rynków nieruchomości mieszkaniowych...

Tabela 5.10. Wyniki estymacji sigma konwergencji dla wskaźnika mieszkań na 1000 mieszkańców

\begin{tabular}{|c|c|c|c|c|}
\hline \multirow{2}{*}{ Gospodarka } & \multicolumn{4}{|c|}{ Wyniki estymacji KMNK } \\
\hline & & $2000-2017$ & $2000-2007$ & 2008-2017 \\
\hline 1 & 2 & 3 & 4 & 5 \\
\hline \multirow{4}{*}{ 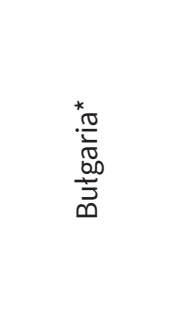 } & $\begin{array}{l}\text { Wyraz wolny } \\
\text { (p-value) }\end{array}$ & $\begin{array}{l}0,1488 \\
(0,000)\end{array}$ & $\begin{array}{l}0,1484 \\
(0,000)\end{array}$ & $\begin{array}{l}0,1542 \\
(0,000)\end{array}$ \\
\hline & $\begin{array}{l}\text { Parametr } \alpha_{1} \\
\text { (p-value) }\end{array}$ & $\begin{array}{l}0,0010 \\
(0,000)\end{array}$ & $\begin{array}{l}0,0012 \\
(0,000)\end{array}$ & $\begin{array}{l}0,0010 \\
(0,000)\end{array}$ \\
\hline & $R^{2}$ & 0,880 & 0,984 & 0,675 \\
\hline & SEE & 0,0018 & 0,0003 & 0,0022 \\
\hline \multirow{4}{*}{$\begin{array}{l}\frac{\pi}{\bar{O}} \\
\frac{1}{1} \\
\frac{1}{0} \\
\text { 운 }\end{array}$} & $\begin{array}{l}\text { Wyraz wolny } \\
\text { (p-value) }\end{array}$ & $\begin{array}{l}0,0473 \\
(0,046)\end{array}$ & $\begin{array}{l}0,0453 \\
(0,000)\end{array}$ & $\begin{array}{l}0,0479 \\
(0,000)\end{array}$ \\
\hline & $\begin{array}{l}\text { Parametr } \alpha_{1} \\
\text { (p-value) }\end{array}$ & $\begin{array}{c}0,00003 \\
(0,623)\end{array}$ & $\begin{array}{l}0,0005 \\
(0,000)\end{array}$ & $\begin{array}{c}-0,00005 \\
(0,754)\end{array}$ \\
\hline & $R^{2}$ & 0,015 & 0,924 & 0,013 \\
\hline & SEE & 0,0014 & 0,0004 & 0,0015 \\
\hline \multirow{4}{*}{$\frac{0}{\frac{0}{2}}$} & $\begin{array}{l}\text { Wyraz wolny } \\
\text { (p-value) }\end{array}$ & $\begin{array}{l}0,0602 \\
(0,000)\end{array}$ & $\begin{array}{l}0,0627 \\
(0,000)\end{array}$ & $\begin{array}{l}0,0657 \\
(0,000)\end{array}$ \\
\hline & $\begin{array}{l}\text { Parametr } \alpha_{1} \\
\text { (p-value) }\end{array}$ & $\begin{array}{l}0,0006 \\
(0,000)\end{array}$ & $\begin{array}{c}-0,00002 \\
(0,870)\end{array}$ & $\begin{array}{l}0,0006 \\
(0,015)\end{array}$ \\
\hline & $R^{2}$ & 0,795 & 0,005 & 0,546 \\
\hline & SEE & 0,0017 & 0,0009 & 0,0017 \\
\hline \multirow{3}{*}{ 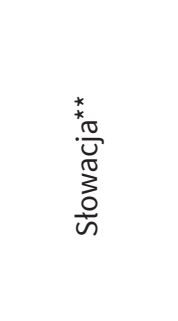 } & $\begin{array}{l}\text { Wyraz wolny } \\
\text { (p-value) } \\
\text { Parametr } \alpha_{1} \\
\text { (p-value) }\end{array}$ & $\begin{array}{l}0,0875 \\
(0,010) \\
\\
0,0023 \\
(0,115)\end{array}$ & - & - \\
\hline & $R^{2}$ & 0,784 & - & - \\
\hline & SEE & 0,0101 & - & - \\
\hline
\end{tabular}




\begin{tabular}{|c|c|c|c|c|}
\hline 1 & 2 & 3 & 4 & 5 \\
\hline \multirow{4}{*}{ 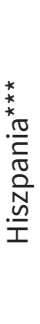 } & $\begin{array}{l}\text { Wyraz wolny } \\
\text { (p-value) }\end{array}$ & $\begin{array}{l}0,1181 \\
(0,000)\end{array}$ & $\begin{array}{l}0,1317 \\
(0,001)\end{array}$ & $\begin{array}{l}0,1299 \\
(0,000)\end{array}$ \\
\hline & $\begin{array}{l}\text { Parametr } \alpha_{1} \\
\text { (p-value) }\end{array}$ & $\begin{array}{l}0,0022 \\
(0,066)\end{array}$ & $\begin{array}{c}-0,0013 \\
(0,080)\end{array}$ & $\begin{array}{l}0,0030 \\
(0,004)\end{array}$ \\
\hline & $R^{2}$ & 0,813 & 0,489 & 0,986 \\
\hline & SEE & 0,0056 & 0,0032 & 0,0012 \\
\hline \multirow{4}{*}{ ড } & $\begin{array}{l}\text { Wyraz wolny } \\
\text { (p-value) }\end{array}$ & $\begin{array}{l}0,0297 \\
(0,000)\end{array}$ & $\begin{array}{l}0,0313 \\
(0,000)\end{array}$ & $\begin{array}{l}0,0345 \\
(0,000)\end{array}$ \\
\hline & $\begin{array}{l}\text { Parametr } \alpha_{1} \\
\text { (p-value) }\end{array}$ & $\begin{array}{c}0,00098 \\
(0,219)\end{array}$ & $\begin{array}{c}0,00071 \\
(0,006)\end{array}$ & $\begin{array}{l}0,0015 \\
(0,000)\end{array}$ \\
\hline & $R^{2}$ & 0,917 & 0,745 & 0,952 \\
\hline & SEE & 0,0016 & 0,0011 & 0,0011 \\
\hline
\end{tabular}

Objaśnienia:

* Dane za lata 2003-2017; ** dane wyłącznie za lata 2001, 2005, 2011, 2017;

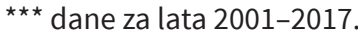

Źródto: opracowanie własne.

Regionalne zasoby mieszkaniowe nie wykazywały istotnych tendencji do gamma konwergencji. Dysproporcje $\mathrm{w}$ bazie mieszkaniowej regionów pozostawały w latach 2000-2017 na tyle trwałe, iż wartości współczynników rang nie spadły poniżej wartości krytycznych (rys. 5.7 oraz tab. 5.11). Oczywiście trzeba mieć na uwadze charakter przedmiotowego wskaźnika - jego inercję. Zmiany po stronie zasobów mieszkaniowych, ze względu na specyfikę procesów budowlanych, mają charakter długookresowy, stąd przyjęty horyzont badawczy może być niewystarczający do przepozycjonowania regionów w rankingu dostępnej infrastruktury mieszkaniowej. 


\section{8}

Konwergencja rynków nieruchomości mieszkaniowych...
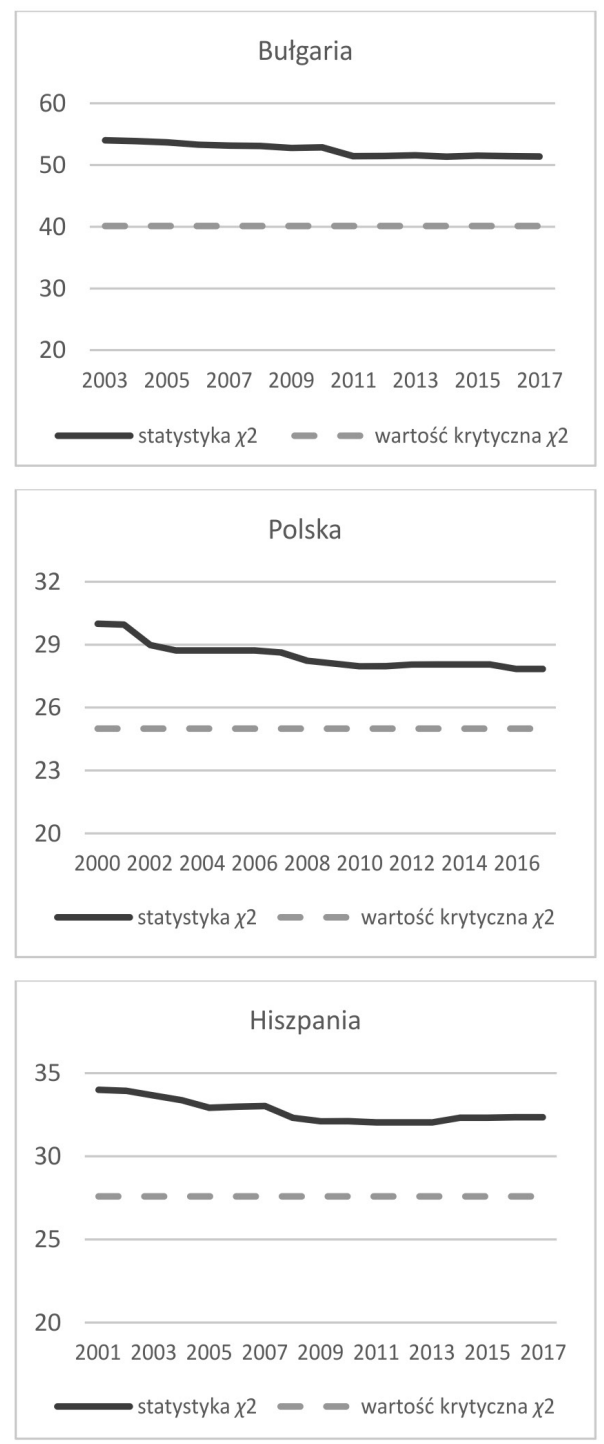
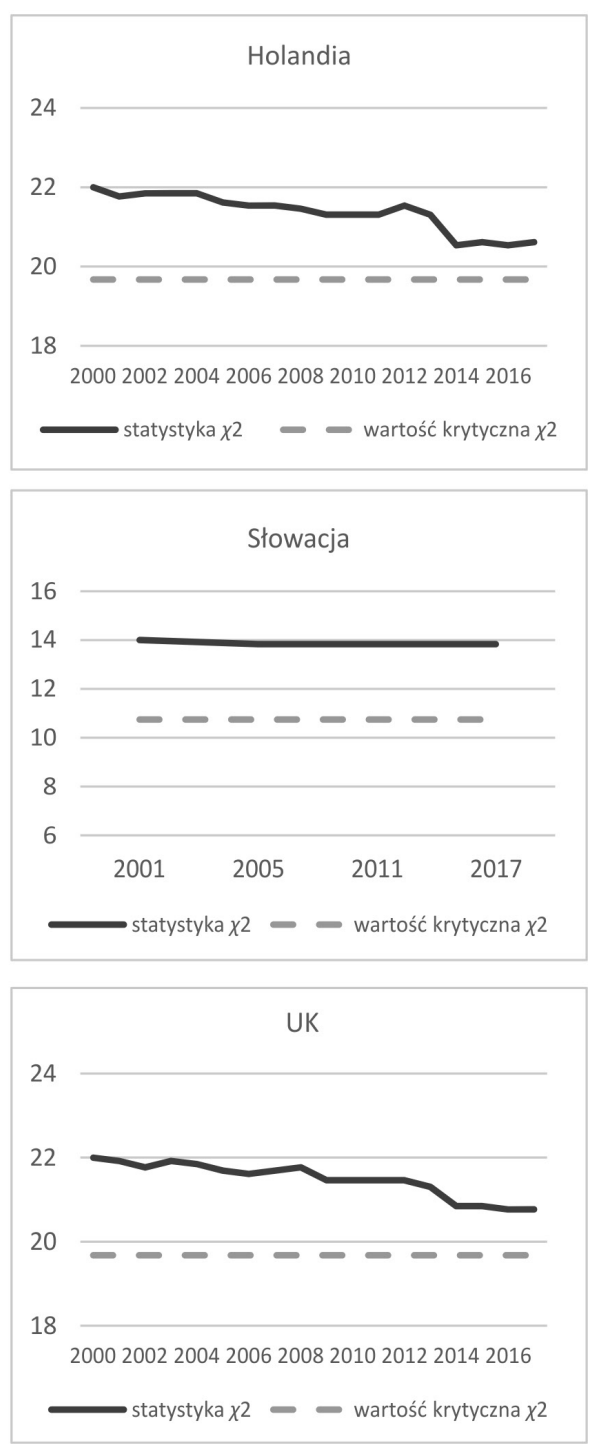

Rysunek 5.7. Identyfikacja gamma konwergencji dla wskaźnika mieszkań na 1000 mieszkańców

Źródto: opracowanie własne 


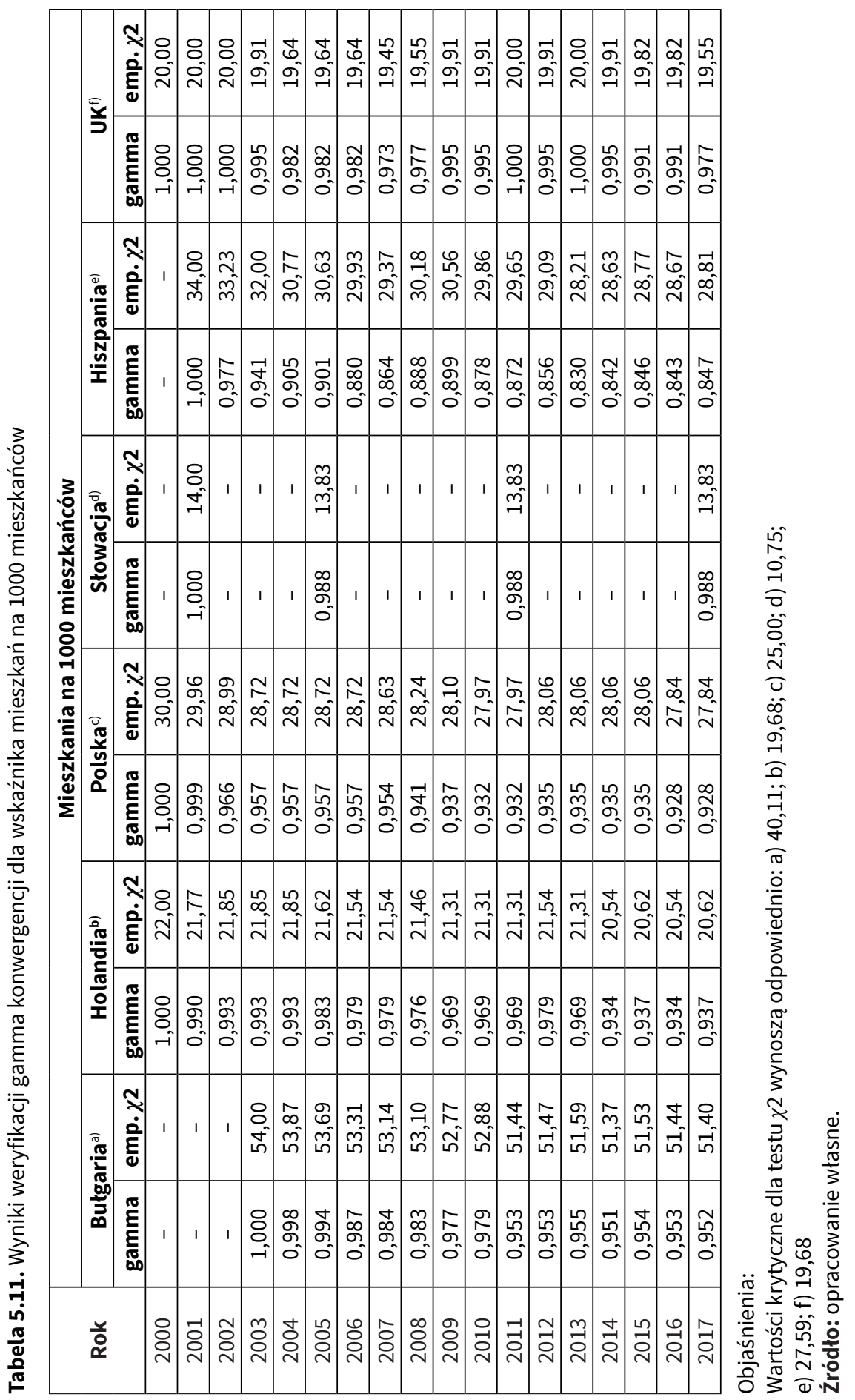


W przypadku wskaźnika siły nabywczej gospodarstw domowych kierunek zmian zachodzących na rynkach regionalnych nie jest jednoznaczny. Beta konwergencję potwierdzono jedynie dla rynków regionalnych Bułgarii oraz Holandii. Tempo zbieżności w obu przypadkach kształtowało się na zbliżonym poziomie $5,5 \%$ rocznie. Zupełnie inny obraz przedstawiają zmiany siły nabywczej zachodzące na rynkach Wielkiej Brytanii, wskazują one na występowanie beta dywergencji. W pozostałych gospodarkach oszacowane współczynniki kierunkowe regresji były statystycznie nieistotne (por. rys. 5.8 oraz tab. 5.12).
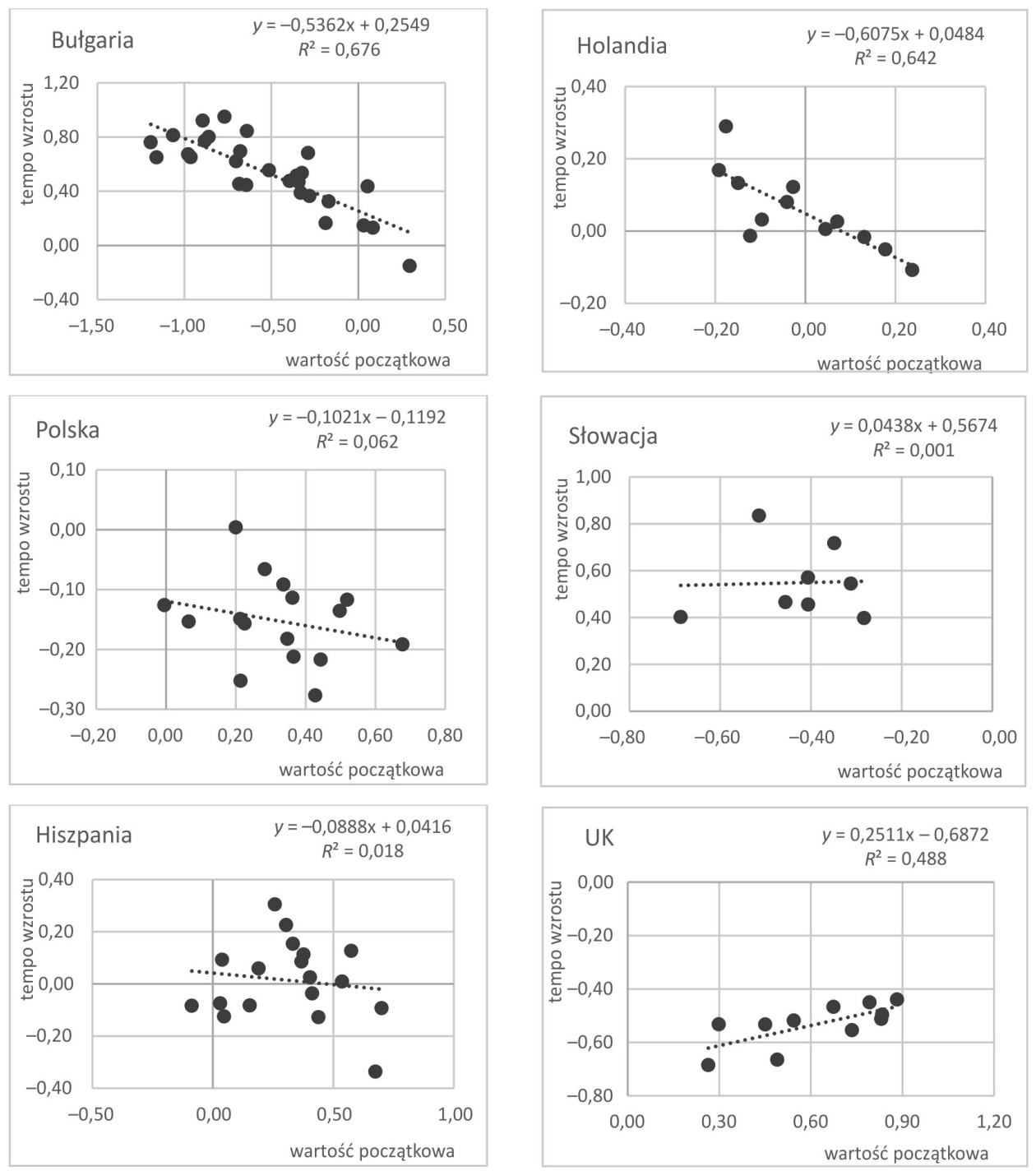

Rysunek 5.8. Identyfikacja beta konwergencji dla wskaźnika siły nabywczej gospodarstw domowych (lata 2000-2017)

Źródto: opracowanie własne 
Tabela 5.12. Wyniki estymacji beta konwergencji dla wskaźnika siły nabywczej gospodarstw domowych

\begin{tabular}{|c|c|c|c|c|}
\hline \multirow{2}{*}{ Gospodarka } & \multicolumn{4}{|c|}{ Wyniki estymacji KMNK } \\
\hline & & 2000-2017 & $2000-2007$ & 2008-2017 \\
\hline 1 & 2 & 3 & 4 & 5 \\
\hline \multirow{5}{*}{ 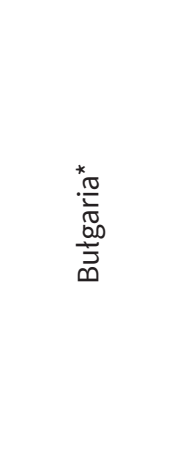 } & $\begin{array}{l}\text { Wyraz wolny } \\
\text { (p-value) } \\
\text { Parametr b } \\
\text { (p-value) }\end{array}$ & $\begin{array}{c}0,255 \\
(0,000) \\
\\
-0,536 \\
(0,000)\end{array}$ & $\begin{array}{l}-0,631 \\
(0,000) \\
-0,539 \\
(0,000)\end{array}$ & $\begin{array}{c}0,692 \\
(0,000) \\
\\
-0,213 \\
(0,050)\end{array}$ \\
\hline & $R^{2}$ & 0,676 & 0,545 & 0,140 \\
\hline & SEE & 0,151 & 0,200 & 0,134 \\
\hline & Beta & $5,48 \%$ & $19,36 \%$ & $2,66 \%$ \\
\hline & Half-life & 12,64 & 3,58 & 26,04 \\
\hline \multirow{5}{*}{$\begin{array}{l}\frac{\pi}{\pi} \\
\frac{0}{0} \\
\frac{\pi}{0} \\
\text { 은 }\end{array}$} & $\begin{array}{l}\text { Wyraz wolny } \\
\text { (p-value) } \\
\text { Parametr b } \\
\text { (p-value) }\end{array}$ & $\begin{array}{c}0,048 \\
(0,034) \\
\\
-0,608 \\
(0,002)\end{array}$ & $\begin{array}{l}-0,166 \\
(0,000) \\
-0,540 \\
(0,000)\end{array}$ & $\begin{array}{c}0,174 \\
(0,000) \\
\\
-0,088 \\
(0,663)\end{array}$ \\
\hline & $R^{2}$ & 0,642 & 0,798 & 0,020 \\
\hline & SEE & 0,068 & 0,041 & 0,051 \\
\hline & Beta & $5,50 \%$ & $11,11 \%$ & $1,02 \%$ \\
\hline & Half-life & 12,60 & 6,24 & 67,72 \\
\hline \multirow{5}{*}{$\frac{\frac{\pi}{v}}{\frac{\pi}{0}}$} & $\begin{array}{l}\text { Wyraz wolny } \\
\text { (p-value) } \\
\text { Parametr b } \\
\text { (p-value) }\end{array}$ & $\begin{array}{l}-0,119 \\
(0,008) \\
-0,102 \\
(0,351)\end{array}$ & $\begin{array}{l}-0,410 \\
(0,000) \\
-0,012 \\
(0,916)\end{array}$ & $\begin{array}{c}0,323 \\
(0,003) \\
\\
-0,010 \\
(0,908)\end{array}$ \\
\hline & $R^{2}$ & 0,062 & 0,001 & 0,001 \\
\hline & SEE & 0,071 & 0,074 & 0,053 \\
\hline & Beta & $0,63 \%$ & $0,17 \%$ & $0,11 \%$ \\
\hline & Half-life & 109,41 & 412,27 & 633,44 \\
\hline
\end{tabular}


Tabela 5.12 (cd.)

\begin{tabular}{|c|c|c|c|c|}
\hline 1 & 2 & 3 & 4 & 5 \\
\hline \multirow{6}{*}{$\begin{array}{l}\frac{\pi}{\tilde{\sigma}} \\
\frac{\pi}{3} \\
\frac{0}{\omega} \\
\frac{0}{\omega}\end{array}$} & $\begin{array}{l}\text { Wyraz wolny } \\
\text { (p-value) }\end{array}$ & $\begin{array}{c}0,567 \\
(0,041)\end{array}$ & $\begin{array}{l}-0,001 \\
(0,998)\end{array}$ & $\begin{array}{r}0,690 \\
(0,001)\end{array}$ \\
\hline & $\begin{array}{l}\text { Parametr b } \\
\text { (p-value) }\end{array}$ & $\begin{array}{c}0,044 \\
(0,932)\end{array}$ & $\begin{array}{l}-0,124 \\
(0,819)\end{array}$ & $\begin{array}{r}0,208 \\
(0,382)\end{array}$ \\
\hline & $R^{2}$ & 0,001 & 0,009 & 0,129 \\
\hline & SEE & 0,169 & 0,177 & 0,091 \\
\hline & Beta & - & $1,89 \%$ & - \\
\hline & Half-life & - & 36,65 & - \\
\hline \multirow{6}{*}{ 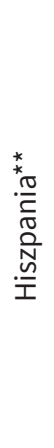 } & $\begin{array}{l}\text { Wyraz wolny } \\
\text { (p-value) }\end{array}$ & $\begin{array}{c}0,042 \\
(0,526)\end{array}$ & $\begin{array}{l}-0,355 \\
(0,000)\end{array}$ & $\begin{array}{r}0,368 \\
(0,000)\end{array}$ \\
\hline & $\begin{array}{l}\text { Parametr b } \\
\text { (p-value) }\end{array}$ & $\begin{array}{l}-0,089 \\
(0,599)\end{array}$ & $\begin{array}{l}-0,175 \\
(0,221)\end{array}$ & $\begin{array}{c}0,017 \\
(0,907)\end{array}$ \\
\hline & $R^{2}$ & 0,018 & 0,092 & 0,001 \\
\hline & SEE & 0,154 & 0,128 & 0,129 \\
\hline & Beta & $0,27 \%$ & $7,31 \%$ & - \\
\hline & Half-life & 258,47 & 9,48 & - \\
\hline \multirow{6}{*}{ 号 } & $\begin{array}{l}\text { Wyraz wolny } \\
\text { (p-value) }\end{array}$ & $\begin{array}{l}-0,687 \\
(0,000)\end{array}$ & $\begin{array}{l}-0,285 \\
(0,000)\end{array}$ & $\begin{array}{l}-0,135 \\
(0,009)\end{array}$ \\
\hline & $\begin{array}{l}\text { Parametr b } \\
\text { (p-value) }\end{array}$ & $\begin{array}{c}0,251 \\
(0,017)\end{array}$ & $\begin{array}{l}-0,394 \\
(0,000)\end{array}$ & $\begin{array}{c}0,694 \\
(0,009)\end{array}$ \\
\hline & $R^{2}$ & 0,488 & 0,787 & 0,554 \\
\hline & SEE & 0,060 & 0,048 & 0,103 \\
\hline & Beta & - & $7,15 \%$ & - \\
\hline & Half-life & - & 9,70 & - \\
\hline
\end{tabular}

Objaśnienia:

* Dane za lata 2003-2017; ${ }^{\star \star}$ dane za lata 2001-2017.

Źródto: opracowanie własne.

Wyraźny spadek zróżnicowania wskaźników siły nabywczej gospodarstw odnotowano dla rynków regionalnych z potwierdzoną uprzednio konwergencją typu beta (Bułgaria i Holandia). Należy ponadto zaznaczyć, iż najsilniejszą dynamiką spadkową w tym zakresie charakteryzowały się lata przedkryzysowe 2000-2007 (por. rys. 5.9 oraz tab. 5.13). 

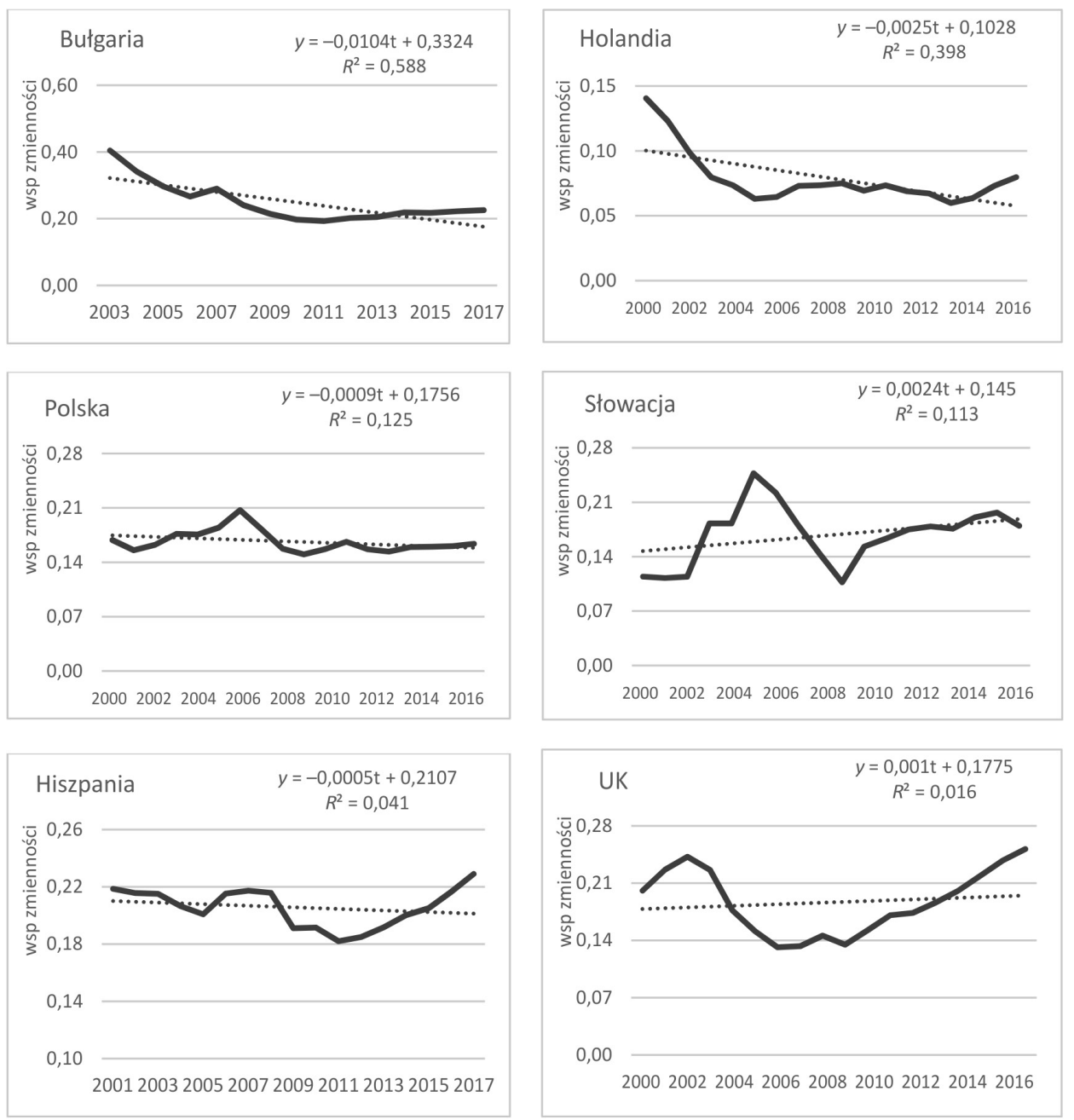

Rysunek 5.9. Identyfikacja sigma konwergencji dla wskaźnika siły nabywczej gospodarstw domowych Źródło: opracowanie własne

Pomimo zauważalnych zmian w sile nabywczej gospodarstw w przyjętym horyzoncie, spowodowanych w głównej mierze fluktuacjami cen na rynkach regionalnych, gamma konwergencja zasadniczo nie występowała. Wyjątkiem są okresowe spadki współczynników konkordancji rang poniżej ich wartości krytycznych w Holandii oraz Słowacji (por. rys. 5.10 oraz tab. 5.14). 
Tabela 5.13. Wyniki estymacji sigma konwergencji dla wskaźnika siły nabywczej gospodarstw domowych

\begin{tabular}{|c|c|c|c|c|}
\hline \multirow{2}{*}{ Gospodarka } & \multicolumn{4}{|c|}{ Wyniki estymacji KMNK } \\
\hline & & $2000-2017$ & $2000-2007$ & 2008-2017 \\
\hline \multirow{4}{*}{ 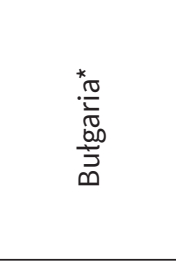 } & $\begin{array}{l}\text { Wyraz wolny } \\
\text { (p-value) }\end{array}$ & $\begin{array}{l}0,3324 \\
(0,000)\end{array}$ & $\begin{array}{l}0,4113 \\
(0,007)\end{array}$ & $\begin{array}{l}0,2104 \\
(0,000)\end{array}$ \\
\hline & $\begin{array}{l}\text { Parametr } \alpha_{1} \\
\text { (p-value) }\end{array}$ & $\begin{array}{c}-0,0104 \\
(0,001) \\
\end{array}$ & $\begin{array}{c}-0,0304 \\
(0,049) \\
\end{array}$ & $\begin{array}{l}0,0006 \\
(0,734) \\
\end{array}$ \\
\hline & $R^{2}$ & 0,588 & 0,774 & 0,015 \\
\hline & SEE & 0,0404 & 0,0300 & 0,015 \\
\hline \multirow{4}{*}{$\begin{array}{l}\frac{.00}{0} \\
\frac{0}{0} \\
\frac{0}{0} \\
\text { 우 }\end{array}$} & $\begin{array}{l}\text { Wyraz wolny } \\
\text { (p-value) }\end{array}$ & $\begin{array}{l}0,1028 \\
(0,000)\end{array}$ & $\begin{array}{l}0,1366 \\
(0,000)\end{array}$ & $\begin{array}{l}0,0713 \\
(0,000)\end{array}$ \\
\hline & $\begin{array}{l}\text { Parametr } \alpha_{1} \\
\text { (p-value) }\end{array}$ & $\begin{array}{c}-0,0025 \\
(0,005) \\
\end{array}$ & $\begin{array}{c}-0,0105 \\
(0,003) \\
\end{array}$ & $\begin{array}{c}-0,00017 \\
(0,809) \\
\end{array}$ \\
\hline & $R^{2}$ & 0,398 & 0,797 & 0,008 \\
\hline & SEE & 0,0170 & 0,0139 & 0,0062 \\
\hline \multirow{4}{*}{ 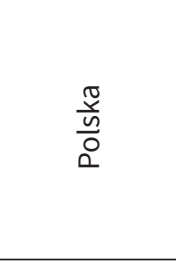 } & $\begin{array}{l}\text { Wyraz wolny } \\
\text { (p-value) }\end{array}$ & $\begin{array}{c}0,176 \\
(0,000)\end{array}$ & $\begin{array}{l}0,1542 \\
(0,000)\end{array}$ & $\begin{array}{l}0,1546 \\
(0,000)\end{array}$ \\
\hline & $\begin{array}{l}\text { Parametr } \alpha_{1} \\
\text { (p-value) }\end{array}$ & $\begin{array}{c}-0,0009 \\
(0,150) \\
\end{array}$ & $\begin{array}{l}0,0050 \\
(0,022) \\
\end{array}$ & $\begin{array}{l}0,0007 \\
(0,163) \\
\end{array}$ \\
\hline & $R^{2}$ & 0,125 & 0,608 & 0,228 \\
\hline & SEE & 0,0136 & 0,0106 & 0,0043 \\
\hline \multirow{4}{*}{$\begin{array}{l}\frac{\pi}{\tilde{N}} \\
\sum_{0}^{0} \\
\frac{0}{v}\end{array}$} & $\begin{array}{l}\text { Wyraz wolny } \\
\text { (p-value) }\end{array}$ & $\begin{array}{l}0,1449 \\
(0,000)\end{array}$ & $\begin{array}{l}0,0939 \\
(0,012)\end{array}$ & $\begin{array}{l}0,1269 \\
(0,000)\end{array}$ \\
\hline & $\begin{array}{l}\text { Parametr } \alpha_{1} \\
\text { (p-value) }\end{array}$ & $\begin{array}{l}0,0024 \\
(0,172)\end{array}$ & $\begin{array}{l}0,0168 \\
(0,017)\end{array}$ & $\begin{array}{l}0,0072 \\
(0,003)\end{array}$ \\
\hline & $R^{2}$ & 0,113 & 0,638 & 0,682 \\
\hline & SEE & 0,0372 & 0,0336 & 0,0158 \\
\hline \multirow{4}{*}{ 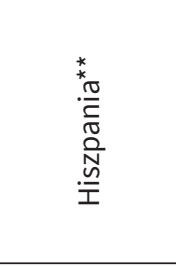 } & $\begin{array}{l}\text { Wyraz wolny } \\
\text { (p-value) }\end{array}$ & $\begin{array}{l}0,2107 \\
(0,000)\end{array}$ & $\begin{array}{l}0,2154 \\
(0,000)\end{array}$ & $\begin{array}{l}0,1866 \\
(0,000)\end{array}$ \\
\hline & $\begin{array}{l}\text { Parametr } \alpha_{1} \\
\text { (p-value) }\end{array}$ & $\begin{array}{c}-0,0006 \\
(0,435)\end{array}$ & $\begin{array}{c}-0,0007 \\
(0,634) \\
\end{array}$ & $\begin{array}{l}0,0026 \\
(0,135)\end{array}$ \\
\hline & $R^{2}$ & 0,041 & 0,049 & 0,256 \\
\hline & SEE & 0,0138 & 0,0069 & 0,0141 \\
\hline \multirow{4}{*}{ 产 } & $\begin{array}{l}\text { Wyraz wolny } \\
\text { (p-value) }\end{array}$ & $\begin{array}{l}0,1775 \\
(0,000)\end{array}$ & $\begin{array}{l}0,2542 \\
(0,000)\end{array}$ & $\begin{array}{l}0,1169 \\
(0,000)\end{array}$ \\
\hline & $\begin{array}{l}\text { Parametr } \alpha_{1} \\
\text { (p-value) }\end{array}$ & $\begin{array}{c}0,00096 \\
(0,614) \\
\end{array}$ & $\begin{array}{c}-0,0152 \\
(0,009) \\
\end{array}$ & $\begin{array}{l}0,0128 \\
(0,000) \\
\end{array}$ \\
\hline & $R^{2}$ & 0,016 & 0,703 & 0,960 \\
\hline & SEE & 0,0413 & 0,0261 & 0,0084 \\
\hline
\end{tabular}

Objaśnienia:

* Dane za lata 2003-2017; ** dane za lata 2001-2017.

Źródto: opracowanie własne. 

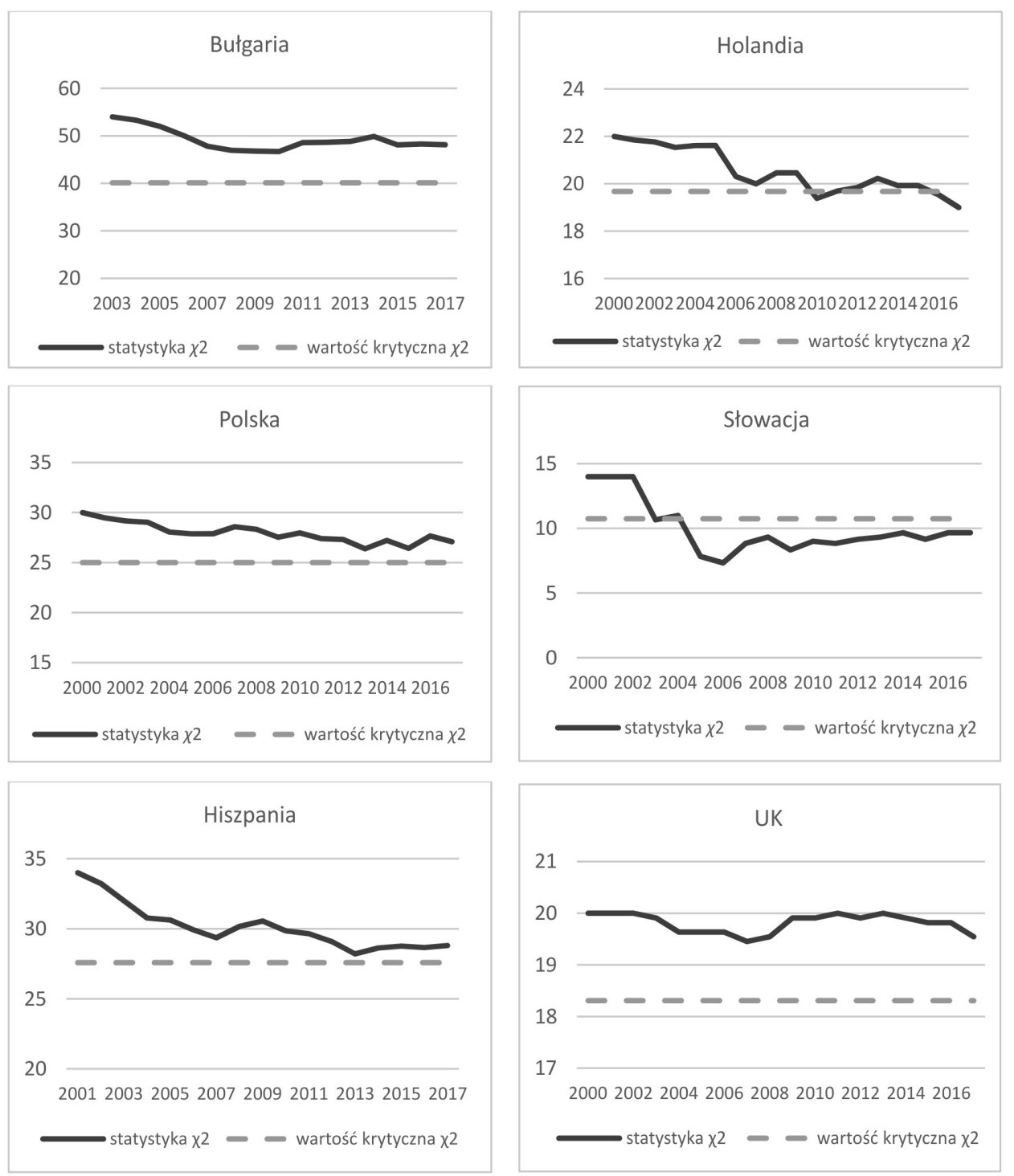

Rysunek 5.10. Identyfikacja gamma konwergencji dla wskaźnika siły nabywczej gospodarstw domowych Źródło: opracowanie własne 


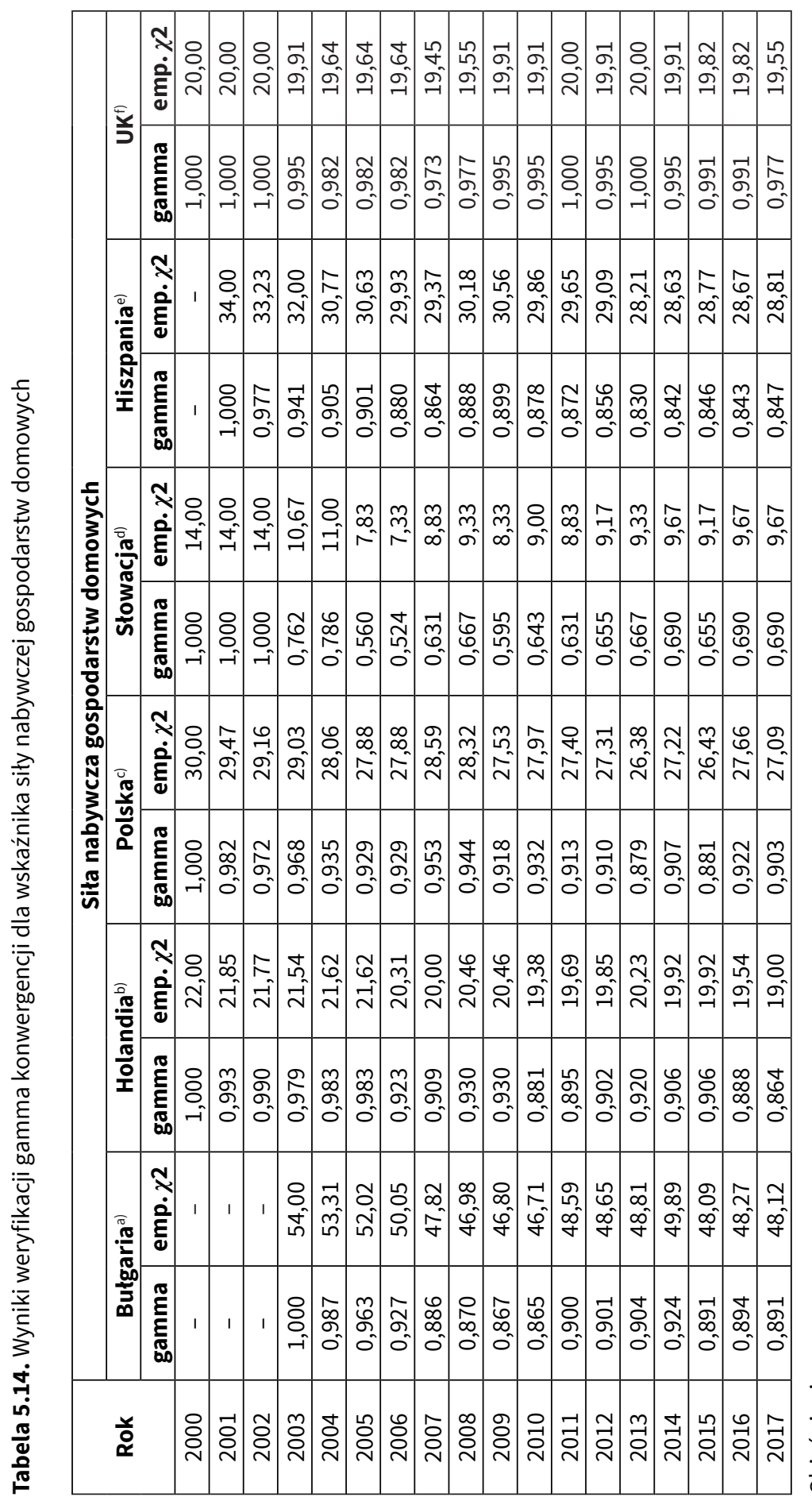

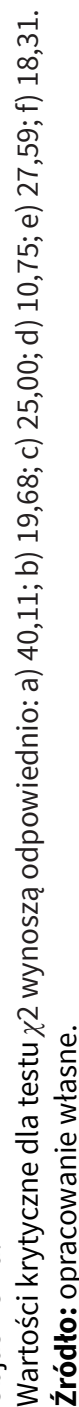




\subsubsection{Wnioski}

Wyniki zrealizowanych badań potwierdziły zachodzenie beta i sigma konwergencji w ramach rynków krajowych. Jej tempo było jednak zmienne w czasie. Silniejsze tendencje do ujednolicania rynków mieszkaniowych występowały w fazie wzrostowej cyklu koniunkturalnego (lata 2000-2007), zdecydowanie słabsze natomiast w latach następujących po globalnym kryzysie gospodarczym (2008-2017). Gamma konwergencji w większości uwzględnionych wskaźników nie zdiagnozowano. Przeprowadzone testy nie potwierdziły konwergencji cenowej w grupie wszystkich badanych krajów, natomiast zidentyfikowano konwergencję klubową.

Rynki regionalne prezentują odmienny obraz zmian. W odniesieniu do regionalnych zasobów mieszkaniowych zidentyfikowana została beta oraz sigma dywergencja. Oznacza to, iż regiony o relatywnie większym zasobie mieszkaniowym nadal pozostawały atrakcyjne inwestycyjnie dla podmiotów realizujących nowe przedsięwzięcia mieszkaniowe. Regionalne różnice w skali budownictwa mieszkaniowego miały swoje przełożenie na rosnące wraz z czasem zróżnicowanie rynków w zakresie ich zasobów mieszkaniowych. Zmiany siły nabywczej gospodarstw pomiędzy rynkami regionalnymi nie miały jednokierunkowego charakteru. Spadek zróżnicowania rynków mieszkaniowych $\mathrm{w}$ tym zakresie obserwowany był przede wszystkim w latach ekspansji cen nieruchomości mieszkaniowych (lata 2003-2008). W pozostałych latach konwergencja była słaba bądź nie występowała. Podobnie jak miało to miejsce $\mathrm{w}$ analizie międzynarodowej, rynki regionalne doświadczały konwergencji cenowej jedynie o charakterze klubowym.

Analiza zmian zachodzących na krajowych i regionalnych rynkach mieszkaniowych pozwoliła wskazać również charakterystyczne tendencje. Zachodzenie konwergencji $\mathrm{w}$ wymiarze międzynarodowym nie zawsze jest zbieżne $\mathrm{z}$ konwergencją $\mathrm{w}$ ujęciu regionalnym. W pewnych obszarach doganianie zachodnioeuropejskich standardów mieszkaniowych przez nowe kraje członkowskie UE następuje poprzez pogłębianie różnic między regionami (dywergencja regionalna). Ponadto wraz ze zmniejszaniem się dystansu między rynkami mieszkaniowymi spada dynamika procesów konwergencji. 

Część 3

Ocena przebiegu konwergencji mieszkaniowej i jej efektów 



\section{Rozdział 6}

\section{Konwergencja europejskich rynków mieszkaniowych na tle konwergencji gospodarczej krajów członkowskich UE}

\subsection{Proces integracji gospodarek europejskich}

Ciekawe spojrzenie na procesy konwergencji gospodarczej dostarczają dane uzyskiwane $\mathrm{w}$ ramach projektu Maddisona ${ }^{1}$. $\mathrm{Z}$ analizy tych danych wynika, że na przestrzeni ostatnich kilkuset lat $\mathrm{w}$ skali świata dominował proces zwiększania dystansu pomiędzy krajem o najwyższym i najniższym PKB per capita (por. Kusideł [2013, s. 137]). Dywergencję gospodarczą w skali świata potwierdzają prace Barro [1997, s. 318] (gdzie przeprowadzono analizę dla 98 krajów świata w latach 1960-1985), prace Kusideł [2013, s. 139] (analiza dla 54 krajów świata w latach 19502010) czy raport OECD [Cingano 2014], gdzie stwierdzono, że nierówności wewnątrz krajów OECD są największe od lat 80. (analiza dla krajów OECD w latach 1985-2005)². Najnowsze dane pokazują jednak, że zróżnicowanie GDP od pewnego czasu spada - por. rys. 6.1.

W literaturze można spotkać pogląd, że proces doganiania bogatszych krajów przez biedniejsze między państwami zachodnioeuropejskimi trwa już od końca XIX w. ${ }^{3}$, choć tempo konwergencji w ciągu ostatnich 20 lat utrzymywało się na stosunkowo niskim poziomie - poniżej $2 \%$ rocznie ${ }^{4}$.

1 https://www.rug.nl/ggdc/historicaldevelopment/maddison

2 W raporcie tym stwierdzono dodatkowo ujemny wpływ wzrostu nierówności dochodowych na wzrost gospodarczy.

3 Według M. Ferry'ego [2008, s. 32] proces ten zatrzymat się podczas drugiej wojny światowej, w latach 70. oraz w latach 1982-1986.

4 Jest to wynik uzyskiwany przez wielu badaczy, w szczególności w pracach Sala-i-Martina, choć są opinie, że rezultat ten jest statystycznym „artefaktem” - por. Monfort [2008, s. 4]. Po raz pierwszy argument ten (tzn. nieprawdziwości 2\% tempa zbieżności) przywołał Quach 
172 Ocena przebiegu konwergencji mieszkaniowej i jej efektów

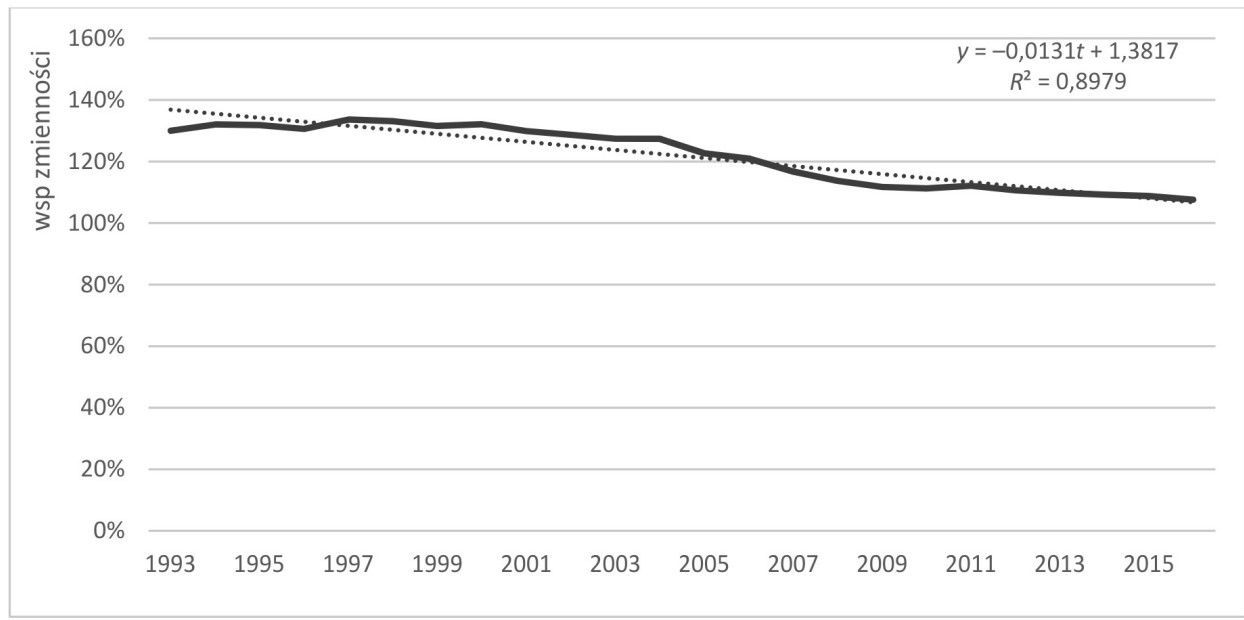

Rysunek 6.1. Współczynnik zmienności dla PKB per capita (w dolarach amerykańskich, ceny state z 2011 r.) dla 169 gospodarek świata

Źródło: opracowanie własne na podstawie danych Maddison Project Database (MPD) 2018

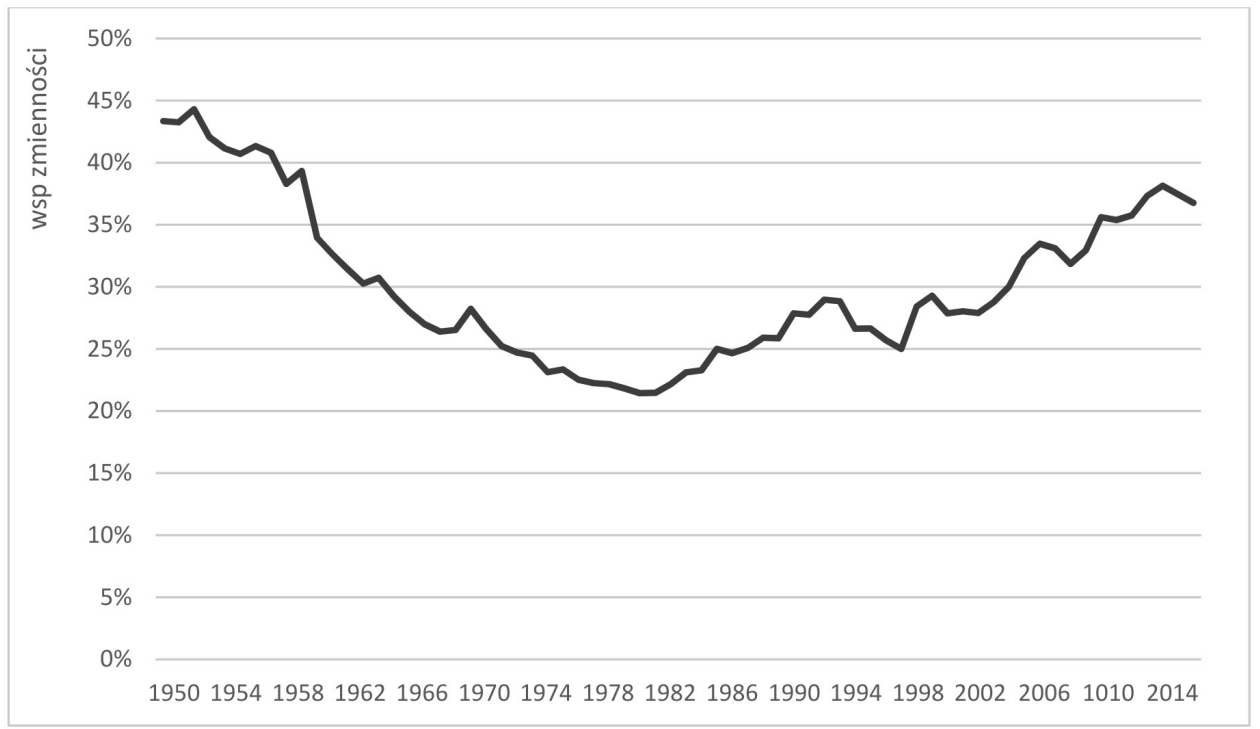

Rysunek 6.2. Zróżnicowanie (mierzone współczynnikiem zmienności) PKB pomiędzy 15 krajami UE

Źródło: opracowanie własne na podstawie danych Maddison Project Database (MPD) 2018 
Analiza rocznych danych o gospodarkach europejskich potwierdza ten pogląd - od 1950 r. (od którego są znane roczne dane o PKB) gospodarki zachodnioeuropejskie o początkowo niskim poziomie dochodu wykazywały wyższe tempo wzrostu gospodarczego. Proces integracji gospodarczej gospodarek zachodnioeuropejskich zatrzymał się w latach 80 . XX w. - por. rys. 6.2.

\subsection{Konwergencja gospodarcza krajów członkowskich UE}

\subsubsection{Polityka spójności jako odpowiedź na rosnące nierówności gospodarcze w UE}

5 marca 1957 r. w Rzymie odbyła się konferencja międzyrządowa w sprawie wspólnego rynku i Euroatomu rozpoczynająca historię Unii Europejskiej (choć pod tą nazwą Unia funkcjonuje dopiero od początku lat $\left.90 .^{6}\right)$. Na konferencji tej podpisano Traktat ustanawiający Europejską Wspólnotę Gospodarczą ${ }^{7}$ - EWG. Traktat Rzymski, bo o nim mowa, sygnowany został przez przedstawicieli 6 krajów: Belgii, Francji, Holandii, Luksemburga, Republiki Federalnej Niemiec (RFN) oraz Włoch ${ }^{8}$. Zadaniem EWG było utworzenie wspólnego rynku oraz stopniowe ujednolicanie polityki gospodarczej państw będących członkami Wspólnoty, ciągłej oraz zrównoważonej ekspansji, stabilizacji, podwyższania poziomu życia, jak

[1996], który sugerował, że stosunkowo stała szybkość konwergencji może być manifestacją znanego w małych próbach obciążenia dla procesów zawierających pierwiastek jednostkowy. We wspomnianym artykule Quach wygenerował niezależne procesy pierwiastka jednostkowego i zastosował do nich test beta konwergencji. W próbach podobnych do Sala-i-Martina otrzymał podobne, dwuprocentowe tempo zbieżności. Sala-i-Martin [1996b, s. 1340-1341] odpiera ten zarzut, dowodząc wiarygodności swoich wyliczeń.

5 Por. Kusidet [2013, s. 146-147].

6 Traktat o Unii Europejskiej, ustanawiający nową nazwę dla Wspólnoty Europejskiej, został przyjęty na spotkaniu 9-10 grudnia $1991 \mathrm{r}$. w Maastricht (stąd jego inna nazwa: traktat z Maastricht). Ostatecznie traktat został podpisany 7 lutego 1992 r., a wszedł w życie 1 stycznia 1993 r. - stąd różne daty w źródłach informujących o oficjalnej zmianie nazwy Wspólnoty Europejskiej na Unię Europejską.

$7 \quad$ Z nazwy tej wykreślono później przymiotnik gospodarczą, zmieniając nazwę dokumentu na „Traktat o ustanowieniu Wspólnoty Europejskiej”. Drugą umową wieńczącą wspomnianą konferencję był Traktat ustanawiający Europejską Wspólnotę Energii Atomowej (Euroatom). Obydwa traktaty noszą nazwę rzymskich, a ich tekst w języku polskim można znaleźć np. na: http://polskawue.gov.pl/files/polska_w_ue/prawo/traktaty/Traktaty_rzymskie.pdf

8 A dokładnie podpisy złożyli reprezentanci Rządu Królestwa Belgii, RFN, Francji, Włoch oraz Wielkiego Księstwa Luksemburga i Królestwa Niderlandów. 
również ściślejszych stosunków między państwami członkowskimi ${ }^{9}$ Zagadnienie osiągania spójności ekonomicznej i społecznej w Europie - głównego postulatu dzisiejszej polityki spójności - miało wówczas postać wzmianki w preambule do Traktatu Rzymskiego [por. Rodrigues-Pose i Fratesi 2004, s. 5]. Od początku istnienia Wspólnoty zakładano, iż będzie ona poszerzała się o kolejne państwa (choć początkowo kraje tzw. szóstki niechętnie przychylały się do wniosków akcesyjnych, niemniej rozszerzenia stały się faktem). W wyniku pierwszego rozszerzenia w $1973 \mathrm{r}$. do Wspólnoty przyjęto Wielką Brytanię, Danię oraz Irlandię. 1 stycznia 1981 r. przyłączono Grecję, zaś 5 lat później, w 1986 r. - Hiszpanię i Portugalię. Czwarte rozszerzenie w 1995 r. dotyczyło Austrii, Finlandii i Szwecji. Dotychczasowe rozszerzenia Unii ${ }^{10}$ miały formalnie miejsce $\mathrm{w}$ pierwszym dniu danego roku, dlatego data największego rozszerzenia - z 1 maja 2004 r. - aż o 10 nowych krajów była pewnym wyjątkiem. Kolejne rozszerzenie Wspólnoty miało miejsce 1 stycznia 2007 r., kiedy to przyjęto Bułgarię oraz Rumunię i ostatnie w 2013 r., kiedy to Unia poszerzyła się o Chorwację i od kiedy możemy mówić o UE28.

Początkowo (tzn. do początku lat 80.) polityka rozwoju regionów nie zajmowała wiele miejsca w politykach Wspólnoty (w 1980 r. przeznaczano na nią zaledwie $11 \%$ całości budżetu). Należy jednakże zauważyć, że do tego czasu rozbieżności w poziomie dochodu poszczególnych krajów tworzących Wspólnotę nie stanowiły problemu, bowiem nie tylko nie narastały, lecz malały - por. rys. 6.2. Widoczny na tym wykresie rosnący trend od lat 80 . we współczynniku mierzącym nierówności w dochodzie per capita krajów Wspólnoty Europejskiej, jak i wzrost poziomu tego współczynnika po kolejnych rozszerzeniach (por. rys. 6.3) stworzyły potrzebę działań skierowanych na przygotowanie słabiej rozwiniętych państw i regionów do spełnienia warunków członkostwa. W tym celu w 1989 r. dokonano zarówno reformy funduszy strukturalnych polegającej na przebudowie zasad ich przydzielania, jak i przeznaczanego na nie budżetu (którego udział wzrósł dwukrotnie na przestrzeni zaledwie kilku lat: 1988-1992). Ostatecznie, wynikiem reformy było skoordynowanie działań finansowanych w ramach trzech funduszy (EFRR, EFS, EFOiG) oraz utworzenie nowego Funduszu Spójności (w celu złagodzenia obciążeń krajów przystępujących do Unii Gospodarczej i Walutowej). Po przeprowadzaniu reformy ponad $2 / 3$ wydatków z funduszy strukturalnych skoncentrowanych było w tzw. regionach zaliczanych do celu 1, którego nazwy zmieniały się w różnych okresach programowania, lecz zawsze dotyczył on wyrównywania nierówności gospodarczych ${ }^{11}$. Kryterium kwalifikacji regionów do

9 Por. Łastawski [2006, s. 116-119] na podstawie Traktatu w sprawie utworzenia Europejskiej Wspólnoty Gospodarczej.

10 W których pominięto niepełne rozszerzenia, jak np. o wschodnie Niemcy z 3 października $1990 \mathrm{r}$.

11 W latach 1988-1993 cel 1 polityki spójności miał nazwę „wspieranie rozwoju i dostosowanie strukturalne regionów słabo rozwiniętych (zacofanych)”, w latach 1994-1999: „rozwój i strukturalne dostosowanie regionów zacofanych”, w latach 2000-2006: „wsparcie regionów 
objęcia funduszami przeznaczanymi na realizację celu 1, to regiony, których PKB per capita mierzone według parytetu siły nabywczej nie przekracza $75 \%$ średniej unijnej. Taka koncentracja środków oznaczała istotny zastrzyk funduszy dla krajów objętych tych celem. Liczba regionów celu $1 \mathrm{w}$ kolejnych okresach programowania rosła; w 1989 r. należały do niego 44 regiony (wszystkie regiony Grecji, Portugalii i Irlandii, południe Włoch, południowo-zachodnie regiony Hiszpanii, a po zjednoczeniu Niemiec landy byłej NRD i wschodni Berlin), zaś w okresie programowania 2000-2006 było to już 167 regionów [por. Rodrigues, Fratesi 2004, s. 8]. Z rys. 6.3. wynika, że od roku 2004 r. polityka regionalna UE stanęła przed największym wyzwaniem od początku funkcjonowania. Przyjęcie 10 nowych krajów odwróciło rosnący od lat 80. trend w nierównościach dochodowych w UE, lecz kosztem wzrostu ich poziomu.

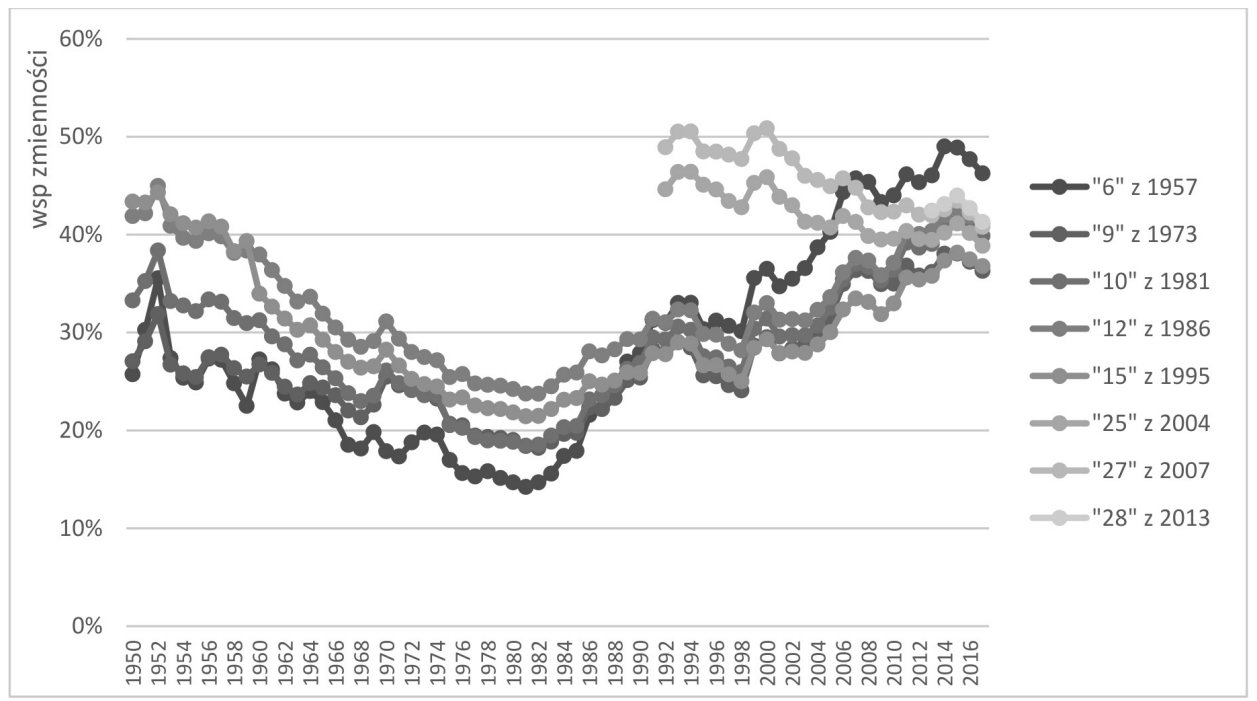

Rysunek 6.3. Zróżnicowanie (mierzone współczynnikiem zmienności) PKB per capita pomiędzy krajami tworzącymi Wspólnotę Europejską w różnych momentach jej istnienia Źródto: opracowanie własne na podstawie danych Ameco (od 1960) i Penn World Table (lata 1950-1959)

Po głębokiej recesji z roku 2008 i potem 2011 gospodarki krajów UE ponownie rosną. Kryzys głęboko odczuły prawie wszystkie kraje członkowskie, co zmieniło długookresowy trend w redukcji nierówności pomiędzy PKB per capita krajów członkowskich. Od kilku ostatnich lat nierówności ponownie maleją, przy obserwowanym wszędzie wzroście gospodarczym [My Region, My Europe, Our Future 2017].

zapóźnionych w rozwoju", a w ostatnim okresie programowania 2007-2013 cel 1 nosi nazwę „konwergencja”. 


\subsubsection{Beta konwergencja gospodarcza wśród krajów UE}

\section{Beta konwergencja dla danych przekrojowych}

Zgodnie z metodologią zaproponowaną w podrozdziale 4.2.1 w pierwszej kolejności oszacowano model beta konwergencji bezwarunkowej dla danych przekrojowych postaci (4.1). Wyniki są następujące ${ }^{12}$ :

$$
\frac{1}{17} \ln \left(\frac{G D P_{-} p c_{i, 2017}}{G D P_{-} p c_{i, 2000}}\right)=0,293^{* * *}-0,027^{* * *} \ln \left(G D P_{-} p c_{i, 2000}\right), R^{2}=0,69
$$

Z powyższego równania, na podstawie wzoru (4.2) można odczytać roczne tempo konwergencji, które wynosi $\beta=2,7 \%$. Dodatkowo na podstawie wzoru (4.4) wyliczono half-life, który wynosi $h l \sim 26$ lat.

Na podstawie powyższego modelu beta konwergencji bezwarunkowej dla danych przekrojowych można zatem powiedzieć, że na przestrzeni lat 2000-2017 wśród gospodarek krajów UE28 obserwowano konwergencję PKB per capita, której tempo zbieżności wynosiło $2,7 \%$ rocznie, co daje podstawę przypuszczać, że dzisiejsze różnice pomiędzy $\mathrm{PKB}$ per capita zmniejszą się o połowę na przestrzeni najbliższych 26 lat.

Jak już wcześniej pisano, wadą modeli beta konwergencji dla danych przekrojowych jest fakt, że poza skrajnymi okresami analizy pomija ona pozostałe lata. Tymczasem dobór pierwszego i ostatniego roku badania może czasami radykalnie wpłynąć na jego wyniki. Aby to zbadać, w poniższej tabeli podano oszacowania tempa konwergencji dla modelu postaci (4.1), gdzie zmienny był początkowy rok analizy.

Tabela 6.1. Roczne tempo konwergencji PKB per capita krajów UE28 (oszacowane na podstawie modelu postaci 4.1) w zależności od początkowego roku analizy

\begin{tabular}{|c|c|}
\hline Skrajne lata analizy & $\begin{array}{c}\text { Współczynnik beta (roczne } \\
\text { tempo konwergencji) } \\
\text { w \% }\end{array}$ \\
\hline 1 & 2 \\
\hline $2000-2017$ & 2,71 \\
\hline $2001-2017$ & 2,72 \\
\hline $2002-2017$ & 2,73 \\
\hline $2003-2017$ & 2,64 \\
\hline
\end{tabular}

12 Dla modelu tego stwierdzono brak zależności pomiędzy składnikiem resztowym i zmienną objaśniającą, można zatem założyć, że współczynnik kierunkowy nie jest obciążony. 


\begin{tabular}{|c|c|}
\hline 1 & 2 \\
\hline $2004-2017$ & 2,60 \\
\hline $2005-2017$ & 2,50 \\
\hline $2006-2017$ & 2,48 \\
\hline $2007-2017$ & 2,19 \\
\hline $2008-2017$ & 1,79 \\
\hline $2009-2017$ & 2,17 \\
\hline $2010-2017$ & 2,04 \\
\hline
\end{tabular}

Źródło: oszacowania własne.

Z powyższej tabeli wynika, że co prawda dobór początkowego roku analizy ma wpływ na tempo konwergencji, lecz nie zmienia wniosku co do występowania beta konwergencji PKB per capita wśród krajów Unii Europejskiej. Z najsilniejszą konwergencją mamy do czynienia w latach 2002-2017 (kiedy to roczne tempo zbieżności gospodarek wyniosło 2,73\%), zaś z najsłabszą w latach 2008-2017 (z rocznym tempem konwergencji rzędu 1,79\%). Należy zauważyć, że rok 2008 to czas, w którym zaczęto obserwować w Europie skutki kryzysu finansowego, co miało swoje odzwierciedlenie w bardzo słabym wzroście GDP krajów UE (lecz dopiero w roku 2009 większość gospodarek odczuło regres).

\section{Beta konwergencja dla danych panelowych}

Poniżej oszacowano panelowe modele beta konwergencji absolutnej realnego PKB per capita dla 28 krajów UE i lat 2000-2017. Oszacowanie modelu postaci (4.8) bez efektów specyficznych dla poszczególnych krajów i lat (tzw. pooled regression) można zapisać następująco:

$$
\begin{gathered}
\ln \left(\frac{G D P_{-} p c_{i t}}{G D P_{-} p c_{i t-1}}\right)=0,425^{* * *}-0,039^{* * *} \ln \left(G D P_{-} p c_{i t-1}\right) \\
i=1, \ldots, 28 ; t=2000, \ldots, 2017 .
\end{gathered}
$$

Analogiczne modele FEM (a) i REM (b) mają odpowiednio postać:

$$
\begin{gathered}
\ln \left(\frac{G D P_{-} p c_{i t}}{G D P_{-} p c_{i t-1}}\right)=0,819^{* * *}-0,079^{* * *} \ln \left(G D P_{-} p c_{i t-1}\right), \\
i=1, \ldots, 28 ; t=2000, \ldots, 2017
\end{gathered}
$$




$$
\begin{gathered}
\ln \left(\frac{G D P_{-} p c_{i t}}{G D P_{-} p c_{i t-1}}\right)=0,462^{* * *}-0,043^{* * *} \ln \left(G D P_{-} p c_{i t-1}\right) \\
i=1, \ldots, 28 ; t=2000, \ldots, 2017
\end{gathered}
$$

We wszystkich trzech powyższych regresjach wartości estymatorów parametru przy $\ln \left(G D P_{-} p c_{i t-1}\right)$ są ujemne i istotne statystycznie, co wskazuje na konwergencję PKB per capita. Jednak tempo konwergencji wyliczone na podstawie wzoru (4.3) jest dość silnie zróżnicowane: od 3,9 do 8,2\% rocznie. Powyższe wyniki potwierdzają tezy przywołane w rozdziale czwartym, że wyniki analizy konwergencji z wykorzystaniem danych panelowych wskazują na znacznie wyższe tempa zbieżności niż w przypadku danych przekrojowych. Przypomnijmy, że na podstawie modelu przekrojowego otrzymano roczną wartość zbieżności rzędu $2,7 \%$, tymczasem w modelach panelowych minimalny wynik to $3,9 \%$ (maksymalny $8,2 \%$ rocznie).

\subsubsection{Relatywna konwergencja}

Jak pisaliśmy w punkcie 4.2.3 proponowane tam podejście jest właściwe, jeśli w danych występuje wspólny trend. W przypadku krajów UE28 takim komponentem jest średnia, która wykazuje silny, deterministyczny, rosnący trend, który wskazuje, że PKB krajów UE28 rosło w latach 2000-2017 o średnio 641 euro per capita - por. rys. 6.4 .

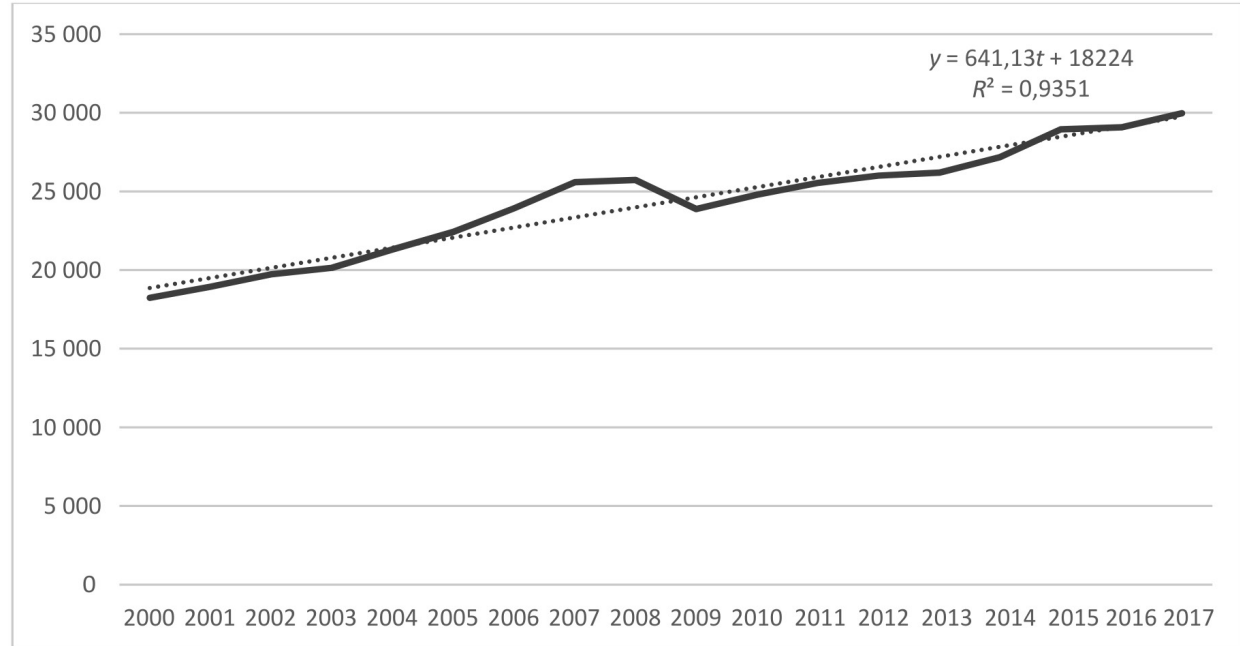

Rysunek 6.4. Średnie PKB per capita dla 28 krajów UE

Źródło: opracowanie własne na podstawie danych Eurostat 
Po zlogarytmowaniu wszystkich zmiennych i zastosowaniu formuły (4.21) i (4.22) sprawdzono, czy wartości wariancji przekrojowej $H_{t}$ dążą do 0, zaś ścieżki zmian wartości PKB w poszczególnych krajach $-h_{i t}$ - do wartości $1^{13}$ (jak już pisaliśmy w punkcie 4.2.3 w długim okresie w warunkach konwergencji $H_{t} \rightarrow 0$ oraz $\left.h_{i t} \rightarrow 1\right)$. Jak pokazuje rys. 6.5, o ile wariancja dla całej UE28 dąży do 0 , to dzieje się to za sprawą spadającej wariancji państw, które dołączyły do UE po 2004 r. (jak widać bowiem, wśród krajów „starej” unii brak jest zjawiska malejącej wariancji).

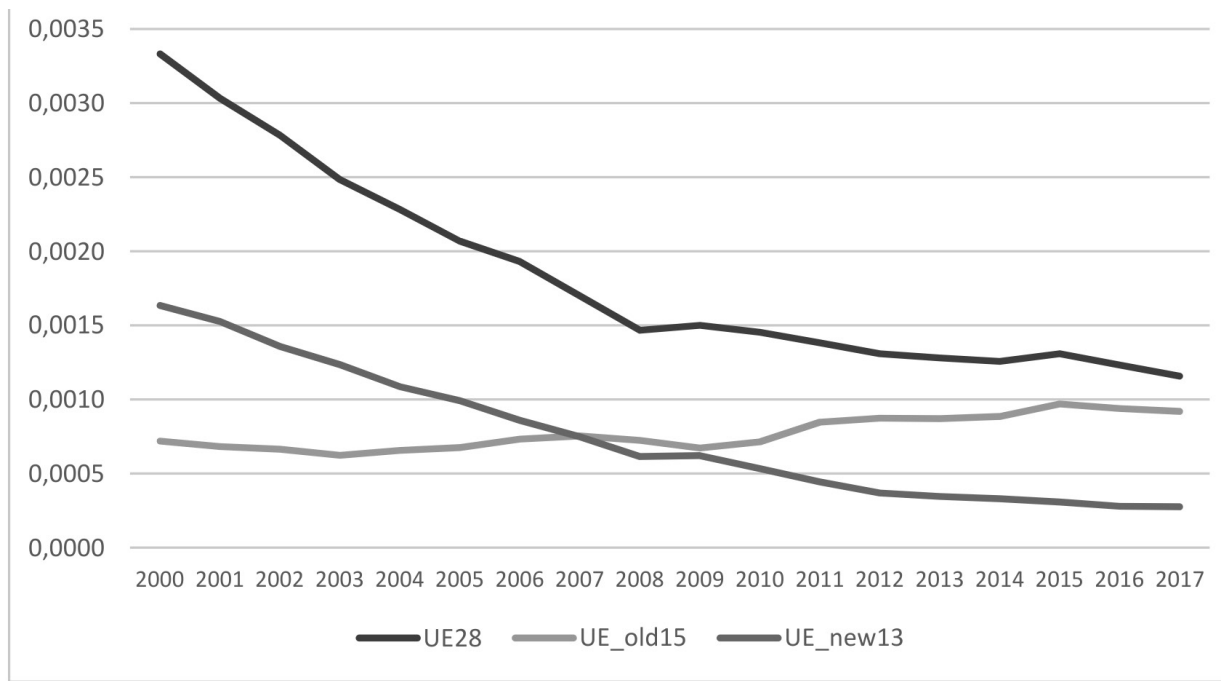

Rysunek 6.5. Przekrojowa wariancja Ht dla PKB per capita 28 państw UE wraz z podziałem na 15 ,starych” i 13 „nowych” państw Źródło: opracowanie własne na podstawie danych Eurostat

W celu zbadania relatywnej konwergencji zastosowano wzór (4.23) dla 2/3 próby z 18 rocznych informacji z lat 2000-2017. Wyniki są następujące:

$$
\log \left(\frac{H_{1}}{H_{t}}\right)-2 \log L(t)=1,128-2,00 * \log (t)
$$

Wartość statystyki t-studenta dla kluczowego w powyższej regresji parametru przy $\log (t)$ wynosi -1,68 i nieznacznie jest mniejsza od wartości krytycznej wynoszącej -1,65. Formalnie rzecz ujmując, należy odrzucić hipotezę o występowaniu relatywnej konwergencji (formalnie - bowiem współczynnik tylko nieznacznie przekracza wartość krytyczną).

13 Ścieżki wzrostu dla poszczególnych państw podzielono na te, które w 2000 r. charakteryzowały się PKB per capita powyżej średniej dla UE28 oraz te, które w 2000 r. charakteryzowały się PKB per capita poniżej średniej dla UE28. 
Brak występowania relatywnej konwergencji wśród wszystkich krajów UE28 nie wyklucza jej występowania w klubach krajów. Aby je wyróżnić nie stosowano jednak algorytmu zaproponowanego w punkcie 4.2.3, lecz przeanalizowano ścieżki wzrostu poszczególnych krajów po usunięciu z nich średniej. Okazało się, że większość krajów dąży do wspólnego punktu równowagi (średniej) albo startując z poziomów powyżej średniej PKB per capita dla UE28 (Belgia, Dania, Niemcy, Hiszpania, Francja, Włochy, Cypr, Malta, Holandia, Austria, Finlandia, Szwecja, Wielka Brytania), albo poniżej tej średniej (Bułgaria, Czechy, Estonia, Chorwacja, Łotwa, Litwa, Węgry, Polska, Rumunia, Słowenia, Słowacja).

Wspólną cechą wymienianych powyżej krajów jest, że dążą do osiągnięcia wartości średnich dla UE28 (albo od góry, albo od dołu). Od tendencji tej wyjątkiem są takie kraje, jak: Irlandia, Luksemburg, Grecja, Portugalia, Słowenia. Kraje te oddalają się od średniej UE28, choć z różnych powodów - Luksemburg i Irlandia osiągają coraz wyższe - w porównaniu do średniej UE - pułapy PKB per capita, natomiast Grecja, Portugalia i Słowenia - coraz niższe. To te właśnie kraje tworzą osobne kluby relatywnej konwergencji.

\subsubsection{Sigma konwergencja}

Zgodnie $\mathrm{z}$ uwagami z rozdziału czwartego, konwergencja typu beta jest warunkiem koniecznym do wystąpienia konwergencji sigma - w badaniach z podrozdziału 6.2.2 warunek ten jest spełniony dla grupy 28 krajów UE w okresie 2000-2017. Dlatego poniżej przeprowadzono analizę sigma konwergencji dla PKB per capita 28 krajów UE.

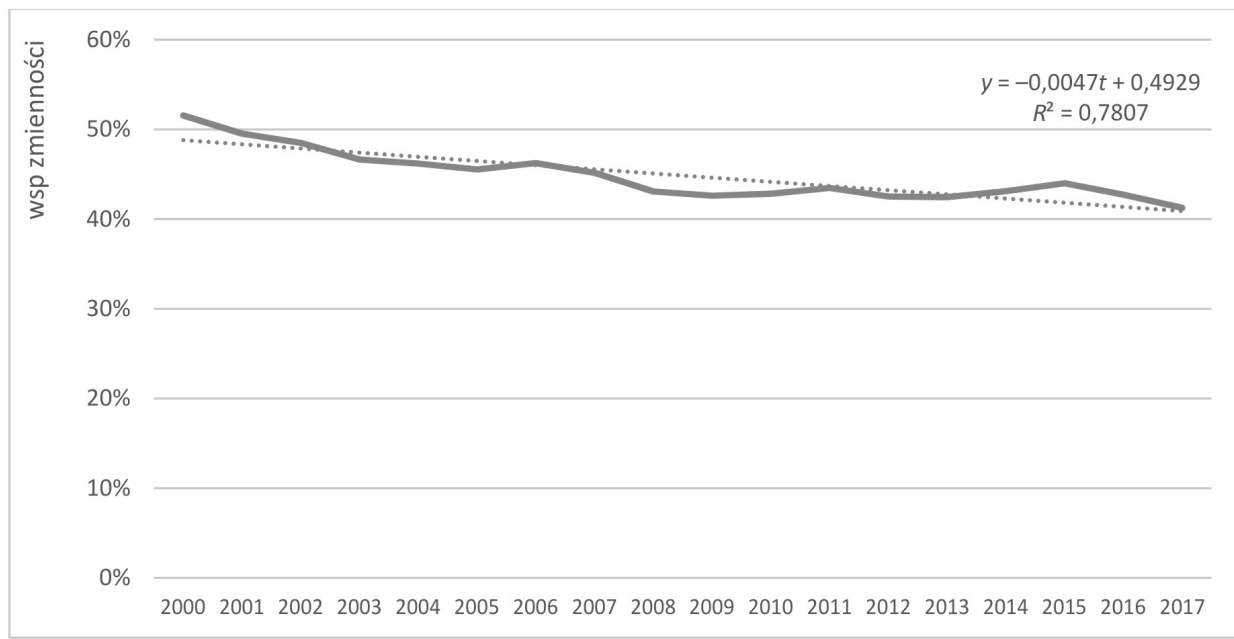

Rysunek 6.6. Sigma konwergencja (mierzona współczynnikiem zmienności) dla UE28 Źródło: opracowanie własne na podstawie danych Eurostat. 
Na rys. 6.6 znajduje się współczynnik zmienności dla PKB per capita policzony dla grupy 28 krajów UE. Wykres ten pokazuje, że zróżnicowanie PKB per capita spadało w całym analizowanym okresie, choć z różnym nasileniem. W szczególności w latach 2008-2015 tempo spadku uległo spowolnieniu.

\subsubsection{Wnioski}

Analiza rocznych danych o Unii Europejskiej pokazuje, że do początku lat 80 . XX w. gospodarki zachodnioeuropejskie zmniejszały dystans w PKB per capita. Proces ten uległ odwróceniu od lat 80 . XX w., od kiedy to zaobserwowano zwiększanie nierówności w poziomach rozwoju gospodarczego UE. Dopiero przyjęcie nowych członków do wspólnoty w 2004 r. odwróciło negatywny trend w nierównościach gospodarczych państw UE - choć kosztem wzrostu poziomu tych nierówności (por. rys. 6.3). Formalne badanie poziomu i trendu w nierównościach gospodarczych może odbywać się za pomocą różnych metod statystycznych (por. diagram z podrozdziału 4.1.2). Do najbardziej popularnych należą metody analizy beta i sigma konwergencji. W przeprowadzonych w tym rozdziale badaniach pokazano, że w latach 2000-2017 zachodził proces beta konwergencji (doganiania gospodarek o niższym poziomie rozwoju gospodarczego) z minimalnym rocznym tempem 2,7\% rocznie. Zmniejszanie nierówności dochodowych wśród krajów UE28 potwierdziły badania sigma konwergencji, które jednak dodatkowo pokazały, że proces wyrównywania PKB per capita wśród UE28 uległ zdecydowanemu osłabieniu w latach 2008-2015.

Ciekawych spostrzeżeń przyniosło badanie relatywnej konwergencji wśród krajów UE28. Ten sposób mierzenia nierówności mocno bierze pod uwagę wspólne trendy występujące wśród badanych obiektów. W przypadku PKB krajów UE jest to wspólny wzrost gospodarek tych krajów, przejawiający się we wzroście średniej wartości PKB UE28. Po wyeliminowaniu tego komponentu okazało się, że większość gospodarek UE15 dorównuje do średniej „od góry”, tzn. zmniejszając swoją relatywną różnicę w PKB do średniej UE28 poprzez mniejsze tempa wzrostu. Tymczasem większość gospodarek, które dołączyły do UE po 2004 r. dorównuje do średniej „od dołu”, tzn. zmniejszając swoją relatywną różnicę do średniej UE28 poprzez wyższe tempa wzrostu PKB. Wyjątkiem są gospodarki Luksemburga, Irlandii, Grecji, Portugali i Słowenii. Dwie pierwsze gospodarki odstają od UE dwupoziomowo: zarówno notują wyższy poziom PKB niż średnio w UE, jak i dodatkowo zwiększają ten dystans poprzez wyższe tempa wzrostu gospodarczego. Gospodarki Grecji, Portugalii i Słowenii niestety oddalają się od średniej UE28 - zanotowały niższy poziom PKB per capita w 2000 r., i dodatkowo oddalają się od niego poprzez niższe tempa wzrostu niż przeciętnie w UE28. 


\subsection{Konwergencja rynków mieszkaniowych na tle konwergencji gospodarczej}

Empirycznie potwierdzona tendencja do zmniejszania nierówności w poziomie rozwoju gospodarczego krajów członkowskich UE, jak również tendencja do spadku zróżnicowania europejskich rynków mieszkaniowych w zakresie przyjętych zmiennych diagnostycznych rodzi pytania o relację pomiędzy tymi procesami. Czy można zatem uznać, iż jednym ze źródeł konwergencji rynków mieszkaniowych jest zachodząca konwergencja gospodarcza, czy też szerzej postępująca intergracja krajów członkowskich UE, której przejawem jest konwergencja ekonomiczna? Oczywiście przyczyny i mechanizmy zmian zachodzących na europejskich rynkach mieszkaniowych mają złożony i wielowymiarowy charakter. Trudno je ująć w jedną spójną koncepcję teoretyczną. U ich podłoża leżą zarówno uwarunkowania ekonomiczne, lecz również polityczne, społeczne, kulturowe czy demograficzne. Ponadto na ścieżkę rozwoju rynków mieszkaniowych w poszczególnych krajach wpływ ma w znacznym stopniu historycznie ukształtowany ład instytucjonalny (poruszana $\mathrm{w}$ rozdziale pierwszym kwestia path dependence rynków nieruchomości).

O ile można w związku z tym stwierdzić, iż konwergencja gospodarcza krajów UE nie jest jedynym źródłem konwergencji mieszkaniowej, to jednak stwarza warunki sprzyjające jej zachodzeniu. Proces ten zauważyć można zwłaszcza pomiędzy krajami starej Unii a nowymi krajami członkowskimi, w głównej mierze z Europy Środkowo-Wschodniej. Pozytywne efekty akcesji do UE nowych krajów obserwowane w wyższej dynamice ich wzrostu gospodarczego wynikają przede wszystkim ze zwiększonego napływu bezpośrednich inwestycji zagranicznych i większej swobody gospodarczej, przyspieszonych reform strukturalnych oraz zrealizowanych transferów finansowych z funduszy strukturalnych [Sawicz 2012, s. 8]. Badania zrealizowane po upływie 5 lat od największego w historii UE jej poszerzenia w 2004 r. wśród głównych korzyści akcesyjnych dla nowych krajów członkowskich wymieniają: wyższe o ok. 1,75 pkt procentowego tempo wzrostu gospodarczego, zwiększoną wymianę handlową w ramach rynku wewnętrznego, szybszy proces modernizacji gospodarek, przejawiający się m.in. rosnącym znaczeniem sektora usług i nowoczesnych technologii, wzrost migracji zarobkowej umożliwiającej poprawę sytuacji finansowej wielu gospodarstw domowych [Five years of an enlarged EU ..., s. 3-5]. Konwergencji realnej towarzyszy również konwergencja nominalna w zakresie stóp procentowych, inflacji oraz finansów publicznych, podnosząca poziom stabilności makroekonomicznej krajów UE.

Wśród istotnych dla rozwoju rynków mieszkaniowych tendencji należy wskazać również działania Komisji Europejskiej zmierzające do budowy jednolitego rynku detalicznych usług finansowych. Istotną częścią tego rynku jest segment kredytowania hipotecznego. Wysiłek integracyjny zmierza do zniesienia różnic pomiędzy krajami członkowskimi w zakresie dostępności i procedur udzielania 
kredytów hipotecznych. Zwiększenie efektywności i konkurencyjności rynków mieszkaniowych kredytów hipotecznych nastąpić ma poprzez realizację czterech głównych celów [White paper on the integration ... 2007]:

1. Stwarzanie warunków dla oferowania kredytów hipotecznych w układzie transgranicznym, a także dywersyfikacji źródeł ich finansowania;

2. Zwiększenie dywersyfikacji produktów kredytowych;

3. Zwiększenie zaufania konsumentów (kredytobiorców);

4. Stwarzanie warunków do mobilności klientów.

Proces doganiania przez nowe kraje członkowskie UE gospodarek bardziej rozwiniętych i towarzysząca mu poprawa standardu życia mieszkańców stwarzają realne szanse także na zmniejszanie dystansu cywilizacyjnego w obszarze mieszkalnictwa. Można zatem wysunąć hipotezę, iż integracja europejska będąca źródłem konwergencji gospodarczej krajów członkowskich, jak również w pewnych obszarach ich konwergencji instytucjonalnej, jest procesem dynamizującym także konwergencję rynków mieszkaniowych. W celu weryfikacji powyższej hipotezy przetestowano istotność PKB per capita mierzonego według parytetu siły nabywczej jako zmiennej objaśniającej beta i sigma konwergencję rynków mieszkaniowych UE ${ }^{14}$.

W przypadku beta konwergencji oszacowano modele konwergencji warunkowej (wzór 4.10) z PKB per capita jako zmienną determinującą ścieżkę rozwoju krajowych rynków mieszkaniowych. Wyniki estymacji modeli panelowych metodami pooled regression, LSDV jak również GMM-sys prezentuje tabela 6.2.

W większości modeli warunkowej beta konwergencji otrzymane oszacowania potwierdzają istotność PKB per capita jako czynnika strukturalnego determinującego jej przebieg. Wyjątkiem jest wskaźnik siły nabywczej na rynku mieszkaniowym, który ze względu na swoją specyfikę pozostaje pod wpływem przede wszystkim wahań cen nieruchomości mieszkaniowych oraz dynamiki średniego wynagrodzenia w badanych gospodarkach. Warto jednak podkreślić nie zawsze identyczny kierunek wpływu PKB per capita na tempo zmian przyjętych wskaźników mieszkaniowych. Ujemne wartości parametrów przy PKB per capita uzyskano dla wskaźnika deprywacji mieszkaniowej, wskaźnika własności mieszkań oraz wskaźnika rozwoju rynku kredytowania hipotecznego (częściowo też dla zasobów mieszkaniowych). Zatem kraje o wyższym poziomie PKB per capita wykazują niższe tempo zmian przedmiotowych wskaźników rynku mieszkaniowego. Może mieć to uzasadnienie w korzystniejszej sytuacji mieszkaniowej występującej zazwyczaj w krajach wyżej rozwiniętych, co przekłada się na niższą dynamikę jej zmian. W interpretacji parametrów oszacowanych modeli należy zachować ostrożność ze względu na wspomniany wcześniej złożony charakter procesów zachodzących na rynkach mieszkaniowych, których nie można w pełni objaśnić, odwołując się jedynie do ekonomicznego wymiaru konwergencji gospodarczej krajów UE.

14 Analiza przeprowadzona została dla wskaźników mieszkaniowych w przypadku, których występowanie konwergencji zostało zweryfikowane pozytywnie (por. rozdział 5) 
Tabela 6.2. Wyniki estymacji warunkowej beta konwergencji

\begin{tabular}{|c|c|c|c|c|c|c|c|}
\hline \multirow{2}{*}{$\begin{array}{l}\text { Zmienna } \\
\text { LnHstock }\end{array}$} & GMM-SYS & LSDV & Pooled & \multirow{2}{*}{$\begin{array}{l}\text { Zmienna } \\
\text { LnHdepriv }\end{array}$} & GMM-SYS & LSDV & Pooled \\
\hline & (1) & (2) & (3) & & (1) & (2) & (3) \\
\hline $\begin{array}{l}\text { LnHstock }(-1) \\
\text { (p-value) }\end{array}$ & $\begin{array}{c}0,984 \\
(0,000)\end{array}$ & $\begin{array}{l}0,8853 \\
(0,000)\end{array}$ & $\begin{array}{l}0,9957 \\
(0,000)\end{array}$ & $\begin{array}{l}\text { LnHdepriv(-1) } \\
\text { (p-value) }\end{array}$ & $\begin{array}{l}0,6927 \\
(0,000)\end{array}$ & $\begin{array}{l}0,6565 \\
(0,000)\end{array}$ & $\begin{array}{l}0,9458 \\
(0,000)\end{array}$ \\
\hline $\begin{array}{l}\text { LnGDPpc } \\
\text { (p-value) }\end{array}$ & $\begin{array}{c}-0,0098 \\
(0,319)\end{array}$ & $\begin{array}{l}\mathbf{0 , 0 1 5 3} \\
(0,008)\end{array}$ & $\begin{array}{c}-0,0115 \\
(0,000)\end{array}$ & $\begin{array}{l}\text { LnGDPpc } \\
\text { (p-value) }\end{array}$ & $\begin{array}{c}-\mathbf{0 , 5 4 0 8} \\
(0,030)\end{array}$ & $\begin{array}{l}-0,356 \\
(0,001)\end{array}$ & $\begin{array}{r}-0,0453 \\
(0,326)\end{array}$ \\
\hline$R^{2}$ & - & 0,994 & 0,992 & $R^{2}$ & - & 0,964 & 0,955 \\
\hline SEE & 0,011 & 0,013 & 0,013 & SEE & 0,210 & 0,221 & 0,234 \\
\hline $\mathrm{AR}(1)$ & $\begin{array}{l}-2,282 \\
(0,022)\end{array}$ & - & - & $\mathrm{AR}(1)$ & $\begin{array}{l}-2,788 \\
(0,005)\end{array}$ & - & - \\
\hline$A R(2)$ & $\begin{array}{l}-1,449 \\
(0,147)\end{array}$ & - & - & $\operatorname{AR}(2)$ & $\begin{array}{c}1,211 \\
(0,226)\end{array}$ & - & - \\
\hline Sargan test & $\begin{array}{l}20,003 \\
(1,000)\end{array}$ & - & - & Sargan test & $\begin{array}{l}21,832 \\
(1,000)\end{array}$ & - & - \\
\hline Wald test & $\begin{array}{l}187,01 \\
(0,000)\end{array}$ & - & - & Wald test & $\begin{array}{c}191,077 \\
(0,000)\end{array}$ & - & - \\
\hline \multirow{2}{*}{$\begin{array}{c}\text { Zmienna } \\
\text { LnHpp }\end{array}$} & GMM-SYS & LSDV & Pooled & \multirow{2}{*}{$\begin{array}{l}\text { Zmienna } \\
\text { LnHowner }\end{array}$} & GMM-SYS & LSDV & Pooled \\
\hline & (1) & (2) & (3) & & (1) & (2) & (3) \\
\hline $\begin{array}{l}\operatorname{LnHpp}(-1) \\
\text { (p-value) }\end{array}$ & $\begin{array}{l}0,9415 \\
(0,000)\end{array}$ & $\begin{array}{l}0,8304 \\
(0,000)\end{array}$ & $\begin{array}{l}0,9427 \\
(0,000)\end{array}$ & LnHowner(-1) & $\begin{array}{l}0,8833 \\
(0,000)\end{array}$ & $\begin{array}{l}0,8502 \\
(0,000)\end{array}$ & $\begin{array}{l}0,9398 \\
(0,000)\end{array}$ \\
\hline $\begin{array}{l}\text { LnGDPpc } \\
\text { (p-value) }\end{array}$ & $\begin{array}{l}-0,066 \\
(0,489)\end{array}$ & $\begin{array}{l}0,0407 \\
(0,225)\end{array}$ & $\begin{array}{l}-0,004 \\
(0,771)\end{array}$ & $\begin{array}{l}\text { LnGDPpc } \\
\text { (p-value) }\end{array}$ & $\begin{array}{c}-0,0306 \\
(0,000)\end{array}$ & $\begin{array}{c}-\mathbf{0 , 0 0 8 2} \\
(0,086)\end{array}$ & $\begin{array}{r}-\mathbf{0 , 0 1 4 4} \\
(0,000)\end{array}$ \\
\hline$R^{2}$ & - & 0,935 & 0,927 & $R^{2}$ & - & 0,987 & 0,983 \\
\hline SEE & 0,080 & 0,280 & 0,280 & SEE & 0,023 & 0,017 & 0,019 \\
\hline $\mathrm{AR}(1)$ & $\begin{array}{l}-1,903 \\
(0,057)\end{array}$ & - & - & $\mathrm{AR}(1)$ & $\begin{array}{l}-2,701 \\
(0,006)\end{array}$ & - & - \\
\hline $\operatorname{AR}(2)$ & $\begin{array}{l}-2,068 \\
(0,039)\end{array}$ & - & - & $\operatorname{AR}(2)$ & $\begin{array}{l}1,654 \\
(0,098)\end{array}$ & - & - \\
\hline Sargan test & $\begin{array}{l}12,319 \\
(1,000)\end{array}$ & - & - & Sargan test & $\begin{array}{l}24,747 \\
(1,000)\end{array}$ & - & - \\
\hline Wald test & $\begin{array}{c}137,414 \\
(0,000)\end{array}$ & - & - & Wald test & $\begin{array}{c}1042,770 \\
(0,000)\end{array}$ & - & - \\
\hline
\end{tabular}




\begin{tabular}{|c|c|c|c|c|}
\hline Zmienna & GMM-SYS & LSDV & Pooled & \multirow{10}{*}{$\begin{array}{l}\text { Zmienne: } \\
\text { Hstock - mieszkania na } 1000 \text { mieszkańców; } \\
\text { Hdepriv - wskaźnik deprywacji } \\
\text { mieszkaniowej; } \\
\text { Hpp - siła nabywcza gospodarstw domowych; } \\
\text { Howner - wskaźnik własności mieszkań; } \\
\text { MortDebt - zadłużenie hipoteczne jako \% PKB } \\
\text { GDPpc - PKB per capita. }\end{array}$} \\
\hline LnMortDebt & (1) & (2) & (3) & \\
\hline $\begin{array}{l}\text { LnMortDebt(-1) } \\
\text { (p-value) }\end{array}$ & $\begin{array}{l}0,8983 \\
(0,000)\end{array}$ & $\begin{array}{l}0,8718 \\
(0,000)\end{array}$ & $\begin{array}{l}0,9035 \\
(0,000)\end{array}$ & \\
\hline $\begin{array}{l}\text { LnGDPpc } \\
\text { (p-value) }\end{array}$ & $\begin{array}{c}-0,1475 \\
(0,184)\end{array}$ & $\begin{array}{c}-\mathbf{0 , 1 3 6 2} \\
(0,004)\end{array}$ & $\begin{array}{c}-0,0013 \\
(0,950)\end{array}$ & \\
\hline$R^{2}$ & - & 0,988 & 0,985 & \\
\hline SEE & 0,125 & 0,116 & 0,128 & \\
\hline $\mathrm{AR}(1)$ & $\begin{array}{c}-2,0465 \\
(0,041)\end{array}$ & - & - & \\
\hline $\operatorname{AR}(2)$ & $\begin{array}{l}0,6204 \\
(0,535)\end{array}$ & - & - & \\
\hline Sargan test & $\begin{array}{l}25,877 \\
(1,000)\end{array}$ & - & - & \\
\hline Wald test & $\begin{array}{c}1420,95 \\
(0,000)\end{array}$ & - & - & \\
\hline
\end{tabular}

Źródło: opracowanie własne.

W kolejnym etapie badania podjęto również próbę odpowiedzi na pytanie o znaczenie tsigma konwergencji zachodzącej między gospodarkami UE dla przebiegu sigma konwergencji rynków mieszkaniowych. W tym celu dla każdego wskaźnika mieszkaniowego, dla którego potwierdzono spadek przekrojowego zróżnicowania w latach 2000-2017, oszacowano liniowy model w postaci:

$$
V_{z, t}=\beta_{0}+\beta_{1} \cdot V_{g d p, t}+\varepsilon_{t}
$$

gdzie:

$V_{z, t}$ - współczynnik zmienności dla wybranego wskaźnika mieszkaniowego, $V_{g d p, t}$ - współczynnik zmienności PKB per capita, $\varepsilon_{t}-$ składnik losowy.

Wyniki estymacji przedstawione zostały na rys. 6.7 oraz w tabeli 6.3. 

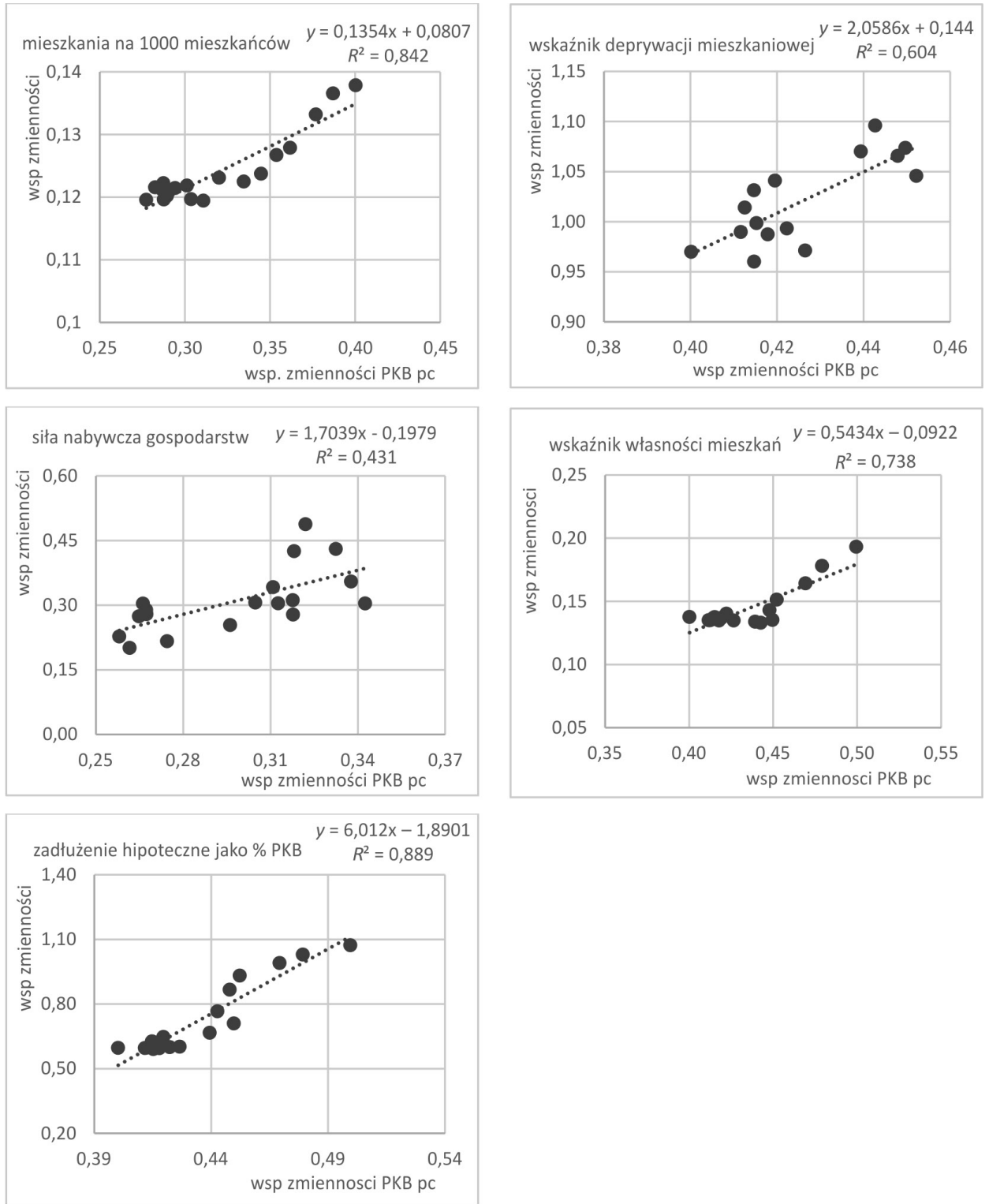

Rysunek 6.7. Sigma konwergencja rynków mieszkaniowych na tle sigma konwergencji gospodarczej

Źródto: opracowanie własne 
Tabela 6.3. Sigma konwergencja rynków mieszkaniowych na tle sigma konwergencji gospodarczej

\begin{tabular}{|c|c|c|c|c|c|}
\hline \multirow{2}{*}{ Zmienna } & \multicolumn{5}{|c|}{ Wyniki estymacji KMNK } \\
\hline & Wskaźnik (1) & Wskaźnik (2) & Wskaźnik (3) & Wskaźnik (4) & Wskaźnik (5) \\
\hline $\begin{array}{c}\text { Wyraz wolny } \\
\text { (p-value) }\end{array}$ & $\begin{array}{l}0,0807 \\
(0,000)\end{array}$ & $\begin{array}{l}0,1440 \\
(0,478)\end{array}$ & $\begin{array}{l}-0,1979 \\
(0,196)\end{array}$ & $\begin{array}{c}-0,0922 \\
(0,019)\end{array}$ & $\begin{array}{c}-1,8901 \\
(0,000)\end{array}$ \\
\hline $\begin{array}{c}\text { Parametr } \beta_{1} \\
\text { (p-value) }\end{array}$ & $\begin{array}{l}0,1354 \\
(0,000)\end{array}$ & $\begin{array}{l}2,0586 \\
(0,001)\end{array}$ & $\begin{array}{l}1,7039 \\
(0,003)\end{array}$ & $\begin{array}{l}0,5434 \\
(0,000)\end{array}$ & $\begin{array}{l}6,0120 \\
(0,000)\end{array}$ \\
\hline$R^{2}$ & 0,842 & 0,604 & 0,431 & 0,737 & 0,889 \\
\hline SEE & 0,0024 & 0,0282 & 0,0586 & 0,0089 & 0,0588 \\
\hline
\end{tabular}

Objaśnienia:

(1) Poziom zaspokojenia potrzeb mieszkaniowych; (2) Wskaźnik deprywacji zasobów mieszkaniowych; (3) Siła nabywcza gospodarstw na rynku mieszkaniowym; (4) Wskaźnik własności mieszkań; (5) Wskaźnik rozwoju rynku kredytowania hipotecznego.

Źródto: opracowanie własne.

W przypadku wszystkich modeli współczynnik zmienności PKB per capita okazał się statystycznie istotną zmienną objaśniającą. Nie formułując zbyt daleko idących wniosków, należy stwierdzić, iż zarówno w wymiarze ogólnogospodarczym, jak i mieszkaniowym gospodarki europejskie doświadczają zjawiska konwergencji (w tym zakresie procesy te są wzajemnie zgodne). Kierunek zmian makroekonomicznych można też uznać za sprzyjający doganianiu przez rynki mieszkaniowe nowych krajów członkowskich, poziomu rozwoju i standardów mieszkaniowych krajów zachodnich. Nie można jednak kategorycznie stwierdzić, iż zmiany w PKB per capita są wyłączną przyczyną konwergencji mieszkaniowej.

Znaczenie makrotrendu konwergencji gospodarczej krajów wspólnoty europejskiej zweryfikowano także w odniesieniu do cen nieruchomości mieszkaniowych i potwierdzonej w ich przypadku konwergencji klubowej. W celu pogłębienia analizy w zakresie potencjalnych determinant cen nieruchomości mieszkaniowych na badanych rynkach europejskich, a w konsekwencji także ich konwergencji klubowej, poza PKB per capita uwzględniono szerszy katalog zmiennych objaśniających.

W literaturze przedmiotu znaleźć możemy przegląd czynników mających zasadniczy wpływ na poziom i dynamikę cen mieszkań. Zawierają go m.in. prace: Droesa i Van de Minne’a [2016], Balazsa i Dubravko [2007], Cohena i Karpaviciute [2017], Genga [2018] oraz Capozza i in. [2002]. Wśród nich najczęściej wymienia się [Żelazowski 2011; Żelazowski 2019]:

- czynniki ekonomiczne obejmujące makro- i mikroekonomiczne wskaźniki koniunktury gospodarczej (dynamika PKB, wartości dodanej, produkcji sprzedanej przemysłu), wskaźniki rynku pracy (stopa bezrobocia, średnie 
wynagrodzenie), wskaźniki rynków finansowych (stopy procentowe, kursy walut, wskaźniki giełdowe, dostępność kredytów bankowych i innych źródeł finansowania zewnętrznego);

- czynniki społeczno-demograficzne uwzględniające m.in. zmiany liczby ludności, saldo migracji, strukturę wiekową, płciową populacji, występujące nierówności społeczne;

- czynniki instytucjonalne dotyczące prawnych oraz administracyjnych uwarunkowań działalności inwestycyjnej na rynku nieruchomości, obrotu nieruchomościami, opodatkowania nieruchomości, modelu realizowanej polityki mieszkaniowej;

- czynniki techniczne i zasobowe związane m.in. z rozmiarami i strukturą zasobów mieszkaniowych oraz ich infrastrukturalnego otoczenia.

$\mathrm{Na}$ potrzeby analizy głównych uwarunkowań konwergencji cenowej europejskich rynków mieszkaniowych dla każdego z wyodrębnionych klubów konwergencji oszacowany został panelowy model cen nieruchomości mieszkaniowych [Lin, Zhang, Li, Dong 2015] w postaci:

$$
\begin{aligned}
& \ln P_{i, t}=\beta_{0}+\beta_{1} \cdot \ln G_{D P p c_{i, t}}+\beta_{2} \cdot \ln \text { Income }_{i, t}+\beta_{3} \cdot \ln \text { UnempRate }_{i, t} \\
& +\beta_{4} \cdot \ln \text { MortDebt }_{i, t}+\beta_{5} \cdot \ln \text { Hstock }_{i, t} \\
& +\beta_{6} \cdot \ln \text { OwnerRate } \text { w }_{i, t}+\beta_{7} \cdot \text { PopulGrowth }_{i, t}+\beta_{8} \cdot \ln \text { PopulDensity }_{i, t} \\
& +\beta_{9} \cdot \ln \text { Popul25-44 } 4_{i, t}+\varepsilon_{i, t}
\end{aligned}
$$

gdzie:

$P_{i, t}$ - średnia cena nieruchomości mieszkaniowych,

$G D P p c_{i, t}-$ PKB per capita według parytetu siły nabywczej,

Income $_{i, t}$ - rozporządzalny dochód brutto,

UnempRate $_{i, t}$ - stopa bezrobocia,

MortDept ${ }_{i, t}$ - zadłużenie hipoteczne gospodarstw domowych w relacji do PKB,

Hstock $_{i, t}$ - zasób mieszkaniowy (liczba mieszkań na 1000 mieszkańców),

OwnerRate ${ }_{i, t}$ - wskaźnik własności mieszkań,

PopulGrowth $_{i, t}$ - zmiana liczby ludności w okresie 5-letnim (w \%),

PopulDensilty ${ }_{i, t}$ - gęstość zaludnienia (liczba ludności na $\mathrm{km}^{2}$ ),

Popul25 - $44_{i, t}$ - odsetek osób w wieku 25-44 lata w ogólnej liczbie ludności, $\varepsilon_{i, t}-$ składnik losowy ${ }^{15}$.

Wyniki estymacji modeli dla wyodrębnionych klubów konwergencji cenowej (klub 1: Francja, Niemcy, Włochy, Belgia, Finlandia, Polska, Holandia, Irlandia, UK; klub 2: Hiszpania, Portugalia, Grecja, Bułgaria) prezentują tab. 6.4 oraz tab. 6.5.

15 Źródła danych dla zmiennych: MortDebt; Hstock; OwnerRate przedstawione zostały w rozdziale 4. W przypadku pozostałych danych wykorzystano bazy Eurostat. 
Konwergencja europejskich rynków mieszkaniowych na tle konwergencji...

Tabela 6.4. Wyniki estymacji modelu LSDV dla klubu 1 konwergencji cenowej

\begin{tabular}{|c|c|c|c|c|c|}
\hline \multirow{2}{*}{ Zmienna } & \multicolumn{5}{|c|}{ Model } \\
\hline & (1) & (2) & (3) & (4) & (5) \\
\hline $\begin{array}{l}\text { LnGDPpc } \\
\text { (p-value) }\end{array}$ & $\begin{array}{l}\mathbf{1 , 0 7 4 6} \\
(0,000)\end{array}$ & & & & \\
\hline $\begin{array}{l}\text { LnIncome } \\
\text { (p-value) }\end{array}$ & & $\begin{array}{l}\mathbf{1 , 1 5 2 7} \\
(0,000)\end{array}$ & $\begin{array}{l}\mathbf{0 , 6 8 0 2} \\
(0,000)\end{array}$ & $\begin{array}{l}0,1382 \\
(0,304)\end{array}$ & $\begin{array}{l}\mathbf{0 , 2 5 2 4} \\
(0,055)\end{array}$ \\
\hline $\begin{array}{l}\text { LnUnempRate } \\
\text { (p-value) }\end{array}$ & & $\begin{array}{r}-\mathbf{0 , 1 6 7 8} \\
(0,000)\end{array}$ & $\begin{array}{r}-\mathbf{0 , 1 6 7 8} \\
(0,046)\end{array}$ & $\begin{array}{r}-0,3484 \\
(0,007)\end{array}$ & $\begin{array}{r}-0,3371 \\
(0,000)\end{array}$ \\
\hline $\begin{array}{l}\text { LnMortDebt } \\
\text { (p-value) }\end{array}$ & & & $\begin{array}{l}\mathbf{0 , 2 7 1 8} \\
(0,000)\end{array}$ & $\begin{array}{l}\mathbf{0 , 3 5 9 1} \\
(0,000)\end{array}$ & $\begin{array}{l}\mathbf{0 , 3 1 2 1} \\
(0,000)\end{array}$ \\
\hline $\begin{array}{l}\text { LnHstock } \\
\text { (p-value) }\end{array}$ & & & $\begin{array}{r}-0,5229 \\
(0,246)\end{array}$ & $\begin{array}{r}-1,2420 \\
(0,002)\end{array}$ & $\begin{array}{r}-\mathbf{1 , 0 5 4 8} \\
(0,008)\end{array}$ \\
\hline $\begin{array}{l}\text { LnOwnerRate } \\
\text { (p-value) }\end{array}$ & & & $\begin{array}{r}-0,1800 \\
(0,292)\end{array}$ & & \\
\hline $\begin{array}{l}\text { PopulGrowth } \\
\text { (p-value) }\end{array}$ & & & & $\begin{array}{l}\mathbf{0 , 0 1 3 4} \\
(0,021)\end{array}$ & $\begin{array}{l}\mathbf{0 , 0 1 4 2} \\
(0,017)\end{array}$ \\
\hline $\begin{array}{l}\text { LnPopulDensity } \\
\text { (p-value) }\end{array}$ & & & & $\begin{array}{r}2,4308 \\
(0,000)\end{array}$ & $\begin{array}{l}\mathbf{2 , 5 0 2 6} \\
(0,000)\end{array}$ \\
\hline $\begin{array}{l}\text { LnPopul25-44 } \\
\text { (p-value) }\end{array}$ & & & & $\begin{array}{r}-0,4427 \\
(0,006)\end{array}$ & \\
\hline LSDV $R^{2}$ & 0,906 & 0,936 & 0,952 & 0,966 & 0,965 \\
\hline Within $R^{2}$ & 0,595 & 0,724 & 0,795 & 0,856 & 0,850 \\
\hline SEE & 0,144 & 0,119 & 0,104 & 0,088 & 0,089 \\
\hline F-statistics & 162,929 & 222,981 & 235,505 & 295,398 & 301,832 \\
\hline AIC & $-174,980$ & $-241,843$ & $-289,197$ & $-349,527$ & $-342,989$ \\
\hline
\end{tabular}

Źródto: opracowanie własne. 
Tabela 6.5. Wyniki estymacji modelu LSDV dla klubu 2 konwergencji cenowej

\begin{tabular}{|c|c|c|c|c|c|}
\hline \multirow{2}{*}{ Zmienna } & \multicolumn{5}{|c|}{ Model } \\
\hline & (1) & (2) & (3) & (4) & (5) \\
\hline $\begin{array}{l}\text { LnGDPpc } \\
\text { (p-value) }\end{array}$ & $\begin{array}{l}1,3318 \\
(0,000)\end{array}$ & & & & \\
\hline $\begin{array}{l}\text { LnIncome } \\
\text { (p-value) }\end{array}$ & & $\begin{array}{l}\mathbf{1 , 1 4 4 5} \\
(0,000)\end{array}$ & $\begin{array}{l}\mathbf{0 , 8 1 5 1} \\
(0,000)\end{array}$ & $\begin{array}{l}\mathbf{0 , 4 2 5 5} \\
(0,000)\end{array}$ & $\begin{array}{l}\mathbf{0 , 4 0 5 6} \\
(0,000)\end{array}$ \\
\hline $\begin{array}{l}\text { LnUnempRate } \\
\text { (p-value) }\end{array}$ & & $\begin{array}{r}-0,2132 \\
(0,000)\end{array}$ & $\begin{array}{r}-0,0983 \\
(0,046)\end{array}$ & $\begin{array}{r}-\mathbf{0 , 2 6 6 7} \\
(0,007)\end{array}$ & $\begin{array}{r}-0,2795 \\
(0,000)\end{array}$ \\
\hline $\begin{array}{l}\text { LnMortDebt } \\
\text { (p-value) }\end{array}$ & & & $\begin{array}{l}\mathbf{0 , 3 9 0 1} \\
(0,000)\end{array}$ & $\begin{array}{l}\mathbf{0 , 3 2 9 4} \\
(0,000)\end{array}$ & $\begin{array}{l}\mathbf{0 , 3 1 2 7} \\
(0,000)\end{array}$ \\
\hline $\begin{array}{l}\text { LnHstock } \\
\text { (p-value) }\end{array}$ & & & $\begin{array}{r}-\mathbf{2 , 6 1 9 8} \\
(0,000)\end{array}$ & $\begin{array}{r}-0,2849 \\
(0,427)\end{array}$ & \\
\hline $\begin{array}{l}\text { LnOwnerRate } \\
\text { (p-value) }\end{array}$ & & & $\begin{array}{r}-0,1949 \\
(0,808)\end{array}$ & & \\
\hline $\begin{array}{l}\text { PopulGrowth } \\
\text { (p-value) }\end{array}$ & & & & $\begin{array}{l}\mathbf{0 , 0 3 0 2} \\
(0,000)\end{array}$ & $\begin{array}{l}\mathbf{0 , 0 1 6 9} \\
(0,000)\end{array}$ \\
\hline $\begin{array}{l}\text { LnPopulDensity } \\
\text { (p-value) }\end{array}$ & & & & $\begin{array}{r}\mathbf{3 , 1 0 2 9} \\
(0,000)\end{array}$ & $\begin{array}{l}3,2603 \\
(0,000)\end{array}$ \\
\hline $\begin{array}{l}\text { LnPopul25-44 } \\
\text { (p-value) }\end{array}$ & & & & $\begin{array}{r}-\mathbf{0 , 8 9 1 7} \\
(0,013)\end{array}$ & \\
\hline LSDV $R^{2}$ & 0,934 & 0,939 & 0,976 & 0,994 & 0,994 \\
\hline Within $R^{2}$ & 0,663 & 0,688 & 0,877 & 0,969 & 0,967 \\
\hline SEE & 0,167 & 0,161 & 0,103 & 0,052 & 0,054 \\
\hline F-statistics & 239,525 & 204,799 & 322,441 & 1029,749 & 1199,716 \\
\hline AIC & $-48,691$ & $-52,193$ & $-113,303$ & $-209,983$ & $-206,639$ \\
\hline
\end{tabular}

Źródto: opracowanie własne.

W zaprezentowanych modelach zweryfikowano w pierszym kroku znaczenie PKB per capita jako czynnika objaśniającego ceny nieruchomości w poszczególnych klubach (modele (1)). W obu przypadkach można uznać ją za istotną zmienną determinującą trajektorie cen na rynkach mieszkaniowych (wysoki poziom współczynnika R-kwadrat). Uwzględniając jednak bardziej szczegółowe 
charakterystyki społeczno-ekonomicznego otoczenia badanych rynków, eksplanacyjne znaczenie PKB per capita wyraźnie spadło, stąd zmienna ta pominięta została w dalszej analizie. Zgodnie z ostateczną wersją modeli (5) czynnikami zasadniczo wpływającymi na ceny mieszkań na poszczególnych rynkach były: sytuacja finansowa gospodarstw, a w konsekwencji także ich potencjał nabywczy na rynkach mieszkaniowych, której wyznacznikami w modelach był średni rozporządzalny dochód brutto oraz stopa bezrobocia, skala zadłużenia hipotecznego gospodarstw (wskaźnik zadłużenia hipotecznego jako \% PKB), jak również statystyki demograficzne obejmujące wzrost liczby ludności w ujęciu 5-letnim, a także gęstość zaludnienia. Ponadto w przypadku klubu 1 istotne znaczenie miał także poziom zaspokojenia potrzeb mieszkaniowych (mierzony liczbą mieszkań na 1000 mieszkańców). Zauważalne są różnice w znaczeniu wymienionych czynników między klubami konwergencji cenowej. Zaznaczyć należy przede wszystkim silniejszy wpływ rozporządzalnego dochodu brutto oraz gęstości zaludnienia na kształtowanie się cen mieszkań na rynkach klubu 2 . W odniesieniu do pozostałych zmiennych różnice w oszacowanych parametrach nie są tak znaczące.

Pomimo relatywnie wysokiego poziomu objaśnienia zmian cen nieruchomości mieszkaniowych w ramach poszczególnych klubów należy mieć na uwadze, iż mechanizm konwergencji cenowej ma złożone podłoże i poza rozpartywanymi uwarunkowaniami na jej przebieg wpływ mają również: unikalny dla każdego kraju ład instytucjonalny czy też przyjęty model polityki mieszkaniowej. 



\section{Rozdział 7}

\section{Próba oceny konwergencji mieszkaniowej wraz z jej efektami}

\subsection{Kierunki zmian na rynkach nieruchomości mieszkaniowych w kontekście procesów konwergencji}

\subsubsection{Zmiany polityki mieszkaniowej i obecna sytuacja mieszkaniowa w państwach UE}

W świetle przeprowadzonych badań należy stwierdzić, iż europejskie rynki mieszkaniowe podlegały $\mathrm{w}$ przyjętym horyzoncie badawczym istotnym zmianom. Miały one zarówno charakter ilościowy, jak i jakościowy, a ich efektem był proces generalnego podniesienia standardu mieszkaniowego gospodarstw, jak również wyraźny rozwój otoczenia instytucjonalnego rynku mieszkaniowego. Należy jednakże zaznaczyć, iż obserwowane ścieżki rozwoju poszczególnych rynków nie były identyczne, różnice zauważalne były $\mathrm{w}$ dynamice, a niekiedy także $\mathrm{w}$ kierunku zachodzących zmian.

Procesy konwergencji mieszkaniowej mają złożone podłoże. Trudno bowiem wskazać jednoznacznie grupę czynników inicjujących oraz podtrzymujących konwergencję przedmiotowych rynków. Są to zarówno uwarunkowania ekonomiczne, które zgodnie z literaturą przedmiotu, jak i wynikami badań własnych mają fundamentalne znaczenie $\mathrm{w}$ tym zakresie, ale należy też podkreślić istotność przemian politycznych, społecznych i demograficznych, których doświadczyły gospodarki Europy Środkowo-Wschodniej od lat 90., a które to przemiany wywarły silny wpływ na kierunek rozwoju ich rynków mieszkaniowych. Urynkowienie sektora mieszkaniowego $\mathrm{w}$ połączeniu $\mathrm{z}$ dynamicznym rozwojem gospodarczym tej części Europy zdynamizowało proces doganiania zachodnioeuropejskich standardów mieszkaniowych. Źródeł konwergencji mieszkaniowej można ponadto upatrywać 
w makrouwarunkowaniach (postępująca integracja europejska, synchronizacja cykli gospodarczych, wspólna polityka monetarna w obrębie strefy euro, zwiększona mobilność kapitału ludzkiego) oraz mikrouwarunkowaniach (poprawa sytuacji ekonomicznej gospodarstw domowych, wzrost świadomości społecznej, ekologicznej, dyfuzja zachodnich wzorców kulturowych). Mikrouwarunkowania kształtują aspiracje i oczekiwania gospodarstw m.in. w zakresie ich sytuacji mieszkaniowej, natomiast makrouwarunkowania determinują $\mathrm{w}$ znacznym stopniu możliwości ich realizacji.

Można oczekiwać, że wraz z sukcesywnym upodabnianiem się standardu mieszkaniowego na rynkach europejskich dynamika konwergencji będzie tracić na sile, podobnie jak ma to miejsce w przypadku konwergencji gospodarczej. Nie należy w związku z tym oczekiwać pełnej unifikacji rynków mieszkaniowych czy standaryzacji usługi mieszkaniowej. Poza uwarunkowaniami makroekonomicznymi, które w kontekście konwergencji gospodarczej krajów UE wykazywać będą mniejsze niż w minionych okresach różnice, nadal funkcjonować będzie szeroki katalog czynników determinujących odmienności między poszczególnymi rynkami krajowymi. Wśród nich istotne znaczenie mają uwarunkowania historyczne, społeczne, kulturowe oraz polityczne. To one w istotnym zakresie kształtować będą path dependence rynków mieszkaniowych w poszczególnych krajach.

Polityka mieszkaniowa nadaje kierunek zmianom, wprowadza nowe instrumenty, pomimo tego, że każde państwo realizuje ją suwerennie, to widoczne są pewne wspólne trendy, podobne procesy wynikające z uwarunkowań społecznych, gospodarczych i politycznych. Zasadnicza zmiana polityki mieszkaniowej nastąpiła w latach 80., uznano, że dotychczasowe instrumenty nie odpowiadają nowoczesnym gospodarkom i ich potrzebom, zastąpiono istniejące sposoby dofinansowania pomocą w postaci dodatków mieszkaniowych, wspierano podmioty o charakterze non-profit, które przejmowały obowiązki mieszkaniowe podmiotów publicznych, reformowano politykę czynszową tak, aby czynsze pokrywały koszty utrzymania budynków mieszkalnych, wspierano własność, łagodzono wymagania kredytowe i wykorzystywano wsparcie w postaci ulg i zwolnień podatkowych [Maclennan, Miao 2017, s. 29-30]. Wzrost popytu w aglomeracjach i niedostateczna podaż przyczyniły się do wzrostu cen, problemy niedostatku mieszkań dostępnych (affordable housing) i rosnących nierówności uległy nasileniu. W obecnej fazie - pokryzysowej - widoczna jest kontynuacja tych procesów. Dynamiczny wzrost gospodarczy będzie następował w rozwijających się aglomeracjach, supermiastach, niedostateczna podaż, w szczególności w krótkim okresie, będzie powodować sukcesywny wzrost cen. Zmniejszenie publicznych wydatków mieszkaniowych ma daleko idące konsekwencje dla gospodarstw domowych, rynków pracy i stosunków gospodarczo-społecznych.

Zmiany warunków politycznych, gospodarczych i społecznych stanowią źródło ewolucji systemów mieszkaniowych. Ich wielowymiarowość i specyfika powodują, że nie jest możliwe dokonanie jednoznacznej klasyfikacji, można starać 
się grupować systemy o podobnych charakterystykach i szukać podobieństw oraz różnic. $\mathrm{W}$ tab. 7.1 przedstawiono podstawowe komponenty polityki mieszkaniowej w wybranych państwach UE. Uwzględniono bezpośrednie odwołanie się do potrzeb mieszkaniowych obywateli w ustawie zasadniczej, główny kierunek wsparcia przez państwo zaspokajania potrzeb mieszkaniowych, regulacje odnoszące się do zasobu czynszowego oraz podmioty odpowiedzialne za interwencję na rynku mieszkaniowym.

Tabela 7.1. Podstawowe komponenty polityki mieszkaniowej w wybranych państwach UE

\begin{tabular}{|c|c|c|c|c|c|}
\hline $\begin{array}{l}\text { Bezpośrednie } \\
\text { odniesienie } \\
\text { do potrzeb } \\
\text { mieszkanio- } \\
\text { wych w kon- } \\
\text { stytucji }\end{array}$ & $\begin{array}{l}\text { Wsparcie pań- } \\
\text { stwa skiero- } \\
\text { wane przede } \\
\text { wszystkim na } \\
\text { własność }\end{array}$ & $\begin{array}{l}\text { Podmioty } \\
\text { wspierane } \\
\text { bezpośrednio } \\
\text { to ograni- } \\
\text { czona grupa } \\
\text { gospodarstw } \\
\text { domowych, } \\
\text { które samo- } \\
\text { dzielnie nie } \\
\text { są w stanie } \\
\text { zaspokoić po- } \\
\text { trzeb mieszka- } \\
\text { niowych }\end{array}$ & $\begin{array}{l}\text { Relacja } \\
\text { najemca - } \\
\text { właściciel jest } \\
\text { zrównoważo- } \\
\text { na pod wzglę- } \\
\text { dem praw } \\
\text { i obowiązków }\end{array}$ & $\begin{array}{l}\text { Ingerencja } \\
\text { państwa } \\
\text { w wysokość } \\
\text { czynszów } \\
\text { na rynku } \\
\text { mieszkanio- } \\
\text { wym }\end{array}$ & $\begin{array}{l}\text { Obowiązki } \\
\text { mieszkaniowe } \\
\text { wykonywane } \\
\text { na poziomie } \\
\text { państwa } \\
\text { (działalność } \\
\text { ustawodaw- } \\
\text { cza, programy } \\
\text { wspierające) } \\
\text { i samorządu } \\
\text { lokalnego } \\
\text { najniższego } \\
\text { szczebla jako } \\
\text { wykonawcy }\end{array}$ \\
\hline $\begin{array}{l}\text { Belgia, Finlan- } \\
\text { dia, Grecja, } \\
\text { Hiszpania, } \\
\text { Holandia, Pol- } \\
\text { ska, Portuga- } \\
\text { lia, Stowenia, } \\
\text { Szwecja, } \\
\text { Węgry }\end{array}$ & $\begin{array}{l}\text { Belgia, Bułga- } \\
\text { ria, Chorwa- } \\
\text { cja, Czechy, } \\
\text { Estonia, Gre- } \\
\text { cja, Irlandia, } \\
\text { Łotwa, Pol- } \\
\text { ska, Rumunia, } \\
\text { Słowacja, } \\
\text { Słowenia, } \\
\text { Szwecja, } \\
\text { Węgry, Wielka } \\
\text { Brytania, } \\
\text { Włochy }\end{array}$ & $\begin{array}{l}\text { Państwa UE } \\
\text { poza Grecją, } \\
\text { Szwecją }\end{array}$ & $\begin{array}{l}\text { Państwa UE } \\
\text { poza Holan- } \\
\text { dią, Włochami } \\
\text { (przewaga } \\
\text { uprawnień } \\
\text { najemców), } \\
\text { Francją, Gre- } \\
\text { cją (przewaga } \\
\text { uprawnień } \\
\text { właścicieli). } \\
\text { W Bułgarii, } \\
\text { Chorwacji, na } \\
\text { Węgrzech pro- } \\
\text { blem niskiej } \\
\text { jakości regula- } \\
\text { cji prawnej }\end{array}$ & $\begin{array}{l}\text { Austria, Bel- } \\
\text { gia, Chorwa- } \\
\text { cja, Czechy, } \\
\text { Estonia, Fran- } \\
\text { cja, Holandia, } \\
\text { Litwa, Łotwa, } \\
\text { Niemcy, Pol- } \\
\text { ska, Słowacja, } \\
\text { Słowenia, } \\
\text { Szwecja, Wiel- } \\
\text { ka Brytania, } \\
\text { Włochy }\end{array}$ & $\begin{array}{l}\text { Państwa UE } \\
\text { poza Belgią, } \\
\text { gdzie kompe- } \\
\text { tencje wystę- } \\
\text { pują głównie } \\
\text { na szczeblu } \\
\text { regionalnym }\end{array}$ \\
\hline
\end{tabular}

Źródło: opracowanie własne na podstawie TenLaw, Pittini i in. 2017.

Jak wynika $\mathrm{z}$ analizy zestawienia przedstawionego $\mathrm{w}$ tab. 1, bezpośrednie odniesienie do potrzeb mieszkaniowych i pomocy w ich zaspokajaniu w ustawie zasadniczej nie jest powszechne. Natomiast warto pamiętać, że nawet gdy się pojawia, 
to nie daje obywatelom podstaw prawnych do skarżenia państwa, gdy nie mają zaspokojonych potrzeb mieszkaniowych. Wskazanie prawa do mieszkania jako jednego $\mathrm{z}$ podstawowych praw społecznych jest traktowane jako manifest wagi problemu mieszkaniowego.

Wsparcie państwowe przez wiele lat koncentrowało się przede wszystkim na umożliwieniu zostania właścicielami jak najszerszej grupie obywateli, wykorzystywano w tym celu bezpośrednie wsparcie finansowe oraz m.in. ulgi podatkowe. W ostatnich latach dostrzeżono, że własność nie przynosi jedynie pozytywnych konsekwencji i kilka państw zmieniło oficjalnie kierunek swojej polityki mieszkaniowej na neutralny, należą do nich np. Hiszpania i Portugalia ${ }^{1}$ (nie wyklucza to wykorzystywania instrumentów wspierających własność). Bezpośrednie wsparcie w postaci przyznania praw do mieszkania społecznego obecnie przede wszystkim dotyczy gospodarstw domowych w potrzebie, co zostało też podkreślone w definicji mieszkalnictwa społecznego, o czym była mowa wcześniej. Nowa regulacja na poziomie unijnym zmusiła kilka państw, m.in. Holandię i Francję, do ograniczenia adresatów pomocy mieszkaniowej. Jedynie Szwecja dokonała zmian, które poszły $\mathrm{w}$ innym kierunku - przyznaje się w tym państwie prawo do mieszkania z zasobu publicznego dla każdego gospodarstwa domowego, nie nazywa się jednak tych mieszkań społecznymi. Wyjątkowa wśród państw unijnych jest Grecja, ponieważ $\mathrm{w}$ zasadzie nie przewiduje zasobu mieszkań publicznych.

Ważnym problemem polityki mieszkaniowej jest wpływ podmiotów publicznych na wysokość czynszu lub możliwość jego zmian, zakres tej interwencji jest widoczny w wielu państwach UE, choć zmniejszył się w ostatnich latach. Na przestrzeni wielu lat widoczne były daleko idące zmiany, które doprowadzały do przekształceń struktury własnościowej, gdy ograniczenia prywatnych właścicieli zasobu czynszowego w zakresie czerpania zysku powodowały ucieczkę z tego typu inwestycji. Pojawiała się wtedy luka w zasobie mieszkań czynszowych, a był on niezbędny ze względu na konieczność chociażby zapewnienia mobilności na rynku pracy. Ujawniło się to wyraźnie, gdy ze względu na powszechność procesów prywatyzacji zasobów publicznych zmniejszył się znacząco udział komunalnego zasobu czynszowego.

Inną ważną sferą polityki mieszkaniowej jest relacja uprawnień i obowiązków stron umów najmu. W ostatnich latach wprowadzono rozwiązania ograniczające pozycję najemcy jako strony umowy, przede wszystkim odnosi się to do możliwości wypowiedzenia umowy przez właściciela, ułatwień w eksmisji lokatora.

Kompetencje i obowiązki w zakresie bezpośrednich działań na lokalnym rynku mieszkaniowym należą przede wszystkim do samorządu lokalnego. Nie ma on możliwości samodzielnego zaspokajania zgłaszanych potrzeb mieszkaniowych, nawet dla zawężonej grupy odbiorców pomocy, więc stara się zaktywizować różnego typu podmioty prywatne działające na zasadach for-profit i non-profit.

1 Bez wątpienia łatwiej zmienić zapis regulacji prawnej niż przekonania i dążenia ludzi. 
Obecny stan systemów mieszkaniowych państw UE w uproszczeniu można analizować na podstawie wskaźników, takich jak: liczba mieszkań na 1000 mieszkańców, udział własności, zadłużenie hipoteczne czy przeciążenie kosztami mieszkaniowymi - por. tab. 7.2. Ewolucja, która jest procesem ciągłym, nie doprowadziła do ujednolicenia rynków mieszkaniowych, co zostało już wcześniej podkreślone. Porównanie komponentów systemów mieszkaniowych przedstawione w tab. 7.2 daje wyraźny obraz aktualnych różnic i podobieństw pomiędzy poszczególnymi państwami.

Tabela 7.2. Poziom zaspokojenia potrzeb mieszkaniowych na poziomie wybranych państw UE w 2017 r.

\begin{tabular}{|l|c|c|c|c|c|}
\hline Państwo & $\begin{array}{c}\text { Wskaźnik } \\
\text { liczby } \\
\text { mieszkań } \\
\text { na 1000 } \\
\text { mieszkańców* }\end{array}$ & $\begin{array}{c}\text { Poziom } \\
\text { własno- } \\
\text { ści (\%) }\end{array}$ & $\begin{array}{c}\text { Udziat } \\
\text { mieszkań } \\
\text { społecznych } \\
\text { (\%) }\end{array}$ & $\begin{array}{c}\text { Zadtużenie } \\
\text { hipoteczne } \\
\text { na } \\
\text { dorosłego } \\
\text { obywatela } \\
\text { (tys. euro) }\end{array}$ & $\begin{array}{c}\text { Przeciążenie } \\
\text { kosztami } \\
\text { mieszkaniowymi } \\
\text { dla gosp. } \\
\text { domowych } \\
\text { ogółem/dla } \\
\text { gosp. domowych } \\
\text { zagrożonych } \\
\text { ubóstwem }\end{array}$ \\
\hline 1 & 2 & 3 & 4 & 5 & 6 \\
\hline Austria & 547 & 55,0 & 20,7 & 14,4 & $7,1 / 40,3$ \\
\hline Belgia & 474 & 72,7 & 6,8 & 25,8 & $9,1 / 34,4$ \\
\hline Butgaria & 551 & 82,9 & 0,2 & 0,7 & $18,9 / 50,1$ \\
\hline Chorwacja & 524 & 90,5 & b.d. & 2,0 & $5,8 / 26,2$ \\
\hline Czechy & 454 & 78,5 & $6-7$ & 5,2 & $8,7 / 44,2$ \\
\hline Dania & 490 & 62,2 & 19,6 & 54,3 & $15,7 / 75,4$ \\
\hline Estonia & 385 & 81,8 & 1,4 & 6,6 & $4,8 / 18,4$ \\
\hline Finlandia & 545 & 71,4 & 13 & 21,7 & $4,3 / 18,2$ \\
\hline Francja & 539 & 64,4 & 16,8 & 18,3 & $4,7 / 20,1$ \\
\hline Niemcy & 490 & 51,4 & 3,9 & 19,9 & $14,5 / 48,5$ \\
\hline Grecja & 601 & 73,3 & b.d. & 6,6 & $39,6 / 89,7$ \\
\hline Węgry & 449 & 85,2 & b.d. & 1,7 & $10,7 / 49,4$ \\
\hline Irlandia & 416 & 69,5 & 8,7 & 23,4 & $4,5 / 19,9$ \\
\hline Włochy & 551 & 72,4 & 3,7 & 7,4 & $8,2 / 32,9$ \\
\hline Łotwa & 476 & 81,5 & 0,3 & 2,7 & $6,9 / 25,6$ \\
\hline
\end{tabular}


Tabela 7.2 (cd.)

\begin{tabular}{|l|c|c|c|c|c|}
\hline \multicolumn{1}{|c|}{1} & 2 & 3 & 4 & 5 & 6 \\
\hline Litwa & 551 & 89,7 & 3 & 3,0 & $7,2 / 26,8$ \\
\hline Holandia & 476 & 69,4 & 30 & 49,1 & $9,4 / 40,9$ \\
\hline Polska & 379 & 84,2 & 7,6 & 3,0 & $6,7 / 30,4$ \\
\hline Portugalia & 573 & 74,7 & 2 & 11,0 & $6,7 / 26,0$ \\
\hline Rumunia & 449 & 96,8 & 1,5 & 0,9 & $12,3 / 36,3$ \\
\hline Stowacja & 352 & 90,1 & 3 & 5,7 & $8,4 / 38,9$ \\
\hline Stowenia & 450 & 75,6 & 6 & 3,5 & $5,2 / 26,7$ \\
\hline Hiszpania & 542 & 77,1 & 2,5 & 13,0 & $9,8 / 36,5$ \\
\hline & 480 & 65,2 & $\begin{array}{c}19 \\
\text { (mieszkania } \\
\text { Subliczne) }\end{array}$ & 50,8 & $8,4 / 38,8$ \\
\hline $\begin{array}{l}\text { Wielka } \\
\text { Brytania }\end{array}$ & 425 & 65,0 & 17,6 & 29,6 & $12,4 / 40,8$ \\
\hline
\end{tabular}

Objaśnienia:

*Ze względu na brak możliwości wskazania we wszystkich badanych państwach liczby mieszkań zamieszkałych w 2017 wykorzystano dostępny wskaźnik wszystkich mieszkań.

Źródło: opracowanie własne na podstawie Pittini i in. 2017; Eurostat Housing Indicators.

Wskaźnik liczby mieszkań na 1000 mieszkańców waha się od 352 na Słowacji do 601 w Grecji i 573 w Portugalii. Nie można jednak zapominać, że w tych dwóch ostatnich państwach jest wiele mieszkań wakacyjnych. Widoczne są jednak już na pierwszy rzut oka różnice pomiędzy państwami „starej” UE i większością krajów postsocjalistycznych. Różnice występują także w udziale właścicieli wykorzystujących własne mieszkania, Niemcy wykazują najniższy udział na poziomie $51,4 \%$, a najwyższy jest w Rumunii i sięga 96,8\%. Poważne odmienności występują w wielkości zasobu mieszkań społecznych - tu liderem jest Holandia, a brak takich mieszkań w Grecji, bardzo niewiele w Bułgarii, na Łotwie czy w Rumunii. Zadłużenie hipoteczne na głowę dorosłego obywatela sięga 54,3 tys. euro w Danii i jedynie 0,7 tys. euro w Bułgarii. Przeciążenie kosztami mieszkaniowymi także kształtuje się na niejednolitym poziomie - ogółem największe problemy mają gospodarstwa domowe w Grecji, Bułgarii i Danii, a wśród gospodarstw domowych na skraju ubóstwa najgorsza sytuacja występuje w Grecji, Danii, Bułgarii i na Węgrzech. 


\subsubsection{Procesy konwergencji w odniesieniu do państw postsocjalistycznych}

W ocenie tendencji weryfikowanych w ramach europejskich rynków mieszkaniowych istotnego znaczenia nabiera ich przestrzenny wymiar. W wymiarze międzynarodowym potwierdzono tendencję do spadku zróżnicowania rynków mieszkaniowych. Szczególnie zauważalne jest to między rynkami rozwiniętymi Europy Zachodniej i rynkami nowych krajów członkowskich UE. Dane statystyczne potwierdzają, iż historyczny dystans cywilizacyjny dzielący Europę Zachodnią i Środkowo-Wschodnią zmniejsza się. Proces ten ma jednak charakter długookresowy i jest naturalną konsekwencją nadal dużych dysproporcji w zasobach mieszkaniowych starych i nowych krajów UE, różnic w ich standardzie jakościowym czy w skali budownictwa mieszkaniowego. Znaczenie ma także samo tempo konwergencji mieszkaniowej, które zgodnie $\mathrm{z}$ wynikami badań waha się od 2,36 do 6,47\%, w zależności od przyjętego wskaźnika mieszkaniowego, co przekłada się na wieloletni proces zacierania różnic między rynkami (wskaźniki half-life wynoszące od 11 do nawet 29 lat).

Wyodrębnienie grupy państw postsocjalistycznych pozwala na dokonanie kilku spostrzeżeń o charakterze generalnym, ale zmusza także do przeprowadzenia podziału wewnątrz tej grupy. Poszukiwanie wyjaśnienia różnic w uwarunkowaniach funkcjonowania rynków mieszkaniowych państw Europy Zachodniej i postsocjalistycznych może mieć różny wymiar, można skoncentrować się na czynnikach ekonomiczno-społecznych [Mandic, Cirman 2012], można badać przede wszystkim założenia instytucjonalne [Lowe, Tsenkova 2003; Stephens, Lux, Sunega 2015]. Bazując na tym drugim podejściu, można zauważyć kilka elementów zasadniczo wpływających na obecny kształt rynków mieszkaniowych państw postsocjalistycznych. Uprawnione jest stwierdzenie, że nie występuje tu tabula rasa, path dependence jest wyraźna i silna i to nie tylko w odniesieniu do okresu gospodarki centralnie sterowanej. Koncentrując się na transformacji, która nastąpiła po 1989 r., można wskazać, że odmiennie niż w państwach Europy Zachodniej polityka mieszkaniowa państw postsocjalistycznych utrwaliła istniejące nierówności [Stephens, Lux, Sunega 2015, s. 1229]. Rozdawnicza prywatyzacja, która pozwoliła na wycofanie się szeroko rozumianego państwa z obowiązków mieszkaniowych względem obywateli, spowodowała zasadniczą zmianę struktury własnościowej - ogromny wzrost udziału prywatnych właścicieli, ale bez znaczącego wzrostu obciążeń hipotecznych. To jeden z najbardziej charakterystycznych elementów rynków mieszkaniowych państw postsocjalistycznych. Powstał on w wyniku swoistego nadania ${ }^{2}$ przez szeroko pojęte państwo mieszkań zakładowych i komunalnych, a w niektórych państwach także spółdzielczych, ich dotychczasowym

2 Autorzy rozumieją pod tym pojęciem przyznanie prawa do nabycia własności za ułamek wartości mieszkania. 
użytkownikom. Źródłem bogactwa mieszkaniowego nie jest więc tu rodzina, jak w państwach Europy Południowej [Allen 2006]. Należy zwrócić uwagę na skutki takiego działania - podział, który istniał wcześniej, grupował osobno beneficjentów państwa, którzy mieli prawa użytkowania mieszkań na podstawie decyzji administracyjnych, użytkowników mieszkań spółdzielczych, którzy płacili określone wkłady ( $\mathrm{w}$ zależności od rodzaju i wysokości wkładu uzyskiwano różne uprawnienia) i prywatnych właścicieli. Ci ostatni posiadali nieruchomości zlokalizowane najczęściej na terenach wiejskich, ale także kamienice, w zasadzie nie mieli prawa decydowania o możliwości ich użytkowania. Grupa beneficjentów prywatyzacji to ci, którzy korzystali z mieszkań na podstawie decyzji przydziałowych, użytkownicy mieszkań spółdzielczych nie mieli zasadniczo tak dogodnej sytuacji (aczkolwiek różne były regulacje w poszczególnych państwach). Bez korzyści zostali ci, którzy nie mieli żadnych praw do mieszkań lub właściciele gruntów wiejskich i kamienic. Osobnym i poważnym problemem był konflikt między uprawnieniami użytkowników mieszkań i byłych właścicieli, którzy starali się o zwrot nieruchomości. Zasadniczo wracały one do byłych właścicieli lub ich spadkobierców, jeśli udowodnili oni swoje roszczenia, ale z gwarancją ochrony najemców. To doprowadzało do dalszej eskalacji konfliktów (szerzej w rozdziale 3).

Osoby, które stały się właścicielami dzięki prywatyzacji, były zamożne z punktu widzenia wartości nieruchomości, ale często zły stan techniczny zasobu generował bardzo poważne koszty. Spowodowało to paradoksalną sytuację, gdy z punktu widzenia majątku mieszkaniowego jego właściciel jest bogaty, ale nie stać go na poniesienie podstawowych wydatków remontowych, ponieważ bogactwo mieszkaniowe nie przekłada się na bogactwo finansowe. Często ta sytuacja dotyczyła osób w starszym wieku, mogły one sprzedać mieszkanie, ale niezbędne byłoby inne miejsce zamieszkania ${ }^{3}$. Odpowiedzią były i są swoiste roszady generacyjne, gdy usamodzielniający się wnuk zajmuje lokal dziadka, który trafia na jego dotychczasowe miejsce.

Należy w tym miejscu podkreślić, że ci, którzy nie byli beneficjentami prywatyzacji, byli pozostawieni bez znaczącej pomocy państwa. Zasób mieszkań społecznych, bardzo zmniejszony prywatyzacją i często zablokowany przez dotychczasowych najemców, nie wchłania nowych osób, które starają się usamodzielnić lub są mobilne w poszukiwaniu pracy. Programy pomocowe dotychczas skierowane były przede wszystkim do nabywców własności na własne potrzeby, czyli co najmniej średniozamożnych.

Można stwierdzić, że wszystkie państwa postsocjalistyczne wykazują dążenie do poprawy jakościowej i ilościowej warunków mieszkaniowych, „goniąc” niejako państwa Europy Zachodniej - potwierdzają to wyniki analizy beta oraz sigma

3 W Polsce sprzedaż przed upływem 5 lat od chwili wykupu oznaczała konieczność zwrotu udzielonej bonifikaty, chyba że pieniądze uzyskane ze sprzedaży przeznaczano na poprawę warunków mieszkaniowych. Powstrzymywało to część nowych właścicieli od sprzedaży. 
konwergencji. Natomiast pomiędzy poszczególnymi systemami mieszkaniowymi w dalszym ciągu istnieją poważne odrębności, które nie zanikają.

Jak wskazano wcześniej, pomiędzy uwarunkowaniami rozwoju państw postsocjalistycznych istnieją różnice, które pozwoliły na wyodrębnienie trzech grup: państw nadbałtyckich, państw reformistycznych Europy Centralnej i państw Europy Południowo-Wschodniej ${ }^{4}$. Podział ten został wykorzystany m.in. do badania zmian ścieżek rozwoju systemów mieszkaniowych państw postsocjalistycznych [Soaita, Dewilde 2017]. Autorzy doszli do wniosku, że mimo upływu lat istniejące grupy dalej rozwijają się we właściwy dla siebie sposób na paralelnych ścieżkach. Na podstawie przeprowadzonych badań wyraźne wsparcie uzyskuje twierdzenie, że nie można nadawać etykiety „postsocjalistyczne” jako główne wytłumaczenie istniejących odrębności między poszczególnymi systemami mieszkaniowymi (podobnie [Tuvikene 2016; Chelcea, Druţă 2016]). Trzy grupy wyodrębnione początkowo były do siebie podobne w ogólnym zarysie, biorąc pod uwagę podstawowe komponenty systemu. Natomiast z biegiem czasu doszło do przekształceń systemowych i zmian warunków na rynkach mieszkaniowych.

Analiza warunków mieszkaniowych w państwach postsocjalistycznych pozwoliła na wskazanie przetasowania, które powoli ${ }^{5}$ następuje - najlepsza sytuacja początkowo istniała w państwach reformistycznych (ale Polska wyróżniała się negatywnie). Teraz można wydzielić państwa nadbałtyckie, Chorwację, Czechy, Słowację i Słowenię jako przykład od średnich do dobrych warunków mieszkaniowych, Bułgarię, Węgry i Polskę jako grupę państw o niższej jakości warunków mieszkaniowych (od gorszego poziomu w Bułgarii, średniego w Polsce i na Węgrzech), Rumunię jako przykład najtrudniejszych warunków mieszkaniowych [Soaita, Dewilde 2017, s. 24]. Oceniając poziom nierówności społeczno-ekonomicznych i mieszkaniowych, zwrócono uwagę na fakt, że w państwach nadbałtyckich istnieje mniejsze zróżnicowanie mieszkaniowe pomiędzy zamożniejszymi i uboższymi gospodarstwami domowymi ze wskazaniem na wyższy poziom warunków mieszkaniowych, co zapewne związane jest także z ubytkiem populacji oraz szybką finansjalizacją rynku mieszkaniowego [Soaita, Dewilde 2017, s. 25]. Ponadto, należy zauważyć, że w państwach takich jak Rumunia czy Bułgaria budownictwo mieszkaniowe nie przyczynia się znacząco do poprawy warunków mieszkaniowych, ponieważ nowo wybudowane obiekty mają niewielki metraż i niską jakość [Soaita 2017].

4 Szerzej opisano to w rozdziale 3, do pierwszej grupy należą Litwa, Łotwa i Estonia, do drugiej Polska, Czechy, Słowacja, Węgry, Stowenia, Chorwacja i do ostatniej Bułgaria i Rumunia, biorąc pod uwagę kraje należące obecnie do UE.

5 Powolność tego procesu wynika z niewielkiej liczby budowanych jednostek mieszkalnych, co oznacza, że zasób powstały w okresie komunistycznym ciągle ma dominujące znaczenie przy ocenie jakości zasobu. 


\subsubsection{Kierunki zmian na poziomie regionów}

Konwergencji rynków mieszkaniowych w wymiarze międzynarodowym towarzyszy jednocześnie proces dywergencji rynków regionalnych. Oznacza to, iż wraz $\mathrm{z}$ tendencją do ujednolicania sytuacji mieszkaniowej pomiędzy rynkami krajowymi następuje pogłębianie różnic między regionami. Można zatem mówić o swoistym dualizmie w rozwoju rynków mieszkaniowych. Dualizm ten obserwowany jest również w kontekście konwergencji gospodarczej. Badania w tym zakresie potwierdzają konwergencję między krajami UE przy dywergencji regionów w poszczególnych krajach [Cinzia, Núñez, Musmeci, Di Salvo, Pilati 2018; Jóźwik 2014; Lucian-Liviu 2016]. Przyczyn tego procesu upatruje się m.in. w konieczności wzrostu konkurencyjności regionów w następstwie swobody przepływu kapitału i zasobów ludzkich w ramach wspólnoty europejskiej. Regiony rozwinięte są w stanie lepiej sprostać tym wyzwaniom, w efekcie czego zwiększają dystans względem regionów mniej rozwiniętych [Martin 2005; Petrakos, Artelaris 2009]. Obserwowana i empirycznie potwierdzona polaryzacja gospodarcza regionów w ramach wielu krajów UE może stanowić wyjaśnienie dywergencji regionalnych rynków mieszkaniowych. Silne gospodarczo regiony najczęściej utrzymują w dłuższym horyzoncie swój potencjał rozwojowy i atrakcyjność inwestycyjną. Uwarunkowania te z kolei mają swoje przełożenie na sytuację mieszkaniową. Szybciej rozwijają się w związku z tym rynki regionalne, które oferują korzystniejsze perspektywy zawodowe dla mieszkańców, wykazują większą chłonność nowych inwestycji mieszkaniowych, oferują wyższą rentowność budownictwa mieszkaniowego.

\subsection{Konwergencja mieszkaniowa a problem nierówności społecznych}

\subsubsection{Kierunki zmian sytuacji mieszkaniowej gospodarstw domowych w różnych grupach dochodowych w latach 2007 i 2017}

Uzyskany obraz zmian zachodzących na europejskich rynkach mieszkaniowych i ich wpływu na sytuację mieszkaniową obywateli nie jest jednak kompletny. Zrealizowane badania odwołują się do terytorialnego (przestrzennego) wymiaru konwergencji, natomiast nie poruszają one sytuacji mieszkaniowej gospodarstw z uwzględnieniem ich statusu ekonomicznego, miejsca zamieszkania (miastowieś), kryterium wieku czy płci. Kwestie te natomiast są w obszarze zainteresowania polityki społecznej, a w jej ramach polityki mieszkaniowej. Generalnej 
tendencji poprawy standardu mieszkaniowego w krajach UE towarzyszą złożone problemy nierówności w dostępie do usługi mieszkaniowej pod względem zarówno ilościowym, jak i jakościowym.

Problem nierówności społeczno-gospodarczych i ich znaczenia dla rozwoju zaczął być dostrzegany w ostatnich latach i wywołał znaczący przyrost literatury analizującej to zagadnienie [Piketty, Saez 2013; Piketty 2015; Sen 2009; Atkinson 2013, Stiglitz 2006, 2012]. Zwrócono także uwagę na znaczenie nieruchomości, zarówno ziemi, jak i jednostek mieszkalnych, ale w rozumieniu bliskim ekonomii klasycznej. Podkreśla się, że należy badać nie tylko wpływ, jaki wywiera zmiana cen na rynku mieszkaniowym na majątek, ale także efekty zmian polityki mieszkaniowej w odniesieniu do realnych dochodów i szeroko rozumianego majątku wszystkich [Maclennan, Miao 2017, s. 136]. Oznacza to powrót problematyki mieszkalnictwa do zagadnień o charakterze makroekonomicznym - podziału, wzrostu i produkcyjności.

Systemy mieszkaniowe oddziałują na procesy ekonomiczne ze względu na przemiany kulturowe, globalizujący się świat, ale także poprzez cechy sobie tylko właściwe. Wzrost liczby ludzi mieszkających w miastach, postępująca koncentracja populacji w najatrakcyjniejszych lokalizacjach powodują wzrost popytu na usługi mieszkaniowe, popytu, który jest nieelastyczny cenowo. Podaż kapitału i pracy staje się coraz bardziej elastyczna, ale podaż powierzchni mieszkaniowych jest nieelastyczna w krótkim okresie. Wzrost popytu mieszkaniowego i powolna odpowiedź strony podażowej powodują wzrost cen szybszy niż wzrost dochodów. Jednakże interwencja państwa w zakresie pomocy mieszkaniowej staje się coraz mniejsza, samorząd lokalny (najczęściej) musi samodzielnie znaleźć rozwiązania. Sytuacja na lokalnym rynku mieszkaniowym może znajdować się pod wpływem zjawisk i procesów zlokalizowanych przestrzennie w innym miejscu (np. wycofywanie zagranicznego kapitału ze względu na kryzys gospodarczy w kraju inwestora). Wskazuje się na niebezpieczeństwo wzrostu luki między właścicielami a najemcami, ale także na spadek jakości życia tych gospodarstw domowych, które nie będąc zamożne, ale aspirując do bycia właścicielami, nie mają innego wyboru, jak tylko nabyć nieruchomości zlokalizowane w dużej odległości od centrum i o niskiej jakości, efekty tego mogą być znaczące dla lokalnych rynków pracy [Maclennan, Miao 2017, s. 142]. Różnica między najdynamiczniej rozwijającymi się miastami i ich rynkami mieszkaniowymi a miastami o niższym potencjale będzie wzrastać, wydaje się, że prowadzona lokalnie polityka mieszkaniowa w supermiastach nie będzie w stanie znaleźć rozwiązania dla rosnących problemów mieszkaniowych.

$\mathrm{W}$ celu zobrazowania różnicy w sytuacji mieszkaniowej gospodarstw domowych porównano obecną sytuację mieszkaniową w wybranych państwach UE $\mathrm{z}$ danymi z roku 2007. Podzielono gospodarstwa domowe na dwie grupy, pierwsza grupa to te, które uzyskują poniżej 60\% krajowej mediany ekwiwalentnego dochodu do dyspozycji, a druga to gospodarstwa, które uzyskują powyżej $60 \%$ krajowej mediany ekwiwalentnego dochodu do dyspozycji. Wybrano kilka wskaźników, 
aby unaocznić różnice w procesach występujących w obu grupach dochodowych. Rysunek 7.1 ilustruje zmiany, które zaszły w odniesieniu do grupy właścicieli.

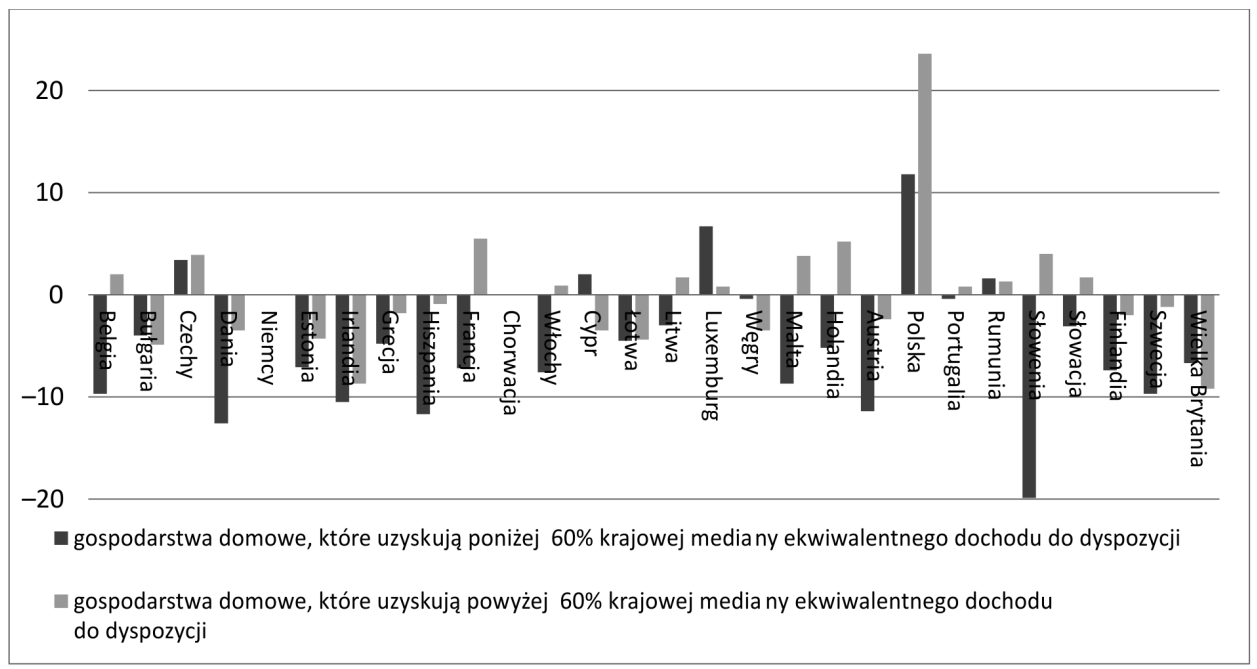

Rysunek 7.1. Różnica procentowa udziału właścicieli mieszkań (2007-2017)

Źródło: opracowanie własne na podstawie Housing Statistics Eurostat

Wyraźnie widoczne jest zmniejszenie udziału właścicieli przede wszystkim w grupie gospodarstw uzyskujących niższe dochody. Wyjątkiem są zmiany w Polsce, ponieważ w obu badanych grupach dochodowych znacząco wzrósł udział właścicieli. Nie dziwi odwrót od własności gospodarstw o mniejszych dochodach. Własność, w szczególności zużytego technicznie zasobu, może stanowić bardzo poważne obciążenie budżetu. Największy ubytek właścicieli w tej grupie dochodowej odnotować można w Słowenii, Danii, Hiszpanii i Austrii.

Badanie grupy najemców zasobu społecznego także wskazuje na poważne różnice pomiędzy poszczególnymi państwami - por. rys. 7.2.

Także w tym wypadku wyraźnie wyróżnia się Polska z bardzo silnym ubytkiem gospodarstw domowych korzystających z zasobu mieszkań społecznych. Duże zmniejszenie gospodarstw domowych w obu grupach dochodowych wystapiło jeszcze w Czechach. W Bułgarii, Estonii, Irlandii, na Łotwie, w Austrii i Słowenii zwiększyły się grupy użytkujących mieszkania społeczne, co ciekawe, w obu grupach dochodowych.

Przeciążenie kosztami mieszkaniowymi ${ }^{6}$ to kolejny wskaźnik, który można wykorzystać do zobrazowania różnic w sytuacji mieszkaniowej gospodarstw - por. rys. 7.3.

6 Przeciążenie kosztami mieszkaniowymi oznacza, że koszty mieszkaniowe przekraczały 40\% ekwiwalentnego dochodu do dyspozycji gospodarstwa domowego. 


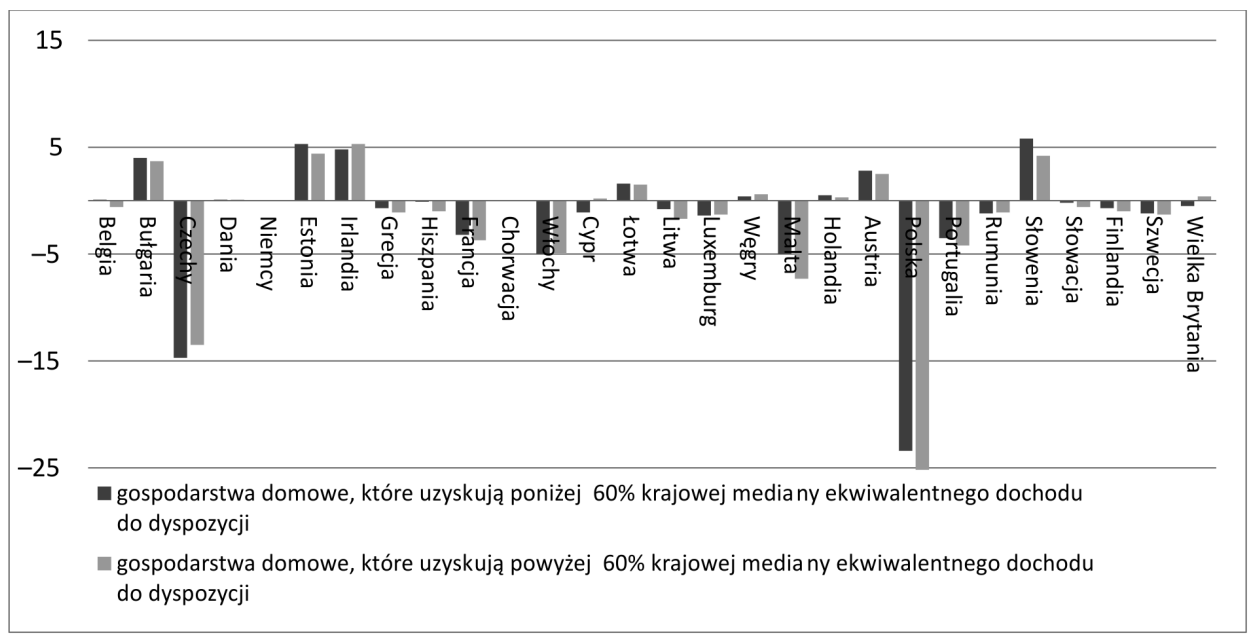

Rysunek 7.2. Różnica procentowa udziału najemców zasobu społecznego (2007-2017) Źródło: opracowanie własne na podstawie Housing Statistics Eurostat

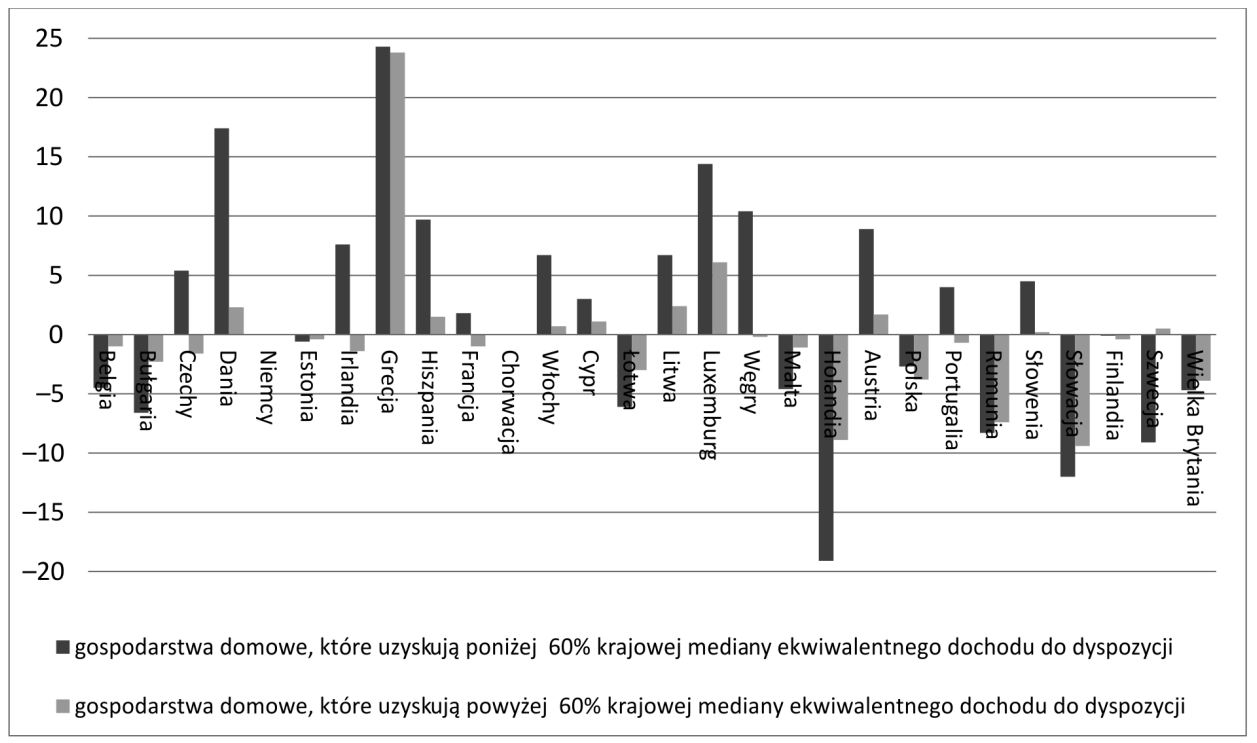

Rysunek 7.3. Różnica procentowa udziału gospodarstw domowych przeciążonych kosztami mieszkaniowymi (2007-2017) Źródło: opracowanie własne na podstawie Housing Statistics Eurostat

Problem przeciążenia kosztami mieszkaniowymi zwiększył się w grupie gospodarstw domowych o niższych dochodach w 14 państwach, poza Grecją największy przyrost zaobserwowano w Danii, Luksemburgu, na Węgrzech i w Hiszpanii. Pozytywne zmiany, czyli zmniejszenie liczby gospodarstw domowych przeciążonych 
kosztami domowymi, najsilniej uwidoczniły się w Holandii, Słowacji i Szwecji. W państwach „starej” UE w grupie gospodarstw domowych uzyskujących wyższe dochody sytuacja jest stabilna, z wyjątkiem przede wszystkim Grecji, w której bardzo wzrosła liczba gospodarstw domowych przeciążonych kosztami mieszkaniowymi.

Stan techniczny zasobu może być analizowany na podstawie wskaźnika poważnej deprywacji mieszkaniowej ${ }^{\top}$ - por. rys. 7.4.

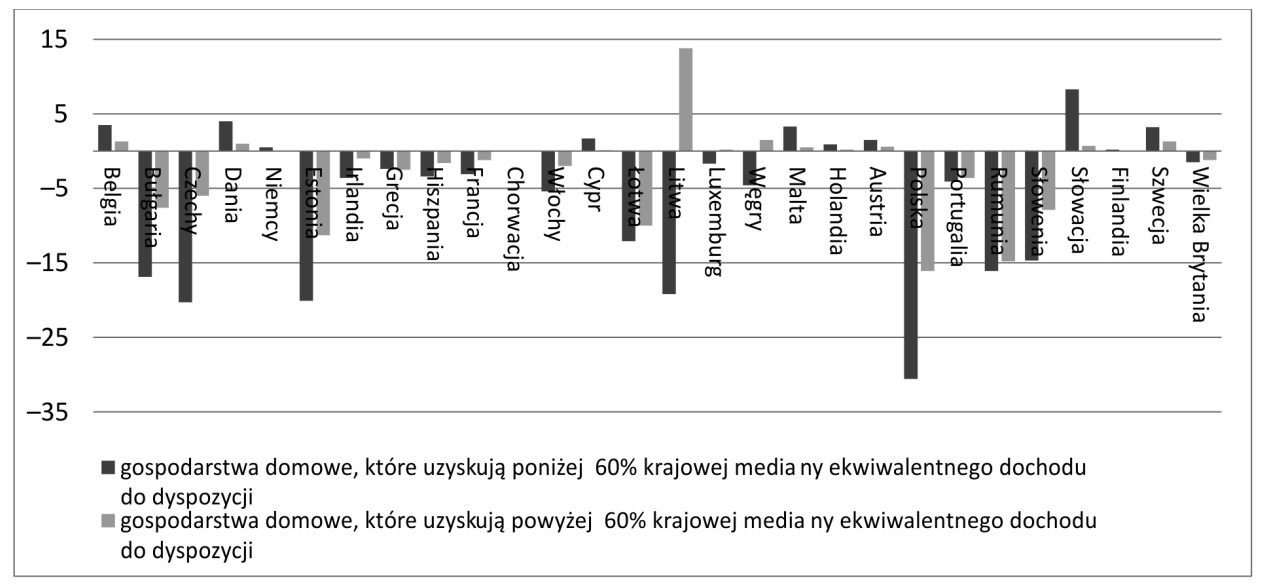

Rysunek 7.4. Różnica procentowa udziału gospodarstw domowych zamieszkujących w warunkach poważnej deprywacji mieszkaniowej (2007-2017)

Źródło: opracowanie własne na podstawie Housing Statistics Eurostat

Analiza zmian $\mathrm{w}$ zakresie poważnej deprywacji mieszkaniowej pozwala na stwierdzenie, że wyraźnie widoczna jest poprawa w grupie państw postsocjalistycznych, w szczególności w odniesieniu do warunków mieszkaniowych mniej zamożnych gospodarstw domowych. W państwach „starej” UE zmieniło się niewiele.

Ostatni wskaźnik, który wybrano do zilustrowania różnicy między latami 2007 i 2017 to przeludnienie mieszkań - por. rys. 7.5.

Podobnie jak w przypadku poprzedniego wskaźnika wyraźnie widoczny jest proces "gonienia” przez państwa postsocjalistyczne. Poprawa była najbardziej znacząca w Estonii, Czechach, Słowenii i na Litwie w odniesieniu do mniej zamożnych gospodarstw domowych, podobnie wyglądała grupa liderów wśród zamożniejszych gospodarstw domowych, zabrakło tam jedynie Czech.

Na podstawie tych przykładów można powiedzieć, że pewne procesy występują wyraźnie $w$ państwach postsocjalistycznych, ponieważ one starają się dorównać do standardów panujących w państwach „starej” UE. Natomiast problem przeciążenia kosztami mieszkaniowymi nie jest już tak prosty w interpretacji.

7 Definiuje się go jako odsetek osób zajmujących mieszkania uważane za przeludnione, w których dodatkowo występuje co najmniej jeden z problemów: brak łazienki lub toalety, nieszczelny dach lub niedoświetlenie mieszkania. 


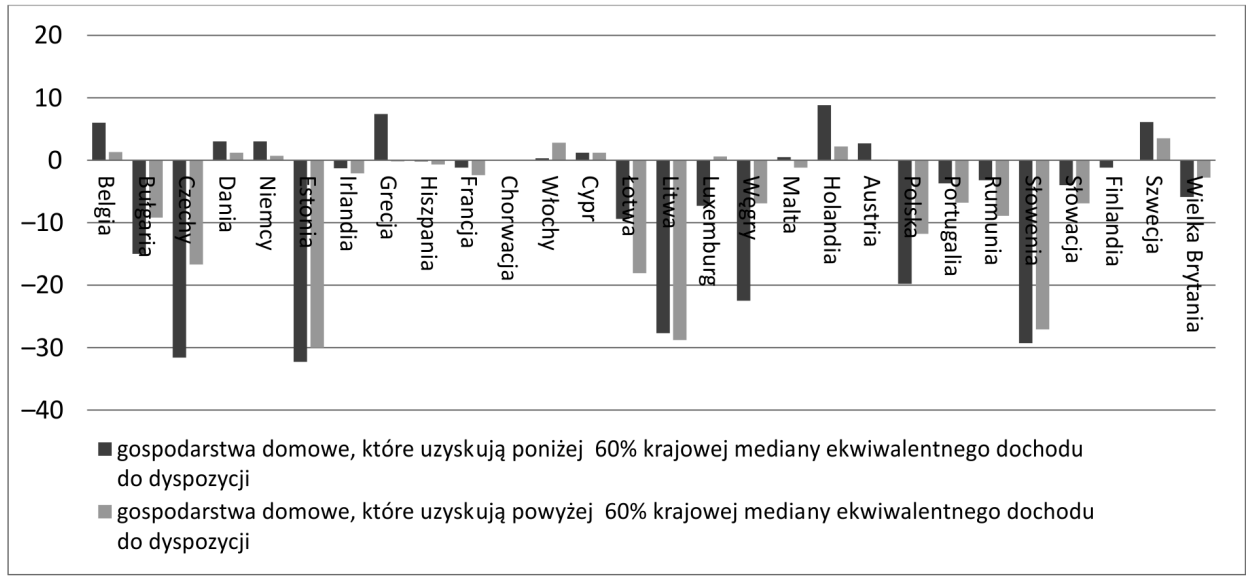

Rysunek 7.5. Różnica procentowa udziału gospodarstw domowych zamieszkujących w warunkach przeludnienia (2007-2017)

Źródło: opracowanie własne na podstawie Housing Statistics Eurostat

\subsubsection{Trendy w zakresie kosztów mieszkaniowych w różnych grupach dochodowych}

Badanie dostępności mieszkań w wybranych państwach UE realizowane na podstawie danych z lat 1995 i 2012 prowadzi do konkluzji, że w większości badanych krajów sytuacja właścicieli o niskich dochodach i najemców w prywatnych zasobach czynszowych pogorszyły się z upływem czasu w stosunku do grupy średniozamożnej i nie wynika to $\mathrm{z}$ oddziaływania globalnego kryzysu ekonomicznego [Dewilde, De Decker 2016]. Autorzy badania wskazują, że proces ten wynika z rosnącej finansjalizacji jednostek mieszkalnych i zmniejszenia podaży mieszkań czynszowych. Niestety, zmniejszenie dostępności mieszkań nie zostało zrekompensowane wzrostem jakości warunków mieszkaniowych.

W celu próby przewidywania zmian, jakie nastąpią, postanowiono zbadać trendy, które wystąpiły w państwach UE, w tym także postsocjalistycznych, w latach 2007-2017 w zakresie przeciążenia kosztami mieszkaniowymi (udział wydatków mieszkaniowych $40 \%$ i powyżej w budżecie gospodarstwa domowego). Grupę badaną podzielono na dwie kategorie - gospodarstwa domowe uzyskujące powyżej i poniżej $60 \%$ krajowej mediany ekwiwalentnego dochodu do dyspozycji. Przeprowadzona analiza pozwala na określenie trendów, które wystąpiły w badanych latach - por. tab. 7.3, rys. 7.6. 


\begin{tabular}{|c|c|c|c|c|c|c|c|c|c|}
\hline 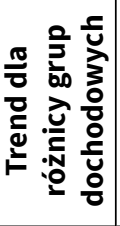 & $\stackrel{\sim}{\neg}$ & & 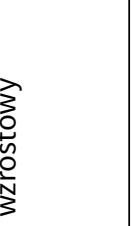 & & 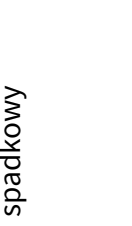 & & 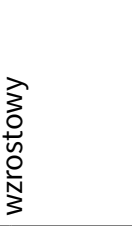 & & \\
\hline 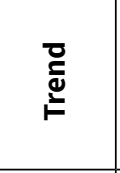 & 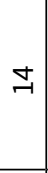 & 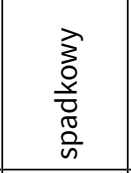 & 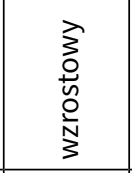 & 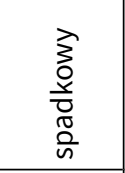 & 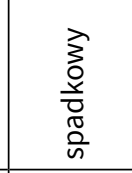 & 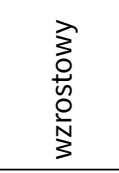 & 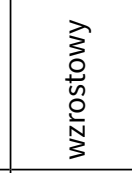 & 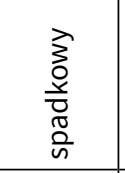 & 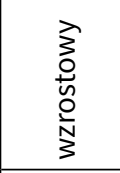 \\
\hline LIOZ & $\stackrel{m}{-}$ & $\stackrel{\infty}{+}$ & $\stackrel{\infty}{m}$ & $\stackrel{m}{\sim}$ & $\begin{array}{l}\dot{+} \\
\vec{m}\end{array}$ & $\stackrel{\forall}{\sigma}$ & $\begin{array}{l}\text { ने } \\
\text { مी }\end{array}$ & $\vec{~}$ & $\begin{array}{l}\stackrel{f}{f} \\
\stackrel{f}{*}\end{array}$ \\
\hline 9I0Z & $\underset{\Im}{\Im}$ & $\stackrel{m}{n}$ & N & $\stackrel{m}{\sim}$ & $\begin{array}{l}\dot{0} \\
\hat{m}\end{array}$ & $\begin{array}{l}\sigma_{0} \\
\stackrel{-}{1}\end{array}$ & $\begin{array}{l}m \\
\text { in }\end{array}$ & $\hat{\kappa}$ & $\begin{array}{r}\dot{f} \\
\dot{f}\end{array}$ \\
\hline SI0Z & $\exists$ & $\underset{\omega}{\mathscr{N}}$ & $\begin{array}{l}\text { m. } \\
\text { गे }\end{array}$ & $\stackrel{n}{\sim}$ & $\begin{array}{l}\dot{0} \\
\hat{m}\end{array}$ & $\vec{\sigma}_{0}$ & $\begin{array}{l}\mathscr{v} \\
\dot{f}\end{array}$ & $\tilde{m}^{-}$ & $\stackrel{\infty}{q}$ \\
\hline troz & 욱 & $\hat{\text { ஸे }}$ & ָ̃ & $\stackrel{\sim}{\sim}$ & $\begin{array}{l}\underset{f}{\tilde{y}} \\
\text {. }\end{array}$ & స̂. & $\stackrel{+}{+}$ & $\overbrace{0}$ & $\begin{array}{l}\vec{f} \\
\dot{f}\end{array}$ \\
\hline EI0乙 & $a$ & $\begin{array}{l}\infty \\
\text { ஸn }\end{array}$ & $\stackrel{\infty}{\stackrel{\infty}{m}}$ & $\stackrel{\forall}{\forall}$ & 㝏 & $\stackrel{\Omega}{N}$ & $\begin{array}{l}\stackrel{\llcorner}{\infty} \\
\text { po }^{0}\end{array}$ & $\stackrel{g}{N}$ & $\begin{array}{l}0 \\
\text { जे }\end{array}$ \\
\hline zLoz & $\infty$ & $\stackrel{n}{n}$ & $\stackrel{\sim}{\infty}$ & $\vec{H}$ & 寸 & 6 & $\mathscr{f}$ & $\tilde{\sigma}$ & $\begin{array}{c}m \\
\hat{\sigma}^{-}\end{array}$ \\
\hline II0Z & $\sim$ & 6 & $\stackrel{\infty}{m}$ & $\stackrel{\infty}{+}$ & $\hat{\tilde{F}}$ & $\stackrel{\sigma}{m}$ & $\stackrel{\infty}{\stackrel{\infty}{\sim}}$ & ڤ̊ & $\underset{\mathfrak{f}}{\stackrel{f}{f}}$ \\
\hline oroz & 6 & ผn & 点 & $\nabla$ & $\stackrel{\text { S}}{\text { N }}$ & $\stackrel{\sim}{\sim}$ & î & $\hat{\omega}$ & $\stackrel{\sigma^{\prime}}{\sigma}$ \\
\hline $600 z$ & $n$ & เก & $\begin{array}{l}\text { Ln } \\
\stackrel{\mathrm{m}}{ }\end{array}$ & $\stackrel{\sigma}{m}$ & in & $\stackrel{m}{i}$ & $\stackrel{\infty}{\sim}$ & $\stackrel{\infty}{\infty}$ & $\mathscr{\vartheta}$ \\
\hline $800 z$ & $\nabla$ & ثิ & $\begin{array}{l}\stackrel{N}{\tilde{m}} \\
\stackrel{m}{n}\end{array}$ & 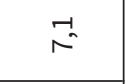 & F & $\infty$ & $\underset{\tilde{m}}{\mathbf{m}}$ & $\stackrel{m}{\sigma}$ & 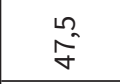 \\
\hline $200 z$ & $m$ & બ) & $\begin{array}{l}\dot{f}_{0} \\
\text {. }\end{array}$ & L & $\begin{array}{l}\text { a } \\
\text { p}^{n}\end{array}$ & $\underset{F}{m}$ & $\hat{\hat{6}}$ & $\stackrel{m}{N}$ & $\begin{array}{l}\infty \\
\infty^{n}\end{array}$ \\
\hline $\begin{array}{l}\text { õ } \\
\text { o } \\
0 \\
0 \\
0\end{array}$ & $\sim$ & 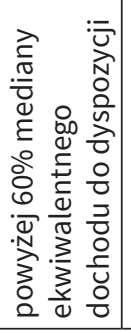 & 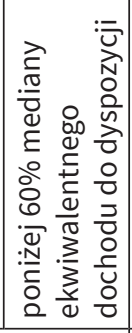 & 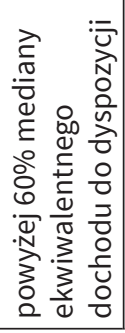 & 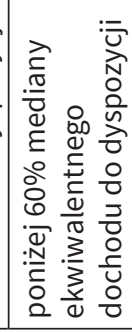 & 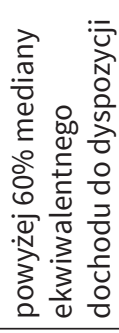 & 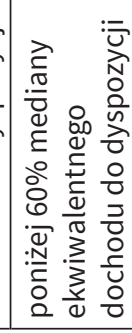 & 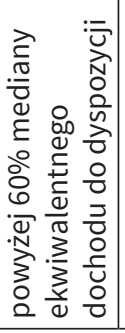 & 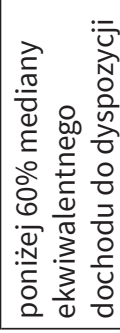 \\
\hline 节 & -1 & \multicolumn{2}{|c|}{ 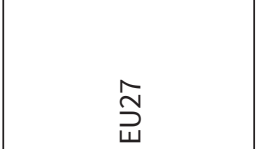 } & \multicolumn{2}{|c|}{$\frac{\frac{\pi}{00}}{\frac{0}{\infty}}$} & \multicolumn{2}{|c|}{ 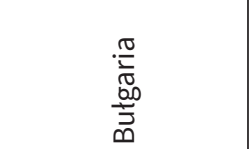 } & \multicolumn{2}{|c|}{$\begin{array}{l}\text { 离 } \\
\text { N }\end{array}$} \\
\hline
\end{tabular}




\begin{tabular}{|c|c|c|c|c|c|c|c|c|c|c|}
\hline$\stackrel{\sim}{\sim}$ & & 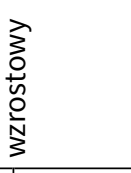 & & 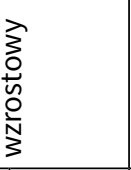 & & 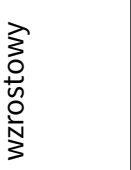 & & 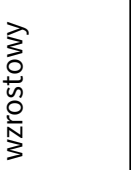 & & 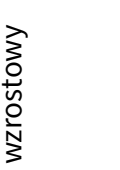 \\
\hline$\underset{J}{\Delta}$ & 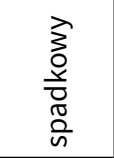 & 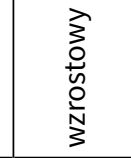 & 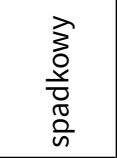 & 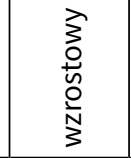 & 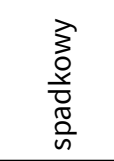 & 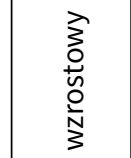 & 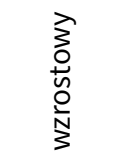 & 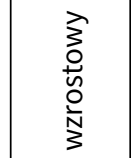 & 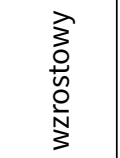 & 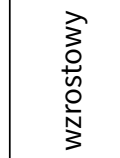 \\
\hline$\stackrel{m}{\rightarrow}$ & $\underset{N}{\Delta}$ & $\stackrel{\forall}{\stackrel{\leftarrow}{N}}$ & $\stackrel{\Omega}{\sim}$ & $\begin{array}{l}\stackrel{1}{0} \\
\stackrel{\infty}{+}\end{array}$ & $\Rightarrow$ & $\begin{array}{c}+ \\
\stackrel{\infty}{-1}\end{array}$ & $\hat{\imath}$ & बे & $\begin{array}{l}\infty \\
\dot{\omega}^{-}\end{array}$ & $\hat{\infty}$ \\
\hline$\underset{\neg}{\sim}$ & $\stackrel{-1}{N}$ & $\stackrel{N}{N}$ & 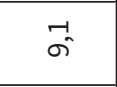 & $\begin{array}{l}m \\
\text { on }\end{array}$ & g. & $\begin{array}{l}m \\
\text { g్ }\end{array}$ & $\hat{\overbrace{}}$ & $\begin{array}{l}0 \\
\infty^{-} \\
-1\end{array}$ & $\hat{\tilde{\omega}}$ & बे \\
\hline$\exists$ & $\stackrel{\mathscr{\Omega}}{N}$ & $\begin{array}{l}\infty \\
\hat{\theta}^{n}\end{array}$ & $\stackrel{+}{+}$ & $\stackrel{\sigma}{\hat{n}}$ & $\underset{-}{6}$ & $\stackrel{\infty}{\stackrel{\infty}{N}}$ & $\sim$ & $\underset{\infty}{\stackrel{N}{-1}}$ & $\underset{\sim}{\tilde{m}}$ & ठே \\
\hline 욱 & $\begin{array}{l}\Omega^{n} \\
\infty\end{array}$ & $\begin{array}{l}\overrightarrow{1} \\
0 \\
0\end{array}$ & $m_{\infty}^{m}$ & $\begin{array}{l}\forall \\
\stackrel{\forall}{n}\end{array}$ & $\sim$ & $\begin{array}{l}\infty \\
\tilde{m}^{\circ}\end{array}$ & $\underset{\sim}{\sim}$ & $\stackrel{-}{\sim}$ & $\stackrel{\sim}{m}$ & $\stackrel{m}{m}$ \\
\hline$\sigma$ & $\stackrel{N}{O}$ & $\stackrel{\sim}{n}$ & ت- & ్ & 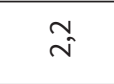 & ڤે & $\underset{-}{\sigma}$ & $\vec{d}$ & $\begin{array}{l}\text { बे } \\
\text { gे }\end{array}$ & $\vec{m}$ \\
\hline$\infty$ & $\stackrel{n}{\circ}$ & ஓे & के & $\hat{n}$ & $\underset{\sim}{0}$ & $\stackrel{\vec{j}}{\stackrel{m}{n}}$ & $\stackrel{\sim}{\sim}$ & $\begin{array}{c}m \\
\mathfrak{m}^{-}\end{array}$ & $\begin{array}{l}\infty \\
\stackrel{\infty}{n}\end{array}$ & ณn \\
\hline$\sim$ & $\stackrel{m}{\exists}$ & $\vec{r}$ & ñ & $\begin{array}{l}m \\
\mathfrak{g}^{\prime}\end{array}$ & $\stackrel{\infty}{\sim}$ & $\begin{array}{l}\text { ஸू } \\
\text { จे }\end{array}$ & $\stackrel{m}{\sim}$ & $\stackrel{m}{\sim}$ & $\dot{\sigma}_{n}$ & 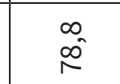 \\
\hline$\bullet$ & $\underset{+}{\stackrel{J}{J}}$ & $\vec{i}$ & $\stackrel{\sigma}{\sigma}$ & $\underset{\mathscr{F}}{\mathscr{f}}$ & $\underset{\sim}{\sim}$ & ్ֶ & $\hat{\imath}$ & $\vec{\sim}$ & นn & $\hat{\tilde{\sigma}}$ \\
\hline เ & $\underset{\sim}{\stackrel{N}{\sim}}$ & $\begin{array}{l}\text { L } \\
\stackrel{2}{2}\end{array}$ & فبْه & فنه & $\stackrel{\infty}{\rightarrow-1}$ & 桴 & $\underset{r}{6}$ & $\begin{array}{l}m \\
\stackrel{m}{\sim}\end{array}$ & $\begin{array}{l}0 \\
\text { O- }\end{array}$ & స̃ \\
\hline$\nabla$ & $\underset{\exists}{ન}$ & $\hat{8}$ & فنه & فْذْ & $\stackrel{m}{\rightarrow}$ & $\stackrel{-}{m}$ & $\hat{\imath}$ & $\underset{\sim}{\sim}$ & $\stackrel{m}{ન}$ & $\begin{array}{l}0 \\
\text { ஸी }\end{array}$ \\
\hline$m$ & $\stackrel{n}{N}$ & $\stackrel{\infty}{\llcorner}$ & فنه & فْهْ & $\stackrel{\mathscr{q}}{\rightarrow}$ & 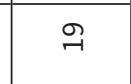 & $\underset{\sim}{\sim}$ & $\underset{\sim}{\sim}$ & $\stackrel{\sim}{m}$ & $\stackrel{+}{0}$ \\
\hline$N$ & 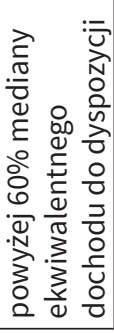 & 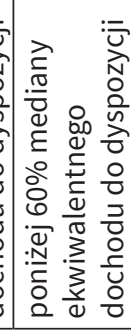 & 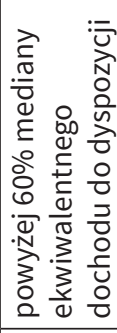 & 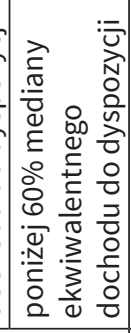 & 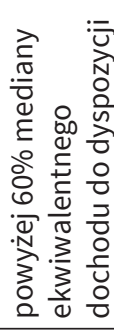 & 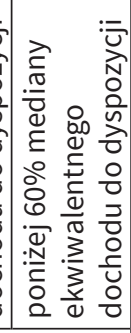 & 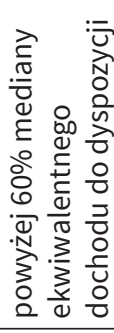 & 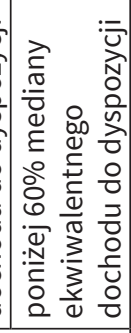 & 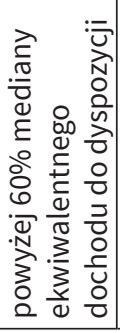 & 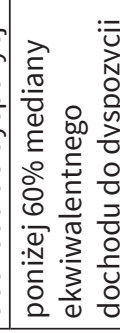 \\
\hline-1 & \multicolumn{2}{|c|}{$\begin{array}{l}\frac{\pi}{\pi} \\
\frac{\pi}{\pi} \\
D\end{array}$} & \multicolumn{2}{|c|}{$\begin{array}{l}\widehat{\circlearrowright} \\
\frac{\vec{\omega}}{2}\end{array}$} & \multicolumn{2}{|c|}{ 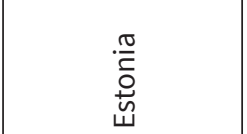 } & \multicolumn{2}{|c|}{$\begin{array}{l}\frac{0}{0} \\
\frac{0}{C} \\
\underline{\underline{T}} \\
\underline{\underline{I}}\end{array}$} & \multicolumn{2}{|c|}{$\begin{array}{l}\frac{\pi}{\widetilde{U}} \\
\frac{\mathbb{U}}{0}\end{array}$} \\
\hline
\end{tabular}




\begin{tabular}{|c|c|c|c|c|c|c|c|c|c|c|}
\hline \multicolumn{3}{|c|}{ 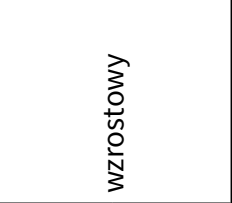 } & \multicolumn{2}{|r|}{ 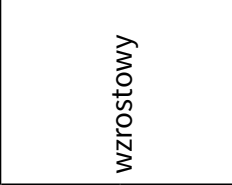 } & \multicolumn{2}{|c|}{ 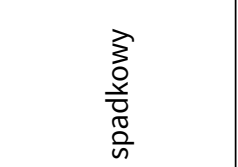 } & \multicolumn{2}{|r|}{ 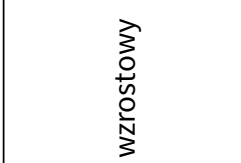 } & \multicolumn{2}{|c|}{ 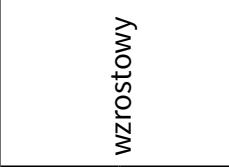 } \\
\hline 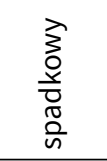 & & 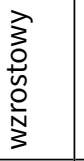 & 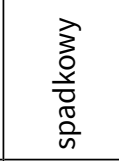 & \begin{tabular}{l}
3 \\
\multirow{3}{3}{} \\
ஸे \\
N \\
N
\end{tabular} & $\begin{array}{l}\text { 3े } \\
0 \\
0 \\
0 \\
0 \\
0 \\
0 \\
\text { n. }\end{array}$ & 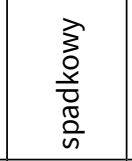 & 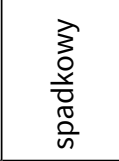 & 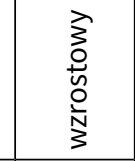 & 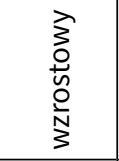 & 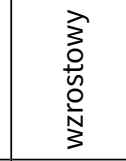 \\
\hline$\stackrel{n}{\sim}$ & & $\begin{array}{l}\tilde{L}^{\prime} \\
\hat{e}^{\circ}\end{array}$ & $\stackrel{+}{i}$ & 离 & $\tilde{0}$ & $\stackrel{\sim}{\mathscr{W}}$ & $\stackrel{\overbrace{}}{\rightarrow}$ & & $\stackrel{+}{-}$ & $\begin{array}{c}m \\
0 \\
0 \\
-1\end{array}$ \\
\hline$\stackrel{\mathscr{0}}{i}$ & & $\begin{array}{c}+ \\
\stackrel{0}{0}\end{array}$ & $\stackrel{n}{\sim}$ & 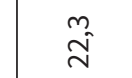 & -1 & $\stackrel{\nabla}{\stackrel{\nabla}{N}}$ & $\hat{i}$ & $\stackrel{\infty}{\tilde{m}^{n}}$ & $\stackrel{m}{\rightarrow}$ & $\stackrel{0}{\tilde{\tau}}$ \\
\hline$\stackrel{n}{\sim}$ & & $\stackrel{-1}{\infty}$ & $\stackrel{\sim}{m}$ & $\stackrel{n}{n}$ & $\stackrel{m}{\rightarrow}$ & $\vec{m}$ & $\stackrel{n}{\sim}$ & $\underset{\sim}{\tilde{m}}$ & 年 & $\stackrel{-}{m}$ \\
\hline$\hat{i}$ & & $\begin{array}{l}0 \\
\stackrel{\text { Iे }}{ }\end{array}$ & $\hat{i}$ & $\begin{array}{l}\text { क् } \\
\text { on }\end{array}$ & $\underset{\sim}{\sim}$ & ஓ & $\stackrel{\stackrel{a}{\sim}}{\sim}$ & $\stackrel{\vec{m}}{\vec{m}}$ & $\stackrel{\sim}{\sim}$ & $\stackrel{+}{\underset{J}{J}}$ \\
\hline$\stackrel{\sim}{m}$ & & $\stackrel{m}{\tilde{m}^{\circ}}$ & $\stackrel{+}{\sim}$ & $\stackrel{\vec{N}}{\sim}$ & $\stackrel{-1}{\sim}$ & $\begin{array}{l}\infty \\
\text { fे }\end{array}$ & $\stackrel{m}{m}$ & ָ̃ & $\stackrel{\infty}{\rightarrow}$ & $\stackrel{n}{\sim}$ \\
\hline$m$ & & 우 & $\stackrel{+}{i}$ & $\stackrel{\sim}{\mathfrak{N}}$ & $\stackrel{m}{\rightarrow}$ & $\stackrel{\text { L }}{\infty^{0}}$ & $\stackrel{\infty}{\sim}$ & ने & $\underset{-}{0}$ & $\stackrel{\text { }}{\stackrel{\sim}{\ddots}}$ \\
\hline$\stackrel{m}{m}$ & & $\stackrel{\infty}{\hat{m}^{n}}$ & $\stackrel{n}{\sim}$ & $\tilde{\mathbb{N}}$ & $\stackrel{\infty}{\rightarrow}$ & $\tilde{m}$ & $\stackrel{\text { q }}{\sim}$ & के & $\stackrel{\infty}{\rightarrow}$ & $\begin{array}{l}\text { L } \\
\text { O̊ }\end{array}$ \\
\hline$m$ & & Nૂ & $\stackrel{\sim}{\sim}$ & $\stackrel{\vec{N}}{\tilde{N}}$ & N) & $\stackrel{+}{\stackrel{\sigma}{+}}$ & $\stackrel{0}{\sim}$ & $\hat{\text { Nิ }}$ & $\underset{-1}{\sigma}$ & $\begin{array}{l}\text { O् } \\
\text { - }\end{array}$ \\
\hline$\nabla$ & & $\stackrel{\sim}{\stackrel{N}{m}}$ & $\stackrel{+}{i}$ & $\begin{array}{l}\stackrel{g}{+} \\
\stackrel{-}{-}\end{array}$ & فْذّ & نهّ & $\stackrel{m}{m}$ & $\begin{array}{l}0 \\
\stackrel{N}{N}\end{array}$ & $\Rightarrow$ & $\hat{\sigma}$ \\
\hline$\stackrel{\infty}{m}$ & & 点 & $\stackrel{\bullet}{i}$ & $\begin{array}{l}0 \\
\stackrel{\sim}{\sim}\end{array}$ & فْذّ & فنه & $\stackrel{\infty}{m}$ & $\underset{\sim}{\stackrel{\Delta}{N}}$ & $\neg$ & 6 \\
\hline$\stackrel{\infty}{m}$ & & $\begin{array}{l}\infty \\
\hat{\sigma}^{0}\end{array}$ & $\stackrel{\infty}{m}$ & 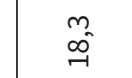 & فْذْ & فنّ & $m$ & $\underset{\sim}{\mathscr{\omega}}$ & $\hat{0}$ & $\stackrel{m}{r}$ \\
\hline 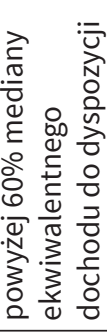 & 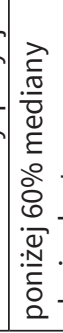 & 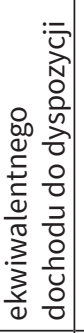 & 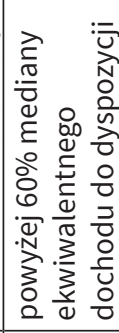 & 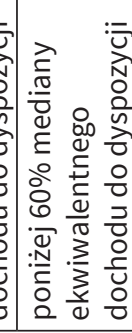 & 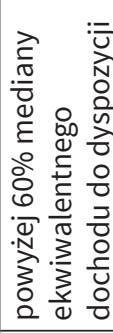 & 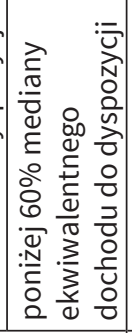 & 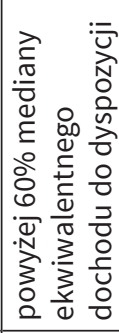 & 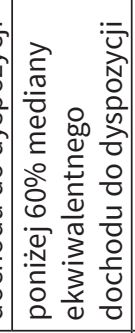 & 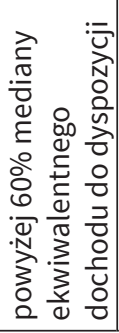 & 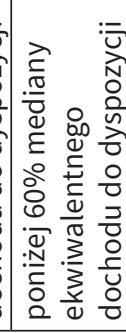 \\
\hline & 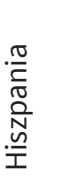 & & & 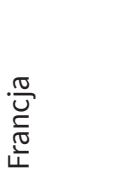 & & 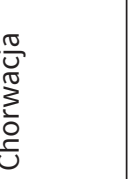 & & $\begin{array}{l}\text { ते } \\
\text { 울 } \\
\frac{3}{3}\end{array}$ & & 亨 \\
\hline
\end{tabular}




\begin{tabular}{|c|c|c|c|c|c|c|c|c|c|c|}
\hline$\stackrel{2}{\sim}$ & & 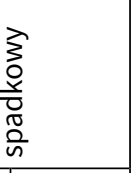 & & 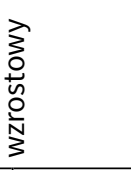 & & 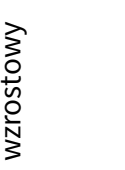 & & 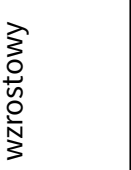 & & 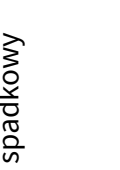 \\
\hline 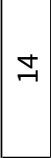 & 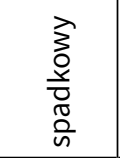 & $\begin{array}{l}\overrightarrow{3} \\
0 \\
0 \\
0 \\
0 \\
0 \\
0 \\
\text { n }\end{array}$ & $\begin{array}{l}\sum_{0}^{>} \\
\text {जू } \\
0 \\
\frac{N}{N} \\
3\end{array}$ & 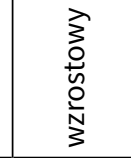 & 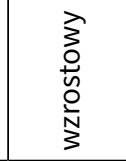 & \begin{tabular}{l} 
o \\
0 \\
\multirow{2}{*}{} \\
0 \\
$\frac{0}{N}$ \\
3
\end{tabular} & 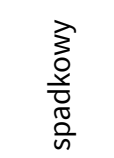 & 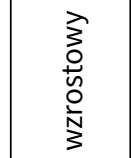 & 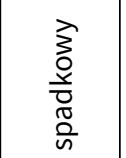 & 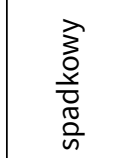 \\
\hline$\stackrel{m}{\rightarrow}$ & $\stackrel{0}{\rightarrow}$ & $\stackrel{0}{\stackrel{0}{\sim}}$ & $\underset{f-}{m}$ & $\begin{array}{l}\infty \\
\stackrel{0}{0}\end{array}$ & $\stackrel{\varphi}{m}$ & $\underset{m}{+}$ & $\stackrel{\sim}{*}$ & $\stackrel{\nabla}{\sigma}$ & $\stackrel{\bullet}{0}$ & $\begin{array}{l}6 \\
\omega\end{array}$ \\
\hline$\underset{\neg}{\sim}$ & $\underset{\rightarrow}{\sigma}$ & $\stackrel{\sim}{\stackrel{N}{N}}$ & $\hat{\imath}$ & $\begin{array}{l}\text { Oे } \\
\text { 尺े }\end{array}$ & $\nabla$ & $\stackrel{N}{\stackrel{N}{m}}$ & $\stackrel{\sim}{F}$ & 穴 & $\stackrel{\bullet}{0}$ & $\hat{\text { மे }}$ \\
\hline$\exists$ & $m$ & ڤ్ & $\stackrel{n}{\sim}$ & $\underset{\tilde{m}}{\tilde{N}}$ & $\stackrel{-1}{\sim}$ & $\stackrel{\Omega}{\stackrel{N}{N}}$ & $\stackrel{n}{\sim}$ & $\stackrel{n}{\vec{m}}$ & $\sigma_{0}$ & $\stackrel{\infty}{+}$ \\
\hline 욱 & $\stackrel{n}{m}$ & $\stackrel{\sim}{\tilde{m}}$ & $\widetilde{N}$ & $\underset{\sim}{\stackrel{\Delta}{N}}$ & $\stackrel{-1}{\sim}$ & $\begin{array}{l}\text { oे } \\
\text { के }\end{array}$ & $\tilde{\infty}^{m}$ & $\stackrel{+}{\infty}$ & $\begin{array}{l}\infty \\
0\end{array}$ & $\begin{array}{l}\infty \\
\omega^{-}\end{array}$ \\
\hline$\sigma$ & L & $\stackrel{\sim}{\infty}$ & $\stackrel{\sim}{\sim}$ & $\begin{array}{l}\infty \\
\stackrel{\infty}{N}\end{array}$ & $\stackrel{\infty}{\rightarrow-1}$ & $\stackrel{\sigma}{\sim}$ & $\hat{\sigma}$ & $\hat{o}$ & $\begin{array}{l}\infty \\
0^{-}\end{array}$ & $\underset{F}{\approx}$ \\
\hline$\infty$ & Ln & $\stackrel{\text { ŝ }}{m}$ & $\stackrel{m}{m}$ & $\hat{m}$ & $\stackrel{n}{\rightarrow}$ & $\stackrel{\sim}{\sim}$ & $\begin{array}{l}0 \\
\stackrel{-}{-1}\end{array}$ & $\begin{array}{l}\infty \\
\infty_{m}^{-}\end{array}$ & $\neg$ & $\begin{array}{l}\stackrel{g}{1} \\
\Rightarrow\end{array}$ \\
\hline$\sim$ & $\begin{array}{l}0 \\
\sigma^{-}\end{array}$ & $\begin{array}{l}\sigma_{n} \\
\stackrel{n}{m}\end{array}$ & $\stackrel{\infty}{+}$ & $\stackrel{\infty}{m}$ & $\stackrel{-}{\rightarrow}$ & $\begin{array}{l}\tilde{N} \\
\stackrel{\sim}{v}\end{array}$ & $\begin{array}{l}\operatorname{Ln}^{\prime} \\
\infty\end{array}$ & $\begin{array}{l}0 \\
\dot{q}\end{array}$ & $\underset{r}{+}$ & $\begin{array}{l}0 \\
\because \\
\Rightarrow\end{array}$ \\
\hline$\bullet$ & $\nabla$ & $\begin{array}{l}\stackrel{\sigma}{m} \\
\vec{m}\end{array}$ & $\stackrel{\forall}{m}$ & $\stackrel{n}{\infty^{\circ}}$ & $\underset{-}{+}$ & $\begin{array}{l}\stackrel{+}{d} \\
\stackrel{\sim}{*}\end{array}$ & $\hat{\kappa}$ & $\hat{\tilde{m}}$ & $\stackrel{\mathscr{G}}{\rightarrow}$ & $\stackrel{m}{m}$ \\
\hline n & $\stackrel{n}{\sim}$ & $\begin{array}{l}\stackrel{n}{\infty} \\
\stackrel{\sim}{N}\end{array}$ & $\stackrel{\infty}{\rightarrow}$ & $\begin{array}{l}\text { ma } \\
\stackrel{\sim}{n}\end{array}$ & $-r$ & N & เ & $\stackrel{m}{m}$ & $\stackrel{n}{r}$ & $\begin{array}{l}0 \\
\stackrel{0}{-1}\end{array}$ \\
\hline$\nabla$ & $\stackrel{m}{\sim}$ & $\stackrel{-1}{\sim}$ & -1 & त) & $\Rightarrow$ & $\hat{\circ}$ & $\stackrel{m}{\sim}$ & $\stackrel{\llcorner}{\sim} \underset{f}{f}$ & $\underset{-}{6}$ & $\underset{\sim}{\stackrel{\sim}{\sim}}$ \\
\hline$m$ & $\stackrel{-}{\sigma}$ & $\hat{\bar{m}}$ & 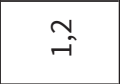 & مै & -1 & $\stackrel{\sim}{\sim}$ & $\sim$ & 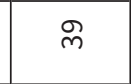 & $\Rightarrow$ & $\stackrel{N}{O}$ \\
\hline$N$ & 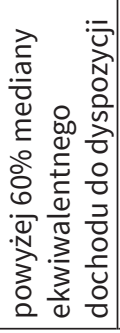 & 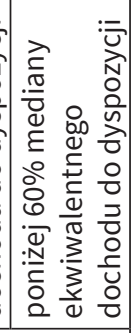 & 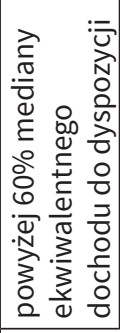 & 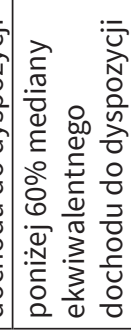 & 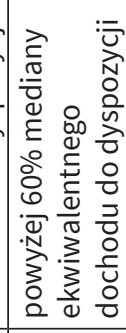 & 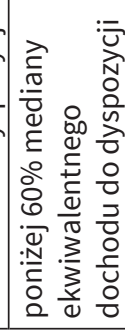 & 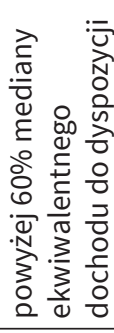 & 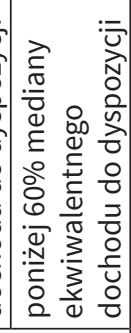 & 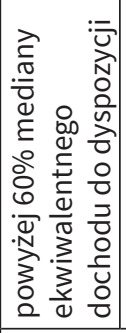 & 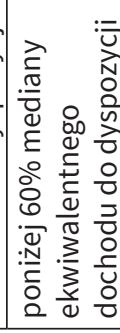 \\
\hline-1 & \multicolumn{2}{|c|}{ 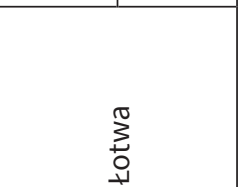 } & \multicolumn{2}{|r|}{$\sum_{\underline{J}}^{0}$} & \multicolumn{2}{|r|}{ 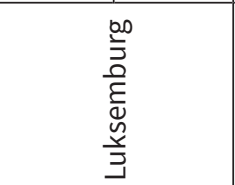 } & \multicolumn{2}{|c|}{$\begin{array}{l}\stackrel{\vec{\nu}}{\Delta 0} \\
\stackrel{\Delta}{3}\end{array}$} & \multicolumn{2}{|c|}{$\frac{\stackrel{\mathbb{\pi}}{ \pm}}{\sum}$} \\
\hline
\end{tabular}


212 Ocena przebiegu konwergencji mieszkaniowej i jej efektów

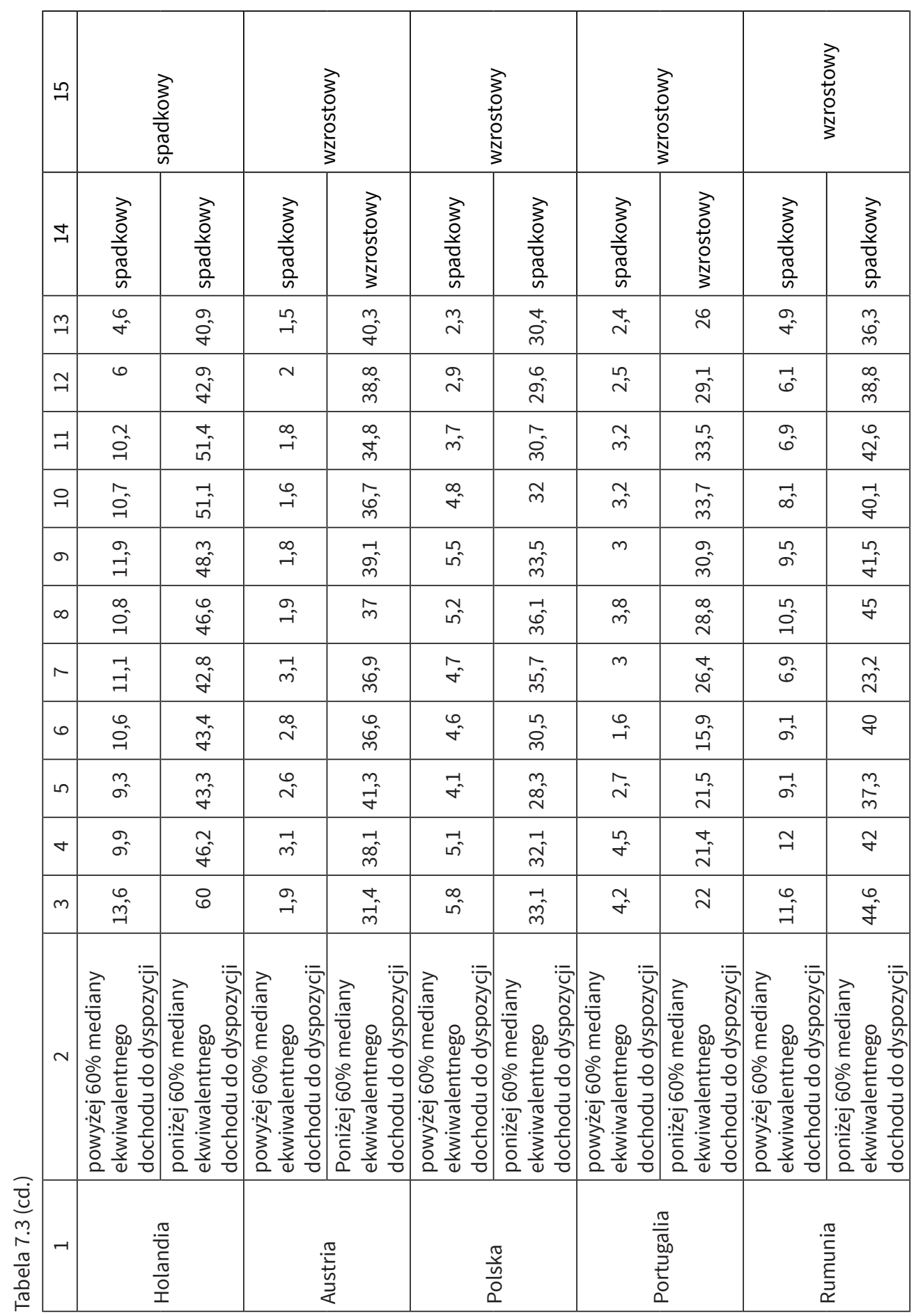




\begin{tabular}{|c|c|c|c|c|c|c|c|c|c|c|}
\hline$\stackrel{\sim}{\sim}$ & & $\begin{array}{l}\sum_{0} \\
\frac{0}{4} \\
0 \\
\text { N } \\
3\end{array}$ & & $\begin{array}{l}3 \\
3 \\
0 \\
\text { Oे } \\
\frac{1}{N} \\
3\end{array}$ & & 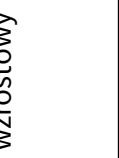 & & 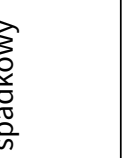 & & 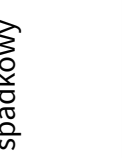 \\
\hline$\vec{J}$ & 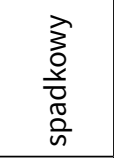 & 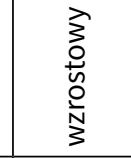 & 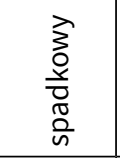 & $\begin{array}{l}3 \\
3 \\
0 \\
0 \\
0 \\
0 \\
0 \\
n\end{array}$ & $\begin{array}{l}3 \\
\vdots \\
0 \\
\text { N } \\
\text { N } \\
3\end{array}$ & 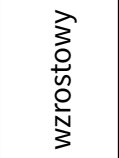 & 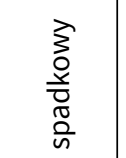 & 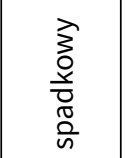 & $\begin{array}{l}3 \\
3 \\
0 \\
0 \\
0 \\
0 \\
0 \\
0 \\
n\end{array}$ & 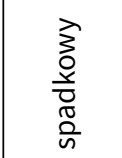 \\
\hline$\stackrel{m}{\rightarrow}$ & $\underset{-}{\stackrel{\sigma}{-1}}$ & $\hat{\tilde{\omega}}$ & $\stackrel{-1}{\circ}$ & $\begin{array}{l}\stackrel{\sigma}{1} \\
\text { ô }\end{array}$ & $\stackrel{\sim}{\sim}$ & 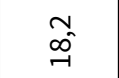 & $\hat{i}$ & $\begin{array}{l}\infty \\
\infty^{0}\end{array}$ & $\mathscr{\sigma}_{0}$ & $\begin{array}{l}\infty \\
\text { of } \\
q\end{array}$ \\
\hline$\underset{\sim}{\sim}$ & $\sim$ & 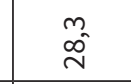 & $\hat{m}$ & $\begin{array}{l}\stackrel{0}{m} \\
\stackrel{m}{n}\end{array}$ & $\stackrel{+}{i}$ & $\begin{array}{l}\text { مी } \\
\text { ने }\end{array}$ & 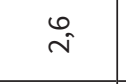 & $\hat{\tilde{m}^{0}}$ & $\begin{array}{l}\dot{0} \\
\dot{\sigma}^{-}\end{array}$ & \begin{tabular}{l}
\multirow{f}{*}{} \\
Tे
\end{tabular} \\
\hline$\exists$ & $\stackrel{0}{\sim}$ & $\hat{\sim}$ & $\stackrel{\sim}{n}$ & $\begin{array}{l}n \\
\stackrel{m}{m}\end{array}$ & $\hat{\sim}$ & $\stackrel{+}{\stackrel{+}{0}}$ & $\stackrel{0}{\sim}$ & बे & $\mathscr{\sigma}^{-}$ & 우 \\
\hline 욱 & $\stackrel{0}{\sim}$ & $\stackrel{\nabla}{\stackrel{\nabla}{2}}$ & जी & $\dot{\sigma}_{\hat{m}}$ & $\stackrel{\infty}{\sim}$ & $\underset{N}{N}$ & $\stackrel{n}{\sim}$ & $\stackrel{m}{\underset{f}{\sim}}$ & $\hat{6}$ & $\hat{\vec{f}}$ \\
\hline$a$ & $\stackrel{0}{\sim}$ & $\begin{array}{l}\text { m } \\
\hat{\omega}^{-}\end{array}$ & $\stackrel{\sim}{\sim}$ & 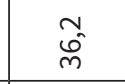 & $\stackrel{\infty}{\sim}$ & $\stackrel{\forall}{\stackrel{\sim}{0}}$ & $m$ & $\vec{\sigma}$ & $\stackrel{m}{*}$ & $\stackrel{\searrow}{\sim}$ \\
\hline$\infty$ & N & $\stackrel{\bullet}{\sim}$ & $\stackrel{-}{\circ}$ & $\begin{array}{c}m \\
\hat{e}^{-}\end{array}$ & $\stackrel{\bullet}{\sim}$ & $\underset{ન}{\stackrel{N}{A}}$ & $\hat{\sim}$ & 명 & $\hat{m}$ & $\stackrel{\bullet}{\sim}$ \\
\hline$\sim$ & $\stackrel{\overbrace{}}{\rightarrow}$ & $\stackrel{n}{\approx}$ & $\stackrel{\text { mे }}{\text { - }}$ & $\stackrel{\phi_{m}}{m}$ & $\hat{i}$ & 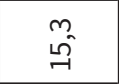 & $\stackrel{\infty}{\sim}$ & $\begin{array}{l}\infty \\
\stackrel{\infty}{f}\end{array}$ & ஸn & $\begin{array}{l}\infty \\
\text { Ni } \\
\end{array}$ \\
\hline 6 & N & $\begin{array}{l}\ddot{N} \\
\stackrel{\sim}{0}\end{array}$ & $\stackrel{\infty}{m}$ & $\stackrel{\sim}{\tilde{m}}$ & $\stackrel{+}{\sim}$ & $\begin{array}{l}+ \\
\stackrel{\sigma}{-1}\end{array}$ & $\underset{\rightarrow}{\stackrel{\sigma}{-1}}$ & $\underset{f}{\stackrel{\sigma}{\gamma}}$ & $\begin{array}{l}\infty \\
\infty\end{array}$ & $\begin{array}{l}\text { O } \\
\text { in }\end{array}$ \\
\hline L & $\underset{-}{6}$ & $\hat{i}$ & $\stackrel{n}{n}$ & $\begin{array}{l}\text { Ln } \\
\text { ơ }\end{array}$ & $\stackrel{+}{\sim}$ & $\begin{array}{l}\text { In } \\
\text { I }\end{array}$ & $\stackrel{\stackrel{\rho}{m}}{ }$ & ति & $\begin{array}{l}\sim^{\circ} \\
\infty\end{array}$ & חొ \\
\hline$\nabla$ & 采 & $\vec{A}$ & $\vec{m}$ & $\hat{m}_{\tilde{\omega}}^{0}$ & $\stackrel{n}{\sim}$ & $\begin{array}{l}\infty \\
\infty_{-1}^{-} \\
-1\end{array}$ & $\begin{array}{l}\dot{m} \\
\dot{m}\end{array}$ & $\stackrel{n}{n}$ & $\stackrel{m}{\sigma}$ & $\hat{\mathscr{b}}$ \\
\hline$m$ & $\stackrel{\infty}{\sim}$ & ָ̃ & 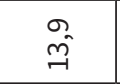 & $\begin{array}{l}\text { ô } \\
\text { on }\end{array}$ & $\hat{i}$ & $\begin{array}{c}m \\
\infty_{-1}^{-} \\
\rightarrow-1\end{array}$ & $\stackrel{m}{m}$ & $\begin{array}{l}\stackrel{S}{\sim} \\
\stackrel{f}{*}\end{array}$ & $\hat{\sigma}$ & $\begin{array}{l}\stackrel{\llcorner}{\varphi_{f}} \\
\stackrel{\varphi}{f}\end{array}$ \\
\hline$\sim$ & 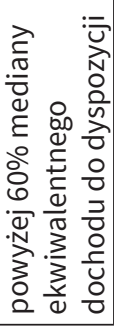 & 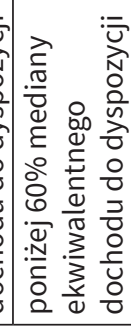 & 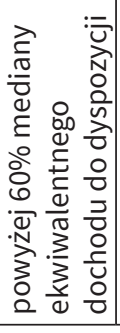 & 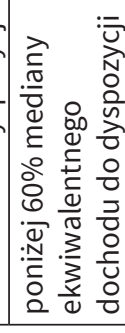 & 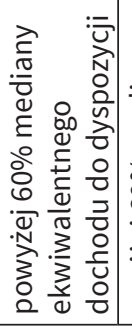 & 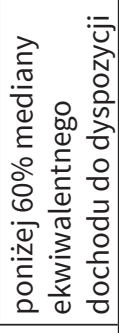 & 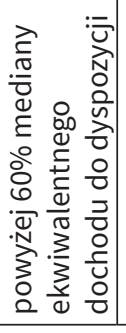 & 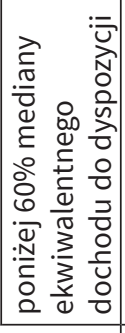 & 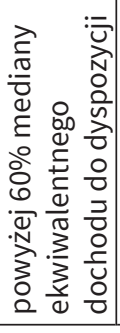 & 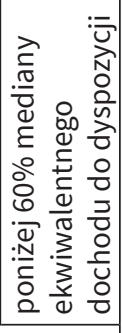 \\
\hline-1 & \multicolumn{2}{|c|}{$\begin{array}{l}\frac{\pi}{\frac{\pi}{\sigma}} \\
\frac{\partial}{\omega} \\
\frac{0}{\omega}\end{array}$} & \multicolumn{2}{|c|}{$\begin{array}{l}\frac{\pi}{\pi} \\
\frac{\pi}{3} \\
\frac{0}{\dot{\omega}}\end{array}$} & \multicolumn{2}{|c|}{$\frac{\frac{\pi}{\sigma}}{\frac{\pi}{\frac{\pi}{T}}}$} & \multicolumn{2}{|c|}{$\begin{array}{l}\frac{\pi}{\mathscr{d}} \\
\sum_{N}^{N} \\
\text { N }\end{array}$} & \multicolumn{2}{|c|}{ 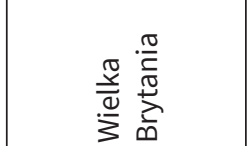 } \\
\hline
\end{tabular}


214 Ocena przebiegu konwergencji mieszkaniowej i jej efektów
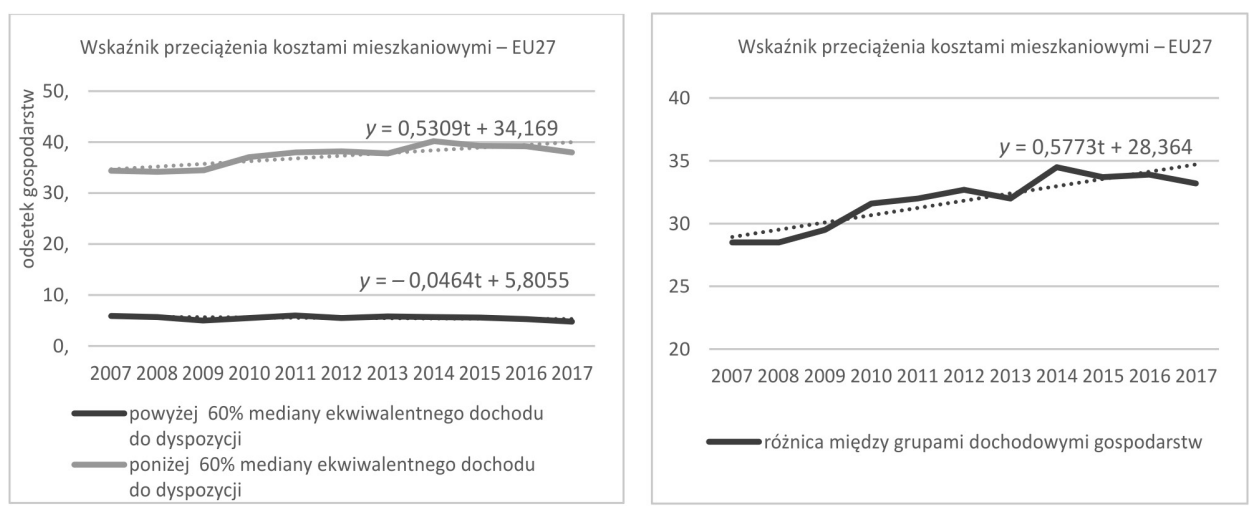

Rysunek 7.6. Wskaźnik przeciążenia kosztami mieszkaniowymi z uwzględnieniem sytuacji finansowej gospodarstw domowych w EU27

Źródto: opracowanie własne

Wzrost przeciążenia kosztami mieszkaniowymi w obu grupach dochodowych wystąpił w Bułgarii, na Cyprze w Finlandii, Grecji, Irlandii, na Litwie i w Luksemburgu. W niektórych państwach UE odnotowano odmienne trendy w badanych grupach dochodowych - sytuację gospodarstw domowych uzyskujących powyżej $60 \%$ krajowej mediany ekwiwalentnego dochodu do dyspozycji ilustrował trend spadkowy, czyli gospodarstwa te były sukcesywnie coraz mniej przeciążone kosztami mieszkaniowymi, ale w grupie mniej zamożnej trend przeciążenia był rosnący, były to: Austria, Czechy, Dania, Estonia, Francja, Hiszpania, Niemcy, Portugalia, Słowenia, Węgry, Włochy.

\subsubsection{Trendy w zakresie przeludnienia mieszkań w różnych grupach dochodowych}

Obraz trendu odnoszącego się do przeludnienia mieszkań (lata 2005-2017) obrazuje tab. 7.4. Spośród badanych państw pogorszenie warunków mieszkaniowych poprzez wzrost przeludnienia w obu grupach dochodowych nastąpił w Danii, Finlandii, Holandii, Szwecji i Włoszech. 


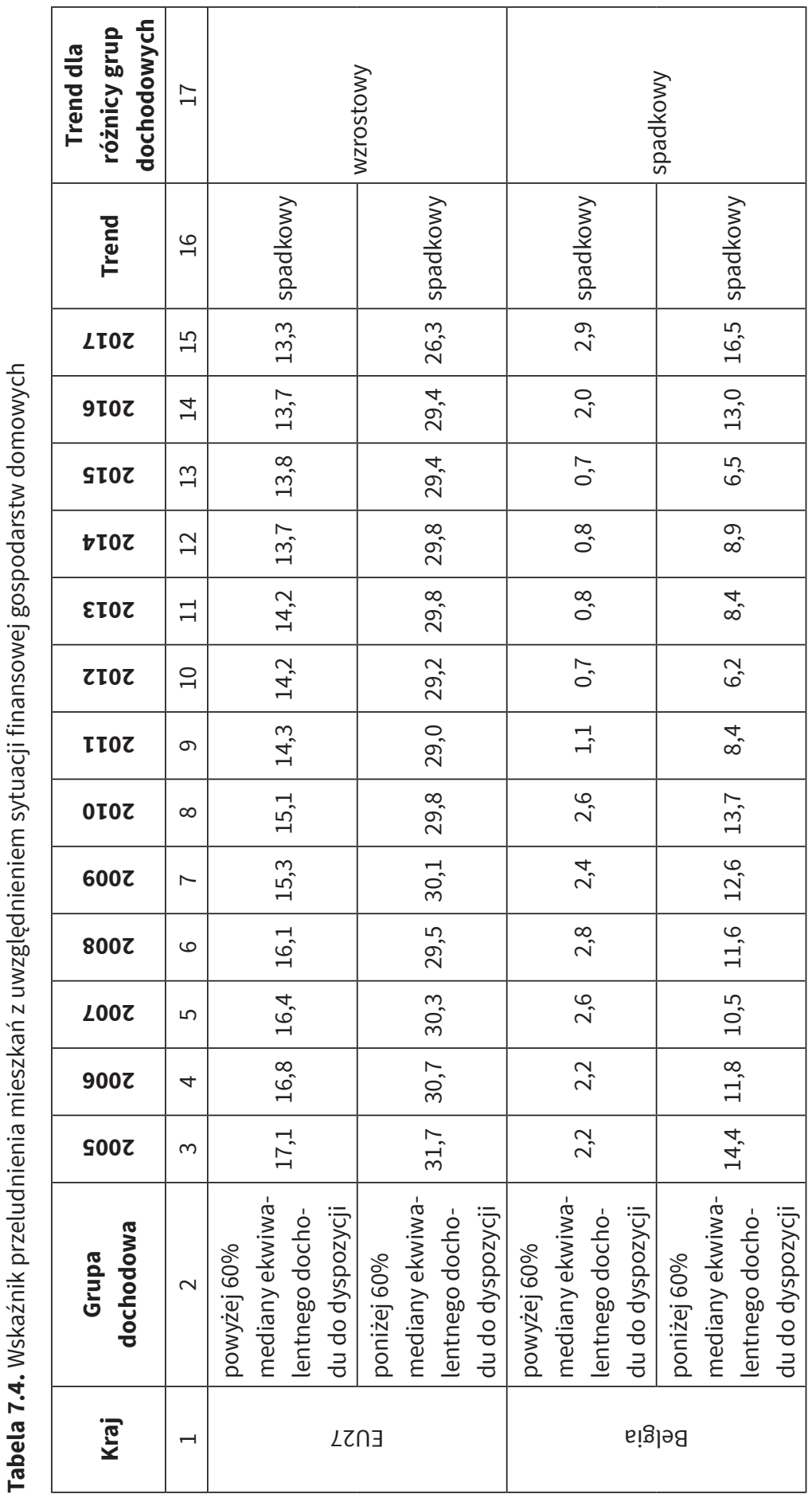




\section{Ocena przebiegu konwergencji mieszkaniowej i jej efektów}

\begin{tabular}{|c|c|c|c|c|c|c|c|}
\hline & & & 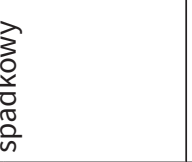 & & 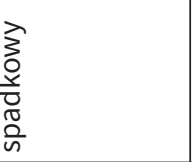 & & 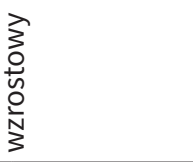 \\
\hline & & 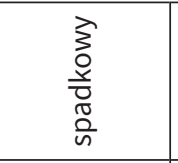 & 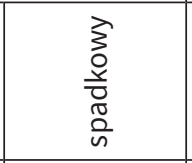 & $\begin{array}{l}\text { ते } \\
\text { o } \\
\text { 离 } \\
\text { in }\end{array}$ & 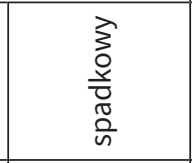 & $\begin{array}{l}\text { 令 } \\
0 \\
\hat{N} \\
\frac{0}{N} \\
3\end{array}$ & 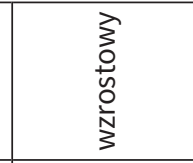 \\
\hline & & $\begin{array}{l}\infty \\
\text { ले } \\
\dot{m}\end{array}$ & $\begin{array}{l}\mathscr{O}_{0}^{0} \\
\stackrel{\infty}{q}\end{array}$ & $\vec{\exists}$ & $\begin{array}{l}\infty \\
\text { से }\end{array}$ & ?ู & ڤ్ \\
\hline & & बे & $\vec{n}$ & นุ & ڤू & $\overrightarrow{6}$ & $\stackrel{\sim}{\stackrel{n}{N}}$ \\
\hline & & में & $\begin{array}{l}\stackrel{L}{\infty} \\
\stackrel{\infty}{\sigma}\end{array}$ & ma & $\stackrel{+}{q}$ & $\stackrel{+}{\omega}$ & $\stackrel{\sim}{\sim}$ \\
\hline & & $\vec{q}$ & 螎 & $\stackrel{m}{\beth}$ & $\hat{f}$ & બે & $\begin{array}{l}\infty \\
\stackrel{+}{\sim}\end{array}$ \\
\hline & & $\begin{array}{l}\stackrel{g}{F} \\
\vec{\gamma}\end{array}$ & ભે & ㅇ. & $\hat{\tilde{y}}$ & $\stackrel{+}{\omega}$ & ڤ్ \\
\hline & & $\stackrel{\mathscr{n}}{\tilde{f}}$ & $\stackrel{\sigma}{\Rightarrow}$ & $\hat{\sim}$ & $\stackrel{\mathscr{n}}{\tilde{q}}$ & 우 & $\begin{array}{l}\stackrel{\infty}{\sim} \\
\stackrel{\sim}{\sim}\end{array}$ \\
\hline & & $\stackrel{t}{\mathscr{g}}$ & స̂े & $\stackrel{\substack{0 \\
\infty \\
\rightarrow}}{\rightarrow}$ & $\stackrel{0}{\hat{\gamma}}$ & $\stackrel{\sim}{\sim}$ & $\stackrel{4}{-3}$ \\
\hline & & $\begin{array}{l}\infty \\
\text { in }\end{array}$ & 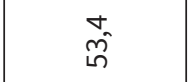 & ñ & $\vec{f}$ & $\stackrel{m}{\omega^{n}}$ & ¿ें \\
\hline & & $\vec{f}$ & ก̌ & $\stackrel{+}{d}$ & 冓 & $\stackrel{0}{i n}$ & $\stackrel{+}{\mathbb{N}}$ \\
\hline & & $\begin{array}{l}\infty \\
\dot{q}\end{array}$ & $\begin{array}{l}\infty \\
\text { กิ }\end{array}$ & $\stackrel{\infty}{\sim}$ & 苑 & $\stackrel{N}{n}$ & $\stackrel{\sim}{\sim}$ \\
\hline & & $\stackrel{\stackrel{n}{\sim}}{\stackrel{f}{f}}$ & $\begin{array}{l}0 \\
\tilde{\theta}\end{array}$ & बे & $\stackrel{n}{\tilde{6}}$ & $\stackrel{+}{\kappa}$ & 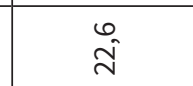 \\
\hline & & $\begin{array}{l}\text { or } \\
\text { भf }\end{array}$ & $\begin{array}{l}\text { Ln } \\
\text { in } \\
i n\end{array}$ & $\begin{array}{l}\text { के } \\
\text { oे }\end{array}$ & 8 & tr & : \\
\hline & & 1 & 1 & $\begin{array}{l}0 \\
\dot{m} \\
\dot{m}\end{array}$ & $\begin{array}{l}\infty \\
\infty \\
\infty \\
\end{array}$ & in & $\stackrel{n}{\pi}$ \\
\hline & & 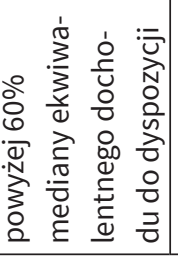 & 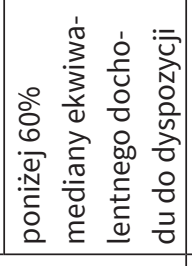 & 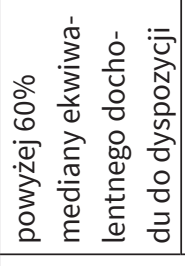 & 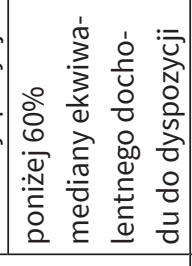 & 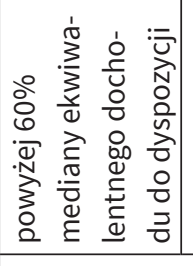 & 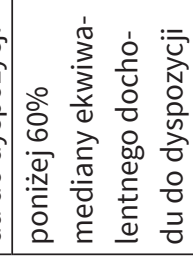 \\
\hline & \multicolumn{3}{|c|}{ e!̣eşłng } & \multicolumn{2}{|c|}{ Кцәәzว } & \multicolumn{2}{|c|}{ ẹuea } \\
\hline
\end{tabular}




\begin{tabular}{|c|c|c|c|c|c|c|}
\hline$\neg$ & & 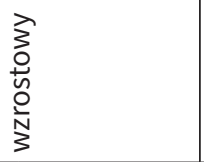 & & 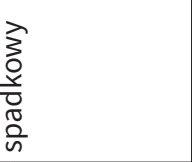 & & 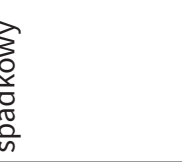 \\
\hline$\underset{-1}{0}$ & 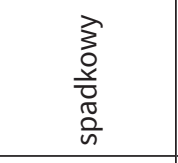 & 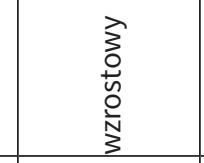 & 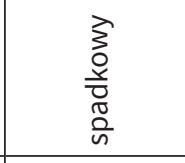 & 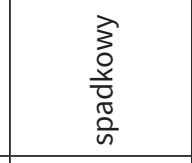 & 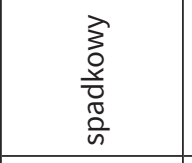 & 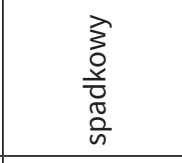 \\
\hline$\stackrel{\overbrace{}}{\neg}$ & हn & 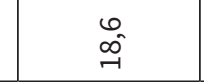 & 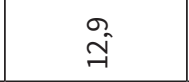 & $\begin{array}{l}\stackrel{0}{0} \\
\stackrel{\leftrightarrow}{-1}\end{array}$ & $\stackrel{g}{\rightarrow}$ & $\stackrel{n}{N}$ \\
\hline$\exists$ & $\stackrel{q}{\leftarrow}$ & 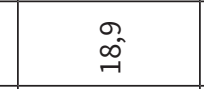 & 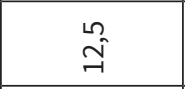 & $\hat{\tilde{\omega}}$ & $\stackrel{\infty}{\sim}$ & $\tilde{m}_{0}^{-}$ \\
\hline$\stackrel{m}{-}$ & $\stackrel{\leftrightarrow}{\leftrightarrow}$ & 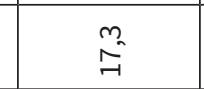 & $\underset{\Im}{\stackrel{\Im}{y}}$ & $\begin{array}{l}\text { 음 } \\
\text { in }\end{array}$ & $\stackrel{\leftrightarrow}{\sim}$ & 8 \\
\hline$\approx$ & $\stackrel{\odot}{*}$ & ñ & $\stackrel{m}{m}$ & $\stackrel{\hat{A}}{\mathrm{I}}$ & $\stackrel{\infty}{\sim}$ & $\stackrel{6}{N}$ \\
\hline$\exists$ & $\stackrel{\infty}{\stackrel{\sigma}{*}^{-}}$ & $\begin{array}{l}\infty \\
0 \\
0\end{array}$ & ¿ิ & $\begin{array}{l}\text { वे } \\
\dot{d}\end{array}$ & $\stackrel{n}{\sim}$ & $\stackrel{+}{\leftarrow}$ \\
\hline 의 & $\stackrel{\sim}{\sim}$ & $\begin{array}{l}0 \\
\stackrel{0}{7}\end{array}$ & $\underset{\sim}{\approx}$ & $\stackrel{\sim}{\tilde{n}}$ & $\stackrel{0}{i}$ & గ్ \\
\hline$\sigma$ & $\stackrel{\sim}{\sim}$ & बे & $\hat{F}$ & $\stackrel{-1}{\sim}$ & $\stackrel{\infty}{\rightarrow}$ & $\hat{6}$ \\
\hline$\infty$ & $\stackrel{\infty}{+}$ & $\begin{array}{l}m \\
\text { gे }\end{array}$ & $\stackrel{-1}{m}$ & $\stackrel{\infty}{\tilde{n}}$ & $\stackrel{0}{i}$ & $\hat{\kappa}$ \\
\hline$\wedge$ & $\stackrel{m}{*}$ & $\begin{array}{l}\infty \\
\vec{i} \\
\end{array}$ & ने & $\begin{array}{l}\text { gे } \\
\text { gे }\end{array}$ & $\stackrel{\infty}{\sim}$ & $\stackrel{+}{\infty}$ \\
\hline 6 & $\stackrel{g}{\sigma}$ & $\begin{array}{l}\infty \\
\infty \\
\infty^{-}\end{array}$ & $\begin{array}{l}0 \\
\vec{y}\end{array}$ & $\begin{array}{l}\infty \\
\dot{f}\end{array}$ & $\stackrel{m}{*}$ & $\stackrel{\infty}{0}_{0}^{\infty}$ \\
\hline ก & $\stackrel{\mathscr{q}}{\sigma}$ & 菅 & 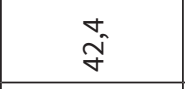 & $\stackrel{\mathscr{9}}{\stackrel{F}{+}}$ & $\stackrel{\sim}{\sim}$ & $\begin{array}{l}\infty \\
\infty \\
\infty\end{array}$ \\
\hline$\nabla$ & $m_{0}^{m}$ & $\begin{array}{l}\stackrel{0}{0}^{-} \\
\dot{-1}^{-}\end{array}$ & 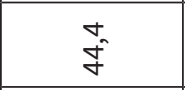 & $\begin{array}{l}0 \\
\text { กิ } \\
\text { กิ- }\end{array}$ & $\stackrel{m}{m}$ & 章 \\
\hline$m$ & in & ڤે & $\begin{array}{l}\tilde{\sigma} \\
\tilde{y}\end{array}$ & $\begin{array}{l}\text { ñ } \\
\text { hn }\end{array}$ & $\stackrel{m}{\sim}$ & के \\
\hline$\sim$ & 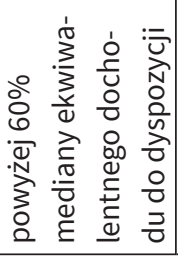 & 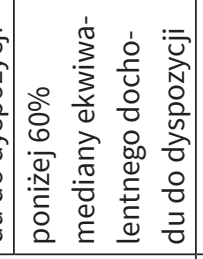 & 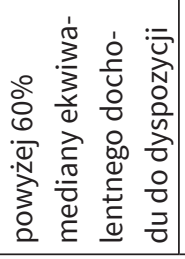 & 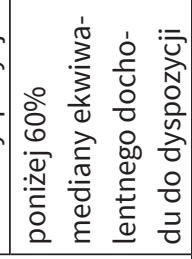 & 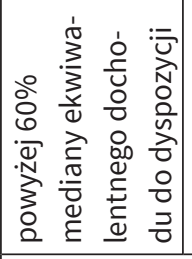 & 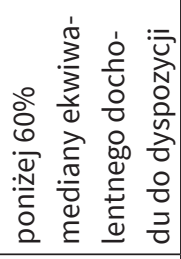 \\
\hline-1 & \multicolumn{2}{|c|}{ КЈயщə!N } & \multicolumn{2}{|c|}{ e!̣uołs] } & \multicolumn{2}{|c|}{ е!рuе|ג } \\
\hline
\end{tabular}




\begin{tabular}{|c|c|c|c|c|c|c|c|}
\hline & & & 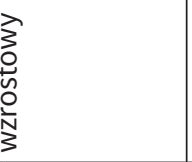 & & 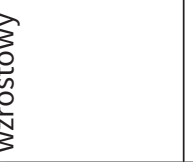 & & 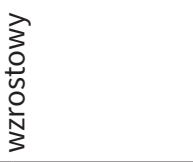 \\
\hline & & $\begin{array}{l}3 \\
0 \\
0 \\
\overline{0} \\
\frac{0}{0} \\
\text { i }\end{array}$ & 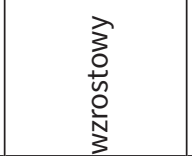 & $\begin{array}{l}\widehat{3} \\
0 \\
\frac{2}{0} \\
\frac{\pi}{2} \\
i n\end{array}$ & $\begin{array}{l}\widehat{3} \\
0 \\
\frac{2}{0} \\
\bar{\pi} \\
\text { in }\end{array}$ & 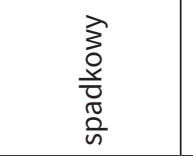 & 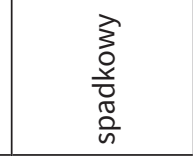 \\
\hline & & : & $\hat{\tilde{y}}$ & $\stackrel{+}{m}$ & $\stackrel{m}{\Rightarrow}$ & E) & 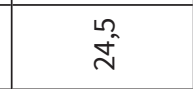 \\
\hline & & $\begin{array}{l}0 \\
\text { ஸे }\end{array}$ & $\tilde{\mathcal{F}}$ & $\stackrel{m}{m}$ & $\hat{\tilde{y}}$ & m & $\stackrel{\vec{\sim}}{\sim}$ \\
\hline & & $\stackrel{m}{\sim}$ & $\stackrel{\circ}{\tilde{y}}$ & $\stackrel{\infty}{m}$ & $\begin{array}{l}+ \\
\exists\end{array}$ & m & के \\
\hline & & $\begin{array}{l}\text { ì } \\
\text { in }\end{array}$ & $\vec{q}$ & $\hat{m}$ & 我 & $\stackrel{q}{q}$ & $\vec{A}$ \\
\hline & & $\begin{array}{l}\text { ̊े } \\
\text { స }\end{array}$ & 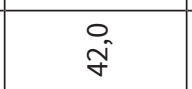 & $\hat{m}$ & $\begin{array}{l}\stackrel{0}{G} \\
\Rightarrow\end{array}$ & N & $\begin{array}{l}\text { के } \\
\text { oे }\end{array}$ \\
\hline & & $\hat{\tilde{N}}$ & बे & $\stackrel{\circ}{\leftarrow}$ & $\begin{array}{l}0 \\
-1\end{array}$ & in & $\stackrel{m}{\tilde{n}^{\prime}}$ \\
\hline & & $\stackrel{\sim}{\sim}$ & $\begin{array}{l}\infty \\
\omega_{m}^{\infty}\end{array}$ & $\begin{array}{l}m \\
\text { m }\end{array}$ & $\begin{array}{l}m \\
\Rightarrow \\
F\end{array}$ & $\stackrel{+}{n}$ & $\stackrel{\text { Ln }}{\text { N }}$ \\
\hline & & $\stackrel{\sim}{\tilde{N}}$ & సे & $\stackrel{\rho}{m}$ & Ň & $\hat{\sigma}$ & ڤ్ \\
\hline & & $\stackrel{\sim}{\tilde{N}}$ & 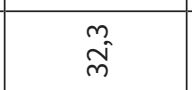 & $\stackrel{\circ}{\circ}$ & $\begin{array}{l}0 \\
0 \\
0\end{array}$ & $\stackrel{\circ}{\circ}$ & $\underset{\sim}{\stackrel{N}{N}}$ \\
\hline & & $\begin{array}{l}0 \\
\dot{J}\end{array}$ & ผ & $\stackrel{\sim}{*}$ & $\begin{array}{l}N \\
\exists\end{array}$ & $\stackrel{m}{n}$ & $\begin{array}{l}\stackrel{+}{0} \\
\text { in }\end{array}$ \\
\hline & & 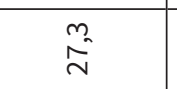 & $\begin{array}{c}m \\
\mathfrak{m}^{\prime}\end{array}$ & $\stackrel{m}{\sigma}$ & $\stackrel{\operatorname{Ln}}{=}$ & $\stackrel{\infty}{\sim}$ & $\stackrel{\sqrt[\sim]{n}}{\sim}$ \\
\hline & & $\stackrel{m}{\stackrel{m}{\sim}}$ & $\underset{m}{m}$ & w & $\hat{\bar{F}}$ & $\overbrace{0}^{n}$ & $\begin{array}{l}L^{n} \\
\infty^{0}\end{array}$ \\
\hline & & 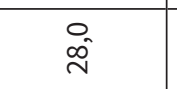 & 离 & $\stackrel{N}{N}$ & $\stackrel{\sim}{\mathcal{M}}$ & $\begin{array}{l}0 \\
\stackrel{6}{N}\end{array}$ & $\begin{array}{l}\stackrel{+}{i} \\
\vec{i}\end{array}$ \\
\hline & & 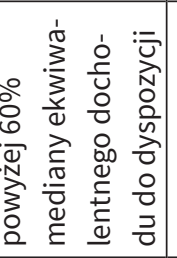 & 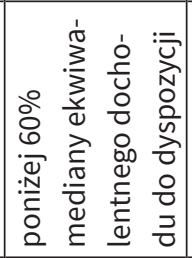 & 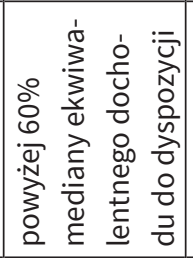 & 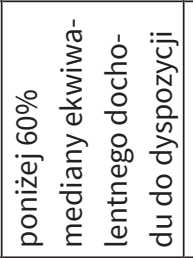 & 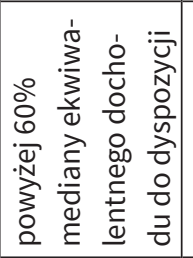 & 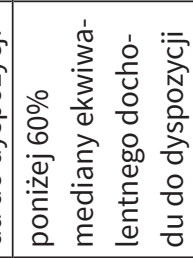 \\
\hline & \multicolumn{3}{|c|}{ קגון } & \multicolumn{2}{|c|}{ ẹuedzs!H } & \multicolumn{2}{|c|}{ еґтuеd } \\
\hline
\end{tabular}




\begin{tabular}{|c|c|c|c|c|c|c|}
\hline 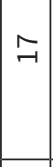 & & 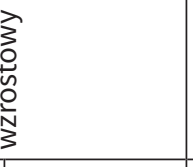 & & 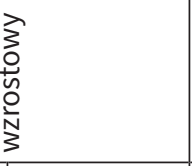 & & 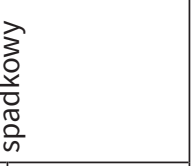 \\
\hline$\stackrel{\varphi}{-1}$ & 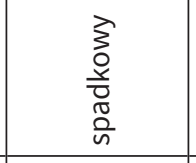 & 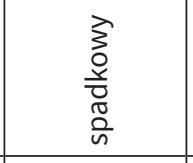 & 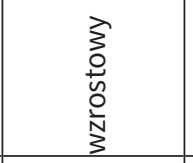 & 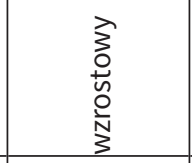 & 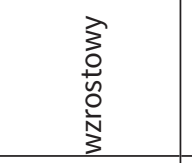 & $\begin{array}{l}3 \\
0 \\
\text { o } \\
\overline{0} \\
\frac{0}{n} \\
\end{array}$ \\
\hline$\stackrel{\sim}{\neg}$ & $\begin{array}{c}\infty \\
\infty \\
\infty \\
m\end{array}$ & $\stackrel{+}{*}$ & $\begin{array}{l}0 \\
\text { d }\end{array}$ & 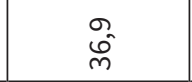 & $\stackrel{m}{i}$ & 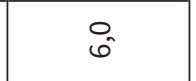 \\
\hline$\vec{t}$ & बें & $\begin{array}{l}\sigma \\
\text { fo }\end{array}$ & $\begin{array}{l}\infty \\
\stackrel{+}{+}\end{array}$ & N) & $\hat{\mathrm{i}}$ & $\hat{\omega}$ \\
\hline$\stackrel{m}{\rightarrow}$ & $\begin{array}{l}\text { ó } \\
\text { of }\end{array}$ & $\begin{array}{l}0 \\
\text { \&े } \\
\text { \&े }\end{array}$ & $\begin{array}{l}\text { mे } \\
\text { N }\end{array}$ & $\begin{array}{l}\infty \\
\stackrel{\gamma}{\gamma} \\
\end{array}$ & $\stackrel{0}{i}$ & $\stackrel{\mathscr{n}}{m}$ \\
\hline$\approx$ & $\begin{array}{l}\text { or } \\
\text { ó }\end{array}$ & $\stackrel{\vec{H}}{\stackrel{-}{+}}$ & $\stackrel{\vec{N}}{\sim}$ & $\begin{array}{l}\stackrel{0}{\text { I }} \\
\text { r }\end{array}$ & $\stackrel{\infty}{\rightarrow}$ & $\stackrel{0}{\leftarrow}$ \\
\hline$\exists$ & $\begin{array}{l}\infty \\
\vec{f} \\
\end{array}$ & $\begin{array}{l}\infty \\
0 \\
0\end{array}$ & $\begin{array}{l}\dot{0} \\
\tilde{N}\end{array}$ & $\hat{F}$ & $\stackrel{g}{\rightarrow}$ & $\stackrel{\text { gे }}{\sigma}$ \\
\hline 의 & 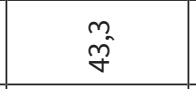 & $\begin{array}{l}0 \\
\infty^{\circ} \\
+\end{array}$ & 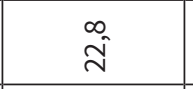 & $\begin{array}{l}\infty \\
\dot{m}\end{array}$ & $\stackrel{i}{i}$ & $\stackrel{\text { R }}{N}$ \\
\hline$\sigma$ & $\stackrel{\stackrel{\leftrightarrow}{~}}{\tilde{\gamma}}$ & $\begin{array}{c}m \\
\stackrel{+}{f}\end{array}$ & $\underset{\sim}{\sim}$ & $\overrightarrow{m^{-1}}$ & $\stackrel{i}{i}$ & $\stackrel{\infty}{\sim}$ \\
\hline$\infty$ & $\stackrel{0}{\dot{q}}$ & \begin{tabular}{l}
\multirow{H}{*}{} \\
$o f$ \\
\end{tabular} & $\vec{i}$ & $\stackrel{\vec{m}}{\text { m. }^{2}}$ & $\hat{i}$ & $\stackrel{n}{N}$ \\
\hline$\sim$ & ذّ & ن் & $\begin{array}{l}\text { on } \\
\text { in }\end{array}$ & น̂ & $\vec{i}$ & น \\
\hline 0 & فذّ & فํ. & $\stackrel{\infty}{i}$ & 요 & $\stackrel{m}{i}$ & $\begin{array}{l}\operatorname{Ln}_{\infty} \\
\infty\end{array}$ \\
\hline n & فㅁ. & فํ. & $\stackrel{m}{i}$ & $\begin{array}{l}0 \\
\dot{m} \\
\dot{m}\end{array}$ & 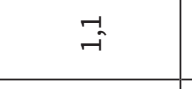 & $\stackrel{\infty}{+}$ \\
\hline$\nabla$ & فं & فㅁ & $\hat{i}$ & $\begin{array}{l}\hat{0} \\
\hat{m}\end{array}$ & $\stackrel{m}{\rightarrow}$ & in \\
\hline$m$ & فذ. & فํ் & $\stackrel{\sim}{i}$ & 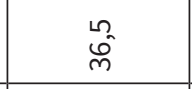 & $\stackrel{n}{\rightarrow}$ & $\ddot{0}_{0}^{0}$ \\
\hline$N$ & 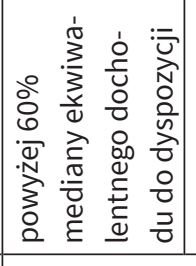 & 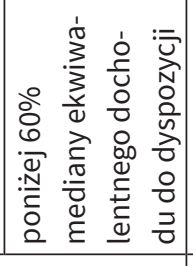 & 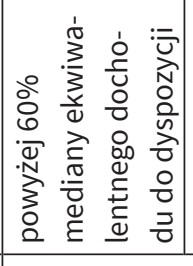 & 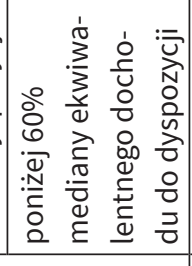 & 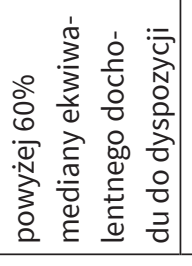 & 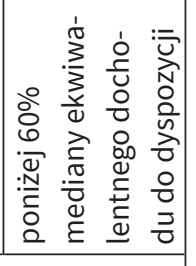 \\
\hline-1 & \multicolumn{2}{|c|}{ е!гемлочว } & \multicolumn{2}{|c|}{ Кцәоłм } & \multicolumn{2}{|c|}{$\lambda \mathrm{d} / \mathrm{J}$} \\
\hline
\end{tabular}




\begin{tabular}{|c|c|c|c|c|c|c|}
\hline 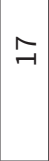 & & 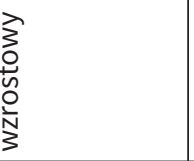 & & 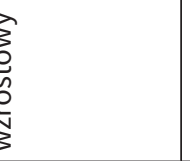 & & 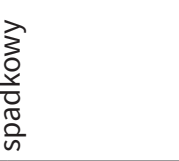 \\
\hline$\stackrel{0}{-1}$ & 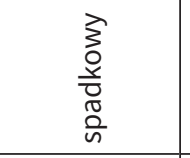 & 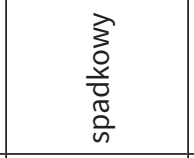 & 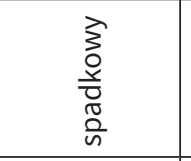 & 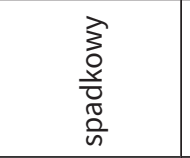 & 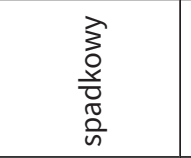 & 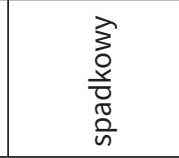 \\
\hline$\stackrel{2}{\sim}$ & $\begin{array}{l}\text { nn } \\
\text { ó }\end{array}$ & 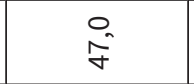 & $\vec{i}$ & $\begin{array}{l}6 \\
\text { Dे }\end{array}$ & กิ & ज̆ \\
\hline$\vec{t}$ & 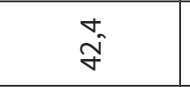 & 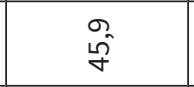 & $\begin{array}{l}0 \\
- \\
-1\end{array}$ & $\stackrel{\circ}{m}$ & $\stackrel{\varphi}{\sigma}$ & $\begin{array}{l}0 \\
\dot{\omega}\end{array}$ \\
\hline$\stackrel{m}{\rightarrow}$ & ने & $\stackrel{+}{\sigma}$ & 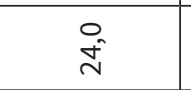 & 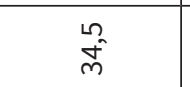 & $\stackrel{+}{\leftarrow}$ & $\begin{array}{l}\infty \\
\stackrel{\infty}{-}\end{array}$ \\
\hline ㄱ & $\stackrel{\text { nn }}{m}$ & $\underset{\stackrel{N}{\infty}}{\stackrel{N}{+}}$ & ֻn & ભ् & $\stackrel{\infty}{m}$ & $\begin{array}{l}0 \\
i \\
-i\end{array}$ \\
\hline$\exists$ & $\stackrel{m}{m}_{m}^{n}$ & $\begin{array}{l}\stackrel{g}{\sigma} \\
\stackrel{+}{\sim}\end{array}$ & $\begin{array}{l}0 \\
\text { i }\end{array}$ & $\stackrel{+}{\stackrel{m}{m}}$ & $\stackrel{\dot{m}}{m}$ & $\begin{array}{l}\text { Oे } \\
\stackrel{\sim}{*}\end{array}$ \\
\hline 윽 & $\hat{m}$ & $\hat{\stackrel{1}{o}}$ & $\stackrel{\infty}{\stackrel{\infty}{\sim}}$ & $\hat{\sim}$ & $\stackrel{\sim}{*}$ & $\stackrel{+}{i}$ \\
\hline$a$ & $\stackrel{+}{\dot{\sigma}}$ & \begin{tabular}{l}
\multirow{2}{*}{} \\
in
\end{tabular} & $\stackrel{m}{\stackrel{m}{\digamma}}$ & $\stackrel{\hat{\sim}}{\tilde{D}^{0}}$ & $\ddot{f}$ & $\begin{array}{l}\infty \\
\stackrel{\sim}{N}\end{array}$ \\
\hline$\infty$ & $\begin{array}{l}\infty \\
\text { กิ }\end{array}$ & $\begin{array}{l}+ \\
6\end{array}$ & $\stackrel{\stackrel{\rho}{ }}{\tilde{y}}$ & $\begin{array}{l}\infty \\
\stackrel{\infty}{n}\end{array}$ & $\stackrel{q}{\sigma}$ & $\begin{array}{l}\text { } \\
\stackrel{\sim}{\sim}\end{array}$ \\
\hline$r$ & กิ & in & $\begin{array}{l}\dot{\sigma}_{0} \\
\dot{f}\end{array}$ & 䓟 & $\ddot{\varphi}$ & $\stackrel{\infty}{\mathbb{N}}$ \\
\hline 6 & $\begin{array}{l}0 \\
\infty^{\circ} \\
n^{\prime}\end{array}$ & $\hat{\tilde{N}}$ & $\stackrel{\sim}{\stackrel{n}{\forall}}$ & ํㅗ & $\stackrel{m}{\sigma}$ & 点 \\
\hline n & $\begin{array}{l}\mathscr{8} \\
\text { Oे }\end{array}$ & $\begin{array}{l}0 \\
\ddot{6}\end{array}$ & $\stackrel{+}{i}$ & $\stackrel{m}{n}$ & $\stackrel{\sim}{*}$ & $\stackrel{0}{i}$ \\
\hline$\sigma$ & ㄱ. & क् & $\hat{\hat{n}}$ & $\hat{8}$ & $\stackrel{\llcorner}{\forall}$ & $\stackrel{\circ}{\stackrel{\circ}{N}}$ \\
\hline$m$ & กิ & $\tilde{\tilde{n}}$ & to & ָే & Ln & $\begin{array}{l}\text { g } \\
\dot{m}\end{array}$ \\
\hline$N$ & 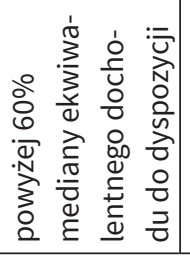 & 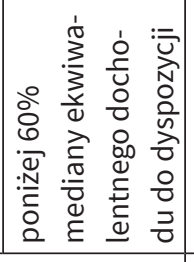 & 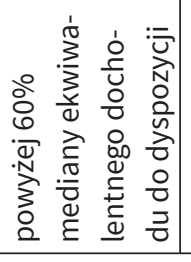 & 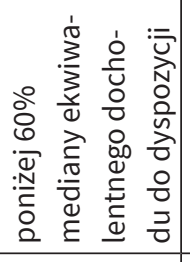 & 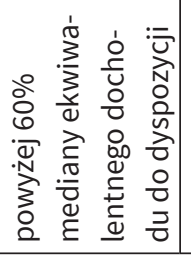 & 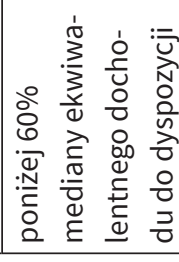 \\
\hline-1 & \multicolumn{2}{|c|}{ емұ07 } & \multicolumn{2}{|c|}{ емҰ!7 } & \multicolumn{2}{|c|}{ 8̊ınquəsynך } \\
\hline
\end{tabular}




\begin{tabular}{|c|c|c|c|c|c|c|}
\hline 气 & & 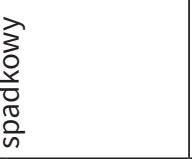 & & 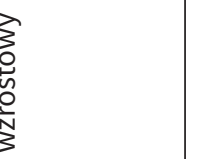 & & 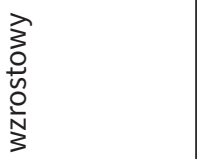 \\
\hline$\stackrel{0}{1}$ & 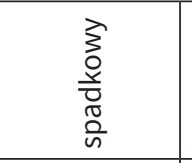 & 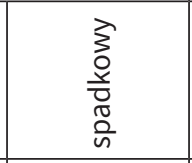 & 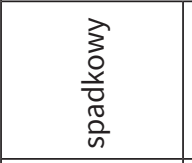 & 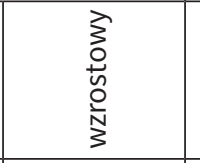 & 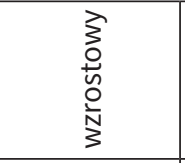 & 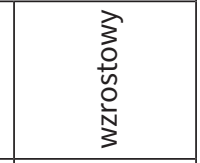 \\
\hline 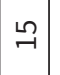 & $\begin{array}{c}N \\
\text { ó }\end{array}$ & $\begin{array}{l}0 \\
\stackrel{\sim}{\mathcal{H}}\end{array}$ & $\stackrel{L}{\sim}$ & શ્ & $\stackrel{\sim}{\sim}$ & $\begin{array}{l}0 \\
\dot{J}\end{array}$ \\
\hline$\vec{J}$ & 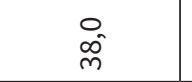 & $\begin{array}{l}\text { î } \\
\text { in }\end{array}$ & $\tilde{i}$ & $\vec{r}$ & $\stackrel{\text { Ln }}{\sim}$ & $\begin{array}{l}0 \\
\stackrel{-}{-}\end{array}$ \\
\hline$\stackrel{m}{\rightarrow}$ & $\stackrel{\stackrel{n}{n}}{\stackrel{n}{m}}$ & 엄 & $\stackrel{\circ}{m}$ & $\hat{\imath}$ & i & $\stackrel{N}{\stackrel{m}{\rightarrow}}$ \\
\hline$\approx$ & $\stackrel{\overrightarrow{0}}{\mathfrak{m}^{-}}$ & $\begin{array}{l}\infty \\
\tilde{\tilde{\sigma}} \\
\end{array}$ & $\tilde{m}$ & $\stackrel{m}{\infty}$ & $\stackrel{\sigma}{\rightarrow}$ & $\begin{array}{l}\text { બે } \\
\text { ઢิ }\end{array}$ \\
\hline$\exists$ & $\begin{array}{l}0 \\
\dot{q}\end{array}$ & $\begin{array}{l}\infty \\
\mathbb{\theta}^{-}\end{array}$ & $\stackrel{+}{f}$ & $\hat{\sigma}$ & $\stackrel{m}{\rightarrow}$ & $\begin{array}{l}\infty \\
\tilde{M}^{-}\end{array}$ \\
\hline 워 & $\begin{array}{l}\vec{f} \\
\vec{f}\end{array}$ & $\begin{array}{l}m \\
\infty^{-} \\
0^{2}\end{array}$ & $\stackrel{n}{m}$ & $\ddot{6}$ & $\stackrel{\infty}{-}$ & స̌ \\
\hline a & $\begin{array}{l}0 \\
-7 \\
\sigma\end{array}$ & $\begin{array}{l}0 \\
\infty_{0} \\
0\end{array}$ & $\stackrel{\llcorner}{m}$ & ñ & $\stackrel{m}{\rightarrow}$ & ז \\
\hline$\infty$ & $\begin{array}{l}0 \\
\dot{f}\end{array}$ & $\hat{0}$ & $\stackrel{6}{m}$ & $\mathscr{\varphi}_{0}$ & $\tilde{i}$ & $\stackrel{n}{*}$ \\
\hline$\sim$ & $\hat{\tilde{y}}$ & $\begin{array}{l}\infty \\
\infty^{\infty} \\
0^{-1}\end{array}$ & $\stackrel{0}{m}$ & in & $\stackrel{m}{\rightarrow}$ & in \\
\hline 0 & $\begin{array}{l}\infty \\
\vartheta_{f}^{\infty}\end{array}$ & 苍 & $\stackrel{\infty}{m}$ & $\stackrel{\sim}{\sim}$ & $\cong$ & $\overbrace{0}^{m}$ \\
\hline n & $\begin{array}{l}\circ \\
\text { ㅁํ }\end{array}$ & है & $\stackrel{\circ}{\leftarrow}$ & $\stackrel{+}{\omega}$ & $\stackrel{n}{\rightarrow}$ & $\stackrel{\infty}{n}$ \\
\hline$\nabla$ & \begin{tabular}{l}
$\stackrel{\llcorner}{\Omega}$ \\
\multirow{\sigma}{*}{}
\end{tabular} & $\hat{i}$ & $\stackrel{L n}{m}$ & $\stackrel{+}{m}$ & $\stackrel{n}{\rightarrow}$ & $\stackrel{\llcorner}{\sim}$ \\
\hline$m$ & \begin{tabular}{l}
$\stackrel{L}{\sim}$ \\
\multirow{F}{*}{}
\end{tabular} & $\begin{array}{l}\infty \\
\tilde{0}^{-}\end{array}$ & $\stackrel{6}{m}$ & r & $\stackrel{6}{r}$ & $\stackrel{\tilde{m}}{n}$ \\
\hline$\sim$ & 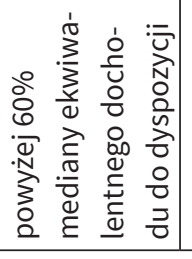 & 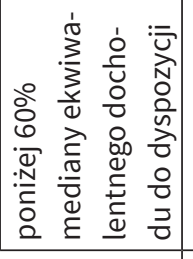 & 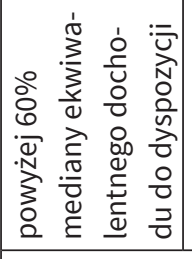 & 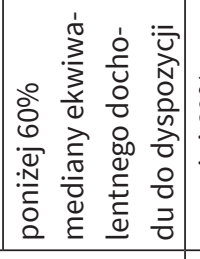 & 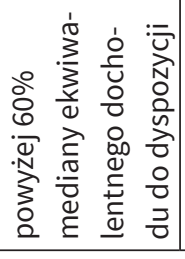 & 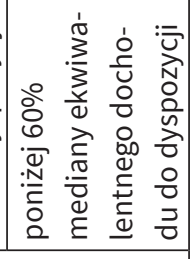 \\
\hline-1 & \multicolumn{2}{|c|}{ Kı $83 \mathrm{M}$} & \multicolumn{2}{|c|}{ eqlew } & \multicolumn{2}{|c|}{ е!puejoH } \\
\hline
\end{tabular}




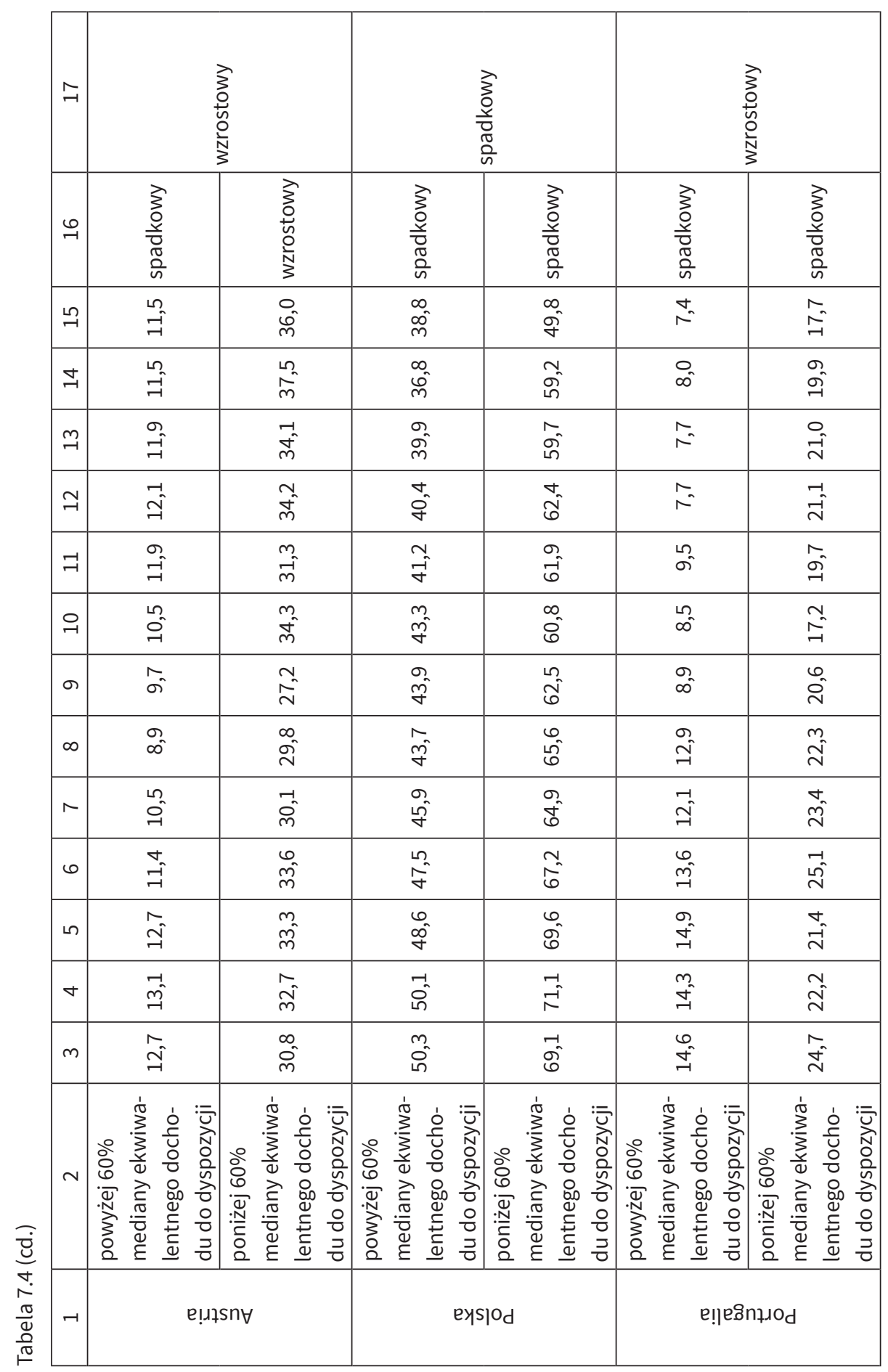




\begin{tabular}{|c|c|c|c|c|c|c|}
\hline$\neg$ & & 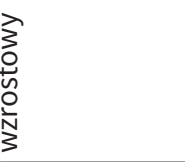 & & 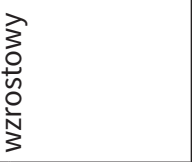 & & 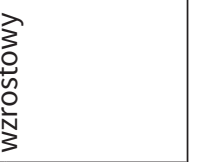 \\
\hline$\stackrel{\varphi}{-}$ & 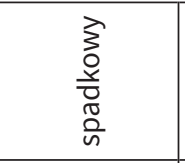 & 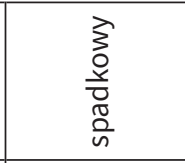 & 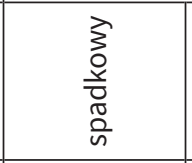 & 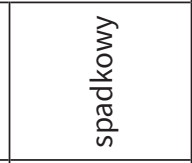 & 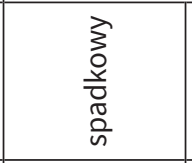 & 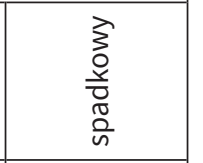 \\
\hline$\stackrel{\sim}{\sim}$ & $\begin{array}{l}\stackrel{\operatorname{Ln}}{\tilde{\gamma}} \\
\vec{\gamma}\end{array}$ & $\begin{array}{c}m \\
\infty_{n}^{m}\end{array}$ & $\begin{array}{l}\infty \\
\Rightarrow \\
\exists\end{array}$ & $\begin{array}{l}0 \\
\stackrel{G}{-1}\end{array}$ & $\hat{m}$ & $\begin{array}{l}0 \\
\text { 占 }\end{array}$ \\
\hline$\vec{A}$ & $\begin{array}{l}m \\
\mathfrak{f}^{\prime}\end{array}$ & $\begin{array}{l}0 \\
\dot{8}\end{array}$ & $\stackrel{m}{-1}$ & $\stackrel{+}{\text { ì }}$ & $\begin{array}{l}0 \\
\text { in } \\
\text { no }\end{array}$ & $\begin{array}{l}\text { N } \\
\text { L̂ }\end{array}$ \\
\hline$\stackrel{m}{\rightarrow}$ & $\begin{array}{l}\text { O̊ } \\
\text { \& }\end{array}$ & $\hat{\overrightarrow{6}}$ & $\overrightarrow{\mathfrak{y}}$ & $\stackrel{\vec{N}}{\sim}$ & 察 & $\begin{array}{l}0 \\
\text { ñ }\end{array}$ \\
\hline$\approx$ & $\stackrel{+}{\stackrel{f}{f}}$ & \begin{tabular}{l}
$n$ \\
\multirow{6}{*}{}
\end{tabular} & $\vec{m}$ & $\begin{array}{l}\text { के } \\
\dot{\sim}\end{array}$ & ثิ & $\stackrel{\substack{\infty \\
\overbrace{}^{0}}}{ }$ \\
\hline$\exists$ & $\begin{array}{l}\text { Ln } \\
\text { ó }\end{array}$ & $\begin{array}{l}\dot{0} \\
\dot{\sigma}\end{array}$ & \begin{tabular}{l}
0 \\
\multirow{J}{*}{}
\end{tabular} & స్ & $\begin{array}{l}\dot{m}^{\prime} \\
\text { no }\end{array}$ & กิ่ \\
\hline 윽 & $\stackrel{-1}{\infty^{\circ}}$ & $\begin{array}{l}0 \\
\tilde{\theta}\end{array}$ & $\begin{array}{l}0 \\
\stackrel{\text { ஸी }}{\sim}\end{array}$ & $\stackrel{\vec{N}}{\stackrel{n}{N}}$ & గ్ & \begin{tabular}{l}
\multirow{N}{N}{} \\
r
\end{tabular} \\
\hline$\sigma$ & $\stackrel{-1}{o-1}$ & 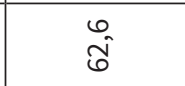 & $\begin{array}{l}0 \\
\stackrel{\sim}{\sim}\end{array}$ & 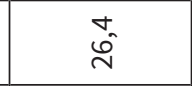 & $\vec{r}$ & $\begin{array}{l}\text { นn } \\
\text { 呙 }\end{array}$ \\
\hline$\infty$ & ֻू & $\begin{array}{l}\vec{q} \\
\overrightarrow{6}\end{array}$ & $\stackrel{m}{m_{m}^{m}}$ & $\begin{array}{l}m \\
\dot{q} \\
\dot{q}\end{array}$ & $\begin{array}{l}0 \\
\stackrel{0}{m}\end{array}$ & 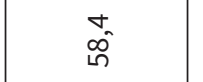 \\
\hline$\wedge$ & $\begin{array}{l}0 \\
\text { in }\end{array}$ & $\begin{array}{l}\text { î } \\
\text { t }\end{array}$ & $\underset{m}{\stackrel{N}{m}}$ & $\begin{array}{l}\stackrel{+}{f} \\
\stackrel{f}{*}\end{array}$ & 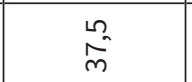 & $\stackrel{M}{n}_{\llcorner}$ \\
\hline 6 & స̂. & $\hat{\overline{6}}$ & $\stackrel{+}{\infty_{m}^{\prime}}$ & $\begin{array}{l}\stackrel{N}{\sim} \\
\stackrel{f}{*}\end{array}$ & $\begin{array}{l}m \\
\vec{\gamma}\end{array}$ & 瓷 \\
\hline n & 点 & $\stackrel{n}{\hat{6}}$ & $\hat{\infty}$ & 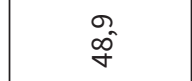 & $\underset{\vec{\sigma}}{\vec{\sigma}}$ & $\begin{array}{l}0 \\
\text { مे }\end{array}$ \\
\hline+ & فهذْ & فْذّ & ণे & 点 & $\begin{array}{l}\vec{f} \\
\text { f }\end{array}$ & $\stackrel{+}{\circ}$ \\
\hline$m$ & فْ & فن & $\hat{q}$ & $\hat{\circ}$ & $\begin{array}{l}0 \\
\dot{f}\end{array}$ & ने \\
\hline$\sim$ & 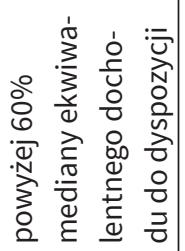 & 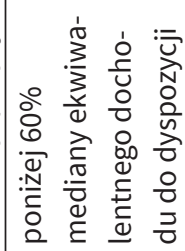 & 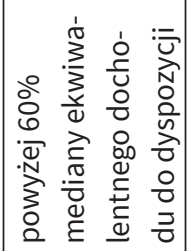 & 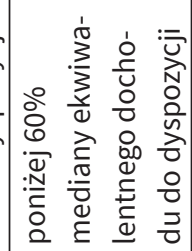 & 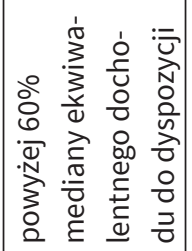 & 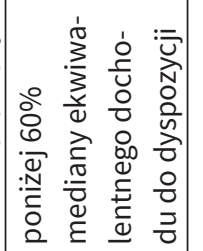 \\
\hline$\rightarrow$ & \multicolumn{2}{|c|}{ e!ununy } & \multicolumn{2}{|c|}{ е!uәл아 } & \multicolumn{2}{|c|}{ ептемоłs } \\
\hline
\end{tabular}




\begin{tabular}{|c|c|c|c|c|c|c|}
\hline$\sqrt{-1}$ & & 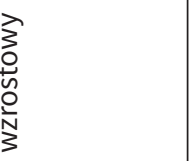 & & 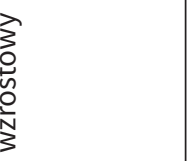 & 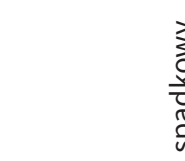 & $\begin{array}{l}\sum_{0}^{2} \\
\frac{2}{0} \\
\frac{0}{0} \\
n \\
n\end{array}$ \\
\hline$\stackrel{\bullet}{-1}$ & $\begin{array}{l}\text { 3े } \\
\text { गे } \\
\text { Ǹ } \\
\text { N } \\
\text { N }\end{array}$ & 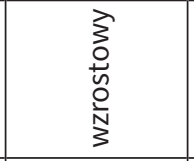 & $\begin{array}{l}\text { 3े } \\
\text { गे } \\
\text { Ǹ } \\
\text { N } \\
\text { N }\end{array}$ & 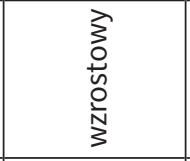 & 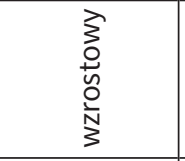 & $\begin{array}{l}\overrightarrow{3} \\
0 \\
0 \\
0 \\
0 \\
0 \\
0 \\
0\end{array}$ \\
\hline$\stackrel{\sim}{\neg}$ & $\stackrel{\varphi}{\sigma}$ & $\begin{array}{l}\infty \\
\stackrel{-}{-}\end{array}$ & $\Rightarrow$ & $\stackrel{-H}{m}$ & $\stackrel{\infty}{\sim}$ & $\stackrel{+}{6}$ \\
\hline$\dot{J}$ & $\stackrel{\infty}{\underset{\sigma}{*}}$ & $\begin{array}{l}\text { Ln } \\
\text { Oे }\end{array}$ & $m^{m}$ & 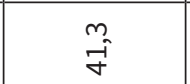 & $\overbrace{}^{\infty}$ & $\stackrel{\forall}{\stackrel{J}{J}}$ \\
\hline$\stackrel{m}{\rightarrow}$ & $\hat{\sigma}$ & $\stackrel{0}{i}$ & क) & \begin{tabular}{l}
0 \\
\hdashline \\
o
\end{tabular} & $\begin{array}{l}0 \\
6\end{array}$ & $\begin{array}{l}0 \\
\stackrel{ \pm}{ \pm}\end{array}$ \\
\hline ユ & 요 & $\begin{array}{l}\infty \\
\text { i }\end{array}$ & $\stackrel{n}{N}$ & 몽 & है & $\begin{array}{l}0 \\
\underset{+}{+}\end{array}$ \\
\hline 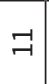 & $\stackrel{\infty}{+}$ & $\stackrel{\infty}{\underset{N}{N}}$ & $\stackrel{N}{\infty}$ & $\hat{N^{\circ}}$ & $\hat{\sigma}$ & 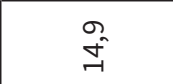 \\
\hline 욱 & $\stackrel{\infty}{m}$ & $\begin{array}{l}0 \\
\text { D }\end{array}$ & $\begin{array}{l}\text { के } \\
\text { - }\end{array}$ & $\begin{array}{l}0 \\
\tilde{m}^{-}\end{array}$ & $\hat{\kappa}$ & $\stackrel{\vec{m}}{\vec{I}}$ \\
\hline$a$ & $\stackrel{\sim}{*}$ & $\stackrel{\overbrace{}}{A}$ & $\begin{array}{l}m \\
0 \\
0\end{array}$ & $\vec{m}$ & $\tilde{m}^{-}$ & $\stackrel{\circ}{\exists}$ \\
\hline$\infty$ & $\stackrel{m}{\sim}$ & $\stackrel{n}{\stackrel{n}{-}}$ & $\stackrel{n}{n}$ & $\begin{array}{l}\text { N } \\
\text { fे }\end{array}$ & ○. & 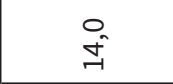 \\
\hline$\sim$ & $\stackrel{-1}{\sigma}$ & $\begin{array}{l}\sigma^{\prime} \\
\sigma_{-1}^{\prime}\end{array}$ & $\stackrel{n}{n}$ & $\stackrel{\sim}{\sim}$ & $\stackrel{\llcorner}{\llcorner}$ & $\stackrel{\overbrace{}}{\sim}$ \\
\hline 6 & $\stackrel{\circ}{\circ}$ & $\begin{array}{l}\infty \\
0_{-1}^{\circ}\end{array}$ & $\stackrel{a}{N}$ & $\stackrel{m}{m}$ & $\stackrel{m}{m}$ & $\stackrel{n}{\sim} \underset{-1}{-1}$ \\
\hline เ & $\stackrel{\sim}{*}$ & 음 & $\stackrel{n}{N}$ & $\stackrel{0}{\hat{m}}$ & $\stackrel{\infty}{+}$ & $\stackrel{m}{\underset{\sim}{*}}$ \\
\hline$\theta$ & $\stackrel{n}{\sim}$ & $\underset{\substack{N \\
\infty \\
-1}}{ }$ & $\stackrel{N}{N}$ & ָ̃ & $\stackrel{\mathscr{\sigma}}{\sigma}$ & $\stackrel{\sim}{\underset{7}{*}}$ \\
\hline$m$ & $m_{n}^{m}$ & $\hat{\sigma}$ & $\begin{array}{l}0 \\
\infty\end{array}$ & $\begin{array}{l}\text { o् } \\
\text { ळे }\end{array}$ & $\stackrel{\sim}{\sim}$ & $\stackrel{+}{\underset{7}{*}}$ \\
\hline$\sim$ & 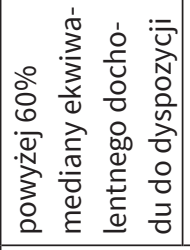 & 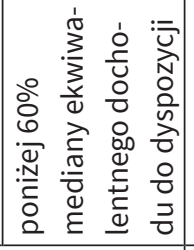 & 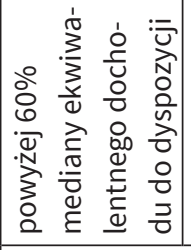 & 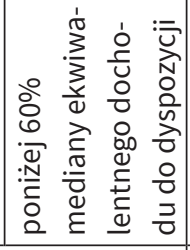 & 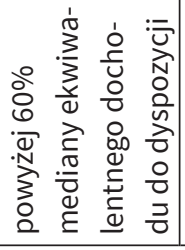 & 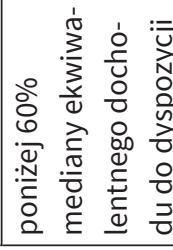 \\
\hline-1 & \multicolumn{2}{|c|}{ ઘ!pueju! } & \multicolumn{2}{|c|}{ е!ฺәмzS } & \multicolumn{2}{|c|}{ е! uеұКıg еяাə!м } \\
\hline
\end{tabular}



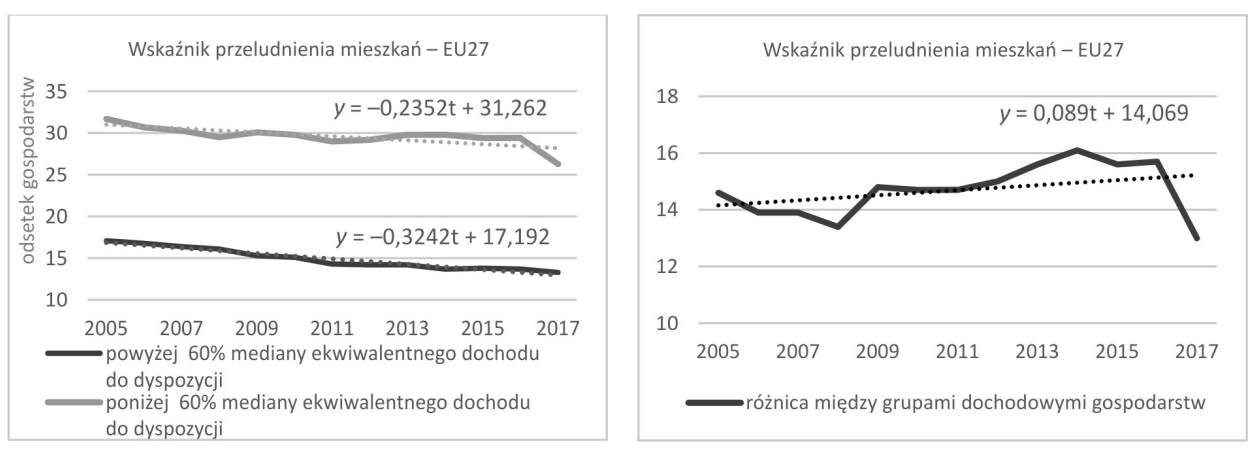

Rysunek 7.7. Wskaźnik przeludnienia mieszkań z uwzględnieniem sytuacji finansowej gospodarstw domowych w EU27

Źródto: opracowanie własne

Trend wzrostowy odsetka gospodarstw domowych mieszkających w warunkach przeludnienia w grupie uzyskującej poniżej $60 \%$ krajowej mediany ekwiwalentnego dochodu do dyspozycji był widoczny w Austrii, Grecji i Niemczech. Zdziwienie budzi fakt, że na Cyprze i w Wielkiej Brytanii trend przeludnienia był wzrostowy w grupie zamożniejszej. W większości krajów UE (19 przypadków), ale również w skali całej wspólnoty europejskiej w przyjętym horyzoncie analizy pogłębiały się różnice między wskaźnikiem przeludnienia mieszkań w badanych grupach dochodowych gospodarstw (rys. 7.7).

\subsection{Wnioski}

Mimo uniwersalnego charakteru potrzeb mieszkaniowych zakres ich realizacji nie jest identyczny na poszczególnych rynkach. Europejskie systemy mieszkaniowe od dziesięcioleci wykazują istotne różnice zarówno pod względem poziomu rozwoju, jak i koncepcyjnego podejścia do kwestii mieszkaniowych. Pod tym względem mamy do czynienia z pełnym spektrum rozwiązań, od systemów bazujących w zasadniczym stopniu na rozwiązaniach rynkowych po systemy podkreślające opiekuńczą rolę państwa i potrzebę interwencjonizmu publicznego w sferze mieszkaniowej. Zidentyfikowane w literaturze różnice w ścieżkach rozwoju rynków mieszkaniowych są konsekwencją procesów historycznych, utrwalonych wzorców kulturowych oraz, o czym należy pamiętać, także podziałów geopolitycznych powojennej Europy.

Rynki mieszkaniowe podlegają jednak stałym zmianom, których kierunek współcześnie nadaje przede wszystkim społeczno-ekonomiczna integracja gospodarek europejskich. Potwierdzają to wyniki zrealizowanych badań, w świetle 
których pomiędzy rynkami europejskimi występuje tendencja do zmniejszania się różnic w dostępie i jakości usługi mieszkaniowej. Sukcesywnie zaciera się historyczny podział na słabo rozwinięte rynki mieszkaniowe Europy Środkowo-Wschodniej i oferujące zdecydowanie wyższy standard mieszkaniowy rynki zachodnioeuropejskie. Procesy te mają jednak długoterminowy charakter i nie gwarantują pełnego ujednolicenia rynków mieszkaniowych. Równolegle z konwergencją krajowych rynków mieszkaniowych występuje zjawisko dywergencji regionalnej, która stanowi wyraz naturalnego procesu szybszego rozwoju regionów o dużym potencjale gospodarczym względem niższej dynamiki zmian w regionach słabszych ekonomicznie.

Zmiany zauważalne są również po stronie otoczenia instytucjonalnego rynków mieszkaniowych ze szczególnym uwzględnieniem realizowanych w poszczególnych krajach modeli polityki mieszkaniowej. W tym zakresie obserwowana jest konwergencja klubowa. Kraje o podobnych cechach strukturalnych i doświadczeniach historycznych wykazują również większe podobieństwo pod względem instytucjonalnej organizacji rynków mieszkaniowych.

Przed rynkami europejskimi stoją jednak nowe wyzwania, których źródłem są zarówno przemiany ekonomiczne, społeczno-kulturowe, a w dłuższej perspektywie także ekologiczne. Już teraz systemy mieszkaniowe mierzyć się muszą z problemem starzenia się społeczeństwa, narastających nierówności społecznych, wzmożoną migracją wewnętrzną jak i falą imigracji spoza UE, pilną potrzebą redukowania negatywnego wpływu budownictwa mieszkaniowego i użytkowania zasobów mieszkaniowych na środowisko naturalne.

Warto w tym kontekście wspomnieć również o popularyzacji w sferze mieszkaniowej koncepcji ekonomii współdzielenia, która fundamentalnie zmienia postrzeganie nieruchomości mieszkaniowych. Mieszkanie przestaje być rozumiane jako trwałe dobro konsumpcyjne, częściej zaś postrzegane jest jako usługa mieszkaniowa. Efektem tych zmian jest zjawisko colivingu, rezygnowanie $\mathrm{z}$ własności na rzecz elastycznych form zaspokajania potrzeb mieszkaniowych, ale również koncentracja zasobów mieszkaniowych w rękach dużych inwestorów, intensyfikacja ruchu turystycznego w miastach, wypieranie dotychczasowych mieszkańców centrów miast przez krótkookresowych najemców czy wzrost cen najmu. Przedstawione tendencje zdecydowanie będą miały wpływ na przyszły kształt rynków mieszkaniowych w Europie. 


\section{Zakończenie}

Przedmiotem rozważań w niniejszej pracy były procesy konwergencji rynków mieszkaniowych. Duże znaczenie społeczno-gospodarcze rynku nieruchomości mieszkaniowych, jego wieloaspektowy wpływ na funkcjonowanie jednostki oraz całej gospodarki stanowią ważną przesłankę do podjęcia badań nad kierunkiem i charakterem zmian zachodzących w sferze mieszkaniowej zarówno $\mathrm{w}$ ujęciu międzynarodowym, jak i regionalnym. Praca wpisuje się w ciąg badań sektora mieszkaniowego realizowanych w wielu krajach. Podejmuje jednak nie tylko najczęściej prowadzone badania nad konwergencją cenową, cechuje ją szersze spojrzenie, uwzględniające konwergencję realną oraz instytucjonalną rynków mieszkaniowych. Podjęta została także próba wskazania przyczyn tego zjawiska oraz jego skutków.

Zakres przestrzenny badań ograniczony został do krajów UE, z uwzględnieniem zmian związanych z poszerzeniem jej granic o kraje słabiej rozwinięte w porównaniu do członków starej Unii. Specyfika badań wymagała uwzględnienia długiego okresu analizy: badania dotyczące zmian zachodzących na rynkach nieruchomości sięgnęły lat 50., badania dotyczące przebiegu procesów konwergencji objęły okres 2000-2017.

Problematyka niniejszej pracy obejmuje cztery, wzajemnie uzupełniające się wątki. Wystąpiła w niej warstwa teoretyczna, w której przedstawiono społeczny i ekonomiczny wymiar rynku mieszkaniowego, ewolucję modeli mieszkaniowych w gospodarkach europejskich, a także istotę teorii konwergencji stanowiącą element ekonomii rozwoju ${ }^{1}$.

Warstwa teoretyczna wymagała uzupełnienia o warstwę metodyczną zawierającą propozycje metod badania zjawiska konwergencji. W pracy wystąpiła również warstwa niezmiernie pracochłonna i trudna na etapie realizacji - warstwa obliczeniowa. Posiada ona cechy diagnostyczne, ukazuje skalę konwergencji cenowej i pozacenowej na rynkach mieszkaniowych w krajach europejskich, dynamikę procesów konwergencji, a także jej zgodność z konwergencją gospodarczą. Ściśle powiązana jest z nią warstwa analityczna podejmująca próbę identyfikacji przyczyn i skutków procesów konwergencji rynków nieruchomości mieszkaniowych.

1 Ekonomia rozwoju urosła do oddzielnej dyscypliny w latach 50. XX wieku, zyskując na znaczeniu w latach 90. ubiegłego wieku. 
Na podstawie przeprowadzonych badań można wysunąć kilka wniosków:

1. Empirycznie została potwierdzona tendencja do zmniejszania nierówności w poziomie rozwoju gospodarczego krajów członkowskich UE, jak również tendencja do spadku zróżnicowania europejskich rynków mieszkaniowych. Tym samym została potwierdzona hipoteza (H1): rynki mieszkaniowe w krajach europejskich podlegają procesom konwergencji.

2. Rynki nieruchomości podlegały konwergencji cenowej, a także pozacenowej. $\mathrm{W}$ ujęciu międzynarodowym analiza cen pozwoliła zidentyfikować dwa kluby, w ramach których średnie ceny nieruchomości wykazywały statystycznie istotny spadek zróżnicowania w uwzględnionym horyzoncie analizy (2000-2017). Do pierwszego klubu zaklasyfikowane zostały rynki mieszkaniowe: Belgii, Finlandii, Francji, Holandii, Irlandii, Niemiec, Polski, Słowacji, Wielkiej Brytanii oraz Włoch (10 rynków). W drugim klubie znalazły się rynki Bułgarii, Grecji, Portugalii oraz Hiszpanii (4 rynki).

Również w ujęciu regionalnym wyodrębnione zostały w poszczególnych krajach grupy rynków mieszkaniowych, w ramach których zróżnicowanie cen wykazywało tendencję malejącą. Liczba zidentyfikowanych klubów konwergencji cenowej wahała się od 1 do 4 klubów. W wybranych krajach pojawiły się również przypadki rynków regionalnych, które zgodnie z przyjętą metodologią nie zostały zaklasyfikowane do żadnego klubu konwergencji cenowej. Były to najczęściej rynki o zdecydowanie odmiennej, długookresowej ścieżce zmian cen względem pozostałych regionów. Wnioski z analizy konwergencji cenowej potwierdzają hipotezę (H3) wskazującą, iż procesy konwergencji mieszkaniowej są zróżnicowane przestrzennie i przyjmują charakter konwergencji klubowej.

Podstawą wnioskowania o zachodzeniu konwergencji pozacenowej w skali międzynarodowej było sześć wskaźników: stopa deprywacji zasobów mieszkaniowych, siła nabywcza gospodarstw na rynku mieszkaniowym, wskaźnik własności mieszkań, wydatki publiczne na mieszkalnictwo, skala kredytowania hipotecznego, liczba mieszkań na 1000 mieszkańców. W toku przeprowadzonych badań potwierdzono zachodzenie beta i sigma konwergencji dla pięciu z sześciu przyjętych wskaźników (za wyjątkiem wydatków publicznych na mieszkalnictwo). Dynamiczne procesy konwergencji wystąpiły przede wszystkim $\mathrm{w}$ obszarze zadłużenia hipotecznego gospodarstw domowych, wskaźnika własności mieszkań oraz wskaźnika deprywacji zasobów mieszkaniowych. Co istotne, konwergencja rynków mieszkaniowych była zmienna w czasie. Silniejsze tendencje do ujednolicania rynków mieszkaniowych występowały w fazie wzrostowej cyklu koniunkturalnego (lata 2000-2007), słabsze natomiast w latach następujących po globalnym kryzysie gospodarczym (2008-2017). W przypadku większości zmiennych nie zdiagnozowano gamma konwergencji.

Analiza regionalna uwzględniająca dwie podstawowe zmienne diagnostyczne (liczbę mieszkań na 1000 mieszkańców oraz siłę nabywczą gospodarstw na rynku mieszkaniowym) zarysowała odmienny obraz zmian zachodzących na rynkach mieszkaniowych. W odniesieniu do zasobów mieszkaniowych rynki regionalne wykazywały 
beta oraz sigma dywergencję. Niejednoznaczny kierunek zmian natomiast uzyskano dla wskaźnika siły nabywczej gospodarstw. W większości rynków regionalnych beta oraz sigma konwergencja nie zachodziła bądź miała statystycznie nieistotny charakter. Nie występowała również konwergencja typu gamma.

3. Badania potwierdziły, że procesy konwergencji determinowane są czynnikami wewnętrznymi i zewnętrznymi, wskazując na trafność hipotezy (H2). Do czynników wewnętrznych należą: czynniki związane przede wszystkim z historycznymi uwarunkowaniami funkcjonowania rynków mieszkaniowych, priorytetami polityki mieszkaniowej, potencjałem gospodarczym i atrakcyjnością inwestycyjną regionu oraz kraju. Czynniki zewnętrzne obejmują procesy społeczno-gospodarcze w skali międzynarodowej. Ich źródłem jest postępująca integracja gospodarek europejskich i towarzysząca jej swoboda przepływu kapitału, migracja zasobów ludzkich, ujednolicanie wzorców kulturowych i stylu życia.

Silną rolę czynników wewnętrznych potwierdza zróżnicowane tempo zmian w krajach starej UE i krajach nowo przyjętych. Kraje starej UE o wyższym poziomie PKB per capita wykazują niższe tempo zmian na rynkach mieszkaniowych. Korzystniejsza sytuacja mieszkaniowa występująca w krajach wyżej rozwiniętych implikuje wyższą inercję tych rynków.

Przyczyny badanych zjawisk daleko wykraczają poza rynek nieruchomości, sięgają przyjmowanych koncepcji polityki mieszkaniowej, czynników warunkujących atrakcyjność inwestycyjną regionu oraz kraju, obejmują procesy społeczno-gospodarcze w skali międzynarodowej łącznie z dążeniem do ujednolicenia wzorców kulturowych i stylu życia. Wskazuje to na rosnącą rolę czynników pozacenowych: czynników instytucjonalnych (w tym strategii mających wspierać własność), a także czynników behawioralnych przejawiających się w napędzaniu zachowań gospodarstw domowych. Dla nowych członków warunki mieszkaniowe w krajach starej UE stały się punktem odniesienia, przyczyniły się do wykreowania nowych standardów mieszkaniowych, prowadząc do upodabniania się (konwergencji) potrzeb. Poprawiająca się sytuacja gospodarcza w nowo przyjętych krajach UE zaczęła tworzyć warunki do przekuwania ujawniających się potrzeb w popyt efektywny.

4. Z powodu przyjmowania w badanych państwach różnych rozwiązań na obszarze polityki mieszkaniowej, różnic w rozwoju rynków hipotecznych, różnego poziomu zamożności społeczeństwa, proces konwergencji nie gwarantuje pełnego ujednolicenia rynków. Można jedynie mówić o upodabnianiu się i synchronizacji kierunku ich rozwoju. Stanowi to potwierdzenie hipotezy (H4): długoterminowym następstwem konwergencji nie jest ujednolicenie systemów mieszkaniowych, lecz zmniejszenie różnic w poziomie rozwoju rynków (ich harmonizacja). Warto zwrócić uwagę, że wniosek ten pozostaje zgodny z istotą terminu „konwergencja”. Termin ten ma wymiar dynamiczny, wskazuje na zachodzący proces. Zgodnie z definicją tej kategorii oznacza ona „upodabnianie się rzeczy początkowo różnych", co wskazuje na zachodzące procesy, a nie warunkuje zupełnego ujednolicenia. 



\section{Bibliografia}

Abbott A., De Vita G., (2013), Testing for Long-run Convergence across Regional House Prices in the UK: A Pairwise Approach, „Applied Economics”, no. 45:10, s. $1227-1238$.

Acemoglu D., Robinson J.A., (2014), Dlaczego narody przegrywają. Źródła władzy, pomyślności i ubóstwa, Wydawnictwo Zysk i S-ka, Poznań.

Allen J., (2006), Welfare Regimes, Welfare Systems and Housing in Southern Europe, „International Journal of Housing Policy”, no. 6(3), s. 251-277.

Andrzejewski A., (1987), Polityka mieszkaniowa, PWE, Warszawa.

Arellano M., Bond S., (1991), Some Tests of Specification for Panel Data: Monte Carlo Evidence and an Apllication to Employment Equations, „Review of Economic Studies", no. 58, s. 277-297.

Arnott R., (1995), Time for Revisionism on Rent Control?, "Journal of Economic Perspectives", vol. 9(1), s. 99-120.

Arthur W.B., (1989), Competing Technologies and Lock-in by Historical Small Events, „Economic Journal”, vol. 99 (March), s. 116-131.

Arthur W.B., (1990), Industry Location Patterns and the Importance of History, „Mathematical Social Sciences”, no. 19, s. 235-251.

Atkinson A.B., (2013), Wealth and Inheritance in Britain from 1896 to the Present, CASE/178.

Augustyniak H., Łaszek J., Olszewski K., Waszczuk J., (2012), Cycles on the Housing and Commercial Real Estate Market, Risk and the Need for Appropriate and Prudent Valuation, National Bank of Poland, Warsaw School of Economics, 23 August.

Aye G., Goswami S., Gupta R., (2013), Metropolitan House Prices in India: Do They Converge?, „Regional and Sectoral Economic Studies”, vol. 13(1), s. 135-144.

Bair S.C., (2010), Przyczyny kryzysu finansowego i diagnoza sytuacji na rynkach, „Bezpieczny Bank”, nr 1(40), s. 37-70.

Balazs E., Dubravko M., (2007), Determinants of House Prices in Central and Eastern Europe, BIS Working Paper, no. 236.

Balchin P., (2013), Housing Policy in Europe, Routledge, London.

Boldrin M., Canova F., (2001), Inequality and convergence in Europe's regions: reconsidering European region al policies, "Economic Policy", vol. 16(32), s. 205-253. 
Ball M., (2003), Markets and the Structure of the Housebuilding Industry: An International Perspective, „Urban Studies”, vol. 40(5-6), s. 897-916.

Ball M., Wood A., (1996), Does Building Investment Affect Economic Growth?, „Journal of Property Research”, vol. 13(2), s. 99-114.

Baltagi B.H., (1995), Econometric Analysis of Panel Data, John Wiley \& Sons Ltd.,Chichester.

Bank for International Settlements, Review, March, Basel.

Bańbuła P., (2006), Oszczędności i wybór międzyokresowy-podejście behawioralne, Materiały i Studia NBP, nr 208.

Barro R., (1997), Makroekonomia, Polskie Wydawnictwo Ekonomiczne, Warszawa.

Barro R., Sala-i-Martin X.X., (1992), Convergence, „Journal of Political Economy”, vol. 100(2), s. 223-251.

Bednarski M., (2013), Szara strefa - rynek pracy - integracja społeczna, „Optimum. Studia Ekonomiczne", nr 6(66), s. 48.

Bekebrede G., Mayer I., (2006), Build Your Seaport in a Game and Learn about Complex Systems, „Journal of Design Research”, vol. 5(2), s. 273-298.

Bengtsson B., Ruonavaara H., (2010), Introduction to the Special Issue: Path Dependence in Housing, „Housing, Theory and Society”, vol. 27(3), s. 193-203.

Bengtsson B., Annaniassen E., Jensen L., Ruonavaara H., Sveinsson J.R., (2006), Varför så olika? Nordisk bostadspolitik i jämförande historiskt ljus [Why So Different? Nordic Housing Policy in a Comparative Historical Light], Egalite, Malmö.

Bernardelli M., Próchniak M., Witkowski B., (2017), Konwergencja dochodowa: mocne i słabe strony istniejących podejść, „Kwartalnik Kolegium Ekonomiczno-Społecznego Studia i Prace”, nr 3, s. 71-86.

Blanco F., Martin V., Vazquez G., (2015), Regional House Price Convergence in Spain During the Housing Boom, „Urban Studies”, vol. 53(4), s. 775-798.

Blundel R., Bond S., (1998), GMM Estimation with Persistent Panel Data: An Application to Production Functions, The Institute for Fiscal Studies, Working Paper Series No. W99/4, Paper presented at the Eighth International Conference on Panel Data Göteborg University, June 11-12.

Bogle J.C., (2009), Dość. Prawdziwe miary bogactwa, biznesu i życia, PTE, Warszawa.

Boldrin M., Canova F., (2001), Inequality and convergence in Europe's regions: reconsidering European region al policies, „Economic Policy”, vol. 16(32), s. 205-253.

Borio C., Drehmann M., (2009), Assessing the Risk of Banking Crises - Revisited, BIS, Quarterly.

Bourne L.S., (1981), The Geography of Housing, Hodder Education.

Boyle G.E., McCarthy T.G., (1997), A Simple Measure of $\beta$-convergence, „Oxford Bulletin of Economics and Statistics", vol. 59(2), s. 257-264.

Bywalec Cz., (2017), Konsumpcja w teorii i praktyce gospodarowania, Wydawnictwo Naukowe PWN, Warszawa. 
Cano Fuentes G., Etxezarreta Etxarri A., Dol K., Hoekstra J., (2013), From Housing Bubble to Repossessions: Spain Compared to Other West European Countries, „Housing Studies”, vol. 28(8), s. 1197-1217.

Canova F., Mercet A., (1995), The Poor Stay Poor: Non-convergence across Countries and Regions, Discussion Paper 1265, Centre for Economic Policy Research, London.

Capozza D., Hendershott P., Mack C., Mayer C., (2002), Determinants of Real House Price Dynamics, National Bureau of Economic Research Working Paper 9262.

Carree M., Klomp L., (1997), Testing the Convergence Hypothesis: A Comment, „Review of Economics and Statistics”, no. 79, s. 683-686.

Case K.E., Quigley J.M., Shiller R.J., (2005), Comparing Wealth Effects: The Stock Market Versus the Housing Market, „Advances in Macroeconomics”, vol. 5(1), s. $1-34$.

Cesarski M., (2010), Modele i warunki mieszkaniowe w powojennej Zachodniej oraz Środkowej Europie, „Problemy Rozwoju Mieszkalnictwa”, nr 4, s. 23-33.

Cesarski M., (2013a), Polityka mieszkaniowa $w$ Polsce $w$ pracach naukowych 1918-2010. Dokonania i wpływ polskiej szkoły badań, SGH, Warszawa.

Cesarski M., (2013b), Powojenna polityka mieszkaniowa w Europie Zachodniej - sektor publiczny a paradygmat wzrostu ekonomicznego, [w:] J. Osiński (red.), Kryzys, niepewność i niestabilność we współczesnej Europie, Oficyna Wydawnicza SGH, Warszawa, s. 255-267.

Cesarski M., (2017), Społeczna polityka mieszkaniowa w poszukiwaniu i urzeczywistnianiu trwałego rozwoju, „Kwartalnik Kolegium Ekonomiczno-Społecznego SGH”, nr 3, s. 11-29.

Chelcea L., Druţă O., (2016), Zombie Socialism and the Rise of Neoliberalism in post-Socialist Central and Eastern Europe, „Eurasian Geography and Economics", vol. 57(4-5), s. 521-544.

Chiu R., (2008), Government Intervention in Housing: Convergence and Divergence of the Asian Dragons, „Urban Policy and Research”, vol. 26, issue 3, s. 249-269.

Cingano F., (2014), Trends in Income Inequality and its Impact on Economic Growth, OECD SEM Working Paper, no. 163.

Cinzia A., Núñez Ferrer J., Musmeci R., Di Salvo M., Pilati M., (2018), Income Convergence in the EU: A Tale of Two Speeds, CEPS Commentary, CEPS, Brussels, 9 January 2018.

Ciołek D., Brodzicki T., (2007), Głębokie determinanty wzrostu gospodarczego - weryfikacja empiryczna z wykorzystaniem metod estymacji panelowych, Analizy i Opracowania KEIE, nr 1, UG, Sopot.

Claessens S., Kose M.A., (2017), Asset Prices and Macroeconomic Outcomes: A Survey, CAMA Working Paper, no. 76, November.

Clapham D., (1995), Privatisation and the East European Housing Model, Urban Studies, 32(4-5), s. 679-694. 
Clapham D., (2006), Housing Policy and the Discourse of Globalization, European Journal of „Housing Policy”, vol. 6(1), s. 55-76.

Clapham D., Hegedus J., Kindrea K., Tosics I., Kay H. (eds.), (1996), Housing Privatization in Eastern Europe, Greenwood Press, London.

Cohen V., Karpaviciute L., (2017), The Analysis of the Determinants of Housing Prices, „Independent Journal of Management \& Production”, vol. 8(1), s. 49-62.

Coleman M.S., Gentle R., (2001), Exploring the Dynamics of Buildings Supply: A Duration Model of the Development Cycle, „Journal of Real Estate Research, American Real Estate Society", vol. 21(1-2), s. 21-42.

Communication from the Commission 2012, EESC, 597/2012-TEN/484, 13 December.

Cunăt V., Cvijanocić D., Yuan K., (2018), Within-Bank Spillovers of Real Estate Shocks, The „Review of Corporate Finance Studies”, vol. 7(2), s. 157-193.

Dańska-Borsiak B, (2011), Dynamiczne modele panelowe w badaniach ekonomicznych, Wydawnictwo Uniwersytetu Łódzkiego, Łódź.

Das S., Gupta R., Kaya P., (2010), Convergence of Metropolitan House Prices in South Africa: A re-examination Using Efficient Unit Root Tests, „Applied Econometrics and International Development", vol. 10(1), s. 173-188.

Del Pero A.S., Adema W., Ferraro V., Frey V., (2016), Policies to Promote Access to good-quality Affordable Housing in OECD Countries, OECD Social, Employment and Migration Working Papers, no. 176.

De Soto H., (2002), Tajemnica kapitatu, Fijor Publishing, Chicago, Warszawa.

Dewilde C., De Decker P., (2016), Changing Inequalities in Housing Outcomes across Western Europe, „Housing, Theory and Society”, vol. 33 (2), s. 121-161.

Dijol J., Ghekiere L., Koessl G., Lakatos E., Pittini A., (2017), The State of Housing in the EU 2017, Housing Europe, Brussels, Belgium.

Dittmann I., (2014), Gamma konwergencja cen na lokalnych rynkach mieszkaniowych w Polsce, Studia Ekonomiczne, nr 181, UE w Katowicach, s. 195-207.

Droes M., Van de Minne A., (2016), Do the Determinants of House Prices Change over Time? Evidence from 200 Years of Transactions Data, European Real Estate Society Conference Paper.

ECB Structural Housing Indicators Statistics, Annual series.

Encyklopedia, (1999), Wydawnictwo Naukowe PWN, Warszawa.

Esping-Andersen G., (1990), The Three Worlds of Welfare Capitalism, Polity Press, Cambridge.

European Commission, (2015), The 2015 Pension Adequacy Report: current and future income adequacy in old age in the EU, Volume I, Joint Report prepared by the Social Protection Committee (SPC) and the European Commission (DG EMPL), Brussels.

Fields D., Uffer S., (2016), The Financialisation of Rental Housing: A Comparative Analysis of New York City and Berlin, „Urban Studies”, vol. 53(7), s. 1486-1502.

Five Years of an Enlarge EU. Economic Achievements and Challenges, (2009), „European Economy”, no. 1, European Communities. 
Friedman M., (1992), Do Old Fallacies Ever Die?, „Journal of Economic Literature”, vol. 30, s. 2129-2132.

Fornero E., Rossi M., Brancati M.C.U., (2016), Explaining Why, Right or Wrong, (Italian) Households Do Not Like Reverse Mortgages, „Journal of Pension Economics \& Finance”, vol. 15(2), s. 180-202.

Forrest R., Williams P., (1984), Commodification and Housing: Emerging Issues and Contradictions, „Environment and Planning A”, vol. 16(9), s. 1163-1180.

Fuente De la A., (1995), Catch-up, Growth and Convergence in the OECD, Discussion Paper 1274, Centre for Economic Policy Research, London.

Fuente De la A., (2002), On the Sources of Convergence: A Close Look at the Spanish Regions, „European Economic Review”, vol. 46(3), s. 569-599.

Fundowicz J., Łapiński K., Wyżnikiewicz B., (2018), Szara strefa 2018, Instytut Prognoz i Analiz Gospodarczych, Fundacja Naukowa.

Gajewski P., (2006), Nowe koncepcje konwergencji, [w:] S. Krajewski, P. Kaczorowski (red.), Wzrost gospodarczy, restrukturyzacja i rynek pracy $w$ Polsce: ujęcie teoretyczne i empiryczne, Wydawnictwo Uniwersytetu Łodzkiego, Łódź.

Galati G., Teppa F., (2010), Heterogeneity in House Price Dynamics, Working Paper, no. 564, De Nederlandsche Bank.

Gawlikowska-Hueckel K., Zielińska-Głębocka A., (2004), Integracja europejska. Od jednego rynku do unii walutowej, C.H. Beck, Warszawa.

Geng N., (2018), Fundamental Drivers of House Prices in Advanced Economies, IMF Working Paper WP/18/164.

Ghiraldo E., Ciula R., Festa M., (2013), Housing Prices: An Analysis of the Dynamics of Italian Market Development, „Territorio Italia”, no. 2, s. 63-83.

Glaeser E.L., Gyourko J., Saiz A., (2008), Housing Supply and Housing Bubbles, „Journal of Urban Economics”, vol. 64(2), s. 198-217.

Glaser M.A., (2011), Durability in Housing-aesthetics of the Ordinary, [w:] L. Sang (ed.), Aesthetics of Sustainable Architecture, 0I0 Publishers, Rotterdam, s. 198-212.

Gnat S., (2016), Tests for the Presence of Price Convergence on Residential Property Market in Several Districts of Szczecin in 2006-2009, „Folia Oeconomica Stetinensia”, vol. 16(1), s. 186-195.

Gorzelak G., (2008), Fakty $i$ mity rozwoju regionalnego, „Zarządzanie Publiczne”, nr 4(6), s. 73-89.

Governa F., Saccomani S., (2010), A neo-liberal Housing Policy? Convergence and Divergence between Italian Local Housing Policy and European Trends, 24th AESOP Annual Conference, Finland, 7-10 July.

Grimes A., Aitken A., (2010), Housing Supply, Land Costs and Price Adjustment, „Real Estate Economics”, vol. 38(2), s. 325-353.

Habitat for Humanity, (2018), Raport, Warszawa, http://habitat.pl/wp-content/uplo ads/2018/04/HabitatPoland_badanie-opinii-publ_mieszkalnictwo2018.pdf

Hall R.E., Taylor J.B., (2007), Makroekonomia, Wydawnicwo Naukowe PWN, Warszawa. 
Harvey D., (2005), A Brief History of Neoliberalism, Oxford University Press, Oxford.

Hegedüs J., Lux M., Teller N. (eds.), (2013), Social Housing in Transition Countries, Routledge, London.

Hiebert P., Roma M., (2010), Relative House Price Dynamics across Euro Area and US Cities. Convergence or Divergence?, ECB Working Paper Series no. 1206/June.

Hilbers P., Lei Q, Zacho L., (2001), Real Estate Market Developments and Financial Sector Soundness, IMF Working Paper.

Hodrick R., Prescott E., (1997), Postwar U.S. Business Cycles: An Empirical Investigation, „Journal of Money Credit and Banking”, vol. 29(1), s. 1-16.

Hoekstra J., (2003), Housing and the Welfare State in the Netherlands: An Application of Esping-Andersen's Typology, „Housing, Theory and Society”, vol. 20(2), s. $58-71$.

Holmes M., (2007), How Convergent Are Regional House Prices in the United Kingdom? Some New Evidence from Panel Data Unit Root Testing, „Journal of Economic and Social Research", vol. 9(1), s. 1-17.

Holmes M., Grimes A., (2008), Is There Long-run Convergence among Regional House Prices in the UK?, „Urban Studies”, no. 45(8), s. 1531-1544.

Holmes M., Otero J., Panagiotidis T., (2017), A Pair-wise Analysis of Intra-city Price Convergence Within the Paris Housing Market, „The Journal of Real Estate Finance and Economics", vol. 54(1), s. 1-16.

Holmes M., Otero J., Panagiotidis T., (2019), Property Heterogeneity and Convergence Club Formation among Local House Prices, „Journal of Housing Economics", vol. 43, s. 1-13.

The Houses that Saved the World, The Economist, 30 March 2002.

Howenstine E. J., (2017), Housing Vouchers: A Comparative International Analysis, Routledge, New York.

Islam N., (1995), Growth Empirics: A Panel Data Approach, „Quarterly Journal of Economics", vol. 110(4), s. 1127-1170.

Islam I., (2003), What Have We Learned From Convergence Debate?, „Journal of Economic Surveys", vol. 17(3), s. 309-362.

Iwanicz-Drozdowska M., (2009), Pokusa nadużycia a kryzys „subprime”, Ekonomiczne Problemy Usług, nr 38, s. 32-37.

Jóźwik B., (2014), Konwergencja gospodarcza w regionach państw członkowskich Unii Europejskiej z Europy Środkowo-Wschodniej, „Roczniki Ekonomii i Zarządzania”, t. 6(42), nr 1, s. 93-113.

Kaczorowski M., (1963), W sprawie elastyczności użytkowania zasobów mieszkaniowych, Prace IBM, nr 40.

Kaplan G., Mitman K., Violante G.L., (2017), The Housing Boom and Bust. Model Meets Evidence, Working Papers 23694, National Bureau of Economic Research Inc.

Kemeny J., (1981), The Myth of Home Ownership: Private versus Public Choices in Housing Tenure, Routledge, London. 
Kemeny J., (1995), From Public Housing to the Social Market, Routledge, London.

Kemeny J., Lowe S., (1998), Schools of Comparative Housing Research: From Convergence to Divergence, „Housing Studies”, vol. 13(2), s. 161-176.

Kemp P.A., (2015), Private Renting after the Global Financial Crisis, „Housing Studies", vol. 30(4), s. 601-620.

Kim Y., Rous J., (2012), House Price Convergence: Evidence from U.S. State and Metropolitan Area Panels, „Journal of Housing Economics”, vol. 21(2), s. 169-186.

Kleinman M., (1996), Housing, Welfare, and the State in Europe: A Comparative Analysis of Britain, France, and Germany, Edward Elgar Publishing, Cheltenham.

Kong J., Phillips P., Sul D., (2017), Weak $\sigma$-Convergence: Theory and Applications, Cowles Foundation Discussion Paper, no. 2072.

Köppe, S., (2017), Britain's New Housing Precariat: Housing Wealth Pathways Out of Homeownership, „International Journal of Housing Policy”, vol. 17(2), s. 177-200.

Krakowińska E., (2008), Mieszkalnictwo jako dobro wiodące w gospodarce, „Studia i Materiały, Wydział Zarządzania UW”, nr 1, s. 75-82.

Kucharska-Stasiak E., (1990), Luka remontowa $w$ zasobach mieszkaniowych $w$ Polsce, Wydawnictwo Uniwersytetu Łódzkiego, Łódź.

Kucharska-Stasiak E., (2016a), Ekonomiczny wymiar nieruchomości, Wydawnictwo Naukowe PWN, Warszawa.

Kucharska-Stasiak E., (2016b), Grey Zone In the Real Estate Market, „Real Estate Management and Valuation", vol. 24(3), s. 83-92.

Kucharska-Stasiak E., (2018), Dysfunkcje na rynku nieruchomości w okresie kryzysu, „Bank i Kredyt”, nr 49(5), s. 493-514.

Kucharska-Stasiak E. (red.), (2004), Zachodnie rynki nieruchomości, TWIGGER, Warszawa.

Kudełko J., Prusek A., Zieliński K., (2011), Europejska polityka spójności oraz jej efekty $w$ Polsce, Wydawnictwo Uniwersytetu Ekonomicznego w Krakowie, Kraków.

Kusideł E., (2011), Convergence on Local Labour Market, „Acta Universitatis Lodziensis. Folia Oeconomica”, nr 252, s. 61-68.

Kusideł E., (2013), Konwergencja gospodarcza regionów Polski i jej znaczenie w osiaganiu celów polityki spójności, Wydawnictwo Uniwersytetu Łódzkiego, Łódź.

Kusideł E., (2013a), Convergence of regional human development indexes in Poland, „Comparative Economic Research”, tom 16(1), s. 87-102.

Kusideł E., (2013b), Konwergencja wojewódzkich wskaźników ładu społecznego, „Acta Universitatis Lodziendzis. Folia Oeconomica”, nr 293, s. 123-130.

Kusideł E., (2014), Zbieżność poziomu rozwoju województw Polski w kontekście kształtowania ładu instytucjonalnego, „Optimum. Studia Ekonomiczne”, nr 3(69), s. $103-117$.

Laferrère A., Le Blanc D., (2004), How do Housing Allowances Affect Rents? An Empirical Analysis of the French Case, Journal of Housing Economics, 13(1), s. 36-67. 
Leamer E.E., (2007), Housing is the Business Cycle, Proceedings - Economic Policy Symposium - Jackson Hole, Federal Reserve Bank of Kansas City, s. 149-233.

Legiędź T., (2005), Motywy działania polityków w świetle teorii wyboru publicznego, „Annales. Etyka w życiu gospodarczym”, nr 8(1), s. 277-283.

Lichtenberg F., (1994), Testing the Convergence Hypothesis, „The Review of Economics and Statistics", vol. 76(3), s. 576-579.

Lin R., Zhang X., Li X., Dong J., (2015), Heterogeneous Convergence of Regional House Prices and the Complexity in China, „Zbornik radova Ekonomskog fakulteta u Rijeci/Proceedings of Rijeka Faculty of Economics”, vol. 33(2), s. 325-348.

Lipski A., (2009), Rola mieszkania w obliczu nowoczesnych form życia rodzinnego, [w:] Problemy polityki społecznej, Studia i dyskusje, PAN. Komitet Nauk o Pracy i Polityce Społecznej, nr 11.

Lis P., (2005), Koncepcje polityki mieszkaniowej, Raporty. Opracowania. Referaty. Akademia Ekonomiczna w Poznaniu, nr 31, s. 5-58.

Lis P., (2008), Polityka państwa w zakresie finansowania inwestycji mieszkaniowych, Wydawnictwo C.H. Beck, Warszawa.

Lis P., (2012), Wahania cykliczne rynków mieszkaniowych. Aspekty teoretyczne i praktyczne, Wyd. Adam Marszałek, Toruń.

Loutskina E., Strahan P. E., (2015), Financial Integration, Housing and Economic Volatility, „Journal of Financial Economics”, vol. 115(1), s. 25-41.

Lowe S., Tsenkova S. (eds.), (2003), Housing Change in East and Central Europe: Integration or Fragmentation?, Ashgate, Aldershot.

Lucas Jr. R.E., (1988), On the Mechanics of Economic Development, „Journal of Monetary Economics", vol. 22, s. 3-42.

Lucian-Liviu A., (2016), Trends in the Relation between Regional Convergence and Economic Growth in EU, 56th Congress of the European Regional Science Association: „Cities \& Regions: Smart, Sustainable, Inclusive?”, 23-26 August.

Łastowski K., (2006), Historia integracji europejskiej, Wydawnictwo Adam Marszałek, Toruń.

Łaszek J., (2004), Bariery rozwoju rynku nieruchomości w Polsce, Materiały i Studia NBP, z. 184.

Łaszek J., (2006), Sektor nieruchomości mieszkaniowych z perspektywy banku centralnego, „Finansowanie Nieruchomości”, nr 3.

Ma L., Liu C., (2015), Is there Long Run Equilibrium in the House Prices of Australian Capital Cities?, „International Real Estate Review”, vol. 18, no. 4, s. 503-521.

Ma W., Li W., Qu K., (2017), Housing Prices, Residential and Nonresidential Investments and Macroeconomics Fluctuations, „Research in Business and Management", vol. 4(2), s. 19-26.

MacDonald R., Taylor M., (1993), Regional House Prices in Britain: Long-run Relationships and Short-run Dynamics, „Scottish Journal of Political Economy”, vol. 40(1), s. 43-55. 
Maclennan D., (2012), Understanding Housing Markets: Real Progress or Stalled Agendas, [w:] D. Clapham, W. Clark, K. Gibb (eds.), The Sage Handbook of Housing Studies, Sage, London, s. 5-26.

Maclennan D., Miao J., (2017), Housing and Capital in the 21st Century, „Housing, Theory and Society", vol. 34(2), s. 127-145.

Malaga K., Kliber P., (2007), Konwergencja i nierówności regionalne w Polsce w świetle neoklasycznych modeli wzrostu, Wydawnictwo Akademii Ekonomicznej w Poznaniu, Poznań.

Mallett S., (2004), Understanding Home: A Critical Review of the Literature, „The Sociological Review", vol. 52(1), s. 62-89.

Malpass P., (2011), Path Dependence and the Measurement of Change in Housing Policy, „Housing, Theory and Society”, vol. 28(4), s. 305-319.

Mandič S., (2010), The Changing Role of Housing Assets in Post-socialist Countries, „Journal of Housing and the Built Environment”, vol. 25 (2), s. 213-226.

Mandič S., Cirman A., (2012), Housing Conditions and Their Structural Determinants: Comparisons within the Enlarged EU, „Urban Studies”, vol. 49(4), s. 777-793.

Mandič S., Clapham D., (1996), The Meaning of Home Ownership in the Transition from Socialism: The Example of Slovenia, „Urban Studies”, vol. 33(1), s. 83-97.

Mankiw N., Romer D., Weil D., (1992), A Contribution of the Empirics of Economic Growth, „Quarterly Journal of Economics”, vol. 107(2), s. 407-437.

Mantey D., (2017), Social Consequences of Gated Communities: The Case of Suburban Warsaw, „The Professional Geographer”, vol. 69(1), s. 151-161.

Martin P., (2005), The Geography of Inequalities in Europe, „Swedish Economic Policy Review", vol. 12 s. 83-108.

Mączyńska E., (2019), Jak Kapitalizm zjada nasza przyszłość, „Eurologistics”, nr 112.

McCabe B.J., (2016), No Place Like Home: Wealth, Community, and the Politics of Homeownership, Oxford University Press, New York.

McCrone G., Stephens M., (2017), Housing Policy in Britain and Europe, Routledge, London.

Min Z., (2014), Opening Remarks at the Bundesbank, German Research Foundation/IMF Conference, June.

Mishkin F.S., (2007), Enterprise Risk Management and Mortgage Lending, Speech at the Forecaster's Club of New York, January.

Monfort P., (2008), Convergence of EU Regions. Measures and evolution, European Union EU Regional Policy Working Papers, 01/2008.

Montagnoli A., Nagayasu J., (2015), UK House Price Convergence Clubs and Spillovers, „Journal of Housing Economics”, vol. 30, s. 50-58.

Montanes A., Olmos L., (2013), Convergence in US House Prices, MPRA Paper, no. 48454.

Muller G., (1995), Understanding Real Estates Physical and Financial Market Cycles, „Real Estate Now”, vol. 12(3), s. 47-52. 
Müller T., (2019), Housing as a Pension: Policy Implications for Europe, [w:] Essays on Housing and Pensions, Springer Gabler, Wiesbaden, s. 37-56.

Murphy A., Muellbauer J., (1994), Explaining Regional House Prices in the UK, Working Papers, no. 199421, School of Economics, University College Dublin.

My Region, My Europe, Our Future, Seventh report on economic, social and territorial cohesion, Luxembourg: Publications Office of the European Union, 2017.

Nissan E., Payne J., (2013), A Simple Test of o-Convergence in U.S. Housing Prices across BEA Regions, „The Journal of Regional Analysis \& Policy”, vol. 43(2), s. $178-185$.

Norris M., Coates D., (2014), How Housing Killed the Celtic Tiger: Anatomy and Consequences of Ireland's Housing Boom And Bust, ,Journal of Housing and the Built Environment, vol. 29(2), s. 299-315.

Norris M., Winston N., (2011), Transforming Irish Home Ownership through Credit Deregulation, Boom and Crunch, „International Journal of Housing Policy”, vol. 11(1), s. 1-21.

North D.C., (1990), Institutions, Institutional Change and Economic Performance, Cambridge University Press, New York.

North D.C., (1994), Economic Performance through Time, „The American Economic Review", vol. 84(3), s. 359-368.

Nowak W., (2003), Koncepcje klasycznej konwergencji w teorii wzrostu gospodarczego, „Studia Ekonomiczne”, nr 3 (XXXVIII), s. 191-210.

Nowak W., (2006), Koncepcje konwergencji $w$ teorii wzrostu gospodarczego, [w:] M.G. Woźniak (red.), Nierówności społeczne a wzrost gospodarczy, MITEL, Rzeszów, s. 253-266.

Nykiel L., (2009), Funkcje i rola państwa na rynku mieszkaniowym, „Studia i Materiały Towarzystwa Naukowego Nieruchomości”, t. 17(4), s. 7-22.

O’Sullivan E., De Decker P., (2007), Regulating the Private Rental Housing Market in Europe, „European Journal of Homelessness”, no. 1, s. 95-117.

Owczarek D., (2011), Zamknięte osiedla, czyli dylemat współczesnych polskich miast. Badanie porównawcze mieszkańców zamkniętych i otwartych osiedli $w$ Warszawie, „Przegląd Socjologiczny”, nr 60(2-3), s. 365-391.

Perez J., Dones M., Liano C., (2009), An Interregional Impact Analysis of the EU Structural Funds in Spain (1995-1999), „Paper of Regional Science”, no. 3(08), s. 509-529.

Petrakos G., Artelaris P., (2009), European Regional Convergence Revisited: A Weighted Least Squares Approach, „A Journal of Urban and Reginal Policy”, vol. 40(2), s. 314-331.

Phillips P., Sul D., (2007), Transition Modeling and Econometric Convergence Tests, „Econometrica”, vol. 75(6), s. 1771-1855.

Piketty T., (2015), Kapitał w XXI wieku, Wydawnictwo Krytyki Politycznej, Warszawa.

Piketty T., Saez E., (2013), Top Incomes and the Great Recession: Recent Evolutions and Policy Implications, „IMF Economic Review”, vol. 61(3), s. 456-478. 
Poggio T., Whitehead C., (2017), Social Housing in Europe: Legacies, New Trends and the Crisis, „Critical Housing Analysis”, vol. 4(1), s. 1-10.

Polakowski M., Szarffenberg R., Zubrzycka-Czarnecka A., Święcicka K., (2017), Polityka mieszkaniowa, Friedrich-Ebert-Stiftung, Warszawa.

Priemus H., (1983), Volkshuisvestingssysteem en woningmarkt, Delftse Universitaire Pers, Delft.

Priemus H., Gruis V., (2011), Social Housing and Illegal State Aid: The Agreement between European Commission and Dutch Government, International Journal of Housing Policy, vol. 11(1), s. 89-104.

Puga D., (2002), European Regional Policies in Light of Recent Location Theories, „Journal of Economic Geograph", vol. 2(4), s. 373-406.

OECD Affordable Housing Database - http://oe.cd/ahd

Quah D., (1993), Galton's Fallacy and Tests of the Convergence Hypothesis, „Scandinavian Journal of Economics", vol. 95(4), s. 427-443.

Quah D., (1996), Twin Peaks: Convergence Empirics across Economies with (Some) Capital Mobility, „Journal of Economic Growth”, vol. 1(1), s. 95-124.

Quigley J.M., (1999), Real Estate Prices and Economic Cycles, „International Real Estate Review", vol. 2(1), s. 1-20.

Raport 2006 o naprawie sytuacji mieszkaniowej, Praca zespołowa wykonana w trybie społecznym, Warszawa, styczeń 2007.

Raport o sytuacji na rynku nieruchomości mieszkaniowych i komercyjnych w Polsce w 2017 roku, NBP, 2018.

REAS, Raport Polski rynek mieszkaniowy. Popyt i preferencje nabywców, maj 2010. Rocznik Statystyczny Rzeczypospolitej Polskiej 2017, GUS, Warszawa, 2017.

Rocznik Statystyczny Rzeczypospolitej Polskiej 2018, GUS, Warszawa, 2018.

Rodrigues-Pose A., Fratesi U., (2004), Między rozwojem a polityka społeczną: oddziaływanie europejskich funduszy strukturalnych $w$ regionach celu 1 , „Studia Regionalne i Lokalne", nr 3(17), s. 6-32.

Rola mieszkalnictwa w rozwoju gospodarczym, (2015), Polski Związek Firm Deweloperskich.

Romer T., (1994), Origins of Endogenous Growth, „Journal of Economic Perspectives", vol. 8(1), s. 3-22.

Ronald R., Dewilde C., (2017), Why Housing Wealth and Welfare?, [w:] Housing Wealth and Welfare, Edward Elgar Publishing, Northampton, s. 1-34.

Sala-i-Martin X.X., (1990), On Growth and States, Praca doktorska, Harvard University.

Sala-i-Matin X.X., (1996a), The Classical Approach to Convergence Analysis, „Economic Journal", vol. 106, issue 437, s. 1019-1036.

Sala-i-Martin X.X., (1996b), Regional Cohesion: Evidence and Theories of Regional Growth and Convergence, „European Economic Review”, vol. 40(6), s. 1325-1352. Savills, (2016), Raport: Around the World in Dollars and Cents. What Price the World. Trends in International Real Estate Trading. 
Sawicz B., (2012), Konwergencja realna regionów Europy Środkowej i Wschodniej i Unii Europejskiej?, „Biuletyn Europy Środkowej i Wschodniej - Puls Regionu”, nr 5.

Scanlon K., Whitehead C., Arrigoitia M.F. (eds.), (2014), Social Housing in Europe, John Wiley \& Sons, New York.

Schneider F., (2009), The Shadow Economy in Europe, ATKEARNEY, Johannes Kepler Universiteat Linz.

Sen A., (2009), The Idea of Justice, Allen Lane, London.

Shiller R.J., (2006), Long-term Perspectives on the Current Boom In Home Prices, „The Economists' Voice”, vol. 3(4), s. 1-11.

Smets F., (2007), Discussion of „Housing and the Business Cycle” by Edward Leamer Presented at the Symposium Housing, Housing Finance, and Monetary Policy.

Soaita A.M., Dewilde C., (2017), A Cluster Analysis of Path-dependent Changes in the Housing Systems of the 11 post-Communist EU States, HOWCOME Working Paper Series 17, 30.

Solow R. M., (1956), A Contribution to the Theory of Economic Growth, „Quarterly Journal of Economics", vol. 70, s. 65-94.

Spójność wewnętrzna a konkurencyjność regionu łódzkiego. Diagnoza strategiczna, raport z badania zamawianego przez Urząd Marszałkowski Województwa Łódzkiego, Instytut Badań Strukturalnych, Łódź 2009.

Sprawozdanie Komisji do Parlamentu Europejskiego, Rady, Europejskiego Banku Centralnego I Europejskiego Komitetu Społeczno-Ekonomicznego. Sprawozdanie przedkładane w ramach mechanizmu ostrzegania na 2019 rok, Bruksela 2019.

Stephens M., Lux M., Sunega P., ( 2015), Post-socialist Housing Systems in Europe: Housing Welfare Regimes by Default?, „Housing Studies”, vol. 30 (8), s. 1210-1234. The State of housing in EU in 2017.

Stiglitz J.E., (2006), Making Globalization Work, W.W. Norton, New York.

Stiglitz J.E., (2012), The Price of Inequality: How Today's Divided Society Endangers Our Future, WW Norton \& Company, New York.

Stiglitz J.S., (2010), Freefall. Jazda bez trzymanki. Ameryka, wolne rynki i tonięcie gospodarki światowej, PTE, Warszawa.

Swan T.W., (1956), Economic Growth and Capital Accumulation, „Economic Record", vol. 32, s. 334-361.

Szelągowska A., (2011), Finansowanie społecznego budownictwa mieszkaniowego, CeDeWu, Warszawa.

Szyszka A., (2009), Behawioralne aspekty kryzysu finansowego, „Bank i Kredyt”, nr 40(4), s. 5-30.

Temple J.R., (1999), The New Growth Evidence, „Journal of Economic Literature”, vol. 37(1), s. 112-156.

TENLAW: Tenancy Law and Housing Policy in Multi-level Europe: Austria R. Hofmann, Belgium M. Haffner, H. Bounjouh; Bulgaria B. Zahariev, D. Giteva, I. Yordanov; Croatia A. Jakopič, M. Žnidarec; Czech Republic P. Podrazil, R. Jadamus, 
P. Petr; Denmark J. Juul-Sandberg; P. Orji, P. Sparkes; Estonia A. Hussar; Finland T. Ralli; France J. Hoekstra, F. Cornette; Germany J. Cornelius, J. Rzeznik; Greece T. Konistis; Hungary J. Hegedüs, V. Horváth, N. Teller, N. Tosics; Ireland M. Jordan; Italy R. Bianchi; Latvia J. Kolomijceva; Lithuania A. Mikelenaite; the Netherlands M. Haffner, M. van der Veen, H. Bounjouh; Poland G. Panek; Portugal D. Correia, N. Santos, M. Olinda Garcia; Romania I. Bejan, F. Botonogu, I. Armasu, Scotland M. Jordan; Slovakia J. Štefanko, M. Filo, Z. Jurcova; Slovenia T. Pertovic; Spain E. Molina Roig; Sweden O. Bååth. https://cordis.europa. $\mathrm{eu} / \mathrm{project} / \mathrm{rcn} / 102183 /$ results/en.

Torgersen U., (1987), Housing: the Wobbly Pillar under the Welfare State, „Scandinavian Housing and Planning Research", vol. 4, s. 116-126.

Trojanek R., (2018), Teoretyczne i metodyczne aspekty wyznaczania indeksów cen na rynku mieszkaniowym, Wydawnictwo UEP, Poznań.

Tuvikene T., (2016), Strategies for Comparative Urbanism: post-Socialism as a de-Territorialized Concept, „International Journal of Urban and Regional Research", vol. 40(1), s. 132-146.

UN Compendium of Housing Statistics 1971, 1975-77.

UN Compendium of Human Settlements Statistics 1983, 1995, 2001, 2011.

UN Demographic Yearbooks 1948, 1955, 1962, 1971, 1979, 1983, 1994, 2000, 2010, 2017.

Van der Heijden H., Dol K., Oxley M., (2011), Western European Housing Systems and the Impact of the International Financial Crisis, „Journal of Housing and the Built Environment", vol. 26(3), s. 295-313.

Van Nieuwerburgh S., Weill P., (2010), Why Has House Price Dispersion Gone Up?, „The Review of Economic Studies”, vol. 77(4), s. 1567-1606.

White Paper on the Integration of EU Mortgage Credit Markets $\{$ SEC(2007) 1683\} \{SEC(2007) 1684\}, Brussels, 18.12.2007

Wilkin J., (2017), Współczesne państwo wobec triady funkcjonalnej: wartości - normy - dobra, „Zarządzanie Publiczne”, nr 39(1), s. 125-133.

Wind B., Lersch P., Dewilde C., (2017), The Distribution of Housing Wealth in 16 European Countries: Accounting for Institutional Differences, „Journal of Housing and the Built Environment", vol. 32(4), s. 625-647.

Wójcik P., (2018), Metody pomiaru realnej konwergencji gospodarczej w ujęciu regionalnym i lokalny. Konwergencja równoległa, Wydawnictwa Uniwersytetu Warszawskiego, Warszawa.

Wójcik P., (2008), Dywergencja czy konwergencja: dynamika rozwoju polskich regionów, „Studia Regioanlne i Lokalne”, nr 2(32), s. 41-60.

Yuill D., M. Ferry, (2008), Przeglą, zmiany, reformy. Najnowsze zmiany w polityce regionalnej w UE i Norwegii, Raport 07/1, [w:] Raporty EoRPA 1/2008: Wzrost czy równość?, Ministerstwo Rozwoju Regionalnego, Warszawa. 
Załęczna M., (2010), Instytucjonalne uwarunkowania rozwoju rynku nieruchomości w Polsce na tle doświadczeń państw zachodnich, Wydawnictwo Uniwersytetu Łódzkiego, Łódź.

Zavisca J.R., (2012), Housing the New Russia, Cornell University Press, Ithaca, NY. Zhang F., Morley B., (2014), The Convergence of Regional House Prices in China, "Applied Economics Letters”, vol. 21(3), s. 205-208.

Żelazowski K., (2009), Efekt majątkowy nieruchomości, „Studia i Materiały Towarzystwa Naukowego Nieruchomości”, t. 17(2), s. 89-96.

Żelazowski K., (2011), Regionalne zróżnicowanie cen i ich determinant na rynku mieszkaniowym $w$ Polsce, „Studia i Materiały Towarzystwa Naukowego Nieruchomości", t. 19(3), s. 98-106.

Żelazowski K., (2018), Konwergencja na regionalnych rynkach mieszkaniowych $w$ Polsce, „Ekonomia XXI Wieku”, nr 3 (19), s. 53-64.

Żelazowski K., (2019), Price Convergence in the Regional Housing Markets in Poland, „Real Estate Management and Valuation”, vol. 27(2), s. 44-52. 


\section{Załącznik}

\section{Źródła danych wykorzystanych w analizie konwergencji rynków mieszkaniowych UE}

\begin{tabular}{|c|c|c|c|}
\hline Zmienna & $\begin{array}{c}\text { Rynki mieszkaniowe } \\
\text { uwzględnione } \\
\text { w badaniu }\end{array}$ & $\begin{array}{c}\text { Okres } \\
\text { badawczy }\end{array}$ & Źródło danych \\
\hline 1 & 2 & 3 & 4 \\
\hline \multicolumn{4}{|c|}{ Konwergencja krajowych rynków mieszkaniowych } \\
\hline $\begin{array}{l}\text { Średnia cena } \\
\text { mieszkania na } \\
\text { rynku wtórnym za } \\
1 \mathrm{~m}^{2} \text { powierzchni } \\
\text { użytkowej } \\
\text { (w euro) }\end{array}$ & $\begin{array}{l}14 \text { rynków: Belgia, But- } \\
\text { garia, Finlandia, Francja, } \\
\text { Grecja, Hiszpania, Ho- } \\
\text { landia, Irlandia, Niemcy, } \\
\text { Polska, Portugalia, Sło- } \\
\text { wacja, Wielka Brytania, } \\
\text { Włochy }\end{array}$ & $2000-2017$ & $\begin{array}{l}\text { Bazy krajowych urzędów } \\
\text { statystycznych, banków } \\
\text { centralnych i komercyjnych, } \\
\text { ministerstw właściwych } \\
\text { do spraw budownictwa, } \\
\text { planowania i zagospodaro- } \\
\text { wania przestrzennego oraz } \\
\text { mieszkalnictwa }\end{array}$ \\
\hline $\begin{array}{l}\text { Średnie miesięczne } \\
\text { dochody } \\
\text { rozporządzalne per } \\
\text { capita wg pps } \\
\text { (w euro) }\end{array}$ & $\begin{array}{l}14 \text { rynków: Belgia, But- } \\
\text { garia, Finlandia, Francja, } \\
\text { Grecja, Hiszpania, Ho- } \\
\text { landia, Irlandia, Niemcy, } \\
\text { Polska, Portugalia, Sło- } \\
\text { wacja, Wielka Brytania, } \\
\text { Włochy }\end{array}$ & 2000-2017 & Eurostat \\
\hline
\end{tabular}


Zat. (cd.)

\begin{tabular}{|c|c|c|c|}
\hline 1 & 2 & 3 & 4 \\
\hline $\begin{array}{l}\text { Wskaźnik własności } \\
\text { mieszkań (\%) }\end{array}$ & $\begin{array}{l}27 \text { rynków: Austria, } \\
\text { Belgia, Bułgaria, Cypr, } \\
\text { Czechy, Dania, Estonia, } \\
\text { Finlandia, Francja, } \\
\text { Grecja, Hiszpania, } \\
\text { Holandia, Irlandia, } \\
\text { Litwa, Luksemburg, } \\
\text { Łotwa, Malta, Niemcy, } \\
\text { Polska, Portugalia, } \\
\text { Rumunia, Słowacja, } \\
\text { Słowenia, Szwecja, } \\
\text { Węgry, Wielka Brytania, } \\
\text { Włochy }\end{array}$ & 2000-2017 & $\begin{array}{l}\text { Eurostat oraz Housing } \\
\text { Statistics in the European } \\
\text { Union } 2010\end{array}$ \\
\hline $\begin{array}{l}\text { Wskaźnik deprywacji } \\
\text { mieszkaniowej (\%) }\end{array}$ & $\begin{array}{l}27 \text { rynków: Austria, } \\
\text { Belgia, Bułgaria, Cypr, } \\
\text { Czechy, Dania, Estonia, } \\
\text { Finlandia, Francja, } \\
\text { Grecja, Hiszpania, } \\
\text { Holandia, Irlandia, } \\
\text { Litwa, Luksemburg, } \\
\text { Łotwa, Malta, Niemcy, } \\
\text { Polska, Portugalia, } \\
\text { Rumunia, Słowacja, } \\
\text { Stowenia, Szwecja, } \\
\text { Węgry, Wielka Brytania, } \\
\text { Włochy }\end{array}$ & 2003-2017 & Eurostat \\
\hline $\begin{array}{l}\text { Liczba mieszkań na } \\
1000 \text { mieszkańców }\end{array}$ & $\begin{array}{l}22 \text { rynki: Austria, Belgia, } \\
\text { Bułgaria, Czechy, Dania, } \\
\text { Finlandia, Francja, } \\
\text { Grecja, Hiszpania, } \\
\text { Holandia, Irlandia, } \\
\text { Litwa, Niemcy, Polska, } \\
\text { Portugalia, Rumunia, } \\
\text { Słowacja, Słowenia, } \\
\text { Szwecja, Węgry, Wielka } \\
\text { Brytania, Włochy }\end{array}$ & 2000-2017 & $\begin{array}{l}\text { Raporty Hypostat } 2011 \\
\text { oraz Hypostat } 2018\end{array}$ \\
\hline
\end{tabular}




\begin{tabular}{|c|c|c|c|}
\hline 1 & 2 & 3 & 4 \\
\hline $\begin{array}{l}\text { Publiczne wydatki } \\
\text { na mieszkalnictwo } \\
\text { (w euro) na } 1000 \\
\text { mieszkańców }\end{array}$ & $\begin{array}{l}26 \text { rynków: Austria, } \\
\text { Belgia, Bułgaria, } \\
\text { Chorwacja, Cypr, } \\
\text { Czechy, Dania, Estonia, } \\
\text { Finlandia, Francja, } \\
\text { Grecja, Hiszpania, } \\
\text { Holandia, Irlandia, } \\
\text { Litwa, Luksemburg, } \\
\text { Malta, Niemcy, Polska, } \\
\text { Portugalia, Stowacja, } \\
\text { Słowenia, Szwecja, } \\
\text { Węgry, Wielka Brytania, } \\
\text { Włochy }\end{array}$ & $2000-2017$ & Eurostat \\
\hline $\begin{array}{l}\text { Zadłużenie } \\
\text { gospodarstw } \\
\text { z tytułu kredytów } \\
\text { hipotecznych w relacji } \\
\text { do PKB }(\%)\end{array}$ & $\begin{array}{l}27 \text { rynków: Austria, } \\
\text { Belgia, Bułgaria, Cypr, } \\
\text { Czechy, Dania, Estonia, } \\
\text { Finlandia, Francja, } \\
\text { Grecja, Hiszpania, } \\
\text { Holandia, Irlandia, } \\
\text { Litwa, Luksemburg, } \\
\text { Łotwa, Malta, Niemcy, } \\
\text { Polska, Portugalia, } \\
\text { Rumunia, Słowacja, } \\
\text { Słowenia, Szwecja, } \\
\text { Węgry, Wielka Brytania, } \\
\text { Włochy }\end{array}$ & $2000-2017$ & $\begin{array}{l}\text { Raporty Hypostat } 2011 \text { oraz } \\
\text { Hypostat } 2018\end{array}$ \\
\hline \multicolumn{4}{|c|}{ Konwergencja regionalnych rynków mieszkaniowych } \\
\hline $\begin{array}{l}\text { Średnia cena } \\
\text { mieszkania na } \\
\text { rynku wtórnym za } \\
1 \text { m² powierzchni }^{2} \\
\text { użytkowej (w walucie } \\
\text { krajowej) }\end{array}$ & $\begin{array}{l}6 \text { rynków: } \\
\text { Bułgaria, } \\
\text { Hiszpania } \\
\text { Holandia } \\
\text { Polska } \\
\text { Słowacja } \\
\text { Wielka Brytania }\end{array}$ & $\begin{array}{l}2003-2017 \\
2001-2017 \\
2000-2017 \\
2000-2017 \\
2000-2017 \\
2000-2017\end{array}$ & $\begin{array}{l}\text { Krajowy urząd statystyczny } \\
\text { Ministerstwo Rozwoju } \\
\text { Krajowy urząd statystyczny } \\
\text { Krajowy urząd statystyczny } \\
\text { Bank centralny } \\
\text { Krajowy urząd statystyczny }\end{array}$ \\
\hline $\begin{array}{l}\text { Średnie miesięczne } \\
\text { dochody } \\
\text { rozporządzalne per } \\
\text { capita (w walucie } \\
\text { krajowej) }\end{array}$ & $\begin{array}{l}6 \text { rynków: } \\
\text { Bułgaria } \\
\text { Hiszpania } \\
\text { Holandia } \\
\text { Polska } \\
\text { Słowacja } \\
\text { Wielka Brytania }\end{array}$ & $\begin{array}{l}2003-2017 \\
2001-2017 \\
2000-2017 \\
2000-2017 \\
2000-2017 \\
2000-2017\end{array}$ & Krajowe urzędy statystyczne \\
\hline
\end{tabular}


248 Załącznik

Zat. (cd.)

\begin{tabular}{|l|l|l|l|}
\hline \multicolumn{1}{|c|}{1} & \multicolumn{1}{|c|}{2} & \multicolumn{1}{c|}{3} & \multicolumn{1}{c|}{4} \\
\hline Liczba mieszkań na & 6rynków: & & \\
1000 mieszkańców & Bułgaria & $2003-2017$ & Krajowy urząd statystyczny \\
& Hiszpania & $2001-2017$ & Ministerstwo Rozwoju \\
& Holandia & $2000-2017$ & Krajowy urząd statystyczny \\
& Polska & $2000-2017$ & Krajowy urząd statystyczny \\
& Stowacja & $2001-2017$ & Krajowy urząd statystyczny \\
& Wielka Brytania & $2000-2017$ & Krajowy urząd statystyczny \\
\hline
\end{tabular}




\section{Spis tabel}

Tabela 2.1. Systemy akumulacji majątku mieszkaniowego a dominujący sposób władania nieruchomościami mieszkaniowymi

Tabela 2.2. Zestawienie instrumentów polityki mieszkaniowej 52

Tabela 2.3. Zmiany populacyjne w państwach europejskich od lat 30. do 70. 57

Tabela 2.4. Populacja w miastach od 100 tys. mieszkańców (w mln) od lat 40. do 80.

Tabela 2.5. Liczba mieszkań w państwach europejskich od lat 50. do 80.

Tabela 2.6. Udział procentowy gospodarstw domowych zamieszkujących własne mieszkania od lat 60. do 80.

Tabela 2.7. Wskaźnik liczby mieszkań na 1000 mieszkańców od lat 50. do 70.

Tabela 2.8. Zmiany populacyjne od lat 80. do roku 2017

Tabela 2.9. Zmiany liczby mieszkań w poszczególnych państwach UE od lat 80. do roku $2017 \quad 65$

Tabela 2.10. Wskaźnik liczby mieszkań na 1000 mieszkańców w wybranych państwach UE od lat 90. do roku 2017

Tabela 5.1. Przegląd literatury poświęconej problematyce konwergencji mieszkaniowej 133

Tabela 5.2. Wyniki estymacji regresji log $(t)$ dla 14 rynków mieszkaniowych 139

Tabela 5.3. Wyniki estymacji regresji log(t) dla zidentyfikowanych klubów konwergencji cenowej

Tabela 5.4. Wyniki estymacji regresji log(t) dla regionalnych rynków mieszkaniowych $\quad 141$

Tabela 5.5. Konwergencja klubowa regionalnych rynków mieszkaniowych $\quad 142$

Tabela 5.6. Wyniki estymacji beta konwergencji $\quad 145$

Tabela 5.7. Wyniki estymacji sigma konwergencji $\quad 148$

Tabela 5.8. Wyniki weryfikacji gamma konwergencji $\quad 150$

Tabela 5.9. Wyniki estymacji beta konwergencji dla wskaźnika mieszkań na 1000 mieszkańców

Tabela 5.10. Wyniki estymacji sigma konwergencji dla wskaźnika mieszkań na 1000 mieszkańców

Tabela 5.11. Wyniki weryfikacji gamma konwergencji dla wskaźnika mieszkań na 1000 mieszkańców

Tabela 5.12. Wyniki estymacji beta konwergencji dla wskaźnika siły nabywczej gospodarstw domowych

Tabela 5.13. Wyniki estymacji sigma konwergencji dla wskaźnika siły nabywczej gospodarstw domowych

Tabela 5.14. Wyniki weryfikacji gamma konwergencji dla wskaźnika siły nabywczej gospodarstw domowych

Tabela 6.1. Roczne tempo konwergencji PKB per capita krajów UE28 (oszacowane na podstawie modelu postaci 4.1) w zależności od początkowego roku analizy $\quad 176$

Tabela 6.2. Wyniki estymacji warunkowej beta konwergencji $\quad 184$ 
Tabela 6.3. Sigma konwergencja rynków mieszkaniowych na tle sigma konwergencji gospodarczej

Tabela 6.4. Wyniki estymacji modelu LSDV dla klubu 1 konwergencji cenowej

Tabela 6.5. Wyniki estymacji modelu LSDV dla klubu 2 konwergencji cenowej

Tabela 7.1. Podstawowe komponenty polityki mieszkaniowej w wybranych państwach UE

Tabela 7.2. Poziom zaspokojenia potrzeb mieszkaniowych na poziomie wybranych państwa UE w 2017 r.

Tabela 7.3. Wskaźnik przeciążenia kosztami mieszkaniowymi z uwzględnieniem sytuacji finansowej gospodarstw domowych

Tabela 7.4. Wskaźnik przeludnienia mieszkań z uwzględnieniem sytuacji finansowej gospodarstw domowych 


\section{Spis rysunków}

Rysunek 5.1. Długookresowe zmiany cen nieruchomości w zidentyfikowanych klubach konwergencji

Rysunek 5.2. Identyfikacja beta konwergencji na europejskich rynkach mieszkaniowych

(lata 2000-2017)

Rysunek 5.3. Identyfikacja sigma konwergencji na europejskich rynkach mieszkaniowych (lata 2000-2017)

Rysunek 5.4. Identyfikacja gamma konwergencji na europejskich rynkach mieszkaniowych (lata 2000-2017)

Rysunek 5.5. Identyfikacja beta konwergencji dla wskaźnika mieszkań na 1000 mieszkańców (lata 2000-2017)

Rysunek 5.6. Identyfikacja sigma konwergencji dla wskaźnika mieszkań na 1000 mieszkańców

Rysunek 5.7. Identyfikacja gamma konwergencji dla wskaźnika mieszkań na 1000 mieszkańców

Rysunek 5.8. Identyfikacja beta konwergencji dla wskaźnika siły nabywczej gospodarstw domowych (lata 2000-2017)

Rysunek 5.9. Identyfikacja sigma konwergencji dla wskaźnika siły nabywczej gospodarstw domowych

Rysunek 5.10. Identyfikacja gamma konwergencji dla wskaźnika sity nabywczej gospodarstw domowych

Rysunek 6.1. Współczynnik zmienności dla PKB per capita (w dolarach amerykańskich, ceny stałe z 2011 r.) dla 169 gospodarek świata

Rysunek 6.2. Zróżnicowanie (mierzone współczynnikiem zmienności) PKB pomiędzy 15 krajami UE

Rysunek 6.3. Zróżnicowanie (mierzone współczynnikiem zmienności) PKB per capita pomiędzy krajami tworzącymi wspólnotę europejską w różnych momentach jej istnienia

Rysunek 6.4. Średnie PKB per capita dla 28 krajów UE

Rysunek 6.5. Przekrojowa wariancja ht dla PKB per capita 28 państw UE wraz z podziałem na 15 ,starych” i 13 „nowych” państw

Rysunek 6.6. Sigma konwergencja (mierzona współczynnikiem zmienności) dla UE28

Rysunek 6.7. Sigma konwergencja rynków mieszkaniowych na tle sigma konwergencji gospodarczej

Rysunek 7.1. Różnica procentowa udziału właścicieli mieszkań (2007-2017) 204

Rysunek 7.2. Różnica procentowa udziału najemców zasobu społecznego (2007-2017) 205

Rysunek 7.3. Różnica procentowa udziału gospodarstw domowych przeciążonych kosztami mieszkaniowymi (2007-2017) 
Rysunek 7.4. Różnica procentowa udziału gospodarstw domowych zamieszkujących w warunkach poważnej deprywacji mieszkaniowej (2007-2017)

Rysunek 7.5. Różnica procentowa udziału gospodarstw domowych zamieszkujących w warunkach przeludnienia (2007-2017)

Rysunek 7.6. Wskaźnik przeciążenia kosztami mieszkaniowymi z uwzględnieniem sytuacji finansowej gospodarstw domowych w EU27

Rysunek 7.7. Wskaźnik przeludnienia mieszkań z uwzględnieniem sytuacji finansowej gospodarstw domowych w EU27 


\section{Spis schematów}

Schemat 4.1. Klasyfikacja zjawiska konwergencji wg różnych kryteriów

Schemat 5.1. Obszary identyfikacji konwergencji pozacenowej na rynkach mieszkaniowych 
